\title{
EDUCACIÓN \\ PARA LA INCLUSIÓN DIGITAL EN \\ PERSONAS MAYORES
}

\section{UNIVERSITAT \\ JAUME I}

Tesis Doctoral

Universitat Jaume I

Departamento de Educación

Julio de 2017

Presentada por: Pilar Escuder Mollón

Dirigida por: Jordi Adell Segura

Salvador Cabedo Manuel 


\section{AGRADECIMIENTOS}

A Salvador y Jordi por hacer realidad este proceso académico, por saber dirigirme; respetando mis tiempos y teniendo en cuenta mis dificultades y objetivos.

A Jordi Adell, por la oportunidad que me ha brindado al dirigir esta tesis, Aprender de él, abrirme los ojos al campo de la educación en TICs, tomar conciencia de la importancia de este tema que afecta no solo a las estructuras educativas sino a las personas y las sociedades ha sido un privilegio.

Gracias Jordi por saber acompañarme no solo en este proceso académico sino desde que empecé a trabajar en la Universitat Jaume I, que mi primer despacho fuera rodeada de los compañeros del CENT (Centro de Educación y Nuevas Tecnologías), enfrente de ti no fue casualidad. Paso a paso fuiste conociendo el crecimiento de la Universitat per a Majors, supervisando con una sonrisa cada una de las propuesta de innovación en TICs, los proyectos en los que nos embarcamos, aportando tus sugerencias y comprometiéndote con ellas.

Me enseñaste, poniéndolo en práctica, que no solo los procesos de educación tienen porqué ser formales, de manera informal cada vez que nos cruzábamos en el despacho o yo por ansias de aprender te abordaba en el tuyo en dabas artículos, me contabas experiencias, me abrías los ojos; y conseguiste que me ilusionara: que quisiera aprender y luego: quise transmitir.

A Salvador Cabedo, por enseñarme que tener un sueño es el primer paso para cumplirlo. Porque has ejercido de "páter" desde el primer día que nos conocimos sabiendo desarrollar en mí todas las mejores virtudes; dejándome trabajar, tener ideas, desarrollar y aprender a aprender.

Gracias por tantas correcciones, por todas y cada una de las indicaciones que en estos veinte años juntos me has puntualizado: de todas y cada una he aprendido. 
Gracias a tu constancia pudimos hacer realidad el que nuestra Universidad contará con un Programa de Formación para Mayores en el que nadie se viera excluido, en el que aprender académicamente pudiera complementarse con una experiencia personal y social.

Y gracias por hacer de tu familia un complemento a la mía, Ma Pilar, Lluís y Albert son sin dudarlo personas importantísimas en nuestro retos y es una suerte poderlos compartir con ellos.

A la Universitat per a Majors, programa del que he recibido muchísimo más de que aquello que haya podido aportar. Poder desarrollar tu investigación en un marco académico y social como es este programa de formación permanente me ha permitido conocer de primera mano a los estudiantes mayores, las diferentes metodologías, poner en práctica innovaciones educativas y ver el resultado en los ojos de las personas.

Gracias a todos y todas los estudiantes de la Universitat per a Majors que desde el año 1998 has participado en este Programa, no podría deciros cuanto he aprendido, no puedo mostraros todo el respeto y el cariño infinito que os tengo.

A mi compañero, amigo y binomio "binario" Roger Esteller, porque sin él no hubiera podido realizarse el sueño: su generosidad ha hecho posible que muchos estudiantes seniors hoy formen parte de la sociedad de la información y la comunicación, porque es y ha sido capaz de apartar sus metas individuales a fin de cumplir con los objetivos de nuestro equipo, porque es un trabajador incansable, un estudioso excepcional. Gracias por acompañarme en este camino, en cada uno de los nuevos retos y en la vida.

A Concha Bru, José Arnay, Juan Antonio Lorenzo, Antonio Rodríguez, Florentino Blázquez, Carmen Palmero, Liberto Beltrán y Adoración Holgado, compañeros y compañeras de los Programas Universitarios para Mayores los que me habéis abierto las puertas de vuestras Universidades, me habéis enseñado a valorar la educación permanente como un valor y responsabilidad social que cualquier centro educativo debe asumir pero también como fuente de conocimiento académico: poniéndola en valor y luchando por su reconocimiento. Sin vuestro empuje emocional y académico este trabajo nunca se hubiera realizado: gracias. 
A Sonia Hetzner, Paul Held, Cathy Fowleh, Anssi kemppi, Velta Lubkina, Massimo Bardus, Georgeta Chirlesan y Cecil Issakainen, compañeros y amigos con los que he compartido investigaciones y experiencias. Con los que he aprendido que los europeos tenemos mucho en común y mucho por colaborar.

A Mónica Sales y Maㅗ Paz García por apoyarme en todo momento, por estar siempre junto a mí. Su grandeza como compañeras la supera su bondad como personas.

A Vicent Querol, porque desde el inicio de esta carrera universitaria hemos estado caminando juntos, aprendiendo el uno al lado del otro. Soñando que una nueva forma de educar era posible, luchando porque la no discriminación por edad ni por territorio fuera una realidad. Porque nadie como él para que me entienda sin hablarnos, para que reconozca las dificultades y sepa cómo resolverlas.

A Raül, compañero incondicional, por su apoyo constante, por su comprensión, cariño y respeto. Por saber reconocer lo tedioso y la intensidad que un trabajo de investigación requiere. Por tener siempre una sonrisa que nos ayuda a superar cualquier dificultad.

A mis abuelos: Adolfo-Emilia y Crescencio-Eduvigis, sin su educación, su forma de vida ejemplarizante y su amor y dedicación a nuestra familia, sin duda alguna mi vida hubiera sido muy distinta. Gracias por mostrarnos el camino del trabajo, la dedicación incondicional a lo que amar y la educación como base de cualquier vida que quiere ser vivida con dignidad.

A mis padres, por enseñarme que no somos aquello que logramos en la vida, somos todo lo que superamos; gracias! 


\section{PRÓLOGO}

El aprendizaje permanente es una necesidad de cualquier miembro de la sociedad, que se justifica en las diferentes investigaciones de índole antropológica y se protege mediante diferentes medidas de índole normativo. Del aprendizaje permanente depende la capacidad de integración, inclusión y participación del ser humano, ya sea para mejorar en el trabajo, estar más adaptado, conocer su entorno o a sí mismo, así como mejorar su calidad de vida. Las instituciones de orden político y educativo ofrecen programas educativos con muy diferentes estructuras y objetivos, que deben ser adaptados y rediseñados de forma continua e implantados de acuerdo con los cambios sociales, económicos, políticos y demográficos que se están produciendo.

La Sociedad del Conocimiento (SC) nos presenta un modelo social en el que el acceso a la información, en sus diferentes servicios y la posibilidad de crear redes entre los ciudadanos modifican la forma en que las personas se relacionan, aprenden y crean el saber de forma global e inmediata, si bien, aparecen con ello nuevos riesgos y peligros.

Las personas mayores mediante el aprendizaje permanente adquieren nuevos conocimientos y utilizan cada vez mejor las herramientas y servicios ofrecidos por las Tecnologías de la Información y Comunicación (TICs). Este primer paso de aprendizaje es necesario, pero no suficiente. Es necesaria también una adaptación a nuevas formas de organización, dominio, creación de contenidos y colaboración, etc. propias de la sociedad actual. Es posible de este modo que puedan sacar provecho propio para mejorar su calidad de vida; también la sociedad puede beneficiarse de su participación e inclusión en las redes de la información y la comunicación.

Instituciones educativas como las universidades facilitan e implementan programas de educación adaptados a las personas mayores en un intento de favorecerles entornos adecuados, en donde sea posible no sólo aprender contenidos, sino también habilidades sociales, así como comprender más acerca de lo que sucede en su entorno 
y los cambios que ellos mismos sufren. Es común impartir este servicio de enseñanza mediante metodologías y herramientas tradicionales, pero cabe el peligro de ignorar otras muchas y numerosas oportunidades de aprendizaje permanente.

Es necesario establecer de forma clara cómo se ve afectada la participación del mayor en la sociedad actual del conocimiento y cómo el dominio de las TICs influye en su vida, en la visión social de su grupo, es sus percepciones afectivas y en el proceso de aprendizaje. Es muy útil investigar cómo les afecta, así como conocer su posible aportación y el impacto, con sus puntos débiles y fuertes.

Mediante este análisis en profundidad será posible, por un lado, que diseñadores de entornos y espacios en Internet tengan en cuenta también las necesidades de los mayores, y que los políticos y responsables sociales puedan entender el impacto que tienen los mayores en la SC, a la vez que las instituciones educativas puedan diseñar e implementar acciones educativas de mayor calidad en la SC.

\section{Palabras clave}

mayores, educación permanente, sociedad del conocimiento, pedagogía, TIC 


\section{CONTENIDO}

SECCIÓN PRIMERA; EDUCACIÓN PERMANENTE

1 INTRODUCCIÓN

2 LA URGENCIA DE UN APRENDIZAJE PERMANENTE

3 LA REVOLUCIÓN GRIS

4 LA SOCIEDAD DEL CONOCIMIENTO DE LAS PERSONAS MAYORES

5 INCLUSIÓN DIGITAL DEL MAYOR

$6 \quad$ ICT50+

$9 \quad$ E-VITA

13 EDUEVAL 
14 SG4ADULTS

15 EHHLSA

SECCION TERCERA; NECESIDADES Y CONTEXTO DE LAS TICS EN LA EDUCACION DE PERSONAS MAYORES

16 EL APRENDIZAJE PERMANTE DESDE EUROPA

17 SENIOR CITIZENS' LEARNING ON-LINE; NEEDS AND EXPECTATIONS

18 USO Y ACTITUD HACIA LA TICS EN LOS ESTUDIANTES DE LA UNIVERSITAT PER A MAJORS

19 THE IMPORTANCE OF COMMUNICATION IN THE LEARNING PROCESS ON INFORMATION AND COMMUNICATION TECHNOLOGIES COURSES FOR SENIORS

20 ENHANCING ICT EDUCATION FOR SENIOR STUDENTS

21 IMPACT ON SENIOR LEARNERS' QUALITY OF LIFE THROUGH LIFELONG LEARNING

22 EL APRENDIZAJE PERMANENTE DESDE EUROPA EN LA UNIVERSITAT PER A MAJORS

24 THE VIRTUOUS CIRCLE OF USE, ATTITUDE, EXPERIENCE AND E-INCLUSION

25 SENIOR STUDENTS IN VIRTUAL SPACES; THE TREASURE WITHIN 
27 ED-WAY PROJECT; INTRODUCING TECHNOLOGY-ENHANCED INFORMAL LEARNING

28 VIRTUAL ON-LINE LEARNING; THE EVOLUTION AND GROW OF SENIOR CITIZENS

29 THE USE OF COMMUNITIES OF PRACTISE TO CRÉATE STORIES FOR SERIOUS GAMES - EXPERIENCES OF THE EUROPEAN ROJECT E-VITA

31 EDUCATION ON SENIOR CITIZENS; NEW UNDERSTANDING AND APPROACHES TO INCREASE QUALITY OF LIFE

32 PEDAGOGICAL PROPOSAL TO INCREASE THE QUALITY OF LIFE ON SENIOR CITIZENS

33 THE QEDUSEN PROJECT; IMPROVING SENIORS' QUALIY OF LIFE THROUGH EDUCATION

34 IMPACTO DE LA CALIDAD DE VIDA DE LOS MAYORES A TRAVÉS DE LAS TIC. CONCEPTOS Y METODOLOGIA PARA UNA ACCIÓN EDUCATIVA

SECION SEXTA VALIDACIÓN Y CALIDAD

35 INDICATORS FOR QUALITY EVALUATION FOR THE DEVELOPMENT OF THE STAFF IN EDUCATIONAL INSTITUTIONS

36 BEYOND QUALITY ASSESMENT TOOLS; POTENTIALITIES OF QEDUSEN EVALUATION TOOLKIT

38 A TOOLKIT TO EVALUATE THE IMPACT OF AN EDUCATIONAL ACTION TO SENIORS' QUALITY OF LIFE 
39 TECHNOLOGY-ENHANCED TRANSVERSAL SKILLS FOR LIFELONG LEARNING: METHOD, COMPETENCES, VALIDATION

SECCION SEPTIMA; CONCLUSIONES 449

41 CONCLUSIONES 450

42 PROPUESTAS 454

43 REFERENCIAS 


\section{PERSPECTIVA Y ORGANIZACIÓN}

\section{- Introducción}

- Proyectos de innovación educativa

- Necesidades y contexto

4

- Educación mediada por la tecnología

- Impacto y calidad de vida del mayor

- Validación y calidad educativa

- Conclusiones

La presente tesis está organizada en 7 secciones bien diferenciadas, ofreciendo en las partes centrales investigaciones propias presentadas en congresos nacionales e internacionales, así como en capítulos de libros y publicaciones en revistas de prestigio.

En primer lugar se presenta la introducción conceptual al objetivo de estudio de la tesis. Se pretende explicitar el punto de partida, contexto, necesidad, retos y los avances que se consiguen, y que en las siguientes secciones serán objeto de estudio más detallado. Esta es la línea orientadora Proyectos europeos e investigaciones que se han realizado.

La sección segunda muestra los Proyectos europeos en los cuales hemos participado como investigadores. Con ello puede observarse la evolución desde el 2005 hasta el presente, a partir de los primeros retos de lograr una adopción de la tecnología para los mayores y de cómo a lo largo de los años estas prácticas iniciales se desarrollaron 
y consiguieron la inclusión y un uso de las herramientas tecnológicas. Éstas trascendían el simple uso, evolucionando hacia un aprovechamiento de las capacidades mucho más complejas, que involucran la experiencia, las emociones, el contexto social y el aprendizaje permanente. Esta progresión sirve para dar ejemplo del progreso de los mayores en la última década, a la vez que nos servirá para proponer y orientar actuaciones futuras.

La sección tercera presenta y analiza en diferentes artículos las características de la educación en personas mayores, estudiando y detallando sus componentes y el porqué del diseño que proponemos, esto es basándonos tanto en las necesidades del estudiante mayor y sus características, como en las potencialidades que tiene una acción educativa en la persona mayor, en concreto en las relaciones sociales y en su entorno en general.

En la sección cuarta se exponen los artículos que proponen ya acciones educativas basadas en la tecnología, analizando prácticas y modelos que son posteriormente evaluados, demostrando su eficacia y resultados. Todo esto ha sido posible gracias a un uso adecuado de las tecnologías de la información y comunicación.

En la sección quinta pretendemos centrarnos en la calidad de vida como elemento que se ve influenciado por una actividad educativa. Dentro de este concepto de calidad de vida se pretende integrar un abanico de componentes tales como la inclusión, la sociabilización, el soporte y el control social, así como el bienestar y crecimiento personal. Se concluye de este modo lo que pretende ser el objetivo final de una actividad educativa dirigida a personas mayores, estudiando las dimensiones que han de ternerse en cuenta y cómo estas pueden ser potenciadas gracias a la educación.

En la sección sexta, pueden leerse los artículos realizados a partir de las investigaciones en el ámbito de la capacitación y evaluación de la calidad de los profesionales de la educación y los centros educativos.

La última sección se presenta a modo de conclusión: la relación existente entre todos los diferentes componentes vistos hasta el momento, personas mayores y tecnología, integrados dentro de una actividad educativa, para promover un cambio y crecimiento hacia una mayor calidad de vida. 


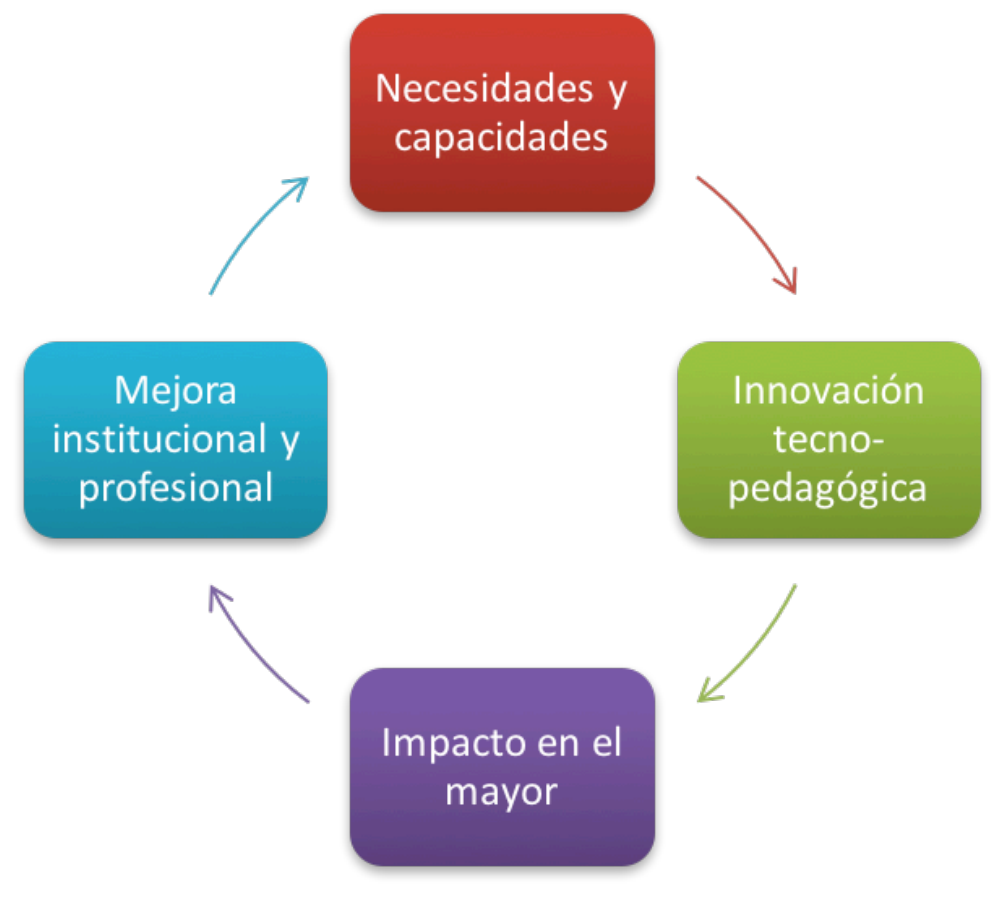

Gráfico 1; Ciclo de innovación y mejora continuada

Dentro del marco de los Proyectos europeos de innovación educativa y de forma continuada, desde 2007, se sigue una espiral de mejora continuada (Gráfico 1). Esto se puee observar, por ejemplo, en los Primeros proyectos europeos (ICT50+, activeICT, SenTrain) que pretendían una adopción de la tecnología por parte del mayor. Después de favorecer este avance y mejora en las pedagogías, evaluar el impacto en el estudiante mayor y promover una mejora institucional para lograr el objetivo de una docencia adaptada a las necesidades de los estudiantes y según las capacidades de la tecnología (tanto como herramienta como en su contexto social), observamos la necesidad de seguir avanzando hacia un uso tecnológico más transversal, que fuera permeable a otras áreas del conocimiento y que fuera usado no solo como herramienta, sino también como método. Los siguientes Proyectos europeos (SeniorsKS, EHHLSA, SenApp) se desarrollaron en esta linea, de modo que el ciclo se repetía, con el fin de promover una mejora en el mayor, no solo en aptitudes, sino en la inclusión digital y calidad de vida (EduSenior), a través de la actuación en los centros y por los profesionales (EduEval).

La educación de personas mayores en tecnología y a través de la tecnología se presenta y entiende como un fenómeno complejo, que debe tener en cuenta diferentes factores y que de forma cíclica (Gráfico 1), debe ir mejorando y avanzando 
hacia nuevas posibilidades tecnológicas, nuevos retos educativos y necesidades de las personas mayores. 


\section{SECCIÓN PRIMERA; EDUCACIÓN PERMANENTE}




\section{INTRODUCCIÓN}

Los avances en el campo de la microelectrónica producidos a finales del siglo XX han permitido que de forma general las familias puedan tener un computador en sus hogares. A finales de los 80 y principios de los 90 el uso que se les podía dar a estos ordenadores era más bien escaso y de forma aislada: escribir, instalar una enciclopedia, diseño, etc. No fue hasta la popularización de Internet que permitió a todos estos hogares y a las empresas poder estar conectados entre si. En los 90 la potencia y capacidades de los ordenadores siguió aumentando, la red creció en cuanto a cobertura de familias, empresas, pero también de servicios y herramientas.

Hoy en día no resulta extraño oír que tal cosa la han leído en Internet o decir que nos pueden enviar unas fotos a nuestra cuenta de correo. La tecnología ha sido adoptada por las personas y ha dado lugar a la Comunicación Mediada por Ordenador (CMO). La CMO ha hecho posible el cambio y aparición de nuevas rutinas sociales (Castells 2001)

No es posible afirmar si ha sido la tecnología la que ha modificado la sociedad o si ha sido la sociedad la que en su continua evolución ha adoptado unas herramientas tecnológicas que le eran más óptimas. En este dilema ya estarían las teorías del determinismo tecnológico, pero que no pretendemos analizar en este trabajo (Roe Smith 1996). A esta nueva sociedad transformada por la CMO, en donde la tecnología y la red hacen posible el acceso, tratamiento y envío de información con una rapidez y globalidad no vista hasta el momento actual, se le denomina "Sociedad de la Información" (SI)

En esta SI ya aceptamos como habitual el leer periódicos on-line, reservar un hotel de nuestro próximo viaje al extranjero o presentar la declaración de la renta mediante nuestro DNI electrónico. Es posible también encontrar extraño que alguien afirme no tener acceso a Internet en casa o no tener correo electrónico. Estas particularidades relativas de la SI aplicadas a las personas mayores se analizarán en detalle en la segunda sección de este trabajo. 
El presente trabajo pretende poner luz en el proceso educativo realizado por personas mayores en la SC. Para eso es necesario presentar, en primer lugar el contexto de la educación ofrecida a personas mayores: qué se pretende y por qué, sus objetivos y el impacto que se logra. La educación ofrecida a personas mayores, que han abandonado el contexto laboral, posee grandes diferencias de la de aquellos más jóvenes, especialmente porque ya no prima la necesidad de mejora de la calificación profesional, sino otros valores diferentes: integración, conocimiento del entorno, adaptación, sociabilización, etc. Todas estas peculiaridades se presentarán en la tercera sección.

En el nivel académico y científico existe la certeza de que en la actualidad se están produciendo no sólo cambios en la forma de comunicación y acceso a la información (como ya se había introducido antes al hablar de la SI), sino también cambios de estructura, actitudes y métodos sociales.,... que afectan a nuevas formas de comunidades, poder, formación, etc. Es en este contexto donde las herramientas tecnológicas no sólo son herramientas, sino que son las personas quienes hacen uso de ellas mediante aprendizaje, sociabilización, soporte, etc., provocando con esto también diferentes efectos tanto positivos (pertenencia a comunidades, integración, etc.) como negativos (brecha digital, perdida de la privacidad, etc. )

El nombre que recibe este fenómeno social, en cambio, sí que es objeto de discusión, podríamos hablar de "Sociedad del Conocimiento" (Crovi 2004) o "sociedad en red" (Castells 2006). Independientemente de qué forma se defina, esta nueva sociedad caracterizada por la CMO es la que será objeto de estudio en la cuarta sección, poniendo al descubierto las potencialidades y riesgos que tiene y centrándonos en las personas mayores.

De este modo, en este trabajo se presentará, en primer lugar, la realidad social, demográfica, económica y académica de las personas mayores, además de la utilización y adopción de la tecnología. En segundo lugar, el contexto de aprendizaje de este colectivo, sus objetivos y requerimientos. En tercer lugar, se explicitarán las potencialidades y riesgos que nos presenta la Sociedad del Conocimiento. 
Las personas mayores deben formarse y adquirir las habilidades y conocimientos necesarios para manejar las herramientas TIC más habituales, por ejemplo el computador, internet, el Google o el email.

Una vez superada esta primera barrera en la que la persona mayor ya tiene los conocimientos suficientes para manejarse con el ordenador e internet, sería una pérdida de oportunidad no pretender que el mayor pueda seguir aprendiendo en la SC, conociendo también de antemano las potencialidades y riesgos, y cómo actuar para maximizar y minimizarlos respectivamente.

Por lo que es necesario comprender cómo la política del "aprendizaje a lo largo de toda la vida" promovida por las instituciones educativas y organismos políticos, se ve afectada y puede ser promocionada desde la Sociedad del Conocimiento. Una acción de este tipo puede afectar de forma muy positiva a las personas mayores, las cuales, cada vez están adquiriendo más habilidades para el manejo de las TICs, pero su uso puede ser aun más transformador y beneficioso, tanto para ellos en términos de calidad de vida como para la sociedad, minimizando el riesgo de dependencias y configurando unos mayores más "productivos". 


\section{LA URGENCIA DE UN APRENDIZAJE PERMANENTE}

\subsection{La pretensión: envejecer mejor}

Para envejecer con éxito, y dado que no podemos luchar contra el envejecimiento primario o genético, debemos afrontar el envejecimiento secundario y el psicosocial. El envejecimiento secundario es el debido al estilo de vida, a las enfermedades, a las agresiones ambientales y a los tóxicos. Puede reducirse manteniendo un estilo de vida activo, que elimine paulatinamente las costumbres perniciosas y estimule las beneficiosas, vigilando la aparición de enfermedades y extremando el cuidado de las que aparezcan, luchando de forma activa contra los peligros ambientales y laborales cuyo control depende de los poderes públicos.

El envejecimiento psicosocial se debe a la pérdida de autoestima que conlleva la edad madura, al estrés, a la soledad y la disminución de la relación con otros, a la pérdida de recursos y la desocupación que conlleva la jubilación y a los prejuicios sociales. Para evitarlo, hay que aprender a minimizar las pérdidas de facultades y a utilizar su capacidad de compensación para suplirlas con otras facultades que se han desarrollado. Tiene que mantenerse activo física y mentalmente, buscando ocupaciones compensadoras para el tiempo libre que le permitan mantener la función laboral y social. Se tiene que buscar garantizar en lo posible una cierta estabilidad socioeconómica. Hay que mejorar la autoestima y luchar por mantener las relaciones con otros o crear relaciones nuevas. En resumen, hay que intentar mantener un estilo personal de vida que nos identifique.

"No intentéis vivir siempre. No tendréis éxito". Al cumplir 90 años, Bernard Shaw, el dramaturgo y crítico literario irlandés, dio este consejo a los jóvenes. De alguna forma, hace siglos que los científicos se empeñan en llevar la contraria al escritor 
aunque, en manos de la ciencia moderna, el ambicioso objetivo de la eterna juventud se ha transformado en uno mucho más pragmático.

Para envejecer adecuadamente deberíamos tener presente los siguientes ítems:

1. Adaptarse a los cambios. Hay que asumir la edad que tenemos. Los años suponen cambios.

2. No resignarse a la enfermedad o la dependencia. La enfermedad no es inherente a la edad.

3. Cambios
a. Físicos
b. mentales (el cerebro es el último que envejece)
c. afectivos
d. socio-familiares

No podemos vivir contra el tiempo (no podemos vivir a los 60 como si tuviéramos 20).

¿Qué deberíamos evitar?

- Tabaco

- Alcohol

- Abuso de fármacos

- Rayos ultravioletas

- Ruidos

- Cuidado con los accidentes de tráfico, ya que $1 / 2$ de los atropellados son personas mayores

- Obesidad.

¿Qué deberíamos hacer?

- Alimentación adecuada

- Actividad física regular

- Relaciones sociales adecuadas (favorecen la dieta, el ejercicio físico, tienden a mejorar la salud mental ...)

- Actividad mental 
- Cuidar de la salud

Y en todo esto, ... ¿que puede hacer la educación por mi envejecimiento saludable?

- Ayudarnos afrontar, desde el desarrollo personal, el hecho de envejecer.

- Facilitarnos el aprendizaje a lo largo de toda la vida.

- Responsabilizar a los distintos sectores de la sociedad.

- Reconocer la diversidad existente entre las personas mayores: no todos somos iguales (lo jóvenes tampoco)

- Concretar la noción de capacitación

- Aportar imágenes reales de las personas mayores que rompen con los estereotipos negativos.

- Fomentar las relaciones intergeneracionales.

\subsection{La calidad de vida como meta}

El interés por lo que incluye la calidad de vida ha existido desde siempre. Sin embargo, la aparición del concepto como tal y la preocupación por su evaluación sistemática y científica es relativamente reciente, aplicándose en primer lugar a los campos de la salud física y ambiental, ampliándose posteriormente a los ámbitos de la salud psíquica y servicios sociales en general.

El concepto "calidad de vida" se ha vinculado siempre, desde sus primeras referencias, al estado de salud de los individuos. Nos dice M. Lalonde (1993) que "el estilo de vida representa el conjunto de decisiones que toma el individuo sobre su salud y sobre las cuales ejerce cierto grado de control". Sin embargo, el concepto es más general y lo constituirian aquellas decisiones que el individuo toma ya no sobre su salud sino también sobre sus sentimientos y comportamientos relacionados con su funcionamiento diario, incluyendo sus condiciones de salud. Por tanto, podemos decir que el concepto de calidad de vida alude a un sentimiento de bienestar psicofísico y socioeconómico, y para su evaluación deberemos tener en cuenta tanto factores 
personales (salud, satisfacción con la vida, independencia, etc...) como socioambientales (redes de apoyo, servicios sociales, etc.).

La OMS concibe la calidad de vida como "la percepción por parte del individuo de su posición de vida en el contexto de cultura y sistema de valores en relación con sus objetivos, expectativas, patrones y preocupaciones" (WHOQOL 1997).

También se ha comprobado que la calidad de vida se encuentra estrechamente relacionada con la participación social. En este sentido se la entiende como "la satisfacción que experimentan los individuos como resultado de su participación en las actividades que realizan en el medio familiar, en el centro de trabajo y en el ámbito de su comunidad, en relación con las cuales se ejercitan sus capacidades humanas y desarrollan su personalidad" (Amat et al., 1989).

En el adulto mayor, según los conceptos que hemos venido trabajando, la calidad de vida resulta dependiente no sólo del estado biológico, sino de las condiciones del medio ambiente relacional en sentido amplio (interacción social, hábitos, grado de alfabetización, uso del tiempo libre, etc.) ya que estos propician un determinado estado de salud, tanto en lo objetivo como en el registro de los subjetivo.

A pesar de que tradicionalmente se ha asociado a la vejez con enfermedad, cada vez se tiene más claro que no existen enfermedades propias de la vejez sino en clara relación con la calidad de vida y el estilo de vida. La edad no determinaría el estado de salud sino que éste, más bien, se relaciona con factores socioculturales y estilos de comportamiento. En este sentido no existe una única forma de vivir la vejez, sino diferentes estilos de vida, dependientes de la particular constitución subjetiva y de la modalidad de relación con el medio ambiente. Cada sujeto atraviesa el proceso de envejecimiento de acuerdo con su biografía y, en función de ésta, configura el estilo de vida que adopta en esta etapa de la vida.

Recientes investigaciones han demostrado la importancia de la educación permanente (en tanto actividad psicosocial) para una mejor calidad de vida. Las conclusiones muestran que los ancianos que no desarrollan actividad alguna, enferman más y mueren más jóvenes que aquellos que se mantienen dinámicos. 
En consecuencia, entre los factores de riesgo principales de deterioro de la calidad de vida, se halla el aislamiento social ligado a la exclusión y rechazo de la vejez. Según Furstenberg, (1989) uno de los criterios para asumirse "viejo" es el descenso de la participación social y el sentimiento de inutilidad que sobreviene.

Al hablar de participación social nos referimos a la "participación social significativa", proceso de interacción personal que consiste en tomar parte en forma activa y comprometida en una actividad conjunta, la cual es percibida por la persona como beneficiosa. La participación social haría referencia a sistemas de apoyo o suministros psicosociales como uniones entre individuos, caracterizados por ayuda material, asistencia física, compartir pensamientos, sentimientos y experiencias, y contactos sociales positivos. La participación social significativa se halla básicamente en cuatro áreas: la educativa, la ocupación laboral, la actividad física y recreativa de carácter grupal, y las relaciones sociales propiamente dichas donde el fin es la interacción mutua y la integración social. Pero más que el número de contactos sociales, es importante la calidad de los mismos.

El hecho de tener todavía objetivos y metas en la vida y de seguir formando parte activa de un grupo social está relacionado con el mantenimiento de un buen nivel de salud. Según Erikson (Erikson \& Erikson 1998) los que envejecen deben mantener una función generativa: por un lado, deben producir y crear; y por otro, relacionarse con los demás y sentirse responsable de ellos, pues se vive en relación con otros, y esto implica orientarse a tareas, cumplir con causas a las cuales servir y relacionarse con otros a través de la comunicación y solidaridad social. Pero la participación social no sólo tiene que ver con la iniciativa que podría vincularse al estilo de vida de cada sujeto, a sus modelos relacionales interiorizados, o desde otra perspectiva a los modelos identificatorios escogidos, sino que tiene que ver también con el lugar que la sociedad asigna a quien envejece.

No existe un consenso respecto al significado del término calidad de vida, aunque es obvio que, se trata de un término amplio que engloba el bienestar físico, social, subjetivo, etc. pero también es importante destacar que tiene dos elementos comunes: utiliza un enfoque multidimensional y hace hincapié en la valoración propia que el individuo hace de su vida. 
Por ello el término calidad de vida viene a ser el resultado de la relación entre las condiciones objetiva de la vida humana y la percepción de ellas por parte del propio sujeto.

\subsection{Fundamentación educativa}

Todas las personas aprenden desde que nacen y a lo largo del transcurso de su vida. Aprender es intrínseco al género humano. Porque, no solo la inteligencia y la memoria intervienen en el proceso de aprendizaje, también hay otros factores. Por lo tanto no podemos afirmar que a medida que las personas envejecen pierden su capacidad de aprender.

Desde el punto de vista internacional el concepto de Educación Permanente o Educación a lo largo de toda la vida, empieza a despertar interés alrededor de 1960, gracias a los debates producidos en la UNESCO sobre la futura educación de adultos.

En la Segunda Conferencia Internacional sobre la Educación de Adultos, celebrada en Montreal en 1960 (UNESCO 1960), se "recomendó a los gobiernos que consideraran la educación de adultos no como un complemento sino como parte integrante de sus sistemas nacionales de educación." Dos años más tarde la UNESCO (1962) invitó a los estados miembros a:

...considerar como parte integrante de todo sistema de educación las diversas formas de educación extraescolar y de educación de adultos, a fin de que todos los hombres y mujeres dispongan durante toda su vida, de los medios de cultura que les permitan lograr su pleno desenvolvimiento y participar activamente en la vida cívica y en el desarrollo social y económico de su país.

Tras sucesivas Conferencias Internacionales sobre la educación de adultos, a finales de 1980 había ya ganado terreno la idea de un "derecho a aprender" diferente al "derecho de la educación", y así en la cuarta Conferencia Internacional sobre la Educación de Adultos (UNESCO 1985) se aprobó el "Derecho a aprender" 
Uno de los Principios de las Naciones Unidas (ONU 1991) en favor de las personas de edad, incluidos en la resolución 46/91, indica que las personas de edad deberán "tener acceso a los recursos educativos, culturales, espirituales y recreativos de la sociedad"

De este modo la UNESCO en su Declaración Mundial sobre la Educación Superior en el siglo XXI establece como acción prioritaria, que "el acceso a los establecimientos de educación superior se abran a los educandos adultos, creando oportunidades de aprendizaje de manera flexibles, abiertas y creativas."

En el espacio Europeo debemos destacar la Declaración final de la III Conferencia Europea de Educación de Adultos de 1995 (MEC 1995) en la que se dice:

... para apoyar la educación y formación que tienen origen en las instituciones públicas y en las iniciativas sociales, para favorecer la coordinación de todos los actores y de cuantos proyectos puedan hacer efectivo en un futuro inmediato el derecho ciudadano fundamental del acceso generalizado a la educación y formación a lo largo de toda la vida de las personas mayores

Así, en Consejo Europeo en junio de 2000 (CE 2000) pidió a la Comisión y a los Estado miembros que definiesen y trabajasen una estrategia coherente capaz de dar acceso a todos los ciudadanos a ofertas de aprendizaje permanente.

En febrero de 2005 los españoles votaron sí al "Tratado por el cual se establece una Constitución Europea" (BOE 2010); en él se señala, el artículo 14, que "toda persona tiene derecho a la educación y a la formación profesional y permanente"

En el ámbito nacional podemos destacar algunos derechos adquiridos, entre ellos el Constitucional de "Derecho a la Educación", y otros que se encuentran dentro de los objetivos generales del Plan Gerontológico (IMSERSO 1992) como son "facilitar el acceso de las personas mayores a los bienes culturales y fomentar entre ellas el empleo creativo del ocio y del tiempo libre, para mejorar su calidad de vida y sentirse útiles"

Por último cabe recordar que la Ley Orgánica de Universidades (BOE 2001) recoge en su título preliminar, artículo 2, y en su título IV "que las universidades deben elaborar 
y aprobar planes de estudio y establecer enseñanzas específicas de formación a lo largo de toda la vida"

\subsection{Universidades para mayores}

El primer proyecto universitario docente de Universidad para Mayores (denominadas entonces Universidades de la Tercera Edad) fue de Pierre Vellas, en la Universidad de Toulusse (Requejo 2009) quien llevó a la practica la idea de facilitar a las personas mayores el acceso a la cultura y contribuir a la prevención del deterioro psicosociológico, en 1973. Desde entonces, prácticamente la totalidad de universidades españolas posee un programa de educación para mayores (Cabedo \& Alfageme, 2005) normalmente, a personas mayores de 55 años. Es desde este contexto donde personas mayores acceden a cursos y otras actividades ofrecidas por la universidad, pero también donde la universidad hace posible el establecimiento de necesidades de investigación e innovación que en otros centros de educación permanente sería difícil aplicar

La primera tipología, pues, de Programas Universitarios para Mayores sería el modelo francés, es decir, programas creados y organizados desde las universidades. Otro modelo sería el británico, que se desarrolla principalmente a iniciativa de las propias personas mayores, tomando características en forma de grupos de discusión. Este modelo encarna una larga tradición de voluntariado y es en la actualidad, el más extendido en Norteamérica.

En los primeros años de la última década del siglo XX se iniciaron en España las primeras experiencias de formación universitaria destinadas a personas mayores. Había sido en la década anterior cuando otras iniciativas de parecida naturaleza habían empezado a florecer en Cataluña. En la actualidad (curso 2011-2012) hay 58 Universidades para Mayores, públicas y privadas, que reúnen alrededor de 35.000 estudiantes mayores.

En definitiva y siguiendo la tipología propuesta por la Comisión Europea, encontraríamos en España, como seguramente en la mayoría del resto de Europa, tres 
tipos amplios de actividades educativo-universitarias en las que participan personas mayores:

- Programas formales, entre los que han emergido a lo largo de la última década y destacan ya con claridad los que más propiamente conocemos como Programas Universitarios para Mayores, diseñados, desarrollados y administrados por las universidades, con intención y estructura académica. Cualesquiera otros programas organizados por centros educativos entrarían también en esta categoría.

- Programas no formales, con intención de educar y con cierta estructura pero que no parten de las universidades ni de otros centros educativos o de formación, sino de ayuntamientos, otras instituciones locales, asociaciones, etc. Es acaso en este apartado en el que mejor encajarían diversos programas como las Aulas de la Tercera Edad, Universidades Populares, Aulas de Extensión Universitaria para la Gente Mayor, etc.

- Actividades informales de aprendizaje, no necesaria ni intencionalmente educativas, que abarcarían una amplia gama de procesos y escenarios en los que participan personas mayores. Habría que referirse quizá especialmente a toda suerte de actividades organizadas por y/o para las personas mayores (por asociaciones, ayuntamientos u otras instituciones).

Los anteriores modelos se han desarrollado de forma diferente en cada país; cada universidad dedica una atención diferente al grupo de "la tercera edad" según decisiones políticas propias y teniendo presente la autonomía universitaria y las políticas nacionales y locales

En algunos países, los estudios universitarios para mayores están integrados dentro de los estudios establecidos de cada universidad (Austria, Alemania, Polonia, Francia, España), en otros países son autónomos (“Fundación para la tercera edad” en Italia) o pertenecen sólo de forma cooperativa a las universidades (Eslovenia)

De forma conjunta, diferentes conferencias y asociaciones han unido a las diferentes asociaciones y universidades para establecer puntos comunes en lo referente a la educación de mayores 
- En 1975, tiene lugar en Toulouse la fundación de la Asociación Internacional de Universidades de la Tercera Edad (A.I.U.T.A.), con el objetivo de favorecer la creación y desarrollo de las universidades para mayores en el mundo. Este organismo esta formado por 300 asociaciones, de ellas 77 universidades.

- La definición de aprendizaje permanente que propone la Comisión Europea es muy amplia. Se partía de la definición establecida en el contexto de la Estrategia Europea de Empleo, pero la fase de consultas reveló, al parecer, una inquietud generalizada ante la presencia demasiado dominante de las dimensiones de empleo y mercado laboral. Así, se fueron consensuando una serie de objetivos del aprendizaje permanente en torno a la realización personal y la integración social, además de los de empleabilidad y adaptabilidad, proponiéndose la siguiente definición de aprendizaje permanente (CE, 2000):

"Toda actividad de aprendizaje realizada a lo largo de la vida con el objetivo de mejorar los conocimientos, las competencias y las aptitudes con una perspectiva personal, cívica, social o relacionada con el empleo"

\subsubsection{FRANCIA}

El modelo francés, (también acogido por Bélgica, Suiza, Pases Bajos y España) se basa en la fuerte implicación de las universidades en la educación de las personas mayores. Las actividades son dirigidas por personal académico, y consisten generalmente en cursos, conferencias, seminarios y talleres de trabajo.

\subsubsection{INGLATERRA}

Por su parte y también desde sus orígenes, el modelo británico se desarrolla principalmente a partir de la iniciativa de las propias personas mayores, tomando característicamente la forma de grupos de discusión. Este modelo encarna una larga tradición de voluntariado y ayuda mutua y, también con variaciones, podría estar bastante más extendido en Norteamérica que en Europa.

La educación en personas mayores en Inglaterra no tuvo el apoyo desde las universidades sino que fueron los mismos estudiantes los que se asociaron y formaron grupos aislados y auto-organizados. En 1982 se fundo la U3A con el 
propósito de unir, estandarizar y dotar de apoyo organizativo todos estos grupos locales. En la actualidad, la U3A esta formado por casi 600 grupos locales y casi 170.000 estudiantes.

\subsubsection{PORTUGAL Y ITALIA}

En Portugal, las universidades para la tercera edad, al igual que otras asociaciones, académicas e institutos similares, fueron creadas por la sociedad civil y no son gestionadas por el Estado. Tampoco pertenecen a las universidades tradicionales si bien un pequeño número de ellas tienen acuerdos con las mismas.

Existen actualmente unas 50 universidades para la tercera edad en Portugal con un total de 7000 estudiantes. La primera universidad se situó en Lisboa en 1976, aunque la mayoría fueron creadas en la década de los 90

\subsubsection{ALEMANIA}

Los estudios superiores abrieron sus puertas a las personas mayores a finales de los 70. Actualmente existen unas 50 universidades e institutos técnicos y pedagógicos que han abierto sus puertas a adultos mayores, aunque no todos del mismo modo si dentro del mismo marco: el de la formación permanente académico general. También de forma general, los "Estudios para mayores" se refieren a personas mayores de 50 años o tercera edad interesadas en continuar sus estudios académicos.

Las universidades que se preocupan de forma activa por la integración de los estudiantes tienen tres objetivos:

- Crear nuevos espacios donde tiene cabida el estudiante mayor: debates, investigación, nuevas actividades.

- Fomentar el aprendizaje conjunto de jóvenes y mayores (intercambio intergeneracional)

- Crear nuevos modelos curriculares y didácticos, uniendo conocimientos académicos con experiencias reales 


\subsubsection{PAÍSES ESCANDINAVOS}

En Suecia (y de forma similar en Noruega y Dinamarca), la educación a personas mayores es desarrollada por asociaciones de mayores ("Folkuniversitetet") las cuales, en ocasiones, cooperan con medios de comunicación y universidades. Estas asociaciones cuentan con una junta directiva conjunta pero independiente y no están integradas dentro de ninguna universidad. Actualmente en Suecia hay 25 Folkuniversitetet y aproximadamente 10.000 estudiantes

Diferente es el caso de Finlandia, donde todas las universidades generales cuentan con un centro para la educación permanente, integrado dentro de la universidad y pagado por ésta. No obstante, este centro está regulado por un consejo asesor a nivel nacional. La universidad de Helskinki, la mayor, cuenta con 3500 estudiantes.

\subsubsection{ESPAÑA}

En España, los programas universitarios para mayores han emergido recientemente, y en el momento actual cerca de 60 universidades españolas, públicas y privadas, están ofreciendo estudios universitarios para mayores de 55 ó 50 años. Entre sus objetivos principales destacan la integración de los mayores en la vida universitaria, el desarrollo de actitudes positivas hacia el envejecimiento, el aumento de las relaciones intergeneracionales y la mejora de la calidad de vida.

Las primeras universidades fueron; Alcalá de Henares 1992, Salamanca 1993 y Granda 1994

\subsection{Análisis histórico de los programas universitarios para mayores}

Las Naciones Unidas ofrecen un marco de actuación, una línea conceptual, y unas líneas de acción, que intentan aunar criterios y esfuerzos para conseguir un doble objetivo simbiótico que rompa la actual tendencia, al menos en los países desarrollados, de aislamiento progresivo de los mayores (tipo asilo de carácter 
asistencial). En primer lugar, se pretende que las personas mayores se incorporen a la dinámica social, y en segundo lugar, que la sociedad saque provecho de esta incorporación activa. Como en toda relación simbiótica, las dos partes se verán beneficiadas por el nuevo estado de cosas. Como se ha reflejado con anterioridad, los aspectos educativos ocupan un lugar fundamental, entendida la educación de mayores como una vía de formación continua y de mejora de calidad de vida. Además, incluye una obviedad, la preocupación por las personas mayores no es una preocupación casual o que responda a una moda. Los esfuerzos de Naciones Unidas en las últimas dos décadas han sido múltiples y han tenido reflejo en varios momentos en los que se han explicitado y se han hecho públicos en foros mundiales. Es en este sentido, las palabras del Secretario General de la ONU, Kofi Annan, en su mensaje del 1 de octubre de 2001 (ONU 2001), Día internacional de las personas de edad:

...Las medidas politicas, y en general las actitudes sobre el envejecimiento, deben evolucionar... Los temas relacionados con el envejecimiento necesitan ser mejor integrados en el más amplio contexto del desarrollo. Las personas de edad deben ser capaces de participar plenamente en las decisiones que afectan a sus vidas.

Mediante la oferta de estudios universitarios para las personas mayores se pretendió desde un primer momento conseguir lo que podríamos denominar el envejecimiento productivo. El período de la vida posterior a la jubilación laboral debe dejar de ser considerado como un residuo existencial y ser reconocido como una época de la vida adulta tan cargada de posibilidades y responsabilidades como lo fueron las anteriores. El envejecimiento productivo pretende resaltar que la persona mayor es en la actualidad socialmente capaz e imprescindible para la toma de decisiones en torno a políticas que les afectan.

La formación que se oferta desde la Universidad debe contribuir al desarrollo y la extensión del conocimiento en general. Mediante los estudios académicos se adquieren los conocimientos necesarios para la aplicación de la información recibida a la realidad personal y a los plurales contextos sociales. Hay que aprender los contenidos de las ciencias y ejercer críticamente el análisis de sus consecuencias en la historia de la humanidad. 
La intervención educativa de la Universidad en el colectivo de las personas mayores debe tender, sobre todo, a satisfacer las preocupaciones de orden moral, estético y cultural que se les presenten con mayor exigencia. Se trata de formar unas personas más dignas, más responsables, más autónomas, más activas, con más capacidad de análisis y acción en todos los sentidos.

El profesor Lemieux (1997), plantea tres objetivos de las Universidades para Mayores:

1. desarrollar la cultura y la investigación: toda construcción educativa sólo es útil para la persona si ésta es capaz de reelaborar sus propios conocimientos.

2. responsabilizar a los estudiantes: quienes adoptan un compromiso al asumir personalmente los resultados obtenidos

3. orientar el incremento de los saberes y del saber-hacer hacia un desarrollo del saber-ser; mediante una continua construcción en la integración del conocimiento.

- En España, hemos asistido en los últimos diez años al florecimiento de los Programas universitarios para mayores. Este desarrollo vertiginoso, proviene de razones obvias de índole social, demográfica, educativa y económica que justifican la necesidad de los mismos.

- Las primeras Universidades que facilitaron este tipo de programas fueron:

- Alcalá de Henares 1992

- Salamanca 1993

- Granada 1994

- Se pudieron realizar estas iniciativas universitarias gracias al apoyo y a la subvención del IMSERSO, que dentro del Plan Gerontológico por el acceso a la cultura de los mayores subvencionó los primeros Programas.

- Las Actas del Primer encuentro de PUM, celebrado en Granada en 1996 (AEPUM 1996) nos indican que fueron los mayores los que tomaron la iniciativa, aunque la respuesta rápida vino de la mano de las Universidades

- Desde el primer momento se vio una gran variedad y riqueza de programas. 
- En la actualidad hay 30.000 estudiantes mayores en las Universidades y son 57 las Universidades españolas que cuentan con programa para mayores.

\subsection{La Universitat per a Majors, de la Universidad}

\section{Jaume I}

El programa universitario de formación de personas mayores Universitat per a Majors (UM) se inició en 1998. En sucesivas reuniones con el grupo de personas que querían cursar estudios superiores, pero no aspiraban a matricularse en estudios universitarios reglados, se estableció una estructura básica que sirviese de soporte a un nuevo plan de estudios elaborado de acuerdo con las demandas e intereses de los estudiantes mayores.

El equipo de gobierno de la Universitat Jaume I consideró muy positiva esta iniciativa y no sólo la aprobó, sino que la alentó y apoyó oficialmente mediante el nombramiento de un Director Académico de formación de mayores.

El Director Académico de formación de mayores, nombrado directamente por el Rector de la Universidad, es el principal responsable del Programa y tiene como misión primordial la coordinación de los estudios ofertados al colectivo de estudiantes matriculados en la UM.

El Director académico está asesorado por un Consejo Docente que está formado por profesores representantes de las distintas áreas de conocimiento que se imparten en cada una de la Facultades y Escuela Superior de nuestra Universidad.

Para la gestión académica del Programa se ha establecido un servicio de administración dirigido en la actualidad por una gestora técnica.

La docencia ordinaria está impartida generalmente por profesores que pertenecen al claustro universitario de la Jaume I. También se invita a profesionales de otras instituciones para impartir docencia en determinadas actividades académicas y en los complementos de formación. 
La participación en la docencia impartida en el Programa de mayores está abierta a los profesores de todos los departamentos de la UJI que deseen colaborar y ofertar alguna de las asignaturas de sus áreas de conocimiento y que resulten de interés para las personas mayores. La demanda por parte de los estudiantes mayores se convierte en criterio determinante a la hora de activar las asignaturas.

Los estudiantes de cada curso, elegidos por sus compañeros como delegados y representantes, forman parte de Consejo de estudiantes que participa activamente en el funcionamiento del plan de estudios. Sus reflexiones y sugerencias constituyen las referencias necesarias para la buena marcha de la UM.

En general, nuestra Universidad sénior ha respondido bien durante los cursos de funcionamiento a los deseos del colectivo de los alumnos mayores. La actividad académica es objeto de evaluación al final de cada curso, habiendo dado como resultado durante todo este tiempo un alto grado de satisfacción tanto por parte de los alumnos como por parte de los profesores. Cabe resaltar que los estudios universitarios para mayores han sido muy bien aceptados por los estudiantes jóvenes y valorados positivamente por la comunidad universitaria.

La persistente demanda de los estudiantes mayores y el convencimiento de que mediante esta oferta de estudios universitarios se contribuye a cumplir una obligación social de estricta justicia con el colectivo de personas mayores, desde la dirección del Programa se ha pretendido mejorar la calidad de la docencia y se ha facilitado en lo posible el acceso de más estudiantes deseosos de matricularse en la Universidad.

En la actualidad el Programa de formación de mayores está adscrito al Vicerrectorado de Estudios y Espacio Europeo de Educación Superior.

\section{ESTRUCTURA Y FUNCIONAMIENTO}

A partir del curso 2010/2011 los estudios se revisaron y configuraron para pasar del sistema de créditos tradicional ( 1 créditos $=10$ horas de clase) a los créditos ECTS. En lugar de tener un primer ciclo y un segundo ciclo, la oferta se estructuró en un grado y 4 postgrados. 
Las asignaturas, tanto del grado como de los postgrados, responden en gran medida a contenidos propios de las Humanidades y se desarrollan de forma activa y participativa, alternándose las exposiciones magistrales con los coloquios y actividades en grupo. La docencia se lleva a cabo también a través de talleres, seminarios, mesas redondas, visitas culturales, excursiones, etc.

En cuanto al profesorado que lleva a cabo todas estas actividades pertenece mayoritariamente a la Universidad; no obstante, se invita a otros profesores/as, profesionales o expertos en algunas materias, cuando se considera oportuno.

Las clases se imparten en el campus Riu Sec dos días por la tarde a la semana, más dos extras para actividades complementarias y talleres opcionales. También se ofertan clases en las distintas sedes que la Universitat Jaume I posee en otras localidades y zonas rurales, donde la oferta educativa es menor pero se mantiene un plan de estudios estructurado academicanmente.

\section{ACCESO A LOS ESTUDIOS}

Cualquier persona mayor de 55 años puede acceder a la UM, sin importar sus estudios anteiores o su perfil intelectual. Excepcionalmente también se permite matricularse a personas menos mayores. Debido a la demanda, se ha establecido la preinscripción, gracias al cual se permite la matriculación solo a las personas que cumplen los criterios.

En los cursos posteriores, la matriculación ya es un proceso normalizado que facilita la inscripción y matrícula en los cursos superiores. Cabe resaltar que son los alumnos mayores quienes se hacen su propia matrícula, al igual que los alumnos jóvenes de la Universidad. Mediante grupos tutorizados, son ellos mismos quienes se sientan en un ordenador e introducen sus datos. Este proceso, aunque los primeros cursos causó un poco de desconcierto, en la actualidad genera la satisfacción que son los mismos alumnos quienes participan activamente, equiparándose en el proceso seguido a la matrícula de los estudiantes de los planes reglados.

\section{PLANIFICACIÓN DE LOS ESTUDIOS DE GRADO}

Durante 3 cursos académicos, los estudiantes cursan 28 créditos ECTS durante los dos primeros y 32 durante el tercer y último curso. Es obligatorio también cursar 20 
créditos ECTS de aptitudes Lingüísticas, Tecnológicas y de Análisis y para el tercer curso, 12 créditos corresponden a un trabajo fin de grado. En total, constituyen 120 créditos ECTS.

Como principal criterio de evaluación se considera que un alumno tiene la asignatura apta si ha asistido el $80 \%$ de las clases, aunque se deja un cierto grado de libertad a los profesores para establecer su criterio de evaluación o recuperación de alumnos suspendidos. En ningún caso se realizan exámenes o pruebas con carácter general.

\section{ACTIVIDADES DE DINAMIZACIÓN SOCIO-CULTURAL}

Durante los tres cursos del primer ciclo los alumnos deben de cursar los créditos de las asignaturas obligadas y participar en las actividades complementarias que desde la dirección del programa se les ofertan. Estas, como su mismo nombre indica, son materias añadidas que giran alrededor de los contenidos ofrecidos en las asignaturas obligatorias y que contribuyen a conseguir los objetivos de los estudios universitarios.

Se trata de visitas a museos, seminarios, exposiciones, etc. no vistas, desde el punto de vista turístico, sino educativo. Aspecto que los alumnos valoran muy positivamente, ya que les permite ver de una forma práctica todo lo aprendido en las clases teóricas.

\section{PROYECTO FINAL DE GRADO Y DE POSTGRADO}

Con estos 12 créditos, se pretende que el alumno mayor se incorpore a la comunidad universitaria y a la sociedad, apoyándose en sus estudios y conocimientos propios. Después de 3 años, al finalizar el grado, se considera que el alumno ya posee conocimientos y base suficiente para desarrollar un proyecto de investigación. Este proyecto es dirigido por un profesor y es defendido ante el resto de los alumnos.

Mediante esta tarea, la sociedad puede absorber los conocimientos y experiencias que el alumno deja plasmados en este documento.

Al terminar los estudios del primer ciclo se concede el diploma universitario "Graduado Universitario Senior en Ciencias Sociales y Humanas".

POSTGRADOS 
Después de haber cursado los tres años de estudios de grado, el alumno está en condiciones de matricularse en las asignaturas que se ofertan a modo de itinerarios desde las distintas áreas de conocimiento de los departamentos universitarios; de este modo, es el propio alumno quien se confecciona su plan de estudios personal. Cada curso académico la oferta de asignaturas se modifica; algunas continúan ofreciéndose, otras se eliminan y otras se añaden según la demanda formulada por los mismos alumnos.

Para obtener el certificado de estudios de postgrado, tendrán que haber cursado 60 créditos ECTS, 24 de los cuales corresponden a aptitudes lingüísticas y tecnológicas. El alumno puede elegir a lo largo de los años los créditos que desee, pudiendo además retomar otro postgrado cuando finalice uno.

Existen 4 postgrados, denominados también "Masteres" cada uno con su oferta de asignaturas:

- Literatura, filosofía e historia

- Calidad de vida y sus componentes

- Sociedad y Cultura

- Comunicación e Historia

\section{APTITUDES LINGÜÍSTICAS, TECNOLÓGICAS Y DE ANÁLISIS}

Los estudiantes matriculados, tanto en el grado como en postgrado, tendrán la posibilidad de cursar a una serie de asignaturas que se ofertan desde la dirección del programa y que son consideradas de gran importancia para la formación integral del estudiante mayor. Entre ellos se ofertarán los siguientes:

- Curso de idiomas, en distintos niveles

- Cursos de informática e internet, en distintos niveles

- Cursos semi-presenciales o totalmente on-line

En especial las nuevas tecnologías, debido a su desconocimiento por los mayores y gran importancia en la sociedad, están siendo impulsadas y promovidas por la UM. Mediante esta actividad se logra no solo que el alumno tenga mayores conocimientos sino que se integre mejor en la sociedad actual. 


\section{ACTIVIDADES EXTRAACADÉMICAS}

La UM no solo imparte asignaturas como mero producto educativo, sino que pretende además ofrecer ambientes de reflexión y abrir espacios de libertad para las personas. En este entorno, por iniciativa de los alumnos y con el soporte del programa, los alumnos mayores realizan otras actividades complementarias:

- Taller de teatro en castellano y valenciano, con representaciones en distintas poblaciones; asi como actividades culturales en general, incluso, con obtención de fondos en proyectos humanitarios.

- Taller de canto. Aportan una distinción digna de señalar en los actos de bienvenida y clausura del curso y en otros eventos.

- Revista "Renaixement" con contenido es aportado exclusivamente por los alumnos, de tirada semestral. La revista ofrece la posibilidad de explicitar las opiniones, historias, reportajes, etc. de mismos alumnos.

Desde el programa de la UM, la realización de estas actividades es vista de una forma muy positiva en cuanto las personas mayores pueden realizar tareas que les satisfacen y son útiles para ellos mismos, para su grupo de mayores y para la sociedad 


\section{LA REVOLUCIÓN GRIS}

\subsection{Adopción de las tecnologías de la información y comunicación por los mayores}

Del 26 julio al 6 de agosto de 1982 en Viena tuvo lugar la Asamblea Mundial sobre el Envejecimiento con el soporte de la ONU (ONU 1983). En esta asamblea se reconoció el hecho innegable de un incremento del envejecimiento general de la población mundial. Las personas mayores constituiran un grupo cada vez más numeroso en proporción a otros grupos sociales. Las personas mayores deben ser tenidas en cuenta en políticas nacionales y mundiales, reconocer su situación, derechos y el potencial que podían ofrecer para el progreso general de la humanidad. A partir de Asamblea surgió el término "generación gris" que es usado ya ampliamente en publicaciones especializadas (p.ej. Cheung-Ming et al. 2007) para referirse a las personas mayores y mencionando la "revolución gris" cuando se quiere destacar el cambio social que se está produciendo por el incremento proporcional de personas mayores.

En la Figura 1 puede observarse la proyección de la evolución de la población por rango de edades. Se puede observar cómo en el 2023 el número de personas mayores de 45 años superará a las menores de 45. Además, puede observarse que la proporción de personas mayores de 55 años irá creciendo progresivamente hasta situarse en el $43 \%$. Estas previsiones vienen respaldadas por informes en donde se asume que la esperanza de vida será cada vez mayor gracias sobre todo a una mayor calidad de vida y aumento de las prestaciones sanitarias. Por tanto, no resulta en absoluto descabellado afirmar que el grupo de personas jubiladas irá creciendo paulatinamente y sólo podría verse reducido por la tendencia existente de retrasar la edad de jubilación. 
De este modo, y según la Figura 1, a medida que los años pasen, el capital social compuesto por las personas sin una actividad específica y obligatoria, como seria el trabajo remunerado, y con mucho más tiempo libre será cada vez mayor.

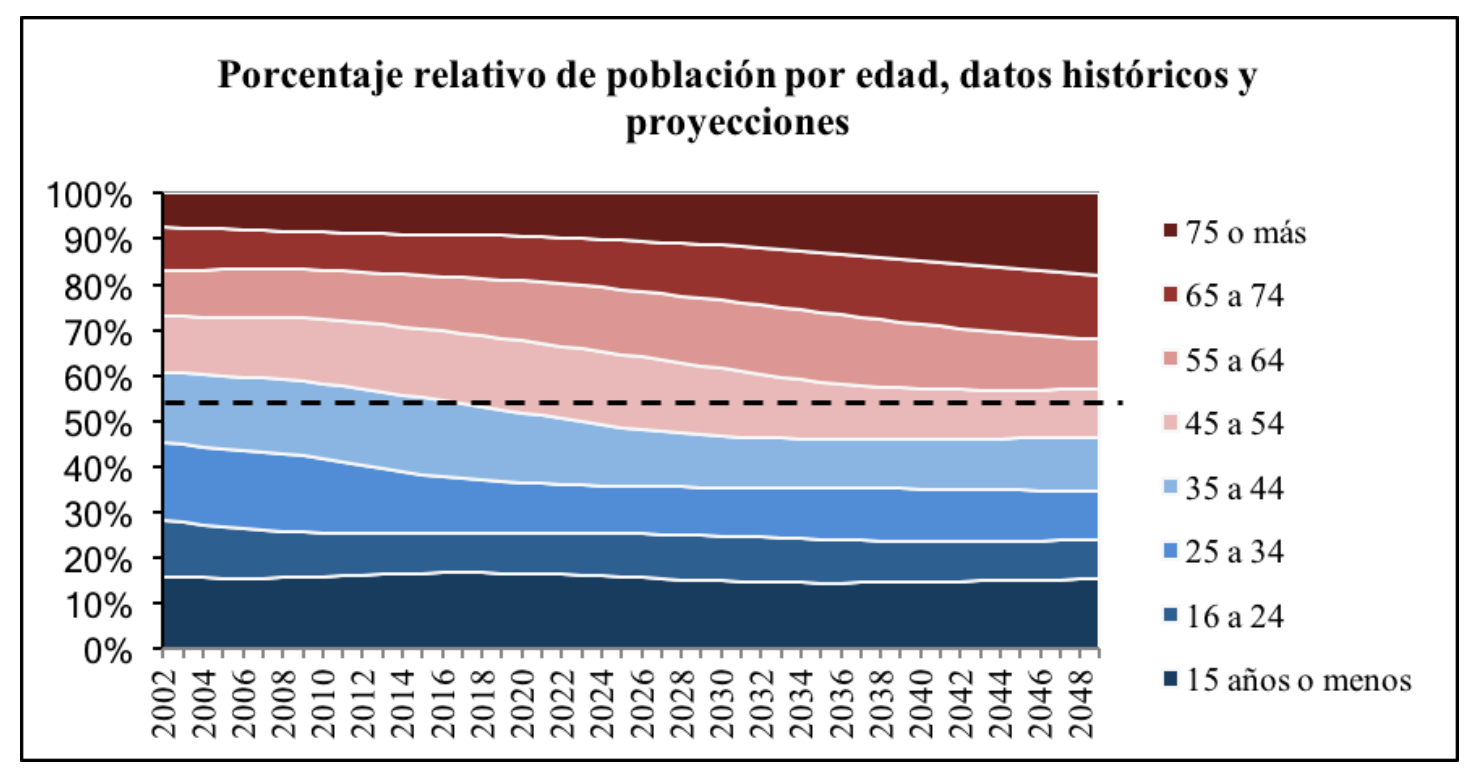

Figura 1. Proyección demográfica relativa por edad. Fuente: INE

El uso de Internet ha ido creciendo paulatinamente en la sociedad española, así se desprende analizando las estadísticas del INE y que se resume de manera gráfica en la Figura 2, en donde se detalla la cantidad de personas en relación porcentual al total en su propio segmento de edad que han usado al menos una vez por semana en los últimos 3 meses internet. Sólo un $10 \%$ de los mayores de 55 años han usado Internet, en frente del $65 \%$ de menores de 34 años que han usado Internet en el 2006. En cambio, en el 2010, esta proporción fue de $22 \%$ para los mayores de 55 y de $82 \%$ para los menores de 34 . 


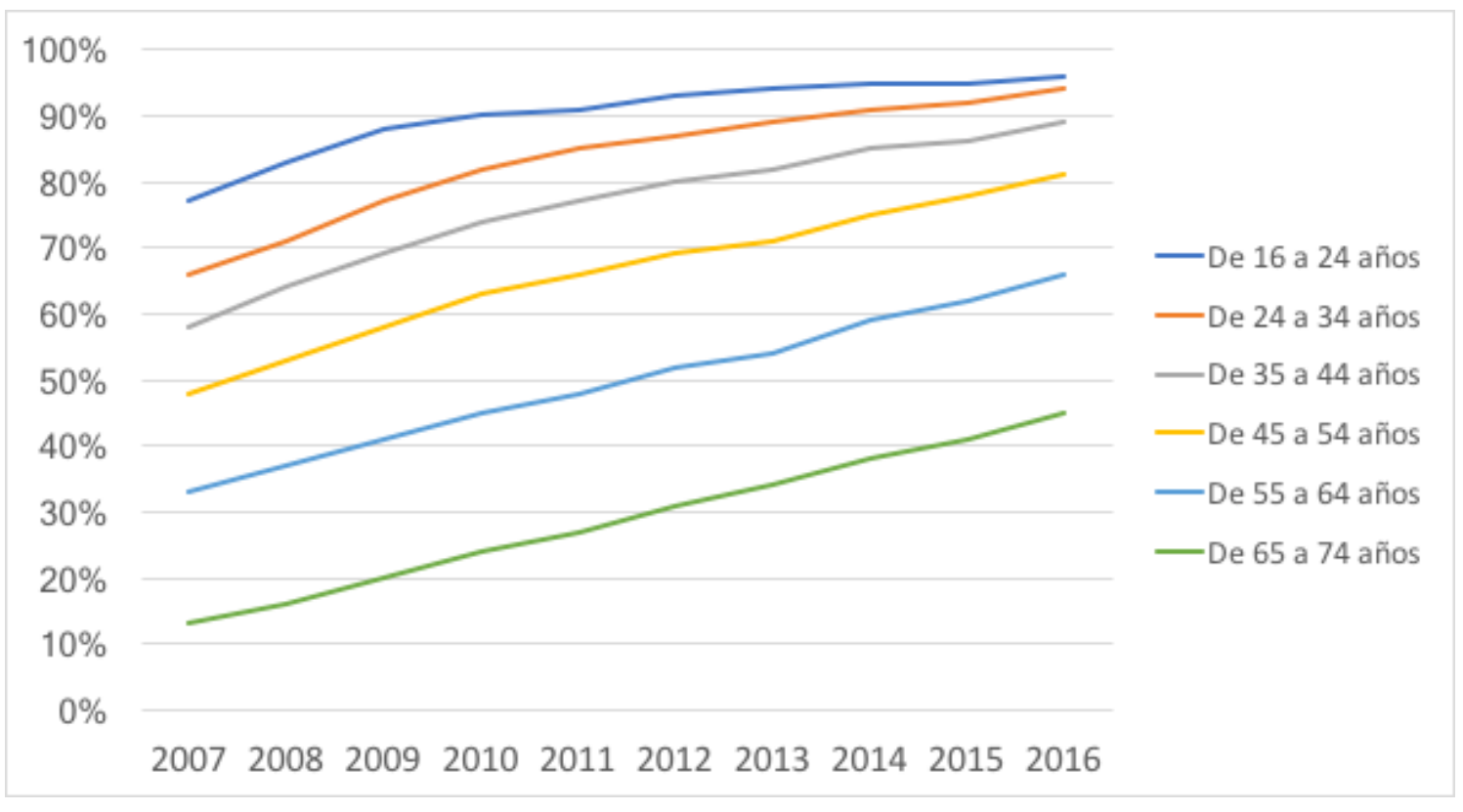

Figura 2.. Porcentaje usuarios de Internet (uso al menos una vez por semana), por edades EU28. Fuente: Eurostat

En la Figura 2 podemos ver un claro incremento en el uso de Internet, pero para nuestro estudio resulta más interesante el incremento relativo. En la figura 3 puede observarse el incremento de usuarios de Internet respecto al total de la población. Todas las edades crecieron en uso, pero el que lo hizo con mayor cantidad de forma proporcional fue el grupo de personas mayores de 65 años, llegándose a triplicar, paso de $13 \%$ en 2007 al 45\% en el 2016, y los mayores de 55 a duplicarse, de 33\% a $66 \%$, mientras otros grupos crecieron pero en menor proporción, constatando que incluso el de los jóvenes se mantuvo relativamente constante. El grupo de mayores, por tanto, crece en uso y aunque sea difícil que llegue a alcanzar al grupo de los jóvenes, queda claro que no por ser un uso relativo menor, deba ser ignorado. Más aun, hemos de considerar que es un grupo en aumento con necesidades e inquietudes que deben ser cubiertas. 


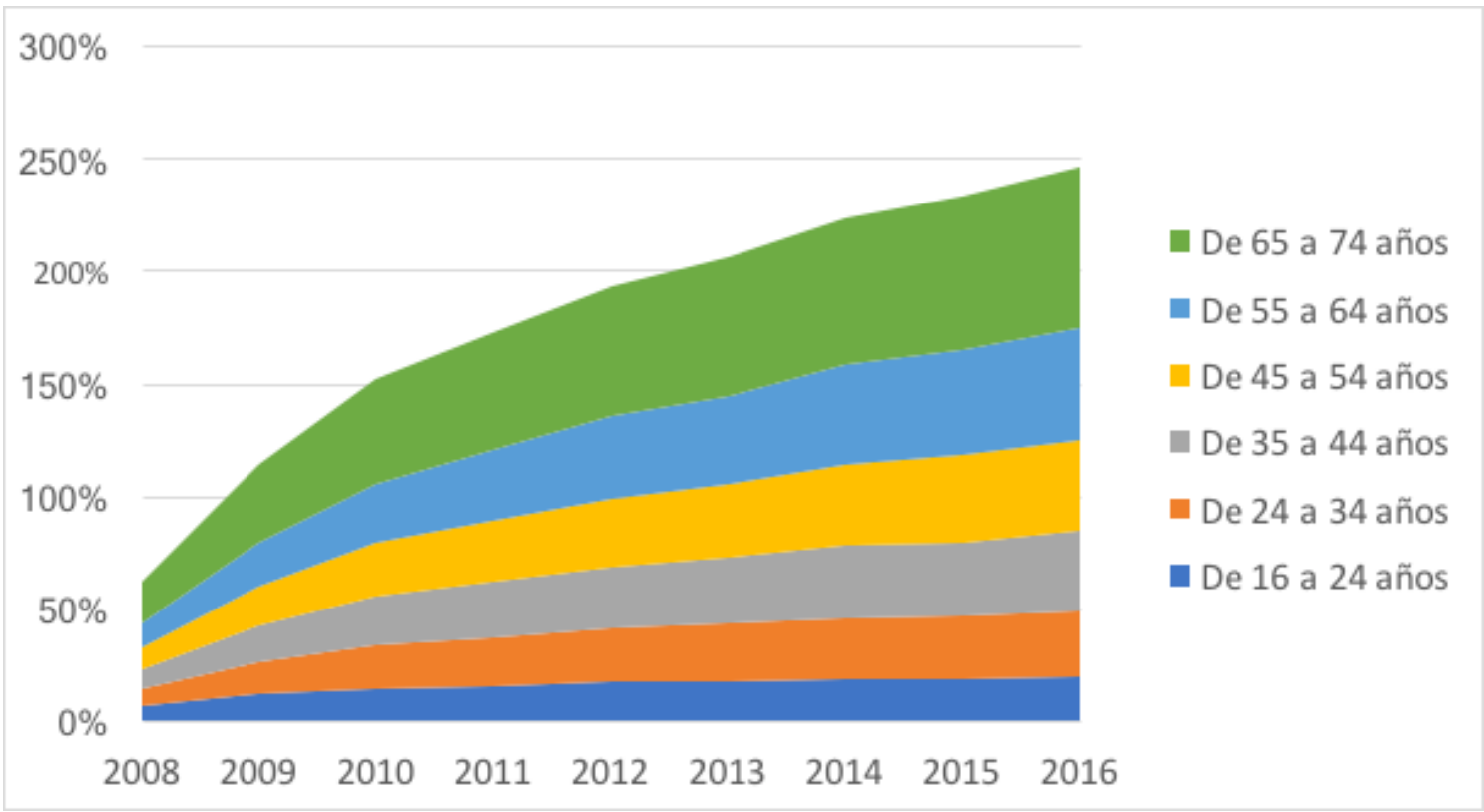

Figura 3. Incremento relativo respecto al 2007 de usuarios de internet (uso al menos una vez por semana, EU28).

La última encuesta que se posee del INE acerca de los motivos por los que una persona no usa Internet pero le gustaría es del 2007; a partir del 2008 dicha pregunta se eliminó. En la Figura 4 pueden observarse los motivos: insuficiente dominio de idiomas extranjeros, falta de tiempo, la conexión que utiliza es demasiado lenta, por los costes adicionales de conexión o de volumen de descarga, por los costes de los contenidos online, falta de interés en los contenidos de Internet, carencia de conocimiento para un mayor uso, motivos relacionados con la seguridad o privacidad y otros motivos varios. 


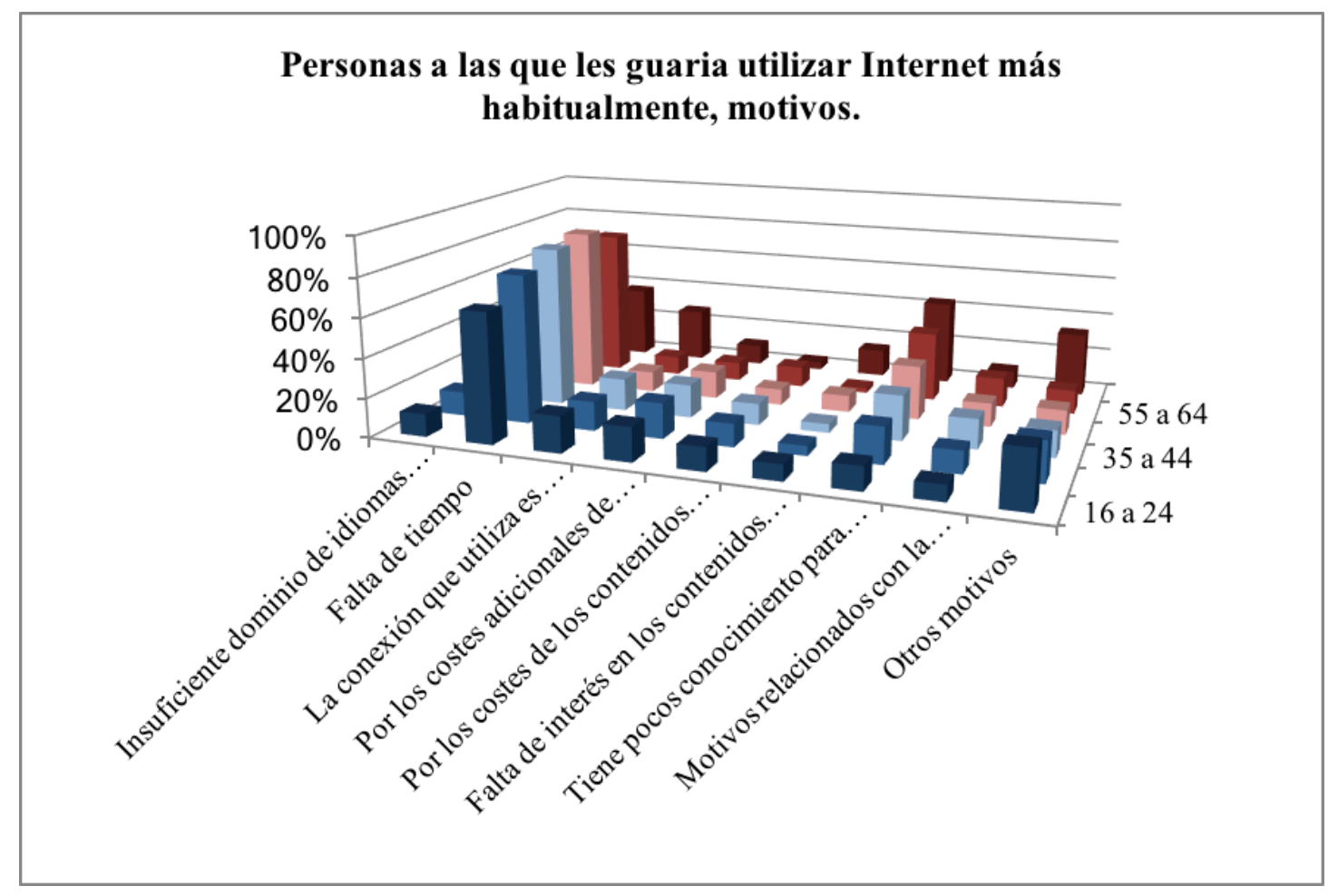

Figura 4. Motivos por los que no se hace un mayor uso de Internet (2007). Fuente: INE

Como principal motivo en jóvenes y jóvenes adultos para "justificar" el no uso de internet encontramos la falta de tiempo. A medida que la persona es más mayor, la falta de conocimientos surge como motivo principal, además de "otros motivos" en los que encajarían, por ejemplo, los relativos a la perdida de facultades físicas que requiere el uso del teclado y ratón o de visión o la motivación.

\subsection{Uso de las nuevas tecnologías}

El uso de las nuevas tecnologías (NT) por personas mayores siempre ha sido menor en relación a los más jóvenes o adultos más jóvenes, ya sea en frecuencia o en tipos de herramientas o usos. Esto se aplica tanto a computadores, al uso de internet, o otros aparatos técnicos como reproductores de audio o video, dispositivos móviles, etc.

Existen dos estereotipos instaurados en la sociedad actual (Aguilar et al. 2003). El primero es la asociación inevitable entre las nuevas tecnologías y la juventud, el 
segundo es el miedo entre los mayores a aprender algo totalmente nuevo. Puede resultar muy desesperante para una persona mayor encontrarse con enormes dificultades en la programación de un DVD-grabador o en el uso de un móvil y constatar que un joven, sin siquiera leer las instrucciones, es capaz de manejarlo todo rápidamente. Hechos cotidianos como éste no hacen más que acrecentar los anteriores mitos, llegando incluso a parecer que es la máquina quien nos domina y se pierde el control (Morris \& Venkatesh 2000), de modo que la "percepción del control" no existe o es escasa; además se tiene el sentimiento de que nunca se llegará a alcanzar ya que los dispositivos se renuevan frecuentemente y aparecen los nuevos. Como consecuencia de esto, puede resultar la convicción de la negación de los mayores ante las nuevas tecnologías. Esta actitud negativa originada por estereotipos, afortunadamente, puede ser reducida. Para ello se deben favorecer nuevos métodos pedagógicos, espacios educativos, instituciones que favorezcan el uso cotidiano y habitual, así como la creación de una mesa social que ejerza un dominio contando con la ayuda de instituciones educativas y otros mayores que han conseguido hacerse con el dominio de las nuevas tecnologías y que demuestran por tanto que aprender y manejar las nuevas tecnologías es posible.

Además de las causas antes citadas, también se ponen de manifiesto motivos técnicos (Selwyn 2003, p. 564), en los que se destaca que parte de los motivos en el freno de uso de las nuevas tecnologías se debe a los aparatos no han sido diseñados en términos de usabilidad para personas mayores, resultando que los mayores se ven física y psicológicamente desaventajados en el uso de nuevas tecnologías, aunque en este mismo estudio, queda al descubierto que esto parece ser más una excusa que un motivo real. Los motivos aportados para no usar las TICs son por este orden: falta de interés y motivación (25\%), demasiado viejo (21\%), no es necesario (13\%), falta de habilidades (13\%). En esta misma línea se muestra Morris \& Venkatesh (2000) donde se afirma que excepto cuando existan motivos físicos o psicológicos justificados, la edad por sí misma no se muestra como un impedimento para la adopción de nuevas tecnologías, pero sí en cambio ciertos estereotipos negativos o más destacables todavía, como son la falta de motivación e ilusión para emprender el nuevo reto del aprendizaje. 


\subsection{La nueva "brecha digital"}

A principios de los 90 la característica diferencial de entre aquellos que usaban o no usaban las TICs y que causaba la llamada "brecha digital" (Ballestero 2002) se producía entre los que tenían acceso a la red y los que no, provocando de este modo grandes desigualdades. En la actualidad se muestra una gran diferencia entre aquellos mayores con una actitud positiva y aquellos en quienes predomina una actitud negativa con respecto al uso y la asimilación de las TICs. Se ha podido comprobar (van Dijk \& Hacker 2003) cómo el problema causado por la llama brecha digital no reside tanto en un problema físico de conexión a la red, sino también en una actitud, habilidad y oportunidad de acceso.

Ya se ha observado en la anterior sección cómo el uso de las TIC's entre los jóvenes es mayor, dado que poseen unas habilidades mayores, propias y adquiridas. Es necesario también preguntarse qué sucederá cuando los jóvenes actuales sean adultos y mayores; ¿tendrá sentido hablar entonces de brecha digital? Hanson (2009) presenta dos hipótesis abiertas, la primera teoría afirma que los mayores serán totalmente capaces, igual que los jóvenes, y el único impedimento futuro para un aprovechamiento de las TICs serán las discapacidades físicas o psicológicas que puedan derivarse de la edad. La segunda teoría afirma que la tecnología evolucionará de tal forma, que cuando los jóvenes sean mayores, seguirán necesitando de adaptación para el uso de la tecnología presente en dicho momento. No puede anticiparse qué va a suceder, pero sí que puede analizarse en detalle qué está sucediendo en la actualidad. Según Hanson, la forma (que no las herramientas) en la que los mayores y jóvenes usan las TIC’s es diferente (basándose en la experiencia personal y las necesidades); además la evolución de la tecnología en el presente no hace prever que llegue un punto histórico donde ya no haga falta seguir aprendiendo más. De hecho sucede todo lo contrario, el número de aplicaciones y herramientas no hace más que aumentar, superando cualquier capacidad humana de poder controlarlas y manejarlas perfectamente. Las personas sólo podemos pretender el focalizar nuestra atención en aquellas que son de nuestro interés y aprenderlas. Es por eso que en el futuro, al igual que ahora, no será tan importante nuestra habilidad 
de usar, sino la de adaptarnos y aprender. La brecha digital seguirá estando entre aquellos que tengan una actitud positiva y los que no.

Considerando sólo el grupo de usuarios de ordenadores e internet, y sin tener en cuenta el uso de herramientas orientadas a contextos laborales, en la actualidad el uso de las herramientas TIC's entre jóvenes y mayores no es tan diferente, además, el objetivo que se persigue tampoco difiere tanto (Eastman \& Iyer 2004): mayormente estar en contacto con amigos y familiares, leer las noticias y acceso a información; es decir, los usos sociales y educacionales de la red. En otros casos, como el aplicado a usuarios mayores mayores de ordendores por Selwyn (2003), muestran como el uso más popular de herramientas es para escribir cartas y en caso de usuarios de internet es leer y enviar correos y en segundo lugar, buscar información. Por supuesto, hay usuarios más avanzados que usan herramientas o servicios que requieren de más habilidad y confianza (manipulación de imágenes, bancos on-line, descarga de material multimedia, etc.), pero estos no son tan habituales. 


\section{LA SOCIEDAD DEL CONOCIMIENTO DE LAS PERSONAS MAYORES}

\subsection{Nuevas Tecnologías}

Los avances en la ciencia son continuos en nuestra civilización. La tecnología avanza de igual modo a lo largo de los periodos históricos (Dosi 1982). No cabe por tanto hablar de nuevas tecnologías si no es centrándonos en un momento histórico, o en nuestro caso, refiriéndonos a un momento vital. Según el determinismo tecnológico (Roe Smith 1996) los cambios sociales se producen de acuerdo con estos avances. Aun siendo discutible esta teoría, sí que está ampliamente aceptado (Castells 2006) el hecho de que, en cierto modo, cada uno de los avances científicos producidos en la civilización tiende a modificar ya sea estructuras sociales o la forma en las que estas interaccionan.

Las Nuevas Tecnologías (NT) contextualizadas en un momento vital sólo son nuevas si éstas nos sorprenden, son significativas si modifican parte de nuestras redes (laboral, familiar, afectivo, etc.) o entorno social y son cruciales si requieren de nosotros una adaptación para poder seguir estando incluidos en ciertas redes o sociedad. No tiene sentido hablar a partir de ahora de una NT que apenas tiene efecto en nuestra vida o que su adopción es casi inmediata (pongamos por ejemplo el mechero en lugar de usar cerillas o el uso del mando a distancia). Nos interesa centrarnos en las NT como si fuera un evento que modifica la conducta de las personas y cuya adopción o no, tiene un impacto significativo en nuestras vidas, en ocasiones positivo y otras veces negativo, llegando a veces a sernos exigido su uso por reglas o presiones sociales. 


\subsection{La Sociedad del Conocimiento}

El origen del término Sociedad del Conocimiento aparece por primera vez hacia la década de los 60, sugerido Peter Drucker (2013). Drucker, que fue un sociólogo y también experto en el área de la gestión empresarial, predijo que además de la tierra, el trabajo y el capital como factores básicos para la producción, la información pasaría a formar parte de los elementos decisivos para el éxito empresarial. En su obra The age of discontinuity de 1968, inaugura un nuevo periodo post-industrial como la era del conocimiento, basada en la producción, distribución y uso del conocimiento y la información. 

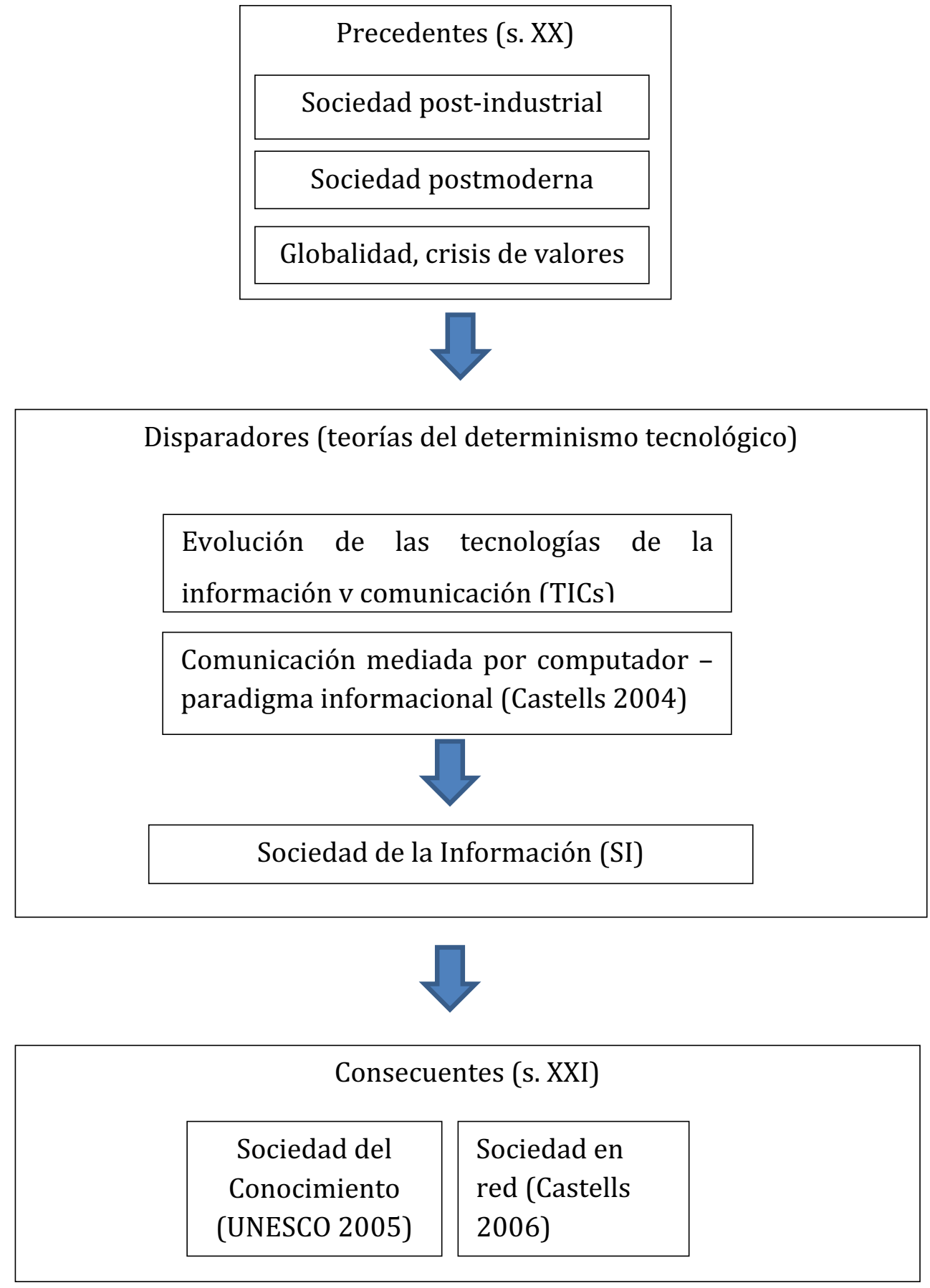

Figura 5. Evolución y relación entre las TICS, SI, y SC. Elaboración propia

Aun no habiéndose popularizado Internet ni las computadoras, Drucker ya anticipaba un cambio social que requería la justa valorización de la sociedad del conocimiento. Castells (2001) en la misma línea también justifica la aparición de nueva sociedad como un cúmulo de cambios anteriores, por ejemplo la crisis del modernismo. La aparición de los computadores y de internet ha favorecido esta revolución. 
La gestión del conocimiento por las empresas ha sido clave en una continua innovación y competitividad (J.C. Ramos 2009). No obstante, la SC también ha influido en lo personal, en las familias, hogares, amigos, y en la forma en cómo nos relacionamos, aprendemos, etc. Sin duda, se hace necesario relacionar la SC con la Sociedad de la Información (SI), encontrando autores que las las consideran y diferencian como dos revoluciones sucesivas: la SI se relaciona con los avances tecnológicos, y la SC más con el cambio social. Es por eso, que resulta difícil aislar ambos conceptos, puesto que más bien, se complementan.

La UNESCO (UNESCO 2005) introduce la "Sociedad del Conocimiento" y lo hace relacionándola con "revolución tecnológica" que se hace patente por los avances actuales en nuevas tecnologías, presentando la Sociedad del Conocimiento como todo un reto al desarrollo humano y de una sociedad más democrática. Parece por tanto existir una relación entre la sociedad tecnológica y la sociedad del conocimiento. No obstante, antes de este informe, en una entrevista a Abdul Waheed Khan, en 2003 (UNESCO 2003), éste ya dejaba clara una diferenciación:

Whereas I see the concept of 'information society' as linked to the idea of 'technological innovation', the concept of 'knowledge societies' includes a dimension of social, cultural, economical, political and institutional transformation, and a more pluralistic and developmental perspective.

Castells (2004 pp. 27-73) afirma, no obstante, que esta sociedad actual no es la "sociedad del conocimiento" (p. 71) afirmando que no lo es más de lo que ha sido en otros periodos históricos. Sí que se puede hablar de una diferencia en la sociedad causada por un nuevo paradigma tecnológico originado por los últimos avances tecnológicos, tanto de procesamiento como de conexión en redes.

La SC se nos hace presente por un nuevo modelo social dominado por la comunicación mediada por ordenador (Castells 2004) y donde la creación de redes entre personas, el flujo de información y la capacidad de procesamiento de la información son sus principales características. Este cambio social podría requerir en primer lugar una adaptación de aquellas personas más acostumbradas a otros modelos sociales (en este caso serian los mayores). ¿Es esta adaptación necesaria? ¿Útil? 
Las TIC's, por ser herramientas cuyo objetivo es hacer posible la información y comunicación, hacen posible que las personas que las utilicen tengan mayores posibilidades de estar al día, tener mejor acceso a la educación, la cultura y la información en general, así como poder enviar mensajes o establecer cualquier otro tipo de comunicación en otros foros. No obstante, la anterior afirmación no puede ser hecha de forma categórica. El aprovechamiento que puede hacer una persona de las TIC's es muy relativo, depende tanto de lo que sepa (habilidades en el uso de las TIC's), de su predisposición y del ambiente.

Se hace necesario un análisis más profundo de las potencialidades que nos ofrece la sociedad del conocimiento, pero también de los riesgos tanto activos como pasivos (por formar parte, y por no formar). Es costumbre suponer que la SC nos aporta grandes ventajas, pero debemos tener claro cuáles son, debemos ponderarlas y valorarlas, saber en qué contexto son aplicables y si merecen la pena. Debemos también clarificar cuales serian los riesgos, si son asumibles o si es posible minimizarlos.

Sólo después de este análisis y conociendo en detalle a que nos enfrentamos, es posible luego intentar entender los motivos por los que una persona mayor maneja las TIC's y si se siente incluido en la sociedad del conocimiento. En el caso de que esta persona no maneje las TIC's, será posible saber si merece la pena motivarla para que empiece a aprender TIC's o en el caso de que haya decidido negarse a aprender, poder entender si sus razones son justificadas. Este análisis es el paso previo necesario para entender el rol que una persona mayor puede jugar en la sociedad del conocimiento.

\subsection{Potencialidades}

Numerosos estudios destacan de qué manera el uso de las TICs por personas mayores tiene un impacto positivo en sus vidas, o en lo que se llamaría "bienestar" o "calidad de vida".

En primer lugar, Internet favorece la comunicación entre las personas y que éstas puedan crear nuevas redes sociales. Esto es muy importante en personas mayores ya 
debido a que posibles problemas de salud, deficiencia o vivir lejos de sus familiares o en zonas rurales, pueden vivir más aislados, con el consiguiente riesgo psicológico y social. Internet favorece las redes sociales (Hogeboom et al, 2010), pero no tanto que se creen unas nuevas, sino que mejora, en cuanto a calidad y cantidad, las interacciones que ya existen fortaleciéndolas de un modo virtual.

Tener una actitud positiva hacia las TICs es primordial para poder aprender, usar y aprovechar de una forma efectiva. Esa actitud positiva hacia las TICs está relacionada con la percepción personal de un envejecimiento útil y productivo (Cody et al., 1999). No puede demostrarse la relación de causa-efecto, pero si cierto tipo de relación.

Uno de los problemas que destacan los mayores con condiciones de salud óptimas es la soledad. El uso de las TICs, además de intentar minimizar dicho problema, también favorecería una accesibilidad a servicios de ocio y entretenimiento y otros referentes.

\subsection{Riesgos}

Los riesgos y peligros a los que una persona está expuesta cuando se conecta mediante un computador a internet varían proporcionalmente al nivel de uso que haga de las herramientas y servicios disponibles, pero también disminuyen según los conocimientos y experiencia que se tengan. Entre los motivos de no uso de las TICs por las personas mayores se destaca el miedo ante los posibles riesgos que más adelante se detallarán y de forma habitual manifiestan una solución que consistiría en aprender para evitar minimizar estos riesgos.

El que más destaca entre los miedos de cualquier persona mayor, sobre todo cuando está aprendiendo, pero también de forma común mientras está navegando o realizando cualquier otra actividad con su computador es el miedo a equivocarse, por tanto, el riesgo y el peligro son ellos mismos: temen borrar un archivo importante, estropear el ordenador o realizar alguna otra acción con repercusiones catastróficas.

Como en cualquier otro contexto social en donde exista una interactuación personal, puede haber cierta pérdida de privacidad; en una fiesta, cuando nos hacen una 
encuesta por teléfono, cuando en una página web nos preguntan de dónde somos. La pérdida de privacidad por tanto debe asumirse en cualquier contexto social, lo que la red hace que sea tan especial es el hecho de la ausencia de control.

La percepción de un cierto riesgo no es malo en si misma ya que ello sirve para que seamos precavidos o cautelosos ante alguien que nos puede engañar, lo malo aquí realmente es la pérdida del control y lo que ello conduce de forma habitual: a una pérdida de oportunidades. El miedo , por tanto, se convierte en una barrera.

Otro de los riesgos es la perdida de privacidad que impide a muchas personas que introduzcan sus datos en servicios que de forma útil y legítima los piden, por ejemplo, al registrarse. Las compras on-line no son utilizadas ante el peligro de fraude

\subsection{Competencias}

Basándose en los estudios anteriores, la SC está caracterizada, en primer lugar, por un uso de las TICs a lo que Castells denomina comunicación mediada por ordenador, y otros autores la designan "Sociedad de la Tecnología"; y en segundo lugar por el papel que tienen estas TICs en la sociedad, ya sea "sociedad en red", "inteligencia colectiva", interacciones, o riesgos. De forma general se puede de este modo afirmar que una persona incluida en la sociedad actual ha de ser capaz de usar y manejar las herramientas tecnológicas que la caracterizan, y también entender sus nuevos modos de funcionamiento.

Con respecto la primera competencia, resulta muy difícil, si no imposible, el saber manejar todas las herramientas y servicios tecnológicos que existen, pero sí que se pretende que las personas tengan un conocimiento básico, además de la capacidad suficiente que les permita aprender nuevas herramientas por sí mismos o al menos, a poder preguntar y pedir ayuda en caso de dudas.

En relación a la segunda de las competencia, una persona que quiera estar incluida en la SC ha de entender cómo funciona ésta. Según Castells (2009) se trata de los nuevos 
grupos de poder, la influencia de los medios, las redes sociales, las nuevas oportunidades de aprendizaje, participación, y colaboración. 


\section{INCLUSIÓN DIGITAL DEL MAYOR}

\subsection{Introducción}

El día 19 de junio del 2000, José Luis Pardos, embajador español en Dinamarca y miembro del Consejo de Dirección de la Internet Society, impartió en Castellón la lección de clausura del curso 1999/2000 de la Universitat per a Majors -UpM-. Esta lección se tituló «La Internet para los m@yores»(2000a). En esta conferencia se animaba a cualquier persona a usar Internet dirigiéndose especialmente a las personas mayores. En esta conferencia introdujo qué era la Internet, qué herramientas podían usarse y algunas utilidades y ventajas para las personas mayores. Además de animar a su uso, Pardos predijo el futuro en el ámbito comercial, cultural y político (2000b). La UpM reaccionó y asumió el reto de la alfabetización digital del mayor. El primer año que se ofreció la docencia en asignaturas de informática e internet fue en el año 2002. En el año 2008 se creó el Seminario Permanente de Nuevas Tecnologías con el propósito de establecer un marco estratégico relacionado con las nuevas tecnologías y la pesona mayor: docencia, investigación, innovación. Fruto de esta actuación, la UpM ha sido pionera en esta área, como se refleja en los resultados: artículos de investigación, conferencias y proyectos (WikiSenior, SenTrain, e-Vita, activeICT). Los resultados también se han visto reflejados en los alumnos, haciendo efectivo un uso y capacidad de manejo de las Tecnologías de la Información y Comunicación -TIC- por parte de los alumnos de la UpM.

En la actualidad no hay nadie que niegue los efectos positivos que ofrece el uso de las TIC. Los gobiernos crean programas -p.ej. el plan Avanza Español- para la promoción de las TIC. La Unión Europea promueve proyectos específicos para mayores -p.ej. 
Grundtvig- junto con otras actuaciones transversales clave para las competencias en las TIC. Las personas demandan y exigen una oferta educativa de calidad; por su parte, las instituciones docentes se esfuerzan en ofrecer una estructura educativa acorde con las necesidades y expectativas de los mayores, mientras que los centros de investigación buscan la justificación de las actuaciones y la innovación para lograr mejores resultados. Como resultado, tenemos a una persona mayor cada vez más tecno-alfabetizada, más competente, capaz y consciente en el uso y capacidades de las TIC. La red está sufriendo cambios, el rol del mayor está cambiando. Las entidades educativas y centros de investigación no deben permanecer estáticos.

Nuestra investigación pretende reconstruir el camino hecho hasta el momento y mostrar los últimos progresos realizados en el área del mayor y las TIC, y por supuesto proponer innovaciones que provoquen la discusión y reflexión en el lector.

\subsection{La persona mayor}

Dentro de cada periodo vital el ser humano presenta diferentes características y peculiaridades. Diferentes áreas de la ciencia se encargan de estudiar en detalle estos periodos: niñez, pubertad, adolescencia, mayor adulto, vejez y ancianidad. En el caso que nos ocupa ahora mismo y que nos interesa en particular es la gerontología o ciencia del mayor.

Existen numerosísimos estudios y publicaciones en el área gerontológica. Encontramos, además, que querer conocer al adulto mayor requiere una intervención multidisciplinar (Pinazo 2005) desde varias áreas: salud, psicología, sociología, educación etc. Nos encontramos, entonces, que desde una aproximación gerontológica es muy difícil definir cómo es el mayor, qué necesidades tiene y cómo pueden cubrirse éstas. Resulta, además, que una agrupación taxonómica del mayor es muy difícil de alcanzar, ya que el proceso de envejecimiento es dinámico y heterogéneo, por lo que, si queremos generalizar, pecamos de ambigüedad, y si se insiste en la especialización se pierde la visión del interés global. 
Aún con todos estos problemas presentes, se hace necesario establecer un punto de partida. De forma general, la meta que deben perseguir las instituciones, políticosociales, y el propio mayor, es lograr una calidad de vida satisfactoria. La calidad de vida es un término subjetivo, se trata de la percepción del individuo de sí mismo, de su actitud y del entorno. ¿Cómo incide entonces la calidad de vida en una persona mayor?

- $\quad$ Cambios en la estructura familiar y en el entorno.

- $\quad$ Perdida del papel social y familiar.

- $\quad$ Soledad.

- Cambios corporales y dependencia.

- $\quad$ Disminución de la actividad.

¿Dónde tenemos que centrar nuestros esfuerzos para impedir que las anteriores situaciones degraden la calidad de vida del mayor?

- $\quad$ Avances en la ciencia -salud y medicina-.

- $\quad$ Política social -ayudas a la dependencia-.

- $\quad$ Educación.

- $\quad$ Nuevas redes sociales.

- $\quad$ Actividad.

Repasando a continuación uno por uno los anteriores conceptos podemos ver el beneficio de las TIC para lograr un aumento de la calidad de vida de la persona mayor.

Sin duda, un aumento de la salud en el mayor influye directamente en su bienestar; pero, aparte de los servicios ofrecidos por nuestro sistema sanitario, el mayor también puede aumentar su salud mediante información y hábitos saludables. La política social debe ser implementada por los diferentes niveles políticos; el mayor puede participar en la representación política y hacerse oír para reclamar sus derechos. Respecto a la educación permanente, representa el factor clave para conseguir una adaptación del mayor a un entorno cambiante. Continuar teniendo contacto social es el principal medio para disminuir las posibilidades de soledad y de exclusión. El permanecer activo representa la última meta a lograr para un aumento 
de la calidad de vida, pero no sólo para estar distraído y animado, sino porque una actividad mental y física adecuada retrasa el envejecimiento.

Teniendo esto en mente podemos pasar ahora a definir las TIC, analizando cómo han cambiado, y que nos pueden ofrecer determinados aspectos de la relación mayor y TIC.

\subsection{La evolución de las tecnologías de la información y comunicación}

Referirnos a los procedimientos y naturaleza de la tecnología, sería como hablar de ciencia (Dosi 1982) ya que ambos van a la par; los resultados de la ciencia se aplican a la tecnología. Por tanto, hablar de Nuevas Tecnologías -NT- seria como hablar de avances en la ciencia. Un avance continuo en la ciencia representa el progreso, mientras que una discontinuidad podríamos asociarla con la presentación de un nuevo paradigma. Este nuevo paradigma está contextualizado históricamente y representa la aparición de un nuevo concepto de progreso. La relevancia de este avance hace entonces que hablemos de NT. Como ejemplo contemporáneo, según Castells (2000, vol. I, p. 59-110), las tecnologías novedosas actuales serian las siguientes: microelectrónica, informática, telecomunicaciones, automatización laser, biotecnología, energías renovables y nuevos materiales.

Qué se debe considerar por NT puede diferir si lo hace un sociólogo, ingeniero o un economista; en cambio, todos ellos estarán de acuerdo en que una NT representa una ruptura, un cambio, que tiene un efecto relevante y que además requiere de una cierta adaptación.

En el ámbito que nos ocupa nos centraremos en las posibilidades de la informática y las telecomunicaciones, es decir, las tecnologías de la información y comunicación TIC-. Entre estas tecnologías encontraríamos, por ejemplo, Internet, el teléfono móvil, reproductores portátiles, etc. o al menos eso es lo que diría un ingeniero. Un sociólogo, en cambio, diriamos que las TIC son realmente las nuevas formas de comunicación y de creación de redes entre las personas. Un economista diría que las 
TIC son una nueva forma fabulosa de marketing y de crear nuevos mercados. Ciertamente, todos ellos tendrían razón y deberíamos advertir que las TIC son mucho más que un artilugio, debemos pensar en ellas como algo que nos afecta y que cambia nuestro entorno y que, por tanto, deberemos comprender, aprender y, si nos es posible, manejar para que nos sean útiles.

Castells huye de destacar al periodo social que estamos viviendo como aquel en el que han aparecido las TIC, ya que, según él, todos los momentos históricos fueron revolucionarios para sus contemporáneos; por ejemplo, la imprenta también podría ser considerada una TIC. Castells prefiere calificar este momento histórico por aquello que lo diferencia de los anteriores: la aparición de la comunicación mediada por ordenador -CMO- que ha hecho posible la creación de una nueva sociedad «la sociedad en red».

Sin duda alguna, esta CMO ha sido posible gracias a los avances en la microelectrónica. Como máximo representante de la microelectrónica, tenemos a Internet, que al fin y al cabo es el nombre propio que se le ha dado a la infraestructura técnica de «la red de redes» por excelencia. Aunque la historia de la construcción de internet se inició a finales de los 60 , nos centramos en explicar qué ha sucedido a partir de la década de los 90 cuando las conexiones a Internet empezaron a estar presentes en los hogares.

Hasta el año 2000, a Internet se la llamaba la «autopista de la información». Curiosamente era cuando la mayoría de conexiones existentes en España eran de tipo modem telefónico -el predecesor de la banda ancha o ADSL-. En el nuevo milenio pasó a llamarse «la sociedad del conocimiento», y se proclamaban sus bondades en posibilidades de información y comunicación; también aparecieron entonces términos como «brecha digital», «analfabetismo digital». En la actualidad, a partir del 2006, la podemos conocer por otros sustantivos: la «blogosfera», «sociedad en red» y, cómo no, también aparecen nuevos términos como «privacidad» y «derechos de contenidos». Internet ha estado en constante evolución, marcada desde sus inicios por las personas (Castells 2001: 23-49). Internet es todo lo anterior, una gran autopista de información que representa la nueva sociedad del conocimiento y permite un nuevo tipo de sociedad: la sociedad en red. 


\subsubsection{WEB 1.0}

Costumbres informáticas tienden a numerar las diferentes evoluciones de un producto en números sucesivos. Por tanto, la versión 1.0 sería la primera, al menos, en el ámbito de nuestra investigación. La web 1.0 podríamos iniciarla en la década de los 90, cuando las empresas empezaban a tener un escaparate en este mundo virtual, simplemente porque hacía parecer a la organización más innovadora. Estas empresas vieron un modelo de negocio que explotar; al fin y al cabo, era como una forma de tener una tienda con costes muy bajos. Empresas de comunicación, gobiernos e instituciones iban poco a poco teniendo su presencia en internet, muchas veces, con la esperanza de grandes beneficios y objetivos prometedores. Este modelo se vió fracasado con la explosión de la burbuja «puntocom» en 2002 y es que tal sistema de negocio no reportó tantos beneficios como se esperaba.

\subsubsection{WEB 2.0}

O’Reilly (2007) definió esta nueva versión de Internet por la aparición de herramientas que hacían posible una mayor interactividad y participación del usuario. No fue una simple evolución, sino revolución: el espacio que dejaron las empresas fue ocupado por los usuarios. Aparecieron nuevas herramientas, algunas creadas por iniciativa de los usuarios y otras promovidas por organizaciones que, sin un ánimo de lucro aparente, facilitaban un uso gratuito de los servicios que ofertaban. La participación de los usuarios fue creciendo mediante herramientas de publicación -p.ej. blogs o wikis-, nuevas herramientas de comunicación -feeds, redes-. Además, nuevas empresas ofrecieron servicios gratuitos -google, youtube-, las empresas requerían del usuario una participación -opiniones, contenidos-. De este modo, la cantidad de información, gracias a las personas, creció enormemente. Esta participación de las personas fue reconocida por la revista TIME (Grossman 2006) eligiendo a «Tú» como la persona del año 2006.

Tú eres la persona del año por tomar las riendas de los medios globales, establecer la nueva democracia digital, por trabajar a cambio de nada y derrotar a los profesionales en su propio terreno. Tú controlas la era de la información. Bienvenido a tu mundo. 


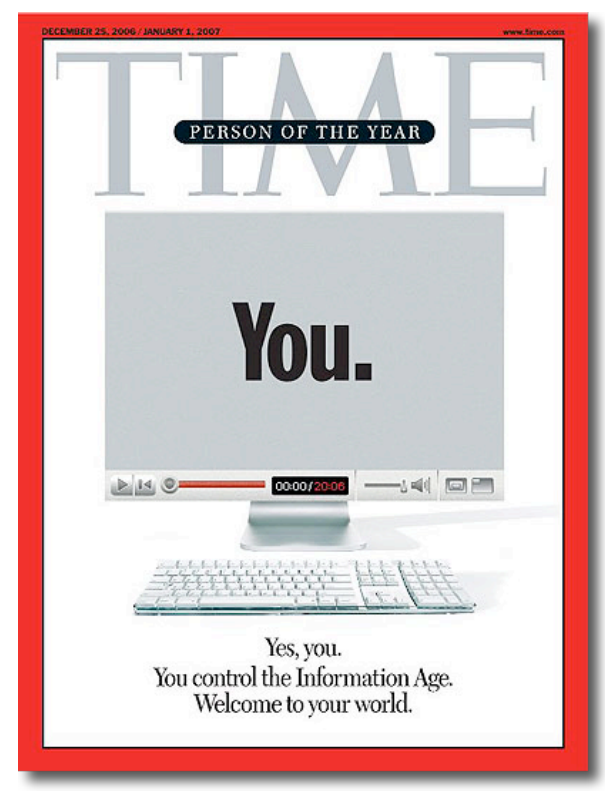

Figura 6.Edición diciembre 2006 de la revista TIME

\subsubsection{LA SOCIEDAD EN RED}

El sociólogo Castells (2006, p. 21) define la sociedad en red como «la estructura social resultante de la interacción entre organización social, cambio social y el paradigma tecnológico constituido en torno a las tecnologías digitales de la información y comunicación».

Esta nueva estructura social se está creando gracias las capacidades de la comunicación mediada por computador -CMO-, y es que la microelectrónica ha hecho posible el almacenaje de información y la transmisión de datos sin precedentes históricos. Pero no sólo se trata de capacidades técnicas, sino de un impacto y modificación en la actual forma de comunicar, compartir, aprender, asociarse, etc. Estas nuevas formas de interactuar entre las personas y de obtener información, no sólo hacen que los medios tradicionales sean susceptibles de ser relegados, sino que ofrecen nuevas formas de creación de contenidos, asociacionismo y de formación de comunidades que difícilmente hubieran sido posible sin la existencia de esta CMO.

\subsubsection{CREACIÓN DE CONTENIDOS}

Cada vez se confía más en los contenidos que instituciones y empresas depositan en sus servidores y son accesibles a través de Internet: lo hacen instituciones educativas 
y también gubernamentales. Los internautas hacen uso de estas ventajas, pero también ellos crean nuevos contenidos. Contenidos, en los que ellos son los expertos, dónde se resuelven las desavenencias y se construyen los resultados con gran calidad. Sobre las posibilidades de estas herramientas, no sólo para la construcción de contenidos, sino también para la cooperación entre personas, es destacable la opinión de J.A. Garcia Álvaro -Dtor. Arbitraje y Mediación- el cual afirma: «La resolución de disputas entre colaboradores y editores en la Wikipedia contempla y emplea la práctica totalidad de métodos extrajudiciales jamás inventados»

\subsubsection{PERTENENCIA A LA RED}

Ya resulta común entre las personas poseer una dirección de correo electrónico, pero también resulta cada vez más habitual el poseer una identidad. No se trata simplemente de tener usuario y contraseña para acceder a la cuenta del banco o nuestro correo, se trata de «ser alguien», un «yo» en la red. El poseer una página personal, un tablón, o muro, donde los amigos nos pueden escribir, el tener un álbum donde las personas pueden comentar las fotos, etc. son ejemplos de posibilidades que la red ofrece y que están creando un sentido de inclusión, ofreciendo herramientas con enormes posibilidades de comunicación al crearse grupos -por afición, geográficos, de estudios, etc.-, además de herramientas de enlace -suscripción, seguidores, confianza, etc.-. En estos grupos creados las personas poseen su propio perfil, de igual modo como en la vida real tendríamos la imagen que queremos transmitir hacia nuestro grupo de amigos.

\subsubsection{DISPOSITIVOS}

Los dispositivos aparecen con funcionalidades añadidas, más personales que nunca; personales en cuanto a individuales y también en cuanto adaptados a nuestros gustos. Sirva de ejemplo la nueva generación de móviles, los cuales aprovechan para algo más que hablar o las cámaras de fotográficas, donde ya no sólo hacen fotos para nosotros, sino para «la red» o «la comunidad». Siguiendo este ejemplo, con móviles podemos oír los programas de radios a las que estamos suscritos, las fotografías pueden geolocalizarse y colocarse sobre un mapa. 
La tecnología suele estar asociada con aquello que podemos ver y tocar, que tiene muchos botones y luces, y que, por norma general, pensamos que puede ser muy complicado o que nunca llegaremos a utilizar. Nada más lejos de la realidad; como ejemplo cercano seria el hecho, cada vez más frecuente, de que se ha convertido llevar una unidad USB de memoria externa en nuestro bolso o llavero, si vamos a la universidad, a casa unos amigos, etc.

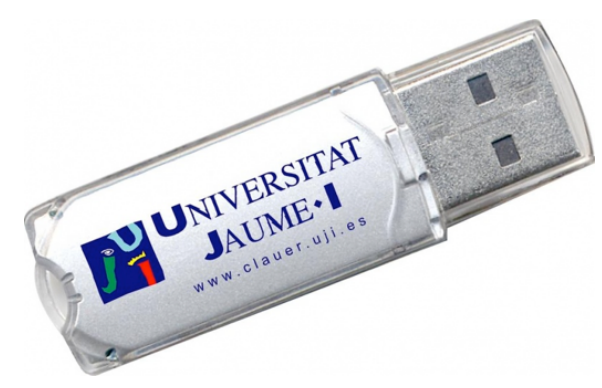

Figura 7. Nuestra memoria USB para el almacenamiento de datos y en el caso del Clauer-UJI, también identificación.

\subsection{Los mayores en la sociedad en red}

En esta sociedad en red, los mayores no han de ser personas excluidas. Deben tener el derecho de poder pertenecer, ser tenidos en cuenta y poder participar. La posibilidad que la red ofrece al mayor es inmensa, al igual que para cualquier persona, pero especialmente permite la creación de nuevos vínculos sociales. Otro aspecto importante de la estructura y el contenido de esta sociedad es su dinamismo, continuamente se está construyendo. Se trata, por tanto, de un área donde las personas mayores tienen mucho que decir, ya que ninguna sociedad puede ser construida sin la experiencia y conocimiento de los que más han vivido.

Si los mayores deben ser tenidos en cuenta en grupos políticos, asociaciones vecinales, culturales, etc. también deben poder actuar a través de las redes virtuales creadas. En este aspecto, nadie más que la persona mayor puede solicitar su inclusión, es su derecho, es una meta que cualquier persona debería poder optar. En este caso, es en parte responsabilidad de las instituciones educadoras, las cuales deben hacer de puerta de entrada para la inclusión en la red y también, es responsabilidad, de las 
instituciones políticas, que tienen el deber de facilitar el acceso, permitiendo que todos puedan tener acceso a internet, desde las zonas rurales hasta personas sin recursos suficientes.

\subsubsection{EXCLUSIÓN E INCLUSIÓN EN LA RED}

Las NT han sido definidas por su gran capacidad en facilitar la comunicación y la información. Pero usar las TIC y pertenecer a la red no son sinónimos, es necesario aclarar los conceptos y comprobar sus potencialidades para posteriormente poder definir una actuación que permita al mayor estar incluido en la red.

\subsubsection{USO DE LAS TIC}

El uso de las TIC ha ido aumentando paulatinamente tanto a nivel español, europeo, como mundial. Incluso las zonas más desfavorecidas -ya sea las zonas rurales o países en vías de desarrollo- están utilizando las TIC para tareas cada vez más cotidianas.

Cada vez más, las personas nos hemos acostumbrando a ciertos hábitos, ya sea por comodidad, por necesidad o por economía. Ciertamente, gracias a las TIC nos hemos aprovechado de enormes ventajas, como la posibilidad de información y de estar en contacto con familiares y amigos. Las posibilidades tecnológicas del ordenador e internet, junto con otros dispositivos, como las cámaras digitales, dispositivos móviles de comunicación, localización, ocio, etc., hacen que sea posible recoger, compartir y utilizar información, que de otro modo nos hubiera sido negada.

Pero también es cierto que este hábito está causando dependencia, ya sea provocada por terceros, cuando nos obligan a usar ciertos servicios de forma telemática, o por el propio individuo, al crear la necesidad de estar conectado o permanecer «on line», ya sea a través de internet o del teléfono móvil (Navarro 2001). Para usar las TIC de una forma útil y responsable es necesario, además de tener acceso, saber usar la herramienta. Es muy difícil saber usar todas las herramientas y posibilidades que nos ofrecen las TIC, pero sí que es posible, en cambio, poseer una actitud positiva, receptiva y crítica. Conocer, ser consciente y estar dispuesto a aprender aquellas TIC 
que nos son útiles es tarea necesaria en la actualidad. Se trata, pues, de ser un «ecitizen» o simplemente un e-ciudadano -ciudadano electrónico-.

\subsubsection{BRECHA DIGITAL}

La brecha digital ha sido definida de multitud de formas, en ocasiones refiriéndose a la diferencia de acceso entre personas a las TIC, basada en criterios tecnológicos, por ejemplo: ancho de banda, coste de productos y servicios informáticos, es decir, estar conectado o desconectado. Trabajos como el de Dijk (2003) analizan una faceta muchísimo más multidimensional: falta de motivación, material, capacidades y uso. De lo que más se ha oído hasta ahora en los medios es de la brecha causada por falta de equipos y conexión y que está siendo resuelto por la economía de escala; los demás motivos -capacidad, uso y motivación - son aplicables en personas mayores, desempleados, amas de casa, etc. y posee base temporal.

Los gobiernos deben actuar para hacer posible la conexión, pero es labor de las instituciones educativas remover los miedos que existan, ansiedad o desinterés injustificado, ofrecer cursos para aumentar las capacidades personales y promover oportunidades de uso. Esta educación no debe ser solamente ofrecida en base a contenidos, sino también a actitudes.

\subsubsection{INCLUSIÓN DIGITAL}

En la comunicación 229 de la Comisión Europea (2005), se crea el marco estratégico i2010 -sucesor de eEurope- con tres propósitos: un espacio europeo único de la información, impulsión de la innovación e inversión de las TIC, y la consecución de una sociedad de la información basada en la inclusión. Este tercer objetivo se detalla en la propuesta:

A menudo no hay conciencia de la contribución vital de las TIC a la calidad de vida y su asimilación es limitada. Para darla a conocer, la Comisión propone la puesta en marcha de iniciativas insignia en el campo de las TIC referidas a retos sociales clave. Las tres prioridades iniciales son: las necesidades de una sociedad que envejece, el transporte seguro y limpio y la diversidad cultural. La primera iniciativa se referirá a la atención a las 
personas en una sociedad que envejece y abordará las tecnologías que inciden en el bienestar, la autonomía y la salud.

Hay que reconocer que es todo un logro que se incluya sentencia tan determinante, dando por obvio que las TIC contribuyen de forma vital a la calidad de vida.

En la comunicación de la Comisión Europea 694 (2007) se define el término «inclusión digital» a las medidas para lograr una sociedad de la información para todos. Se relaciona la inclusión digital con términos como justicia social y se fijan objetivos como eliminar las diferencias de disponibilidad, accesibilidad física y económica y de competencias digitales.

Como ejemplos aplicados, tenemos trabajos como el de Webb (2006) realizado sobre adultos excluidos por razones étnicas y concluye que estos pueden usar las TIC para facilitar la comunicación entre la sociedad que les acoge, aunque deja claro que gran parte de la responsabilidad es del propio sujeto, haciendo las TIC únicamente de facilitador. Winden (2001) se centra en la exclusión social que se podría producir en una gran ciudad, definiéndola no como la privación material sino como la ausencia de acceso a los servicios y de participación. Este trabajo propone herramientas políticas -en ocasiones sobredimensionadas- basadas en TIC para luchar contra la exclusión. Admite las posibilidades de las TIC para crear redes y facilitar la participación, pero no encuentra evidencias de que los grupos discriminados se reintegren.

Las TIC no son la panacea para un problema multidimensional como es la exclusión social que puede depender de muchos factores. Uno de los motivos de esta inutilidad es la aparición de la brecha digital -en acceso y educación-. Las nuevas tecnologías aumentarán los poderes sociales, políticos y económicos de la gente $\mathrm{y}$, por consiguiente, implicarán una disminución relativa del poder de los que no tienen acceso. Las TIC son una muy buena herramienta para evitar la exclusión social, pero sólo a largo plazo y como medidas complementarias.

\subsubsection{ACCESIBILIDAD}

Las herramientas de las TIC son accesibles si éstas son fáciles de usar por las personas. Este término ha sido normalmente asociado a personas con discapacidades, 
a las que resulta dificultoso el manejo del ratón o la visión de la pantalla. No obstante, el término de accesibilidad tiene más componentes y se refieren no sólo a la posibilidad de manejo, sino también de «experimentar»-refiriéndome en el sentido de sentir, percibir, vivir- lo que pudiera producirse debido a cambios cognitivos o de percepción. Hanson (2009) plantea la hipótesis de que, en el futuro, las tecnologías avancen tanto, que sean muy difíciles de usar para cualquier mayor. Por supuesto, también plantea la opción contraria: que las tecnologías avancen tanto que hagan muy fácil el manejo del computador. Sea cualquiera la opción que suceda, se propone un tópico, aunque por repetido, no menos importante: las nuevas herramientas para el acceso a la red deben ser diseñadas no sólo en términos de funcionalidad, sino también de accesibilidad y es que la nueva red no debería ser excluyente por sí misma por ser complicada.

\subsubsection{ACTITUD}

Entre todas las barreras que pueden darse para impedir la inclusión del mayor en la red, la última y más decisiva es la que corresponde al mayor. Estudios como el de Czaja (1998) profundizan en la actitud del mayor desde diferentes aspectos: afirma cómo después de haber evaluado el comportamiento entre jóvenes y mayores, al realizar diversas tareas con el ordenador, no había diferencias de actitud de forma general destacables, pero sí de falta de confort, eficacia y control. Todo esto era subsanable mediante una exposición progresiva y adecuada al computador. En igual sentido aparece Jay (1992), afirmando que las actitudes negativas desaparecen al aplicar una experiencia directa con los computadores de forma positiva.

Ante las anteriores afirmaciones, cabe resaltar pues la dificultad que supone por tanto, romper esta primera barrera, en la que el mayor renuncia a estas tecnologías, pero también lo fácil que es cambiar esta actitud, una vez se ha vencido esta primera dificultad. No obstante, debe destacarse que, en este caso, el contacto que se produzca y posterior experiencia son cruciales; si no se realiza adecuadamente, las actitudes negativas podrían incrementarse, produciendo entonces un «renegado digital»con una actitud muy difícil de modificar. 


\subsection{Aprender nuevas tecnologías}

Aunque la ciencia de la computación se inició alrededor de 1940 -y de forma muy relativa-, no fue hasta la década de los 60 que se introdujo en las empresas. Se puede decir, por tanto, que el manejo de este tipo de herramientas era muy exclusivo, sólo reservado a personal técnico y especializado. A partir de los 80 empezaron a introducirse en los colegios e institutos y poco después en los hogares. Nos encontramos en que cualquier persona que ha nacido alrededor de la década de los 70, ha crecido con los ordenadores ya presentes; son «nativos tecnológicos». Esto no significa que para estos nativos tecnológicos manejar el ordenador y aprender nuevas habilidades sea fácil, sino que debe establecerse claramente una diferenciación entre aquellos que han manejado ordenador en el trabajo o en casa y poseen ciertas habilidades comunicativas mediante computador, y aquellos que tienen su primer contacto con el ordenador.

\subsubsection{PEDAGOGÍA}

El aprendizaje del manejo del computador y de las herramientas que nos proporciona internet es especialmente dificultoso para las personas mayores (Clemente 2008) y requiere de una pedagogía específica especialmente diseñada según sus condiciones (Monstad 2006). Numerosos estudios como en Repetto (2008) resaltan las características del aprendizaje de TIC en mayores, destacando la necesidad de mayor contacto e interacción personal además de otras características de tipo cognitivo; resalta además la gran potencialidad de aprendizaje que posee el hecho de poder contextualizar el contenido de lo que se está aprendiendo en una persona mayor, tan cargada de conocimientos y experiencias, y anima esta vía de aprendizaje. Este aprendizaje también debe ir más allá del propio contenido, se debe promover la concienciación y abrir nuevos horizontes.

En sintonía con estas ideas aparece la metodología usada en la Universitat per a Majors de Castellón (Esteller, 2009a, Esteller, 2009c), la cual no consiste sólo en enseñar herramientas sino también realizar otras actividades que potencien una 
predisposición positiva, un aprendizaje cómodo, contextualización de lo aprendido, consciencia, iniciativa, y el auto-aprendizaje.

Se ofertan unos cursos específicos para el mayor, a diferentes niveles, pero además una serie de actividades encaminadas, primero, a informar y contextualizar sobre la realidad de las TIC, su impacto en la sociedad y el potencial que posee. Luego, se pretende que interactúen y participen a través de internet, para finalmente poder crear contenido, ya sea de forma colaborativa o individual. También se promueve la participación del estudiante en su propio aprendizaje, teniendo un rol activo en proyectos, seminarios y talleres; de este modo pasan de ser receptores de aprendizaje a ser protagonistas.

Cabe destacar cómo los efectos de las anteriores actividades no influyen sólo en aquellos que participan directamente, sino que poseen un efecto de reacción en cadena como motivadores y de actitudes positivas.

Se pretende, pues, que mediante la realización de las anteriores tareas y la participación activa la integración del mayor en la sociedad en red pueda llegar a ser efectiva (Esteller, 2009b). Se trata de pasar de que la red sea una herramienta usada para comunicarse y compartir conocimiento, a que la red sea «el» medio dónde formar grupos, aprender, expresarse, etc., sin sentirse un extraño.

\subsubsection{PROPUESTA}

Cada vez más, las personas tienen mayor contacto con los ordenadores y con herramientas tecnológicas, así sucede a lo largo de la vida laboral o social. Cuando una persona se hace mayor y se retira de la vida laboral, cabría esperar pues que ya no fuese necesaria ninguna actuación educativa para la formación en NT, pero esto no es exactamente así; el mayor tiene una base de conocimientos muy buena y está cada vez mas formado en NT, pero estos conocimientos adquiridos a lo largo de toda la vida no son necesariamente los que va a necesitar en este nuevo periodo vital. Ya se definieron en la segunda sección de esta investigación las diferentes características diferenciadoras y que, por tanto, provocan un cambio de requerimientos y necesidades. Estos cambios hacen a su vez necesario aplicar una adaptación y, por tanto, un aprendizaje. En conclusión, las herramientas de comunicación o de manejo 
de la computadora que una persona haya realizado en su edad juvenil o laboral son diferentes de cuando sea mayor, y requerirán de una actuación educativa en NT, aunque clarificando que existirá una muy buena base en lo que a manejo de NT se refiere.

Por tanto, en un futuro, los cursos básicos e introductorios de aprendizaje de computador e internet podrían llegar a ser innecesarios, excepto en contadas ocasiones, a favor de otros cursos específicos sobre materias que para la persona mayor sean de interés específico.

Los cursos de larga duración -de un curso académico completo- permiten una enseñanza global, de amplio espectro, pasando por multitud de posibilidades y herramientas, enseñando cada utilidad en su contexto y también enlazando diferentes utilidades como un todo. Los cursos o talleres más cortos -de unas pocas semanas-y de contenido más específico permiten a todo aquel alumno que ya posee una base suficiente en el manejo y conocimientos, el poder aprender a usar una herramienta que le interese de forma particular. Aparte de esta doble oferta, hay que tener presente que no es suficiente enseñar contenidos o manejo, sino también conocimientos y aptitudes, se debe buscar la activación del mayor (Esteller, 2009b) para que sea capaz de aprender por sí mismo, de participar, de resolver dudas y de formularlas adecuadamente, etc. La oferta de actividades para promover el aprendizaje formal e informal (Esteller, 2009c) puede ser complementaria y potenciadora de la enseñanza formal; en este caso, se trata de ofertar una serie de talleres, seminarios, proponer medios para su participación, etc. tendentes a lograr que todo lo aprendido lo contextualice a sus propias necesidades e intereses y de este modo use las TIC desde su perspectiva, ya sea para participar, divertirse, aprender, escribir, etc. Este cambio metodológico pretende ya no sólo enseñar las NT para que el mayor pueda usarlas para su provecho, sino que esté integrado en la sociedad en red y que, de esta forma, tanto el mayor como la sociedad puedan beneficiarse de su inclusión. Estas oportunidades se detallan en la sección siguiente. 


\subsection{Los mayores y las nuevas tecnologías}

La persona mayor esta cada vez más presente en la web; proporcionalmente, las personas mayores de 70 años son las que más han crecido en el uso de las NT (Hanson 2009). Cada vez más, las personas mayores contarán con mayor presencia e influencia en la red.

El uso de las NT puede aportar beneficios a las personas. Al fin y al cabo son herramientas diseñadas cada una con una utilidad específica: usar un GPS para no perderse, una cámara digital para luego hacer un álbum y compartirlo, un reproductor MP3 para escuchar música o podcasts -similar a programas de radio pero en diferido-, una dirección de correo para enviar un documento al instante, navegar para distraerse, la creación de un perfil para ser diferenciados en la red, el darse de alta para suscribirse a una red de información, el rellenar un formulario para pedir información, etc. Se podrían escribir hojas enteras sobre las diferentes posibilidades existentes, pero esto escapa del propósito de este artículo. Se pretende no obstante estudiar cuál es la relación y su impacto -a veces positivo, en ocasiones negativo- del uso de estas herramientas en la vida cotidiana del mayor.

\subsubsection{INFORMACIÓN Y OCIO}

Dada la cantidad enorme de páginas web disponibles por instituciones, gobiernos, empresas y también por las personas, Internet se presenta sin duda como la fuente más importante de información a nivel mundial, y esto se puede interpretar como una gran oportunidad para aprender, o simplemente pasar el rato. La comunicación entre personas o la interactuación en la red, ha pasado de ser algo para conseguir un objetivo concreto -p.ej. enviar un correo para cerrar un contrato o buscar información sobre nuestro próximo viaje- a ser algo como objetivo por sí mismo: navegar por navegar, distraerse en el medio, comunicarse y establecer contactos por 
que sí. El hecho de que suceda esto, apoya la teoría que la red posee un rol cada vez más importante en nuestra vida diaria habitual.

\subsubsection{INCLUSIÓN}

Es innegable que la sociedad actual está convirtiéndose cada vez más en una sociedad tecnológica; así lo demuestran las estadísticas tanto a nivel nacional o europeo, con un incremento paulatino de uso de las TIC. Se crean nuevas redes y nuevos flujos de información. El gran facilitador de esto ha sido Internet; ahora es fácil, rápido, cómodo y económico crear contenidos y distribuirlos cómo también crear vínculos entre personas. Es por eso que la gente tiende a usar este medio. Ejemplo de este tipo de nuevas redes serian: asociaciones vecinales o culturales, un grupo de amigos con una afición común, un estamento gubernamental publicando información, etc. No se trata de una discriminación hecha a conciencia al eliminar el acceso a la información o a las redes existentes en medios tradicionales, sino que es la tecnología la que los hace posible, y no hubieran podido existir si no hubiera sido por las TIC.

Estudios como el de Serdult (2006) relacionan la inclusión en la red como la posibilidad de participación democrática y defensa de los derechos en una sociedad, la cual tenderá a formalizar, de modo electrónico, sistemas de participación tradicionales.

El peligro entonces aparece, si al carecer de los medios o conocimientos para acceder a estas redes estamos provocando nuestra propia discriminación. No es necesario convertirse en un experto de las TIC para estar incluido en la sociedad tecnológica. El primer paso sería no negarse a aprender y usar las TIC. La formación y conocimientos requeridos para tener acceso es relativamente fácil. El siguiente paso, aunque no imprescindible, sería el de creador de contenidos o el de agente.

\subsubsection{INTERGENERACIONALIDAD}

Las barreras intergeneracionales hacen que diferentes generaciones pierdan contacto, provocando de este modo familias incomunicadas o con escasa relación. Unas buenas relaciones familiares o intergeneracionales son la base de un aprendizaje mutuo e intercambio personal; hay que eliminar, por tanto, cualquier 
barrera que provoque la ausencia de estas relaciones. La principal causa de aparición de esta barrera es la diferencia entre las generaciones, pero no tanto por la edad, sino por otros motivos -diferencia de hábitos, forma de pensar, etc.- El uso de internet entre diferentes generaciones ha sido, de forma general, mucho más estudiado como una causa de conflictos y de ruptura en las familias (Nie 2002, Mesch 2006) que por su potencial en unir a las diferentes generaciones.

La introducción de la tecnología en los hogares incide en la dinámica familiar. Son los más jóvenes quienes lideran este uso, poseen mayores conocimientos y además son los que más defienden el uso del ordenador para la realización de numerosas tareas. Deben ser los mayores quienes se adapten a esta situación. El aprendizaje, la adaptación y el uso son los factores claves para potenciar estas nuevas formas de contactos intergeneracionales.

\subsubsection{CALIDAD DE VIDA}

Ya se había introducido el concepto de calidad de vida en la sección que trata sobre el mayor. La calidad de vida es muy difícil de cuantificar y medir la influencia que se ejerce sobre ésta. Escuder (2007) muestra la relación entre la calidad de vida y la educación, exponiendo de qué forma los beneficios aportados por una educación integral pueden favorecer el aumento de calidad de vida de las personas mayores. Cucity (2005) no pretende demostrar la relación entre la calidad de vida y el aprendizaje de las TIC, pero observa cómo ciertas necesidades y carencias que existen en las personas mayores son subsanables mediante las oportunidades que ofrecen las NT y es que para cada aspecto negativo aparece su posible reparación mediante las TIC.

Esta metodología puede ser aplicada para demostrar la relación directa que podría existir a priori entre un riesgo y su solución. Entre los más probados tenemos: falta de adaptación, subsanada mediante la posibilidad de aprendizaje de las TIC; falta de contacto intergeneracional o familiar que puede compensarse por una mayor adaptación del mayor a la sociedad actual; falta de participación, resuelto mediante las herramientas colaborativas; aislamiento debido a discapacidades o zonas rurales frente a los cuales tenemos las posibilidades de comunicación de las TIC. Hay que 
resaltar que esta relación se cumple sólo si existe una predisposición del mayor. Ante un bloqueo o aislamiento provocado por él mismo, la vida del mayor cedería a una degradación enorme de la calidad de vida. Las situaciones de depresión u otras enfermedades sólo son salvables mediante ayuda médica, soporte familiar y amigos, pero también por las nuevas tecnologías; así lo muestran los estudios de Anderson (2005) y Shaw (2004).

Además de la relación existente entre las herramientas disponibles y su capacidad de influir en las personas, observamos también cómo otros factores mucho más complejos pueden ser influenciados por las TIC aunque de forma indirecta pero destacable: autonomía, control, independencia y libertad para la toma de decisiones.

\subsubsection{VENTAJAS PARA LA SALUD}

Existen dos formas de observar cómo las TIC pueden mejorar la salud. La primera seria como medio de información; éste es el caso propuesto por Ianculescu (2008), que ha realizado pruebas mediante un entorno virtual para el paciente, donde se le asiste de forma personalizada para una toma de decisiones saludables. Aparte de esta forma tan directa, también nos ofrecen mucha información acerca de la salud navegando por la red-, pero esta información debe tomarse con cautela ya que podría no ofrecer información cierta ni adecuada para todos.

Desde otro punto de vista, la realización de tareas complejas, y sobre todo, aquellas a las que el cerebro no está acostumbrado -que requieren unas aptitudes totalmente nuevas- retrasan el deterioro neuronal. Estudios recientes demuestran de qué forma las TIC pueden aminorar el envejecimiento cerebral. Como ejemplo, tenemos el de Small (2009), el cual afirma que la realización de actividades mentales estimulantes mejora la salud del cerebro y las habilidades cognitivas. En su estudio, concluye que el hecho de realizar una tarea como la búsqueda de información -por ejemplo, con el Google- supone una actividad de las áreas del cerebro de la lectura, lenguaje, memoria, habilidades visuales, razonamiento, toma de decisiones y otras zonas indirectas, que de forma habitual no son activadas simultáneamente. Es esta interacción en un proceso complejo no rutinario la que produce este efecto totalmente beneficioso. 


\subsubsection{ASISTENCIA A DISCAPACITADOS}

Las TIC pueden mitigar los efectos de una situación debida a la discapacidad desde dos aspectos diferentes. El primer aspecto, sería como un promotor de la comunicación producida por motivos de una falta de movilidad: las TIC pueden jugar un papel importante para salvar su aislamiento. Internet ha hecho posible acercar a una persona al resto del mundo, además de la cantidad de servicios disponibles de forma virtual, reduciendo de este modo la necesidad de desplazamiento. Tal como apoya Kahana (2006) una asistencia mediada por computador permite un modo de vida más autónomo, retrasando en lo máximo posible el internamiento.

El segundo aspecto, seria la aplicación de tecnologías de ayuda directa cómo la teleasistencia, o en el campo de la domótica las casas adaptadas mediante componentes electrónicos, con diversas ventajas: mejor manejo de electrodomésticos, automatización de acciones básicas, seguridad, monitorización de la salud, conexión con un centro sanitario, etc.

\subsection{Aprender a través de las nuevas tecnologías}

Las NT pueden ser usadas como facilitadoras del aprendizaje. En ocasiones simplemente como asistencia y ayuda, otras como método. A continuación un breve repaso sobre su potencial, haciendo hincapié en su uso por los mayores.

\subsubsection{ASISTENCIA A LA ENSEÑANZA}

Centros docentes y estudiantes se han dotado de nuevas herramientas que permiten aumentar la calidad de la enseñanza. Algunos ejemplos serían: los elementos multimedia como grabación de las clases para una posterior visualización y repaso, programas que permiten una auto-evaluación, asistencia a la enseñanza a modo de tutor o ayudante, pizarras virtuales, etc.

Algunas de estas herramientas no hacen uso de las capacidades de una red, son meros instrumentos electrónicos que asisten a una labor docente, no obstante es necesario 
reconocerles su mérito. Beltran (2003) apoya la afirmación de que el ordenador y las nuevas tecnologías pueden ser usadas como un acentuador de la capacidad cognitiva y mental del estudiante; se trata pues, de reforzar mediante metodologías basadas en las TIC el aprendizaje en mayores para cubrir cualquier deficiencia específica (Monstad 2006).

\subsubsection{ACCESO A LA INFORMACIÓN}

Si hay un resultado que ha facilitado internet es el acceso casi inmediato a una cantidad ingente de información, pero no sólo eso, sino que la información puede ser publicada por cualquier persona, y de forma casi instantánea. En consecuencia de esto tenemos que todo aquello que se escribe está disponible al mundo entero de forma inmediata. Estas características han producido que los medios de comunicación tradicionales hayan visto en internet una seria competencia, ya que ante cualquier evento, acontecimiento, desastre, etc. siempre hay alguien que se encuentra en el lugar y publica imágenes, videos, comentarios, etc.

Internet como fuente de información también ha sido competencia para otros medios muy respetados como, por ejemplo, la enciclopedia Encarta de Microsoft, o la Enciclopedia Británica. Y es que Internet no sólo permite que multitud de usuarios se agrupen para crear contenido -como sucedería en una herramienta de tipo wiki, como la Wikipedia-, sino que además permite complementar lo que se está consultando con videos, imágenes, enlaces, y quizá lo más importante: con los propios comentarios y debates entre las propias personas.

Dos son las habilidades que ha de tener un usuario de Internet para aprender a partir de los contenidos:

- Buscar información de forma adecuada, para encontrar la más relevante y útil.

- Reconocer el nivel de fiabilidad de la información encontrada para aprovechar o desestimar.

Estas habilidades son alcanzables con un poco de formación inicial, y muchísima práctica. 
Destacable es, además de las propias páginas personales que se pueden encontrar en internet, la cantidad de instituciones que día a día se suman para ofrecer información. Encontramos fundaciones, instituciones, gobiernos y universidades que tienden a recopilar y almacenar información, muy fiable y de alta calidad. Por ejemplo: digitalización de videos, documentales, libros o manuscritos cuyos derechos de autor han terminado o bien han sido cedidos, bibliotecas digitales de libros, tesis, artículos de investigación, etc.

\subsubsection{COMUNIDADES}

El Internet actual hace que la creación de grupos de personas sea muy fácil. Existen herramientas de redes sociales que permiten a un grupo de personas establecer un contacto y también, si así lo pretenden, mantener una relación social muy positiva y enriquecedora.

Los foros y chat -IRC- han sido las herramientas usadas tradicionalmente para compartir entre un grupo de usuarios los conocimientos. Existen multitud de foros, unos generalistas y otros de temas específicos. Los generalistas han sufrido un gran decaimiento a favor de los específicos; y es que para que un foro funcione necesita de una comunidad de usuarios que lo alimenten -con contenidos, que resuelvan dudas, etc.- y esto se ha dado en aquellos foros donde se tratan temas específicos que son de especial interés para una persona: una afición, un tema muy concreto, etc. Ante el avance de las herramientas web 2.0, muchos foros están siendo sustituidos por su equivalente de comunidad en una red social, pero este cambio de herramienta no cambia su sentido colaborativo y de ayuda original, sino que lo amplia con otras características que las redes sociales permiten: aspectos personales, de identidad y flujo de información.

Generalmente estos foros no son organizados, sino que son escritos a medida que surgen las dudas o una persona desea que alguien le ayude en un problema particular, manteniendo un marcado carácter práctico. Sus contenidos no favorecen una enseñanza formal, pero en cuanto a la enseñanza no formal e informal, donde prima la práctica, el autoaprendizaje y la propia iniciativa del estudiante pueden ofrecer enormes posibilidades. Pero no hay sólo foros, sino que nuevas herramientas 
de comunicación hacen posible que el aprendizaje en comunidad y de forma colaborativa sea posible, así lo muestra Traver (2009) con la WikiSenior, en la que los alumnos mayores escriben contenidos, con la principal característica y ventaja que los textos se van retocando y mejorando entre todos. Este proceso de escritura colaborativa es lo que hace posible el aprendizaje.

\subsubsection{APRENDER ON-LINE}

La principal característica del aprendizaje on-line es que salva distancias y flexibiliza el horario. En consecuencia, la oferta crece enormemente al no estar restringida a una zona geográfica; cualquier persona puede inscribirse en cualquier curso del mundo sólo con unas pocas restricciones -p.ej. el idioma-.

La educación on-line mediante las clases virtuales se ha mostrado como una herramienta complementaria de la educación presencial y resulta enormemente potente para el aprendizaje del alumno (Means 2009). Esta información avala el uso de herramientas de colaboración y de tutorización como clave para el éxito del aprendizaje, por ejemplo: debates entre compañeros de clase, seguimiento de las actividades por parte del tutor, promoción del alumno para que investigue y busque por su cuenta, etc.

La oferta de la educación virtual o semi-virtual por parte de las instituciones de educación formal han crecido enormemente, aunque la oferta específica para mayores es aún escasa (Lorente 2008). Cabria plantearse el futuro de esta metodología de enseñanza aplicada a personas mayores, que prima el contacto social y un entorno que difícilmente se puede lograr mediante las TIC. Pese a los avances en comunicación y didáctica, Ruiz (2005) no ve la enseñanza on-line como un sustituto de la formación presencial, pero sí que apoya estas tecnologías como soporte, para mantener el contacto con el grupo, y como complemento y tutorización siempre de forma personalizada, intentando de esta forma continuar manteniendo un cierto contacto humano. Aún la reticencia que un alumno podría tener ante la implantación de un aula virtual o semi-virtual, no hay que olvidar que los avances en las TIC están haciendo posible la aplicación de nuevas formas de comunicación y colaboración, y que con técnicas adecuadas -creación de perfiles personalizados, grupos, etc.- este 
medio de comunicación no sería tan deshumanizado. Por último, es interesante recalcar que en ciertas situaciones -mayores discapacitados o en zonas rurales- ésta sería la única forma de seguir aprendiendo. Merece, por tanto, que le dediquemos atención y esfuerzo en mejorar las posibles carencias pedagógicas y sociabilizadoras que tengan las clases on-line y lograr que la integración del alumno en un aula virtual sea lo más parecida -o incluso mejor- a un aula real.

\subsection{La persona mayor en la red}

Internet ha cambiado y seguirá cambiando, aparecerán nuevos artilugios, nuevas tecnologías y nuevas formas de interactuar, comunicarse y de crear información; las personas aprovecharan estas posibilidades y la sociedad en general sufrirá cambios.

El interés de un adolescente en las TIC es muy diferente al de una persona adulta, y una persona que está en periodo laboral tiene una motivación en el aprendizaje diferente al de otra que tenga más tiempo libre y puede dedicarse a lo que más le apetezca. El aprovechamiento de las TIC también es diferente en el caso de una persona que posea alguna discapacidad, viva en una zona desfavorecida o haya tenido un cambio familiar o cualquier otro cambio en el entorno. Cada cambio y cada situación concreta, así como nuevas etapas vitales, demandan nuevos conocimientos y aptitudes, y requieren, por tanto, de una adaptación que debe ser asumida.

Las TIC pueden ser aprovechadas en cada momento vital de manera muy diferente, y es sobre todo el mayor quien, de forma consciente y reflexiva, debe conocerlas, evaluar si desea utilizarlas, si quiere vivir en la nueva sociedad en red, si quiere actuar y construir la nueva sociedad y defender sus derechos a través de ella y en ella. Esta decisión puede ser únicamente suya, pero tanto los poderes públicos como las instituciones educativas tienen la obligación de tender la mano y ofrecer esta oportunidad.

La oferta educativa deberá adaptarse, en primer lugar, al estudiante, y, en segundo lugar, al contenido. Sin duda ninguna, el nivel aumentará, el contenido cambiará, y lo que es más importante, la metodología tendrá que adaptarse a las nuevas demandas. 
Se trata de un cambio continuo, un aprendizaje permanente porque se debe estar en disposición de aprender a lo largo de toda la vida. 


\section{SECCIÓN SEGUNDA; PROYECTOS DE INNOVACIÓN EDUCATIVA}




\section{ICT $50+$}

\section{$\operatorname{licts} 50^{+}$}

Logotipo del proyecto

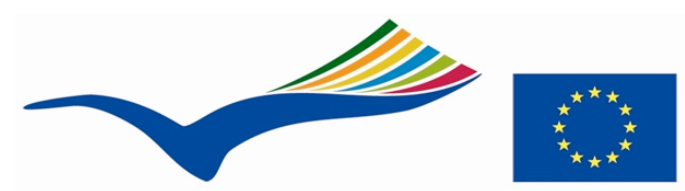

Education and Culture

Lifelong learning programme

GRUNDTVIG

Este proyecto fue financiado desde el Programa Grundtvig de la Unión Europea

Coordinado por la Universitat Jaume I, y formado por un total de 6 socios, con una duración de septiembre de 2005 agosto 2007, página web: www.ict50plus.uji.es, con título "Information and communication technology empowerment for fifty-year-olds +" y los siguientes socios:

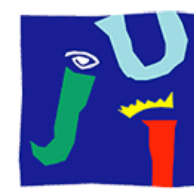

UNIVERSITAT

JAUME• I

THE FINNISH MS SOCIETY

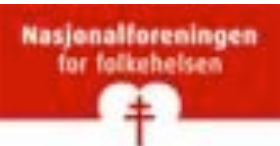

Universitat Jaume I

coordinador

Finnish MS Society

Finland

Landåstorget Seniorsenter

Norway 


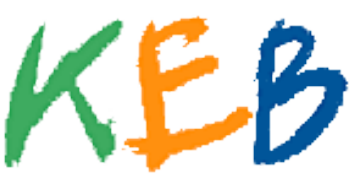

s

0

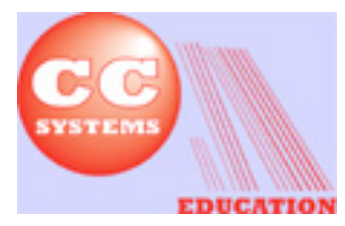

KEB Rheinland-Pfalz LAG e. V.

Germany

Senioren-Lernen-Online

Germany

CC Systems Plc.

Czech

El principal objetivo de este proyecto era promover la adopción de las tecnologías de la información y comunicación en personas mayores de 50 años. Por ello, cada uno de los socios exploraba diferentes aspectos de esta adopción. Como miembro del equipo de investigación realizamos pruebas de laboratorio para comprobar la aplicación de diferentes métodos y actividades para la enseñanza tecnológica en mayores, favoreciendo el uso y adopción.

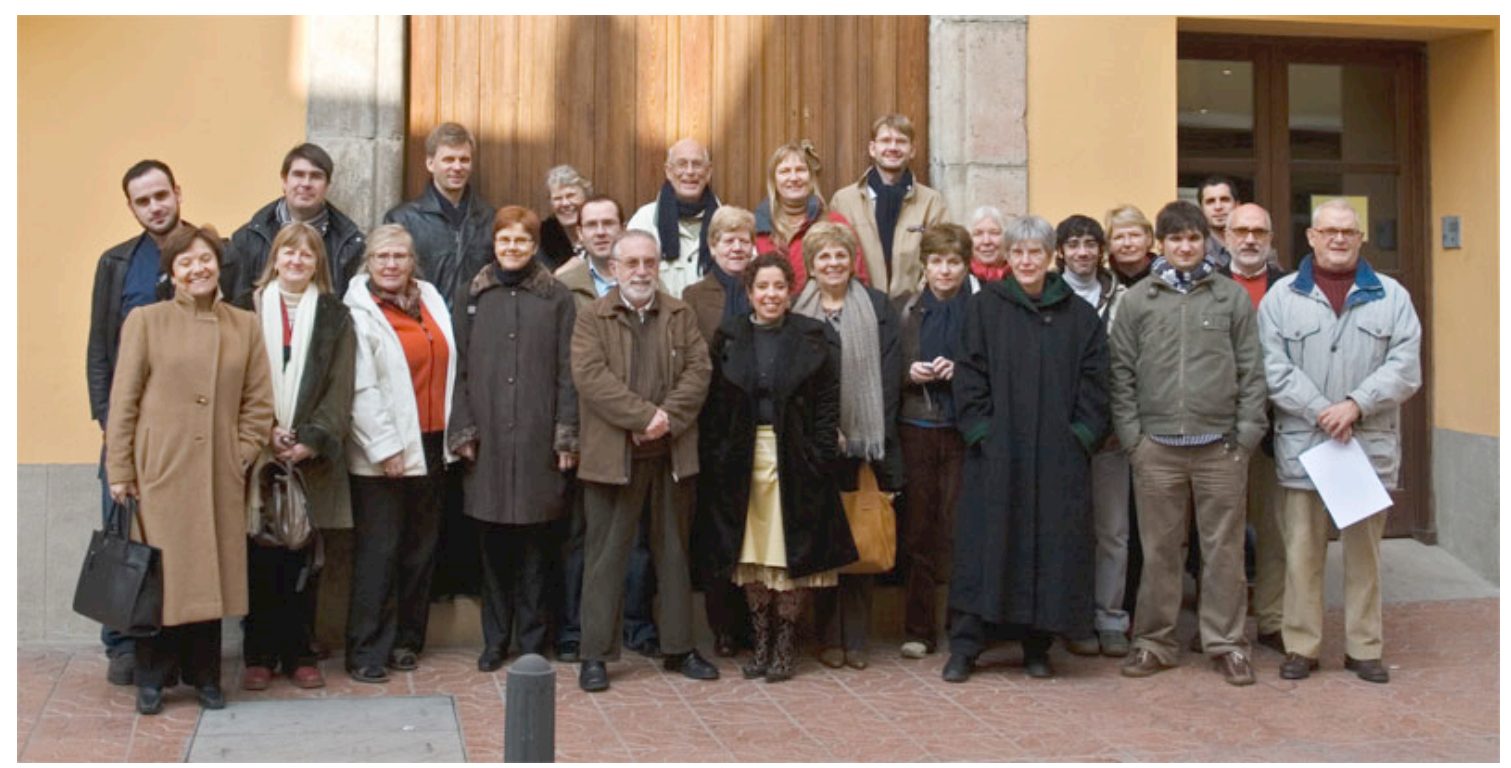

Reunión del consorcio en Vinarós, 5 de julio de 2007

Resultado de este proyecto, fue la presentación de dos ponencias en el VI European Congress of the International Association of Gerontology and Geriatrics, en San Petersburgo, julio 2007, publicado en International association 
of Gerontology and Geriatrics. St. Petersburg, num. 3. vol. 20. 2007, ISSN 15619125.

- The influence of life-long-learning on quality of life in senior citizens. Pilar Escuder-Mollon

- ethodology and didactics in ICT courses for senior citizens at the senior citizens' university; Roger Esteller-Curto, Pilar Escuder-Mollon, S.J. Monstad 


\section{SENTRAIN}

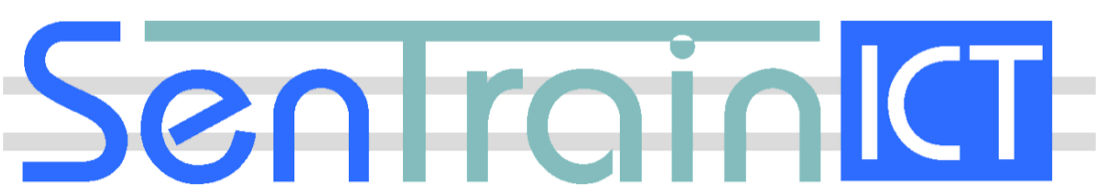

Logotipo del proyecto SenTrain

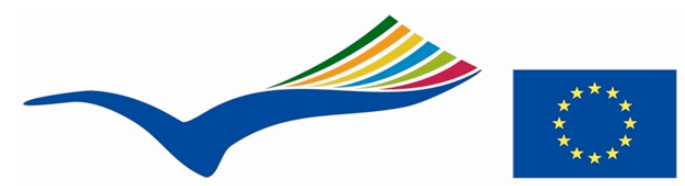

Education and Culture

Lifelong learning programme GRUNDTVIG

Este proyecto fue financiado desde el Programa Grundtvig de la Unión Europea

Coordinado por la Universidad de Erlangen-Nuremberg, por su instituto de innovaciones educativas y formado por un total de 8 socios, con una duración de enero de 2006 a diciembre de 2007, con título "SenTrain, Train the trainers" y los siguientes socios:
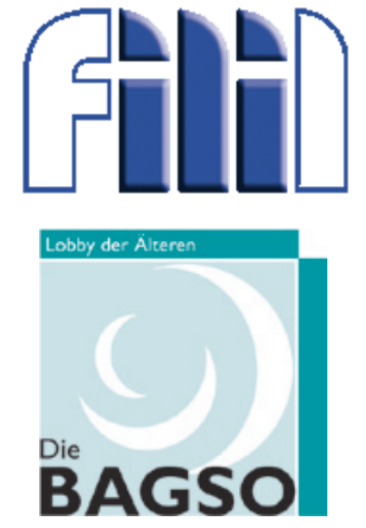

Bayerisches
University of Erlangen-

Nurembergcoordinador

Alemania

German National Association for Senior

Citizens' Organisations

Alemania

Bavarian Senior Citizens Network, DE

Alemania 


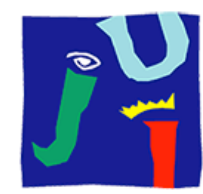

UNIVERSITAT

JAUME•I
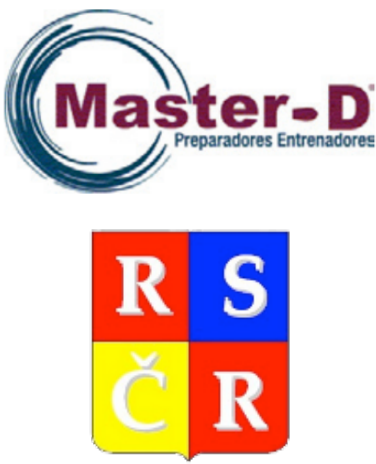

THE THIRD AGE TRUST

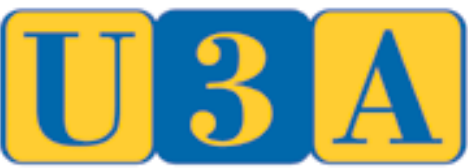

THE UNIVERSITY OF THE THIRD AGE

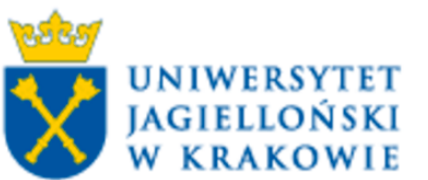

Universitat Jaume I

España

Master Distancia S.L.

España

Union of seniors Czech Republic

República Checa

The Third Age Trust

Reino Unido

Jagiellonian University

Polónia

En este proyecto se tuvo como objetivo investigar cuales eran las necesidades de un alumno voluntario para que se convirtiera en formador-tutor en docencia de nuevas tecnologías, acompañando de este modo al profesor y ayudándole. Se realizó una guía (libro), de la cual, consto como autora de 2 capítulos del manual "SenTrain: Competencias formativas para personas de la tercera edad"

- Successful communication in a learning context, communication in the group

- Feedback that furthers teaching and learning 


\section{ACTIVEICT}

\section{@ctiveict ))}

Logotipo del proyecto

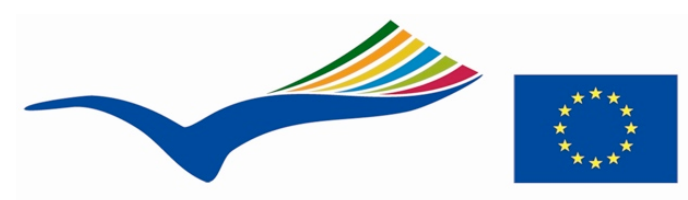

Education and Culture

Lifelong learning programme

GRUNDTVIG

Este proyecto fue financiado desde el Programa Grundtvig de la Unión Europea

Coordinado por la Universitat Jaume I, y formado por un total de 12 socios, con una duración de septiembre de 2008 a agosto 2010, página web activeict.uji.es, con título "Information and communication technology empowerment for fiftyyear-olds +" y los siguientes socios:

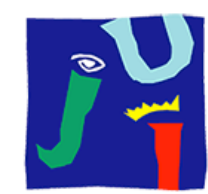

Universitat Jaume I

España

coordinador

UNIVERSITAT

JAUME• | 

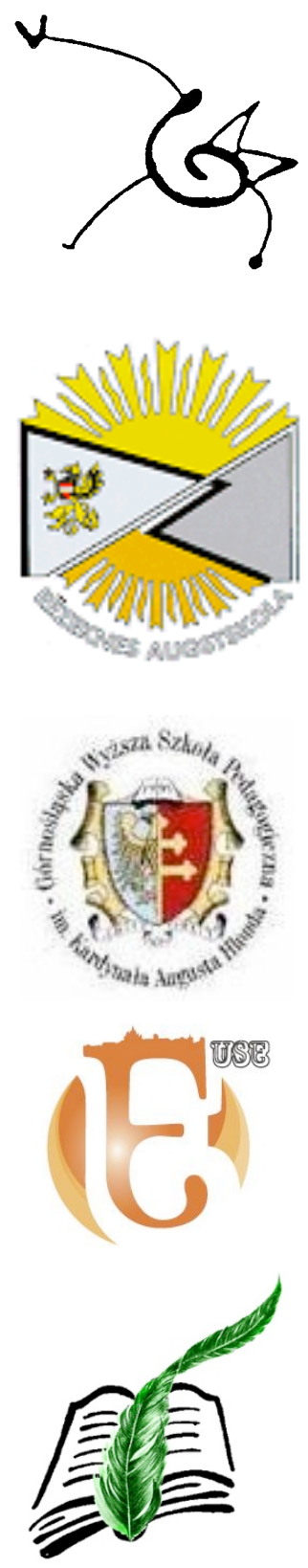

$\mathrm{S}$

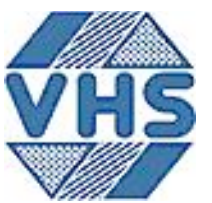

\section{0}

Università delle LiberEtà del Fvg

Italia

Personality Socialization Research Institute Letonia

Cardinal August Hlond Upper Silesian College Of Pedagogical Education

Polónia

Universidad Sénior de Évora

Portugal

Association for Education and Sustainable Development

Rumania

Volkshochschule Lingen

Alemania

Senioren -Lernen-Online

Alemania 

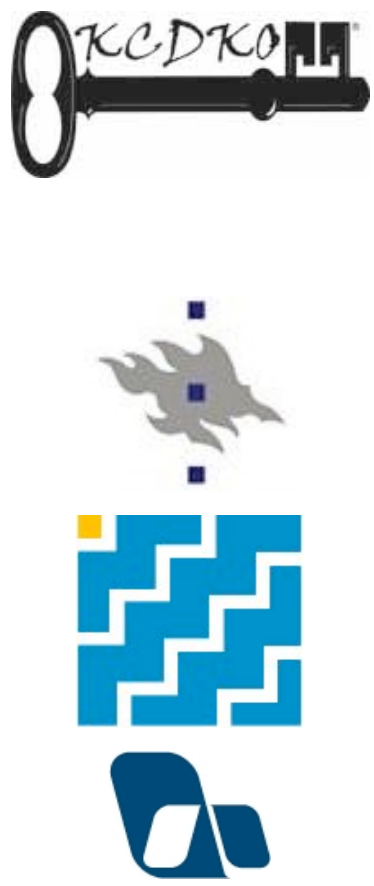

The Cracow Centre of Improvement of

Educational Personnels

Polónia

Universidad de Helsinki

Finlándia

Sastamala Community College

Filándia

Villa Montesca Research and Training Centre Italia

El principal objetivo de este proyecto era el diseño de herramientas educativas y pedagogías innovadoras basadas en la tecnología para promover un uso activo de las tecnologías de la información y comunicación por parte de los estudiantes mayores.

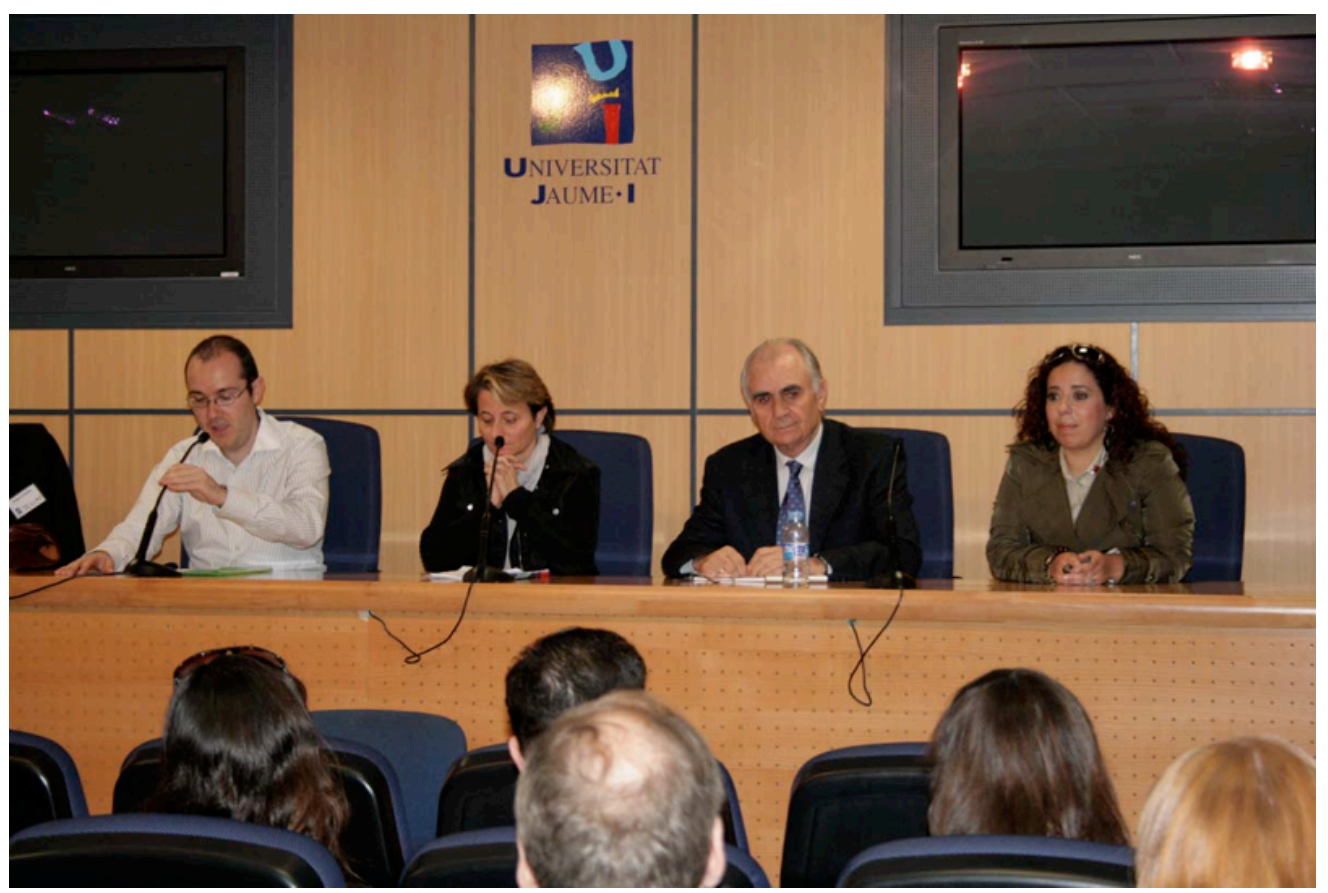


Presentación del proyecto en la UJI. De izquierda a derecha. Roger Esteller, Eva Alcon de Vicerrectora de Cooperación Internacional y solidadridad de la UJI, Salvador Cabedo, Director académico de la Universitat per a Majors, Pilar Escuder

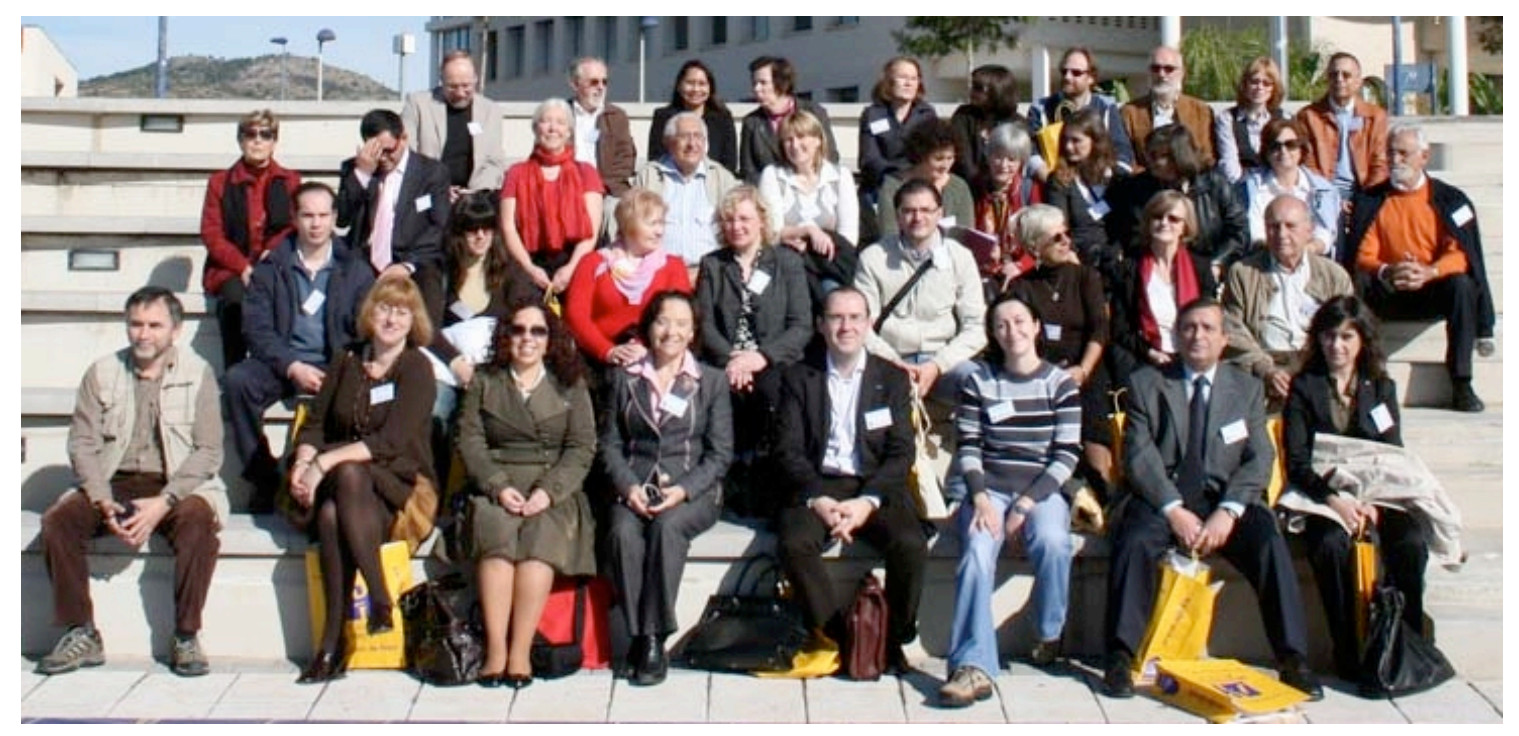

Reunión en la Universitat Jaume I del consorcio. 7 de noviembre de 2008

Resultado de este proyecto, por parte de la Universitat Jaume I, fue creación de la primera wiki para personas mayores, http://www.wikisenior.es, junto con una metodología para la activación de los mayores.

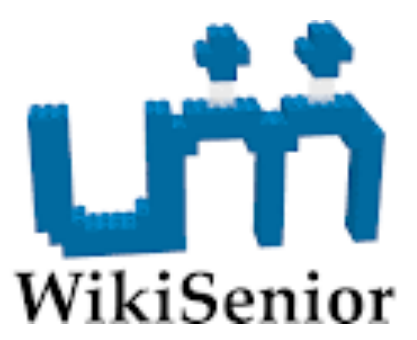

La Universidad Jaume I creó la primera wiki de mayores: www.wikisenior.es

La propuesta metodológica para la activación de los mayores fue presentada en dos congresos:

- Methodological proposal for an ICT activation among senior learners, R. Esteller, P.Escuder y J.Traver, presentado en 1st International Conference on 
Education and New Learning Technologies, 6-8 de julio de 2009, en Barcelona y publicado los proceedings, páginas 4455-4463, ISBN: 978-84-612-9801-3, ISSN: $2340-1117$

- Pilot experience of using a Wiki for Learning and communicating among senior students, J. Traver, R.Esteller y P. Escuder 


\section{E-VITA}

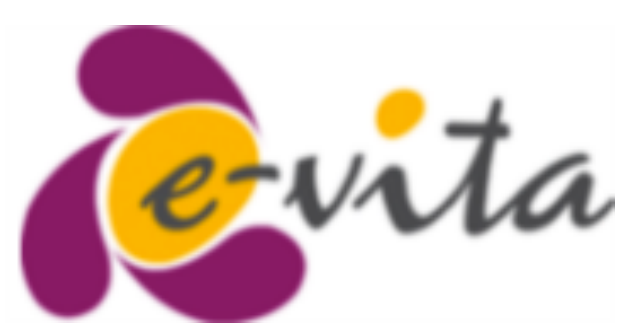

Logotipo del proyecto e-Vita

Coordinado por i-Maginary de la Universitat Milá, Programa de Aprendizaje permanente de la Unión Europea, tipo Transversal KA3 en ICT, y formado por un total de 7 socios, con una duración de noviembre de 2008, a octubre de 2010, con título "e-Vita: European Life Experiences” y los siguientes socios

\section{magınary}
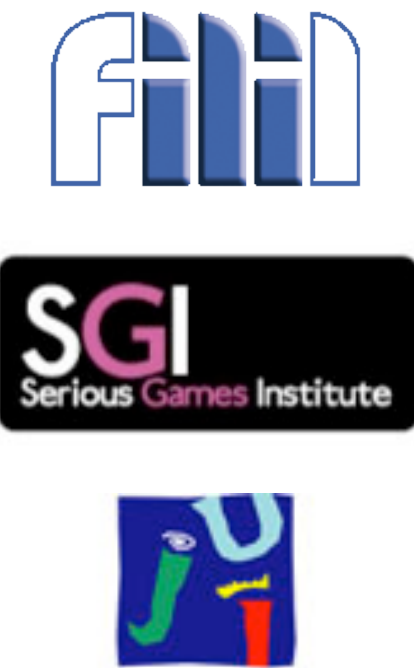

UNIVERSITAT

JAUME $\mathbf{I}$

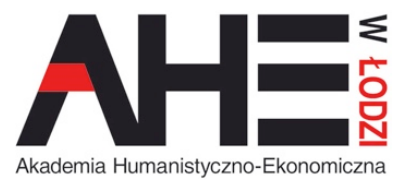

imaginary

Italia

Coordinador

Institute for Innovation in Learning,

Friedrich-Alexander-Universität of

Erlangen-Nürnberg. Alemania

Serious Games Institute, Coventry

University.

Reino Unido

Universitat Jaume I

España

Academy of Humanities and Economics in Lodz

Polónia 


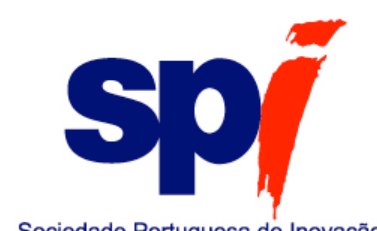

Sociedade Portuguesa de Inovação

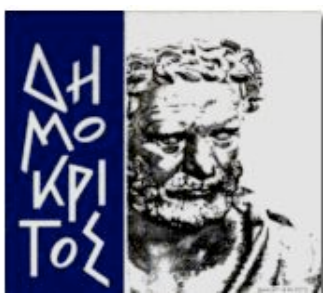

Sociedade Portuguesa de Inovação

Portugal

National Centre for Scientific

Research "Demokritos"

Grecia

En el proyecto e-Vita se pretendía explorar las positiblidades de los juegos series para un aprendizaje intergeneracional. Partiendo de historias que los mayores habrían vivido durante una época en la que no existía aún la Unión Europea, durante la Gerra Fria o otros escenarios, los estudiantes jóvenes podrían jugar y simular situaciones en las que deberían tomar decisiones, conseguir metas, o conseguir puntos. Se produjeron 4 tipos de juegos: experiencial, pregunta-respuesta, narrativo y exploratorio. Al producir 4 tipos de juego, se pretendía de este modo evaluar cual de ellos tenia mejor aceptación y potencial para la educación y aprendizaje intergeneracional.

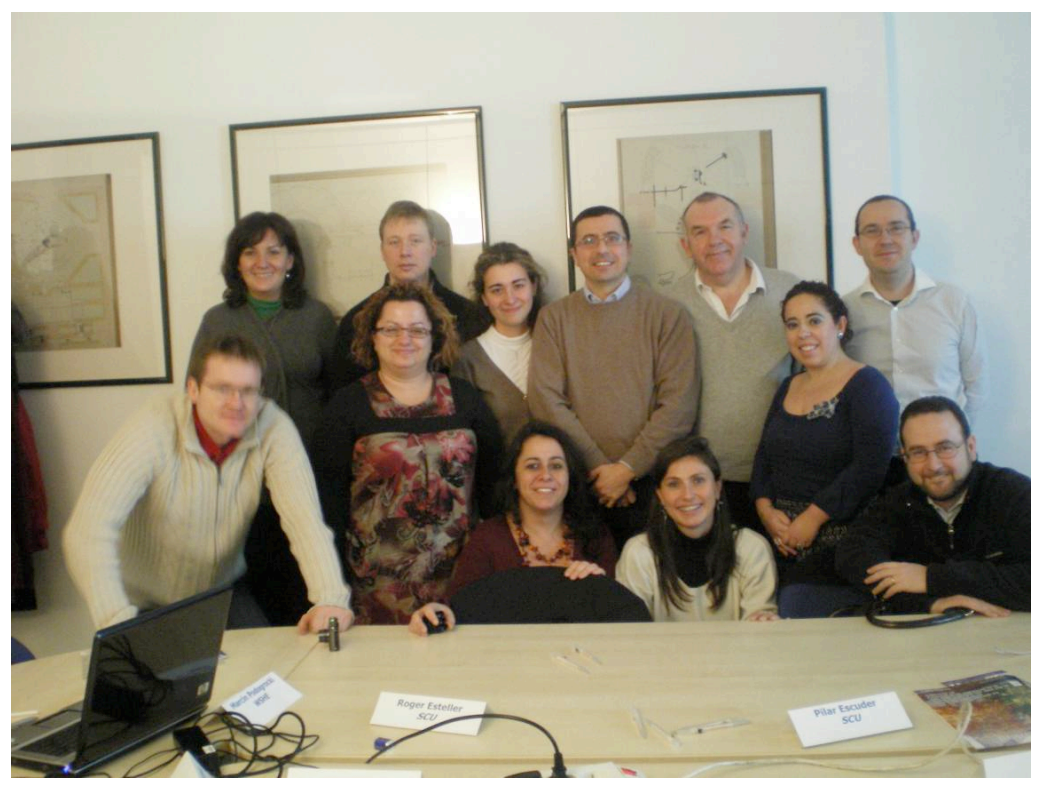

Reunión del proyecto en Milan, 8/1/2009 


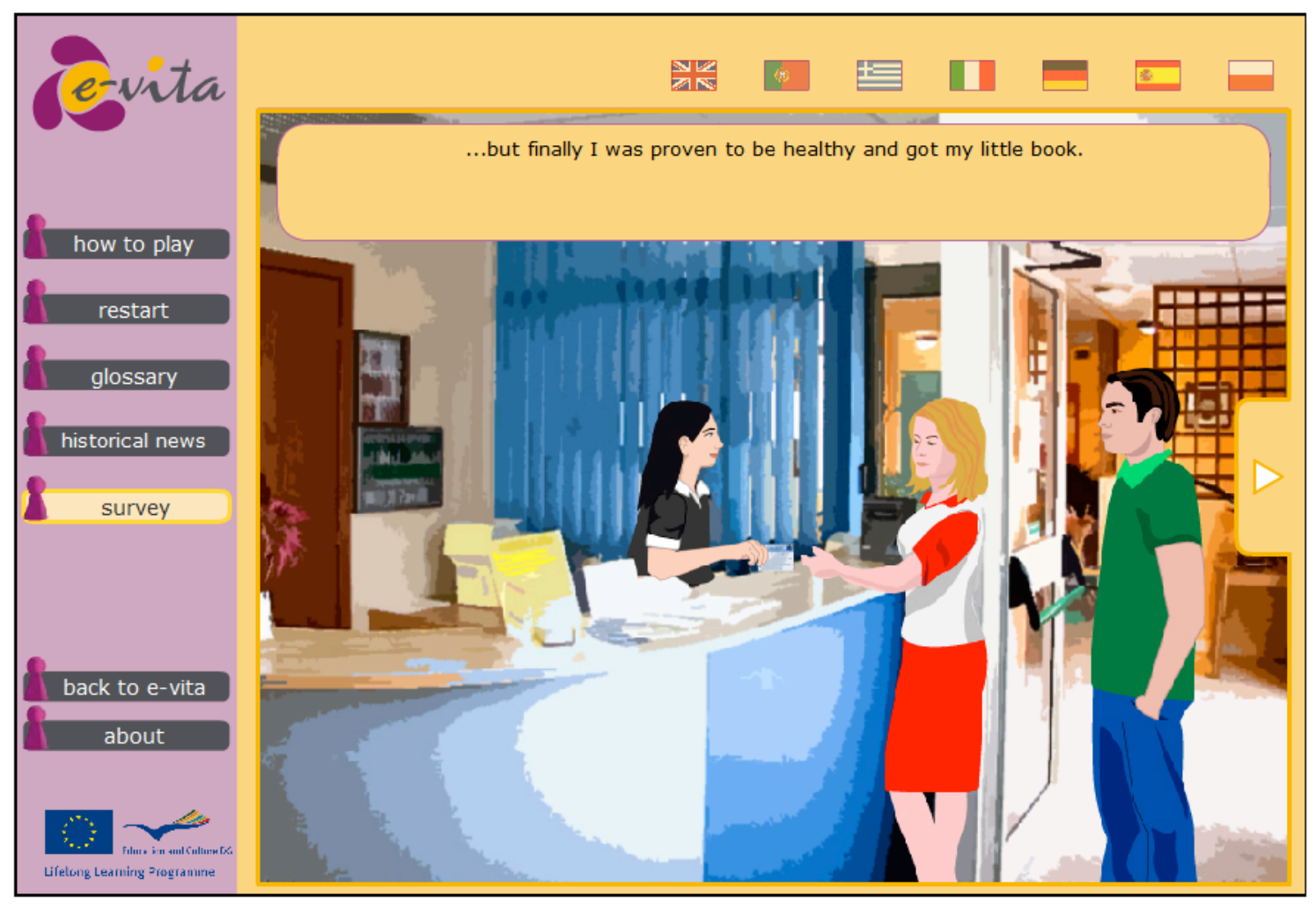

Captura de pantalla del juego

Además de la participación en el proyecto y la producción de los Deliverables, los resultados fueron publicados en:

- The use of communities of practise to créate stories for serious games Experiences of the European roject E-Vita. P.Escuder, R. Esteller, J. Segura. En la conferencia EDEN 2010 "European Distance and E-Learning Network" 9-12 de junio de 2010, Valencia, proceedings publicados EDEN 2010 ISBN 978-963-069429-2 


\section{SENIORSKS}

\section{seniors in the knowledge society}

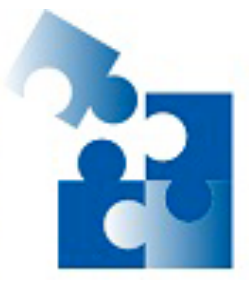

Logotipo del proyecto
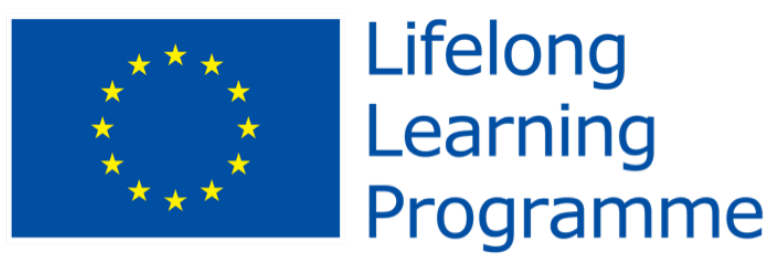

Este proyecto se financió gracias al Programa de Aprendizaje Permanente de la

\section{Unión Europea}

Coordinado por la Universitat Jaume I, y formado por un total de 10 socios, con una duración de septiembre de agosto 2012 a julio de 2013, página web seniorsk.eu, con título "Seniors in the Knowledge Society" y los siguientes socios:

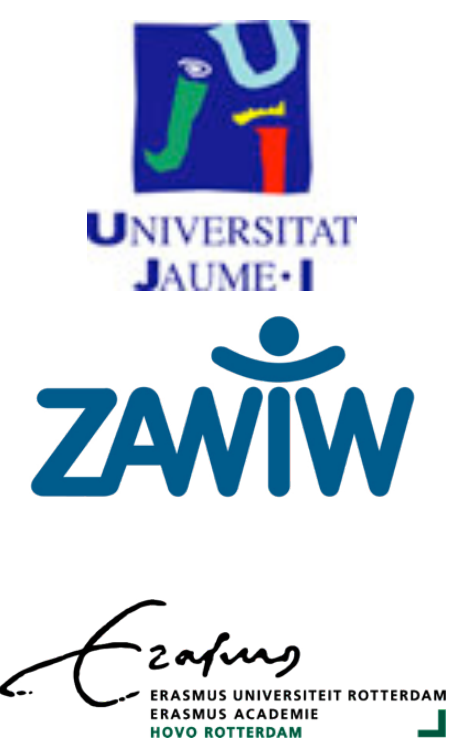

Universitat Jaume I

España

coordinador

Centre for General Scientific Continuing Education (ZAWiW) of Ulm University Alemania

Erasmus Universiteit Rotterdam

Holanda 


\section{Uni}

Graz
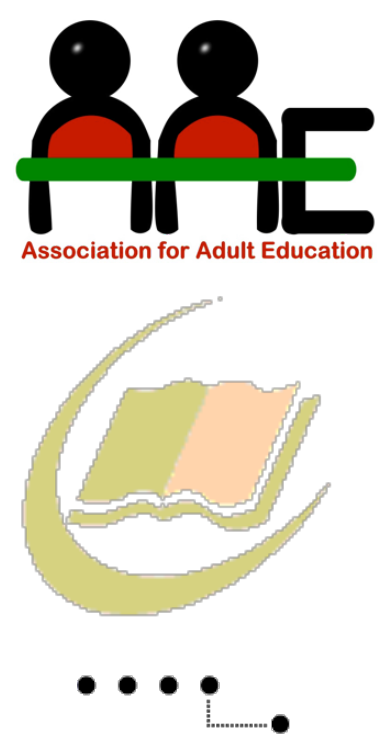

Bern University of Applied Sciences

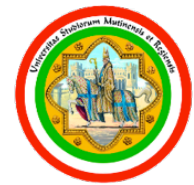

UNIVERSITÀ DEGLI STUDI DI MODENA E REGGIO EMILIA

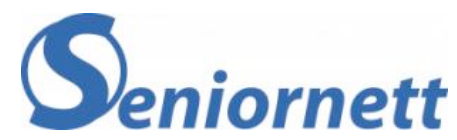

Czech University of Life Sciences Prague República Checa

Graz Department for Generational Issues Austria

Hellenic Association for Adult Education Grecia

Centre for Continuing Education at the Technical University in Zvolen

Slovakia

University of Applied Sciences, Suiza

University of Modena and Reggio Emilia Italia

\section{Seniornett Norge \\ Noruega}

El principal objetivo de este proyecto fue evolucioanr en el concepto de adopción de la tecnología por los mayores mediante actividades eductivas, hacia el de la inclusión de los mayores en la sociedad del conocimiento a través de actividades de diferente tipo. Cada uno de los socios trabajaba en uno de los aspectos que puede favorecer la inclusión digital del mayor publicándose una guía para instituciones educativas para promover esta inclusión. 
Los siguientes fueron los resultados más destacados:

- Seniors in the Knowledge Society: context, practises and innovation. R. EstellerCurto, P.Escuder Mollon (editores). "Seniors in the Knowledge Society" Grundtvig Learning Partnership. Castellón, Universitat Jaume I

- The virtuous circle of use, attitude, experience and e-inclusion. Roger EstellerCurto, Pilar Escuder-Mollon, Raul Marin. Journal Paper eLearningPapers. eLearningEuropa | Issue 29, 2012, ISSN 1887-1542

- Non-practical ICT courses for seniors for a comprehensive involvement to provide a global understanding of the Knowledge Society. Roger Esteller-Curto, Pilar Escuder-Mollon. Journal Paper 4th World Conference on Educational Sciences. Barcelona, Spain February 2012, Procedia-Social and Behavioral Sciences Journal, volumen 46, pp 2339-2346, ISSN 2356-2361. 


\section{EDUSENIOR}

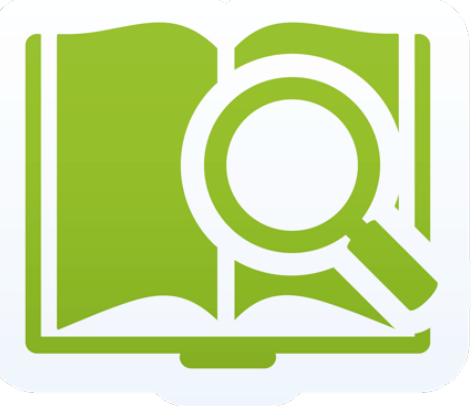

Lototipo del proyecto EduSenior

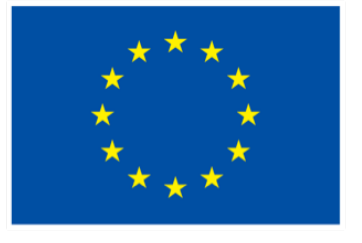

Lifelong

Learning Programme

Este proyecto se financió gracias al Programa de Aprendizaje Permanente de la

\section{Unión Europea}

Coordinado por la Universitat Jaume I, del tipo Grundtvig dentro del Programa de Aprendizaje permanente de la Unión Europea y formado por un total de 7 socios, con una duración de octubre de 2012, a enero de 2014, página web: activeict.uji.es, con título "Evaluation toolkit on seniors education to improve their quality of life" y los siguientes socios

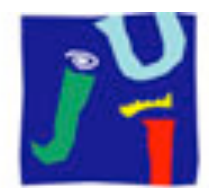

Universitat Jaume I

coordinador

UNIVERSITAT

JAUME・I 


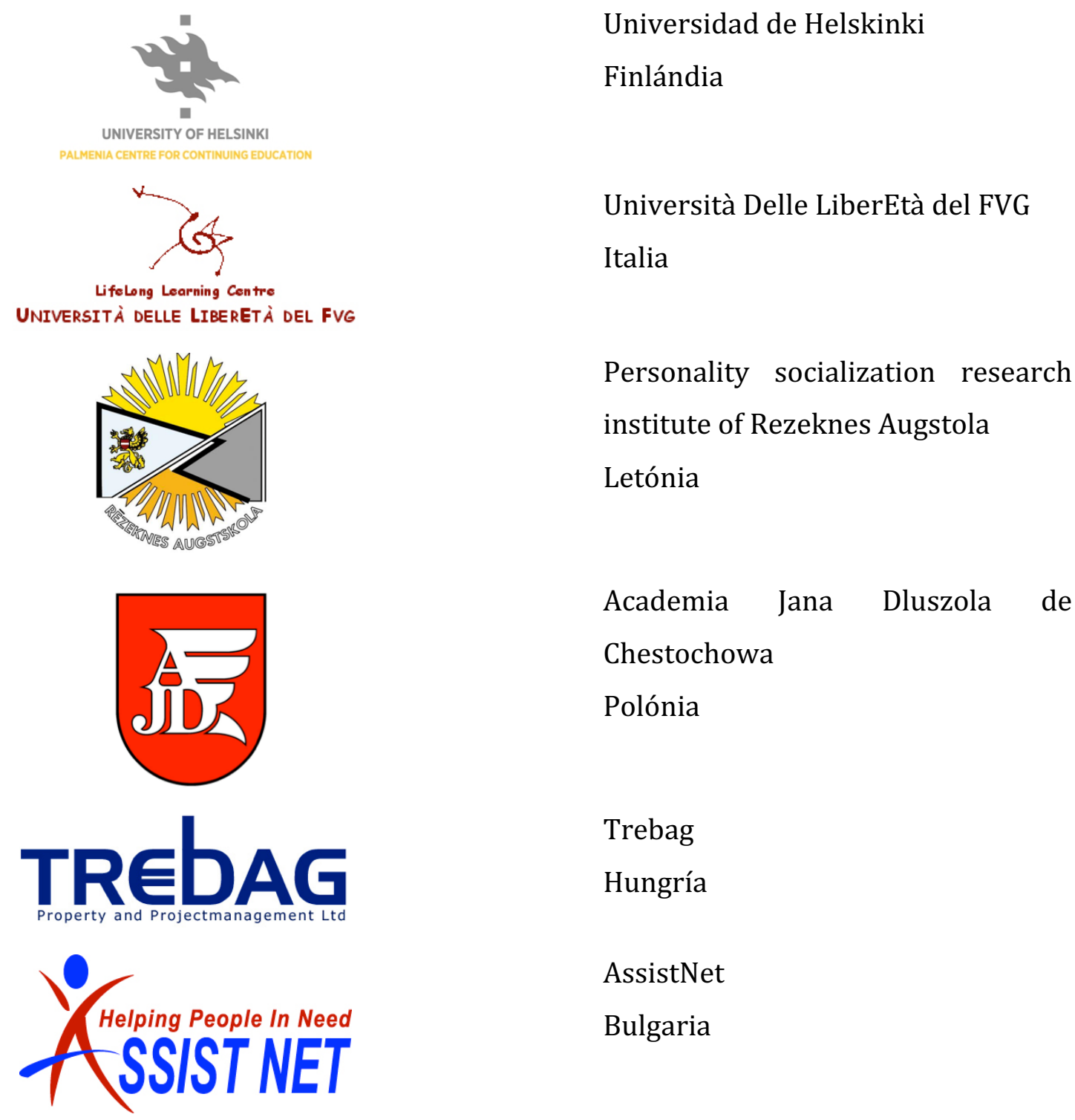

El propósito del proyecto fue investigar la relación existente entre una oferta educativa y la calidad de vida de las personas mayores, proponiendo un modelo educativo, contenido y pedagogía adecuada para que otras instituciones pudieran adoptar una enseñanza diseñada a personas mayores, junto con una herramienta de evaluación. 


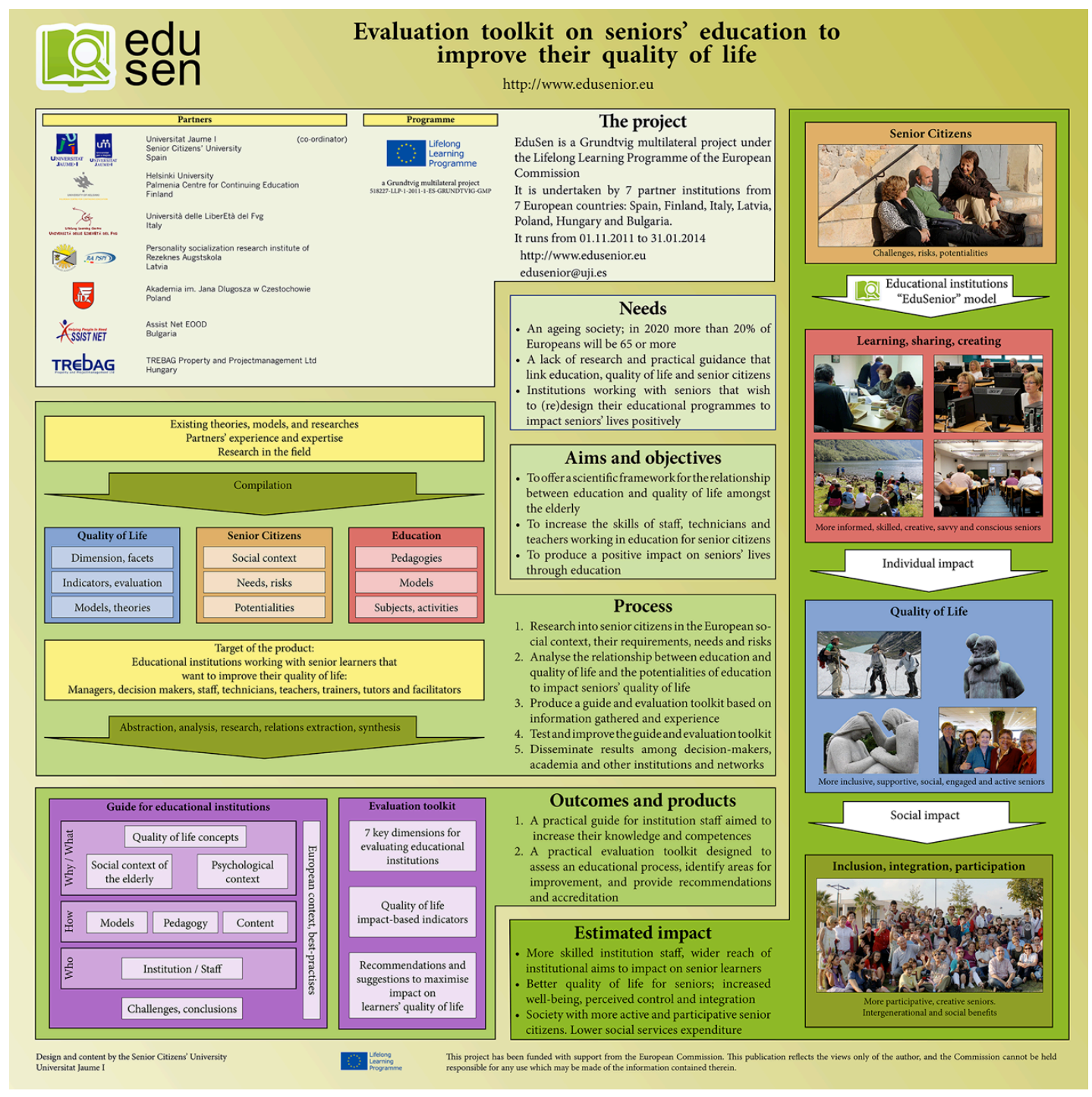

Poster-resumen del proyecto

Resultado de este proyecto se publicaron dos manuales:

- Education and quality of life of senior citizens, editores (por orden) Pilar Escuder-Mollon, Salvador Cabedo, publicación conjunta por la Universidad Jaume I (ISBN: 978-84-8021-986-0 e ISBN ejemplar digital 978-84-697-01096) y por la Universidad de Helsinky ( ISBN: 978-952-10-7760-9 e ISBN ejemplar digital 978-952-10-7761-6)

- Evaluation toolkit for educational institutions. Increasing impact on senior learners' quality of life. Coordinadores (por orden) Pilar Escuder-Mollon, Salvador Cabedo Publicacion conjunta de la Universitat Jaume I (ISBN: 978-848021-990-7, ISBN ejemplar digital 978-84-697-0101-0) y Rēzeknes 
Augstskola, ISBN: 978-9984-44-135-1 ISBN ejemplar digital 978-9984-44136-8)

De ambos manuales se realizaron copias en castellano, polaco, letón, húngaro, búlgaro e italiano

Y también se publicaron numerosos papers:

- Beyond quality assessment tools; potentialities of the QEduSen evaluation toolkit. Pilar Escuder-Mollon, Roger Esteller-Curto. 6th International conference on education, research and innovation, 18-20 de noviembre 2013, Sevilla, Proceedings ISBN: 978-84-616-3847-5 | Abstracts ISBN: 978-84-6163849-9

- QEduSen project; improving seniors' Quality of Life through education. Pilar Escuder-Mollon. International Scientific Conference Society, Integration, Education. Rezekne Higher Education Institution. Faculty of Pedagogy. Rezekne Augstskola. Mayo 2013, Rezekne, Letonia. Proceedings ISSN: 16915887

- Pedagogical Proposal to Increase the Quality of Life on Senior Citizens. Pilar Escuder-Mollon, Roger Esteller-Curto, Cecil Issakainen, Velta Lubkina, Slavina Lozanova 5th World Conference on Educational Sciences, Febrero 2013. Roma, Italia. Procedia-Social and Behavioral Sciences Journal, ISSN: 1877-0428

- Presentaicón del proyecto en la conferencia LINQ 2013; European conference in Learning innovations and quality, 16-17 de Mayo en Roma.

- A toolkit to evaluate the impact of an educational action to seniors' quality of life. Roger Esteller-Curto, Pilar Escuder-Mollon, Luis Ochoa. Presentado en: International Scientific Conference Society, Integration, Education Rezekne Higher Education Institution. Faculty of Pedagogy. Rezekne Augstskola. Mayo 2013, Rezekne, Latvia. Publicado en el libro de actas: ISSN 1691-5887 


\section{SENAPP}

\section{Sen App}

Logotipo del proyecto

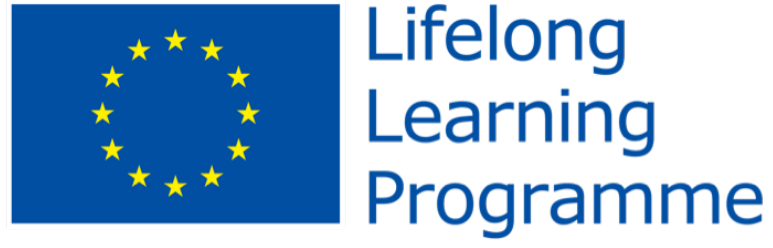

Este proyecto se financió gracias al Programa de Aprendizaje Permanente de la Unión Europea

Coordinado por la Universidad de de Erlangen-Nuremberg, por su instituto de innovación educativa, se trata de un proyecto Grundtvig del programa de Aprendizaje Permante de la Unión Europea, "Serniors learning with apps" of Adult Education Staff y formado por un total de 4 socios, desde enero de 2014 hasta marzo de 2016. La página web www.senapp.eu muestra las actividades y resultados más relevantes, los siguientes fueron los socios:

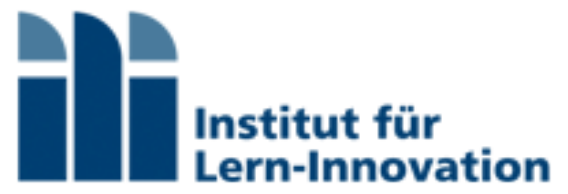

Instituto de innovación educativa, Universidad Erlangen-Nuremberg Alemania, Coordinador 


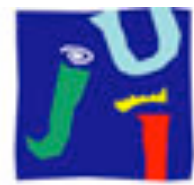

UNIVERSITAT

JAUME-I
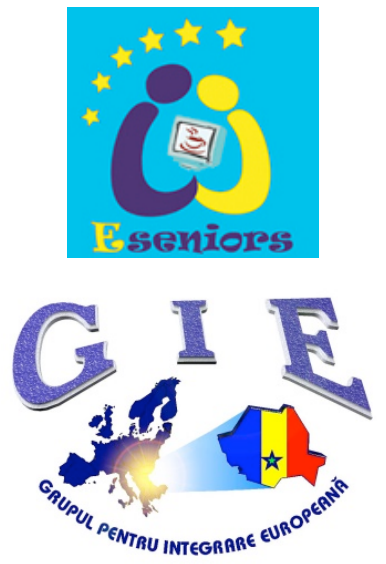

Universitat Jaume I

España

Asociación e-Seniors

Francia

Grupo para la ingración europea

Rumania

El objetivo de este proyecto fue el desarrollo de una aplicación (entorno on-line virtual) de aprendizaje para personas mayores para el aprendizaje de tablets. Para esto se desarrollaría una guía metodológica para instituciones educativas que desaran implantar este modelo, a la vez que un curso de tablets con 25 unidades lectivas que se utilizaría para testear la validez del método tecno-pedagógico usando tablets.

Resultado de este proyecto ha sido:

- Pedagogical and Tutoring Concpet (entregable 2). P. Escuder-Mollon, R.EstellerCurto, S. Hetzner y M.Zwanziger. disponible en http://www.senapp.eu/images/WP2-

D2.1_Pedagogical\%20and\%20tutoring\%20concept_final.pdf

- Seniors learning with apps; the tablet as a mean and end. P. Escuder-Mollon, S. Hetzner, A. Tenckhoff, R. Esteller-Curto, C. Escura-Forcada. Presentado en EDULEARN15 Barcelona Proceedings (7th International Conference on Education and New Learning Technologies), en julio de 2015. Publicado en los proceedings Pages 7613-7622, ISBN: 978-84-606-8243-1, ISSN: 2340-1117 


\section{EDUEVAL}
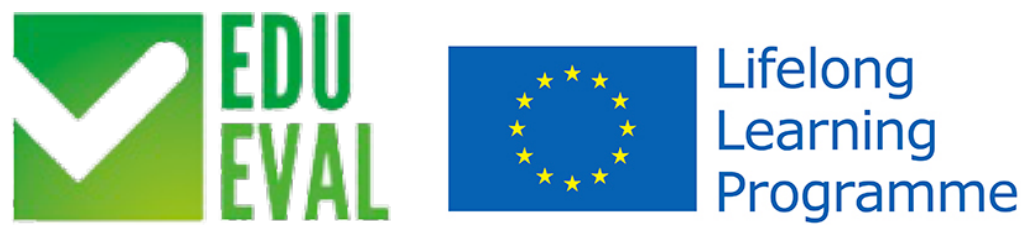

Logotipo del proyecto EduEval

Coordinado por la Universidad de Milan, se trata de un proyecto Grundtvig del programa de Aprendizaje Permante de la Unión Europea, "Evaluation for the Professional Development" of Adult Education Staff y formado por un total de 6 socios, desde enero de 2014 hasta febrero de 2016. La página web www.edueval.eu muestra las actividades y resultados más relevantes, los siguientes fueron los socios:
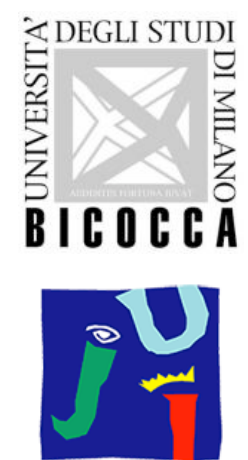

UNIVERSITAT

JAUME• I
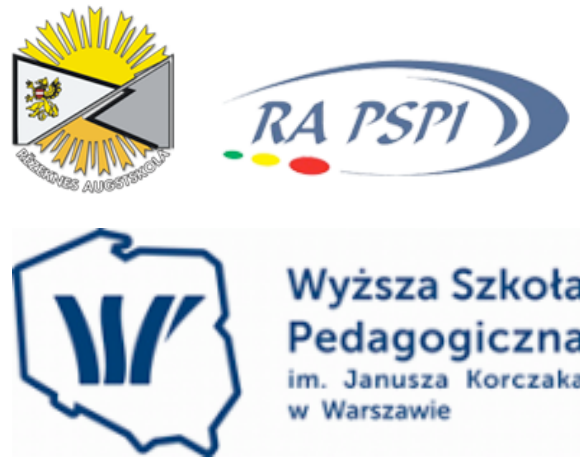

Wyższa Szkoła

Pedagogiczna

im. Janusza Korczaka w Warszawie
Universidad de Milan

Italia

Coordinador

Universitat Jaume I

España

Rezekne Academy of

Technologies

Letónia

Pedagogical University of

Warsaw

Polónia

Universidad de Bari

Italia 


\section{TEI of Crete}

Technological Educational Institute of Crete
Technological

Institute of Crete

Grecia

Educational

El principal objetivo de este proyecto era proporcionar a los profesionales de la educación de un curso, métodos y herramientas para que fueran capaces de realizar una evaluación de su centro educativo. No se pretendía una evaluación formal o que sirviera para la acreditación. El aspecto innovador de este proyecto radica en el hecho que la evaluación, realizada por personal interno, sirviera para la mejora de la calidad y aumento de la eficacia de las acciones del centro educativo.

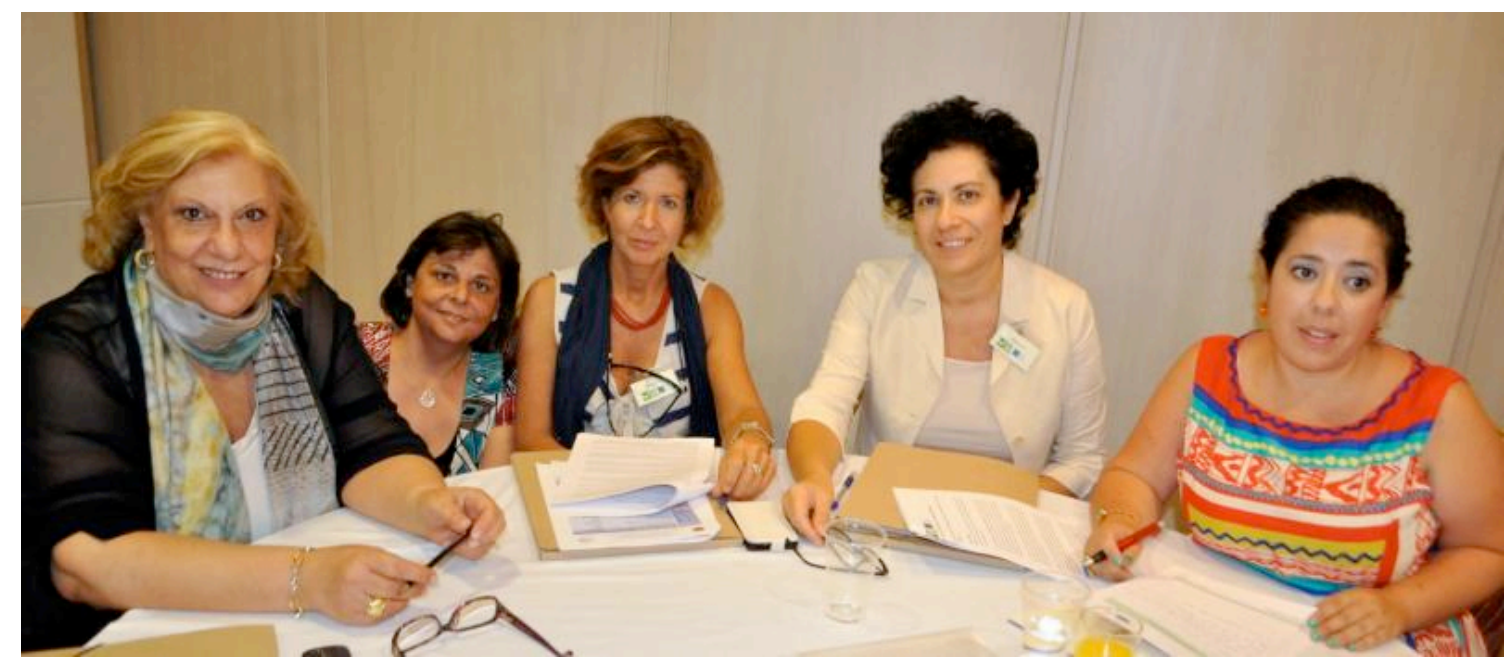

Grupo de trabajo durnate la reunión en Creta 14/07/2014

Las publicaciones relacionadas con este proyecto son:

- Capítulo "Indicators in an evaluation process" del libro "The Evaluation of Adult Education Staff" P.Escuder-Mollon, R.Esteller-Curto. Pensa Multimedia Editore, ISBN 978-88-6760-341-1

- Indicators for quality evaluation for the development of the staff in educational institutions. Pilar Escuder-Mollon, R.Esteller-Curto, E. Biffi, K. Koutra. Presentado en ICERI2015 8th International Conference of Education, Research and Innovation, 18-20 noviembre de 2015, Sevilla, Spain. Publicado en ICERI2015 proceedings, pp 1564-1568, ISBN: 978-84-608-2657-6, ISSN: 2340-1095 


\section{SG4ADULTS}

SG4ADULTS

Logotipo del proyecto

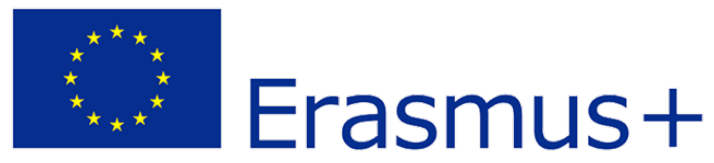

Programa bajo el que se enmarca el proyecto SG4Adults

Coordinado por el centro de formación de Amberes, se trata de un proyecto Erasmus+ KA2 espécifico para adultos "Serious Games for Entrepreneurship Skills", con un total de 6 socios, y de duración desde septiembre de 2014 , hasta agosto 2016. La página web www.sg4adults.eu muestra las actividades y resultados más relevantes, los siguientes fueron los socios:

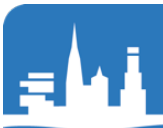

CVO Antwerpen

centrum voor volwassenenonderwijs

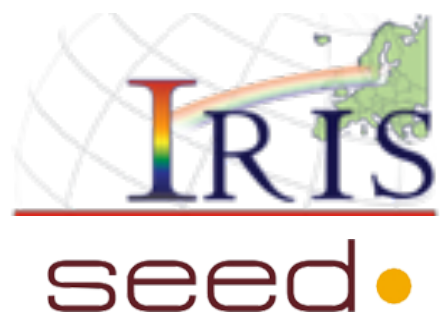

Centro de formación CVO Amberes

Bélgica. Coordinador

Centro de formaicón profesional IRIS

Grécia

Expertise for development, SEED

Suiza 


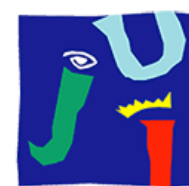

UNIVERSITAT

\section{JAUME•I}
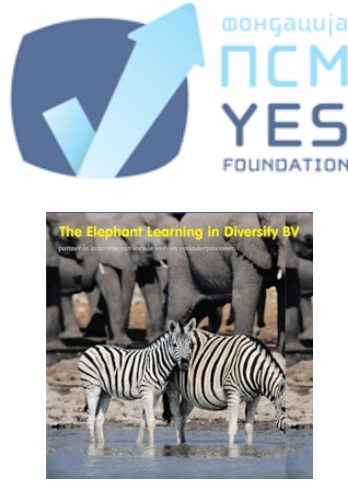

Universitat Jaume I

España

Youth Entrepreneurial Service

Macedonia

The Elephan: Aprendizaje en la

Diversidad

Holanda

El propósito de este proyecto fue el desarrollo de un juego de tablero para promover comptencias y aptitudes de emprendimiento, tales como liderazgo, pensamiento creativo, estrategia de equipo, competitividad, etc. Para ello se desarrolló el juego Bize-Bee

Tablero del Juego Biz-e-Bee

La Universitat Jaume I fue la responsable de las primeras fases de análisis de requisitos y de contextualización pedagógica Output "Needs Analyss Report" (disponible en http://www.sg4adults.eu/files/needs-analysis.pdf) y finalmente de la de prueba y testeo en estudiantes mayores, no para unas aptitudes de negocios, sino de emprendimiento en el sentido más general. 


\section{EHHLSA}

El EHHLSA es una asociación estratégica del programa europeo Erasmus+ con título "European home learning service for seniors association", coordinado por la universidad de Erlangen-Nuremberg, por su instituto de Innovación Educativa, formato por un total de 5 socios. Iniciado en septiembre de 2014 y finalización agosto 2017.
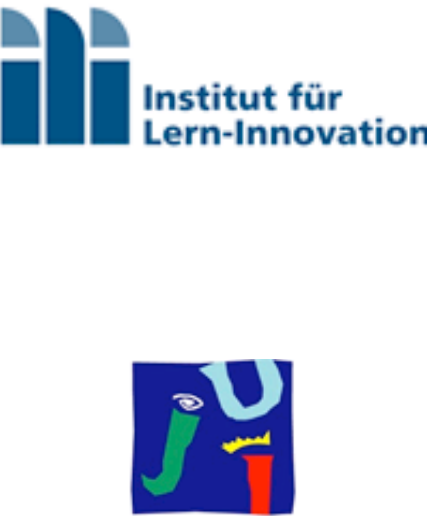

$\mathbf{U}_{\text {NIVERSITAT }}$

JAUME・I

Opetus ja ohjaus

DCU

Dublin City University

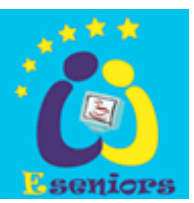

Universidad de Erlangen-

Nuremberg. Instituto de innovación en la educación. Alemania (coordinador)

Universidad Jaume I

España

Cooperative Teaching and Tutoring

Finlándia

Dublin City University

Irlanda

Asociación e-Seniors

París

El objetivo principal de este proyecto es desarrollar un programa marco y guía pedagógica dirigida a profesores de estudiantes mayroes para que puedan implantar sus cursos en entornos virtuales de aprendizaje. Se han creado 3 cursos on-line dirigidos a mayores para ser usados como laboratorios, probando de este modo la 
efectividad e impacto de la acción educativa propuesta. A la finalización del proyecto, se creará un modelo educativo on-line para mayores.

Hasta el momento, estos son los papers publicados en relación al proyecto:

- Seniors students in virtual spaces; the treasure within. Pilar Escuder-Mollon, J. Adell, S. Cabedo, A.M. Lipphard, R.Esteller-Curto, presentado en la conferencia ICERI2015 8th International Conference of Education, Research and Innovation, noviembre de 2015, publicado ICERI2015 Proceedings, página 1569-1571, ISBN: 978-84-608-2657-6, ISSN: 2340-109

- Senior citizens learning on-line; needs and expectations. P. Escuder-Mollon, A.M. Lipphardt. Presentado en INTED2017 11th International Technology, Education and Development Conference, 6-8 de marzo de 2017, Valencia. Publicado en INTED2017 Proceedings, páginas 10110-10116, ISBN: 978-84-617-8491-2, ISSN: 2340-1079.

- Virtual on-line learning; the evolution and grow of senior citizens. P. EscuderMollon, C. Fowley, R. Esteller-Curto, presentado en INTED2017 11th International Technology, Education and Development Conference, 6-8 de marzo de 2017, Valencia, Spain, publicado en INTED2017 Proceedings, pages 9541-9545, ISBN: 978-84-617-8491-2, ISSN: 2340-1079

Del 6-8 de marzo de 2017, en la conferencia 11th International Technology, Education and Development INTED 2017, P.Escuder-Mollon y R.Esteller Curto, fueron los organizadores de una sesión especial "Technology enhanced education to adults and seniors", por este motivo, de forma conjunta con otros investigadores se presentaron un total de 6 papers todos en la temática de los proyectos EHHLSA y EdWay 


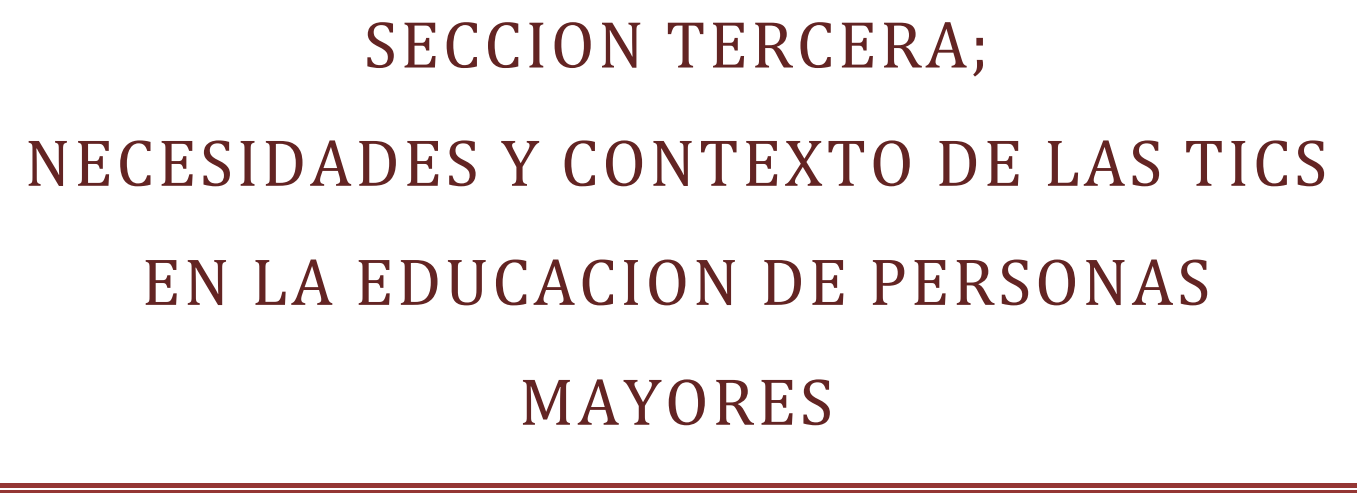


La educación en personas mayores difiere enormemente de la dirigida a personas jóvenes y adultas, en muchos aspectos, entre los que se encuentran (Knowles, Holton \& Swanson 2012):

- Objetivos. Comúnmente, en los jóvenes y adultos con propósito laboral existe la finalidad de consecución de un título o grado, capacitación profesional o certificación; esta motivación es extrínseca. En adultos mayores o mayores, los objetivos se dirigen a conseguir metas personales (curiosidad, interés), o otros propósitos transversales (sociabilización, adaptación) esta suele ser una motivación intrínseca.

- La experiencia en personas mayores es una característica que debe ser tenida en cuenta como potenciadora de la educación. Se promueve el uso de principios constructivistas, mediado por tecnologías de la información y comunicación.

- Responsabilidad, motivación y necesidad de ser los propios directores de su propio aprendizaje.

- Aplicación directa de las habilidades alcanzadas en aquello que necesitan

En esta sección se presentan diferentes papers en los que se realizan propuestas innovadoras en la educación de mayores, centrándose en la importancia, los retos, y el beneficio que tienen el uso de las nuevas tecnologías, teniendo como centro la persona mayores, para luego en secciones posteriores, se aborda el uso de las tecnologías como herramienta pedagógica.

De igual modo, en esta sección también se muestran los beneficios de esta educación en mayores, tanto en aspectos de integración, participación, bienestar y calidad de vida, de nuevo, el centro de atención es la persona mayor. En secciones posteriores se centrará el estudio de la calidad de vida con enfoques pedagógicos. 


\section{EL APRENDIZAJE PERMANTE DESDE EUROPA}

Autores (por orden de publicación):

P. Escuder-Mollon

Capítulo parte del libro "Jornadas de mayores y nuevas tecnologías". Salvador Cabedo Manuel (director), 2008. Publicacions de la Universitat Jaume. ISBN: 978-84-8021670-8, Castellón, Spain. 


\subsection{Motivación}

La sociedad del conocimiento, a la vez que otras tendencias globalizadoras y el impacto de las nuevas tecnologías de la sociedad de la información, plantean a los ciudadanos del siglo XXI tantos beneficios como retos. Ya que, para poder aprovechar estas oportunidades y participar activamente de la sociedad, no quedándonos excluidos o marginados de ella, es necesario adquirir continuamente conocimientos y aptitudes nuevas.

Porque, uno de los grandes peligros de esta "nueva" sociedad es el de crear mayores desigualdades, no tan solo entre generaciones, si no entre clases, géneros, etc. Por eso, es necesario el aprendizaje permanente, aquel que nos aporte las condiciones suficientes para asumir los nuevos retos.

No es este, un discurso nuevo, al comienzo del siglo XXI, los cambios y avances tecnológicos han hecho que desde los contextos culturales más referentes se trabaje por conseguir una sociedad de la información para todos/as.

Algunos datos, nos pueden ayudar a conocer el momento "tecnológicos de los mayores":

- Uno de cada diez mayores tiene en su casa un ordenador personal, frente al $30 \%$ del total de la población española.

- Solo el 7,5 \% de los que tienen PC suelen utilizarlo.

- España está en cuarto lugar por la cola, respecto a la Comunidad Europea, respecto a los recursos tecnológicos utilizados por los mayores de 50 años 


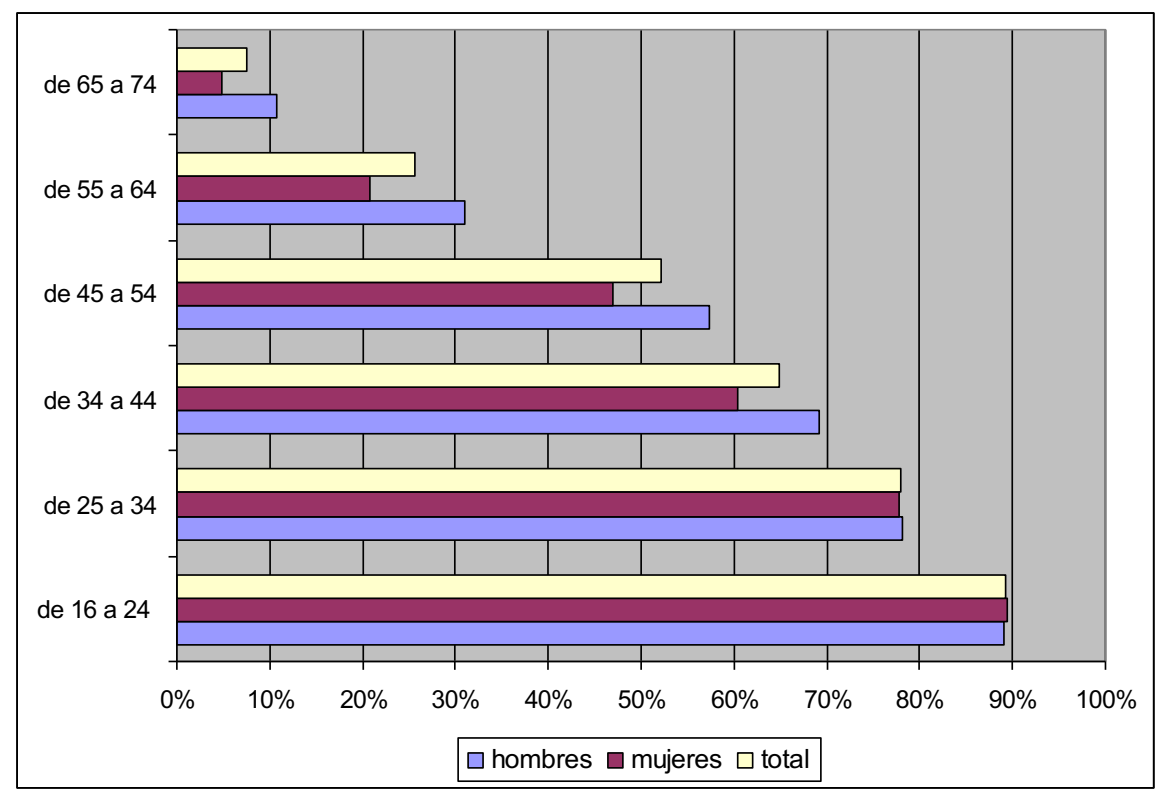

Grafico 1. Porcentaje de utilización de las nuevas tecnologías, por edades y sexos ${ }^{1}$

\section{El Aprendizaje Permanente desde Europa}

En el primer tratado de la Unión Económica Europea (Roma 1957) no aparece el concepto de educación, éste tratado predominan acciones prioritarias económicas e institucionales. Es en el tratado de la Unión Europea de Maastricht (1992) donde se introducen articulados referentes la educación (126 y 127), que se mantienen con escasos cambios en tratados posteriores (artículos 149 y 150 Amsterdam 1997 y Niza 2001). En todos estos tratados, la educación solo aparecía acompañada del objetivo de la formación y el empleo aunque en el preámbulo del tratado de Ámsterdam se dejaba entrever un propósito de educación más general

"promover el desarrollo del nivel de conocimiento más elevado posible para sus pueblos mediante un amplio acceso a la educación y mediante su continua actualización"

La comisión europea publicó en el $2000^{2}$ un memorando sobre el aprendizaje permanente con la finalidad de materializar una estrategia global en todos los estados

\footnotetext{
${ }^{1}$ Instituto Nacional de Estadística. Encuesta sobre Equipamiento y Uso de Tecnologías de la Información y Comunicación en los hogares 2007. Resumen de datos de Personas por sexo, características demográficas y tipo de uso de TIC

${ }^{2}$ Comisión de las Comunidades Europeas. "Memorando sobre el aprendizaje permanente" SEC (2000) 1832 de 30.10 .2000
} 
miembros que hiciera realidad el acceso universal y continuo al aprendizaje, y su participación de forma sostenida en la sociedad del conocimiento

En una decisión del $2001^{3}$, la Comisión añade el aspecto personal y social a la idea de "Aprendizaje Permanente":

"Toda actividad de aprendizaje realizada a lo largo de la vida con el objetivo de mejorar los conocimientos, las competencias y las aptitudes con una perspectiva personal, cívica, social o relacionada con el empleo"

El proceso de construcción de la Unión Europea se ha centrado, fundamentalmente, en medidas y en políticas de carácter económico, monetario e institucional, poniéndose de manifiesto una falta de iniciativas y de medidas políticas, sociales y culturales que posibilitasen la existencia de una Europa fuerte, potente y con capacidad real de influencia a todos los niveles.

Sólo el impulso de ciertas medidas pueden servir para institucionalizar una Europa Real. Las sucesivas declaraciones de la Sorbona (1998), de Bolonia (1999), de Praga (2001) o de Berlín (2003) están implicando un avance significativo con relación al objetivo anteriormente planteado y una apuesta decidida en la construcción del espacio europeo de enseñanza superior.

\subsection{Proyectos Grundtvig}

El programa Sócrates fue creado por la Decisión ${ }^{4}$ del Parlamento Europeo y el Consejo en 1995 por un periodo de 1995 a 1999.

El principal objetivo por el que se creó el programa Sócrates era contribuir al desarrollo de una enseñanza y una formación de calidad y de un espacio europeo

\footnotetext{
${ }^{3}$ Comisión de las Comunidades Europeas. Comunicación de la Comisión. Hacer realidad un espacio europeo del aprendizaje permanente. 2001. Comisión de las Comunidades Europeas. Bruselas 21.11.2001. Comunicación 20019678 final

${ }^{4}$ Diario Oficial, L 087 de 20.04.1995
} 
abierto de cooperación en materia de enseñanza. Esta primera fase, solo contemplaba 3 sub-programas;

- Enseñanza superior: Erasmus

- Enseñanza escolar: Comenius

- Acciones transversales: 1.idiomas (Lingua), 2. enseñanza abierta y a distancia y 3. Intercambio de información y de experiencias

La continuidad del programa Sócrates se basa en la Decisión ${ }^{5}$ del Parlamento Europeo y del Consejo en 1998 por un periodo del 2000 al 2004 (posteriormente se extendió hasta el 2006). Por primera vez, se reconoce la educación de personas adultas, que fueron incluidas en el sub-programa Grundtvig

El sub-programa Grundtvig se divide a su vez en 4 acciones, a resaltar la acción 1 y 2:

1. Proyectos de cooperación

2. Asociaciones de aprendizaje

En el periodo 2007-2013 el programa Sócrates pasa a llamarse "Programa de aprendizaje Permanente"6, el sub-programa Grundtvig se mantiene

\section{- Grundtvig 1: Proyectos de cooperación y cursos}

En los proyectos promovidos por Grundtvig 1 participan socios de un mínimo de tres países (con un promedio de seis) que elaboran productos y resultados innovadores para la educación de adultos europea en todas sus etapas: análisis de la demanda, asesoramiento, desarrollo de ofertas, concepción didáctica del material educativo y de autoaprendizaje, certificación del aprendizaje y aseguramiento global de la calidad. También puede concederse ayuda a programas de formación para personal docente y administrativo de la educación de adultos.

- Grundtvig 2: Asociaciones de aprendizaje

\footnotetext{
${ }^{5}$ Diario Oficial, C 314 de 13.10 .1998

6 Education, Audiovisual \& Culture Executive Agency. Programmes 2007-2013 http://eacea.ec.europa.eu/about/programmes2007_en.htm
} 
Las asociaciones de aprendizaje son pequeños proyectos de cooperación de centros de educación de adultos, principalmente locales, de al menos tres Estados europeos.

Sus componentes principales son los intercambios europeos en diferentes campos temáticos y la colaboración activa de los propios alumnos adultos en los proyectos. Mediante procedimientos simplificados de solicitud, gestión y selección se facilita el acceso a estos proyectos

\section{3 ¿Por qué Grundtvig?}

Nikolai Frederik Severin Grundtvig fue un escritor, religioso y pedagogo danés que en el siglo XIX pionero en la tradición del aprendizaje permanente. Muy en línea con los objetivos del aprendizaje a lo largo de toda la vida, su obra Memorandum sobre este tema sigue estando de gran actualidad. Para Grundtvig cada persona debe poder acceder en cualquier etapa de su ciclo vital a una educación de calidad que tiene que ofrecerle, además de conocimientos, educación cívica y contribuir a su desarrollo como persona.

Afirmaba que los libros no solo son para los intelectuales y que cualquier persona debía tener derecho a la educación y participación en la vida pública. La educación no debe ser impartida sólo para adquirir conceptos, sino también responsabilidad cívica y realización personal y cultural

\subsection{Proyecto "ICT50+"}

El proyecto "Information and communication technology empowerment for fiftyyear-olds +" es una asociación de aprendizaje que se inició en agosto del 2005 y que finalizó en el julio de 2007. 
La Universitat per a Majors fué la coordinadora, y junto con 5 universidades e instituciones, se pretendía el compartir conocimientos relacionados con la enseñanza de las nuevas tecnologías a personas mayores. Más exactamente, los objetivos fueron;

- Compartir prácticas acerca de la educación de TIC para los mayores.

- Recolección de métodos y didácticas para el (re)diseño de cursos orientados a la mejora de las aptitudes y habilidades de las TIC a los mayores de 50 años, de esta forma, que tengan mayor control sobre los factores que influencian sus vidas.

La motivación para la realización de este proyecto fue clara; observar otros sistemas de enseñanza de nuevas tecnologías a personas mayores, sistemas de educación formar, no formal e informal, otras actividades y sistemas de motivación y aprendizaje. En definitiva estamos hablando de un proyecto en el que la principal misión es compartir experiencias, por eso el trabajo durante los dos años se dividió en dos fases;

- Durante la primera fase (1r año) se pretendió que cada organización conociera a las demás. Estaba claro que se trataba de organizaciones diferentes y aunque enfocadas a las nuevas tecnologías y mayores, cada una perseguía unos objetivos mediante metodologías diferentes;

○ Educación no formal y mediante el uso de voluntarios

○ Formación orientada especialmente a las mueres

- Nuevas tecnologías para la creación de grupos sociales en zonas rurales

○ Enseñanza de nuevas tecnologías en asociaciones de la tercera edad

Diferentes objetivos y diferentes entornos permitieron una transferencia de procesos innovadores mayor. Notese además, que una de las prioridades de la Comisión Europea es que no se unan en estos grupos de aprendizaje instituciones idénticas.

- Durante el segundo año, cada una de las instituciones realizó una actividad. Esta actividad podía ser o bien un curso, un proceso o una investigación siempre de los fines de cada una de las instituciones y con los medios 
disponibles. La realización de esta actividad, aunque realizada de forma individual por cada institución debía ser planificada y evaluada dentro del proyecto. Gracias a este trabajo compartido se cumplía otro objetivo de las asociaciones de aprendizaje; cada una de las instituciones podia aportar sus conocimientos y experiencia para lograr que la actividad alcanzara los objetivos marcados.

La principal actividad a realizar fué la realización de una clase virtual. Dados los medios requeridos no todas las instituciones pudieron implementarla, en su lugar realizaron otras actividades orientadas a la comunicación en zonas rurales de personas discapacitadas o de investigación respecto a las diferencias pedagógicas en personas mayores

De forma adicional, también los alumnos pudieron participar, aportando su punto de vista, experiencias e incluso participando activamente mediante la realización de artículos. Así como en otras areas de actuación, la unión europea promueve la mobilidad de estudiantes jóvenes (p.ej. erasmus) en el caso de los mayores no es una excepción. Por tanto, la participación de mayores también formó parte desde un principio.

La Universitat per a Majors dentro de este marco realizó la actividad propuesta: fue la clase pilo on-line virtual realizada el 01/02/2007

Esta experiencia piloto solo contemplaba una clase ( $1 \mathrm{~h}$ aprox. de duración) pero fue un laboratorio perfecto, de lo que una clase virtual debería ser, lo que fue y cuales serian las propuestas para una posterior prueba.

Se parte de que la relación entre el profesor y el estudiante, y entre los mismos estudiantes es irremplazable, no obstante, el objetivo de esta prueba piloto fue crear el entorno y espacio adecuado donde el estudiante y el profesor se sintieran cómodos y de esta forma poder contribuir a un proceso educativo satisfactorio. Considerando todas las ventajas que las clases presénciales ofrecen, se intentó simular esta situación en una clase virtual:

- El profesor debía ser visto y oído, de tal forma que los estudiantes tuvieran contacto visual 
- La tecnología debía permitir retroalimentación de los estudiantes hacia el profesor (intentando que los estudiantes fueran vistos y oídos por el profesor)

- Los estudiantes no se deberían sentir solos; los estudiantes forman un grupo y debería ser posible compartir ideas y establecer vínculos

La prueba fue realizada con 80 estudiantes, divididos en diferentes escenarios: grupos de estudiantes en dos clases, grupos reducidos, individuales y otros estudiantes. Estos tres grupos previos estaban controlados y se les efectuaron evaluaciones, más estudiantes asistieron desde clase

Los resultados destacables de esta clase virtual fueron los siguientes

- 37 estudiantes dos clases, 14 estudiantes en grupos, 29 estudiantes de forma individual

- $72 \%$ opinó que poder ver a los demás estudiantes era importante o muy importante

- $74 \%$ se sintió integrado o muy integrado

- Ante la pregunta si le gustaría asistir a otra clase de este tipo, un $89 \%$ respondió que si. un 100 \% de los estudiantes individuales, contestó que si

- Comparado con una clase normal, esta clase virtual fue $14 \%$ mejor, $37.5 \%$ igual

- $48 \%$ oyeron al profesor bien la clase entera, un $35 \%$ intermitentemente

- $45 \%$ consideran que la visibilidad de la pantalla es buena, un $38 \%$ intermitentemente

- un $80 \%$ de los estudiantes afirmaron que las condiciones de esta clase virtual son buenas para el aprendizaje. Un $95 \%$ de los estudiantes individuales contestaron afirmativamente

A resaltar, que hubo problemas de conexión debido al proveedor de servicios de Internet en la sede de Vinaroz, no obstante estas dificultades, los resultados son muy positivos. 
Las conclusiones de esta experiencia son:

- El profesor debe ser conocedor de las nuevas formas de tener retroalimentación. El lenguaje corporal se limita enormemente y el/la profesora debe usar sustitutos. Este nuevo sistema de enseñanza debe ser aprendido y practicado. Nuevos conceptos pedagógicos deben ser considerados (pragmática, retroalimentación, participación). La tecnología roba posibilidades pedagógicas, pero puede ofrecer otros.

- Los estudiantes que asistieron desde las clases, sintieron como si el profesor les hubiera sido robado, ya que normalmente en las aulas, el profesor aparece en carne y hueso. Para los estudiantes desde casa, fue como un regalo ya que no podían imaginarse la situación de recibir una clase desde la misma clase. Adicionalmente, los estudiantes que se encontraban en las dos clases se distrajeron debido al montaje tecnológico que se instaló. Después de la experiencia y de la evaluación, la mayoría de estudiantes se sintió cómodo y remitiría la experiencia, aunque no lo considera un sustituto para las clases presénciales

- La herramienta y tecnología debe ser mejorada; una forma de levantar la mano, chats, alguna forma de señalar las diapositivas, etc. Aunque la herramienta no es compleja, los estudiantes deben tener conexión a Internet y unos conocimientos básicos (informática e Internet) para asistir a la clase.

- Se hace necesaria la participación de un dinamizador. El contacto humano es irremplazable y los estudiantes no deben sentirse solos ni aislados. El dinamizador puede estar en las clases y motivarles para la participación y posterior debate. Sin un dinamizador, seria muy difícil alcanzar todos los objetivos que un proceso educacional integral requiere

- Una clase virtual puede ser grabada y reproducida infinidad de veces, puede alcanzar a más estudiantes y repetirse cuantas veces haga falta. Adicionalmente las clases virtuales de este tipo ofrecen enormes ventajas para alumnos con discapacidades o que viven en zonas virtuales y que sin estas posibilidades técnicas no podrían asistir a clase. 
El desarrollo y conclusiones de esta experiencia fueron expuestos en el VI congreso europeo de la asociación internacional de geontologia y geriatria en San Petersbugo (5-8 julio, 2007)

Además de profesorado, investigadores y personal administrativo, es destacable la participación de los alumnos; un grupo de estudiantes participó de forma muy activa a lo largo del proyecto; 15 estudiantes en la reunión de Castellón, 3 en la reunión de Bergen y 5 en la reunión de Vinaroz. Su participación incluyo la realización de trabajos, exposición y discusión junto con el grupo de trabajo del proyecto.

Otros estudiantes participaron mediante la realización de actividades en los propios cursos de mayores de nuevas tecnologías. Otros muchos más se beneficiarán de forma directa en futuros cursos gracias a la experiencia adquirida a través de proyectos como este y que permiten que la docencia de nuevas tecnologías a personas mayores se haga con altos niveles de calidad e innovación.

\subsection{Proyecto "SenTrain"}

El proyecto "SenTrain; Train the Trainers" es un proyecto que se inició en agosto del 2005 y que finalizó en el diciembre de 2007. Se trata de un proyecto de cooperación coordinado por Friedrich-Alexander-Universität de Erlangen (Alemania). La universitat Jaume I formaba parte de un consorcio de otras 6 universidades e instituciones con el propósito de realizar un manual pedagógico y herramienta de certificación que serviría para capacitar a futuras personas mayores como voluntarios para el apoyo o realización de clases de nuevas tecnologías. Estos conceptos pedagógicos desarrollados deben ser tenidos en cuenta por cualquier profesor que pretenda dar clases a personas mayores. Al igual que para la enseñanza en colegios e institutos (adolescentes principalmente) existe el denominado "CAP" (Curso de adaptación pedagógica) podriamos equiparar el curso de SenTrain a un CAP pero para mayores 
Durante estos 29 meses, se realizó un trabajo de investigación, desarrollo y curso piloto.

La amplia experiencia en materia de educación en nuevas tecnologías a personas mayores de estas 7 instituciones permitió la realización del análisis y posterior desarrollo de los que serian los materiales didácticos. Estos materiales son el producto final del proyecto y su objetivo es servir de guía docente para cualquier persona interesada en impartir clases de nuevas tecnologías a personas mayores.

Las unidades didácticas son:

1. Evaluación de los conocimientos previos de los alumnos, de sus necesidades y del contexto de aprendizaje.

2. Pautas para la impartición de cursos

3. Estructuración del proceso de enseñanza/aprendizaje.

4. Presentación de los contenidos educativos

5. Motivación de los alumnos de la tercera edad

6. Comunicación efectiva

7. Retroalimentación, evaluación y autoevaluación

8. Aprendizaje y memoria en la tercera edad

9. Aspectos específicos de género

10. Enseñar con las tecnologías de la información y comunicación Este curso piloto se realizó la primera quincena de noviembre y contó con 20 estudiantes mayores

Los formadores voluntarios aprendieron que tres cosas son fundamentales:

- Conocimientos: Lógicamente, el formador ha de conocer y dominar la materia que va a impartir.

- Habilidades: El formador no sólo ha de contar con suficientes conocimientos sobre los contenidos del curso. También debe conocer cómo se desarrolla el proceso de enseñanza - aprendizaje y poseer habilidades y técnicas pedagógicas (técnicas de comunicación, motivación, planificación y organización del curso, técnicas de evaluación...) 
- Actitudes: como la asertividad, responsabilidad, motivación, flexibilidad... han de estar presentes en el formador. En el caso de las Nuevas Tecnologías nos parece además imprescindible, que los formadores voluntarios conozcan la visión de las mismas por parte de las personas mayores y los beneficios que pueden aportarles.

No pretendemos solamente que los alumnos reciban un curso puntual de Nuevas Tecnologías. Nuestro principal objetivo es que el alumno pierda el miedo y que comprenda de qué forma pueden influir las nuevas tecnologías en su vida y como esta puede mejorar.

\subsection{Impacto}

Tal y como se define en los objetivos de la Comisión Europea, las acciones Grundtvig se realizan con el objetivo de provocar un impacto en las organizaciones, profesionales y estudiantes siempre con el fin último de proporcionar a las personas adultas de posibilidades para mejorar sus conocimientos y capacidades para su mejor adaptación tanto al mundo laboral como a la sociedad.

El impacto que provocan estas acciones en cada una de las instituciones así como en la sociedad en general es difícil de cuantificar y de valorar. Existen referencias y datos que nos pueden ayudar en este proceso [MEC 2003]

En primer lugar, existe un impacto claro y directo que afecta directamente a la institución que participa en la asociación, el 90 \% de instituciones declararon que la imagen de la institución habia mejorado y en un $93 \%$ que había reforzado las perspectivas internacionales de trabajo de la institución

Respecto a la calidad del trabajo, un 60 \% calificaron como alta o muy alta la repercusión de la participación en la asociación en la calidad de la formación, es destacable no obstante que el $30 \%$ de instituciones afirmaron que era demasiado pronto para juzgar si había habido un impacto positivo. Finalmente, un $87 \%$ de 
instituciones afirmaron que participar en este tipo de proyectos les habia ofrecido una oportunidad para aprender buenas prácticas.

El impacto en el estudiante que ha participado en la asociación también es destacable, ya que desde la participación activa se produce desde una mayor comprensión intercultural y uso de las lenguas hasta mayor motivación

Por parte del personal, lo que más ha repercutido es el desarrollo del proyecto en si mismo y la adquisición de nuevas y deas y aptitudes.

Aún cuando los proyectos Grundtvig no han de estar necesariamente centrados en las tecnologías de la información y comunicación, la participación en este tipo de proyectos por parte de alumnado y profesorado, hace que su impacto tanto en el estudiante como personal sea muy elevado (77 \% de instituciones así lo admiten)

\subsection{Conclusiones}

Desde las diferentes instituciones tanto a nivel comunitario, nacional, regional o local se hecha en falta una referencia explícita y apoyo a la educación de personas adultas, más aún si buscamos leyes donde se refieran a la educación de personas mayores huyendo de referencias a la formación para el empleo.

La Comunidad Europea no incluyo la formación de adultos dentro de sus acciones hasta el año 2000, y en esta convocatoria (2000-2006), 7761 instituciones participaron en asociaciones de aprendizaje y se realizaron 455 proyectos de cooperación, redes grundtvig y seminarios temáticos ${ }^{7}$

Habiendo un total de 31 paises elebibles, resulta que de media hubo 35 instituciones por pais y año que participaron en asociaciones de aprendizaje.

Este tipo de proyectos debe siempre ser visto como la persona mayor el objetivo final y es que a él van dirigidos todos los recursos y esfuerzos. La educación para mayores

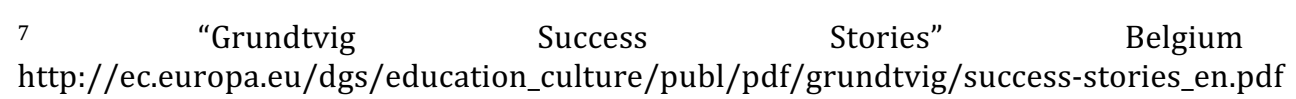

2007 
al igual que para los niños, adolescentes y adultos también merece la atención de las instituciones y organismos

Aún cuando el alumno es el principal objetivo, no nos olvidemos que el proceso educativo es algo mucho más complejo que una simple enseñanza de materias y hay que tener en cuenta un conjunto de aspectos humanos, sociales que van a influir en la metodología y didáctica. Las instituciones y personas que trabajan en este tipo de instituciones y como responsables de aplicar estos procesos también deben aprender. Se convierten pues en alumnos, que mediante las asociaciones de aprendizaje pueden aprender.

El siguiente paso a una asociación de aprendizaje seria la creación de proyectos de cooperación, donde se pasa del aprendizaje a la acción y ya se pretende crear productos innovadores

\subsection{Bibliografía}

[MEC 2003] Memoria 2001. Dirección general de educación, formación profesional e Innovación Educativa. Subdirección general de programas europeos. Ministerio de educación cultura y deporte. 2003

[COM] Página web de la Comisión Europea. http://ec.europa.eu/education/programmes/llp/index_en.html

[EACEA] Página web. "Education, Audiovisual \& Culture Executive Agency", Comisión Europea. http://eacea.ec.europa.eu/llp/index_en.htm

[AN] Pagina web. "Agencia Nacional Sócrates". Ministerio de Educación y ciencia: http://www.mec.es/programas-europeos

[EAC 2006] Educatin and Culture. "Adult education trends and issues in Europe",. European Commision. 2006 


\title{
17 SENIOR CITIZENS' LEARNING ON- LINE; NEEDS AND EXPECTATIONS
}

Autores (por orden de publicación)

P. Escuder-Mollon, A.M. Lipphardt

Presentado en: INTED2017 11th International Technology, Education and Development Conference, 6-8 de marzo de 2017, Valencia

Publicado en: INTED2017 Proceedings, páginas 10110-10116 ISBN: 978-84-6178491-2 ISSN: 2340-1079.

\begin{abstract}
Senior citizens access educational programmes because of personal aims and motivations, being one of the main important characteristic the face-to-face contact the sociabilization with classmates. Even that enormous advantages, educational institutions are increasingly offering virtual learning spaces to students to acquire competences and skills regardless of time and space. In the EHHLSA KA2 Erasmus+ project we analysed the expectations and interests of the senior citizens about virtual learning, and the preferred topics. We also wanted to know their preferred method for learning and if they had experience on ICT mediated education, we wanted to know their experience to conclude the best approach to offer an on-line learning activity.
\end{abstract}

Keywords: virtual learning, senior learners, pedagogy, e-learning, andragogy. 


\section{$17.1 \quad$ Background}

Virtual environments are being increasingly used, mainly for offering blended courses or completely on-line courses. On-line courses are a big opportunity to reach students that had difficulties of reaching the training centres because of distance or time restrictions. Also for institutions, it is a big opportunity, as on-line courses make possible to lower expenses, offer cheaper courses and wider the target population. Universities and other educational centres are offering the on-line courses for their formal courses. Other institutions offer non-formal courses open to the public, this is the case of edx.com, cursera, or any other generic MOOC platform. All this resources represent valuable opportunities to learn on a specific skill or competence. Mostly young adults and adults access those learning platforms, while senior citizens do not use ICT as youngers (at least statistically according to eurostats $95 \%$ for people 25 to $34,70 \%$ for people 55 to $64,49 \%$ for people 65 to 74 [1]).

Based on the analysis performed during the first phase of the EHLSSA project [2], the main reason that senior citizens argue to not access the on-line platforms is because they think that those are too difficult to use, they have not yet found a topic they are interested on or because their motivation are more focused on face-to-face learning environments where there exists a more social contact.

Any of the 3 reasons provided previously by the seniors could be accepted but that does not mean that the gap could not be overcome or at least, solved someway. This is also the purpose of the EHLSSA project and the aim of the Senior Citizens' University, of the Jaume-I University in Castellón.

The EHLSSA is a KA2 Erasmus+ Strategic partnership project (http://ehlssa.odl.org) coordinated by the University of Erlangen Nuremberg, the Institute for Innovation in Learning. This project intends to support and strengthen e-inclusion for seniors by offering new learning opportunities. Either in formal or informal settings, digital competences provide seniors skills that enhance individual empowerment and 
participation in society. In doing so, the project contributes to active ageing in later life. 3 on-line courses for senior learners are being developed, and also a pedagogical guide to transfer the practises to any institution that aims to create on-line courses focused to senior learners.

The Senior Citizens' University is the lifelong learning programme of the Jaume-I University, in Castellon. There, 954 students over 55 year old, attend to classes in the city campus and also in the rural areas. The subjects are mainly from the area of humanities, but also other from health, economy, sciences are part of the curricula that try that senior citizens become more adapted and capable in this always changing society. In this context, the main motivation to learn is mainly, personal, joined with the aim to meet other people with the same interest doing something useful and enjoyable. Finally, the senior citizens seemed not to get adapted to technology based learning environments because of technological gap on the adoption internet services and computers tools compared to youngers, affirming that those are difficult to use, and difficult to learn through them.

\subsection{Methodology}

Total of 187 surveys are valid, which also included an interview to the participants. As an introduction, the EHLSSA project was presented to the interviewees, then the aim of the survey was explained. The total number of responses can be seen in Figure 1

Figure 1. Surveys distributed to senior leaners

\begin{tabular}{|l|l|}
\hline Partners & Quantity \\
\hline ILI (DE) & 32 \\
\hline E-SENIORS (FR) & 18 \\
\hline DCU (IE) & 41 \\
\hline
\end{tabular}




\begin{tabular}{|l|l|}
\hline UJI (ES) & 68 \\
\hline PALMENIA (FI) & 28 \\
\hline
\end{tabular}

The distribution of ages can be observed in Figure .

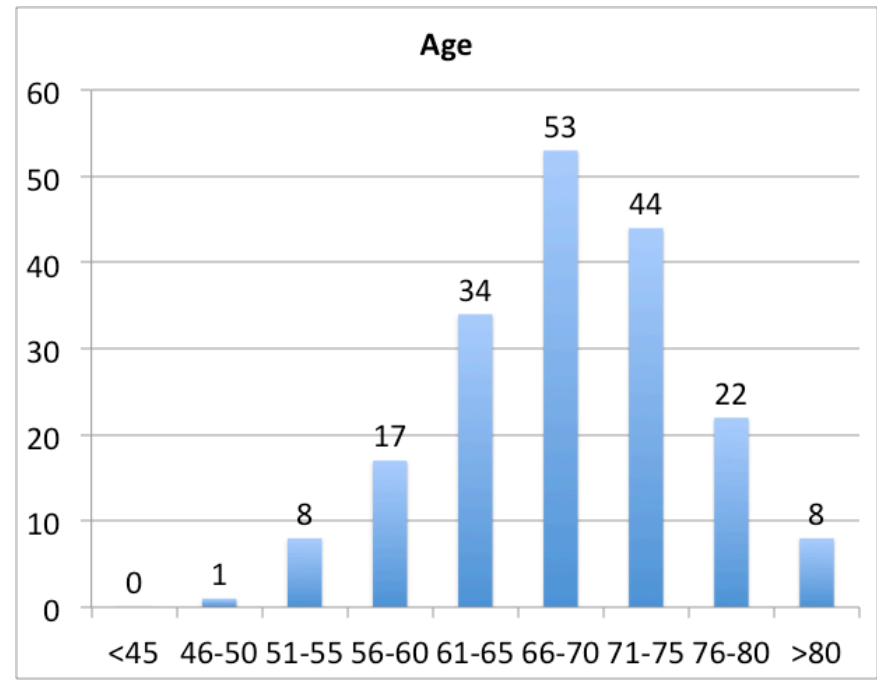

Figure 2. Distribution of ages

The questionnaire used and detailed numbers can be observed in the EHHLSA project website[2]. Here we only summarise the most significant conclusions. The group of responded was divided by none or low-ICT skilled seniors (average use 3 ore less hours per week) and others with ICT-experience (using more than 3 hours per week)

\subsection{Results}

Regarding the internet access and ICT interests very few people said that they are not capable to access Internet independently $12 \%$. The vast majority has a computer to access Internet, while tablets and smartphone is also high.

In the survey, senior citizens replied to two questions regarding the years they had been using computers and the frequency of computer usage nowadays. The average 
time they are using computers is $13,8(\sigma=7,9)$ years and the average hours per week they use the computer is $10,8(\sigma=8,9)$. 16 people did not answer this question without any reply, none of this value was considered, not even " 0 ".

As there is noticeably a high standard deviation values, the average of weekly hours of computer use cannot be considered representative for the general population of citizens above the age of 55. Even though it is true that the average hours of computer usage per week - regarding the interview participants - is $10,8,68 \%$ of the respondents access 10 or less hours per week, while $21 \%$ of these access 2 or less hours (included those that do not use computers at all, that is 11\%). Therefore, the level of adoption of the technology among senior citizens is small, as only $32 \%$ use internet more than 10 hours per week, which would be considered the minimum for a person, to have experience and practise in this tool. Below this quantity, it would be considered an occasional user.

About having a computer or tablet, and the capacity of accessing internet, the first result is that half of the respondants had a computer $(46 \%$ of the respondants said that had a computer and $20 \%$ said that had a tablet), and the other half, did not have a computer, so it would be expected that they do not access internet. However, only $9 \%$ said that they do not use computer at all, and $26 \%$ said that they access the internet 3 hours or less per week. So the first conclusion is that approximately $40 \%$ of the senior access Internet from other computers. $88 \%$ said that they can access Internet independently and $6 \%$ can access internet with help. Only $6 \%$ do not access the Internet at all. The reason for that was clarified within the following questions.

About the ICT topics they would like to know more, it seems that the preferred options are basic topics: surfing, searching, email, etc. It is interesting that at the same time those topics are the one that are complex and make them feel more insecure. Although surfing can be considered a basic skill, it becomes very complex when landing to strange pages, causing stressful situations: losing the control, feeling insecure, or even with the sense of losing privacy.

Having analysed the qualitative answers, it should be noted that seniors do not have difficulties to use a web searcher tool. What causes them problems is how to find something reliable and trustworthy. For this reason, the consortium suggests to focus 
on the topics related to awareness and capacity to distinguish dangerous pages in parallel when offering an introduction to surfing and searching for basic users. The approach would be then double: introduce the basic tools, while offering the necessary background and guided practise for the learners to increase their confidence.

The use of folders, files and the options of the file administrator (usually in Windows) cause a lot of troubles and stress: unable to find files, loosing data, etc. Seniors say that they spend a lot of time and also it is difficult to find somebody to help them.

Senior learners also have difficulties to understand certain tools or to know what to do in case of error, mistakes, or problems. Support here is a crucial part for seniors to increase their confidence and keep learning. While young people and adults tend to try to use Google to find solutions to their doubts, seniors seems to find difficulties on this, sometimes because of how the question is made, the technical language of the solution, the majority of times or the complexity of the page (ads, versions, complex terms...). The consortium proposes to offer to senior learners an environment where they feel comfortable and confident, where they can ask questions and help each other without fear.

The reason senior citizens want to use digital devices is mainly because they want to be up to date (curiosity, general need, to be able to control things). This is a very generalistic reason, but also senior citizens specify by justifying the need of communication, sharing things (images), and getting information and learning. Even buying or booking is also a reason, though it is not so common as the first-mentioned ones. Creativity or publishing is not among the reasons why seniors want to use digital devices, that means they still use the ICT as passive users (reading, communicating directly with know people) instead of active users (sharing with the world, writing...). Not being a topic on which seniors are interested, EHLSSA advises not to include it directly to the on-line course curriculums (to become a writer), but at least, explain how the internet makes possible active citizenship (sharing, communicating as a mass media...) that will make also increase the awareness and understanding of websites. 
The main topics senior citizens prefer to learn are ICT topics and sciences; secondly those subjects that are related to society and present facts (economy, ethics, media), finally the ones from the humanities area (as arts, history).

It has not been noted a main trend on the learners about the topic they most prefer. The qualitative answers are very broad and reach all the possible spectrum of science and hobbies. Languages is a topic they feel interested, but the consortium suggests not to focus on that, as it is very complex and because there are already a lot of (online) resources available to learn languages.

The main topics seniors with ICT experience (more than 10 hours usage a week) are interested in are (answer "yes, I want to know more"):

1. Surfing on the web (59\%)

2. Information seeking/Research (55\%)

3. E-Mail (45\%)

4. To $\mathrm{read} / \mathrm{see}$ videos, news, reports... (43\%)

5. Write texts using word processors $(43 \%)$

6. Organise photos $(42 \%)$

7. Google $+(34 \%)$

8. Shop or buy $(31 \%)$

Tools and services they do not know or in which they are not interested in are:

1. Domotics (26\%)

2. Self directed writing: Blog, wiki (21\%)

3. Cloud services $(21 \%)$

4. Google $+(20 \%)$

The most chosen topics seniors interested are (multiple options were possible):

1. Computer tools, internet services (40\%)

2. General science and technology (33\%)

3. Economics, current affairs, media insights (32\%)

4. Healthy lifestyle and physical activity (32\%)

5. Ethics and politics (32\%)

6. Philosophy $(30 \%)$ 
7. Cinema, literature, media discussion (30\%)

8. Ancient history (27\%)

9. Modern history (27\%)

10. Europe: significance, history and culture (27\%)

11. Genealogy $(27 \%)$

12. Writing workshop (27\%)

13. Stress, emotions and wellbeing $(25 \%)$

14. Psychology, personal development (24\%)

15. Citizens' rights and duties (23\%)

16. psycho-social changes of the elderly (23\%)

17. Changes of the information and knowledge society (22\%)

18. Music education (21\%)

19. Collaborative and creative tools (21\%)

20. Social networks $(20 \%)$

Seniors with ICT experience present following issues when dealing with computer tools and Internet services:

Loss of control: security and privacy, fearful of doing it incorrectly and loose data, as:

- Virus

- Website asking personal data

- Managing the Windows and file system

- Loosing data (documents, images)

- Psychological: frustration, stress, anxiety, mainly when data is lost, or it is not possible to know what happened

- Physical: vision problems, keyboard.

- Need of skills with positive attitude: difficulties on certain topics that could be learnt and acquired, usually searching or buying a guide

- Need of skills with negative attitude: too complex websites and tools, internet full of lies, and virus

- Even the barriers acknowledged previously, a huge quantity of learners did not have remarkable problems or barriers when dealing with computers, or some of them already were aware of the solution for their difficulties:

- Practise more, need more time 
- Write the steps better as it is very easy to forget things

- Request for help and assistance in certain topics

- To have a good teacher

- Some people did not had any experience at all on on-line learning (75 out of 187 repliers said that they did not have any experience), some still had a negative attitude (18 respondants), while the others simply were not capable to say if they would like or not (30). 28 respondents said that they have a positive attitude to try on-line learning.

- The explanations why many people had a negative attitude towards e-learning were mainly:

- Bad experience:

- Difficult to ask

- Too time demanding

- Technical difficulties that cannot be solved

- General answer: "it depends"

- Topics (better the ones more specific)

- ICT level required

- In case of senior citizens without ICT experience, we asked they would like to learn using a computer, and after that, if they would like to learn from home. They had the chance to add suggestions

- Senior learners provided suggestions about how on-line learning should be provide. The most important statements can be summarized as follows:

- Simply instructions

- Tutorial type

- Not too much text

- Videos, + interactive

- As a reference book

- Through tutors (not teachers)

- Lot of networking between participants

- Virtual teacher (visual contact)

- More freedom 
In the case of senior citizens with low ICT skills they preferred mainly the face-to-face teaching method, this was the case of 62 respondents (33\%), while 9 said they preferred the on-line way. The majority of the cases preferred a blended way, taking advantage of both methods and even mixing with other methodologies (as group learning, open discussion, etc.)

Considering only the senior citizens without ICT experience 19 out of 49 (39\%) preferred face-to-face teaching.

The reasons the seniors provided because they do not liked on-line learning was because following characteristics:

- Contact is lost with other classmates and the trainer

- It is difficult to work in groups or in pairs, chatting, discussing or participating in open discussions

- Difficult to learn practical subjects

- It is easy to feel alone and lost

Almost two third of the respondents said that they are interested in learning on-line.

The recommendations is that the on-line learning should be easy to follow. Others understood this on-line learning as a something mandatory in the present society, being an activity that everybody should use. This is therefore an external requirement. There is not an internal motivation to keep learning using an on-line environment, although to the direct questions (and general to all the respondants), 61 $\%$ answered they would be interested in on-line courses.

\subsection{Conclusions}

The main topics senior citizens prefer to learn are ICT topics and sciences; secondly those subjects that are related to society and present facts (economy, ethics, media), finally the ones from the humanities area (as arts, history). 
It has not been noted a main trend on the learners about the topic they most prefer. The qualitative answers are very broad and reach all the possible spectrum of science and hobbies. Languages is a topic they feel interested, but the consortium suggests not to focus on that, as it is very complex and because there are already a lot of (online) resources available to learn languages.

The EHLSSA suggestion is to create a course on the ICT topics, as it is one of the main interests of the senior learners.

For other subjects, the consortium suggests an interdisciplinary approach, finding a subject that could be seen from different perspectives.

- Provide tools to help seniors to understand (philosophy)

- Help seniors to understand present facts (media, economy, society) while linking with the past (history)

- Could apply in a practical the concepts learn to their own life

Focusing in one single area (as Philosophy, economy or phycology) or focusing in one topic (as cuisine, roman history, theatre...) could be risky, as some seniors could enjoy it a lot, while others feel a lack of interest. Elderly are very heterogeneous, instead of providing specific content, let's provide a new perspective they can explore from their personal life experience.

Offering a single topic from different perspectives, as far as possible (philosophy, history, sociology, economy, personal life...) increases also other transversal skills: analysis, understanding and abstraction. As said by some respondents, the chosen topic does not matter that much. It is more important that the course is well developed and implemented. The consortium suggests not to worry about the topic to choose too much, but select the subject also because of the potentiality when delivering the course, as EHLSSA could select a very interesting subject for the seniors, that later is very difficult to implement.

The seniors' experience when learning on-line differs greatly, there is a $50-50$ quantity of learners that had a good experience and bad. What is most feasible is a blended approach, with both methods of teaching. As it is not the aim of the project (EHLSSA aims at a completely virtual course), the consortium suggests that the on- 
line environment should implement the characteristics that senior learners most missed when learning on-line or found more difficulties while adding their suggestions:

Easy guidance and planning, as it is easy to get lost, or distracted; clear steps, easy to access resources.... It must be user friendly and with clear language, also adding tutors to follow the learning process.

Level separation, as it happens that some learners know a lot about the topic and the other learners get intimidated to participate.

Take advantage of networking between the learners, so they can support each other.

The main majority of the senior citizens said they would like to try an on-line course, but EHLSSA should accept the challenge carefully, trying to design an on-line course that fit their expectations. Otherwise it would be disappointing and loose the motivation for them to enroll again in other course.

\subsection{Acknowledments}

Part of this work has been produced in the framework of the project "European Home Learning Service for Seniors Association". This project has been funded with support from the European Commission. This communication reflects the views only of the author, and the Commission cannot be held responsible for any use which may be made of the information contained therein. Project reference: 2014-1-DE02-KA204001664, website: http://ehlssa.odl.org

\subsection{References}

[1] Eurostats (2016). Internet use in last 3 months EU27 
[2] EHLSSA. European Home Learning Service for Seniors Association. http://ehlssa.odl.org

[3] Petter, C., \& Helling, K. Designing ICT-based Learning Scenarios for Special Target Groups-Meeting Senior Learner Needs.

[4] Ala-Mutka, K. \& Punie, Y. (2007). Ageing Societies, Learning and ICT. eLearningpapers, 6.Retrieved, August, 18, 2008 http://publications.jrc.ec.europa.eu/repository/handle/JRC41179

[5] Escuder-Mollon, P., \& Esteller-Curto, R. (2013) Seniors in the Knowledge Society: context, practises and innovation.

[6] Esteller-Curto, R., Escuder-Mollon, P., \& Marin, R. (2012, July). The Virtuous Circle of Use, Attitude, Experience and Digital Inclusion. eLearning Papers, (29). Retrieved from http://www.openeducationeuropa.eu/en/article/The-VirtuousCircle-of-Use\%2C-Attitude\%2C-Experience-and-Digital-Inclusion 


\section{USO Y ACTITUD HACIA LA TICS EN LOS ESTUDIANTES DE LA UNIVERSITAT PER A MAJORS}

Autores (por orden de publicación):

P. Escuder-Mollon

Capítulo parte del libro "Aprendizaje y acceso a la red: la tecnología para los mayores. II jornadas de mayores y nuevas tecnologías". R. Esteller Curto, R. Marin-Prades (editores), 2008. Publicacions de la Universitat Jaume. ISBN: 978-84-8021-882-5 (ePub), 978-84-8021-854-2 (impreso) , Castellón, Spain.

\section{Abstract}

Según fuentes del INE, un $20 \%$ de las personas mayores de 55 años en el estado español, han accedido en los últimos 3 meses a Internet y tan sólo un 15 \% de forma habitual. Sin embargo los alumnos de la Universitat per a Majors, según una encuesta realizada en septiembre de 2011, alcanza el 75 \% de uso habitual de las TICs. Se trata por tanto de un grupo específico con un uso y actitud más predispuesta y positiva que la media nacional. En este contexto se pretende comprender y mostrar cuales son los perfiles, rasgos y características que posee este grupo específico con el objetivo de reconocer la relación que pudiera existir entre la pertenencia a una institución educativa formal: en este caso universitaria de personas mayores, como potenciadora mediante cursos, actividades y un entorno educativo adecuado en una predisposición positiva y una mayor motivación de las personas mayores hacia las nuevas tecnologías.

Palabras

clave:

nuevas

tecnologías,

uso,

mayores 


\subsection{La revolución gris}

\subsubsection{ADOPCIÓN DE LAS TECNOLOGÍAS DE LA INFORMACIÓN Y COMUNICACIÓN POR LOS MAYORES}

Del 26 al 6 de agosto de 1982 en Viena tuvo lugar la Asamblea Mundial sobre el Envejecimiento de la ONU (ONU 1983), en esta asamblea, se reconoció el hecho innegable de un incremento del envejecimiento general de la población mundial; las personas mayores serian un grupo cada vez más numeroso en proporción a otros grupos sociales. Las personas mayores debían tenerse en cuenta en políticas nacionales y mundiales, reconocerse su situación, derechos y el potencial que podían ofrecer para el progreso general de la humanidad. Fue a partir de asamblea que surgió el término "generación gris"8 y es usado ya ampliamente por publicaciones especializadas (p.ej. Cheung-Ming et al. 2007) para referirse a las personas mayores y haciendo referencia a "revolución gris" cuando quiere destacarse el cambio social que se está produciendo por el incremento proporcional de personas mayores.

En la figura 1 puede observarse la proyección de la evolución de la población por rango de edades, se puede observar como en el 2023, el número de personas mayores de 45 años superará a las menores de 45 . Además puede observarse que la proporción de personas mayores de 55 años irá creciendo progresivamente, hasta situarse en el $43 \%$. Estas previsiones vienen respaldadas por informes en donde se asume que la esperanza de vida será cada vez mayor gracias sobre todo a una mayor calidad de vida y aumento de las prestaciones sanitarias. Por tanto, no resulta en absoluto descabellado afirmar, que el grupo de personas jubiladas irá creciendo paulatinamente y sólo podría verse reducido por la tendencia existente de retrasar la edad de jubilación.

\footnotetext{
${ }^{8}$ La palabra "gris" (o en inglés grey o silver) es relativa al pelo de las personas que se vuelve gris conforme envejecen.
} 
De este modo, y según la figura 1, a medida que los años pasen, el capital social compuesto por las personas sin una actividad específica y obligatoria como seria el trabajo remunerado y con mucho más tiempo libre será cada vez mayor.

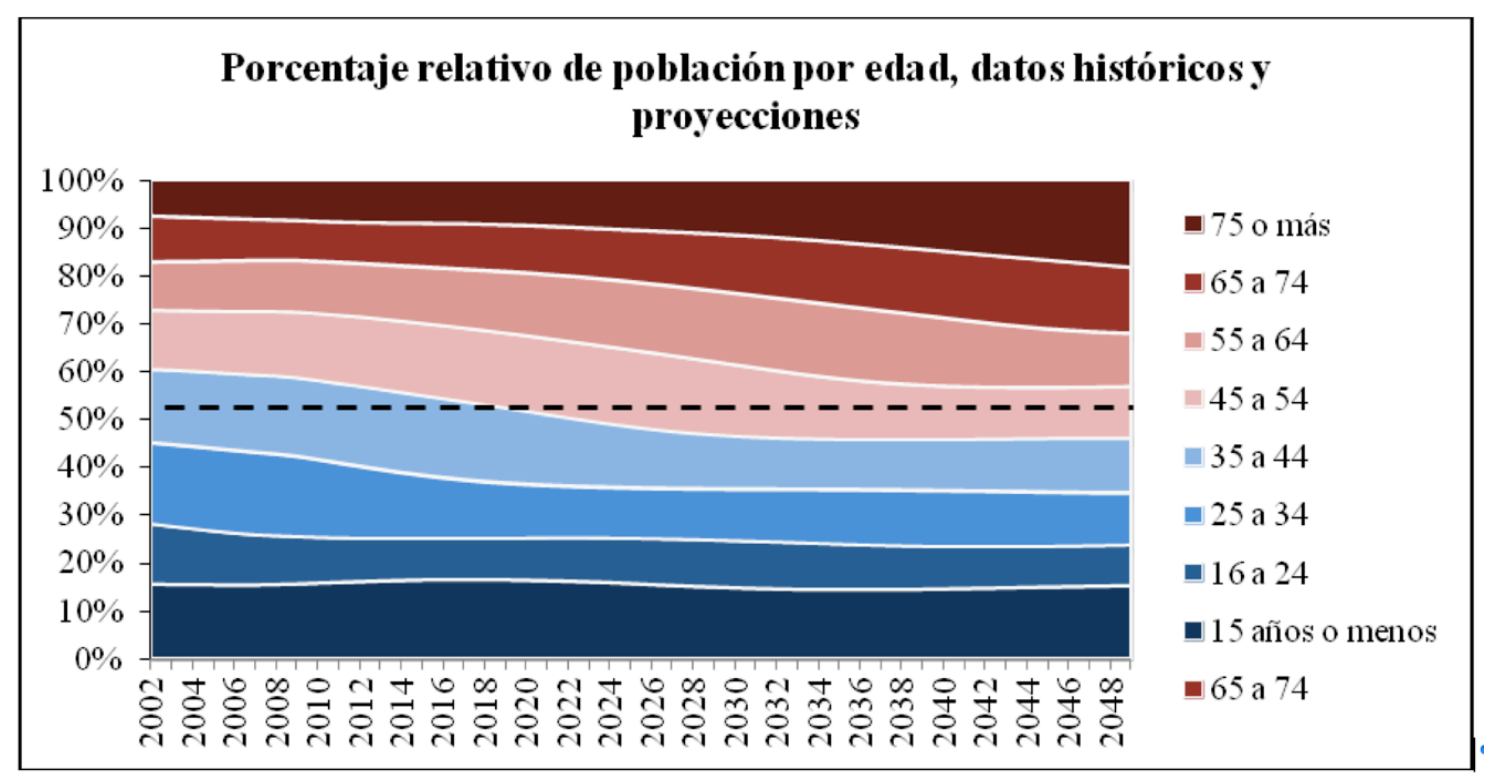

Figura 1. Proyección demográfica relativa por edad. Fuente: INE

El uso de Internet ha ido creciendo paulatinamente en la sociedad española, así se desprende analizando las estadísticas del INE y que se resumen a modo gráfico en la figura 2, en donde se detalla la cantidad de personas a modo porcentual respecto al total en su propio segmento de edad que han usado al menos una vez por semana en los últimos 3 meses Internet. En el 2006, sólo un $10 \%$ de los mayores de 55 años usaron la Red, en frente del $65 \%$ de menores de 34 años que han usado Internet en el 2006. En cambio, en el 2010, esta proporción fue de 22 \% para los mayores de 55 y de $82 \%$ para los menores de 34 . 


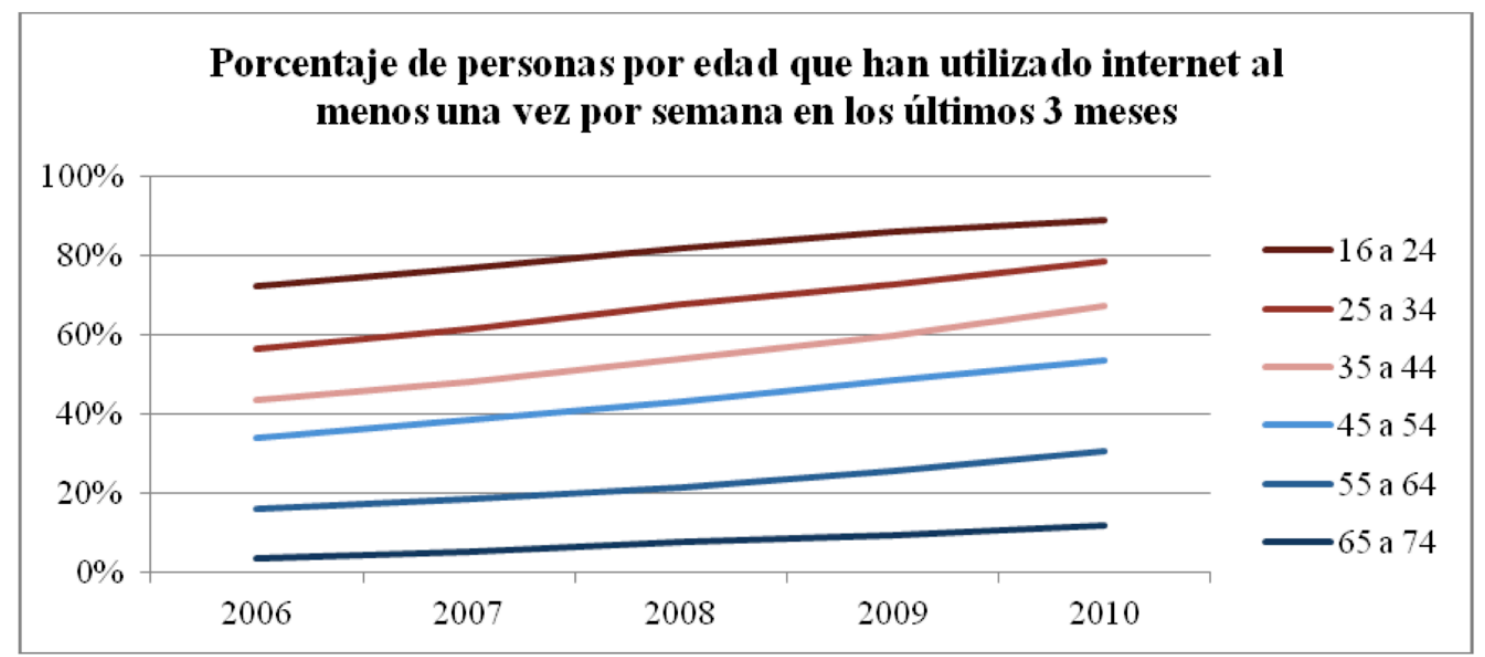

Figura 2. Porcentaje usuarios de Internet. Fuente: INE

Podemos ver, en la figura 2, un claro incremento en el uso de Internet, pero para este estudio resulta más interesante el incremento relativo; en la figura 3 puede observarse el incremento de usuarios de Internet respecto al total de la población; todas las edades crecieron, pero el que lo hizo en mayor cantidad de forma proporcional fue el del grupo de personas mayores de 65 años, llegándose a triplicar (paso de 3\% en 2006 al 9\% en el 2010), y los mayores de 55 a duplicarse, mientras otros grupos crecieron pero en menor proporción, pudiendo decir que incluso el de los jóvenes se mantuvo relativamente constante. El grupo de mayores por tanto, crece en uso y aunque sea difícil que llegue a alcanzar al grupo de los jóvenes, queda claro que no por ser un uso relativo menor, deba ser ignorado. Más aun hemos de considerar que es un grupo en aumento con necesidades e inquietudes que deben ser cubiertas. 


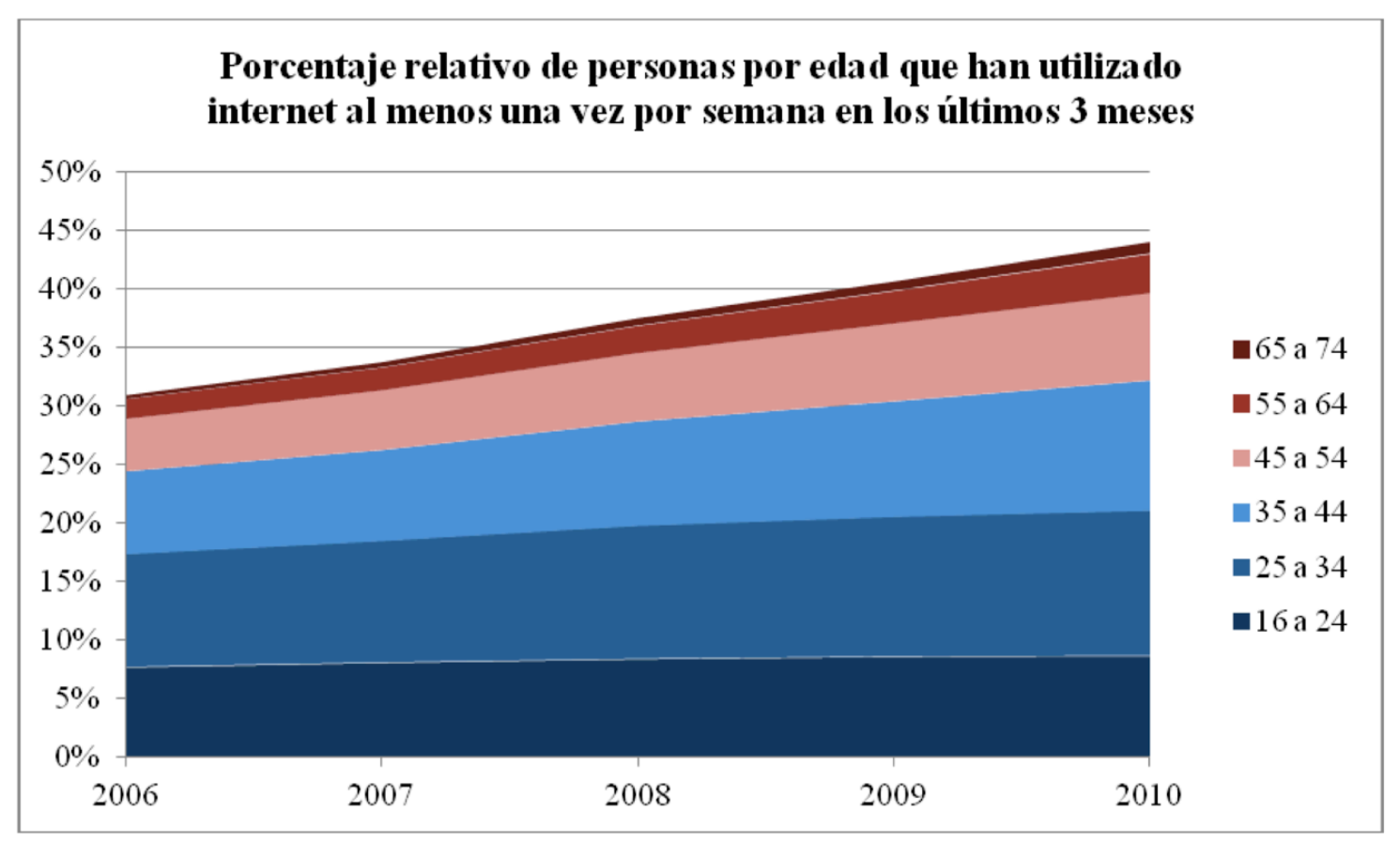

Figura 3. Incremento relativo al año anterior de usuarios de Internet. Fuente: INE

La última encuesta que se posee del INE acerca de los motivos por los que una persona no usa Internet pero le gustaría es del 2007, a partir del 2008 dicha pregunta se eliminó. En la figura 4 pueden observarse los motivos: Insuficiente dominio de idiomas extranjeros; falta de tiempo; la conexión que utiliza es demasiado lenta; por los costes adicionales de conexión o de volumen de descarga; por los costes de los contenidos online; falta de interés en los contenidos de Internet; tiene pocos conocimiento para un mayor uso; motivos relacionados con la seguridad o privacidad; otros motivos. 


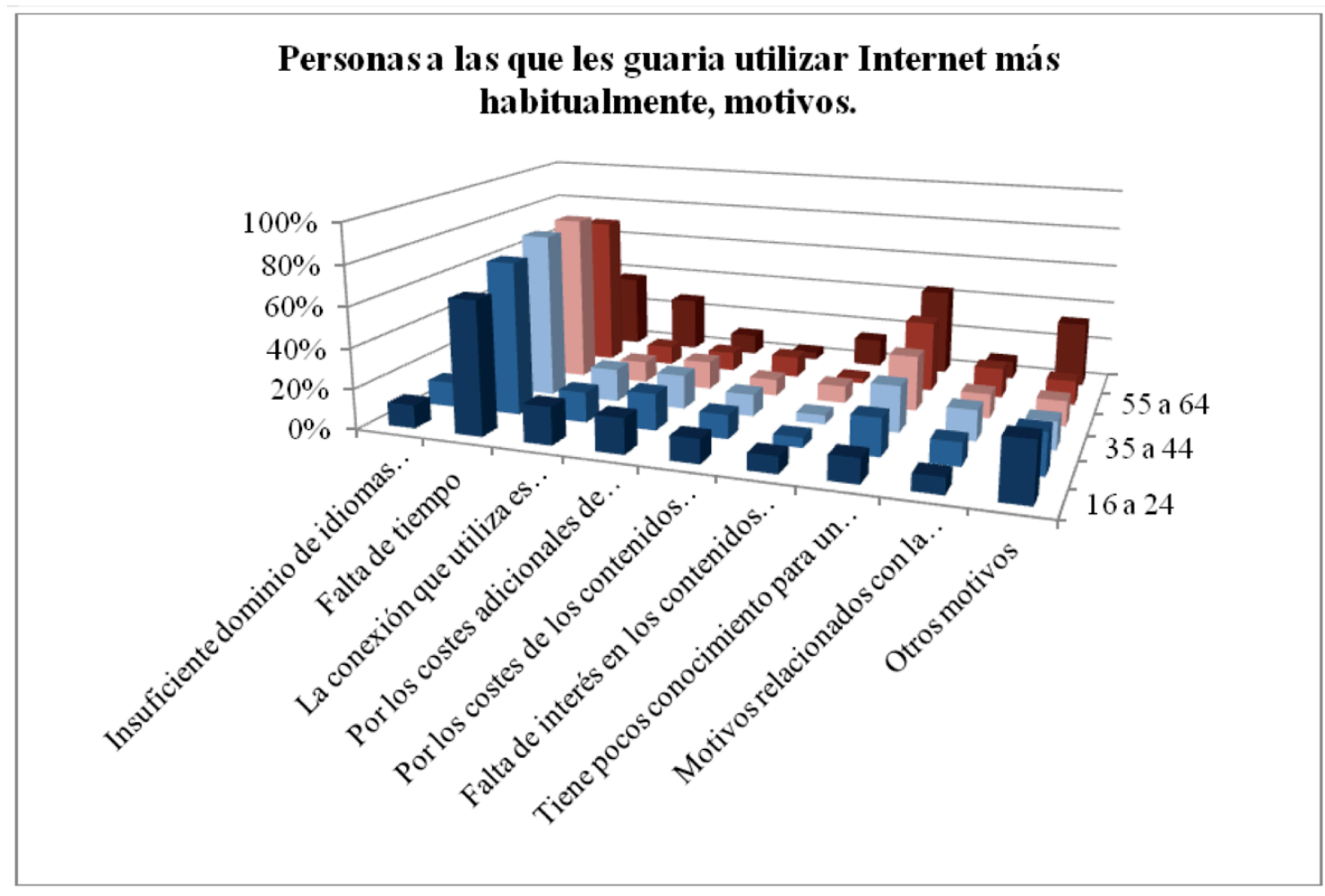

Figura 4. Motivos por los que no se hace un mayor uso de Internet (2007). Fuente: INE

Así encontramos como principal motivo en jóvenes y jóvenes adultos para "justificar" el no uso de internet es la falta de tiempo, a medida que la persona es más mayor, la falta de conocimientos surge como motivo principal, además de "otros motivos" en los que encajarían, por ejemplo. los relativos a la perdida de facultades físicas que requiere el uso del teclado y ratón o de visión o la motivación.

\subsubsection{USO DE LAS NUEVAS TECNOLOGÍAS}

El uso de las nuevas tecnologías (NT) por personas mayores siempre ha sido menor en relación a los más jóvenes o adultos más jóvenes, ya sea en frecuencia o en tipos de herramientas o usos. Esto se aplica tanto a computadores, al uso de internet, o otros aparatos técnicos (reproductores de audio o video, móviles, etc.).

Existen dos estereotipos instaurados en la sociedad actual (Aguilar et al. 2003), el primero es la asociación inevitable entre las nuevas tecnologías y la juventud, el segundo un miedo entre los mayores a aprender algo totalmente nuevo. Puede resultar muy desesperante para una persona mayor encontrarse con enormes 
dificultades en la programación de un DVD-grabador o en el uso de un móvil y encontrar que un joven, sin siquiera leer las instrucciones, es capaz de manejarlo todo rápidamente. Hechos cotidianos como este no hacen más que acrecentar los anteriores mitos, llegando incluso a parecer que es la máquina quien nos domina, se pierde el control (Morris \& Venkatesh 2000), la "percepción del control" no existe o es escasa, y además se tiene el sentimiento de que nunca se llegará a alcanzar ya que los dispositivos se renuevan frecuentemente y aparecen de nuevos. Como resultado de esto puede resultar la negación de aquellos mayores ante las nuevas tecnologías. Esta actitud negativa originada por estereotipos, afortunadamente, puede ser reducida. Para ello se deben favorecer nuevos métodos pedagógicos, espacios educativos, instituciones que favorezcan el uso cotidiano y habitual así como la creación de una mesa social que ejerza un dominio contando con la ayuda de instituciones educativas y otros mayores que han conseguido hacerse con el dominio de las nuevas tecnologías y que demuestran por tanto que aprender y manejar las nuevas tecnologías es posible.

Además de las causas antes citadas, también se ponen de manifiesto motivos técnicos (Selwyn 2003, p. 564), en los que se destaca que parte de los motivos en el freno de uso de las nuevas tecnologías es que los aparatos no han sido diseñados en términos de usabilidad para personas mayores, resultando en que los mayores se ven físicamente y psicológicamente desaventajados en el uso de nuevas tecnologías, aunque en este mismo estudio, deja al descubierto que esto parece ser más una excusa que un motivo real, ya que el motivo dado por no usar las TICs son por este orden: falta de interés y motivación (25\%), demasiado viejo (21\%), no es necesario (13\%), falta de habilidades (13\%). En esta misma línea se muestra Morris \& Venkatesh (2000) donde afirman que excepto cuando existan motivos físicos o psicológicos justificados, la edad por sí misma no se muestra como un impedimento para la adopción de nuevas tecnologías, pero sí en cambio ciertos estereotipos negativos o más destacables todavía: la falta de motivación e ilusión para emprender un nuevo reto, en este caso de aprendizaje. 


\subsubsection{LA NUEVA “BRECHA DIGITAL”}

A principios de los 90 la característica diferencial de entre aquellos que usaban o no usaban las TICs y que causaba la llamada "brecha digital" (Ballestero 2002) se producía entre los que tenían acceso a la red y los que no, provocando de este modo grandes desigualdades. En la actualidad se muestra una gran diferencia entre aquellos mayores con una actitud positiva y entre aquellos que predomina una actitud negativa con respecto al uso y la asimilación de las TICs. Se ha podido comprobar (van Dijk \& Hacker 2003) como el problema causado por la llama brecha digital no reside tanto en un problema físico de conexión a la red, sino también en un la actitud, habilidad y oportunidad de acceso.

Ya se ha observado en la anterior sección como el uso de las TIC's entre los jóvenes es mayor, además que poseen unas habilidades mayores; propias y adquiridas. Es necesario también preguntarse qué sucederá cuando los jóvenes actuales, sean adultos y mayores; ¿tendrá sentido hablar entonces de brecha digital?. Hanson (2009) presenta dos hipótesis abiertas, la primera teoría afirma que los mayores serán totalmente capaces, igual que los jóvenes y el único impedimento futuro para un aprovechamiento de las TICs serán las discapacidades físicas o psicológicas que puedan derivarse de la edad. La segunda teoría afirma que la tecnología evolucionará de tal forma, que cuando los jóvenes sean mayores, seguirán necesitando de adaptación para el uso de la tecnología presente en dicho momento. No puede anticiparse qué va a suceder, pero sí que puede analizarse en detalle qué está sucediendo en la actualidad. Según Hanson, la forma (que no las herramientas) en la que los mayores y jóvenes usan las TIC's es diferente (basándose en la experiencia personal y las necesidades), además la evolución de la tecnología en el presente no hace prever que llegue un punto histórico donde ya no haga falta seguir aprendiendo más, de hecho sucede todo lo contrario, el número de aplicaciones y herramientas no hace más que aumentar, superando cualquier capacidad humana de poder controlarlas y manejarlas perfectamente; las personas sólo podemos pretender el focalizar nuestra atención en aquellas que son de nuestro interés y aprenderlas. Es 
por eso que en el futuro, al igual que ahora, no será tan importante nuestra habilidad de usar, sino la de adaptarnos y aprender. La brecha digital seguirá estando entre aquellos que tengan una actitud positiva y los que no.

Considerando sólo el grupo de usuarios de ordenadores e internet, y sin tener en cuenta el uso de herramientas orientadas a contextos laborales, en la actualidad el uso de las herramientas TIC's entre jóvenes y mayores no es tan diferente, además, el objetivo que se persigue tampoco difiere tanto (Eastman \& Iyer 2004): mayormente estar en contacto con amigos y familiares, leer las noticias y acceso a información; es decir, los usos sociales y educacionales de la red. En otros casos, como el estudiado en Selwyn (2003) a usuarios mayores de ordenadores, muestran como el uso más popular de herramientas es para escribir cartas y en caso de usuarios de internet es leer y enviar correos y en segundo lugar, buscar información. Por supuesto hay usuarios más avanzados que usan herramientas o servicios que requieren de más habilidad y confianza (manipulación de imágenes, bancos on-line, descarga de material multimedia, etc.), pero estos no son tan habituales.

\subsection{Los estudiantes de la Universitat per a Majors}

Las universidades han sido históricamente centros de estudio e investigación en donde, principalmente, los jóvenes adquieren las competencias para lograr un título a modo de acreditación para el mercado laboral. También centros de investigación, en donde tiene lugar la innovación y desarrollo en las diferentes ciencias. No obstante, el modelo europeo de universidades les asigna también un rol social, y por tanto, son también responsables de integrarse e integrar la sociedad de su entorno, reconocer sus necesidades y aportarles solución.

El programa universitario de formación de personas mayores Universitat per a Majors (UM) de la Universitat Jaume I se inició en 1998. En el curso 2011/2012 se han matriculado 917 personas mayores de 55 años, el $9 \%$ se encuentran activos laboralmente, mientras el resto son jubilados, prejubilados o desempleados. 
El 60\% de estas personas están matriculadas en algún curso del área de nuevas tecnologías. Área que se estructura a través del Seminario Permanente de TICs que organiza asignaturas teóricas, cursos y talleres, Jornadas, etc. El 24\% de los inscritos lo hacen en cursos y talleres de nivel básico, alrededor del $62 \%$ en niveles medios y el resto de cursos de nivel superior. A lo largo del curso académico, aprenden a manejar muchas y muy diversas herramientas, supone un aprendizaje de gran utilidad para seguir el resto de asignaturas y por tanto de los estudios, un reto de integración en una sociedad académica y un estimulo para seguir desarrollando sus aptitudes tecnológicas.

Para intentar comprender cual es el uso y actitud de los mayores de la UM, se realizó una encuesta cuantitativa durante la matrícula en el curso 2011/2012, realizando en total encuestas a 828 estudiantes mientras realizaban la matrícula. De estas 828 encuestas recibidas, se han rechazado 296 por incompletas y han sido validadas 532.

\subsubsection{EXTRACCIÓN DE DATOS}

\section{A. FRECUENCIA}

Pregunta "De forma general, ¿con qué frecuencia te conectas a internet?”, sólo una respuesta posible:

\begin{tabular}{|l|l|l|l|}
\hline 0 & Nunca & 58 & $11 \%$ \\
\hline 1 & Ocasionalmente & 76 & $14 \%$ \\
\hline 2 & Semanalmente & 39 & $7 \%$ \\
\hline 3 & Varias veces por semana & 137 & $26 \%$ \\
\hline 4 & Todos los días & 162 & $30 \%$ \\
\hline 5 & Varias veces al día & 60 & $11 \%$ \\
\hline
\end{tabular}

Resulta destacable cómo un 75 \% de los encuestados se conecta a Internet con una frecuencia de semanalmente o más, esto demuestra que nos encontramos con un 
grupo realmente excepcional de mayores, ya que según el INE el índice de uso de Internet en personas mayores de 55 años es del $15 \%$. Esta diferencia es fruto del continuo esfuerzo de la Universidad para Mayores en pro de la alfabetización digital de los mayores. Exceptuando a los estudiantes de primer curso, el promedio de cursos tecnológicos realizados por los mayores es de 4,15.

Para las tablas siguientes, se han considerado únicamente al grupo que se conecta, al menos ocasionalmente, ya que las que no se conectan podrían ofrecer información errónea acerca del uso de herramientas y motivación para el uso de Internet. La población resultante se queda por tanto en 474 :

\section{B. TIEMPO CONECTADO}

Pregunta "De forma general, cada vez que te conectas a Internet, ¿durante cuánto tiempo estas conectado?", sólo una respuesta posible.

\begin{tabular}{|c|c|c|c|}
\hline 1 & $\begin{array}{l}\text { Entre cinco minu } \\
\text { hora }\end{array}$ & 76 & $16 \%$ \\
\hline 2 & Una media hora & 39 & $8 \%$ \\
\hline 3 & Una hora & 137 & $29 \%$ \\
\hline 4 & Dos horas & 162 & $34 \%$ \\
\hline 5 & Unas cuatro horas & 60 & $13 \%$ \\
\hline 6 & Más de 5 horas & 0 & $0 \%$ \\
\hline
\end{tabular}

Tabla 1. Tiempo de conexión

Dado que en 11 casos, se han encontrado preguntas sin respuesta, estos casos se eliminan, quedando finalmente una población de 474

C. USO DE HERRAMIENTAS 
Pregunta: "Indíquenos el uso que hace de los siguientes servicios y herramientas". Media resultante de todas las respuestas marcadas en una escala, donde $0=$ No lo uso nada, y $3=$ Soy un experto.

$\begin{array}{lc}\text { Correo electrónico (e-mail) } & 1,86 \\ \text { Navegación por Internet } & 1,81 \\ \text { Uso de buscadores (como Google, bing, etc.) } & 1,76 \\ \text { Redes sociales (como Facebook, twitter, etc.) } & 0,75 \\ \text { Álbumes web (como flickr, picasa, etc.) } & 0,52 \\ \text { Seguidor o lector de blogs o podcasts } & 0,48 \\ \text { Creador o escritor de blogs o wikis } & 0,32 \\ \text { Servicios en la nueve (Google Docs, dropbox, sites, etc) } & 0,41 \\ \text { Más de una cuenta de correo (además de su correo principal) } & 1,16 \\ \text { Comercio electrónico (compras, reservas, billetes, etc) } & 0,81 \\ \text { Redes P2P (como emule, torrent, rapidshare, etc) } & 0,40 \\ \text { Gestiones administrativas o bancarias (banca electrónica) } & 0,92\end{array}$

Tabla 2. Uso de herramientas ( $0=$ no lo uso, $3=$ soy un experto)

El correo electrónico es la herramienta más utilizada seguida de navegadores y herramientas on-line.

Estos datos muestra la relación entre conocimientos y necesidades, cuantas más habilidades tiene el estudiante utiliza unas herramientas más especificas.

Del mismo modo podemos relacionar la satisfacción que producen las relaciones sociales con el uso de herramientas que permiten establecer y desarrollar las mismas.

\section{USO DEL ORDENADOR E INTERNET}

Pregunta: "Yo uso el ordenador e Internet de forma habitual para...". Media resultante de todas las respuestas marcadas en una escala, donde $0=$ No nunca, y $3=$ Siempre. 
Leer páginas de amigos y familiares para saber qué hacen 1,03

Leer páginas de información general, aficiones y actividades (no 1,33 noticias)

Estar en contacto con amigos y familiares

Escribir cartas, realizar documentos, hojas de cálculo, etc.

Buscar y aprender sobre cosas que tengo curiosidad

Escribir y publicar contenidos que yo creo

Tabla 3. Yo uso el ordenador para... ( $0=n o$, nunca; 3 = siempre)

Los mayores usos que se hacen de Internet son: buscar y aprender, leer noticias y actualidad y estar en contacto con los amigos. Destaca por tanto el uso educativo que, que este grupo específico, realizan de internet, haciendo por tanto de esta muestra un buen grupo para analizarlo.

\section{E. ACUERDO/DESACUERDO}

Pregunta: "Indique si está de acuerdo con las siguientes afirmaciones". Media resultante de todas las respuestas marcadas en una escala, donde $-2=$ Totalmente en desacuerdo, 0 =neutro, $2=$ Totalmente de acuerdo.

Internet me ha facilitado crear nuevos contactos y amigos $\quad 0,52$

Internet me ha facilitado mantener contactos y amigos que ya tengo $\quad 0,82$

Considero Internet un espacio, donde me siento cómodo y a gusto $\quad 0,84$

Considero Internet como un lugar, del cual es posible obtener mucha 1,22 información útil y valiosa

Considero que Internet puede ser útil para mi desarrollo personal $\quad$ 1,03

Me asombro de toda la información disponible en Internet $\quad 1,16$

No me gusta dejar un correo de un amigo sin contestar: me gusta leer el 0,94 correo frecuentemente

Internet me parece un lugar muy peligroso, donde es muy fácil ser 0,33 engañado 
En internet encuentro mucha información falsa y engañosa $\quad 0,26$

Me costaría vivir si Internet desparecería $\quad-0,42$

Si no aprendo a usar Internet, podría sentirme discriminado y excluido $\quad 0,04$

A veces, cuando estoy navegando por internet y me pierdo, pienso que $-0,33$

esto no es para mi

El entorno en el que vivo (familiares, amigos, actividades) parece que 0,16

me obliga a usar Internet

Tabla 4. ¿Está usted de acuerdo? (-2 totalmente en desacuerdo, +2 totalmente de acuerdo)

\subsubsection{F. SITUACIONES}

Las siguientes preguntas aparecen según toda la población, independientemente de si no usan internet: Pregunta "Imagine las siguientes situaciones, y elija la que más se ajuste a lo que haría" Sólo una respuesta posible.

Es su cumpleaños, imagine que un amigo le acaba de regalar un teléfono móvil táctil, que permite hacer fotos, conectarse a internet, usarlo como radio, descargar libros, usarlo como GPS (navegador con mapas) y como diccionario...

a

Preferiría devolverlo, me parece muy complicado para mi

b

Me lo quedo, pero creo que sólo lo usaré para llamar por teléfono

$18 \%$

Me lo quedo, y además le pediré que me explique cómo usar todas las

C opciones que permite hacer

Me lo quedo, iré probando a ver si consigo hacer funcionar lo que

d tiene

Está delante de su ordenador, en casa sin nadie. Le ha salido un mensaje de error muy extraño y preocupante...

a

Busco en Internet dicho mensaje a ver si obtengo alguna pista de lo que sucede 
b

Llamo enseguida por teléfono a un amigo / familiar para que me resuelva la duda

Me anoto el mensaje, y apago el ordenador, mañana intentaré

C comentarlo con los amigos en el café

d

Apago el ordenador, mañana otro día, quizá ya no salga

Está navegando por una página en internet que ha hecho un amigo suyo que usted conoce, visualiza una información histórica incorrecta acerca de un hecho que usted sabe perfectamente acerca de su pueblo o ciudad...

a

La página web posee un lugar para colocar comentarios y observaciones, escribo ahí la corrección

b

Busco el correo electrónico de mi amigo (el autor de la página) y le envio un correo electrónico pidiéndole rectificación

Algún día de estos, cuando vea por la calle a mi amigo, le diré que rectifique la página

No tiene importancia, no merece la pena preocuparse por una página

d web entre millones que hay

Acaba de realizar un viaje turístico. Ha hecho amigos en dicho viaje que son de otra parte de España y usted tiene algunas fotos que les ha hecho que quizá les puedan gustar. Antes de despedirse, le dieron su teléfono y una dirección de correo electrónico.

a

No digo nada, ¿por qué les podrían interesar mis fotos?

$\mathrm{b}$

Yo mismo les enviaré las fotos por correo electrónico

C

Le pido a mi hijo/hija que envíe las fotos en ni nombre por correo electrónico.

Publicaré mi álbum en Internet. Ellos podrán coger las fotos que más

d les gusten

\section{ANÁLISIS}


Los alumnos mayores de la UM presentan además de un nivel de uso muy alto de las aplicaciones básicas (correo electrónico, navegación, buscadores) donde en una escala de 0 a 3 ( $0=$ nada, $1=$ poco, $2=$ si, $3=$ soy un experto), lo usan a un nivel de experiencia de 1,86 el correo, 1,81 la navegación, 1,76 los buscadores. En el uso de otras aptitudes más complejas de Internet (creador de blogs, wikis, reserva de billetes), desciende hasta 0,32 .

Sin duda alguna los mayores están ganando en aptitudes tecnológicas, pero también poseen una alta motivación y actitud positiva. Esto no es de extrañar, ya la acción educativa de la UM está específicamente diseñada para crear un entorno que favorezca la adopción de la UM y que ya fue presentado en Esteller (2009) y en Escuder-Mollón (2010). En todos los casos de usos (correo, navegación, buscadores, redes sociales, blogs, nube, etc.) de media, los alumnos de primer curso, poseen un nivel subjetivo de conocimientos promedio de $+0,14$ puntos.

La actitud se muestra muy positiva, tal y como afirman en la investigación cuantitativa $(-2=$ desacuerdo, $0=$ neutro, $2=$ acuerdo), y para la afirmación "Considero que Internet puede ser útil para mi desarrollo personal" es de 1,03, y que "Considero Internet un espacio, donde me siento cómo y a gusto" es de 0,84 . También hay que tener en cuenta, que consideran "Internet un lugar muy peligroso, donde es muy fácil ser engañado": 0,33. La diferencia de los alumnos de primer curso respecto a los posteriores es también significativa, pero se ha producido en mayor medida en los valores de "Internet me ha facilitado crear nuevos contactos y amigos" $(+0,33)$, "Me costaría vivir si Internet desparecería" (+0,31) y "Si no aprendo a usar Internet, podría sentirme discriminado y excluido" $(+0,32)$

Ante nueva tecnología, también se muestran muy predispuestos a usarla o aprenderla, tal y como se desprende de las opciones elegidas en la sección F de la encuesta (consulte la página 153); ante un dispositivo móvil nuevo y complicado, un $36 \%$ de alumnos probaría de aprenderlo por el mismo, o ante un error en una página un 67 \% de alumnos actuaría para solicitar la corrección del error.

Los resultados para los estudiantes recién llegados a la UM $(n=126)$ presentan la siguiente diferencia de valores "Considero que Internet puede ser útil para mi desarrollo personal" es de 0,52 (en lugar de 0,92), y que "Considero Internet un 
espacio, donde me siento cómo y a gusto" es de 0,31 en lugar de $(0,75)$. También hay que tener en cuenta, que consideran "Internet un lugar muy peligroso, donde es muy fácil ser engañado": -0,15 (en lugar de 0,11).

Ejemplo del entorno creado es el que puede ser demostrado empíricamente; ha sido observado que muchos de los mayores que creían que no podrían aprender nunca TICs se han animado hasta que no han visto ha sucedido que sus compañeros. Además, la UM promueve el uso de las TICs mediante la publicación y difusión de información mediante la web.

Cada vez más, los mayores solicitan la inscripción en cursos de TICs, pero muy importante después de esto es que lo aprendido no puede ni debe ser guardado, sino usado, y las TICs tienen una característica muy importante y diferencial respecto a cualquier otra área y es que es una herramienta práctica que puede producir un gran impacto. Maximizar este impacto y que sea visible hacia los demás; las instituciones publicas, la sociedad, medios de comunicación y los propios estudiantes provoca que crezca una ilusión y motivación propia.

En internet existe muchísima información y los alumnos mayores son conscientes de esto siendo la afirmación que más de acuerdo están (1,12 entre una horquilla de -2 y 2), Los alumnos que reconocen este hecho, aceptan que Internet puede ser útil para el desarrollo personal, aunque en ningún caso se sienten obligados $(-1,93$ entre una horquilla de -2 y 2 ).

Existe cierta inseguridad y sensación de peligro por navegar por internet, curiosamente, dichas personas son las que lo usan porque se sienten obligados y además acceden en menor medida.

De este análisis podría desprenderse que de forma subjetiva el acceso a internet es agradable y cómodo por los mayores, y en general no causa estrés ni sentimientos negativos. La actitud es positiva y no se distingue un objetivo primario de "aprender" aunque sí que se encuentra entre los usos principales

La investigación cualitativa ha revelado que las personas mayores si se encuentran en un entorno educativo adecuado, pueden perfectamente involucrarse en actividades tecnológicas complejas, pero además esto les provoca enorme satisfacción. 
Analizando la relación entre las diferentes respuestas, tanto entre los bloques de preguntas, C, D, y E, y con las respuestas de los mismos bloques, se pueden extraer las relaciones entre variables que se muestran a continuación. De este modo es posible conocer la relación entre usos, actitudes y opiniones acerca de las TICs, sus usos y aprovechamientos.

Todas las correlaciones marcadas con ** indican una significancia de $\mathrm{p}<0,01$, si están marcadas con $*$, indican una significancia de $\mathrm{p}<0,05$. Las correlaciones están realizadas sobre el total de la población que al menos usa Internet ocasionalmente ( $\mathrm{n}=463)$. También se ha realizado un análisis de correlaciones entre las respuestas de los alumnos de primer curso $(n=100)$ y los restantes $(n=363)$. En el caso de que la diferencia de correlaciones entre el análisis del primer curso y de los alumnos de segundo y posterior cursos fuera significativa, esta se ha indicado entre corchetes. Por ejemplo, en la Figura 8, aparece que la relación entre AD_MANTENER_AMIGOS y AD_COMODO es de $0,543^{* *}(\mathrm{p}<0,01)$. Dado que el grupo de primer curso, la correlación es de: $0,708^{* *}$ y entre los alumnos de segundo curso y posteriores es de $0,510^{* *}$, esta diferencia significativa se indica entre corchetes del siguiente modo: $[+0,198]$, esto significa que la existe una mayor correlación entre el grupo de primer curso, que en el grupo de segundos y posteriores.

Cuando la correlación era superior a 0,5 se ha indicado con una línea continua, en cambio si era menor, con una línea discontinua. En algunas ocaciones, se ha indicado también cuando la correlación era próxima a 0 , ya que indica queno ha relación aparente. En caso de que la correlación fuese negativa, se ha indicado gráficamente mediante una línea de doble grosor.

El criterio que se ha seguido al distinguir y analizar de forma individual ciertas variables en lugar de otras es su importancia relativa en el grafo general de correlaciones. 


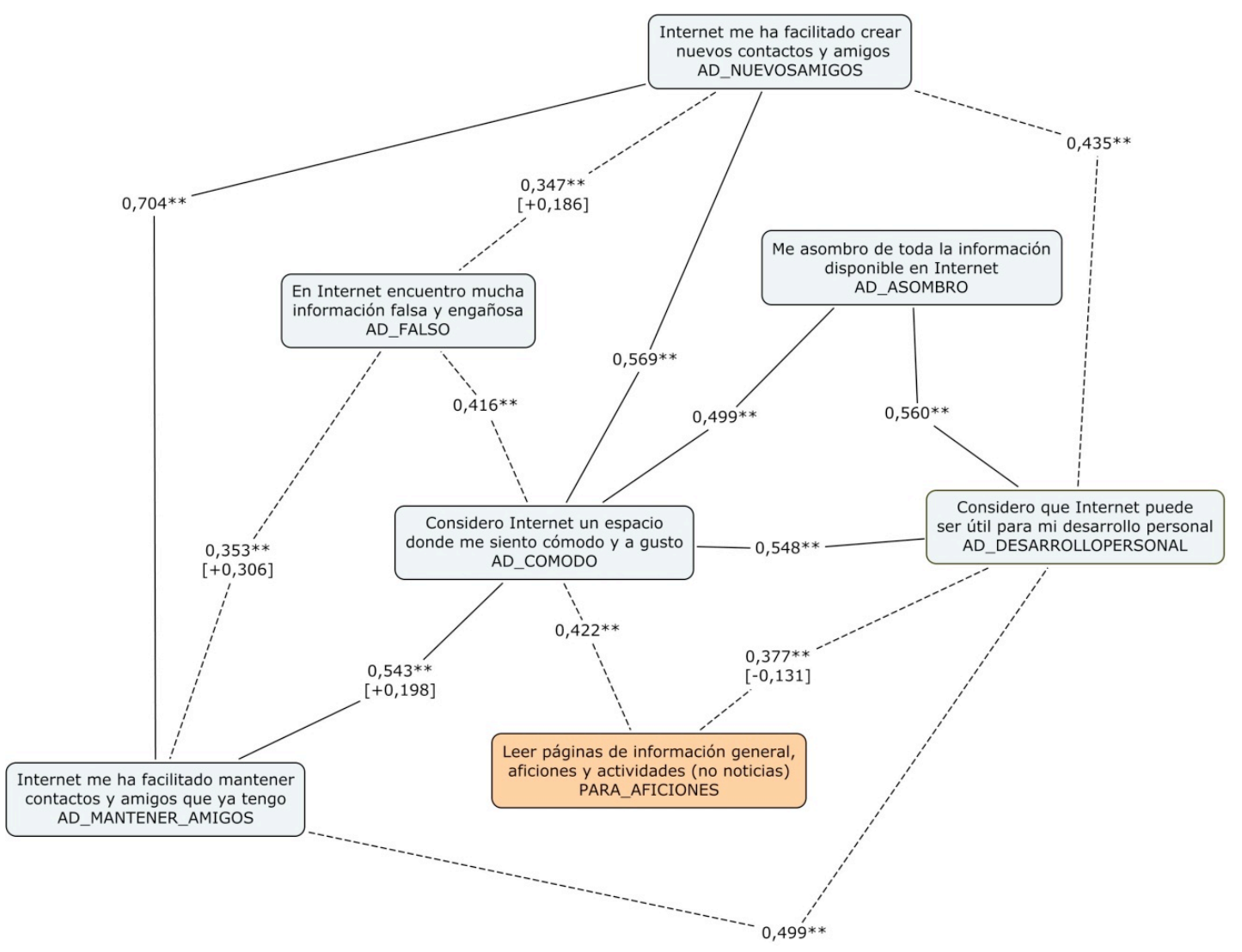

Figura 8. Correlaciones en relación a la Comodidad

En la Figura 8, se muestra gráficamente las correlaciones que tienen relación a la comodidad. Puede verse de este modo cómo este concepto está relacionado con el uso relativo a crear y mantener amigos. 


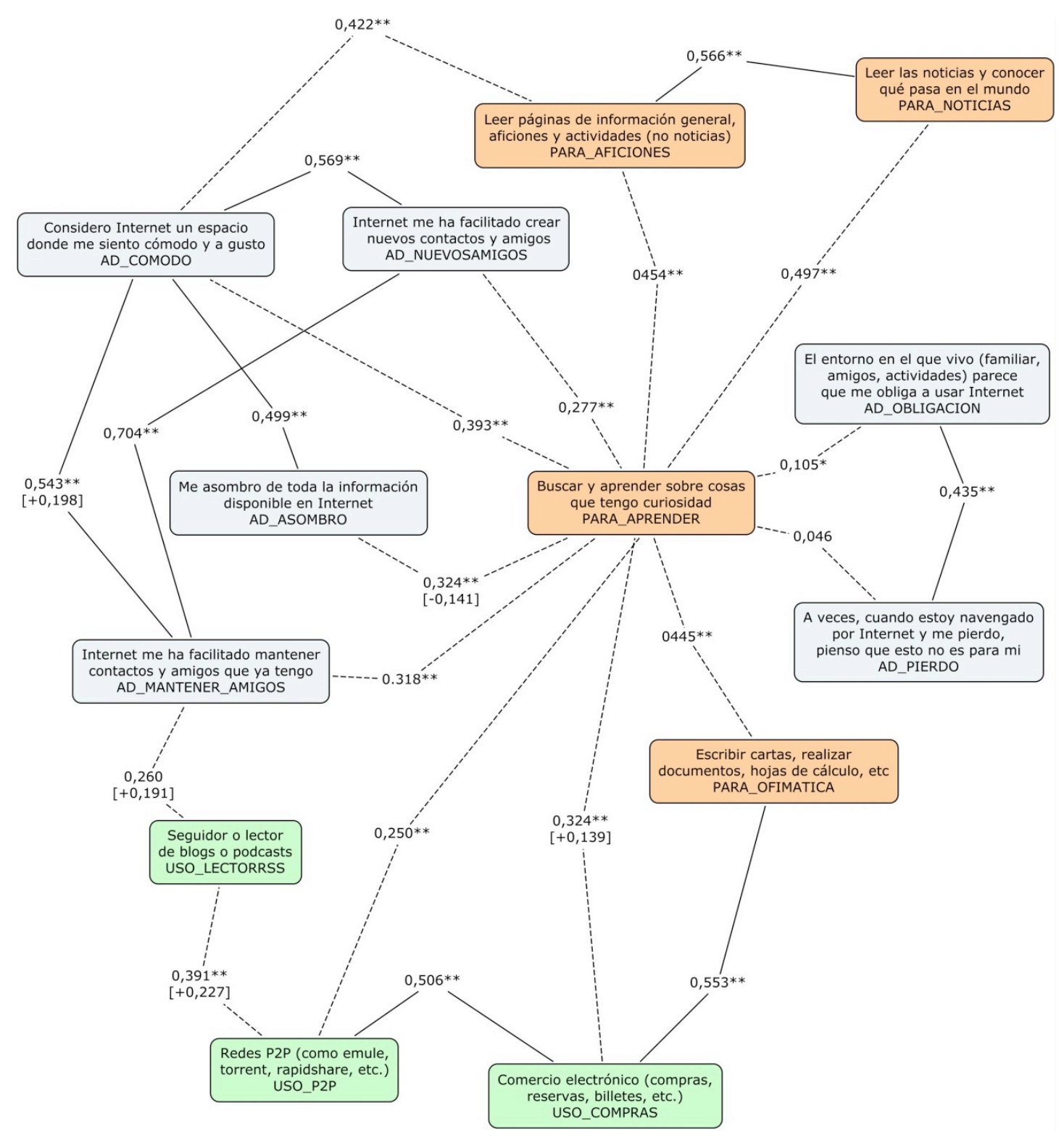

Figura 9. Correlaciones en relación al Aprendizaje

Tal como se visualiza en la Figura 9, no existe ninguna correlación entre variables mayor 0,5 . No es posible distinguir por tanto un uso o una actitud que sirva para diferenciar y caracterizar de forma clara la utilidad de aprendizaje. No obstante es destacable las correlaciones tan bajas que existen entre PARA_APRENDER y AD_OBLIGACION y AD_PIERDO y también otros usos avanzados como serian redes USO_P2P, USO_COMPRAS o AD_MANTENER_AMIGOS, y la alta que existe con PARA_AFICIONES y PARA_NOTICIAS. 


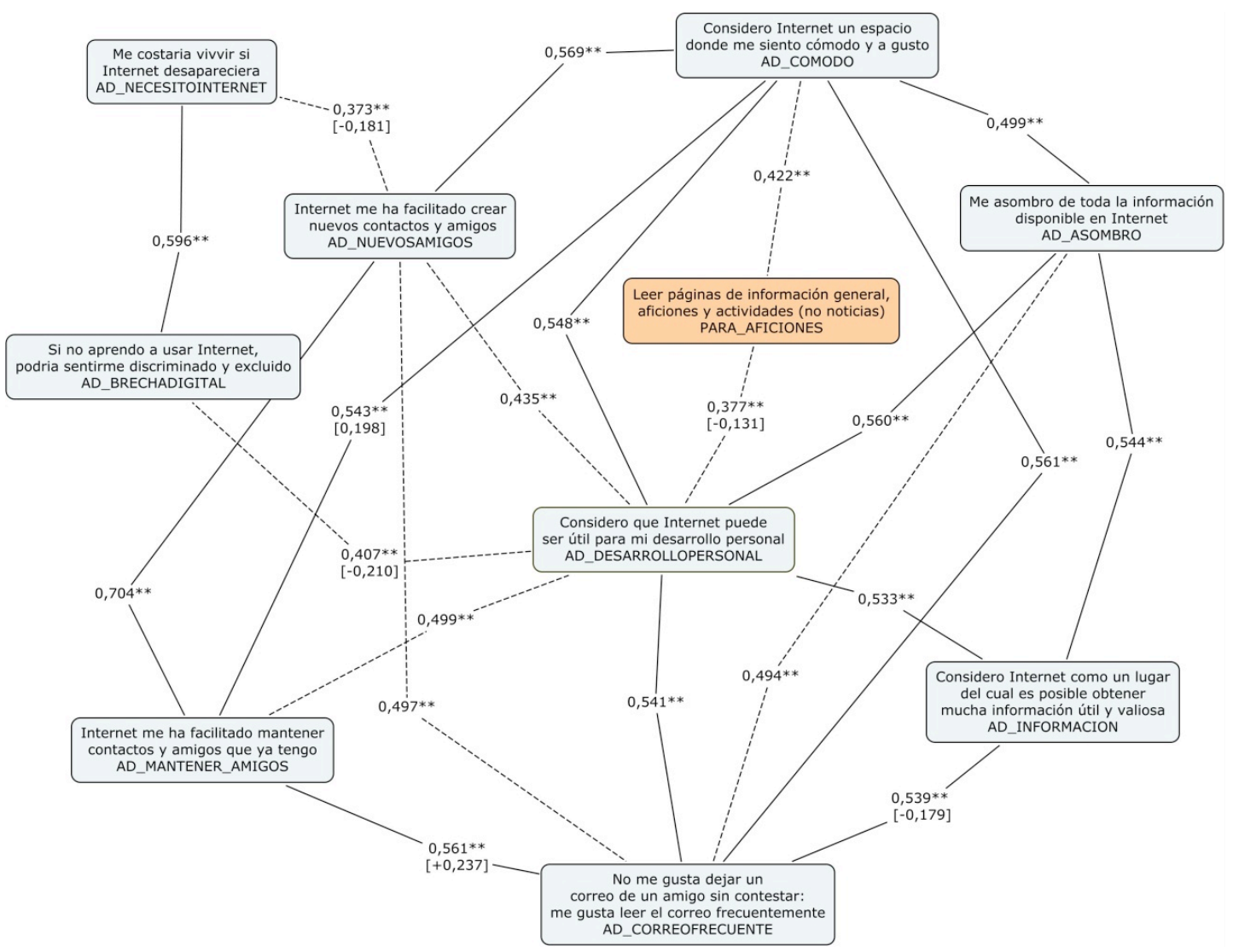

Figura 10. Correlaciones en relación al Desarrollo personal

El uso de internet como desarrollo personal, es mayormente aceptado, relacionándolo en conceptos como comodidad, asombro, obtención de información y asumiendo el peligro de que si no se usa Internet, podría sufrirse la exclusión. 


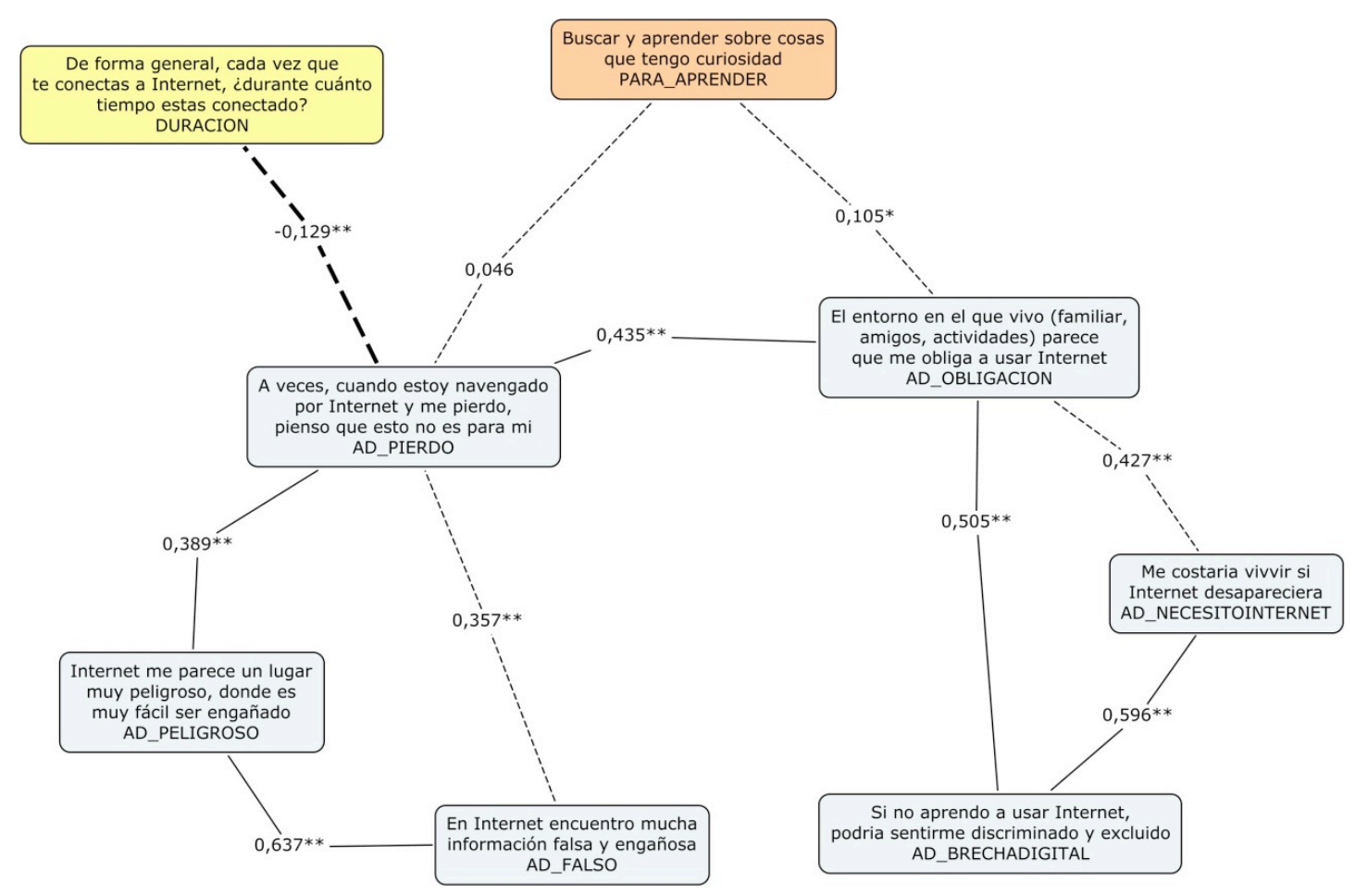

Figura 11. Correlaciones relativas a peligro en Internet

Los conceptos de perderse en internet, pensar que es peligroso, hay mucha información falsa y que usa internet por obligación va relacionado, siendo esto inversamente proporcional a la duración de conexión. Sería equivalente a decir que la sensación de peligro o de inseguridad está relacionada con conexiones cortas y breves, en lugar de estar más tiempo conectado y disfrutar navegando o buscando. 


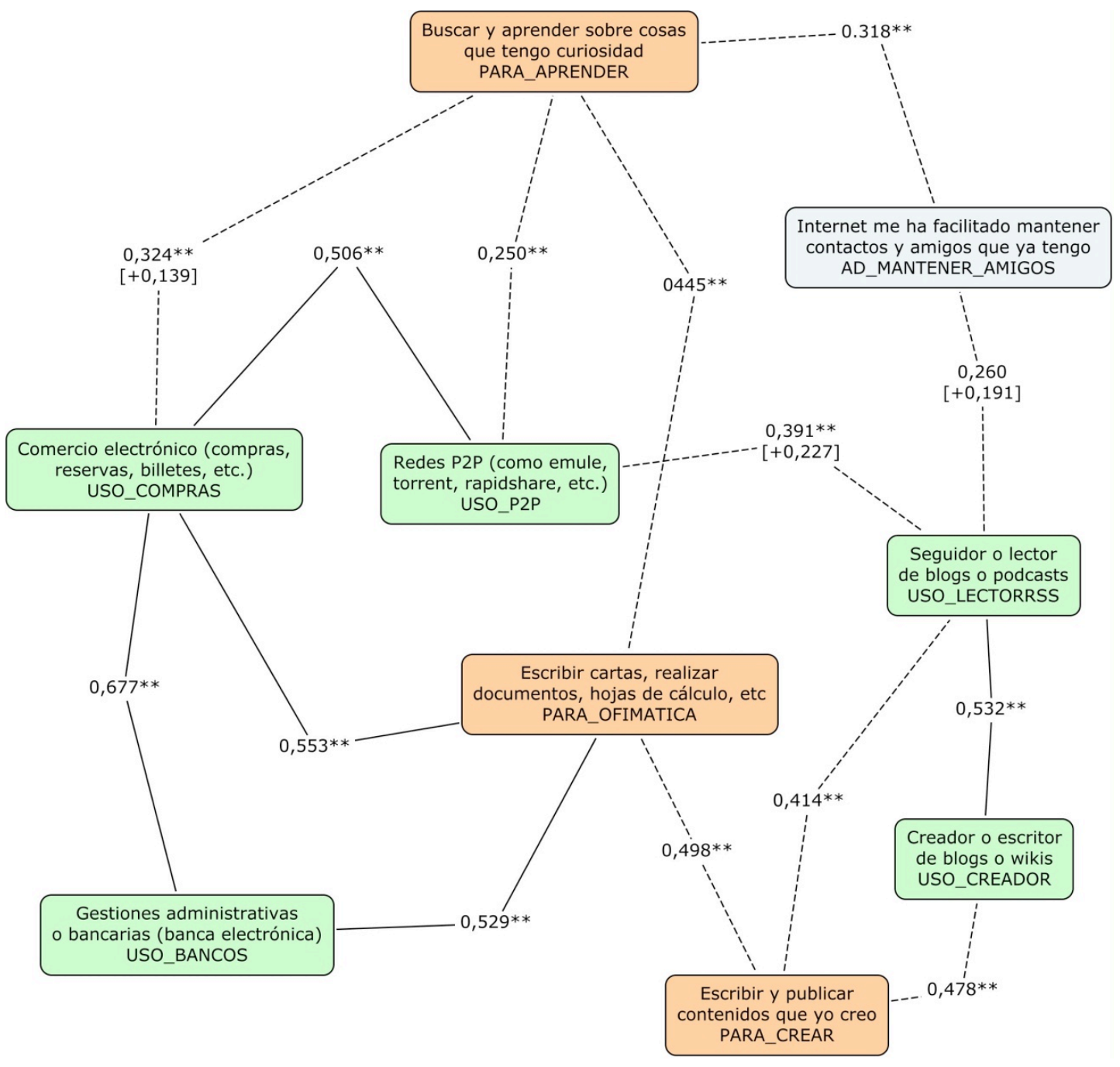

Figura 12. Correlaciones en relación a usos complejos de las TIC

\subsection{Conclusiones}

En el contexto educativo de la Universidad para Mayores de la Universitat Jaume I de Castellón (UM), se cuenta con un grupo de estudiantes cuyo nivel de acceso y uso las TICs supera con creces a la media española. Según el INE, el número de personas mayores de 55 años que ha accedido al menos una vez a Internet en los últimos 3 meses es del $20 \%$ y un uso habitual el $15 \%$, en el caso de la UM es del $75 \%$. Esto hace que extrapolar las conclusiones de esta investigación al resto de mayores de España o Europa sea totalmente incorrecta, no obstante, ese no era el propósito de 
esta investigación. El grupo de investigación son alumnos mayores que están interesados en aprender y que en la actualidad ya están cursando este tipo de educación formal en la que no solo se presenta una vía de trabajo, que es la realización de cursos: como hemos podido comprobar en otros programa de educación de adultos, sino que tiene un desarrollo más expansivo: seminarios, utilización en el aula, cursos teóricos, clases virtuales, Jornadas, Proyectos, etc.

Respecto a un aprendizaje vía no-formal o informal (Comisión Europea 2000, MEC 2008), el aprendizaje formal hace posible una planificación y diseño a medio y largo plazo, el cual se oferta estructurado en base a unos objetivos globales y estratégicos. El aprendizaje en instituciones formales, también permite crear un entorno de adecuado y donde los cursos se complementan con talleres y actividades con otro nivel de objetivos.

En las clases de informática e Internet de la UM, se persigue que los contenidos que se enseñen sean incorporados por las personas mayores en sus rutinas diarias o hábitos, por ejemplo, al buscar información sobre un hotel, o al informarse sobre un evento reciente.

De los resultados de la investigación cuantitativa, se destaca la capacidad de asombro que muestran ante la gran cantidad de información que hay en Internet o el uso de internet para saber qué sucede (p.je. noticias), conocer otras cosas (p.ej. aficiones) o crear nuevos contenidos (puede consultarse en detalle la Tabla 4) podría entenderse como muestra de que en cierto modo existe una actitud abierta hacia el uso de las TIC.

Por tanto, las Nuevas Tecnologías se ofrecen como una magnífica oportunidad de aprender, comunicar, crear y sociabilizarse. Pero representa un reto en tres vertientes:

- es necesario ganar en aptitudes y habilidades en el manejo de las herramientas TICs (ordenador, navegador, móvil...)

- es necesario usar de forma conveniente los servicios y herramientas; saber distinguir lo que es útil o fiable, de lo que no es, los posibles peligros, potencialidades, lo que podemos aprovechar y sacar provecho, etc. 
- dado el impacto de las TICs en diversos niveles de la sociedad y donde la comunicación mediada por ordenador es una de sus principales características, es necesario el rol que las personas podemos jugar en dicha sociedad, cómo podemos actuar, ejercer nuestro poder y en definitiva, ser partes activas de una sociedad que está continuamente avanzando.

En la educación, las nuevas tecnologías, se plantean como un arma con enorme potencial, y con un doble sentido dependiendo de rol que esté jugando el alumno en su proceso de aprendizaje. Así pueden ser:

- como una materia especifica enseñar, a aprender su manejo y comprender su utilidad y desarrollo

- o como un instrumento que debe ser usado para desarrollar otras aptitudes y habilidades: nuevos conocimientos, facilitar acciones, etc.

Hasta el momento, y por parte de muchas instituciones tanto educativas, bien formales o informales, como sociales, los principales esfuerzos se habían centrado en "enseñar la materia tecnología". En este punto creo que es momento de reconocer que un numero incipiente, pero en aumento constante, de personas necesitan que las TICs contemplen recursos para toda la sociedad, incluyendo en ellos a las personas mayores.

\subsection{Referencias}

Aguilar, L., García Tobío, J., Millán, J. C., Rodríguez Malmierca, M. J., Perenas, M. P., \& Orive, P. (2003). Los mayores y las nuevas tecnologías de la comunicación. Revista multidisciplinar de gerontología, 13(1), 37-42.

Ballestero, F. (2002). La Brecha digital : el riesgo de exclusión en la sociedad de la información. Madrid: Fundación Retevisión. 
Cheung-Ming, Alfred Chan, Tak-Cheng, Sheung \& Philips, David (2007). The Aging of Asia: Policy Lessons, Challenges. Jorunal of the East Asia Foundation, 2(2). 2007. Disponible en http://globalasia.org/articles/issue3/iss3_11.html

Comisión Europea. (2000). Memorándum sobre el aprendizaje permanente. SEC(2000) 1832.

Dijk van, J., \& Hacker, K. (2003). The Digital Divide as a Complex and Dynamic

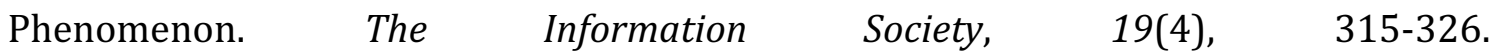
doi:10.1080/01972240309487

Eastman, J. K., \& Iyer, R. (2004). The elderly's uses and attitudes towards the Internet. Journal of Consumer Marketing, 21(3), 208-220. doi:10.1108/07363760410534759

Esteller, R., Escuder, P., \& Traver, J. (2009a). Enhancing ICT education for senior students: Senior Citizens' University in Spain is promoting a comprehensive formal, non-formal and informal approach to ICT learning among senior citizens. Lifelong learning in Europe, 3.

Escuder-Mollón, P., \& Esteller-Curto, R. (2011). Mejora de la calidad de vida del mayor a través de la e-inclusión en la sociedad del conocimiento: propuesta de una intervención educativa. Aprendizaje a lo largo de la vida, envejecimiento activo y cooperación internacional en los programas universitarios para mayores (Vol. 1, pp. 469-487). Presentado en el IV congreso iberoamericano de universidades para mayores, Alicante: Asociación estatal de programas universitarios para mayores.

Hanson, V. L. (2009). Age and web access: the next generation. Proceedings of the 2009 International Cross-Disciplinary Conference on Web Accessibililty (W4A) (p. 715).

ONU, 1983. Vienna International plan of action an aging. Disponible en http://www.un.org/es/globalissues/ageing/docs/vipaa.pdf

MEC (2008). Reconocimiento de los aprendizajes no formales e informales. Ministerio de Educación Política Social y Deporte. Disponible en http://www.oecd.org/dataoecd/5/2/41680537.pdf 
Morris, M. G., \& Venkatesh, V. (2000). Age differences in technology adoption decisions: Implications for a changing work force. Personnel psychology, 53(2), 375403.

Selwyn, Neil, Stephen Gorard, John Furlong, and Louise Madden. 2003. 'Older adults' use of information and communications technology in everyday life." Ageing and Society 23(5):561-582. Retrieved July 18, 2011. 


\title{
19 THE IMPORTANCE OF
}

\section{COMMUNICATION IN THE LEARNING}

PROCESS ON INFORMATION AND

COMMUNICATION TECHNOLOGIES

COURSES FOR SENIORS

Autores (por orden de publicación)

Pilar Escuder-Mollon, Roger Esteller-Curto

Presentado en: International Conference on Education and New Learning Technologies (EDULEARN09), Julio 2009, Barcelona.

Publicado en: International Association of Technology, Education and Development, pages 4445-4454, Proceedings ISBN: 978-84-612-9802-0, Proceedings ISSN: ISBN 2340-1117

\begin{abstract}
Teaching ICT (Information and Communication Technologies) to seniors is a very complex soci- educational process as it not only involves training but also personal, integration and motivational oriented pedagogy. Communication plays a key role in this educational intervention. In this paper we first define the characteristics of and the role communication has in the learning process in the ICT senior learner context. Secondly, we outline all the potential, qualities and possible benefits and influence of communication. We propose how to guide the learning process to promote and open ways of communication at various levels (group, individually, between learners), media (verbal, visual and written), and aims (feedback, evaluation, motivation). Finally we focus on barriers (tension, attitudes) that interrupt communication and must be foreseen and eliminated.
\end{abstract}


Keywords - teach, communication, ICT, senior, elderly, education

\subsection{Background}

Seniors (55+) do not learn Information and Communication Technologies (ICT) to get a better job; they learn ICT because they want to be up to date in this technology society (e.g. to take advantage of all the options the net offers). Their learning pace is different from younger generations. They often begin the courses without any experience of computers and the internet. Although they can feel highly motivated at the beginning of the course, they often become discouraged or disappointed, firstly because they find the new skills to be acquired and concepts to be understood too difficult for them, and secondly because they expected more from the Internet.

Communication in the classroom is a key factor to take into account because of the special goals of these learners (motivated by pure personal interest) and their involvement in the classes (as a challenge). In an ICT class, communication is not usually as fluent as in other subjects where the learner feels more confident and relaxed (e.g. humanities subjects); they often feel bewildered, disorientated and intimidated as their learning requires a high practical involvement and interaction with the computer. Trainers should be aware of the communication role that can be applied in an ICT learning environment, but also which techniques are most useful to overcome the barrier that can exist and that prevents the learners gaining confidence and learn efficiently.

This study focuses on senior students attending the Senior Citizens' University (SCU) ICT courses (281 students, average 66 years old). Computer and internet courses have been run since 2002 for seniors, since then, 793 students have registered. At the start of each year, a user-needs analysis is carried out by the teacher. At the end of the course, the students give feedback on the teacher's 
didactic skills. All these data plus the teachers' observation are gathered and constitute the basis of the results.

\section{THE JOHARI WINDOW}

The Johari window is intended to illustrate the process of "giving and receiving feedback". The model, presented as a communication window through which information about oneself and others is given and received, helps to analyze and improve communication.

The whole area of a rectangle represents a complete description of a person, that is, his/her appearance, behaviour, opinions, feelings etc..

\begin{tabular}{c|c|c|}
\multicolumn{1}{c}{} & \multicolumn{1}{c}{ Known to self } & Not known to self \\
\cline { 2 - 3 } $\begin{array}{c}\text { Known } \\
\text { to } \\
\text { others }\end{array}$ & Arena & Blind Spot \\
Not & & \\
$\begin{array}{c}\text { Known } \\
\text { to } \\
\text { Others }\end{array}$ & Façade & Unknown \\
\cline { 2 - 3 } & &
\end{tabular}

Fig.1. Johari Window

The four different kinds of content involved in any communication with another person are represented within the squares.

- Anything known to me and to others is the Arena area (free or open area). It gathers everything I know about myself and the things that others know about me. This area is the one that we employ when meeting people for the first time and that is what other people know about us.

- What I know but others do not know about myself is called the Façade (secret area). This constitutes a person's privacy.

- The blind spot is what others know about me but I don't. It is part of the knowledge visible to others but not perceived by the subject. It is related to the appearance we project, which does not always coincide with the one we would like to project.

- What neither I nor others know about myself will become the so called unknown area or unknown activity area. They are already existing processes, unknown to the subject and to others, which will surface eventually, showing 
that such hidden motivations and behaviour have influenced the relationship from the beginning. This zone is not usually dealt with in group dynamics.

When a group is constituted, we find that individuals show:

- A much reduced open zone. The relationship level is very poor. Group members have very little in common.

- $\quad$ The other zones are very wide.

According to each case, we can observe some areas that will prevail:

- The façade: the others have practically no knowledge about me. Mechanisms hidden to others are common.

- The blind spot (there is very little self knowledge, but there is a lot of mutual observation and behaviours are perceved which the individual himself may not be aware of).

- The unknown area: where unconscious mechanisms are the ones that dominate.

Through the Johari window we can see the main aim of group processes which consists in the

widening of the open zone at the expense of the other areas. That will allow:

- $\quad$ Sincere, spontaneous and understanding personal relationships.

- An increase in the group cohesion.

- The liberalization of the energy used to defend each member's privacy, which is now focused on the group activity.

- The acceptance of the others.

Antons considers that the following techniques help towards the development of the areas:

Providing information about oneself and about what we consider intimate and private will make the façade smaller.

Facilitating feed-back processes will make the façade smaller 


\subsection{Attending class}

\subsubsection{COMMUNICATION DEFINITION}

Communication means sharing, it is a means of giving or receiving information.

It is not enough to transmit a message. The message must be received and must have the same meaning both for the sender and the receiver. The one who receives the information must be able to decode what he has been sent. Sensations are translated into concepts and these must be clear both for the sender and for the receiver.

\section{ESSENTIAL ELEMENTS OF THE COMMUNICATION PROCESS}

These elements are tightly interlinked. For example, according to the receiver, a different code, channel etc will be chosen.

- The sender. The author of the communication, the sender is the subject who sends the message.

- The receiver. The addressee of the message, the one who receives it. The receiver usually shows a receptive attitude to understand and assimilate the message and give an answer, if required.

- The code. The set of signs and rules which constitute the message. There are three kinds of coding: linguistic, voiced and visual.

- Message. The message is the information sent to the receiver. It is the content of the communication. Channel.

- Channel. The channel is the path through which the message is transmitted (air, paper, phone...)

- Context: The context is the circumstance or moment in which the message is transmitted.

For a communication to take place there must be an absence of noise, that is to say, any elements likely to distort or prevent communication. This refers not only to sounds, but it could also be the using of a different code, the selection of the 
wrong channel... Redundancy is also necessary, that is to say, everything that favours, intensifies and makes communication possible (it does not refer to the repetition of the message).

\section{CODIFICATION AND MAIN PRINCIPLES OF COMMUNICATION}

We usually translate our perceptions into linguistic signs. Language has two characteristics that usually identify it. On the one hand, it is lineal, it needs space and time. On the other hand, it is highly articulated, i.e. the basic units can be used more than once.

The communication requires a number or principles to a reality to be codificated in an effective message:

- Principle of relevance: The message must be adequate to the condition of the addressees. The coding of the message must suit the speaker and the situation or communication context. For that reason, knowledge of the addressees is needed, together with a variety of registers, which means adaptability and flexibility in communicating.

- Principle of simplicity: This principle consists in reducing the ideas to the simplest and easiest of terms. A simple language and the economy of words facilitate communication.

- Principle of definition: The concepts and the value of the terms we refer to must be clarified and fixed. They must be explained before enlarging, defined before developing. To achieve that, ambiguities must be avoided as well as exceptional terms (which must be explained if used).

- Principle of structure: It is essential to organise the message in consecutive steps and to have them very clear before beginning communication.

- Principle of repetition: the ideas, concepts and key words of the message must be repeated, and, when a particular concept needs to be emphasised, it should be explained slowly. In order not to tire the audience repeating the same words, we can use synonyms or analogies that repeat the content and meaning.

- Principle of comparison. When we want to contrast the ideas given, the bigger the contrast, the clearer the ideas become. 
- Principle of stress. This principle summarises everything, and consists in emphasizing the aspects of the message that we consider more important. We can use volume, gesture, pauses etc. in order to emphasize.

\subsubsection{VERBAL COMMUNICATION}

Verbal communication uses words, either verbally or written, as a vehicle for the exchange of information between two people. Verbal language is the result of a context where other kinds of communication are included.

As a message can be interpreted in many ways depending on the circumstances of the time and place it was produced in, the social characteristics of the speakers and the kind of relationship that links them, the physician must investigate all the aspects, before being satisfied with the level of understanding achieved on a topic.

Requirements for the production of a communication.

- Clarity. The sender and the addressee must not use different codes.

- Accuracy: Everything must be set and named using the correct reference.

- Objectivity and veracity. We have to show our intention in the message.

- Opportunity. It is necessary to look for the best moment to communicate.

- Continuity. We have to insist. We must not give up after the first refusal.

- Interest. Related to opportunity, interest must be created at the start of a communication. Diffusion: The message must influence others.

\subsubsection{NON-VERBAL COMMUNICATION}

According to semiotics, non-verbal communication (as gestures, body movements etc.) includes behaviour corresponding to a zoological semiotic system of communication (signs shared by animals).

A socio-cultural educator should be familiar with non-verbal language for the following reasons: 
- It is essential to communicate adequately. When we speak we use gestures, position, tone of voice etc, more than we use verbal language.

- Non-verbal language is an important way to obtain feedback. The reaction to our words can often be appreciated through spontaneous and inconsistent gestures, looks etc.

- We can assess the reality and reactions of each member of the group by means of non-verbal language. That way it will be easier to understand and diagnose the group situations and problems

\subsubsection{FEEDBACK AND RETROACTION}

In the communication, the same presence (context, environment) of oneself can have an impact in the kina of the personal interaction. To speak with another person is a dynamic process, because the person reacts and this response can influence in our future reactions.

Feedback is the information given back about how a message has been received, understood and experienced by a person. At this stage in communication the roles of the sender and the receiver are reversed and communication truly happens. There is communication only when the receiver also sends and vice-versa. This way our capacity to communicate with others can be improved. To a great extent, their effectiveness depends on the group and the people concerned.

\section{FEEDBACK FUNCTIONS}

Feedback is useful for:

- To provide support,

- to stimulate and reinforce positive behaviours when those are recognised.

- To correct behaviours that are not helpful for the person or the group

HOW IS THE FEEDBACK PRODUCED

- Letting the other person know what we think and feel about ourselves 
- Letting the other person know what we think and feel about him/her (confrontation)

- Telling each other what one thinks and feels about oneself and about the other (feedback dialogue)

\section{THE FEEDBACK CAN BE}

- Consistent: the feedback information can be shown with a nod or paraphrase.

- Inconsistent. With gestures, yawns etc. the person unknowingly sends feedbacks Spontaneous

- Non spontaneous, induced

- Without words. E.g. leaving the room where they were

- Formal. With fixed rules, e.g. answering a questionnaire

- Informal. Without rules, e.g. applause

\section{RULES FOR A POSITIVE FEEDBACK}

To avoid misunderstandings, clarify relationships among people and help to understand the other better.

Feedback must be:

- Descriptive: it does not have to be valued or interpreted. By avoiding the use of moral judgements, the receiver's tendency to be defensive and reject information decreases.

- $\quad$ Specific. It has to be focused on the moment and situation it refers to.

- Adequate. The other participants' needs have to be considered. It has to be useful, i.e. it has

- to refer to conduct the receiver can modify (if not, it can only be frustrating)

- Unimposed command. The most effective feedback takes place when the receiver himself has asked the question which later will be answered by the observer.

- Clearly formulated. That can be checked if the receivers can rephrase the message in their own words

- Correct. The sender as the receiver of the feedback can check and contrast the information transmitted to the rest of the members 
In order to obtain positive feedback it is indispensable:

- For the person who applies the feedback

To give information as early as possible, in an open, sincere and truly helpful way. This information has to avoid moral judgements and must not be imposed or not opportune (the feedback has to refer to specific things of the moment).

The information must undergo the scrutiny of the group, not just our examination, as we can all be wrong.

- $\quad$ For the one that receives the feedback

To listen in a sincere attitude, to ask for information and clarification and not to defend and argue

\subsubsection{BARRIERS THAT DISTURB THE COMMUNICATION}

As seen before, communication is a complex process. That is why there exist a lot of reasons which can make it defective.

We can say that there are a lot of factors that make the message transmission more difficult between the sender and the receiver.

On the part of the receiver:

- A stereotype is the image we have of other groups or category of people, clichés of thought related to characteristics of people or groups of people. They can be positive, negative or mixed and they are indiscriminately applied to all the members of the stereotyped group. Stereotypes predispose the receiver to interpret the message according to criteria already fixed in the receiver's mind before the actual communication, and these criteria are equally applied to all the individuals included in the stereotype.

- The first impression is the process by which people tend to judge a specific action or event, according to a general impression. It is a variant of the stereotype. When we trust the person transmitting the message, there are 
many possibilities that we will agree with what he says, whereas if we dislike that person, the message will be ignored, distorted...

- Projection. The attribution of our own characteristics to other people is called projection. Our perceptions are thus distorted by our emotions or personality traits.

- Tendency to evaluate, which is the natural tendency to judge what our interlocutor says on the basis of our conceptual system. This starts before the issuer has completed the message, severely hampering our understanding of it.

- Inference. To infer is to induce one thing from another. It is to understand something different from what has been said (understanding what the listener wishes to understand).

On the part of the issuer:

- Disturbances -Interference:

- Innovation consists in taking for granted knowledge that the receiver does not possess.

- Noise: The unwanted items not intentionally produced by the sender are called noise. o Redundancy: In a pejorative sense, redundancy refers to banalities, all those parts of the message which are not important in the message.

- Context. The context may be also a source of disturbance, since a message can be interpreted in different ways depending on the context in which it was framed.

- Attitudes: an attitude is "an idea with an emotional load that predisposes to a type of action concerning a particular class of social situations". If you do not believe in the value of what you are transmitting, you will hardly do it efficiently.

- Absence or deficiency of feed-back: this deficiency is the greatest barrier to communication. A positive feed-back ability permits the detection and overcoming of communication barriers and the verifying of the assumptions made by the receiver in interpreting the message. 
- Absence or deficiency of empathy. Empathy is the ability to place oneself in other people's situation. It is to be able to think and feel what the other person feels. There is empathy when you come out of yourself to take other people's position, with no need for agreement, confusion or identification with their current situatio.

\subsubsection{GROUP DYNAMICS}

Working with groups is really exciting because there is an exchange of experiences, enriching discussions take place and people share the information each one possesses.

A group is an integration of people who meet with common objectives. In the case of company training, they work with groups whose size varies depending on the needs detected.

Each participant has special characteristics, so the managing of groups is a complete task for the instructor, who should be responsible for directing the learning, which is not achieved without the integration of the groups.

The integration of groups can be achieved using techniques and group dynamics.

\section{TYPES OF GROUPS}

- Noisy: murmurings and talking in low voices, which cause the instructor and other colleagues to be distracted.

Recommendations:

- $\quad$ The instructor must be very attentive to such interruptions.

- Look at the participants who are talking

- Ask them some questions or stand very near them.

- If noise is widespread, perhaps it is best to change to a much more participatory technique or a take break.. 
- Silent: If the group is in complete silence, investigate the causes. The process to break the tension may have failed, there is not enough confidence to participate or they are not sufficiently interested in the topic.

Recommendations:

- Using participatory techniques reinforces integration.

- Investigate the causes; act.

- Indifferent: They are not interested in the seminar or its contents. The topics covered are simple and are known by the group. There is nothing new. They are certain they are wasting time.

Recommendations:

- Prior to the course, investigate the level and experience of participants.

- Express your willingness to incorporate issues of interest to the participants into the course content.

- Change your techniques to encourage participation.

- Deal with examples appropriate to the needs and context.

- Aggressive: The arrogant and authoritarian attitude of the instructor provokes an aggressive and hostile reaction from the group towards the same instructor, and the session becomes a struggle of forces that leads to the failure of the course. Sometimes aggression is combined with irony and causes the participants' abandonment.

Recommendations:

- Act with simplicity, modesty and humility. You need to remember that you are not the holder of the truth and that you are also learning with the group.

- Participating: This is the ideal group an instructor would like on a course. If the real interests of the group are stated, if their motivations are known, if the right techniques are used and constantly assessed, the interest and participation of each member of the group will be guaranteed.

Recommendations: 
- Take the maximum advantage of that participation and keep the pupils' interest.

\subsubsection{TENSIONS}

A group's life is somewhat dynamic (something that changes and varies) and sometimes, due to the influence of a number of external forces or internal imbalances, tensions emerge.

The stress of the group is an emotional state of latent dissatisfaction which can be experienced more or less consciously and can inhibit the development of the group or take the shape of a crisis that shocks the group.

The states of stress are experienced with intensity and impotence. But they are obligatory for the maturing of the group.

The tensions can be:

- Individuals: those are before the belonging to the group, from each individual. These tensions can be found in the framework of a larger resonance

- Socials: situation caused by the group itself. According Mucchielli they can be:

- Tensions from anxiety of the group: caused by feelings of insecurity, fear. They are manifested as silences, inhibitions, avoidance attitudes ...

- Tensions due to latent or open conflict: the most common are the struggles for power or between arising subgroups.

- Tensions due to opposition to the leader: They oppose his desire of power or his incompetence.

- Tensions due to frustration: Frustration for not reaching the objectives, relationships, etc. They are usually accompanied by anger and dissatisfaction either manifested or silent.

The group tends to avoid tensions, but they remain dormant, hindering the progress of the group, blocking the behaviour of members. The tension is the prelude to the frustration. 
Tensions are going to generate a series of symptoms (aggression, the start of subgroups, jokes, irony...) that try to find a solution. If a solution is not achieved, the tensions generate the use of defence mechanisms at individual and group level.

\subsection{Summary}

- Communication means sharing. it is a way of providing or collecting information.

- The communication process has several key elements: the sender, the receiver, a code, the message, the channel and the context.

- Verbal communication is the one that uses the spoken or written word as vehicle for information exchange between two people.

- For communication to take place must meet several requirements: clarity, accuracy, objectivity, opportunity, continuity, and diffusion.

- We can distinguish different types of communication: vertical, horizontal, external, internal, formal and informal.

- An important part of the communication will be the feedback that is the communication to a person, during which he/she provides information on how the message, their ideas, behaviour, etc. are experienced, perceived and understood.

- A number of barriers that hinder communication, such as stereotypes, the first impression, attitudes etc. should be taken into account.

- A series of behaviours are included within the non-verbal communication category such as body movement, gestures, etc. All this non-verbal communication will be interesting for the socio-cultural educator

\subsection{Conclusion}

It is task of the teacher and facilitator to enable and empower seniors to learn and allow them to take maximum advantage of the concepts and skills they acquire. 
Furthermore, during the class and activities, through communication, the teacher will put the curricula activities into practice (training), but also will focus on motivating and encouraging seniors, thus allowing them to achieve personal fulfilment and social integration (the complete task of psychosocial education). For this reason, the communication process is very complex as it relates not only to technical concepts, but to social management.

Some may consider the teacher's task to be very easy, as only consisting of delivering explanations; this however, is far from the truth. The teacher and the facilitator must guide the learning process. With seniors this has a high emotional component. The teacher not only has to teach, but also ensure learner motivation levels do not fall, and encourage them to continue exploring and also enjoying the experience of learning together.

Initially, the teacher may feel that ICT seniors are withdrawn and reserved. If this first contact is not made very carefully, the senior can easily become demotivated and may drop out of the class. Some learners must overcome many barriers that prevent them from learning (e.g. they may think it is very difficult and they will never learn) and also from communication (frustration, anxiety, e.g. why ask?

why try to understand?). With the ICT learning process, as it demands high levels of activity from the learner (mainly practical), the teacher must not let any barrier come in the way of communication and consequently learning

Teachers frequently use technical words that we think everyone understands (e.g. cursor, windows, press $\mathrm{X}$ and $\mathrm{Y}$ simultaneously...). The teacher must be very careful to choose the right elements in his or her message. The context of the message is crucial, as it may either be placed correctly in the activity that is being performed, or, on reception, the learner may misplace it in another task. As a first step therefore, the context must be clearly established. Furthermore, the message recipient frequently does not have a clear conception of what is being taught. In this case non-verbal feedback must be taken into account, or the teacher may even request verbal feedback.

It is very difficult to make things as simple as possible (by avoiding useless complexity) and be precise at the same time. The relevance of an explanation or an 
answer to a learner's question may vary widely across the group, as each recipient will have different motivations and aims. The teacher must attempt to maintain a very careful balance: when he/she is talking to the group, he/she should try to explain the concepts to the whole group (remove individual interest or detailed explanation), except in the case that explanation could be used to give an example or an interesting point of view.

Learners often ask increasingly complex questions. In our experience, if the question does not fall within the context of the activity in progress, it is sometimes very difficult to first understand the question itself, and this the first challenge for the teacher. In this case, and in others where the learner is required to explain or ask something, the role of the teacher changes completely. The teacher is now the one that has to give feedback (and sometimes very clear feedback) to gently inform the learner that what he/she is explaining or has asked is well formulated or not completely clear.

Attempts to mix seniors with adolescents and young adults do not produce very good results. They work at different paces and the group does not become cohesive. But when the group is approximately at the same level and with social similarities, feelings of integration are much higher. The teacher and facilitator can use this opportunity to advantage by allowing seniors to support each other.

Seniors must use ICT for their own purposes or needs: communication, leisure, entertainment, information, etc. Once they know how to use the basic tools, they can learn a lot from each other (group learning). Very often they share files and keep in touch through e-mail before they acquire more confidence and begin writing to family and other friends. During their learning process they frequently share and enjoy web pages (as well as their photos and other issues). A highly active group dynamic is a very powerful tool and it allows seniors to continue learning (and practising) outside the classroom. The role of the teacher must not be to impose partners or groups, but rather to encourage groups to emerge through group activities in the classroom.

The group dynamic is very important because feedback from the group will be more useful to the teacher, as it will stem from non-intentional signals and non-visual language; e.g. their attitudes, what are they most afraid of, what they would like to 
learn, the things they like to send by e-mail, the most commonly shared web pages, etc. The group dynamic will also reduce the size of the "unknown" square in the Johari window.

The teacher of ICT to seniors must be considered a professional, and as such, must receive the right training. The ability to communicate adequately is one of the main skills they must possess. To communicate does not only mean being able to express oneself properly, but also being able put oneself in the learner's shoes and understand their position. In this case, giving explanations that the learner will understand, and the ability to interpret feedback are two communication skills that must be considered as basic teaching skills.

\subsection{References}

[1] Antons,K.Prácticadeladinámicadegrupos:ejerciciosytécnica.Herder.2001

[2] Baskin, Colin; Barker, Michelle and Woods, Peter. When group work leaves the classroom does group skills development also go out the window?. British Journal of Educational Technology. Vol 36 No 12005

[3] Brookhart,Susan. ClassroomAssessment: TensionsandIntersectionsinTheoryand Practice Teachers College Record Volume 106 Number 3, 2004, p. 429-458

[4] Escuder,Pilar.Theinfluenceoflife-long-learning onquality of life in seniorcitizens. VI European Congress of the International Association of Gerontology and Geriatrics. St. Petersburg. July 2007.

[5] Esteller, Roger. Escuder Pilar, etal. Methodology and didactics in ICT courses for senior citizens at the senior citizens' university. VI European Congress of the International Association of Gerontology and Geriatrics. St. Petersburg. July 2007.

[6] Glendednning Frank .Editor. Teaching and learning inlater life, theoretical implications. Ashgate Publishing. 2000.

[7] JulieCotton. The Theory of Learners: An Introduction Kogan Page.1995

[8] Katelyn Y.A. McKennaand Amie S.Green.Virtual Group Dynamics. Group Dynamics: Theory Research, and Practice. Vol 6, No 1.2002 
[9] Lawrence R. Frey. Dennis Gouran, Marshall Scott Poole. The Handbook of Group Communication Theory and Research. SAGE Publications, Inc. 1999

[10] McNickle, Cathy. The impact that ICT has on how we learn - pedagogy, andragogy or heutagogy?. 16th ODLAA Biennial Forum Conference Proceedings. Sustaining Quality Learning Environments. 2003

[11] Mortensen, C. David. Editor. Communication Theory. Transaction Publishers. 2007

[12] Monstad, Sturle .J. Gerontology and ICT. Document prepared for the 2.ICT50+ seminar, Castellon, Spain. May 2009. Retrieved 01/02/2009 2006 http://www.elearningeuropa.info/files/media/media10167.pdf

[13] Mucchielli, Alex. Psicología de la comunicación, Paidós, Barcelona. 1998

[14] Repetto, Manuela. Trentin, Guglielmo. ICT and lifelong learning for senior citizens. Journal of e- Learning and Knowledge Society. Vol. 4, n. 1, February 2008 (pp. 189 - 198 )

[15] Stewart L. Tubbs Sylvia Moss. Human communication: Principles and Contexts. McGraw-Hill Higher Education. 2007 


\section{ENHANCING ICT EDUCATION FOR SENIOR STUDENTS}

Autores (por orden de publicación): Roger Esteller-Curto, Pilar Escuder-Mollon, José Traver-Ardura

Publicado en: Lifelong learning in Europe, digital technologies supporting lifelong learning $(3,2009)$. KVS Foundation; Finnish Adult Education ISSN: 1239-6826

\section{Abstract}

The use of Information and Communication Technologies (ICT) is increasing across all levels of society, not least among senior citizens (those aged 55 and over). Educational institutions are working to teach ICT to this group of learners. The most basic ICT skills include practical computer and Internet use. Other competences such as the capacity to adapt, learning independently, asking for help and helping others require a more complex educational intervention. Informal and non-formal learning are therefore complementary ways of reaching a proficiency in ICT. In this article we present the courses and activities offered by the Senior Citizens' University (SCU) at Jaume I University in Spain. The aims, methodology and content are described, together with examples from ongoing projects and activities, and they are proposed as a way to promote ICT learning among seniors. We also present the advantages of formal learning and propose the introduction of non-formal activities for meeting educational requirements that go beyond simply learning to use a tool.

\section{$20.1 \quad$ Background}

ICT competences among the elderly have advanced, and continue to do so, but not at the same pace as among younger generations (empirica \& Work Research Centre Dublin, 2006) 
Adolescents and young adults are the main users of ICT tools. They use ICT to expand their personal relationship networks and for enjoyment or entertainment. They have a sense of ownership of the net and, on the whole, are unafraid of trying out anything new or unfamiliar (Horrigan, 2009; Jones \& Fox, 2009)

In contrast, seniors mainly use the net as a basic communication tool (electronic mail or chat), for information (searching and reading) and other services (access to organisations they already know: banks, colleges). In most cases, these functions are considered sufficient to meet their needs, as they essentially want to communicate with friends and relations through emails or messaging services and consult certain websites for information (empirica \& Work Research Centre - Dublin, 2006; Jones, 2009)

However, the experience of the Senior Citizens' University (SCU) belies this generalisation and shows that with the right kind of educational intervention (Esteller, et al., 2007) - in other words if it is motivational, enjoyable, and free of pressures - seniors will be keen to continue learning. Senior students are open to discovering new possibilities (communication, leisure, entertainment, information, etc.) and, wherever possible, will take advantage of them.

Against this backdrop, we cannot deny senior students the opportunity to continue learning about the more complex facets of the Internet simply because we believe they have enough knowledge to meet their own needs or because we think they might not be interested. Numerous studies have demonstrated that ICT use among seniors is very useful, motivating and enjoyable (Kaye, 2009; Eastman \& Lyer, 2004). We consider education to be a right, recognised in legislation at all levels, and that it also brings huge benefits to learners and the society in general (Escuder, 2007). The Internet has created new kinds of links and information flows with enormous potential for participation and interaction from which seniors must not feel excluded. Furthermore, the society cannot be built without the participation of seniors. 


\subsection{Motivation}

In an attempt to bridge the digital divide and also as a result of the demand from seniors, many educational institutions are now offering ICT courses and activities for this group of citizens. Consequently, seniors are acquiring increasingly higher levels of competence in using the Internet and communicating through it, and greater inclusion in today's society. (Kim \& Kim, 2001; Parson \& Hick, 2008)

The main aim of a basic course at the SCU is to enable students to use a browser, learn to navigate websites, search for content, and use a mailing tool (Web 1.0 tools). Perhaps because other media (forums, mailing lists, chats, personal web pages, etc.) can be more complex and their meaningfulness is not so immediately obvious to seniors, they tend not to use them so widely (empirica \& Work Research Centre Dublin, 2006). This tool-based teaching increases the seniors' web experience but not their web expertise (Chadwick-Dias, Tedesco, \& Tullis, 2004).

Moreover, Web 2.0 (O’Relly, 2005) now offers new ways of making contact with other people; it goes further than previous methods of communication and also has great potential for content creation. Web 2.0 is not only a series of tools that we can learn to use; it is also a philosophy, a way to keep in touch, learn, share - and to be integrated in the "network society" (Castells, 2006).

Any curriculum designed for seniors must include activities and exercises that will motivate them, and take into account the pace they require. Courses for seniors are very different from those offered to other citizens. These differences arise because their learning capacity is not the same as that of younger learners (Monstad, 2006) and also because their interests are entirely personal - learners attending senior universities are not driven by professional or career demands as shown in Cabedo et al. (2006). Learning to use computers and software is similar to learning a new language, and requires a completely new set of skills (Repetto \& Trentin, 2008, pp. 189-198; Cuciti, 2005; Esteller, et al., 2007). For that reason, ICT education for 
seniors is not only about teaching, explaining things and letting learners practise; it constitutes a complex educational process where other concepts must be considered. Teaching Web 2.0 raises new challenges, which the SCU is trying to deal with through a complex educational intervention.

\subsection{The Senior Citizens' University}

The Senior Citizens' University (SCU) is an adult education project within the structure of the Jaume I University in Spain. The concept of including senior citizens in university communities was first proposed in 1986 by Lemieux and Vellas. Today, 57 (or 80 per cent of) Spanish universities (Cabedo, 2006), run such a project and over 30,000 students are enrolled on their courses. These learners are aged 55 and over, and their chief motivations are interest in the subjects taught, keeping up to date, curiosity and keeping their minds active. The university provides a social, academic and research framework. These qualities are what clearly differentiate the senior citizens' university programmes in Spain from other adult learning institutions. The first Spanish programme began in 1992 in the University of Alcalá de Henares. The SCU at the Jaume I University was founded in 1998 with 38 learners. ICT courses were offered for the first time in 2002. In the last academic year (20082009), 753 students registered for SCU courses. Their average age was 66. The aims of the SCU are to:

- Foster greater participation of senior citizens in today's society.

- Contribute to the process of adaptation to change that senior citizens face today.

- Provide an appropriate space for the interchange of knowledge and experiences scientific and cultural nature.

- Evaluate, recognise and build upon the experiences senior citizens have acquired throughout their professional and working lives.

- Provide a forum for seeking solutions that encourage successful intergenerational relationships. 
- Enable senior citizens to become aware of aspects of university life that, among other positive outcomes, may contribute to a better quality of life.

The formal learning programme we offer allows us to establish very clear learning objectives and competences that can be achieved through a curriculum. The subjects taught are essentially from the humanities disciplines such as art, history and psychology, but also include other subjects like economics and health, and extraacademic activities (drama, hiking, choir, a magazine, radio programme, etc). The teachers are all university professors, and all courses are tailored-made for seniors.

This formal structure has significant advantages. It enables an environment that provides a framework for formal classroom teaching, but also encourages a broader form of education, promoting tolerance, integration, respect, socialising, and so on. The SCU teaching staff and facilitators are essential figures in this process, and they all participate actively in the learners' education throughout the academic year. Further, the learners' progress can be monitored, corrective measures taken and evaluation carried out.

Specifically in the context of ICT learning, formal learning also allows us to:

- Define the aims and competences that the learner should achieve, thus allowing a learning path and a final goal to be set. At the end of the course the learner, the teacher and the complete learning process can be evaluated against these goals.

- Give the learner initial guidance to acquire the most basic computer and Internet user skills, which are particularly hard to acquire in isolation.

- Teach a variety of Internet applications and computer tools with a wide range of application possibilities. This is important since before exploring a specific tool in detail, it is helpful to have an idea of its full potential.

- Propose exercises and tasks that allow learners to consolidate what they have learnt, recognise their doubts, and expose failings in the methodology. The tasks and exercises are chosen specifically to provide real-world examples of how computers and the Internet can be practically useful.

We soon became aware that formal learning in ICT classes was defective and insufficient. This led to the creation of the "Permanent New Technologies Seminar" 
during the 2006-2007 academic year. The seminar provides a framework in which to establish a methodology to improve educational intervention, to achieve learners' aims and also to provide a space for study and reflection. The results of the seminar were first noted during the 2008-2009 academic year and are summarised below.

As described above, while formal education was able to provide great benefits, with ICT teaching we needed to go further. Non-formal and informal learning at SCU are also encouraged through activities such as seminars and workshops designed to complement students' learning. It has become evident that these activities are just as important as the formal courses.

These activities aim to:

- Turn students into active users of ICT (Esteller, Escuder, \& Traver, 2009), able to incorporate ICT to their daily lives outside the classroom. An active ICT user reflects a complex status, not only based on skills or competences, but on the capacity to be aware of the reality and consequences of the Internet and with the abilities to act and influence through it. To become an active ICT user does not require one to know every tool and option, but to be able to understand how Web 2.0 works and the influence it has on the society and individuals' lives.

- Increase students' capabilities and expertise, and boost their motivation and confidence so they can continue learning by themselves, ask for help, and also help others.

- Give learners the active role they deserve by enabling their participation in the learning process, encouraging them to create content and promoting their initiatives. The elderly must not be considered as passive individuals who cannot do anything useful. Their knowledge, experience and free time can be utilised (but not abused). Through volunteer work or other channels of participation in the decision-making levels of an institution, seniors can provide great benefits to the institution, to society and what is more important, to themselves.

- Integrate seniors into the "network society" (Castells, 2006). The potential of Web 2.0 (O'Relly, 2007) has been recognised worldwide (Grossman, 
2006). Seniors should be an integral part of that network. They are capable of participating and defending their rights, by fostering their Internet citizenship and e-inclusion (EC, 2007).

\subsection{SCU activities}

The activities we offer at the SCU can vary greatly. They have been designed to fulfil the aims outlined above. This section summarises the activities carried out by the SCU in the 2008-2009 academic year.

\subsubsection{THEORETICAL LECTURES AND SEMINARS}

Theoretical lectures and seminars offer the chance to explain and show the impact of ICT in society, what Web 2.0 is and how it works. Some lectures and seminars deal with recent Internet history, the dot-com bubble crash, collaborative websites, and examples of their usefulness and impact in real life. Websites cannot be explored in detail because these lectures are addressed to seniors in general, both with and without ICT knowledge. In addition, more detailed information is given to ICT learners (allowing them to practise later).

\subsubsection{THE FAMILIAR WEB}

As a person is learning something new, he or she may be afraid of practicing or trying out new things (e.g. driving, speaking a new language, travelling abroad). The SCU's website which provides details of all the subjects taught and extra-curricular activities (hiking, drama group, trips, photo albums, students' work) has been modified to allow student participation and interaction. As beginner learners recognise the SCU environment, they find it easier to begin to explore and participate in the Internet through the SCU website. 


\subsubsection{INFORMATION}

Through our classes, a mailing list and a blog, we reported on the relationship between the virtual and the real world by keeping track of news items dealing with the two worlds and how they impact on each other. Providing this information proved to be a relatively simple task, as traditional media (TV and newspapers) frequently report ICT-related news, and there is also a wealth of higher quality, innovative information on the Internet. This task was carried out at all course levels. Practically all the students considered this information to be very useful and appreciated it, although we also noted that it was not always completely understood. In these lectures and communications, we tried to use simple language and also provide background information.

\subsubsection{PRODUCTION OF CONTENT}

Everybody is free to write, participate and exchange information and knowledge. Students can communicate through electronic mail, but we also show them other means of communication (blogs, Wikis, commenting on the SCU website, photo submission and comment, etc.). Enabling seniors to move from knowing how to use the tools or merely being aware of their possibilities to a state where they know how to participate in the society, influence and defend their rights, and create content is a more challenging task. Sometimes they simply do not want to (not always for any clear reason), or they do not know what to write about because they think they have nothing sufficiently important to say. We proposed two approaches for the students who expressed an interest in creating some type of web content: They could form groups and write about their common interests (e.g. cooking, travel, local customs, etc.) or write about events in the local institution (in this case, activities and other events in the SCU).

20.4.5 GIVING LEARNERS A CENTRAL ROLE 
In Grundtvig learning partnerships, the learners take centre stage. Their involvement and opinion is crucial in these projects. Volunteer work for example as trainers (or teaching assistants) takes full advantage of their knowledge, and motivates them and other learners to continue (such as in the SenTrain project, see below). The most advanced learners can also participate in organising conferences or preparing materials in book or manual form (Cabedo et al., 2008, pp. 177-248)

\section{$20.5 \quad$ Our ICT courses}

The SCU at Jaume I University offers ICT courses at three levels each year: basic, intermediate and advanced. The main characteristic of these courses is that they are very broad-based, that is, they do not focus on only one computer application or Internet service.

The basic level is designed for people with no experience of computers or the Internet. They learn to use the mouse and the keyboard, and the operating system (Windows) with its own language and interface (windows, clicking, double clicking, dragging and dropping, copying, pasting). They then learn to use the tools (browsers and mail tools) and to apply them for their own purposes (searching, learning, entertainment, etc). On completing the 50 hour course, they have become basic Internet users.

The duration of the intermediate level course is also 50 hours. The students learn to use the Internet for their own needs: to buy online, chat, use translation websites, and so on. The course focuses on the use of web pages (museums, maps, media, blogs, Wikis), security (virus, mails) and information search (web pages, images, programmes). On completion of this level, students should have gained sufficient skills to take advantage of the Internet and also to become independent learners. However, we came to the conclusion that this is not entirely true in reality as we observed a lack of initiative and determination to keep trying, testing and asking for help accurately (that is, asking the right questions in order to solve the problem they are experiencing). 
The advanced level is designed for students who want to use specific computer tools (image uploading, social networks, bookmark services), but also to continue learning more about areas covered in the intermediate level (e.g. search tags, payment services, security advice, etc).

Other courses that we offer are 15 hour workshops that have been created to cover specific areas of ICT, such as photography, blog creation, presentation tools, window maintenance and open software. The workshop contents vary each year depending on demand.

\subsection{The ActiveICT project}

The Grundtvig learning partnerships which are part of the Lifelong Learning Programme (formerly Socrates Programme) supported by the European Commission (2009) and the Europe-wide network of national agencies, provide an excellent opportunity for adults to participate actively in European projects.

In 2005-2007 the SCU coordinated the ICT50+ project (http://www.ict50plus.org) and is currently leading the ActiveICT project. Both projects are related to seniors and ICT, and not only provide an invaluable opportunity for the institution to improve its ICT teaching methodology, but also enable seniors to become involved in the partnership activities. Furthermore, the Grundtvig cooperation project SenTrain (http://www.sentrain.org) was created to develop and test materials to train seniors to become trainers. SCU was a partner in this project that offered learners a pilot course to become trainers (volunteer tutors). The project was carried out in 2005-2007.

The ActiveICT learning partnership is currently in progress (the project period is 2008-2010), and involves 12 institutions in nine European countries (http://www.activeict.org). Its main objective, besides those that are common to all learning partnerships (EC, 2009), is to increase institutional competence for encouraging seniors to become actively involved in ICT. 
These above-mentioned projects have clearly had a great impact on learners in the following ways:

- The SCU's competences are enriched by expertise from other organisations. This knowledge can be applied to new activities, courses and processes that directly benefit learners.

- Some learners have the chance to travel to other countries where they meet other students and learn about different institutions. These visits promote highly motivating information exchanges. Students' awareness and interest also increases. This motivation enables them to overcome the 'knowledge recipient' barrier and to become more autonomous in their learning. This enthusiasm is passed on to other learners and to their institution, and results in individual initiatives to take on activities and become an active part of the learning process through suggestions, producing material, helping others, and so on.

- Participating in a European project involves shared international activities with other partners. These activities offer an excellent opportunity to practise a language or raise cultural awareness. Many learners can benefit from this experience both during the project and once it has ended.

- In general, seniors learn their ICT skills and then practice them. These projects also enable them to become aware of how that learning process occurs and discover details that had previously been invisible to them. This gives them an understanding not only of the content but also of the method, which in turn enables us, as teachers, to improve the course.

The participation in a learning partnership project raises the quality of education (teaching, courses offered, pedagogy, etc) in the institution. However, it also has a huge impact on the learners, by increasing their motivation, which in itself has a considerable knock-on effect among all students. The ActiveICT project aims to turn seniors from learners into active participants in society through ICT, to be integrated in the "network society", to participate, to create new content and foster their net citizenship and e-inclusion. All this has enormous benefits for the learners themselves and for the society as a whole. 


\subsection{Web 2.0 user activation}

Internet is constantly growing and evolving and new ways of communication are reshaping and widening the scope of possibilities that users can aspire to. The revolution we are witnessing today is driven by a new set of characteristics and a philosophy that demands that users, not big corporations and organisations, become the main actors in the Internet. This is the era of Web 2.0.

Web 2.0 enables users to communicate better with each other, overcoming physical distances to keep in touch with family or friends. Web 2.0 also offers a way for people to express themselves. Finally, Web 2.0 tools and their underlying philosophy greatly improve web usability for everybody, the elderly in particular.

At the SCU we have designed a realistic, well-reasoned path to achieve full competency with Web 2.0 tools, which leads to more active ICT users. We have defined a set of stages through which users can gradually move forward as they become comfortable and aware of their own potential to create content and contact other people:

- Reader users: Users in the first stage are those with Web 1.0 knowledge. This is the starting point towards Web 2.0 integration. These users should be able to navigate websites, search for information, and send and receive emails.

- Collaborative authors: The first step in using a Web 2.0 tool should be taken through working in groups. We suggest using a Wiki as a collaborative tool where users share information and start creating content without fear of making mistakes, as any mistakes will be corrected by their Wikicolleagues.

- Individual authors: When users feel comfortable about creating content and sharing it with friends or family, they may start creating and publishing information on their own. They are ultimately responsible for the contents created, the style, layout, and so on, of any published information. This is the most difficult stage as users are taking their first Web 2.0 steps on their 
own.

- Integration in virtual social networks: As users become familiar with ways of sharing information and creating contacts with other Web 2.0 users, they can create or join a range of issue-related communities. They find common interests with people they do not know personally and establish a link. This is the highest level of Web 2.0 integration.

\subsection{Wikisenior}

We began applying the above-mentioned stages at the start of the 2008-2009 academic year. The project was presented to the student community as a whole and also directly to the 282 learners attending our ICT courses. The 103 students enrolled in the intermediate and advanced Internet courses were encouraged to become active. A total 24 learners finally took part in a pilot Wiki collaboration course (Traver, Esteller, \& Escuder, 2009) and nine learners did it by independently. Following the pilot course, reactions were observed in the rest of the student community and approximately 50 other learners joined the active community.

We set up a Wiki as a collaborative tool to create content and share information among users. We defined a methodology (Traver, Esteller, \& Escuder, 2009) and a programme to integrate students into Web 2.0. We defined popular topics and sections in the Wiki and we created a sandbox, a set of pages for users' tests. The users learnt how to use the tool and they began to create their first articles in the sandbox. When the articles were finished by the first author, we moved the pages to the main section outside the sandbox. The finished articles were edited and corrected by other Wiki users and eventually they initiated rounds of discussions about content and suggestions for the improvement of each article.

The programme not only covered using the tool and the web 2.0 philosophy. A parallel objective was to induce users to become collaborative authors: moving from writing to editing and improving other learners' content. 
A commonly used engine was installed and configured to fully integrate this tool into the SCU website. This gave users a friendly environment that they were already familiar with.

We made a preliminary analysis of the common techniques of working on a Wiki. In addition, we produced a report on the initial anxieties expressed by the students. This information was used to draw up a set of strategies to deal with the most common situations, and the most appropriate strategies were chosen for each individual person. The most common fears and basic solutions are described in the insert.

Common problems for Wikiseniors

\begin{tabular}{|l|l|l|}
\hline PROBLEM & DESCRIPTION & SOLUTION \\
\hline block & $\begin{array}{l}\text { Users do not know } \\
\text { where to start. }\end{array}$ & $\begin{array}{l}\text { Users are advised to use a top-down writing } \\
\text { strategy, creating an index of contents, then } \\
\text { developing sections and subsections and } \\
\text { finally filling each of these sections; hence } \\
\text { the work is subdivided into small sections } \\
\text { instead of a long text. }\end{array}$ \\
\hline Incorrect & $\begin{array}{l}\text { Users think that their } \\
\text { articles will contain lots } \\
\text { of mistakes. }\end{array}$ & $\begin{array}{l}\text { Articles written in a Wiki will be read by } \\
\text { other Wiki-colleagues who can correct any } \\
\text { mistakes. An article in a Wiki is never } \\
\text { finished, as it is being continually re-worked } \\
\text { to improve its quality, structure or layout. }\end{array}$ \\
\hline $\begin{array}{l}\text { Public } \\
\text { pages }\end{array}$ & $\begin{array}{l}\text { Everybody can read } \\
\text { what users write. Users } \\
\text { tend to be afraid to } \\
\text { ablish their written } \\
\text { anybody can read }\end{array}$ & $\begin{array}{l}\text { This shyness will eventually disappear as } \\
\text { and friends and receive feedback about } \\
\text { their work. }\end{array}$ \\
\hline
\end{tabular}




\begin{tabular}{|l|l|l|}
\hline & $\begin{array}{l}\text { them. This may make } \\
\text { them fearful in their first } \\
\text { attempts to use a Wiki. }\end{array}$ & \\
\hline Problems & $\begin{array}{l}\text { The final article does not } \\
\text { writing the } \\
\text { source code }\end{array}$ & $\begin{array}{l}\text { The best way to solve this problem in to } \\
\text { writen in a Wiki and choosing a } \\
\text { in a Writing } \\
\text { layout for the article }\end{array}$ \\
$\begin{array}{l}\text { requires users to learn } \\
\text { how to use a set of codes } \\
\text { to indicate styles (italic, } \\
\text { bold or underscore } \\
\text { letters, sections, etc.) }\end{array}$ & practise and try out different styles. \\
\hline
\end{tabular}

When students read completed articles by other people, they feel encouraged to finish their own. Reading a variety of articles gives students a great deal of ideas about presentation and publishing layouts that they can use. We also realised that users feel comfortable editing pages in Wiki source code, which is easier than HTML. They were also pleased by the professional appearance of their pages (Wikipedia style).

This methodology, based on proactive teaching, has been highly advantageous for senior learners. Common Wiki problems, such as digital vandalism or a sense of ownership were addressed from the outset. Difficulties experienced by early users were also dealt with to avoid the same situation arising with others.

These approaches enabled seniors to learn how to write together and support each other. The role of the teacher and facilitator was crucial in motivating them and helping them to learn how to use the tools (Traver, Esteller, \& Escuder, 2009).

The impact on other learners was substantial once the content had been created, and in turn led to greater interest - and sometimes surprise - than expected in all areas of the university and the local community (e.g. newspapers, other 
seniors). We believe that this reinforcement and recognition of their work was crucial to them.

After writing and participating in the SCU platform, students are motivated to create content and publish it (e.g. write blogs, upload their holiday photos), later join networks (e.g. feeds, links) and participate in the knowledge society (e.g. help others, shape new models of information).

Educational institutions can only encourage and empower seniors to become net-citizens. In the end, it is their choice whether they become active or not. Whatever path they decide to follow, it is vital they are given that opportunity, and they, and society as a whole, have the chance to reap the benefits of their reasoned, rational decisions.

\section{$20.9 \quad$ References}

Cabedo, S., et al. (2006). Los programas universitario para mayores en España: una investigación Sociológica [The university programs for seniors in Spain: A sociological study]. Castellón, Spain: Publicacions de la Universitat Jaume I.

Cabedo S., et al. (2008). Jornadas de mayores y nuevas tecnologías [Conference about seniors and new technologies]. Castellón, Spain: Publicacions de la Universitat Jaume I.

Castells, M. (2006). Informacionalismo, redes y sociedad red: una propuesta teórica [Informationalism, networks, and the network society: A theoretical blueprint]. In La sociedad red: una vision global. Madrid: Alianza Editorial.

Chadwick-Dias, A., Tedesco, D., \& Tullis, T. (2004). Older adults and web usability: Is web experience the same as web expertise? In Extended Abstracts of the 2004 Conference on Human Factors and Computing Systems, Vienna, 1391-1394.

Cuciti, J. M. (2005). Computer instruction and andragogy: Best methods to teach the elderly E-mail as a communication tool. University of Oregon. Applied 
Information Management Program. Retrieved February 1, 2009 fromhttp://aim.uoregon.edu/research/pdfs/Cuciti2005.pdf.

Eastman, J. K. \& Lyer, R. (2004). The elderly's uses and attitudes towards the Internet. Journal of Consumer Marketing, 21(3), 208-220.

empirica, Gesellschaft für Kommunikations- und Technologieforschung mbH \& Work Research Centre - Dublin. (2008, April). Seniorwatch 2. Assessment of the senior market for ICT. Progress and developments. Bonn and Brussels: European Commission, Information Society and Media Directorate General.

Escuder, P. (2007, July). The influence of life-long-learning on quality of life in senior citizens [Abstract]. Proceedings of the VI European Congress of the International Association of Gerontology and Geriatrics, St. Petersburg, Russia, 20(3) pages 234-235. Petersburg.

Esteller, R., \& Escuder, P. (2009, February). Structure of the teaching and learning process of information and communication technologies for seniors. International Scientific Conference Society. Integration. Education. Rezeknes Augtskola. Proceedings book. ISBN 978-9984-44-018-7. Rezekne, Latvia.

Esteller, R., Escuder P., et al. (2007, July). Methodology and didactics in ICT courses for senior citizens at the senior citizens' university [Abstract]. VI European Congress of the International Association of Gerontology and Geriatrics. Abstract book, 20(3). St. Petersburg. 235-236

Esteller, R., Escuder, P., \& Traver, J. (2009, July). Methodological proposal for an ICT activation among senior learners. International Conference on Education and New Learning Technologies. Proceedings CD. ISBN 978-84-612-9802-0. Barcelona, Spain

European Commission (EC). (2007). Communication on: European i2010 initiative on e-Inclusion: "To be part of the information society". COM(2007) 694 final. Brussels: Commission of the European Communities. 
European Commission. (2009). Aims and objectives of the Grundtvig program. Retrieved September 1, 2009 from http://ec.europa.eu/education/lifelonglearning-programme/doc86_en.htm

Grossman, L. (2006, December 16). Person of the year: You. TIME Magazine, 168(26), $38-41$.

Horrigan, J. (2009, March 25). The mobile difference. Retrieved May 10, 2009, from http://www.pewInternet.org/Reports/2009/5-The-Mobile-Difference-Typology.aspx.

Jones, S., \& Fox, S. (2009, January 28). Generations Online in 2009. Retrieved May 10, 2009, from http://www.pewInternet.org/Reports/2009/Generations-Onlinein-2009.aspx.

Kaye, H. S. (2009, March). Computer and Internet use among people with disabilities. Disability statistics report (13). Washington DC: U.S. Department of Education, National Institute on Disability and Rehabilitation Research.

Kim, M-C., \& Kim, J-K. (2001). Digital divide: Conceptual discussions and prospect. Proceedings of the First International Conference, Human.Society@Internet, Seoul, South Korea, 2105, 78-91.

Lemieux, A., \& Vellas, P. (1986). L'education universitaire des personnes agées [The universitary education of the elderly]. Perspectives, 22(1), Montreal, 30-34

Monstad, S. J. (2006, May). Gerontology and ICT. Document prepared for the 2. ICT50+ seminar, Castellon, Spain. Retrieved February 1, 2009, from http://www.elearningeuropa.info/files/media/media10167.pdf.

O’Relly, T. (2007). What is Web 2.0: Design patterns and business models for the next generation of software. Communications \& Strategies, 1, 17. Available online at http://ssrn.com/abstract=1008839.

Parsons, C., \& Hick, S. (2008). Moving from digital divide to digital inclusion. Currents: New scholarship in the human services, 7(2). Retrieved September 1, 2009 from http://www.ucalgary.ca/currents/files/currents/Parsons_final_0.pdf. University of Calgary press. 
Repetto, M., \& Trentin, G. (2008). ICT and lifelong learning for senior citizens. Journal of e-Learning and Knowledge Society, 4(1), 189-198.

Traver, J., Esteller, R., \& Escuder, P. (2009, July). Pilot experience of using a wiki for learning and communicating among senior students [CD]. Proceedings of the International Conference on Education and New Learning Technologies, Barcelona, Spain. 


\section{IMPACT ON SENIOR LEARNERS' QUALITY OF LIFE THROUGH LIFELONG LEARNING}

Autores (por orden de publicación)

Pilar Escuder-Mollon, Roger Esteller-Curto, Luis Ochoa, Massimo Bardus

Presentado en: 5th World Conference on Educational Sciences, 5-8 Febrero 2013. Roma, Italia

Publicado en: Procedia-Social and Behavioral Sciences Journal, Volumen 131, mayo 2014, páginas 510-516, ISSN: 1877-0428

DOI: https://doi.org/10.1016/j.sbspro.2014.04.157

\section{Abstract}

Learning in later life (citizens over 65 or retired) is becoming common; job related needs or labour market qualification requirements are replaced by more personal aims such as curiosity, understanding the environment, feeling more integrated, pleasure or keeping active. These personal aims can be seen from the quality of life (QoL) perspective, where education increases well-being and understanding of self and society, and helps senior learners to feel they are participating in and form part of society. The thesis presented in this paper is that education increases QoL. Taking into account that QoL has both objective and subjective facets, and education is a complex long-term process, this article shows the relation that exists between a lifelong learning activity in senior citizens and the impact on their QoL. This research has been conducted within the QEduSen project (supported by the Lifelong Learning Programme of the European Commission) using quantitative and qualitative research methods.

Keywords: quality of life, lifelong learning, pedagogy, senior citizens, elderly, QEduSen; 


\section{$21.1 \quad$ Introduction}

Each life stage - childhood, adolescence or adult - has its own most suitable pedagogies and aims, and the same can be said for senior education. When seniors (citizens over 65 or retired) attend class, they are not pursuing professional goals or seeking competitiveness. Their objectives are more related to personal interests, sociability, adaptation and integration in today's society, participation, active citizenship, and above all, improving their quality of life through a lifelong learning process. Enhancing seniors' quality of life is therefore the main aim to be achieved through education.

The European project (within the European Commission's LifeLong Learning Programme) QEduSen started on November 2011, with seven participating adult education institutions. The aims of the project are to develop two products: a guide and an evaluation tool for educational institutions that want to increase the impact of education on their learners' quality of life.

The first stage of the project is now completed. It consisted of a study into the relationship between education and quality of life among senior learners. Quantitative and qualitative research was undertaken with learners to discover their perceptions of quality of life due to education. Staff and teachers groups with experience in teaching seniors were also surveyed to gather their approaches to improving their impact on learners.

Results show that in this context (senior citizens who were not challenged or disabled) and when basic needs are covered (safety, income, reasonable health), education impacts their quality of life (physiological well-being, enjoyment and personal adaptation in the main). This research shows that the methodologies and the environment must be carefully chosen on the basis of the needs of these learners, but more important is the human factor, the teachers and staff, and their ability to communicate and transmit attitudes as well as knowledge. We also found that 
subjects dealing with psychological and physical health were accepted more readily by learners since they recognised that they had some beneficial impact on their lifestyles.

\subsection{Quality of Life and education among the elderly}

The most significant QoL dimensions and facets that should be taken in consideration when talking about individuals' QoL can be extracted from the main theories on Quality of Life (QoL) developed in recent years. The World Health Organisation defines QoL (WHO 1997) as "individuals' perception of their position in life in the context of the culture and value systems in which they live and in relation to their goals, expectations, standards and concerns". Cummins' comprehensive QoL scale aimed at the general population (Cummins 1997) affirms that QoL is both objective and subjective, and has seven domains: material well-being, health, productivity, intimacy, safety, community, and emotional well-being. But the most notable consideration is that, according to Cummins, (1997) "subjective domains comprise domain satisfaction weighted by their importance to the individual". The WHO also evaluates QoL from objective and subjective perspectives. Objective indicators such as access to basic needs, food, income, health, security, transportation, etc., are important for QoL, but they must be weighted from the individual subjective point of view, the cultural and value systems of the rest of the community and its expectations. Indeed, Schalock \& Verdugo 2003 (p.11-30) state that once a person's basic and most fundamental needs are met (income, health and social contact), improved QoL is based on subjective factors, but mainly on "the perception of the individual" and it is based on "needs, election and individual control".

QoL can be seen from a hedonic perspective (satisfying one's own needs, pleasure, wishes), and it is related to ownership of material property, money, pursuing pleasure, not being in pain, etc. When a person is facing risk of exclusion, is very poor 
or has nowhere to live, QoL can be improved through social services, health providers and direct policies from decision makers (such as transportation, security, etc).

When basic needs are covered, the eudaimonic perspective prevails (from the Greek, eudaimonia means literally "the state of having a good indwelling spirit, a good genius", Encyclopaedia Britannica). This perspective regards QoL as a long-term, highly subjective state that is related to attitude, motivation, integration, community participation, perceived control and personal aims in life. From this perspective, education can promote QoL.

Education should not be considered in a context where teachers provide learners with information to memorise, but in the broader sense of the word, through specific subjects, activities, pedagogies, and models of education, in a context of an educational institution, comprising managers, staff, technicians, trainers, tutors, facilitators and the learners themselves. All these factors encourage learning among the elderly in a challenging society, providing the attitudes and competences necessary to remain as part of the community, through participation, being active, understanding, etc.

QoL varies according to a person's life stage (young, adult or elderly) but also according to specific situations that may jeopardize elements of previous QoL (disability, exclusion, etc.). In this paper we focus on the elderly (more than 65 years old) with no specific challenges.

To understand QoL among the elderly, we first need to know more about their physical, psychological and social conditions. This research was carried out in previous QEduSen project studies.

Eighteen characteristics (Table 1) were extracted from the existing QoL theory; senior learners (Table 2) were then asked to place them in order of importance. 
Table 1. Facets taken from QoL theory for the "QoL preferences" survey

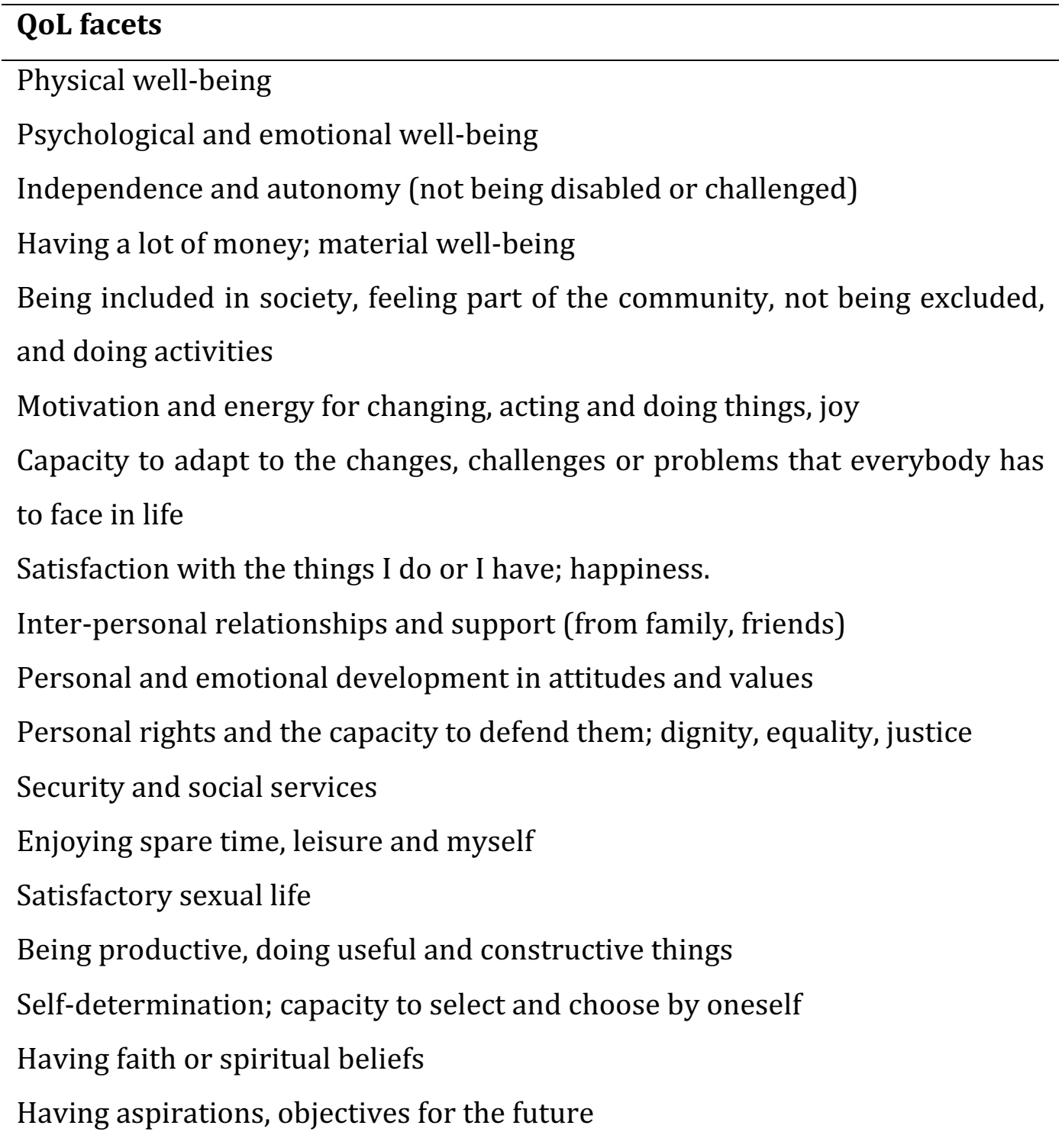

The "QoL preferences" survey was carried out in four institutions: the Senior Citizens' University (SCU), at Jaume I University, Spain; the Universutà delle LiberEtà del FVG (ULE) in Údine, Italy; and Akademia im. Jana Dlugosza w Czestochowie (AJD), Czestochowa in Poland; and the Palmenia Centre for Continuing Education (PCCE) in Helsinki, Finland. The full survey is available at the QEduSen project website (http://www.edusenior.eu). The general statistical information from this survey can be consulted in Table 2 . 
Table 2. Institutions that carried out the "QoL preferences" survey

\begin{tabular}{|c|c|c|c|c|c|c|}
\hline Institution & $\begin{array}{l}\text { Surv } \\
\text { eys }\end{array}$ & Valid & $\begin{array}{l}\text { Aver } \\
\text { age } \\
\text { Age }\end{array}$ & $\begin{array}{l}\text { St.De } \\
\text { v. } \\
\text { Age }\end{array}$ & $\begin{array}{l}\text { Male - } \\
\text { Female }\end{array}$ & $\begin{array}{l}\text { Retire } \\
\text { d }\end{array}$ \\
\hline Senior Citizens' University (SCU) & 73 & 63 & 66.9 & 6.0 & $\begin{array}{l}38 \%- \\
62 \%\end{array}$ & $100 \%$ \\
\hline $\begin{array}{l}\text { Universutà delle LiberEtà del FVG } \\
\text { (ULE) }\end{array}$ & 57 & 56 & 62.4 & 10.8 & $\begin{array}{l}61 \%- \\
39 \%\end{array}$ & $79 \%$ \\
\hline $\begin{array}{l}\text { Akademia im. Jana Dlugosza w } \\
\text { Czestochowie (AJD) }\end{array}$ & 25 & 23 & 68.6 & 7.7 & $\begin{array}{l}25 \%- \\
75 \%\end{array}$ & $96 \%$ \\
\hline $\begin{array}{l}\text { Palmenia Centre for Continuing } \\
\text { Education (PCCE) }\end{array}$ & 25 & 25 & 72.1 & 9.6 & $\begin{array}{l}76 \%- \\
24 \%\end{array}$ & $100 \%$ \\
\hline
\end{tabular}

Learners at the SCU, AJD and PCE were asked to order the 18 characteristics (Table 1) from the most to the least important. The results are reported in Figure 1 (1 indicates that the item was chosen as first option most frequently). The initial survey resulted in a large number of invalid surveys because of the difficulties in ordering the answers, and consequently the survey was changed for the ULE to require learners to rank the characteristic from 1 to 5 only ( 5 being the most important)

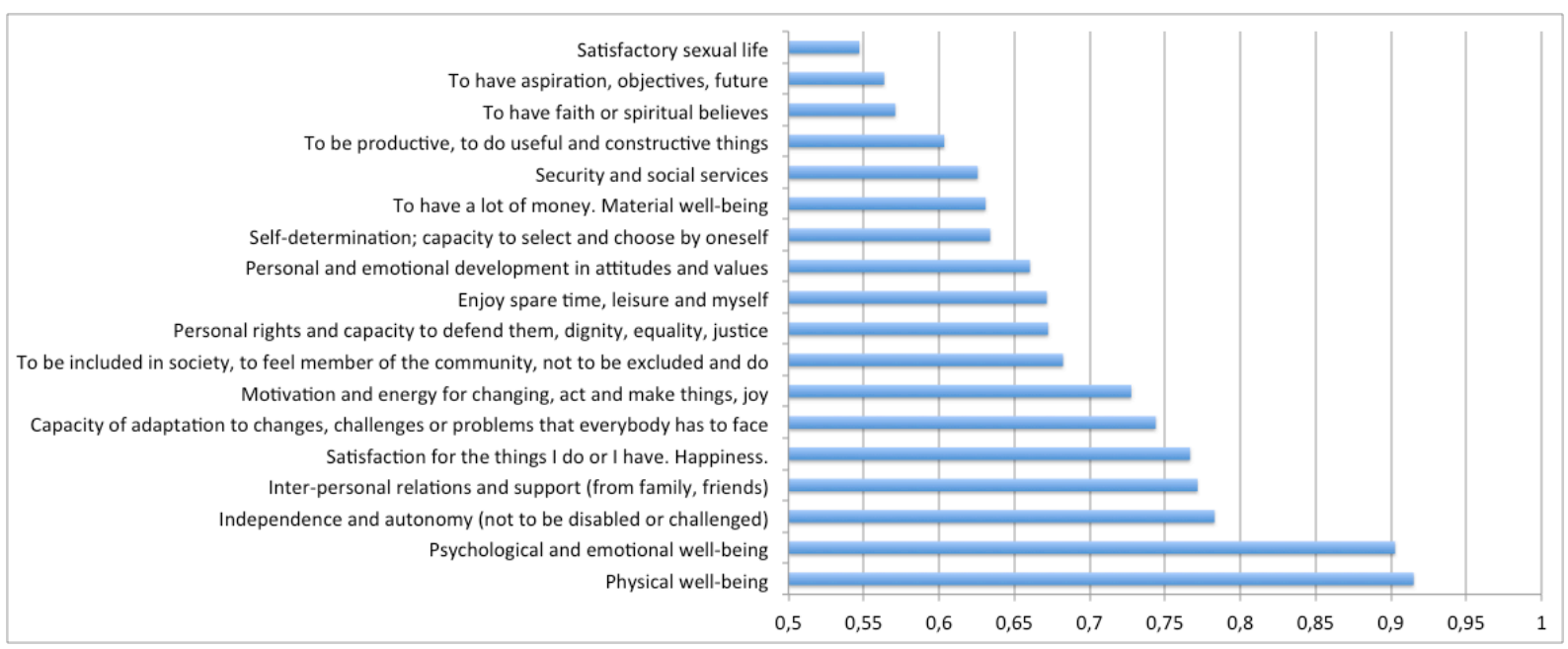

Figure 1. Results from the SCU, AJD, and PCCE: "QoL preferences" survey (ordered by highest preference) 
Figure 1 shows that Physical well-being is the most important component of QoL for senior learners, followed by the Psychological component. In Figure 1, if a component was always chosen as the first option in all the surveys, it would have a value of 1 ; if it was always chosen as the last option, it would have a value of 0 . In fact, the raw data from the survey revealed that $52 \%$ of the learners considered Physical well-being to be the most important component for their QoL, and 45\% considered Psychological well-being as the most important factor. Only $3 \%$ indicated other components as the most important.

The above-mentioned components were followed, in order of importance, by independence, inter-personal relations, support and satisfaction. These are factors that educational institutions should therefore aim to promote.

Figure 2 shows the same results, but the survey was performed using a scale from 1 to 5 rather than ordering the 18 components.

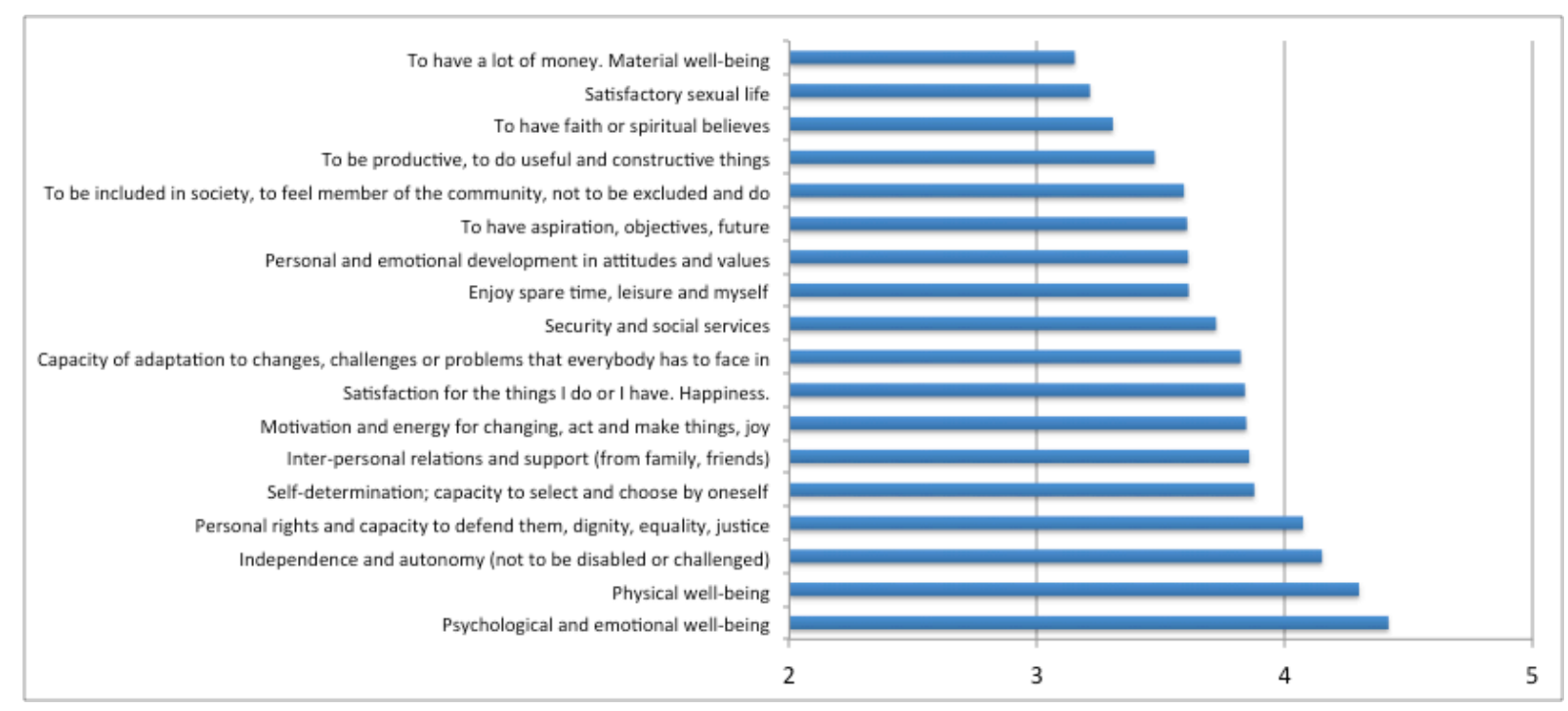

Figure 2. Results from the ULE: "QoL preferences" survey (marking from 1 to 5, where 5

$$
\text { = indispensable) }
$$

\section{$21.3 \quad$ Research}


Three of the QEduSen project partners carried out a survey among their own learners with the aim of discovering seniors' subjective perception of the impact of education on their QoL. Bearing in mind that QoL has a very important subjective component, it is oportune to value the impact of education from the senior learners' perspective. Although QoL has components that might not appear to be influenced by education among the elderly (such as transport, security, income, etc), there are also some components that can be measured (listed in Table 1). We asked learners how education impacted on these components (the statements are reported in Table 3).

Table 3. Questions asked to the learners. "Subjective impact of education on QoL" survey

\begin{tabular}{|c|c|}
\hline Facet & Statement \\
\hline $\begin{array}{l}\text { Physical well- } \\
\text { being }\end{array}$ & $\begin{array}{l}\text { My physical well-being and objective health (pain, medication), as } \\
\text { well as subjective health, have improved since I have been } \\
\text { attending <name of institution>. Furthermore, I now have a much } \\
\text { better understanding of some aspects of my health and I am able to } \\
\text { face any problem. }\end{array}$ \\
\hline
\end{tabular}

Psychological My psychological well-being, objectively and subjectively, has well-being, improved since I have been attending < name of institution>. In general, I know myself better and I have more control over my negative emotions or destructive feelings. Furthermore, I am happier and I face the day with more energy and hope.

Environment My knowledge of the environment has improved. I now have a much better understanding of the local (friends, family) and the global (society, news) environment. Furthermore I feel more included (family, neighbourhood, society in general)

Energy

Since I have been attending <name of the institution>, I have more energy and motivation, I feel able to act. For example, if I have a goal (to travel, to do other activities, etc), now I am more capable of acting to achieve it (to convince others, to learn). Now I know and 
can act to influence other people and change things to achieve what I want.

Adaptation Since I have been attending < name of institution>, I am able to adapt better to the changes that occur in my environment, such as reduced income, illness, the death of a friend, the divorce of a son, etc. I can now adapt in different ways, by understanding, putting things in perspective, assuming, accepting, etc.

Enjoyment Since I have been attending<name of institution>, I now enjoy my spare time much more, doing useful activities or simply activities that give me satisfaction even if they are not necessarily productive.

Support

Since I have been attending <name of institution> I now have the objective or subjective perception that I have more social support from classmates or from others (family, friends). My social relationships have increased or are of better quality.

Personal <name of institution $>$ has allowed me to grow as a person in a development general way: knowledge, values, attitudes, specific information or social skills.

The institutions that carried out the survey were the Senior Citizens' University (SCU), at Jaume I University, Spain, the Universutà delle LiberEtà del FVG (ULE) in Údine, Italy, and Akademia im. Jana Dlugosza w Czestochowie (AJD), Czestochowa in Poland. Statistical data is reported in Table 4

Table 4. Statistical data on the "Subjective impact of education on QoL" survey

\begin{tabular}{|c|c|c|c|c|c|c|}
\hline Institution & $\begin{array}{l}\text { Surv } \\
\text { eys }\end{array}$ & Valid & $\begin{array}{l}\text { Aver } \\
\text { age }\end{array}$ & $\begin{array}{l}\text { St.De } \\
\text { v. }\end{array}$ & $\begin{array}{l}\text { Male - } \\
\text { Female }\end{array}$ & $\begin{array}{l}\text { Retire } \\
\text { d }\end{array}$ \\
\hline & & & Age & Age & & \\
\hline Senior Citizens' University (SCU), & 68 & 58 & 65 & 6 & $41 \%$ & $100 \%$ \\
\hline
\end{tabular}


$59 \%$

Universutà delle LiberEtà del FVG $38 \quad 29 \quad 63.7 \quad 8.9 \quad 35 \quad \% \quad-\quad 76 \%$

(ULE)

$65 \%$

$\begin{array}{llllllllllll}\text { Akademia } & \text { im. Jana } & \text { Dlugosza } & \text { w } & 16 & 13 & 67.1 & 5.8 & 13 & \% & -94 \%\end{array}$

Czestochowie (AJD)

$87 \%$

Figure 3 shows that the factor with the greatest impact on the elderly's QoL is Personal Development ( $\bar{x}=6.89 \sigma=1.19$ ), followed by Enjoyment and Psychological status; Adaptation has the least impact on the education they receive ( $\bar{x}=5.24 \sigma=1.75$ ). They therefore feel that they do not need to attend courses in order to face the changes that occur in their families, friends or communities. They enjoy attending the classes, which is to be expected given that they register in the SCI because of personal motivation. What is interesting is that they are convinced that their Psychological well-being has been enhanced by the education they receive $(\bar{x}=5.82 \sigma=1.30)$. The impact on their Physical well-being or their perception of the Support received is limited, but the high variance in the responses ( $\sigma=1.62$ and $\sigma=1.60$ respectively) should be noted. This indicates that some learners claim education has a high impact on these QoL components, while others consider that education has no impact on their QoL. In the context of the SCU, it should be mentioned that there are some optional subjects related to physical exercise (trekking) or psychology (self-help groups)

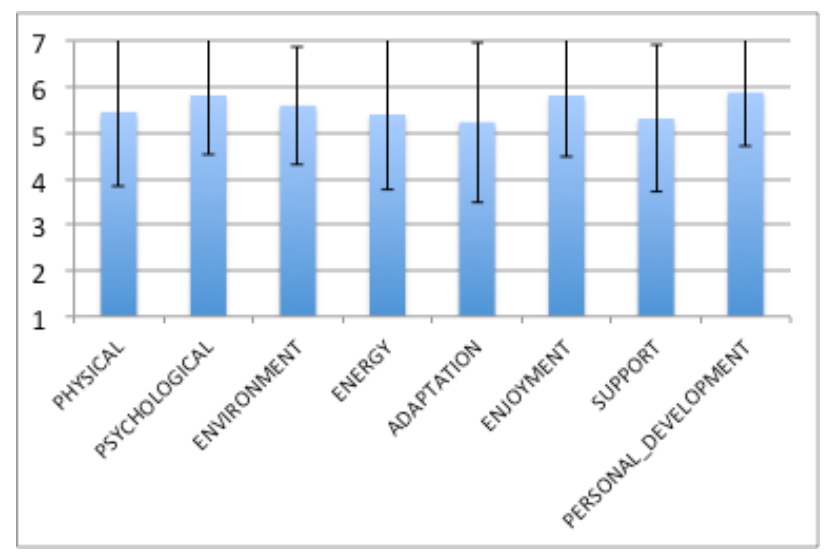

Figure 3. Results from the SCU: "Subjective impact of education on QoL" 
Figure 4 reports the results from ULE. As in the case of the SCU, education allows them to grow personally $(\bar{x}=5.09 \sigma=1.68)$.

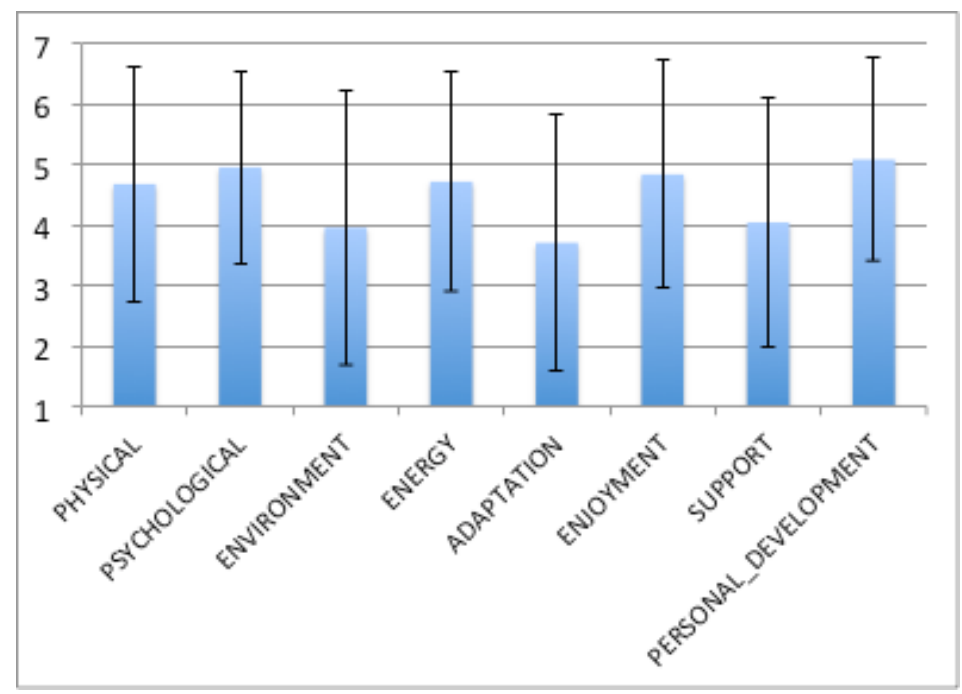

Figure 4. Results in the ULE: "Subjective impact of education on QoL"

In the AJD (Figure 5) the impact of education on learners' Physical well-being is significantly high $(\bar{x}=5.43 \sigma=2.14)$. This is due to the fact that in this institution, physical activity has greater importance than in the SCU and the ULE, and activities like gymnastics, yoga, sports, competitions, self-defence, swimming etc, are accompanied by lectures about healthy life-style, and health-related subjects.

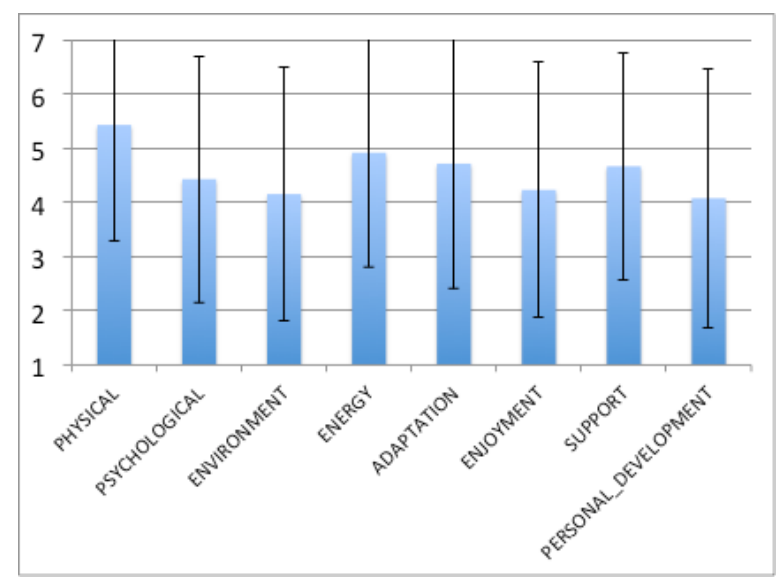

Figure 5. Results from the AJD: "Subjective impact of education on QoL" 
A comparison of the three institutions' overall scores in all QoL components reveals averages of: SCU $\bar{x}=5.57$, ULE $\bar{x}=4.50$ and AJD $\bar{x}=4.58$. The most feasible explanation of why the SCU has a greater subjective impact on learners' QoL seems to be because the staff and teachers of the institution have received specific training in QoL among the elderly and ways in which their activities can increase that QoL. Learners also have the opportunity to attend courses on subjects related to their own perception of society and themselves: humanism, sociology and psychology of the elderly and gerontology.

Following this explanation of how general education impacts senior learners' QoL, we also aimed to discover the specific educational factors that have the greatest impact on their perception of QoL. Those educational factors are summarised in Table 5.

Table 5. Educational factors included in the "Subjective impact of education on QoL" survey

Educationa SCU ULE
1 factor

\begin{tabular}{|c|c|}
\hline $\begin{array}{l}\text { Environme } \\
\text { nt }\end{array}$ & $\begin{array}{l}\text { Physical (premises, buildings, classrooms) but also metaphysical } \\
\text { (shared spaces of coexistence, intergenerational) }\end{array}$ \\
\hline Pedagogy & The way that the classes are designed, participation, debate, etc. \\
\hline $\begin{array}{l}\text { Teacher/tra } \\
\text { iner }\end{array}$ & $\begin{array}{l}\text { Knowledge and experience of the subject, personal skills, good } \\
\text { communicators. }\end{array}$ \\
\hline Staff & Technical and support staff \\
\hline Classmates & Relationships with classmates outside the classroom \\
\hline $\begin{array}{l}\text { General } \\
\text { Subjects }\end{array}$ & $\begin{array}{l}\text { Main subjects that } \text { Broad culture } \\
\text { are mandatory } \text { courses } \\
\text { during the (theoretical) and conferences } \\
\text { academic year foreign languages } \\
\text { (humanities, }\end{array}$ \\
\hline
\end{tabular}




\begin{tabular}{|c|c|c|c|}
\hline & $\begin{array}{l}\text { psychology, } \\
\text { society, history, } \\
\text { arts) }\end{array}$ & & \\
\hline $\begin{array}{l}\text { ICT and } \\
\text { Language }\end{array}$ & $\begin{array}{l}\text { ICT and language } \\
\text { courses }\end{array}$ & ICT courses & ICT courses \\
\hline Work & $\begin{array}{l}\text { Learning through } \\
\text { research work } \\
\text { undertaken by } \\
\text { learners for } \\
\text { presentation to } \\
\text { their classmates }\end{array}$ & & \\
\hline Stimulation & $\begin{array}{l}\text { Museum visits, } \\
\text { cultural trips, etc. }\end{array}$ & & \\
\hline $\begin{array}{l}\text { Extra- } \\
\text { academic }\end{array}$ & $\begin{array}{l}\text { Optional activities: } \\
\text { drama, choir, } \\
\text { trekking, radio, } \\
\text { learners' magazine }\end{array}$ & & \\
\hline Physical & & $\begin{array}{l}\text { Courses for } \\
\text { physical well-being, } \\
\text { gymnastics, } \\
\text { dancing, }\end{array}$ & $\begin{array}{l}\text { Activities done in the } \\
\text { open air or related to } \\
\text { physical well-being }\end{array}$ \\
\hline Handicrafts & & $\begin{array}{l}\text { Artistic laboratory, } \\
\text { handicrafts, } \\
\text { ceramics, sewing }\end{array}$ & \\
\hline
\end{tabular}

Table 5 shows that SCU, ULE and AJD share certain common educational factors, but because the offer of activities/subjects is different in each institution, some questions were adapted to the specific characteristics of the institution. All learners were asked 
to respond by saying how much each educational factor (Table 5) influenced their QoL (Table 1). Results are shown in Figure 6.

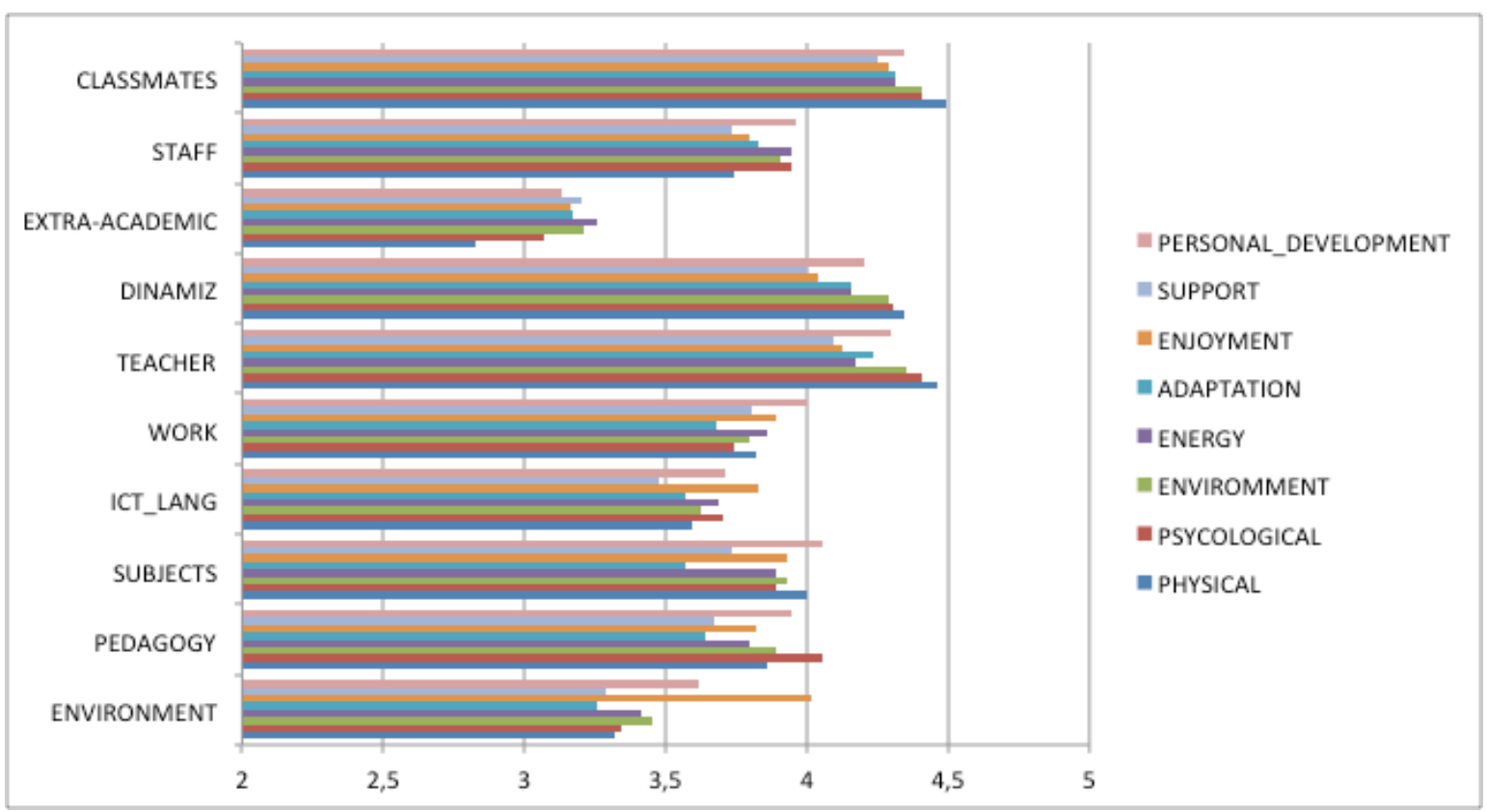

Figure 6. Results in the SCU: "Subjective impact of education on QoL" detailed by educational factor

Figure 6 presents the results obtained in the SCU. It can be seen that the extraacademic activities do not have a great impact on their QoL (hiking, drama, choir, magazine, radio). However, it should be noted that these results are not reliable due to the high variance (from $\sigma=1.53$ to $\sigma=1.83$ ), caused by the optional nature of these extra academic activities. The conclusion can be drawn, therefore, that for some learners, these activities are very significant, while for other learners, they have no importance. In contrast, the influence of the teacher on their QoL appears to be very high, and in addition this is a very reliable result, with low variance (from $\sigma=0.79$ to $\sigma=1.18$ ); in other words, many learners claim that their QoL is influenced by the teacher. Teacher and classmates have the greatest impact on their QoL, even in aspects of physical well-being. 


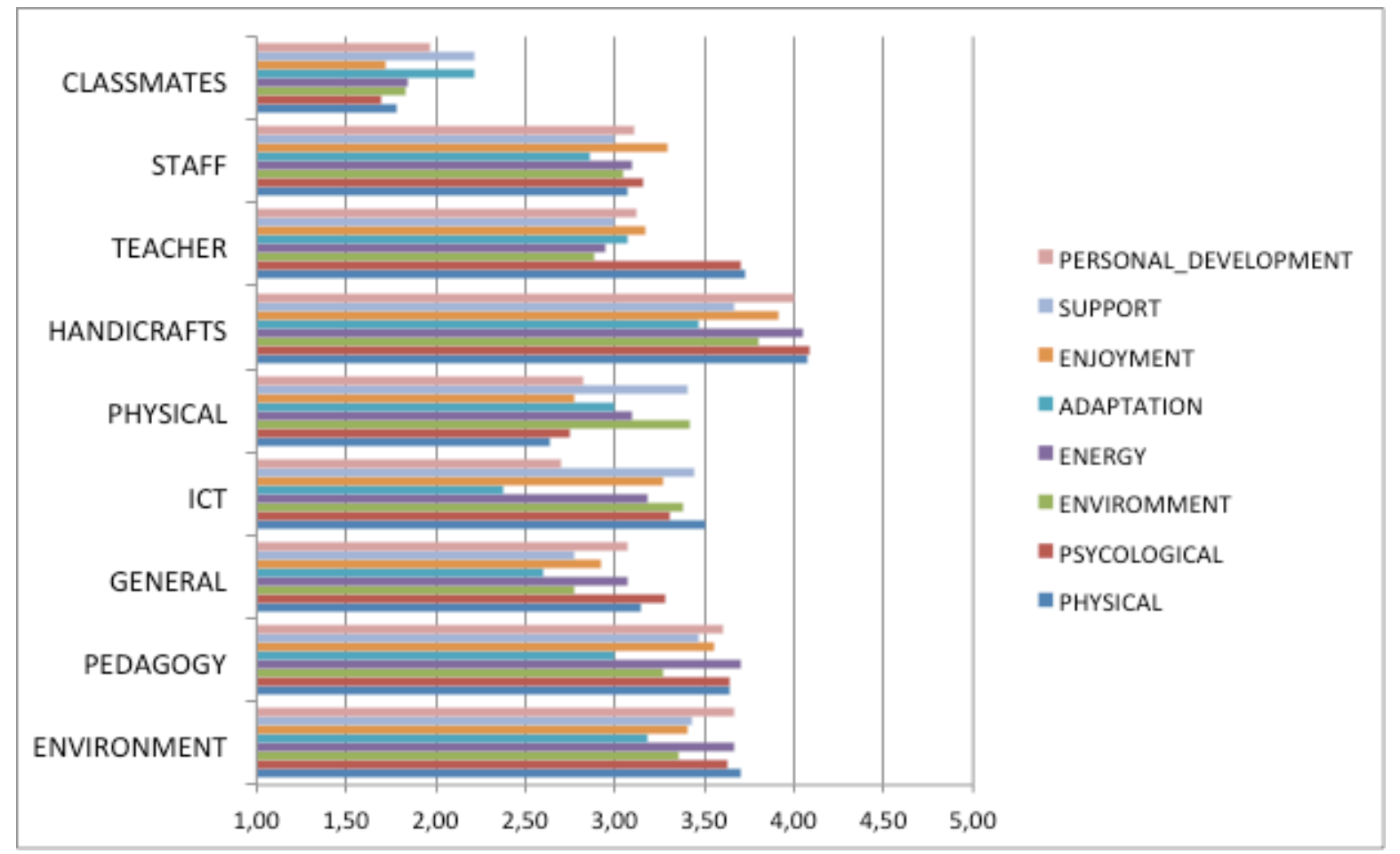

Figure 7. Results in the ULE: "Subjective impact of education on QoL" detailed by educational factor

In the ULE (Figure 7), handicrafts appear to have the greatest impact on QoL. This kind of activity can be seen as a way of being active, creative and working in groups that promote socialising and give support. 


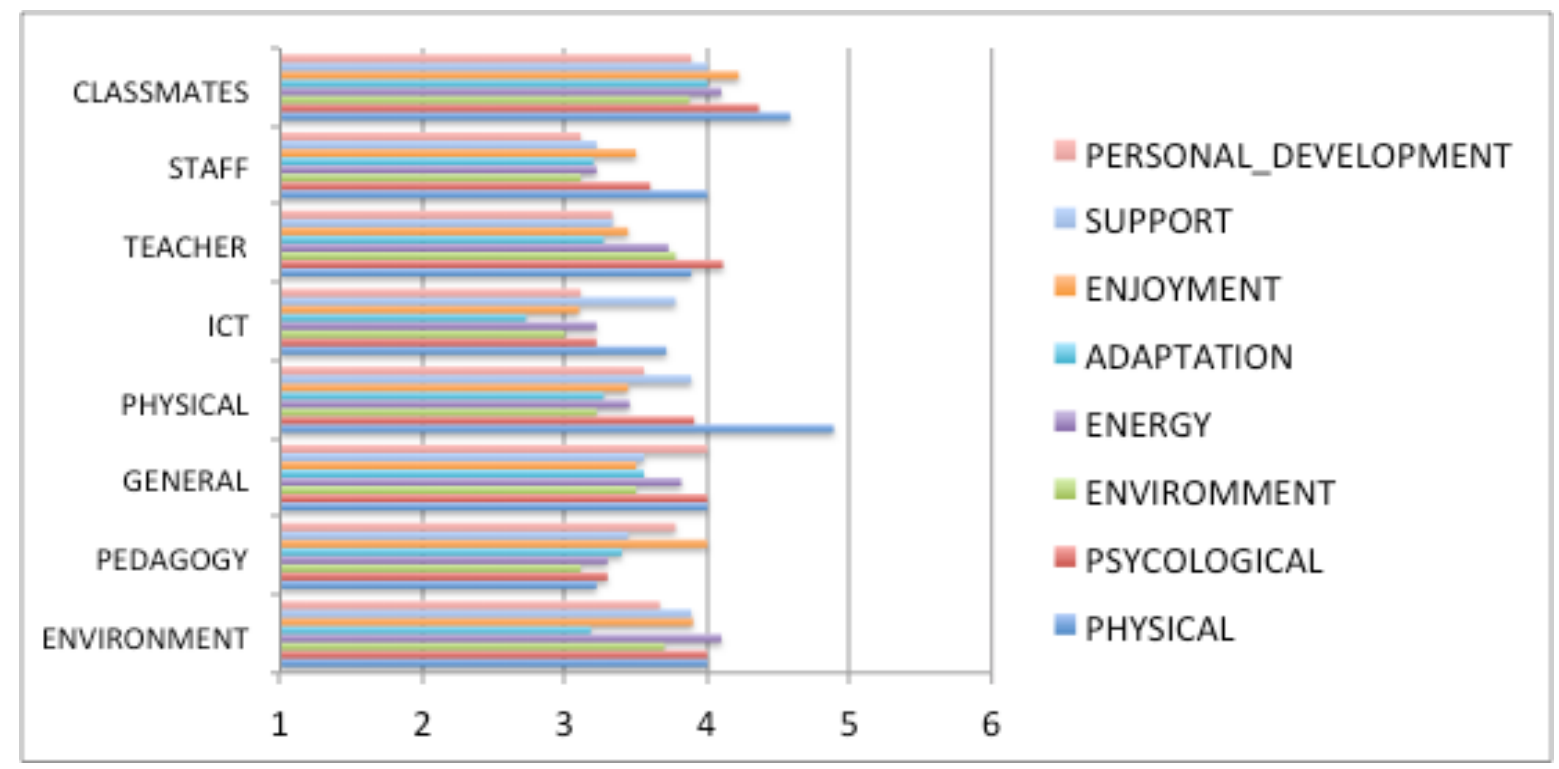

Figure 8. Results in the AJD: "Subjective impact of education on QoL" detailed by educational factor

In the AJD (Figure 8), Physical activities appear to have more impact on learners' Physical well-being ( $\bar{x}=4.89 \sigma=0.33)$. As mentioned above, the AJD offers a wide range of physical activities adapted to seniors, alongside courses about healthy life-style and other health-related subjects.

\section{$21.4 \quad$ Conclusions}

When basic needs are covered, QoL can be influenced through education. In all the surveys, the learners coincided that the teacher and their classmates have the greatest effect on their QoL. Learners stated that the courses and pedagogies were not as important as the teacher. In qualitative interviews, learners were not able to distinguish between pedagogies, and claimed to sometimes choose courses and activities according to the teacher, not the content. In conclusion, the most important factor in enhancing a learner's QoL is the teacher, regardless of the pedagogy and the course content. This affirmation is, clearly, only true from the learners' point of view. 
Teachers, on the other hand, use pedagogies as tools in their courses and activities, and are also passionate about the content they teach (indeed, most of the teachers of adults interviewed also enjoyed teaching seniors).

The teacher, then, must be understood to comprise social skills (communication, assertiveness), tools (pedagogies) and contents (the teacher's expertise in his or her subject). An individual survey was carried out at the SCU into learners' preferred subjects, finding no common results for the subject, but rather for the teacher. Learners therefore have "favourite teachers" rather than "favourite subjects". The way that the teacher communicates and transmits his or her subject, motivates learners and constantly encourages their personal improvement is the main factor impacting on increased QoL among learners.

\subsection{Acknowledgements}

This research was undertaken as part of the "Evaluation toolkit on seniors' education to improve their quality of life" (http://www.edusenior.eu) project, funded with support from the Lifelong Learning Programme of the European Commission, reference 518227-LLP-1-2011-1-ES-GRUNDTVIG-GMP. This communication reflects the views of the author only, and the Commission cannot be held responsible for any use which may be made of the information contained therein.

\section{$21.6 \quad$ References}

Brockett, R. G. (1985). The Relationship Between Self-Directed Learning Readiness and Life Satisfaction Among Older Adults. Adult Education Quarterly, 35(4), 210-219. doi:10.1177/0001848185035004003

Campbell, A. (1981). The sense of well-being in America : recent patterns and trends / Angus Campbell. New York: McGraw-Hill. 
Chung, M. C. (1997). A critique of the concept of quality of life. International Journal of Health Care Quality Assurance, 10(2), 80-84.

Cummins, R. A. (1997). Comprehensive quality of life scale : adult: manual (5th ed. (ComQol-A5).). Burwood Vic.: Deakin University School of Psychology. Retrieved from http://www.deakin.edu.au/research/acqol/instruments/comqol-scale/comqola5.pdf

Kubovy, M. (1999). On the pleasures of the mind. In D. Kahneman, E. Diener, \& N. Schwarz (Eds.), Well-being: The foundations of hedonic psychology (Russel Sage Foundation., pp. 134-188). New York.

Landmin, L. (1997). Elderlearning: New Frontier In An Aging Society (1st ed.). Rowman \& Littlefield Education.

Maslow, A. H., \& Cox, R. (1987). Motivation and personality (Vols. 1-1). New York; Reading, Ma ; Menlo Park, Ca... [etc.], Etats-Unis: Longman.

Myers, D. G., Diener, E., \& Scientific American, inc. (1997). Pursuit of happiness. New York: Scientific American, Inc.

Myers, D. G. (2000). The funds, friends, and faith of happy people. The American psychologist, 55(1), 56-67.

QEduSen (2012). Evaluation toolkit on seniors' education to improve their quality of life. http://www.edusenior.eu

Rapley, Mark (2003) Quality of Life Research. A Critical Introduction, London: Sage Ryan, R. M., \& Deci, E. L. (2001). On happiness and human potentials: a review of research on hedonic and eudaimonic well-being. Annual Review of Psychology, 52(1), 141-166. doi:10.1146/annurev.psych.52.1.141

Schalock, R. L. (2000). Three Decades of Quality of Life. Focus on Autism and Other Developmental Disabilities, 15(2), 116-127. doi:10.1177/108835760001500207

Schalock, R. L., \& Verdugo, M. A. (2002). Handbook on quality of life for human service practitioners. Washington, DC: American Association on Mental Retardation. 
Schalock, R. L. (2004). The concept of quality of life: what we know and do not know. Journal of Intellectual Disability Research, 48(3), 203-216. doi:10.1111/j.13652788.2003.00558.x

Schuller, T. (2004). The benefits of learning. London: RoutledgeFalmer.

WHO. (1997). WHOQOL. Measuring Quality of Life. World Health Organisation. Recuperado a partir de http://www.who.int/mental_health/media/68.pdf 


\section{EL APRENDIZAJE PERMANENTE DESDE EUROPA EN LA UNIVERSITAT PER A} MAJORS

Autores (por orden de publicación)

Pilar Escuder-Mollon

Publicado en: Jornadas sobre asociacionismo en los programas universitarios de mayores. Eva Leal Gil (Coord.), páginas 155-169. Universidad de Valladolid, 2011. ISBN 978-84-8448-660-2.

\section{Abstract}

Esta comunicación pretende introducir en primer lugar las diferentes acciones educativas de la Unión Europea que son aplicables a las Universidades para Mayores. En segundo lugar, y en base a la experiencia de la Universitat per a Majors, se realiza una descripción de los proyectos europeos en los que se ha participado. La participación en proyectos europeos ha generado oportunidades en el contexto educativo de personas mayores, ya sea en cuanto a innovación o incremento de la oferta educativa. Los estudiantes mayores también han tenido la oportunidad de participar, esto ha provocado un enriquecimiento tanto de los resultados del propio producto como una influencia en su educación. Este artículo, pretenden en tercer lugar, mostrar el impacto que estos proyectos tienen en la comunidad así como servir de base de buenas prácticas para cualquier institución que desee embarcarse en proyectos de este tipo.

Palabras clave: Grundtvig, proyectos europeos, mayores 


\section{$22.1 \quad$ Introducción}

Actualmente la educación es parte de una de las acciones prioritarias de la Unión Europea, no sólo mediante intenciones orientadas hacia la estandarización de los estudios (conocido Plan Bolonia o el EEES), sino también en fomentar la formación e innovación de los diferentes estratos educativos existentes. No obstante, las acciones en el ámbito educativo en la Unión Europea son relativamente recientes, estas no aparecen hasta la década de los 90 y lo hacen en contextos orientados hacia ámbitos laborales o productivos.

El proceso de construcción de la Unión Europea se ha centrado, fundamentalmente, en medidas y en políticas de carácter económico, monetario e institucional, poniéndose de manifiesto una falta de iniciativas y de medidas políticas, sociales y culturales que posibilitasen la existencia de una Europa fuerte, potente y con capacidad real de influencia a todos los niveles (Orte et al. 2004).

En el primer tratado de la Unión Económica Europea (Roma 1957) no aparece el concepto de educación, en éste tratado predominan acciones prioritarias económicas e institucionales. Es en el tratado de la Unión Europea de Maastricht (1992) donde se introducen artículos referentes la educación (126 y 127) que se mantienen con escasos cambios en tratados posteriores (artículos 149 y 150, Ámsterdam 1997 y Niza 2001). En todos estos tratados, la educación sólo aparecía acompañada del objetivo de la formación y el empleo aunque en el preámbulo del tratado de Ámsterdam se dejaba entrever un propósito de educación más general:

"promover el desarrollo del nivel de conocimiento más elevado posible para sus pueblos mediante un amplio acceso a la educación y mediante su continua actualización "

La comisión europea publicó en el 2000 (Comisión 2000) un memorando sobre el aprendizaje permanente con la finalidad de materializar una estrategia global en 
todos los estados miembros que hiciera realidad el acceso universal y continuo al aprendizaje, y su participación de forma sostenida en la sociedad del conocimiento

En una decisión del 2001 (Comisión 2001), la Comisión añade el aspecto personal y social a la idea de "Aprendizaje Permanente":

"Toda actividad de aprendizaje realizada a lo largo de la vida con el objetivo de mejorar los conocimientos, las competencias y las aptitudes con una perspectiva personal, cívica, social o relacionada con el empleo"

\subsection{Proyectos Grundtvig}

El programa Sócrates fue creado por la Decisión (Parlamento Europeo 1995) del Parlamento Europeo y el Consejo en 1995 por un periodo de 1995 a 1999.

El principal objetivo por el que se creó el programa Sócrates era contribuir al desarrollo de una enseñanza y una formación de calidad y de un espacio europeo abierto de cooperación en materia de enseñanza. Esta primera fase, solo contemplaba 3 sub-programas;

- Enseñanza superior: Erasmus

- Enseñanza escolar: Comenius

- Acciones transversales: 1. Idiomas (Lingua), 2. Enseñanza abierta y a distancia y 3. Intercambio de información y de experiencias

La continuidad del programa Sócrates se basa en la Decisión del Parlamento Europeo (Parlamento Europeo 1998) y del Consejo en 1998 por un periodo del 2000 al 2004 (posteriormente se extendió hasta el 2006). Por primera vez, se reconoce la educación de personas adultas, que fueron incluidas en el sub-programa Grundtvig.

El sub-programa Grundtvig se divide a su vez en 4 acciones:

- Proyectos de cooperación 
- Asociaciones de aprendizaje

- Ayudantías para personal educativo

- Redes de cooperación

En el periodo 2007-2013 el programa Sócrates pasa a llamarse "Programa de Aprendizaje Permanente" (o sus siglas en inglés LLLP LifeLong Learning Program), el sub-programa Grundtvig se mantiene (EACEA 2007).

Los objetivos generales y operativos que se persiguen con los programas educativos Grundtvig (Parlamento Europeo 2006) pueden consultarse en la propia web informativa de la Comisión Europea (Comisión Europea 2011), no obstante, me centraré en las dos prioridades que marcan las líneas maestras de los proyectos ya que estos son los criterios que marcan su elegibilidad:

1. (a) Realización de movilidades de investigadores, profesorado, técnicos y de alumnos y (b) creación de asociaciones de aprendizaje entre instituciones. En ambos casos se pretende reforzar la dimensión europea y la calidad de las organizaciones de educación de adultos por medio de la cooperación transnacional e intercambio de conocimientos y buenas prácticas.

2. Proyectos multilaterales. En estos casos, diferentes instituciones se asocian para producir resultados teóricos y prácticos concretos aptos para su difusión: métodos, herramientas, materiales, cursos, etc. y que por tanto, introduzcan o difundan innovaciones con un significativo posible impacto.

Existe una relación entre las dos prioridades anteriores y las 4 acciones principales existentes en los programas Grundtivg:

Bajo la prioridad 1, se encuadran las "Asociaciones de aprendizaje" y "Formación continua"; visitas e intercambios, ayudantías, voluntariado, y otras acciones destinadas a la formación del personal educativo y participación de los alumnos adultos.

Bajo la prioridad 2, se encuadran los "Proyectos de cooperación", "Redes" y otras medidas de acompañamiento. 
Una gran diferencia entre las acciones anteriores es que las que responden a la prioridad 1 están diseñadas para facilitar la formación y aumento de calidad de las instituciones educativas de adultos mediante un intercambio de experiencias, visitas de estudio, participación en congresos, etc. En cambio, dentro de la prioridad 2, se exige la realización de un producto innovador, fundamentado en la capacidad que los socios ya deben poseer (los cuales ya se les evalúa y se considera como expertos). Dicho producto es fruto de un análisis e investigación, todo esto para que produzca un impacto en la comunidad educativa o científica (mediante planes de diseminación y explotación)

\subsection{Caso de estudio: participación en proyectos en la Universitat Jaume I}

La Universitat per a Majors ha participado o está participando en los siguientes proyectos europeos:

- ICT 50+: Information and communication technology empowerment for fiftyyear-olds +, asociación de aprendizaje Sócrates-Grundtvig 2" 2005-2007.

- SenTrain, Train the Trainers. Proyecto de cooperación Sócrates-Grundtvig 1" 2006-2008.

- ActiveICT, Active citizenschip through ICT at all ages; asociación de aprendizaje LLLP -Grundtvig 2008-2010.

- E-Vita, European Life experiences, Proyecto de cooperación transversal LLLP KA-3 centrado en TICs. 2008-2010.

- SeniorsKS, Seniors in the Knowledge Society; asociación de aprendizaje LLLP Grundtvig. 2011-2013.

En base a la experiencia de la Universidad, la participación en los anteriores proyectos produce un impacto significativo tanto a nivel de los alumnos, como del profesorado, institución y sociedad, pero se hace necesario diferenciar los proyectos 
en dos grandes grupos de igual modo que se han diferenciado las dos prioridades en la anterior sección: 


\subsubsection{ASOCIACIONES DE APRENDIZAJE}

Las asociaciones de aprendizaje ICT50+, activeICT y SeniorsKS tienen un mismo denominador común: la pedagogía, cursos, actividades y procesos centrados alrededor de las nuevas tecnologías y los mayores. En el proyecto ICT50+ se pretendía estudiar y promover pedagógicas adecuadas y de calidad, junto con cursos $\mathrm{y}$ actividades basados en herramientas TICs para aumentar las capacidades y habilidades de los mayores.

En el proyecto activeICT, se analizaron las TICs desde un punto de vista de utilidad en donde la persona mayor podía usarlas de forma activa para participar, compartir, aprender, etc. Los diferentes socios intercambiaron de este modo experiencias y conocimientos para crear nuevas pedagogías y actividades orientadas a promover un uso de las TICs que trascendía el saber usar, sino el conocer, comprender, adaptar y usar servicios disponibles de Internet. Se realizaron en total 6 reuniones transnacionales en las que tuvieron oportunidad de participar tanto profesores como alumnos. Se realizaron evaluaciones por separado para preguntar acerca de su participación en la propia reunión con en el propio proyecto. En el gráfico 1 se muestran los resultados de la reunión realizada en Évora (Portugal) en Febrero del 2010, realizada en total a 35 estudiantes: 


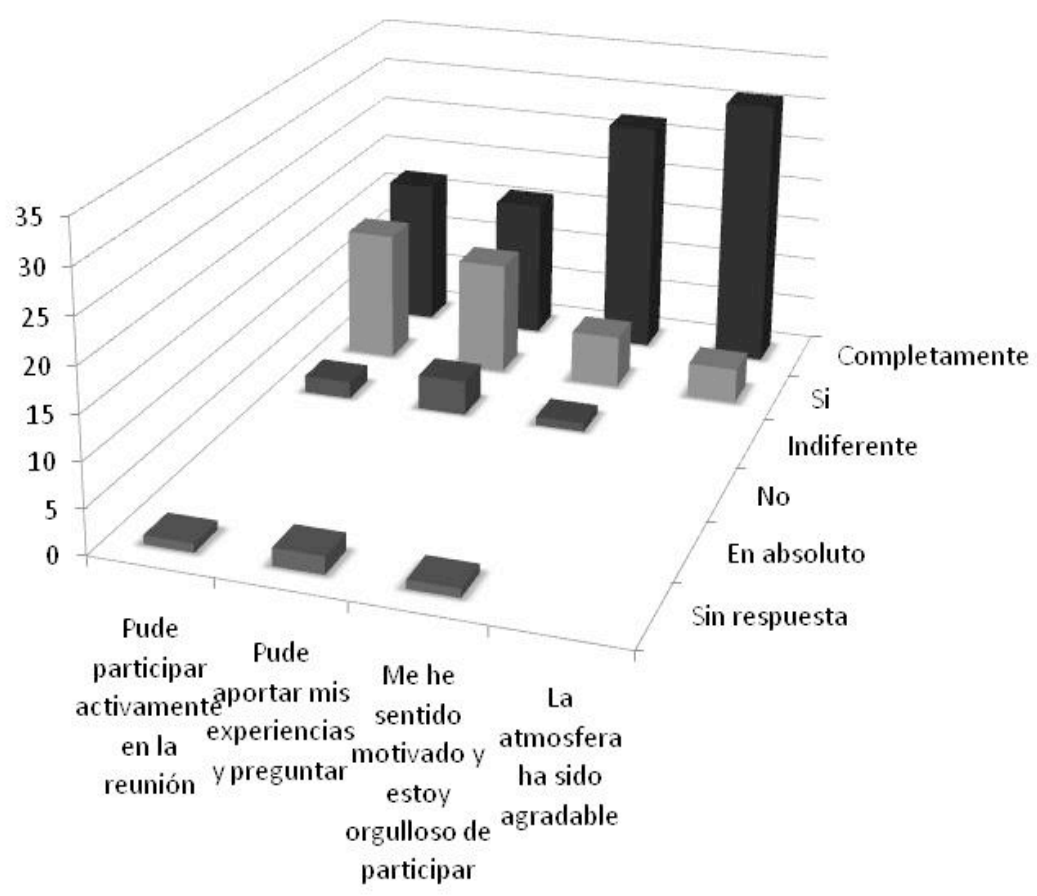

Grafico 1. Resultado de la evaluación de los estudiantes en el proyecto activeICT en

\section{Portugal}

En el gráfico 2, se muestran los resultados de la última reunión del proyecto realizada en Kracow y Mysslowice (Polónia) en Junio 2010 a un total de 15 estudiantes:

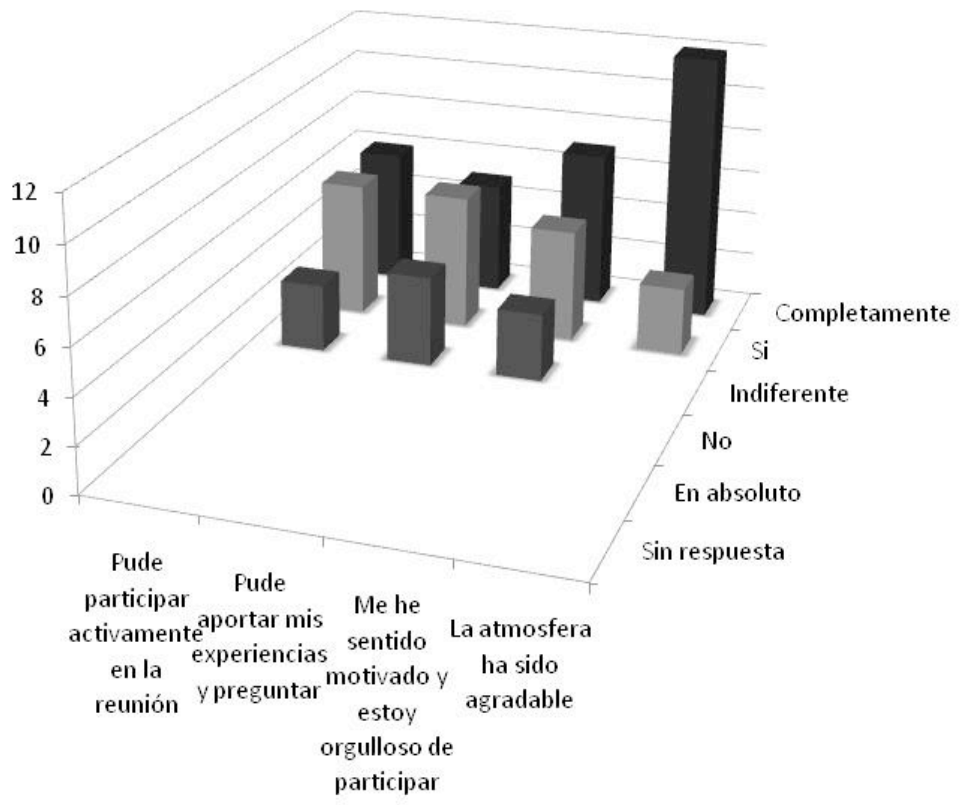

Gráfico 2. Resultado de la evaluación de los estudiantes en el proyecto activeICT en Polónia 
Además, las respuestas cualitativas de los estudiantes a las evaluaciones han sido siempre positivas o muy positivas, y sólo siendo observables algunos comentarios no positivos en cuanto a las calidades de hoteles o salas de reuniones.

De forma periódica (en cada una de las 6 reuniones) se realizaban evaluaciones a los delegados, pero de forma adicional en la última reunión se realizó una evaluación por institucion esta vez sólo los responsables (gestores o profesores), los resultados se pueden observan en el Gráfico 3:

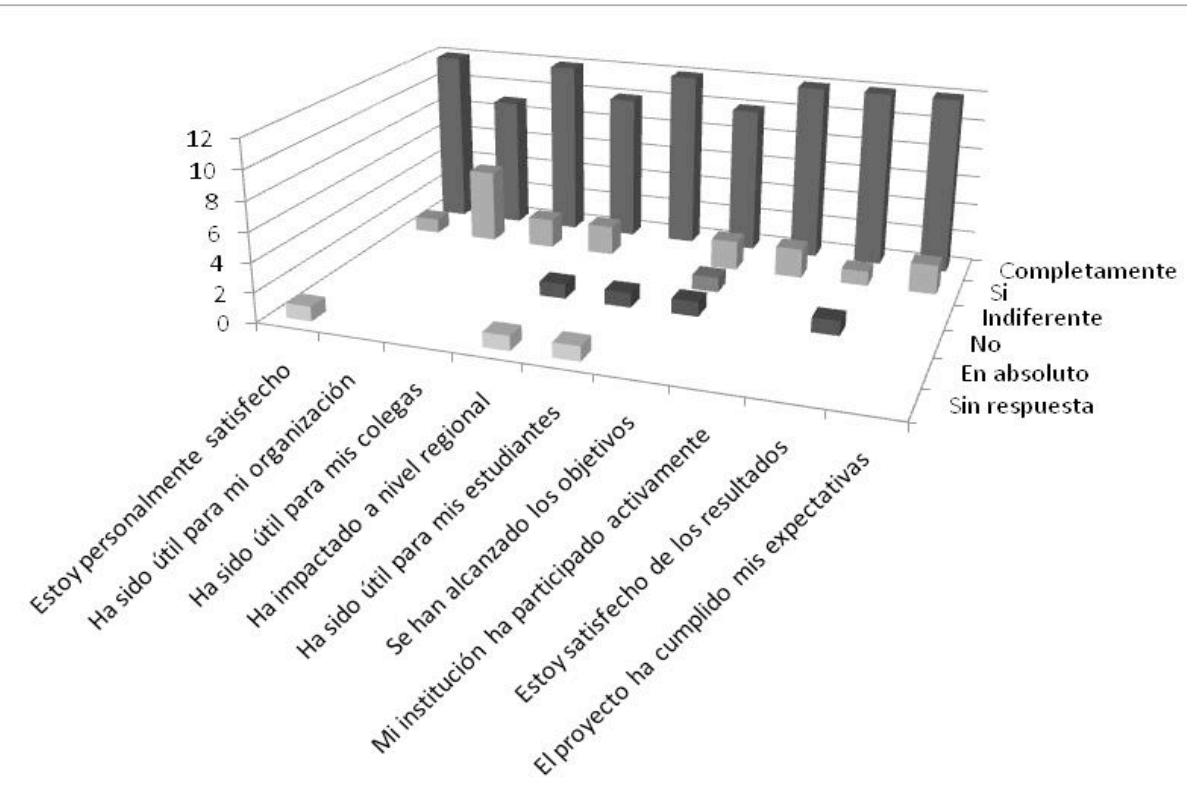

\section{Gráfico 3. Evaluación final del proyecto activeICT por las instituciones}

De forma cualitativa, los resultados e impacto de la participación en este proyecto, son resumidos en la sección de conclusiones de esta comunicación.

El proyecto SeniorsKS, aunque también contextualizado en las TICs no se centra en éstas, sino en la Sociedad del Conocimiento, sociedad fruto del cambio sufrido por el creciente uso de las nuevas tecnologías y que hace necesario una adaptación e integración de los mayores. Este fenómeno de adaptación e integración es presentado por la Comisión Europea como "e-inclusión" y es mediante el proyecto SeniorsKS que se pretende el diseño de acciones educativas para facilitar esta e-inclusión.

Durante los años que han durado estos proyectos, las instituciones han compartido conocimientos y experiencias en un marco de investigación e innovación y han creado 
de forma conjunta nuevas metodologías, actividades y procesos. En el caso de la Universitat per a Majors, los resultados de los proyectos fueron presentados en diferentes congresos científicos como es el caso del VI Congreso Europeo acerca de Salud y envejecimiento activo celebrado en San Petersburgo en julio de 2007 y donde se presentaron dos artículos, el primero sobre la experiencia del proyecto ICT50+ (Monstad et al. 2007) y el segundo acerca de una de las actividades realizada por la Universitat per a Majors: una clase virtual (Esteller et al. 2007).

El proyecto activeICT también tuvo impacto en las redes científicas; la metodología presentada por la Universitat per a Majors, denominada "activación", fue presentada en la Conferencia Internacional de Educación y Tecnologias Educativas celebrada en julio de 2009 en Barcelona (Esteller 2009) además de la experiencia de puesta en práctica de la primera wiki para mayores; http://www.wikisenior.es (Traver et al. 2009).

No como producto directo de los anteriores proyectos, pero como ejemplo del impacto que posee la pertenencia en foros de investigación e intercambio entre profesionales, se realizó un artículo publicado en el número de septiembre de 2009 de la revista europea "Lifelong learing in Europe", publicada en Helsinki y de ámbito europeo (Esteller et al. 2009)

\subsubsection{PROYECTOS DE COOPERACIÓN}

Los proyectos de cooperación tienen un objetivo más claro y definido; producir un producto innovador, además diseminarlo y explotarlo son partes primordiales del plan de ejecución del proyecto.

En el caso del SenTrain se pretendió dotar a los alumnos mayores con conocimientos suficientes de informática de un manual-curso para que éstos pudieran formarse como voluntarios y así tutorizar a otros alumnos. Además de este manual el resultado del SenTrain fue establecer una acreditación europea aplicable a formadores voluntarios mayores en nuevas tecnologías. 
El proyecto e-Vita es de tipo transversal basado en nuevas tecnologías. Esto significa que unía tanto a jóvenes como a mayores. En este caso, se pretendía producir una serie de juegos serios (juegos pedagógicos) aplicados a jóvenes pero que debían enseñar hechos históricos, costumbres y otros aspectos acerca de una Europa pasada que presentaba ciertos retos quizá desconocidos para los jóvenes actuales; dificultades para el libre movimiento, divisas, hábitos, etc. En este proyecto, las personas mayores proporcionaron las historias de vida que formaron parte de los juegos y que sirvieron de diferente modo (ya que se produjeron 4 tipos de juegos) para no sólo enseñar al joven una Europa anterior, sino también otras competencias transversales mediante la inmersión, pretendiendo que el joven conozca, comprenda y sienta las dificultades existentes y aprenda valores como la solidaridad, colaboración, etc. Algunas de las innovaciones paralelas (aparte del producto final en si) fueron presentadas en la conferencia EDEN en junio de 2010 en Valencia (Escuder et al. 2010).

\section{$22.4 \quad$ Experiencia}

Una Europa que apueste por el aprendizaje a lo largo de toda la vida y una Europa de la cultura, implica, también, una apuesta por el refuerzo de la dimensión cultural de las universidades en todos los aspectos y dimensiones de la vida y de las personas.

La existencia de mayores en las universidades comienza a ser un hecho normal, a pesar de su carácter minoritario y de los escasos años de existencia de estos programas universitarios.

Los retos sobre el futuro de la universidad y de la educación están relacionados con la sociedad del conocimiento. Nuevos conceptos toman importancia en esta sociedad del conocimiento:

- formación a lo largo de toda la vida

- importancia de la inversión en capital humano 
- necesidad de mantener la cohesión social como factor de estabilidad en las sociedades

- generalización de las nuevas tecnologías de la información y de la comunicación

El futuro de las sociedades pasa por la educación, por la formación y el conocimiento. Sólo las sociedades que inviertan en educación podrán mantener su liderazgo económico, su cohesión social y su bienestar individual y colectivo. Mediante los proyectos Grundtvig la Comisión Europea hace realidad el principio de "aprendizaje a lo largo de toda la vida" y responde al reto educativo de las personas adultas. Las instituciones de investigación y de educación de personas mayores son las candidatas a estos proyectos siguiendo las prioridades marcadas por la Comisión.

Las instituciones que solicitan la participación en estos proyectos son en principio instituciones altamente comprometidas con la educación de personas mayores y donde el aprendizaje permanente no sólo es entendido como algo que debe ser promovido y ofertado a los alumnos, sino también a los profesores, técnicos, gestores y otros actores sociales. La educación en personas adultas requiere de aplicaciones pedagogías específicas, cursos o actividades, procesos que evalúen y aumenten la calidad, gestionen de forma adecuada este tipo de intervenciones y maximicen el impacto, todo esto en un contexto de mejora continua. Sólo si estos principios son asumidos de forma institucional puede ser entendida la participación en proyectos educativos europeos.

Desde un punto de vista de la Universidad, la institucionalización definitiva de los intercambios favorecería el intercambio de buenas prácticas, la homogenización de los programas y la creación de titulaciones específicas y conjuntas. A través de estos proyectos se fomenta la construcción de un espacio Europeo de Enseñanza Superior, que afecta a la programación y a la investigación. Se generan aprendizajes no formales en contextos culturales, económicos y sociales que liberan de prejuicios y abren nuevos horizontes a los participantes.

En relación a los estudiantes, es necesario tener en cuenta que los alumnos mayores juegan un papel más activo en su propia educación; ya no son receptores pasivos de conocimiento que sólo esperan asistir a clase, sino que reclaman su rol cada vez más 
activo, y a su vez, las instituciones educativas universitarias, también reclaman este rol.

En mi opinión los estudiantes mayores que crean que la oferta académica que realiza la propia universidad ha de ser siempre divertida se equivocan, deben saber que acceden a las aulas universitarias para ser educados y para ocupar un tiempo de ocio y no ocioso, entendiendo este como un tiempo de reflexión, de análisis, de aprendizaje y de crecimiento personal, por tanto puede y debe ser una educación gratificante. La existencia de programas y proyectos de investigación es por tanto una de las demandas constantes de los estudiantes universitarios mayores los cuales les permiten aumentar otras competencias y habilidades.

Si superamos las teorías que nos hablan de la educación basada en el rendimiento académico y las habilidades alcanzaremos nuevos objetivos que desarrollen capacidades prácticas para la vida y es en este tipo de proyectos donde los estudiantes son verdaderos actores sociales. Se familiarizan con formas de investigación en las que se potencia: la capacidad de análisis, el pensamiento crítico, la toma de conciencia del entorno social y las capacidades de comunicación.

\section{Impacto}

De forma empírica podemos asegurar que la participación en diferentes experiencias y proyectos produce los siguientes resultados:

- Aumentan la competencia de los profesores y técnicos. Este sería el primer impacto directo producido por la propia participación de los socios en un proyecto; en un contexto de colaboración y de intercambio de prácticas, en donde diferentes instituciones de diferentes tipos (de investigación, educativas, políticas, etc.) pueden aunar esfuerzos desde sus propias áreas como expertos para incrementar la calidad, efectividad e impacto de los objetivos de cada institución. Los propios profesores y personal de las instituciones se consideran desde este punto de vista como estudiante que ha de aprender y formarse de forma continua para poder efectuar mejor su trabajo. 
- Estimulan la investigación e innovación. Sólo desde un espacio abierto, en donde se facilita la colaboración y la aceptación e incorporación de metodologías novedosas es posible alcanzar innovación y producir nuevos resultados. Esta innovación surge de la propia sinergia fruto de la colaboración de los investigadores.

- Producen nuevos productos. Tanto de cursos, actividades o herramientas como de pedagogías, metodologías y procesos. No sólo fruto del intercambio entre socios de productos ya existentes, sino de la unión y combinación de éstos junto con una investigación e innovación

- Incrementan la participación y motivación de los alumnos. La participación en estos proyectos incrementa las aptitudes de los alumnos tanto del área que sea propia del proyecto (en nuestro caso de las nuevas tecnologías) como de otras transversales como de los idiomas o comunicativas y sociales. En base a nuestra experiencia, las asociaciones de aprendizaje (en donde la participación de los alumnos ha sido muy activa) han servido para influenciar de forma muy positiva en su aprendizaje, mostrando cómo la educación y formación por parte de los alumnos no es un proceso en un solo sentido (del profesor hacia el alumno) sino que ellos son también unos actores cruciales de la educción y donde su participación activa resulta muy conveniente tanto pare ellos como enriquecedora para el resto del consorcio y de la sociedad. El impacto producido por los productos de los proyectos (de los cuales ellos pueden sentirse partícipes) ha incrementado enormemente su sentido de participación y motivación.

- Favorecen un contexto Europeo de trabajo, de intercambio y de innovación. Todos los proyectos al ser realizados en un contexto europeo hacen posible un intercambio cultural y social con otros mayores y profesionales, con necesidades muy similares, pero también contextos muy diferentes. Esto en ningún caso ha sido un problema, sino algo que ha servido para enriquecer el producto final y a las personas que participaron.

Los dos tipos de proyectos Grundtvig existentes tienen dos finalidades e impacto totalmente diferentes: Las asociaciones están diseñadas para promover el 
intercambio y aprendizaje tanto de personal (profesores, gestores) como de los alumnos, por tanto, en este caso el proceso es tan importante como el resultado. Los proyectos de cooperación pretenden dar respuesta a una necesidad global relativa a los retos educativos de las personas adultas e instituciones produciendo resultados innovadores, por tanto, el resultado final es lo más importante, además de cómo puede aprovecharse (diseminarse y explotarse).

La realización de este tipo de proyectos representa una carga de trabajo adicional en las tareas diarias tanto para profesores como para el personal gestor, pero cuyos beneficios repercuten muy positivamente en la propia institución, permitiéndole no solo alcanzar con mayor calidad y efectividad los objetivos propios de la institución, sino también permitir ampliar horizontes a nuevos acercamientos y metodologías pedagógicas.

Estos proyectos permiten responder desde un contexto europeo a los desafíos de la aplicación la educación permanente tanto de los propios alumnos mayores como de las personas que intervienen en su aplicación. Sin más se hace necesario agradecer a la Unión Europea por establecer los Programas de Aprendizaje a lo largo de toda la vida, y a la agencia nacional educativa española (Organismo Autónomo de Programas Educativos Europeos - OAPEE) también por su apoyo tanto financiero como ayuda en cualquier otra duda o problema en la solicitud, gestión y finalización de los proyectos.

\section{$23.1 \quad$ Referencias}

ActiveICT. Active citizenschip through ICT at all ages. http://www.activeict.eu

Comision (2000). Comisión de las Comunidades Europeas. Memorando sobre el aprendizaje permanente SEC (2000) 1832 de 30.10.2000

Comision (2001). Comisión de las Comunidades Europeas. Comunicación de la Comisión. Hacer realidad un espacio europeo del aprendizaje permanente. 2001. Comisión de las Comunidades Europeas. Bruselas 21.11.2001. Comunicación 20019678 final 
Comisión Europea (2011). Programa de aprendizaje permanete. Convocatoria general de propuestas 2011-2013. Prioridades estratégicas. http://ec.europa.eu/education/llp/doc/call11/prior_es.pdf e-VITA. European Life experiences . http://www.evitaproject.eu EACEA (2007). Education, Audiovisual \& Culture Executive Agency. Programmes 2007-2013 http://eacea.ec.europa.eu/about/programmes2007_en.htm

Escuder, P. (2007, July). The influence of life-long-learning on quality of life in senior citizens. Proceedings of the VI European Congress of the International Association of Gerontology and Geriatrics, St. Petersburg, Russia, 20(3) pages 234-235. Petersburg.

Escuder, P. (2008) El aprendizaje permanente desde Europa en Jornadas de mayores y nuevas tecnologías. Salvador Cabedo (director). Mayo 2008. ISBN: 978-84-8021670-8. Publicacions de la Universitat Jaume I. Castelló.

Escuder, P. Esteller, R. \& Segura J (2010). Comunities of practise as creators of stories for serious games. Experiences from European project e-Vita en EDEN June 2010. Valencia.

Esteller, R., Escuder P., et al. (2007, July). Methodology and didactics in ICT courses for senior citizens at the senior citizens' university [Abstract]. VI European Congress of the International Association of Gerontology and Geriatrics. Abstract book, 20(3). St. Petersburg. 235-236

Esteller, R., Monstad, S. J. \& Escuder P. (2007) Methodology and didactics in ICT courses to senior citizens at the senior citizens' university en VI European Congress. Healthy and active ageing for all Europeans. Julio 2007, St. Petersburg, Russia. Abstract book ISSN 1561-9125 num. 3. vol. 20. 2007. International Association of Gerontology and Geriatrics.. St. Petersburg.

Esteller, R. (2008) Participación activa en la sociedad a través de las tecnologías de la Información y Comunicación en Jornadas de mayores y nuevas tecnologías". Salvador Cabedo (director). May 2008. ISBN: 978-84-8021-670-8. Publicacions de la Universitat Jaume I. Castelló. 
Esteller, R., Escuder, P., \& Traver, J. (2009, July). Methodological proposal for an ICT activation among senior learners. International Conference on Education and New Learning

Esteller, R. Escuder P., Traver J (2009). Enhancing ICT education for senior students: Senior Citizens' University in Spain is promoting a comprehensive formal, non-formal and informal approach to ICT learning among senior citizens en Lifelong learning in Europe. Num. 3/2009, September 2009. ISSN 1239-6826. KVS Foundation; Finnish Adult Education Research Society. Helsinki, Finland

ICT50+. Information and communication technology empowerment for fifty-yearolds + http://www.ict50plus.eu

Longworth, N. 2005. El aprendizaje a lo largo de la vida en la práctica. Madrid. Paidós.

Orte C. Gambús M. 2004. Los programas universitarios para mayores en la construcción del Espacio Europeo de Enseñanza Superior. Palma de Mallorca: Universitat de les Illes Balears.

Parlamento Europeo (1995). Decisión 819/95/CE y del Consejo de 14 de marzo de 1995 por la que se crea el programa de acción comunitario SOCRATES, luego modificada por la Decisión 578/98/CE del Parlamento Europeo y del Consejo de 23 de febrero de 1998.

Parlamento Europeo (1998). Propuesta de Decisión del Parlamento Europeo y del Consejo por la que se establece la segunda fase del programa de acción comunitario en materia de educación Sócrates. Diario Oficial, C 314/04 de 13.10.1998

Parlamento Europeo (2006). Diario oficial, L 327 de 24.11.2006. Decisión 1720/2006/EC del Parlamento Europeo de 15 de noviembre de 2006 por la que se establece un programa de acción en el ámbito del aprendizaje permanente.

SeniorsKS. Seniors in the Knowledge Society; asociación de aprendizaje LLLP Grundtvig. http://www.seniorsks.eu

SenTrain. Train the Trainers. http://www.sentraint.eu 
Traver, J., Esteller, R., \& Escuder, P. (2009, July). Pilot experience of using a wiki for learning and communicating among senior students [CD]. Proceedings of the International Conference on Education and New Learning Technologies, Barcelona, Spain. 


\section{SECCION CUARTA; EDUCACIÓN MEDIADA POR LA TECNOLOGÍA}




\section{THE VIRTUOUS CIRCLE OF USE,}

\section{ATTITUDE, EXPERIENCE AND E-INCLUSION}

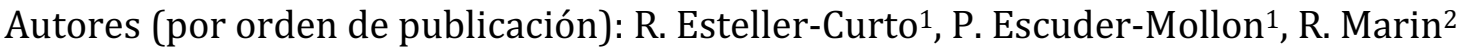

1. Universitat Jaume I

Publicado en: Journal Paper eLearningPapers. eLearningEuropa, Issue 29, 2012, ISSN 1887-1542

\section{Abstract}

Citizens are becoming increasingly active users of ICT, not only to communicate with friends or surf, but also to share, create, learn and build virtual communities. Older people's participation through the Internet is also growing, although compared with adults and young adults they are not such frequent users. Individuals are motivated to use ICT in many different ways: work, enjoyment, interest, personal fulfilment, pleasure, etc. Motivation and attitude when using ICT are what affect us: sensations, emotions, experiences, and shift our use of ICT from basic to more social and creative tools, driving us to e-inclusion and to active participation in society.

This article shows how use, aptitude, attitude, experience and e-inclusion are related, and explains how we can encourage individuals to become e-included in today's society. An initial description of the basic concepts is followed by a focus on senior citizens. E-inclusion is not only a question of frequency and aptitude, but also of attitude and experience, all of which increase together and, through synergy and feedback, nourish further combined growth of frequency, level of use, aptitude, attitude and experience.

\section{Key words}

e-inclusion, ICT, experience, seniors, education 


\section{$24.1 \quad$ The Knowledge Society}

The Knowledge Society (KS) is a term commonly used in the social sciences (Krüger 2006). This concept attempts to summarise the social transformations that are happening today. The concepts of Information Society (IS) and KS are frequently linked; in fact a UNESCO document (2005, p. 28) presents a sequence of causality. Crovi (2004) deconstructs the concept of KS, proposing a perspective from which KS can be understood as a revolution in the sources of factors of production, but also in a cultural and social sense. She brings together the concepts of IS and KS in a new term: Information and Knowledge Society (IKS). In this way technology and cultural ideas are combined and compared (Crovi 2004, p.22) to hardware and software in a simile involving computers. Crovi affirms that the KS "is a society where the basic capital is the collective knowledge and information, distributed in everyplace, continuously valuated and in real time synergy". Internet (the network of networks) frequently springs to mind when we refer to KS and IS, but again, we should remember that network and information can be shared at different levels; hardware and software, IS and KS, technology and society.

Castells (2006, p. 27-75) states that societies have always been organised in networks, and that information has always been a key factor. What sets the present apart is the exponential rise of information and communication technologies. Castells calls this development the "informational paradigm". In this context, technology (the microchip and the network) and its capacity to process and transmit information is what has allowed change in the social structure to take place. He presents this change as a revolution, similar to other historical revolutions such as the invention of the printing press or the steam engine. However, as will be explained below, Castells is somewhat critical of the term knowledge society.

UNESCO (2005, p.27) recognises that the technological base leads in this case to what they call "knowledge societies", affirming that "the new information and communication technologies have created new conditions for the emergence of knowledge societies". Castells also acknowledges the important role of technologies 
in this changing society, but later qualifies this by arguing that technologies enable a "net society" not a "knowledge society".

Based on this difference in the concepts, meaning and impact of the IS and the KS, two contrasting ideas can be extracted to further understanding of social changes and how they can be related to individuals:

- The evolution of ICT has played a key role in how actors in today's society (citizens, companies, government) access and transform information. This new capacity and new ways of using technology we refer to as the IS.

- The use of ICT has brought about a change in how people learn, organise, defend their rights, access information, buy, build links with each other, socialise, create new contents, produce new channels of power (bottom up and horizontal as well as top down), etc. This change is so dramatic and farreaching compared with any previous event that it is reshaping the social structure. We refer to this as the KS.

The bases of the IS and the KS are ICT. People use ICT directly, but not without involving an individual effort to learn to use, adapt and interact with the device in the appropriate language. Everybody would like ICT to be easy to use, convenient, errorfree, easily connected to other devices and to communicate without losing data, and to quickly find what we are looking for. To make this work easier for the user, ICT designers and manufacturers follow the principles of functionality and usability in creating their products. For a device to work, it does not have to be attractive, comfortable or intuitive, although these factors would help the person that is going to work with it.

Two points of view emerge here: one the human perspective, and the other hand, the technology. These two perspectives have different aims and requirements, and both have to give way: people have to learn to use the technology, and technology must be also designed with concepts of usability in mind. The discussion therefore focuses on the interface as this is where humans interact with technology, and also where technology communicates with humans. 
The evolution of ICT and their growing intervention in our daily lives means that more and more routines are now technology mediated. The interface is no longer a clear bridge that separates humans and technology. It is a fuzzy component that interrupts our perceptions as humans and that technology designers try to include in their specifications.

In this way, we shift from usability to new concepts like virtual screen, simulation (Turkle et al. 1984, Turkle 1999), experience and symbolic communication, where people are considering technological tools as an extension of their life: identification, social enjoyment, creativity, etc. Now technology is more human than ever, it allows us to experience.

\section{$24.2 \quad$ Usability vs. Experience}

Software and hardware are designed for people to use; therefore, they should be user friendly (Nielsen 1994). Interface usability and accessibility are two parameters that facilitate human-machine interaction. Interest in these principles first arose in the 90s with attempts to make machines more convenient and intuitive for people. The term usability refers to the ease and convenience of use. The principle of accessibility focuses on making technologies easy for the disabled to use. On the other hand, the concept of user experience (Hassenzahl \& Tractinsky 2006) attempts to cover the sensations, emotions and affect that devices awaken in people. Technology must be attractive, fun and stimulating. McCarthy \& Wright (2004 p. ix) affirm:

We don't just use technology; we live with it. Much more deeply than ever before, we are aware that interacting with technology involves us emotionally, intellectually, and sensually.

A positive experience has a greater impact on people than a usable system. Based on Nurkka et. al. (2009) and McCarthy \& Wright (2004, p. 34, p.80) it is possible to know, recognise and evaluate the sensations and feelings experienced with technology. 
As science and technology have evolved, ITC modify two human related factors: complexity and experience. These two factors are subjective and depend on the individual's skills and willingness to engage with technology, in other words, aptitude and attitude, or at least this is an intuitive assumption that we might believe is true and logical, but we will have the chance to verify whether this is the case later in this paper.

\section{3 e-adoption vs e-inclusion}

In a world where technologies, tools and services are widely available, people can use and take advantage of them. When a person does not know how to use them, he/she can learn these skills. This is known as e-adoption, and it is commonly applied to contexts other than individuals, such as the use of ICT by families or companies in eBanking, eGoverment, eCommerce, etc. E-adoption means using, increasing skills and taking advantage of the possibilities technology offers. On the other hand, einclusion is a more complex status, related to participation of people in communities and in other dimensions of society based on knowledge and relationships, work, culture, politics, etc. (Castells 2005; p. 7). In fact, an e-inclusion evaluation analysis would need to consider not only individual factors, but community and social factors, while e-adoption would only require an analysis of the level of skills to use a certain tool or service.

In the report "e-Inclusion: New challenges and policy recommendations" (Kaplan 2005), Viviane Reding affirms:

e-Inclusion is about using Information and communication technologies (ICT) to empower all Europeans. This means more than just increasing access and making services widely available and easier to use, although these steps are important. It means also assisting people to use ICT to make their lives richer and more fun and by helping them to participate more fully in their lives as members of their families, neighbourhoods, regions, countries and as Europeans. 
Information and communication technologies (ICT) are becoming key enablers of modern life. They are used at work, in day-to-day relationships, in relating with public services as well as in culture, entertainment and leisure, and in community and political participation. Most public policies can no longer be implemented without them. ICT are the engine powering modern health policies, security policies, environment policies, etc.

In this context, e-inclusion is essentially social inclusion in a knowledge society. It goes beyond accessing ICT tools and services or even being digitally literate. A definition of e-inclusion should focus on people's empowerment and participation in the knowledge society and economy: skills and competences (both ICT-related and regarding new ways of working using ICT), awareness and willingness, social capital and the means to grow it are also key factors of e-inclusion.

An e-included person participates effectively in all dimensions of the economy and society based on knowledge through the ICT. The relevance of a person in a community is key to determining whether he/she is included or excluded. His/her participation is a measure of his/her membership.

It should be noted, following Kaplan (2005, p.7), that a person who is not using ICT is not excluded, so long as this lack of use is voluntarily. Indeed, a sufficiently informed person who does not use ICT voluntarily could be e-included, but at least a basic use of ICT must be established.

Some of the indicators proposed to measure a person's e-inclusion are:

- Identity on the net. In real life we have a name and surname; we may have a passport, an ID, a phone number and a postal address. That allows other people to contact as, and creates our identity: our childhood, work life, friendships and family. On the net it is also possible to have an identity-not necessarily a true one-but one that references us that may even be more faithful than the real one (Turkle 1984). This net-identity lets others know what we are like and enables them to contact us. Electronic mail is the most basic identification on the net, but there are many other ways of having an identity: blogs, albums, an alias in a forum, a nick in a wiki or a wall in a social network. 
- Virtual Communities. In real life, an included person belongs to several communities; work colleagues, family, neighbours, classmates, etc. The virtual world also has communities; perhaps the most common are Facebook or Twitter, but those are only one kind of community. A person may also belong to a virtual community where he/she establishes emotional feelings and longterm relationships with others, regardless of whether she/he only uses electronic mail or enjoys posting comments to his/her favourite author in a blog.

- Participation. The net can be a place for action and creativity. When a person is aware of the impact of the net, he or she inevitably acts to correct a mistake s/he has spotted (or contacts the author). The net also broadens out individuals' capacities in their hobbies, interests and curiosity, and gives them a space in which to defend their rights.

\subsection{Information Society vs. Knowledge Society}

Technological evolution in ICT is allowing far greater quantities of information to be transmitted, stored and processed than in any other period in history. This capacity, together with falling prices of devices, has given a large percentage of society access to the net, to download and upload information, and thereby create the IS. Computer Mediated Communication (CMC) and the new social structures that have been created have enabled the "net society" (Castells 2001, Castells 2006) or what other authors prefer to call the KS.

When a person is learning about ICT, he/she should first acquire the knowledge and skills to use the computer and the browser, tools and services, but will this person be aware of the potentialities and impact of these new environments that he/she is learning about? Will he/she be able to adopt the technologies to his/her daily routines and life, to a new group of friends, or will he/she feel accompanied when s/he is alone? The KS presents a new social structure where ICT play a crucial role, 
but it is not enough to learn to use new tools: we must also understand them and use them consciously.

\subsection{The new digital divide}

The concept of the digital divide emerged in 90 s to differentiate those who use ICT from those who do not. The digital divide created a risk of exclusion in the same way as illiteracy did some decades ago. Ballestero (2002) defined this term as the technical capacity to access and use the net, in which broadband capacity played a major role. With increased broadband speeds, this concept has become obsolete, but it has been replaced by a new risk: the new digital divide is now a question of access, knowledge, skills, opportunities for use, experience and motivation (van Dijk \& Hacker 2003). Bridging this gap is now more complex than the previous digital divide.

\section{$24.6 \quad$ Research}

EuroStat (2011) reports an increase of broadband Internet access in households from $30 \%$ in 2006 to $68 \%$ in 2011. There are, however, large differences depending on the ICT user's age : 91\% of 16-24 year-olds access the net at least once a week. That percentage falls as the age increases; 25-54 year-olds: $76 \%$; 55-74 year-olds: $40 \%$. It is not difficult to evaluate individual use of a tool or service; we only need to ask to how many hours the person uses and takes advantage of a specific tool or service. Evaluation of experience and e-inclusion, however, presents much greater problems.

There appears to be a negative correlation between age and use, but what about other variables such as attitude, experience and e-inclusion? We have drawn from the model devised by McCarthy \& Wright (2004, p. 80) to evaluate experience. This model proposes four threads: emotional, senses, compositional and spatial-temporal. Similarly, the work of Nurkka et al. (2009) relates the experience to values, meaning, affective state and emotion. To evaluate e-inclusion we drew on the concepts and 
definitions from Kaplan (2005) and other regulations from the European Commission. The aspects and questions applied in the questionnaire were taken from Esteller-Curto (2012).

A quantitative study was carried out on 95 people of different ages, all of them ICT users at different levels and ages $\left(\bar{x}=46.9, \sigma_{\bar{X}}=13.6\right)$. There is a clear difference in use depending on age (as noted above), but when only citizens currently using ICT are considered, is there any difference in other aspects such as attitude, experience and e-inclusion? How can citizen e-inclusion be achieved?

\section{$24.7 \quad$ Results}

Figure 1 shows the relationship between use and aptitude. As expected, we found a high correlation. A person who uses ICT frequently has better aptitudes/skills, while the inverse is also true. Aptitude among seniors $(\bar{x}=2.06)$ and use is in general lower than among the younger age group $(\bar{x}=3.04)$

Figure 2 reveals a lack of correlation between attitude and use; they are independent. In general, all respondents had a neutral attitude (not very positive, not very negative), and also, use was not found to depend on attitude. This may suggest that some people (considered to be resigned) have a negative attitude to ICT, even though they know how important technology is or they are forced to use it. On the other hand, some people are highly motivated, but have not yet reached high levels of ICT use, even though they are motivated.

The attitude in both groups is very similar (seniors: $\bar{x}=2.85$, younger adults: $\bar{x}=2.75$ ); in general terms they both appear to regard ICT as positive.

Use and experience (Figure 3) are highly correlated ( $\mathrm{r}=0.53$ in younger adults but $\mathrm{r}=0.39$ in seniors). Considering both variables independently, seniors present a lower ICT use $(\bar{x}=2.58)$ although they have greater experience $(\bar{x}=3.32)$ than younger adults (use $\bar{x}=3.10$, experience 3.25 ). It is difficult to understand how users can 
perceive some kind of experience without using technology directly, so this correlation is logical, but the difference between younger adults and seniors shows that experience in ICT is very subjective and can be based on other aspects, such as attitude, sense of usefulness, or seniors' needs and experiences.

Figure 4 shows no evidence of a relationship between ICT experience and attitude ( $r=0.28$ in seniors and $r=0.22$ in younger adults, figures that are not significant). We therefore need to go back and explore the main difference in use of ICT between seniors and younger adults. An analysis of the survey data shows that $87 \%$ of younger adults use ICT mainly at work (even though people were only asked about the use of internet services and tools outside the workplace). They also use many banking, calendar and cloud services, while seniors are not significant users of these services. All respondents use services such as e-mail for private use, web browsers, search engines, social networks etc. These tools and services are more related to ICT experience than advanced tools.

Above, we explained that attitude and use are not correlated. There is little difference in attitude between seniors and younger adults $(\bar{x}=2.85$ and 2.75$)$, nor in e-inclusion $(\bar{x}=3.18$ and 3.27$)$. Figure 5 shows that the relationship between attitude and einclusion is not significant ( $\mathrm{r}=0.31$ in seniors, $\mathrm{r}=0.44$ in younger adults). From this data we can conclude that attitude does not seem to be important to a person's einclusion. Use and e-inclusion have the strongest correlation (Figure 6), but it is still not high ( $\mathrm{r}=0.42$ in seniors and 0.46 in adults). This data leads us to form two hypotheses:

a. Use and attitude are not related to e-inclusion, which would mean that a person can be e-included without using ICT or with a negative attitude.

b. Use and attitude are related to e-inclusion, although this correlation is not very high, perhaps due to hidden variables.

Experience and e-inclusion have a slightly higher correlation ( $\mathrm{r}=0.65$ in seniors and 0.52 in younger adults), as displayed in Figure 7. These results support hypothesis b. An individual's e-inclusion is a very complex status that cannot be concluded from attitude and use only, although a combination of aptitude, use, attitude and 
motivation is important in ensuring that individuals enjoy, feel and experience in their use of ICT.

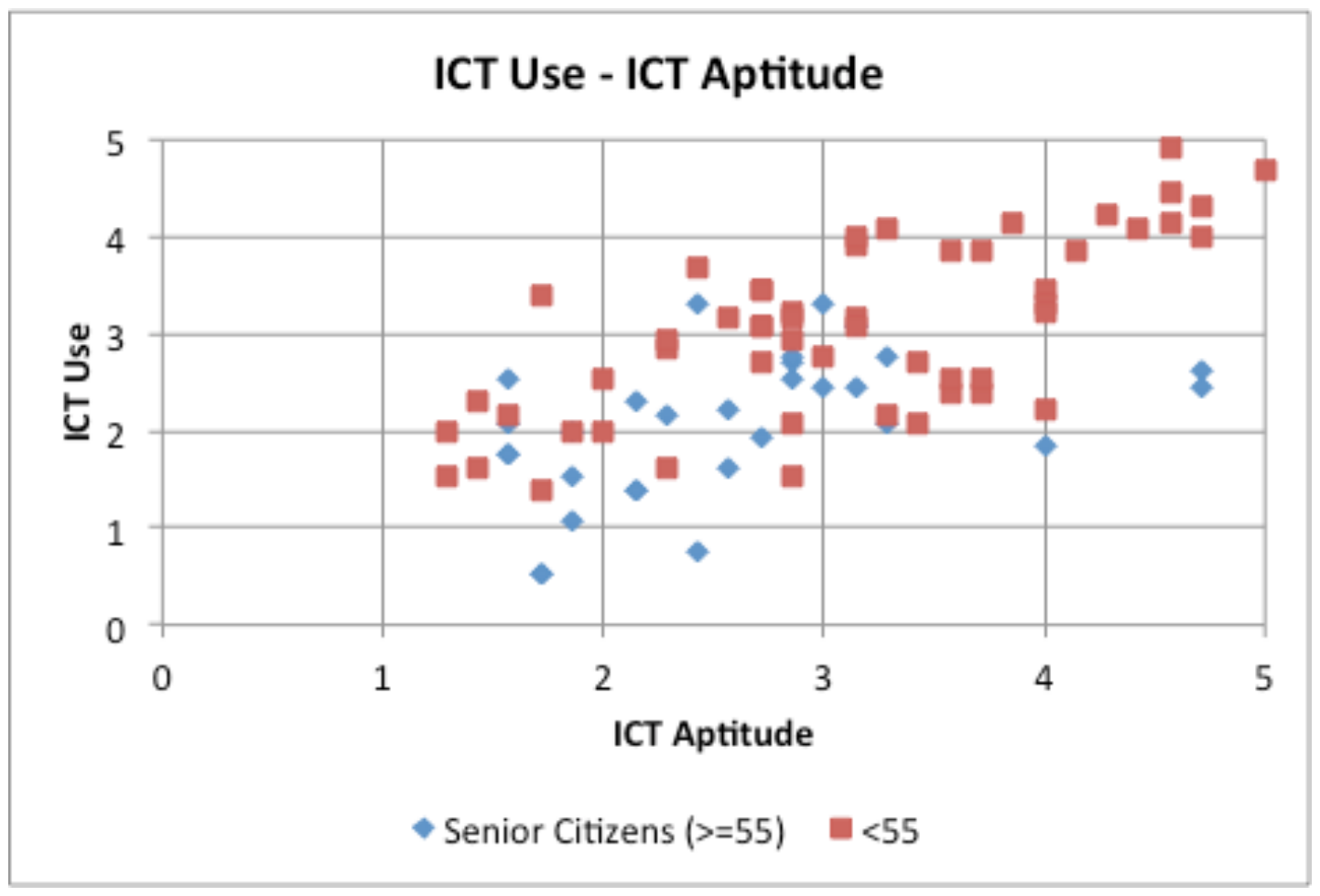

Figure 1. Relation between Use and Aptitude

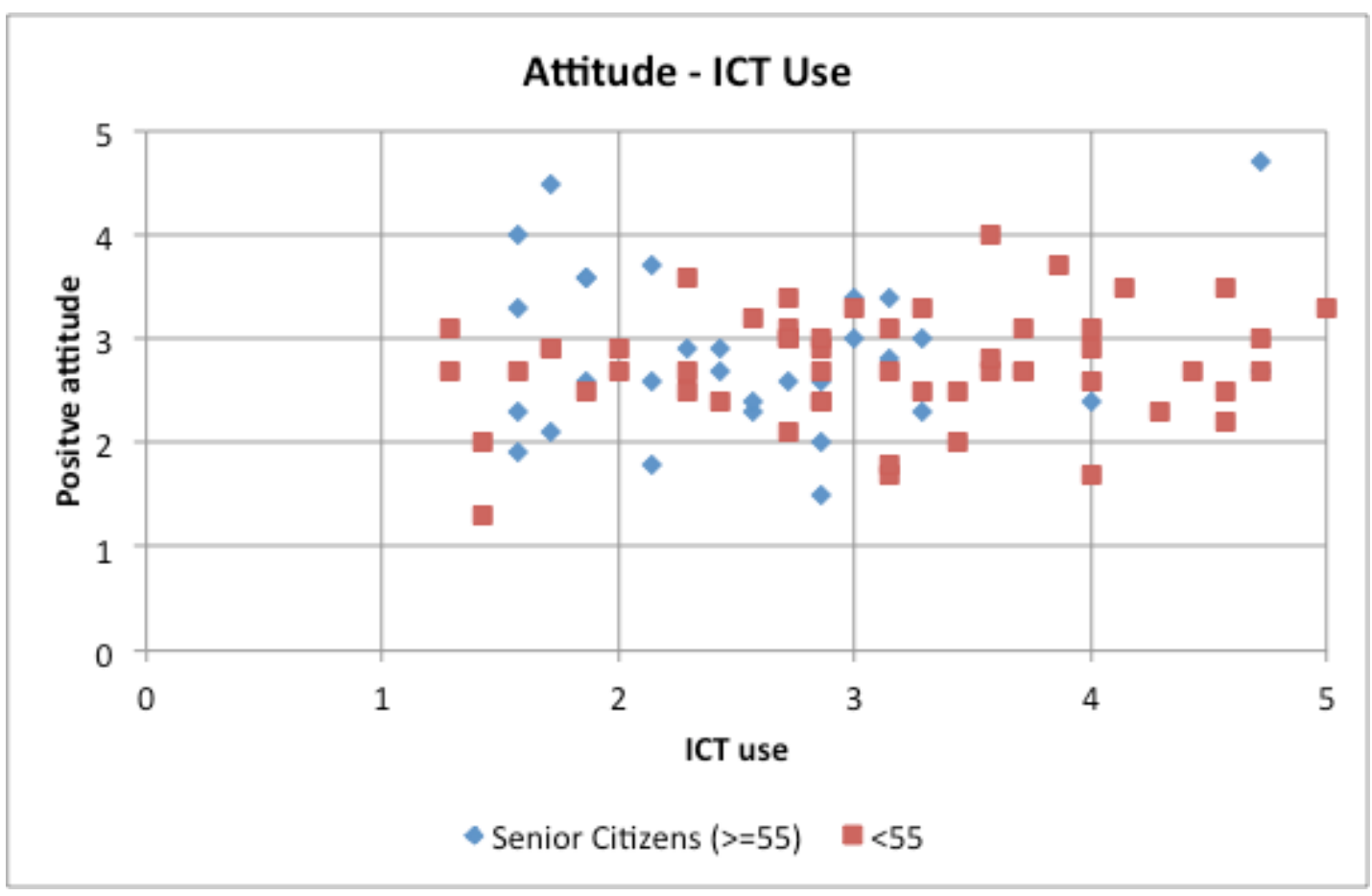

Figure 2. Relation between Attitude and ICT Use 


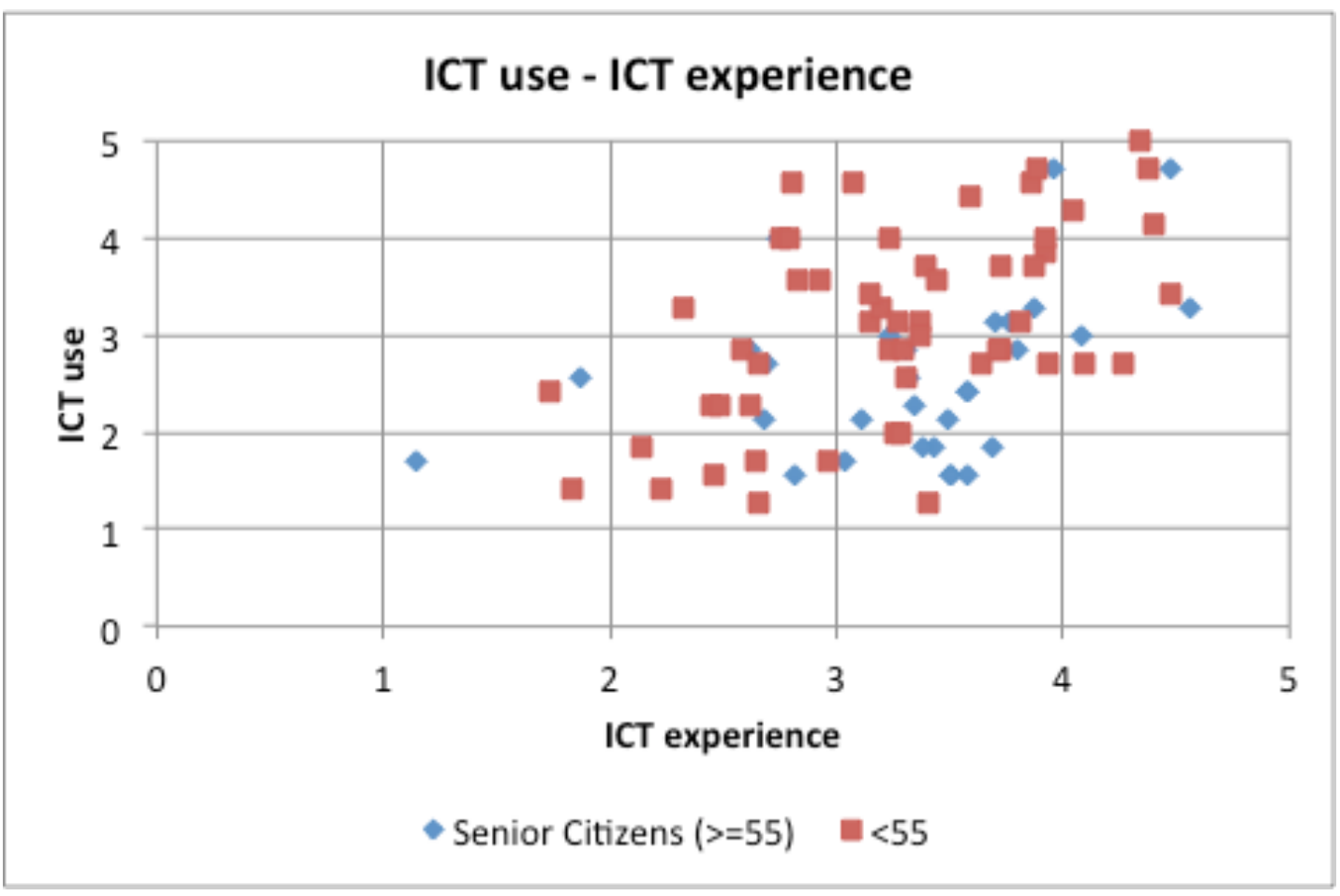

Figure 3. Relation between ICT Use and Experience

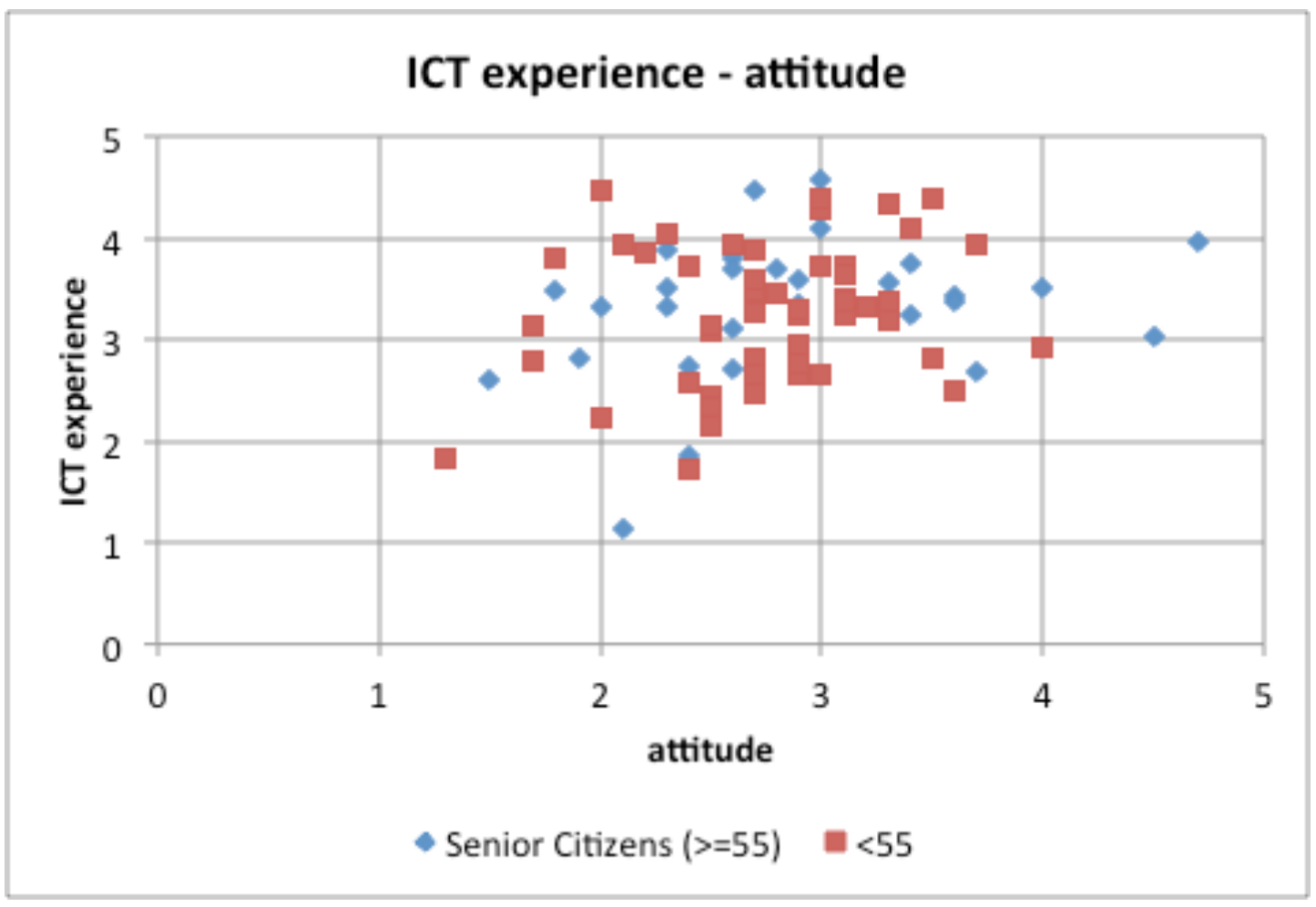

Figure 4. Relation between ICT Experience and Attitude 


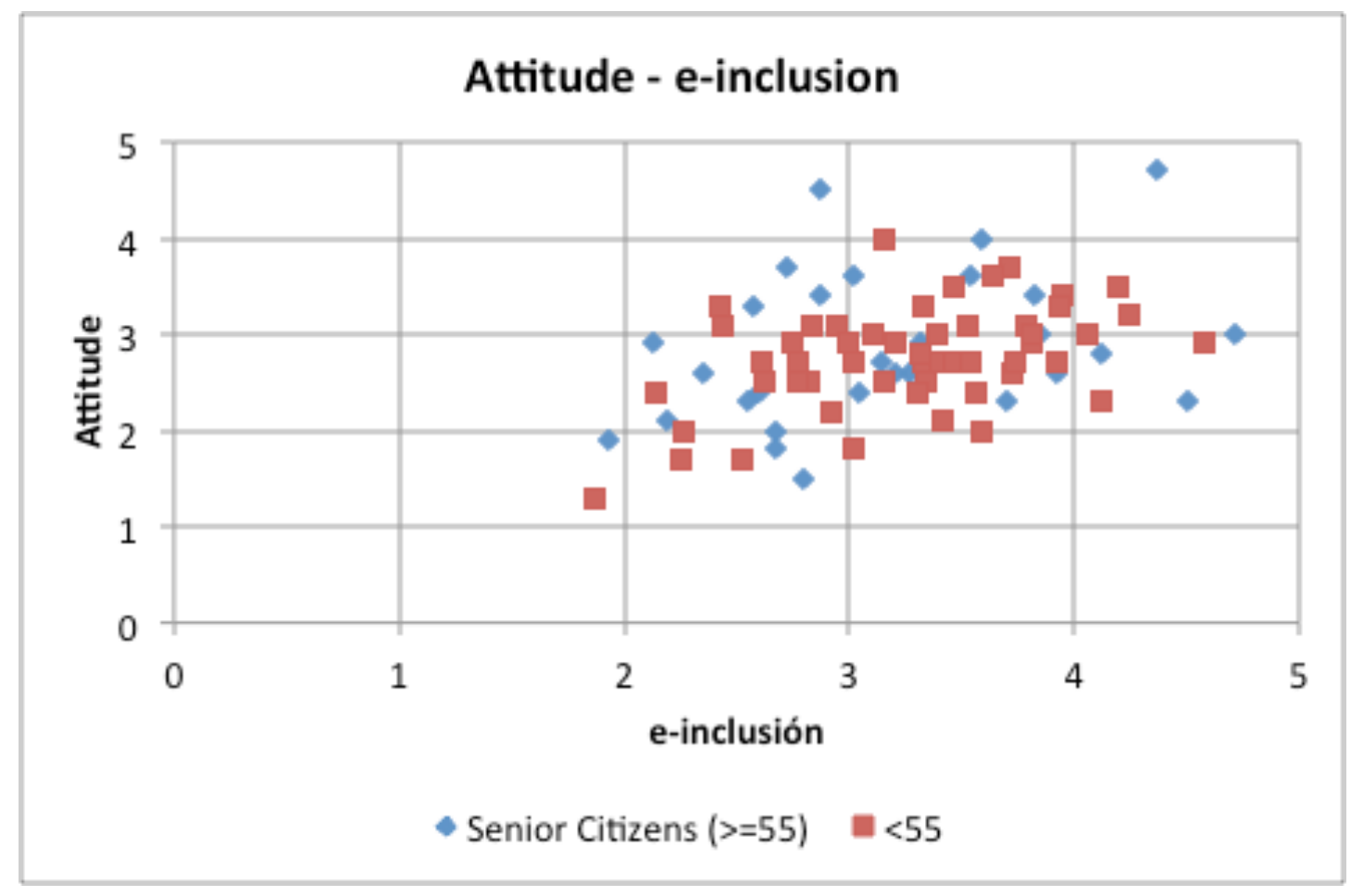

Figure 5. Relation between Attitude and e-inclusion

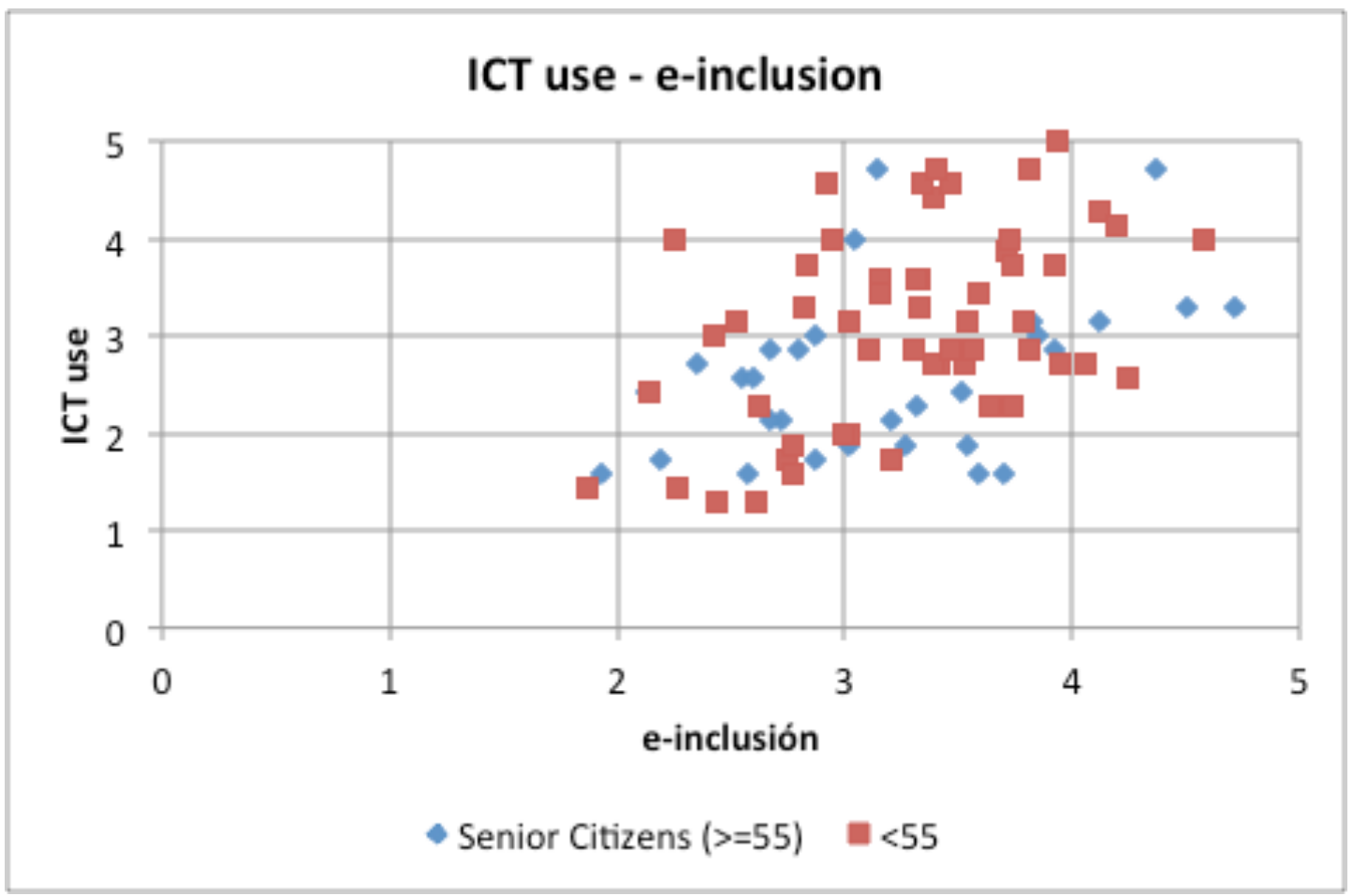

Figure 6. Relation between ICT Use and e-inclusion 


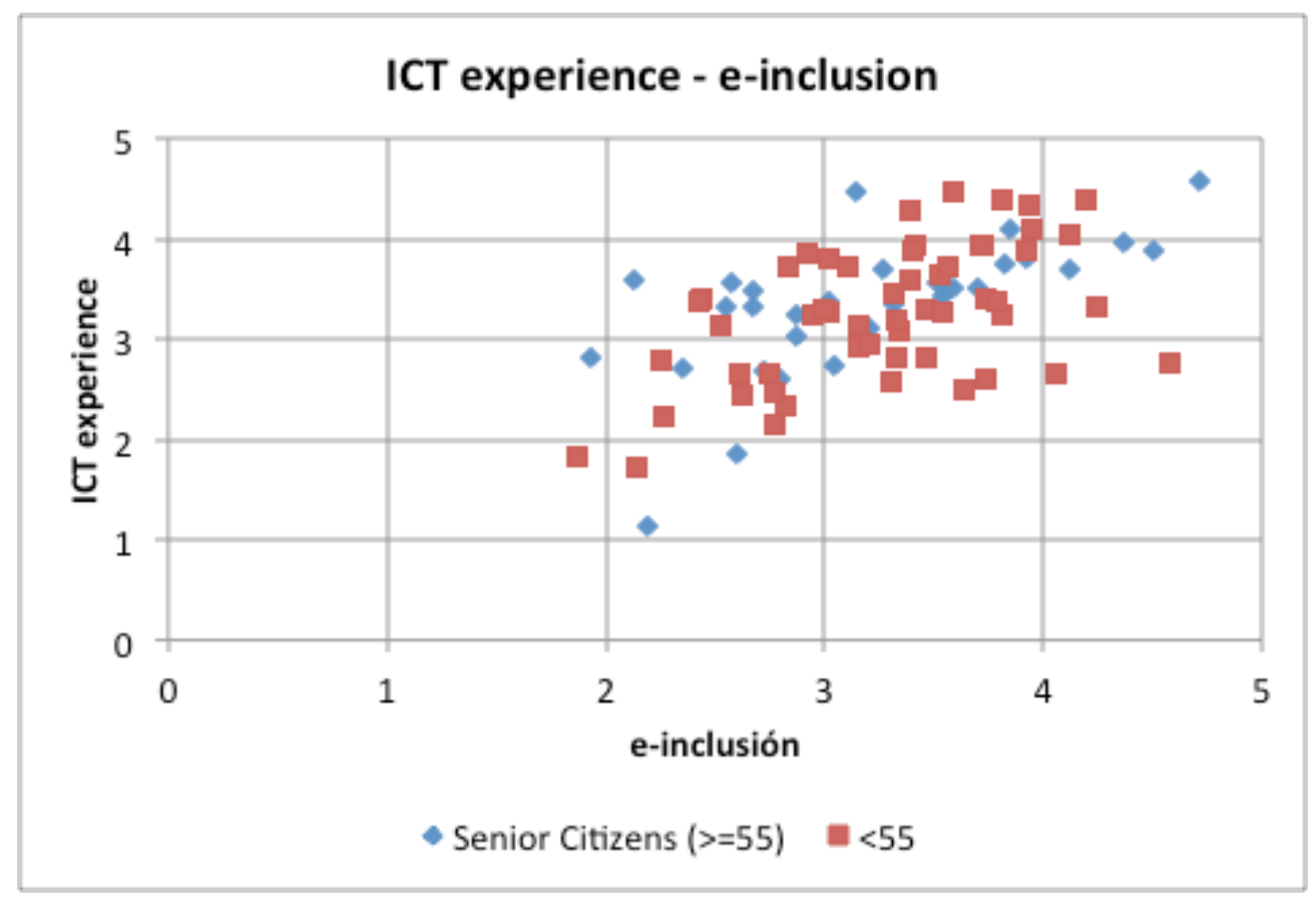

Figure 7. Relation between ICT Experience and e-inclusion

\subsection{Conclusion}

The concept of e-inclusion is related to being member of communities as part of the knowledge society and having an identity on the net. As explained above, this is a very abstract concept, and we need to have a clear focus in order to define it. The present study revealed a high correlation between frequency of use $(r=0.55, \mathrm{p}<0.01)$ and level of use of ICT tools $(r=0.57, p<0.01)$. Attitude has no significant correlation with einclusion or experience.

From previous assumption, an individual's attitude is not important, but the use he/she makes of it. But what kind of use is important? Our analysis of the questionnaire results revealed that people who are capable of using advanced ICT tools (access to cloud services, use of a word processor) were more e-included, which at first glance may be contradictory, as these services are not commonly used to empower people in communities. However, in fact it does makes sense, because the 
most advanced users of this kind of tool are also high users of other basic, more social and creative tools. We can conclude that the more advanced a user of ICT a person is, the more e-included he or she will be. The way to become e-included, therefore, is to become a high skilled ICT user with broad aptitudes.

This suggests that when we want a person to be e-included we should teach advanced ICT tools. That is, of course, a fairly depressing thought. We can turn it around by proposing that only people with sufficient ICT skills can be considered e-included: reaching a high proficiency in the use of ICT tools makes a person capable of being eincluded. Is this a necessary and sufficient condition?

A person may become an advanced ICT user through the demands of their job, or in the case of a retired citizen (a senior) because of other motivations and pleasures found through using ICT. Motivation and attitude is not important for e-inclusion, but it is a very decisive factor. In fact, we find that attitude and experience play an important role in increasing use and aptitude, which in the end leads to e-inclusion.

Based on the aptitudes and attitudes, users can be divided in four groups: not interested, resigned, motivated and involved. Figure 8 shows just how different people can be.

- Because of increasingly large numbers of tools and services now available on the net, fewer people fall into the "Not interested" group (as Eurostats reveals year on year). The reason given by seniors is that it is too complex (19\%) or too dangerous (28\%).

- ICT users may fall into the "resigned" group, which make their use of ICT very specific to cover their work related tasks in case of younger adults or, in case of seniors, because their friends and families oblige them (only $10 \%$ of seniors expressed this view).

- The "Motivated" group, even when they have less aptitude than the "Resigned" group, shows high experience and e-inclusion. We found that attitude is not related to experience and e-inclusion in the whole group, but we can see this relationship is on the rise among this segment of people. 
- "Involved" users are those with a high frequency of ICT use, with greater skills and better attitude, which leads them to be more e-included.

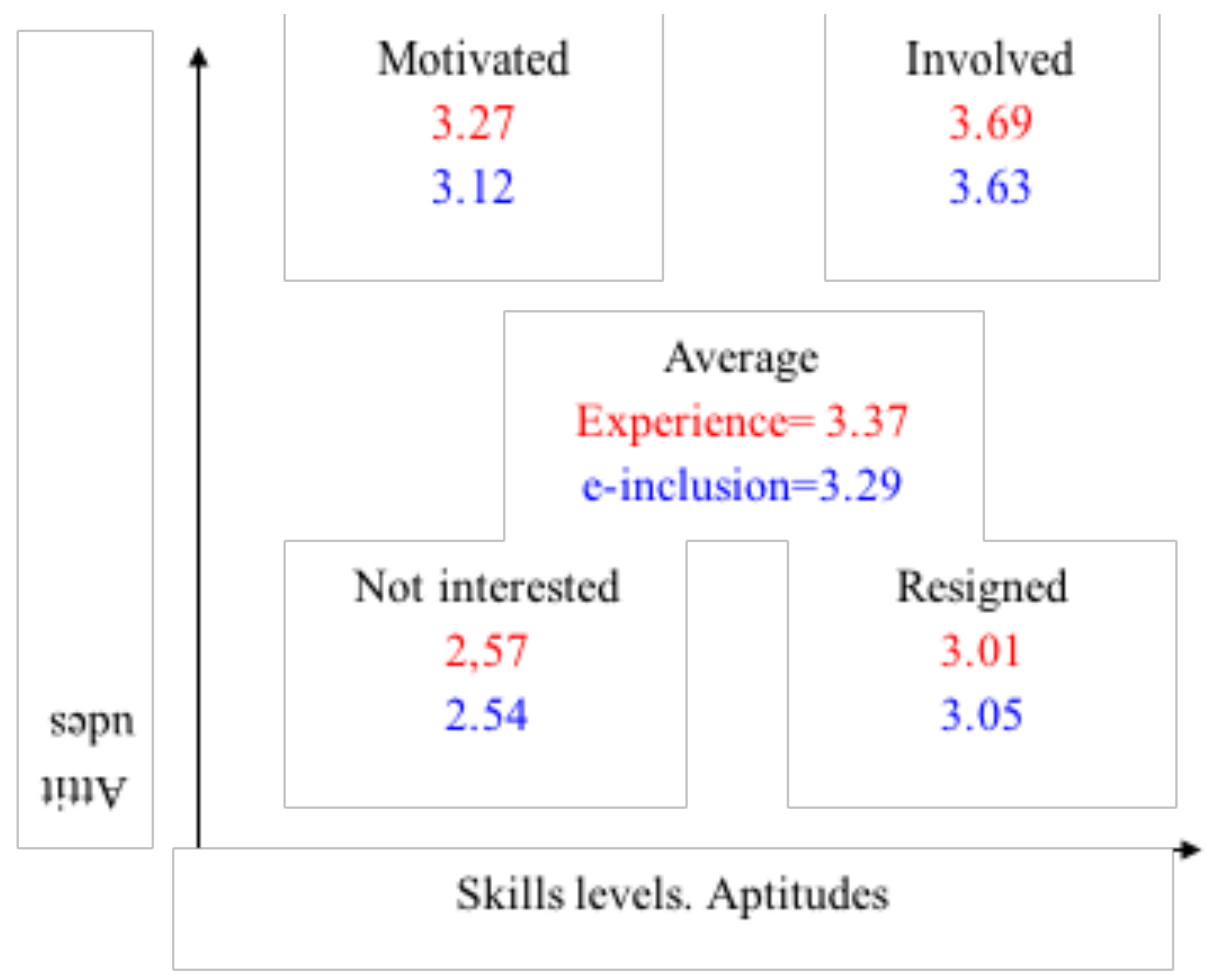

Figure 8. Classification of individual's experience and e-inclusion according to Aptitudes and Attitudes

Figure 9 shows the virtuous circle of e-inclusion. A person starts to learn and use ICT. If he/she is a senior citizen (retired), then this learning is not related to work issues but to other personal interests and social influence (friends, family). If the senior citizen is skilled in the use of ICT because he/she learnt previously, this does not mean that he/she does not have to learn new tools or services. If the senior finds the net useful and enjoyable, he/she becomes a frequent user. Then he/she starts to experience ICT and to be e-included. E-inclusion is not only a matter of frequency and aptitude, but also of attitude and experience, all of which increase together and have a synergy and feedback that again means the frequency, level of use, aptitude, attitude and experience increase together.

Only learning can make a senior be e-included, active, participative in the net and adapted to the knowledge society. However this statement should be clarified to avoid misunderstanding, because a senior will only keep learning if there is feedback 
from the above-mentioned factors that make this lifelong learning enjoyable, beneficial and fruitful, which drives the offer of an adequate learning methodology specifically aimed at seniors

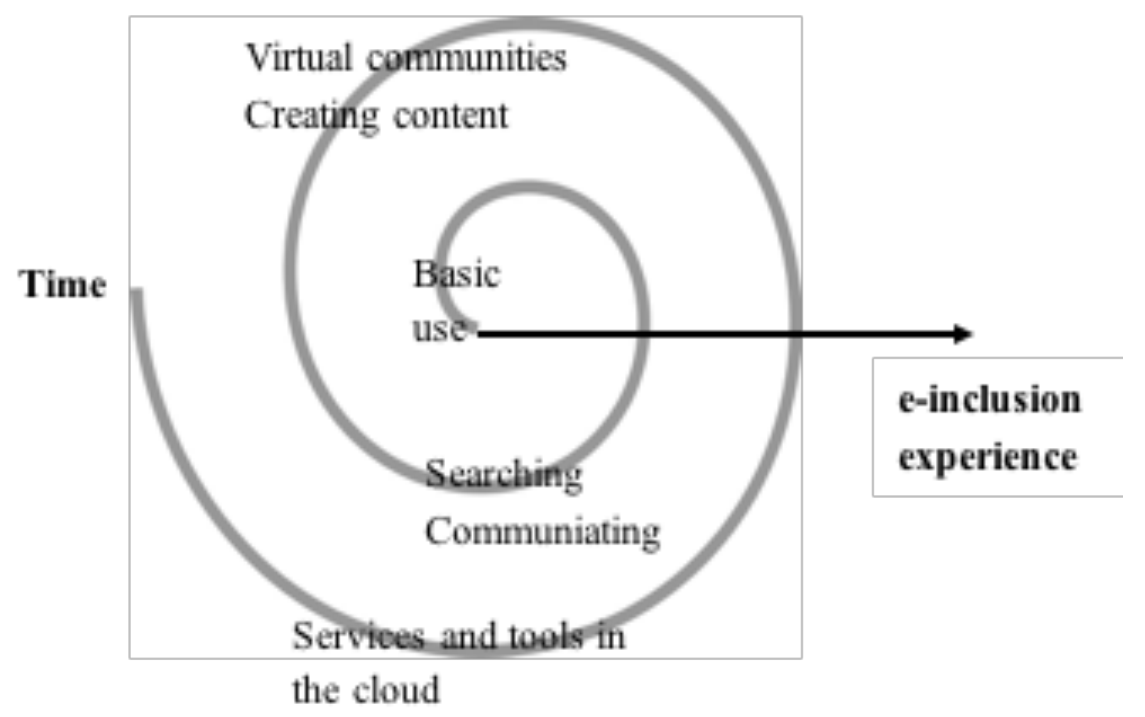

Figure 9. Virtous cycle for e-inclusion

\section{$24.9 \quad$ Acknowledgments}

- To the Senior Citiziens' University at the Jaume I University in Castellón, Spain. http://mayores.uji.es

- To the Grundtvig Learning Partnership SeniorsKS "Seniors in the Knowledge Society" supported by the LifeLong Learning Programme of the European Commission http://www.seniorsks.eu Note: This learning partnership project has been funded with the support of the European Commission. This communication reflects the views only of the authors, and the Commission cannot be held responsible for any use which may be made of the information contained therein. 


\section{$24.10 \quad$ References}

Ballestero, F. (2002). La Brecha digital : el riesgo de exclusión en la sociedad de la información. Madrid: Fundación Retevisión.

Castells, M. (2001). La galaxia Internet (The Internet Galaxy). Barcelona: Plaza \& Janés.

Castells, M. (2006). Informacionalismo, redes y sociedad red: una propuesta teórica in La sociedad red: una visión global (The Network Society: A Cross-Cultural Perspective),pp. 27-75. Alianza Editorial.

Chadwick-Dias, A., Tedesco, D., \& Tullis, T. (2004). Older adults and web usability: is web experience the same as web expertise? CHI'04 extended abstracts on Human factors in computing systems (pp. 1391-1394).

Crovi, D. (2004). Sociedad de la información y el conocimiento: algunos deslindes imprescindible. Sociedad de la información y el conocimiento: entre lo falaz y lo posible. Buenos Aires: La Crujía, 17-55.

Esteller-Curto (2012). El factor humano en las nuevas tecnologias: experiencia y einclusión (The human factor in the new technologies: experience and e-inclusion) in Aprendizaje y acceso a la red: la tecnología para los mayores. Roger Esteller Curto and Raúl Marín Prades (eds.) p. 303-328. Publicacions de la Universitat Jaume I. Castelló El País. (2010, March 10). El día que la burbuja "puntocom" pinchó. El País. Retrieved from

http://www.elpais.com/articulo/economia/dia/burbuja/puntocom/pincho/elpepue co/20100310elpepueco_3/Tes

EuroStat (2011). Internet use in households and by individuals in 2011. Available at http://epp.eurostat.ec.europa.eu/cache/ITY_OFFPUB/KS-SF-11-066/EN/KS-SF-11066-EN.PDF

van Dijk, J., \& Hacker, K. (2003). The Digital Divide as a Complex and Dynamic Phenomenon. The Information Society, 19(4), 315-326. doi:10.1080/01972240309487 
Grossman, L. (2006, December 16). Person of the year: You. TIME.

Hassenzahl, M., \& Tractinsky, N. (2006). User experience-a research agenda. $\begin{array}{llll}\text { Behaviour \& Information } \quad \text { Technology, 25(2), } & \text { 91-97. }\end{array}$ doi:10.1080/01449290500330331

Kaplan, D. (2005). e-Inclusion: New challenges and policy recommendations. Retrieved from http://www.epractice.eu/en/library/281387

Karsten, K. (2006). El concepto de -Sociedad del Conocimiento-. Biblio 3W, Revista Bibliográfica de Geografía y Ciencias Sociales, Universidad de Barcelona, 11(683). Recuperado a partir de http://www.ub.edu/geocrit/b3w-683.htm

Krüger, K. (2006). El concepto de -Sociedad del Conocimiento-. Biblio 3W, Revista Bibliográfica de Geografía y Ciencias Sociales, Universidad de Barcelona, 11(683). Retrieved from http://www.ub.edu/geocrit/b3w-683.htm

McCarthy, J., \& Wright, P. (2004). Technology as Experience. The MIT Press.

Nielsen, J. (1994). Usability engineering. Morgan Kaufmann.

Nurkka, P., Kujala, S., \& Kemppainen, K. (2009). Capturing users' perceptions of valuable experience and meaning. Journal of Engineering Design, 20(5), 449-465. doi:10.1080/09544820903158835

Oreilly, T. (2007). What Is Web 2.0: Design Patterns and Business Models for the Next Generation of Software. SSRN eLibrary.

Roe Smith, M. (1996). Historia y determinismo tecnológico. Madrid: Alianza.

Turkle, S., Project, H. E.-B., \& Societies, A. C. of L. (1984). The second self: Computers and the human spirit.

Turkle, S. (1999). Cyberspace and Identity. Contemporary Sociology, 28(6), 643-648. doi: $10.2307 / 2655534$

UNESCO. (2005). Towards knowledge societes . Paris, France: Unesco. 


\section{SENIOR STUDENTS IN VIRTUAL SPACES; THE TREASURE WITHIN}

Autores (por orden de publicación): P. Escuder-Mollon, J. Adell1, S. Cabedo, AM. Lipphardt, R. Esteller-Curto

Publicado en: CERI2015 Proceedings, pages 1569-1571, 2015. ISBN: 978-84-6082657-6, ISSN: 2340-1095. 8th International Conference of Education, Research and Innovation (ICERI 2015), 18-20 November. Seville, Spain

\section{Abstract}

Virtual learning spaces are offered to students to acquire competences and skills regardless of time and space. This kind of learning is not advised in children, neither in senior citizens as some of the competences they have to reach need a face-to-face contact and real group interaction. Even we are aware of the limitations of full virtual learning, it is necessary to acknowledge the enormous advantages it provides, increasing the access of people to education. We consider that the virtual teaching is now consolidated with enough quality as a viable approach for senior citizens that do not have possibilities to attend real classes, or that want to use computer mediated learning, what makes possible an digital inclusion and also an increase of quality of life. We show the experience of the EHLSSA KA2 Erasmus+ Strategic Partnership and the Senior Citizens' University of the Jaume I University in Castellón, Spain.

Keywords: senior, virtual learning, elderly, pedagogy, gerontology, blended learning, moodle 


\section{$25.1 \quad$ Background}

Virtual environments are being increasingly used, mainly for offering blended courses or completely on-line courses. On-line courses are a big opportunity to reach students that had difficulties of reaching the training centres because of distance or time restrictions. Also for institutions, it is a big opportunity, as on-line courses make possible to lower expenses, offer cheaper courses and wider the target population. Universities and other educational centres are offering the on-line courses for their formal courses. Other institutions offer non-formal courses open to the public, this is the case of edx.com, cursera, or any other generic MOOC platform. All this resources represent valuable opportunities to learn on a specific skill or competence. Mostly young adults and adults access those learning platforms, while senior citizens do not use ICT as youngers (at least statistically according to eurostats 93\% for people 25 to $34,54 \%$ for people 55 to 74 [1]).

Based on the analysis performed during the first phase of the EHLSSA project [2], the main reason that senior citizens argue to not access the on-line platforms is because they think that those are too difficult to use, they have not yet found a topic they are interested on or because their motivation are more focused on face-to-face learning environments where there exists a more social contact.

Any of the 3 reasons provided previously by the seniors could be accepted but that does not mean that the gap could not be overcome or at least, solved someway. This is also the purpose of the EHLSSA project and the aim of the Senior Citizens' University, of the Jaume-I University in Castellón.

The EHLSSA is a KA2 Erasmus+ Strategic partnership project (http://ehlssa.odl.org) coordinated by the University of Erlangen Nuremberg, the Institute for Innovation in Learning. This project intends to support and strengthen e-inclusion for seniors by offering new learning opportunities. Either in formal or informal settings, digital competences provide seniors skills that enhance individual empowerment and 
participation in society. In doing so, the project contributes to active ageing in later life. 3 on-line courses for senior learners are being developed, and also a pedagogical guide to transfer the practises to any institution that aims to create on-line courses focused to senior learners.

The Senior Citizens' University is the lifelong learning programme of the Jaume-I University, in Castellon. There, 954 students over 55 year old, attend to classes in the city campus and also in the rural areas. The subjects are mainly from the area of humanities, but also other from health, economy, sciences are part of the curricula that try that senior citizens become more adapted and capable in this always changing society. In this context, the main motivation to learn is mainly, personal, joined with the aim to meet other people with the same interest doing something useful and enjoyable. Finally, the senior citizens seemed not to get adapted to technology based learning environments because of technological gap on the adoption internet services and computers tools compared to youngers, affirming that those are difficult to use, and difficult to learn through them.

Because of previous motivation, on-line courses have not been used so extensively on adult learners compared to young adults. Related to the three barriers described before, that is the difficult interface, the offer of adequate courses and fulfil of socialization needs, in this papers we want to focus on the overcome of the third barrier, trying that seniors learners also enjoy learning using on-line platforms in both a formal and informal way, while they socialise.

\subsection{Context}

The Senior Citizens' University (SCU), started in the course 2011/2012 a pilot curse (using Moodle) with 30 students (senior learners over 55), after this experience, each year the number of subjects and students have been increasing reaching to $12 \%$ (that is 114 learners) of the total students from the SCU (in the course 2014/2015 954 students were enrolled in the SCU). Each of the subjects lasts for a trimester and are part of the optional list of subject. 
The subjects offered last year has been:

- Political structure of the ancient Rome

- Local Geographical and natural resources

- Revolutions, the motor of history

- Technology and society, recent history

As it can be seen, the subjects belong to the humanistic area, and while some of them are referred to past history, the teachers always try to contextualise and link those concepts to the present situation or regional context. The learners attend the courses mainly because of two reasons. The first is because they feel interest on the subject or at least, they think that can be interesting although they could not feel motivated on the topic directly; they know the trainer because of previous courses or they know a classmate that has attended a virtual course before and has explained them the positive experience. It must be pointed out that the topic is not the most important issue when choosing a course, but who is the teacher. The second reason a senior learner chooses a virtual course is because they like to share this virtual space with other learners. Although the senior citizens' target of this educational program are not on danger for exclusion or other social risks, they are active senior citizens, that like to join with others on useful and creative activities. The existence of virtual communities (as can be Facebook) or using computer for communication (as sending e-mails to relatives) is an activity that requires already existing networks and also a reason and purpose. All the learners in the virtual classroom have one common activity that is about learning together a topic, that helps to build a new community.

The participation in the virtual classroom is therefore directed by the interest to learn a new topic and also to share a space with other learners.

\section{3 learning process}

The learners have a lot of life experience, and the trainers take advantage of this characteristic; the pedagogy applied for the learning process is mainly the social 
constructivism. Although the teaching-learning process could be simple, it is important to remark a fact pointed out by all almost all the learners, that is the fact that during the participation in this learning activity, senior learners acquire 3 competences, that represents a triple challenge:

- The senior learner, as it happens in any ordinary subject, have to learn about the topic that is being taught, it can be historical facts, relations, social aspects, etc. This varies from one subject to other.

- The virtual environment is not simple (we use moodle). The use of forums, shared documents, wikis, blogs, participating in groups, uploading tasks, searching for information and sharing, etc. represents a very complex activity that should be driven to one specific aim. Senior citizens are not so used to the internet tools and services, and when having to use all those together the difficulty appears to be bigger.

- Senior learners are not used to the on-line methodology. It even happened that senior learners were capable to understand the methodology and course process after finishing the course. Somebody could consider this a failure of the trainer, but taking into account complexity of the process, we are sure that this is a completely success.

During the on-line course, we provide learners materials (as PDF, videos, or webpages). During the learning activities, they have to participate in forums, shared pages (as wikis) or posting messages (simple blogs). The forums are a platform for debates, discussion, agreements and conclusions. The wikis is a platform for workgroup, analysis and synthesis. Learners tend to thing on the final result of the activity, as it can be a summary, the most relevant items, or the report after the agreement during discussion. Here the hardest work (for both the trainer and the learner) is to think from the other side; that is from the process. We do not want learners to demonstrate by writing reports they have learnt a lot, we aim that they share and provide new points of view. To communicate using the computer becomes then a triple challenge (as said before): they talk about a topic they are learning about, they use a tool that feel not confident (yet) and we "force" them to reach the knowledge by networking. 


\subsection{Conclusions}

The use of virtual environments facilitates the e-adoption, to share the virtual environment, facilitates the digital inclusion (e-inclusion). To share a space for learning fulfil helps seniors that live away from educational centres or have a disability to move, to grow as individuals and get adapted. Our experience shows that no matter the topic chosen (health, arts, history, economy, science, etc), as senior learners are not learning because they need an official degree, but to learn because personal interest and motivation, trainers should link the content of the subject for making senior citizens to learn facts, but always from a understanding perspective, that is explaining better the past and the present and to know what is happening the present society. Being critical, but positive, capable to discuss, explain, and adopt new points of view or perspectives are skills promoted during all the courses. It can be said, that the content of the course and the competences related to the topics of the subjects are as important as other transversal skills, related to soft skills: communication, discussion, control, responsibility, creativity, adoption of new opinions and discovery.

The virtual classroom are spaces where learners also tend to share and participate in more informal way, as forums where they can chat about the topics of the classrooms or provide help in case somebody does not know how to use a specific tool. Those spaces resulted in a place where the learner get support from other learners, creating links between learners outside the classroom; it is common to organise a live meeting so learners can meet each other. 


\subsection{Aknowledments}

Part of this work has been produced in the framework of the project "European Home Learning Service for Seniors Association". This project has been funded with support from the European Commission. This communication reflects the views only of the author, and the Commission cannot be held responsible for any use which may be made of the information contained therein. Project reference: 2014-1-DE02-KA204001664, website: http://ehlssa.odl.org

\subsection{References}

1. Eurostats (2014). Internet use in las 3 months EU27

2. EHLSSA. European Home Learning Service for Seniors Association. http://ehlssa.odl.org

3. Petter, C., \& Helling, K. Designing ICT-based Learning Scenarios for Special Target Groups-Meeting Senior Learner Needs.

4. Ala-Mutka, K. \& Punie, Y. (2007). Ageing Societies, Learning and ICT. $\begin{array}{llll}\text { eLearningpapers, } & \text { Retrieved, } & \text { August, } & 18,\end{array}$ http://publications.jrc.ec.europa.eu/repository/handle/JRC41179

5. Escuder-Mollon, P., \& Esteller-Curto, R. (2013) Seniors in the Knowledge Society: context, practises and innovation.

6. Esteller-Curto, R., Escuder-Mollon, P., \& Marin, P. (2012, July). The Virtuous Circle of Use, Attitude, Experience and Digital Inclusion. eLearning Papers, (29). Retrieved from http://www.openeducationeuropa.eu/en/article/The-Virtuous-Circle-of-Use\%2CAttitude\%2C-Experience-and-Digital-Inclusion 


\title{
26 SENIORS LEARNING WITH APPS; THE TABLET AS A MEAN AND END
}

Autores (por orden de publicación): P. Escuder-Mollon ${ }^{1}$, S. Hetzner ${ }^{2}$, A. Tenckhoff ${ }^{2}$,R. Esteller-Curto ${ }^{1}$, C. Escura-Forcada ${ }^{3}$

1. Universitat Jaume I

2. Institut für Lern-Innovation FAU Erlangen-Nürnberg

3. Centre for the innovation and development of education and technology

Publicado en: 7th International Conference on Education and New Learning Technologies EDULEARN15 Barcelona

Publicado en: Proceedings, July 2015, Pages 7613-7622, ISBN: 978-84-606-8243-1, ISSN: $2340-1117$

\begin{abstract}
The use of tablets and smartphones (Android or IOS based systems) is increasing by all the population. Senior citizens are not an exception, and they are now becoming owners of one of these gadgets. According to a survey carried out in the frame of the SenApp (Seniors Learning with Apps) project, senior citizens are interested in this technology, even if sometime they do not know exactly which are the benefits of using those gadgets. It is also becoming common amongst seniors to have a tablet or/and smartphone and use them in a simple way (only as a phone or as a book reader). Seniors are becoming adopters of the technology, but they are not taking fully advantage of it. It is necessary to go further to reach digital inclusion. SenApp project proposes a learning roadmap that could be applied to senior citizens, linking educational content, a learning app (embedded in the tablet) and a social platform (to increase networking among seniors). The first prototype has been created (including 10 learning units) and these results are included in the paper. SenApp is a project of the Lifelong learning programme of the European Commission (http://www.senapp.eu).
\end{abstract}


Keywords: tablet, senior citizens, digital inclusion, pedagogy

\section{$26.1 \quad$ Background}

The elderly have traditionally been an excluded group of users of information and communication technologies (ICT); at least that is what statistics show comparing the different groups of population. According to Eurostat, in 2004 in EU27, only 10\% of senior citizens (individuals between 65 and 74) accessed the Internet (at least once a week) while $44 \%$ of adults (individuals between 25 and 65) were already ICT users. In 2013 figures increased: 34\% in seniors and 74\% in adults.

Senior citizens become ICT-competent thanks they attended to courses, by asking for help to the family or friends and in some cases becoming self-learners in case they had some computer and Internet basic experience. It is fair to acknowledge that two major advances have made the difference between 2004 and 2013, and it is expected to do so in future years. The first evolution has been on the increase of seniors' motivation and interest so they moved forward towards technology, the second change has been on the other side, where the technology now seems to be nearer to the seniors, thanks to the usability and services available, but also the learning process (that is thanks pedagogy adaptation). What makes the most powerful this change is that both aspects are closely linked by a virtuous circle [1] where a correct pedagogy make seniors feel confortable with ICT and increases seniors' interest, then there are more motivated to keep learning and using ICT, wanting to know and use more.

Senior citizens are capable and enthusiastic in acquiring ICT-skills and gaining knowledge [2]. They prefer skills, which are practical and applicable in real life, and they appreciate the social way of learning, like peer-tutoring. In addition seniors are usually very active in the learning-teaching process; willing to contribute to participate in the proposal, design and activities development. It is thanks to the courses where seniors learn to deal with the computer, tools and services available on the Internet where they increase the ICT use (that is e-adoption), but we should 
not miss the fact that this expertise reached is only the first part of the lessons to learn and skills to achieve. The ICT is richer than a simple tool, it provides the availability of the experience [3]. As said in McCarthy and Wright [4] "We don't just use technology; we live with it. Much more deeply than ever before, we are aware that interacting with technology involves us emotionally, intellectually, and sensually."

So we can consider that the capability of feeling the experience on the technology as building a bridge to overcome the digital divide and get the e-inclusion. Around 20022006 the digital divide was produced by the lack of access to the broadband. Today, the new digital divide is produced be-cause of experience, access, skills and usage access [5] so the increase of hard skills is only the first step, soft skills should be also taken into consideration when learning ICT.

The learning ICT must be understood as a learning experience, where senior citizens can start to use new tools and services being useful for them, but also enjoying, feeling that they can take part of the information society and increasing a the positive attitude towards new innovations and possibilities. This can be reached by putting (and increasing) on the ICT some of the ordinary real-life procedures and situations of communication, creativity, sharing with others and creating useful and valuable links with other people that can be then transformed to support networks, friendship or collaboration in common interests.

\subsection{Benefits of technology}

The use of ICT by general population should be seen as a tool that makes possible they reach other aims: learning, sharing, creating, communicating, buying, etc. that is the most common use: the ICT seen as a tool. The perception of the ICT can be seen by some people as something with so much possibilities, options and also complexities that using them creates a stressful experience, among other negative sensations as unusefulness and even sometimes rage. All those negative emotions then could lead 
to drop outs and rejection to technology, while the positive ones, have made the technology to be so common in our lives.

Fortunately, the interfaces and usability facilities, make that using the PC, smartphones, tablets, etc. an enjoyable experience, beyond the use. We cannot separate this use of technology that would be directly related to the expertise of an individual but also with the experience [3], enjoying the technology, being confortable and feeling it as a positive experience.

We should focus on both perspectives about ICT. First it is the useful variety of services and App that senior citizens can take advantage for their own profit, covering a need that they already had, make their life more confortable. On the second place, the technologies give benefits to seniors because those make possible new opportunities for communication, creativity, expression and other basic need of the human mind. Although technology cannot substitute the person-to-person social interaction, it cannot be denied that those provide big potentialities for anybody, more for the seniors, as it happens for those that live in rural areas, are disabled or found that sometimes, the best way to communicate with their grandchildren is using the same technology-language.

The benefits that ICT provide to a person should be firstly associated to cover their basic needs and requirements, only by this way it is possible that the learners finds useful the technology, as it provides a good way to fulfill that need. Is in the second term, where the learner acquired habits and has a positive attitude, that can face more complex skills on ICT, skills not related to the use of apps or Internet services, but social skills, which are far more complex, but that provide also enormous pleasure and experience.

From most basic levels, the ladder to become ICT-competent drives also the learner through the benefits of ICT, making the learning an enjoyable but also a very fruitful activity. As said by the sociologist Castells [6], the great difference that makes this period of time of any other lived before is the capacity of the people of creating networks, the computer mediated communication has established a new paradigm, also known as the information age or the knowledge society. The closed relation between the ICT, the present society and the networks make possible the individual 
to take advantage of new possibilities thanks to technology, those benefits should be learnt by stepping in that ladder:

Table 1. Ladder from e-adoption to e-inclusion

\begin{tabular}{|c|c|}
\hline Skill, competence & Benefit \\
\hline $\begin{array}{l}\text { Basic operations with the interface. Search } \\
\text { and retrieve information and data. Receive } \\
\text { and send messages. }\end{array}$ & $\begin{array}{l}\text { Read information. Communicate with other } \\
\text { colleagues by sending messages. }\end{array}$ \\
\hline $\begin{array}{l}\text { Follow links, networks and social relations } \\
\text { among people: creators or information and } \\
\text { consumers }\end{array}$ & $\begin{array}{l}\text { Discover, link information, compare, basic } \\
\text { learning }\end{array}$ \\
\hline $\begin{array}{l}\text { Request and perform activities using the } \\
\text { technology through the web, as buying, } \\
\text { eBanking or eGovernment }\end{array}$ & $\begin{array}{l}\text { Access to services, new opportunities, } \\
\text { access to rights }\end{array}$ \\
\hline $\begin{array}{l}\text { Give opinions, provide feedback, write } \\
\text { comments and short public messages }\end{array}$ & Sense of public identity, self-fulfilment \\
\hline Publish content (texts, images, video...) & Creativity, participation, recognition \\
\hline $\begin{array}{l}\text { Participate in social communities, } \\
\text { collaborative networks }\end{array}$ & Learn, teach, give and receive support \\
\hline
\end{tabular}

\subsection{The use of ICT for learning and learning ICT}

The double use of the ICT for learning ICT can make the learning process very challenging. In the SenApp project, we aim to use the tablet to learn to use the tablet, which makes impossible that a learner without tablet knowledge to go through the 
first learning units, as those learning units will be in the same tablet, and it is expected that some learners do not have the necessary skills even to access the content. Therefore, the first learning steps should be guided by a trainer, tutor or other classmate with good skills. In this case, the SenApp learning environment can mediate on this task, lowering the responsibility of the trainer or classmate, facilitating the learning in a guided way.

Even the use of the tablet for learning tablet create some difficulties on the methodology on which we are aware, it also provides benefits that can be exploited. It is the aim of the SenApp methodological proposal to lower those difficulties and increase the benefits, that proposal is detailed in further section.

SenAPP project aims to create a learning app for seniors to support them to become ICT competent using a tablet. This project recognises the clear need of increase the involvement of seniors in the information and knowledge society (that is e-adoption and e-inclusion), by applying the ICT as a medium as well as a learning content.

To reach previous aims, a roadmap should be followed, starting from the non ICT user to reach the digital inclusion (that is the e-inclusion). This is the roadmap proposed that will be tested after the design of the prototype

- Discovery of the technology, awareness of the Internet potentialities, general knowledge about the possibilities and understanding how can I benefit of those. The milestone would be to reach the awareness.

- Learning to use: the interface (that is the logic, language) the possibilities (with most basic tools and services), and uses (to incorporate to own daily life routines). The milestone would be to reach the e-adoption

- Learning to discover, to try, to learn by one self and to learn other subjects, to share, to gain security and confidence. The milestone would be to gain expertise and decide whether is something is useful or not

- The last step in the learning roadmap is to reach the digital inclusion. That is to have a positive but also critical thinking about the technology and their relation in society, to have skills to create networks between members of the society (could be family, friends, or associations), or to influence others (media, power) or create and collaborate (share the expertise and help to build and participate in the construction of the knowledge society), experiencing the ICT

When talking about the ICT, it becomes common to think on computers (as PC or similar) and the Internet (mainly surfing, mailing), but it is important to point out 
that what has made the ICT so important in present society are not the machines or the network it self, but the way that the people uses it and how we use it to connect people, knowledge or information. In fact, the sociologist Castells [5] prefers to call this society as the net-society thanks to the high connectivity that exists between information creators and information consumers. The computer mediated communication then becomes new way, with new capabilities of human interaction interfaces.

In the SenApp project, we have centered our efforts in the Tablet gadget, because it allows a new level of interaction never seen in computers and that affect the learning process and also the experience of the users. We do not aim to focus on smartphones although it is possible to link some of the skills and competences necessary to use both gadgets, even both share the same operating system (iOS in Apple, and Android on Google based systems)

It is important to remark the characteristics of Tablets from two perspectives, as a justification (the reason SenApp project is centered on tablets) and also the potentialities (as its role to make possible the e-inclusion of seniors and reach the ICT-benefits)

- Interface: Compared to the PC, the tablet can be managed using the most primitive tool that the human being has ever had, that is their fingers. The keyboard, and the mouse make de need to learn an artificial language used to manage the computer. Words like click, double-click, right-click, cursor, shift, etc. represent actions that the learner should be aware to apply, but also to know when to execute them. The tactile interface of the tables, make it simpler, using the human gesture of pointing with the finger. It is easier to learn, and more natural; this makes the barrier between technology and human to dissolve.

- Unfortunately, there is one lack on the tablets, that is that those are difficult to be used for writing large texts, but those can be substituted by accessory keyboards only when necessary.

- Portability. Nowadays, laptops have become very light and easy to carry everywhere, we can buy netbooks lighter than $1 \mathrm{~kg}$. Never before, personal computers has been so portable, even that affirmation difficult to reject, the 
laptops are not really portable, as it can be observed in an ordinary day: in a bus stop, in a line, while waiting for somebody, in a restaurant, etc. it is easier to see somebody spending time with a tablet than with a laptop. The tablet can fit in a handbag or in an ordinary suitcase (not laptop-suitcase). It is a gadget it is not strange to carry with us and use with us. It is starting to become common to see in the classrooms, museums, to be in contact using virtual communities while being in the hotel or in airports. Note that a businessman, surely would carry a laptop in an airport or hotel, but a tourist, prefers to use a tablet.

- The tablet (or big smartphones) has become then not only the most portable gadget, but the most personal internet connection. It allows us to be connected to Internet everyplace. No matter where you are, if you have a doubt, a problem, or simply you want to share something with your friends, you will probably get a connection to the internet. A proof of this is how common is becoming to get a free wifi in restaurants, commercial malls, and other public buildings.

- Connectivity: The use of instant-message programmes or photo-sharing programmes are very enjoyable, those allow to send messages to our friends and get in contact about what they are doing, send a photo of where we are or what we are enjoying. We are doing this kind of communication with our friends because we expect from them that they are connected. Even if this kind of communication is useless (without a purpose) that makes possible to create links between people; everybody is connected, everybody is available.

- The fact that we carry always the smartphone and it is always connected to the internet opens news opportunities for communication never seen before, that is the share-capabilities in our connected community.

\section{4 training approach}

Based on the results of the desk research mostly of the learners already had contact with Personal Computers and Internet, but it occurs some senior citizens had zero experience on ICT. The tablet in this case should be taught as the first tool to access Internet. 
Reasons not to use tablets seem related with the perceived difficulty for using them (complexity), fear for the loose of security (loose data, privacy) and not being useful (or at least, not knowing what to use them for). Based on the experience of already users of tablets and also trainers, the tablet provides some characteristics that should be primary exploited

- Tactile interface; using the hand as the most basic took to operate it (compared to mouse)

- Freedom of use; being capable to carry everywhere (compared to a laptop)

- Enjoying; now the tablet is mostly used to enjoy technology (compared to PC, used to work)

In a second term, it is best to try to link the use with some routine that the senior citizens could take advantage (as learning, sharing, reading, etc). This should not be introduced as something mandatory where the senior learner must use, but as something that the tablet could offer, so the learner then can use or not.

The use of tablets is closely linked to Internet, with great capacities for connecting people and networking. This is a good potentiality as increases the catalogue of tools and services available (thanks to internet) but also to create opportunities to link senior citizens and also seniors with other generations. A tablet that connects to Internet also becomes more difficult to use (mostly when creating new user accounts, privacy, new functions...) but this not should be avoided. Simple and popular services should be the first entry point.

The learning steps proposed by the trainers propose to act into 3 main pillars

- Increase confidence, motivation and a positive attitude, reducing anxiety, and the fear of loosing security and failure.

- Teach by practise and showing, demonstration and location of interests

- Provide support, tuition and provide help

A smooth introduction to the interface, buttons, and how to open and close applications is the first step for teaching to use the tablet. All users affirm that the tablet (compared to PC) has a more usable interface but when write some text is 
required, and then it becomes really difficult (although some have solved that using speech recognition).

Following can be seen the first 10 units offered in tablet training in the pilot test

Table 2. 10 first learning units for the pilot test

\begin{tabular}{|c|c|}
\hline Lesson & Competences \\
\hline 1 & $\begin{array}{l}\text { - To switch on and off the Tablet } \\
\text { - To unlock the screen } \\
\text { - Use the Tablet in a confortable position, and environment conditions } \\
\text { - Get used to it (touch, feeling) } \\
\text { - Open an App } \\
\text { - Basic displacement of the screen using the finger } \\
\text { - Basic buttons of the tablet (Home) }\end{array}$ \\
\hline 2 & $\begin{array}{l}\text { - Understand the interface of the Tablet (the parts and details of the screen, } \\
\text { how to change from one desktop to other) } \\
\text { - Open Apps and change from one to other (Android: home and back keys. } \\
\text { iPad: home button) } \\
\text { - Open an App and manage it, with the capacity to go deeper in some } \\
\text { sections/menus and go out }\end{array}$ \\
\hline 3 & $\begin{array}{l}\text { - Make photos and see them in the Photo Album } \\
\text { - Open other Apps (to see videos and books) } \\
\text { - Change between apps } \\
\text { - How to take care of the tablet, charge and store it. } \\
\text { - How to increase/lower the volume and the light }\end{array}$ \\
\hline 4 & $\begin{array}{l}\text { - Learn to use the Keyboard } \\
\text { - Write Lower case, upper case } \\
\text { - The use of the dictionary as a corrector } \\
\text { - How to move to other parts of the text and change the sentences }\end{array}$ \\
\hline 5 & $\begin{array}{l}\text { - Use the voice recognition software of the tablet } \\
\text { - Learn to speak clearly, step by step (sentence by sentence or even shorter) } \\
\text { - Get used to correct any misunderstanding } \\
\text { - To know the possibility to have an external keyboard }\end{array}$ \\
\hline 6 & - Open the navigator and surf to some pages on the Internet \\
\hline 7 & - Learn to use the Forum of the SenApp learning environment \\
\hline 8 & $\begin{array}{l}\text { - Understand the configuration section of the tablet } \\
\text { - Learn to find and connect to a Wifi connection } \\
\text { - Learning to try and test if it is working or not (by opening a webpage) }\end{array}$ \\
\hline 9 & $\begin{array}{l}\text { - Use the mailing system in the tablet (Gmail in Android and Mail in iPad) } \\
\text { - Read mails and write } \\
\text { - Use the contact address book }\end{array}$ \\
\hline 10 & - Learn the option to share content in the tablet \\
\hline
\end{tabular}




\section{$26.5 \quad$ Research}

Interviews were carried out following the Focus Groups methodology (Barnett 2002). The template for the interviews and methodology followed can be seen in the Annex I. The total people reached is following:

- ILI: 7 non-users, 5 users and 2 trainers

- eSenior: 3 non-users, 3 users, 3 trainers

- SCU: 12 non-users, 8 users, 3 trainers

- GIE: 6 non-users, 4 users, 2 trainers

Being a qualitative interview, main ideas were extracted, taking into consideration firstly the most common among all the population, but also the ones that were considered more interesting based the aims and context of the project.

Obstacles found, difficulties. Replies from trainers

New learners' attitude: fear of being unable to use it, fear of low security; Differences between seniors, pre-experiences; Being afraid of making mistakes; Being afraid of forgetting; "Retired teachers learn less than others" (ILI); Problems with tactile screen (at the beginning) ; Learners question "Will it be really useful for me?"; Differences in tablets versions that learners bring to classroom (SCU); Two needs for basic and advanced levels with different human/technology weigh (SCU)

How increase motivation on learners. Replies from trainers

Practising and showing (almost everybody); Identification of interest; Demonstration of possibilities; Showing videos; Make things as simple as possible; Thanks to the workshops (SCU)

Apps/Services more used. Replies from trainers

google searches, Youtube (GIE); Email (ILI, SCU); In general: books, maps, contacts, dictionaries, news, magazines, tv, weather forecast, radio, (all); Dropbox Siri, Groups, Skype, Citymap, Taurus

Suggestion to new trainers. Replies from trainers 
pace: "Slow, slow, repeat, repeat", patience; To be calm; Motivate by showing; Many daily life examples; Remember that seniors are learning because they enjoy it (make an enjoyable experience)

How to make learners more independet. Replies from trainers

Starting by taking classes; Repetitions, exercises; Loosing fear; Do not seek for apps, ask others (ILI)

Benefits for senior citizens. Replies from trainers

For the seniors

- To be much more up-to-date; To become independent; To discover new knowledge and useful information; It is lighter

Perceived from the seniors:

- Self esteem, satisfaction; Stay in contact with family, social networking, membership in virtual communities

Recommended tools. Replies from trainers

Good ICT manual; Presentation with steps, clear slides, printed materials; Videos; Courses with intensive support and tutoring; Method: theoretical (concept) and practical. Later exercises (students should practise at home and come to class with questions)

PC-expertise, attitude. Replies from users

expertise

- Almost everybody have a PC and internet; Uses: Information, communication, reading, news, music, games and e-mail

attitude

- Everybody feels enthusiastic or interested (ILI, SCU, eSenior); Feel confortable, as a hobby, enjoying

Motivation and interest, method for learning. Replies from users

Interest

- Stay in contact with relatives, searching, reading (ILI, SCU); Friends and family 
has been the main motivation; PC is for working, tablet for enjoying (SCU); As a PC abroad

Method of learning

- Relatives, courses (ILI, SCU); Being curious, by myself (intuitive, discovering) (eSenior)

Property of the tablet. Obtaining method, satisfaction. Replies from users

Property

- Usually they do not own a tablet (GIE); Nearly everybody own one (ILI, eSenior) and it is Android (2/3), or Adroid/Mac 50/50 (SCU); Usually it is has been bought by my own or on request

Satisfaction

- Very happy (99\% ILI, SCU, eSenior); I wish my wifi was faster (eSenior); Not quite happy when there is not a Wifi Connection

Reason for using. Replies from users

It is portable (a lot); Surfing; Traveling; "For everything we can do on the internet" (eSenior); Gaming (1) or let my grandsons playing (3); Writing (!); Speech recognition

Needs. Replies from users

To know much better about the tablet possibilities; To know all the apps available that could be useful for me; To increase the security during surfing and other services

Frequency and place of using. Replies from users

At home (nearly everybody); During travels (some); "Everywhere, always with me" (3 in SCU); Daily (nearly everybody

Connection with other devices. Replies from users

Usually they do not connect the table with the PC/laptop (2/3); None has a tablet with SIM, they connect with Mobile (or would like to learn how to do); Few have installed a Cloud service for photos

Expectation, desires, hopes. Replies from users

Learn more things; Browse better the internet; To have a better internet connection; 
A cleaner tablet (Android user, eSenior) ; To become simpler (iPad user, eSenior) ; To try to solve some errors (e.g. opening some pages or videos, Android user in SCU) ; To use the Cloud (SCU)

Preferred learning place. Replies from users

With a trainer/course; With a trainer with a lot of patience; With lessons available (even mandatory!!, eSenior) ; Alone and with a trainer ; Alone, not being afraid (5)

PC-internet ownership and knowledge. Replies from no tablet users

Usually they have a computer and consider they have enough/good expertise (SCU, eSenior, ILI); The computer is usually shared by the husband/wife; usually none although some would be accessible at home (GIE); Not use at all (2 at ILI)

Level of knowledge about tables. Replies from no tablet users

- $\quad$ Zero, none $(50 \%)$

- They heard about it: it seems they know what those are useful for (50\%)

- Easy to use, handling, touchable, for surfing, gaming, reading

- The same than a PC (nearly)

Reason not learning/using tablets. Replies from no tablet users

It seems too complicated (windows, touchable); It is difficult to read on the screen; Fears, security, data loos, privacy; It seems too complicated; What is it useful for ?; It would be nice to have a mouse (!); Expenses (1/4); Time restriction (only one)

Reasons to start use tablets. Replies from no tablet users

those were easy to use and read; I had help or good training; I knew the added value of the tablet; I had a good book (in paper!!) that I could learn from; It had a mouse/keyboard; It has internet: wifi/3G

Expected use: books, email, photos, communicate with relatives/children, information, magazines, reading, radio, tv, information, to use being away, to connect to internet 


\subsection{Conclusions}

We aim to use the tablets (iOS or Android based) to learn about how to use the tablet to reach the senior learners become self-directed in their educational process. This arises some pedagogical challenges:

- Our teaching experience would advice to use another learning environment (TV, book, PC, projector, other tablet) while the learner tries step by step the task

- Rely on short term memory of the senior learner is very risky

- What to teach first? The virtual learning environment or the tablet interface? (both are simultaneous)

- Full virtual learning environment looses real human contact (and this is really appreciated by senior learners)

- That can lead to failing in motivation, encouragement and even learning effectiveness

But with following potentialities:

- Greater impact

○ No distance limitation

○ No time limitation

- Easy reuse of materials

- Virtual community

○ To get and give help

- As a learner

O Own pace and possibility to reuse

○ Learning APP is a perfect complement for ordinary courses

Based on previous defined situation and needs of senior citizens and the specific context of ICT learning, and the roadmap defined before, the pedagogical approach should be to divide the course in teaching units, from the most basic and low level skills and competences to the most advances and more abstract. Thanks to this it will be possible to reach e-adoption and later e-inclusion. 
Each teaching unit has to fit following requirements

- Senior learners should know the purpose of what they are learning. Therefor, each teaching unit, should have a clear aim, but also it should explain why it is important and the expected benefit

- It should use the life experience of the learner covering needs and show examples that could be applied to their own life

- Andragogy principles and inspiration from connectivism theory will be examined and they will form the base for the proposed methodology

- The methodology will not be restricted on a single pedagogy but it will try to adopt the most appropriate elements of each approach to support the use of mobile learning and training.

SenApp develops a non-formal, flexible and accessible App-based ICT qualification course that matches the very specific needs of this highly heterogeneous target group. Furthermore, the use of eLearning as training mode will best support flexibility of content and learning schedule, which is a fundamental requirement of training offers for this large and much diversified group.

\subsection{Aknowledments}

This work has been produced in the framework of the project "Seniors Learning with Apps". This project has been funded with support from the European Commission. This communication reflects the views only of the author, and the Commission cannot be held responsible for any use which may be made of the information contained therein. Project reference: 539394-LLP-1-2013-1-DE-GRUNDTVIG-GMP, website: www.senapp.eu 


\section{$26.8 \quad$ References}

[1] Esteller-Curto, R., Escuder-Mollon, P., \& Marin, P. (2012, July). The Virtuous Circle of Use, Attitude, Experience and Digital Inclusion. eLearning Papers, (29). Retrieved from http://www.openeducationeuropa.eu/en/article/The-VirtuousCircle-of-Use\%2C-Attitude\%2C-Experience-and-Digital-Inclusion

[2] Naumanen, M., \& Tukiainen, M. (2009). Guided participation in ICT-education for seniors: Motivation and social support. In 39th IEEE Frontiers in Education Conference, 2009. FIE '09 (pp. 1-7). doi:10.1109/FIE.2009.5350544

[3] Chadwick-Dias, A., Tedesco, D., \& Tullis, T. (2004). Older adults and web usability: is web experience the same as web expertise? In CHI'04 extended abstracts on Human factors in computing systems (pp. 1391-1394).

[4] McCarthy, J., \& Wright, P. (2004). Technology as Experience. The MIT Press.

[5] Van Dijk, J., \& Hacker, K. (2003). The Digital Divide as a Complex and Dynamic Phenomenon. The In-formation Society, 19(4), 315-326. doi:10.1080/01972240309487

[6] Castells, M. (2006). La sociedad red: una visión global. Madrid: Alianza Editorial.

[7] Barnett, Jacqueline M. (2002). Focus Groups Tips for Beginners. Retrieved from http://www-tcall.tamu.edu/orp/orp1.htm 


\title{
27 ED-WAY PROJECT; INTRODUCING TECHNOLOGY-ENHANCED INFORMAL LEARNING
}

Autores (por orden de publicación): R. Esteller-Curto ${ }^{1}$, P. Escuder-Mollon ${ }^{2}$, E. Leen-Thomele ${ }^{3}$, C. Fowley ${ }^{4}$, G. Chirlesan ${ }^{5}$

1. Centre for the Innovation and Development of Education and Technology, España.

2. Universitat Jaume I, España.

3. Innovation in Learning Institute, Friedrich-Alexander Erlangen-Nuremberg University, Alemania.

4. Intergenerational Learning Programme. Dublin City University, Irlanda.

5. Group for the European integration, Rumania

Publicado en: 7th International Conference on Education and New Learning Technologies EDULEARN15 Barcelona

Publicado en: Proceedings, July 2015, Pages 7613-7622, ISBN: 978-84-606-8243-1, ISSN: $2340-1117$

\begin{abstract}
The use of tablets and smartphones (Android or IOS based systems) is increasing by all the population. Senior citizens are not an exception, and they are now becoming owners of one of these gadgets. According to a survey carried out in the frame of the SenApp (Seniors Learning with Apps) project, senior citizens are interested in this technology, even if sometime they do not know exactly which are the benefits of using those gadgets. It is also becoming common amongst seniors to have a tablet or/and smartphone and use them in a simple way (only as a phone or as a book reader). Seniors are becoming adopters of the technology, but they are not taking fully advantage of it. It is necessary to go further to reach digital inclusion. SenApp project proposes a learning roadmap that could be applied to senior citizens, linking
\end{abstract}


educational content, a learning app (embedded in the tablet) and a social platform (to increase networking among seniors). The first prototype has been created (including 10 learning units) and these results are included in the paper. SenApp is a project of the Lifelong learning programme of the European Commission (http://www.senapp.eu).

\section{$27.1 \quad$ The Ed-Way project}

The name of the project "Education on the way" ("Ed-Way")[1] makes direct reference to the two main keystones the project is developing:

"Education" understood as continuous or life-long learning through the different stages and circumstances of life. This includes formal contents but also competences, skills, qualifications and values. This concept becomes a basic aspect for achieving the objective of building in balance and tolerance the multicultural and diverse societies of the future that European countries are facing.

"On the way" meaning not only "through life" or towards our near future but also, literally, "on the go" as a direct reference to the new technologies that are emerging during the last years and that bring us never-known-before possibilities: technologies that we carry with us (tablets, smartphones, smart-glasses, wearables...) and that include a wide scope of possibilities of cooperation, equity, integration, disparitiesreduction, inclusion and communication due to their usability, connectivity and impact. Technology that moves along with the user means also a new chance for learning and an opportunity to introduce informal learning into the reality of individuals as a strong way for educating, teaching and training.

The logic of this technology-enhanced continuous or life-long learning process is at the reach of almost the totality of the European population and consequently its applicability would have a considerable impact in the creation of a European Area of Skills and Qualifications. Therefore, the creation of training and conceptual materials for this purpose for educators, facilitators, teachers, trainers and those responsible of 
adults and seniors becomes essential. They become the specific target group of this project.

Additionally, as the Population Division, DESA, from the United Nations estimates (World Population Ageing 1950-2050 report)[2], "about 37 per cent of the European population is projected to be 60 or over in 2050 ". This sector of the population are in some cases at risk of social exclusion and technologically marginated despite the fact they are a basic participant of the "intelligence society". In this sense, Education on the way will produce tools and resources that will help to:

Educate, train and qualify the adults and young professionals of today that will be the elderly of tomorrow. The existence of a future society where the elderly are integrated, participants and active contributors of the society relies on the present preparation of their members.

Prepare the instruments and technologically applied pedagogies that will contribute to an active and collaborative ageing of the elderly in present societies. This will occur not only by them achieving a mastery of new technologies in general but also by (through the customary use of new technologies) awakening their social awareness, collaborative integration, participation, learning to learn skills... which will keep them integrated in the knowledge society and away from the risk of exclusion and social margination.

The project facilitates, by means of utilization of new technologies, the recognition and use of non-formal and informal learning (and its permeability with interdisciplinary formal pathways) in the field of adult education and training, paying particular attention to the acquisition of personal, social and formal skills, competences and qualifications. Additionally, it deploys an specific pedagogy and training in the acquisition of new social habits, customs and resources linked to them 


\subsection{Learning informally}

By definition, the informal learning is produced unintentionally [3]. Once it is planed and directed, it becomes formal or informal. The formal learning is strictly organised and concluding with a certificate or any other kind of recognition (as it happens in secondary school, vocational training, university studies, languages certification, etc.). The informal learning is more flexible, it can have aims, timetables and even evaluation as the formal learning, but it is not officially regulated, and is far more flexible and can miss some of previous components (as evaluation, or curricula). The informal learning is usually organised in a more flexible way, as it can be workshops, seminars, attendance to conferences, self-learning activities or any other educational event not regulated.

Although the formal and informal education has received the main attention during the last decades, there is a growing interest on informal education as it allows acquiring competences and skills that cannot be learn inside a classroom [4][5]. This informal education is produced usually in places where high components of iteration between other people and also where the individual has to deal with an emotional task or activity. Those places can be the workplace, dealing with collaborative work, or assuming responsibilities. Informal learning happens while people is doing other things: working, traveling, doing some activity with friends or family, etc.

We propose the informal learning to happen inside the classroom, but still without being the main target of the training activity; that is while the trainer is teaching other subjects (economy, arts, sciences, business, etc.). Three positive aspects raise from this approach:

- We add activities in the course to potentiate the interaction and group dynamics of the students; they become more active, aware and responsible of the main subject of the course and the learning objectives. By motivating them to take a more active role during the teaching-learning process, we also encourage them to 
incorporate the main subject of the course to their personal needs and interests. We provide tools and guide to the teacher to go through this path, making possible a new concept of education, not understood as content-delivery process or memory-based evaluation which was used in traditional schools, but on skills and abilities of the present society, based on the capacity to use and apply the knowledge to real situations.

- Informal learning is only produced after months or even years, some attitudes and skills can only be acquired after years experience. By promoting the informal learning inside a course or other planed learning activity we aim to initiate a habit on the students; those are the soft skills and transversal competences we aim: responsibility, leadership, collaboration, teamwork, problem solving, initiative, etc.

- Information and Communication Technologies (ICT) as computer and the Internet use are becoming more necessary for daily routines, communication with friends and family, and also in the workplace. First step is to learn ICT, that is to use a specific tool or service, but secondly, everybody should learn to apply those tools for our purposes. That makes ICT meaningful.

\subsection{Method}

In Ed-Way project we promote the informal learning by proposing activities that increase motivation, emotions and experience with a technology mediated communication approach.

The method proposed is grounded on the Field theory [6] and Gestalt psychology [7]. The competences, skills and values proposed are going to be acquired transversally while learning other subjects; we guide the learners through several states, motivating them by mixing emotions, personal interest and the aim of personal growth to make possible, thanks to the ICT, that everybody could learn the subject from a net-based perspective. Thanks to this approach we make possible that 
students acquire transversal skills and values and keep learning informally once the course ends.

We propose 7 areas where the activities, methods and skills and competences are grouped. Those areas of expertise are provided as steps or phases where a learner can be guided, starting from being guided and directed to a more independent and autonomous learner, although it is not a requirement to follow this path, it represents a natural way to grow as a learner. Table 1 shows those areas and the experiential learning (emotional) proposed.

Table 1. List of the areas included in the Ed-Way manual for trainers

\begin{tabular}{|c|c|c|c|}
\hline Step & Title & ICT tools model & $\begin{array}{l}\text { Experiences, including } \\
\text { tasks to increase emotion }\end{array}$ \\
\hline 1 & Awareness & Readers, Searchers & $\begin{array}{l}\text { Motivation as a learning } \\
\text { experience }\end{array}$ \\
\hline 2 & $\begin{array}{l}\text { Involved } \\
\text { learner }\end{array}$ & $\begin{array}{l}\text { Blended learning, technology } \\
\text { in the classroom, autonomous } \\
\text { learning }\end{array}$ & $\begin{array}{l}\text { Situational leadership } \\
\text { (directing, coaching, } \\
\text { supporting, delegating) }\end{array}$ \\
\hline 3 & Collaboration & Collaborative tools & $\begin{array}{ll}\text { Teamwork } & \text { (forming, } \\
\text { storming, } & \text { norming, } \\
\text { performing) } & \end{array}$ \\
\hline 4 & $\begin{array}{l}\text { Complex } \\
\text { thinking }\end{array}$ & Virtual sharing spaces & $\begin{array}{l}\text { Perception phases (Grow } \\
\text { model) }\end{array}$ \\
\hline 5 & Networking & $\begin{array}{l}\text { Virtual learning networks, } \\
\text { social networks }\end{array}$ & $\begin{array}{l}\text { Use of language, diversity } \\
\text { management }\end{array}$ \\
\hline 6 & Power & Creativity tools & $\begin{array}{l}\begin{array}{l}\text { Building new realities } \\
\text { (objectives, emotions, } \\
\text { needs, alternatives, action) }\end{array}\end{array}$ \\
\hline
\end{tabular}




\begin{tabular}{|l|l|l|lr|}
\hline 7 & Adaptation & New ICT tendencies and tools & $\begin{array}{l}\text { Managing changes } \\
\text { positively }\end{array}$ \\
\hline
\end{tabular}

The evaluation and validation of the acquisition of skills and competences in an informal learning is difficult, even more when those competences are soft skills and transversal attitudes and values, which require a long-term teaching process. However, we propose a method for evaluation based on individual subjective perception:

- Self-reflection of the learner; if he/she is aware of the process and what happened, the problems, challenges and the lessons learnt

- Results of the activity; mainly in the activities that consist on creating or sharing content it is possible to measure the quantity of the interactions between the learners and the content created. Even so, we propose the quantitative evaluation, instead of quantitative, being more important the quality of the experience than the quantity.

- The trainer in the activities we propose should be considered a facilitator. We remind that the trainer already teaches the main subject of the course, while these kinds of activities are proposed to reinforce the main contents and aims while the learners make a more dynamic activity in a more independent way. The trainer here becomes a facilitator, helping and guiding. The trainers' participation in this activity should provide enough freedom to the learners so they can use the ICT tools as they think convenient, solving communication, leadership or doubts by their own. Only with this freedom space, it will be possible an informal learning. On the other side, that does not mean that students will be left alone. The trainers' guidance and accompaniment is crucial for to reach the learning objectives (and not to get too spread results) and at the same time for evaluation of the learners.

Finally, in Ed-Way, we aim to create a virtual badge to provide visibility to the skills and competences acquired and assesses. We offer it as an example for any institutions willing to implement a similar way for accreditation, or also use it directly from our project. 


\section{$27.4 \quad$ Result}

We finished the analysis phase and the project is on the stage of manual production, a draft of the manual is available to trainers and ready for evaluation. There are 7 units, useful for trainers that are willing to adopt the model we propose.

The validation of the model has been done by implementing the methods proposed in 4 activities of the University of the Third Age of Castellón (average age 61). The method has been applied while learners were attending subjects "Local history and arts", "The UNESCO World natural heritage resources", "Knowledge and information society" and also in a workshop for ICT learning for advanced groups.

As stated in the previous section, the validation of the competences acquired is done by the subjective perception of the learner, quantitative and qualitative group dynamics, and trainers feedback. In Table 2 it can be observed the competences reached by the application of the activities described in Table 3 .

Table 2. List of the competences reached thanks to the activities proposes

\begin{tabular}{|l|l|l|}
\hline Unit & Activities & Competences \\
\hline Awareness & $\begin{array}{l}\text { Getting information and } \\
\text { understanding context: } \\
\text { newsclips, reflection, changes, } \\
\text { impact, potentialities }\end{array}$ & $\begin{array}{l}\text { Responsibility, Self-improvement, } \\
\text { Individual leadership }\end{array}$ \\
\hline lnvolved & $\begin{array}{l}\text { Blended learning by ways of } \\
\text { learner }\end{array}$ & $\begin{array}{l}\text { Control, autonomy, responsibility, } \\
\text { independent learning } \\
\text { planification }\end{array}$ \\
\hline Collaboration & $\begin{array}{l}\text { Sharing spaces as a group, } \\
\text { constructing common aims } \\
\text { and using organisative tools }\end{array}$ & $\begin{array}{l}\text { Teamwork, } \\
\text { initiative, Leadership, flexibility, } \\
\text { role awareness }\end{array}$ \\
\hline
\end{tabular}




\begin{tabular}{|l|lr|lr|}
\hline $\begin{array}{l}\text { Complex } \\
\text { thinking }\end{array}$ & $\begin{array}{l}\text { Data representation, } \\
\text { brainstorming, discussion. } \\
\text { "Learning by research" activity }\end{array}$ & $\begin{array}{l}\text { Problem solving, abstraction, } \\
\text { analysis, creativity. }\end{array}$ \\
\hline Networking & $\begin{array}{l}\text { Virtual learning networks, } \\
\text { using social networks, } \\
\text { networks of interest and } \\
\text { linking }\end{array}$ & $\begin{array}{l}\text { Self improvement, personal } \\
\text { relations, human awareness }\end{array}$ \\
\hline Power & $\begin{array}{l}\text { Publishing of content in web } \\
2.0 \text { tools, receiving feedback }\end{array}$ & $\begin{array}{l}\text { Communicator, } \\
\text { orientation, role } \\
\text { handling rejection }\end{array}$ & awareness, \\
\hline Adaptation & $\begin{array}{l}\text { New tools for learning, learn to } \\
\text { learn, learn to provide help }\end{array}$ & $\begin{array}{l}\text { Flexibility, versatility, } \\
\text { self-control }\end{array}$ & internal \\
\end{tabular}

The manual can be used by trainers, by offering the background, methods and experiences so they can use the Ed-Way approach in their courses by guiding the learners from a directed way of learning (in the first units of the manual) to a more independent and flexible education (the last learning units of the manual). As stated before, we used it in 4 activities, in Table 3 it can be observed the summary:

Table 3. List of the learning activities that included the Ed-Way methods, used for method validation

\begin{tabular}{|l|l|l|}
\hline Activities & Method & $\begin{array}{l}\text { Participan } \\
\text { ts / drops }\end{array}$ \\
\hline Local history & $\begin{array}{l}\text { Application of "Learn researching" method, together with } \\
\text { Creativity and power. Students had firstly to choose what } \\
\text { they wanted to research, usually they chose some } \\
\text { historical or artistic part they liked in their town. They } \\
\text { used Internet and also other resources (even interviews } \\
\text { with experts) to get more information. The group meet }\end{array}$ & \\
\hline
\end{tabular}




\begin{tabular}{|c|c|c|}
\hline & $\begin{array}{l}\text { once per month with a facilitator and they publish the } \\
\text { results in a blog. Finally, the results were presented } \\
\text { publicly in an event and also video (activity about } \\
\text { communication). } \\
\text { Length: } 2 \text { semesters ( } 8 \text { moths), blended learning }\end{array}$ & \\
\hline $\begin{array}{l}\text { The UNESCO } \\
\text { World heritage } \\
\text { resources and } \\
\text { properties }\end{array}$ & $\begin{array}{l}\text { This courses was used to apply the deep thinking method, } \\
\text { to understand, analyze, and try to solve the present social } \\
\text { challenges about preservation of the natural and } \\
\text { historical resources and other singular places, including } \\
\text { even immaterial resources. } \\
\text { This was a course offered completely on-line, which } \\
\text { required a very active and autonomous role of the } \\
\text { learner. This also included collaborative works } \\
\text { Length: } 1 \text { semester ( } 4 \text { months), virtual learning }\end{array}$ & 68 / 18 \\
\hline $\begin{array}{l}\text { Knowledge and } \\
\text { information } \\
\text { society }\end{array}$ & $\begin{array}{l}\text { Increasing the awareness and understanding of the social } \\
\text { context. Put together with workshops about the future } \\
\text { innovations and challenges (as privacy, biotetics, } \\
\text { dependency, gadgets in our hose, etc.) was used to apply } \\
\text { the methods about awareness and adaptation. } \\
\text { Length: } 10 \text { weeks ( } 2 \text { h. per week plus homework) }\end{array}$ & $89 / 0$ \\
\hline $\begin{array}{l}\text { ICT course, } \\
\text { advanced level }\end{array}$ & $\begin{array}{l}\text { In the basic ICT levels (computer and internet skills) we } \\
\text { train students on the use of services and tools. On the } \\
\text { most advanced levels, they are becoming sufficiently } \\
\text { autonomous to try to learn by themselves, teach each } \\
\text { other and share their ideas and give and receive } \\
\text { suggestions. They used forums, shared documents and } \\
\text { social networks to communicate virtually } \\
\text { The attendance to this course were organized in groups, } \\
\text { and methods to increase teamwork, autonomy and learn }\end{array}$ & $48 / 13$ \\
\hline
\end{tabular}


to learn was applied.

Length: 35 sessions, 3 groups of 16 students each

All the activities had a high use of information and communication technologies (as it has the Ed-Way method), in almost all the students (except those that already had experience in virtual learning or use of blogs), it was observed that excluding the necessary effort to learn the main topic of the subject (arts, UNESCO sites, society and ICT), there was a noticeable struggle on the emotional, communicative and collaborative tasks, sometimes because students did not know how to manage these kind of activities, or because they feel lost. In this case the role of the facilitator was crucial. In most the cases this extra effort was rewarded after observing the results of the learning process, that was reflected in the competences acquired:

- Students could learn the topics of the course from a very different perspective, not restricted on books or fixed, but open and with some degrees of freedom.

- They had to learn new methods of learning, collaborating, sharing and discussing. In some of the courses, it was so different from the traditional way of learning that it took some weeks to understand the process (courses last a semester; 4 months, but the "Local history and arts" that lasts 2 semesters)

- They had to use the ICT for a purpose in a course that lasted a semester, not as a tool or service, but as something that has an objective and has a results (as it happened in wikis, blogs, or videos after they were published)

\subsection{Conclusion}

The informal education, the teaching of soft skills and the validation and visibility of the competences acquired is being considered as one of the key aspects for a lifelong learning process. In Ed-Way we potentiate this informal education, making possible its permeability with interdisciplinary formal pathways. We offer a manual and an on-line environment where trainers will be able to practice the methods proposed to later on offer them to their students. 
Although the acquisition of the soft skills and other transversal competences require a long term activity, from the feedback provided by the learners, the application of the methods we proposed caused a learning that goes further than the simple course content. Those are directly correlated with the competences, skills and also values that we try to impact by the Ed-Way method;

Learners were intrinsically highly motivated to learn the main topics of the topics (arts, World heritage resources, the society and ICT), as they were given some freedom to explore and choose the topics they feel more interesting. The facilitator in each of the course guided the learners to focus on the main objectives of the course.

As it was introduced in the previous section, it was observed some students had difficulties on the activities requiring the use of soft-skills and transversal competences (as teamwork, communication, publishing), moreover as those required the use of ICT. The fact the students could adapt to this learning method is an evidence that the necessary skills were acquired although not without effort.

\subsection{Acknowledgements}

This paper has been developed from the experience in the KA2 Erasmus+ Strategic Partnership project "Education on the way: Introducing technology-enhanced informal learning" with reference 2015-1-ES01-KA204-016354 www.ed-way.eu This paper reflects the views only of the author, and the Commission cannot be held responsible for any use which may be made of the information contained therein.

\subsection{References}

1. Education on the way: Introducing technology-enhanced informal learning [Internet]. Centre for the innovation and development of education and technology [cited 2016 september 29] http://www.ed-way.eu 
2. United Nations, editor. World population ageing, 1950-2050. New York: United Nations; 2002. 483 p.

3. Cedefop: European guidelines for validating non-formal and informal learning. Publications Office. Cedefop references series; 2015.

4. Marsick VJ, Watkins KE. Informal and Incidental Learning. New Directions for Adult and Continuing Education. 2001 Mar 1;2001(89):25-34.

5. Coffield F, editor. The Necessity of Informal Learning. Bristol: Policy Press; 2000. 90 p.

6. Lewin K, Rivera JD. Field Theory As Human-Science: Contributions of Lewin's Berlin Group. Gardner Press; 1976. 552 p.

7. Köhler W. Gestalt Psychology: An Introduction to New Concepts in Modern Psychology. Liveright; 1970. 388 p. 


\title{
28 VIRTUAL ON-LINE LEARNING; THE EVOLUTION AND GROW OF SENIOR CITIZENS
}

Autores (por orden de publicación): P. Escuder-Mollon¹, C. Fowley², R. Esteller-Curto ${ }^{3}$

1. Universitat Jaume I, España.

2. Centre for the Innovation and Development of Education and Technology, España .

3. Dublin City University, Irlanda.

Presentado en: INTED2017 11th International Technology, Education and Development Conference, 6-8 de marzo de 2017, Valencia

Publicado en: Published in INTED2017 Proceedings, pages 9541-9545, ISBN: 978-84617-8491-2, ISSN: 2340-1079, doi http://dx.doi.org/10.21125/inted.2017.2253

\begin{abstract}
Senior learners tend to prefer face-to-face learning, as usually among their motivations to learn are not only the interest on the topic, but also the personal relations and sociabilization. That makes the design and offer of on-line learning activities challenging. In this paper, in the frame of the EHHLSA KA2 Erasmus+ project, we focus on leaner evolution, the change produced in their skills and competences. We show in the paper how the senior learners acquire competences not only related to the content of the subject but new ways of communication, collaboration, learning and sharing using the ICT. Their feedback and also the teachers' experience has showed the impact the participation in this kind of education had in their technological attitudes and competences and growing as individuals and as a members of the technological society.
\end{abstract}

Keywords: senior, virtual learning, elderly, pedagogy, gerontology, blended learning. 


\section{$28.1 \quad$ Background}

Virtual environments are being increasingly used, mainly for offering blended courses or completely on-line courses. On-line courses are a big opportunity to reach students that had difficulties of accessing training centres because of distance or time restrictions. Also for institutions, it is a big opportunity, as on-line courses have lower costs, offer cheaper courses and wider the target population. Universities and other educational centres are offering the on-line courses for their formal courses. All this resources represent valuable opportunities to learn on a specific skill or competence. Mostly young adults and adults access those learning platforms, while senior citizens do not use ICT as youngers (at least statistically according to eurostats $95 \%$ for people 25 to $34,70 \%$ for people 55 to $64,49 \%$ for people 65 to 74 [1]).

Based on the analysis performed during the first phase of the EHLSSA project [2], the main reason that senior citizens argue to not access the on-line platforms is because they think that those are too difficult to use, they have not yet found a topic they are interested on or because their motivation are more focused on face-to-face learning environments where there exists a more social contact.

Any of the 3 reasons provided previously by the seniors could be accepted but that does not mean that the gap could not be overcome or at least, solved someway. This is also the purpose of the EHLSSA project and the aim of the Senior Citizens' University, of the Jaume-I University in Castellón.

The EHLSSA is a KA2 Erasmus+ Strategic partnership project (http://ehlssa.odl.org) coordinated by the University of Erlangen Nuremberg, the Institute for Innovation in Learning. This project intends to support and strengthen e-inclusion for seniors by offering new learning opportunities. Either in formal or informal settings, digital competences provide seniors skills that enhance individual empowerment and participation in society. In doing so, the project contributes to active ageing in later life. 3 on-line courses for senior learners are being developed, and also a pedagogical guide to transfer the practises to any institution that aims to create on-line courses focused to senior learners. 
The Senior Citizens' University is the lifelong learning programme of the Jaume-I University, in Castellon. There, 954 students over 55 year old, attend to classes in the city campus and also in the rural areas. The subjects are mainly from the area of humanities, but also other from health, economy, sciences are part of the curricula that try that senior citizens become more adapted and capable in this always changing society. In this context, the main motivation to learn is mainly, personal, joined with the aim to meet other people with the same interest doing something useful and enjoyable. Finally, the senior citizens seemed not to get adapted to technology based learning environments because of technological gap on the adoption internet services and computers tools compared to youngers, affirming that those are difficult to use, and difficult to learn through them.

Because of previous reasons, on-line courses have not been used so extensively on adult learners compared to young adults. Related to the three barriers described before, that is the difficult interface, the offer of adequate courses and fulfil of socialization needs, in this papers we want to focus on the overcome of the third barrier, trying that seniors learners also enjoy learning using on-line platforms in both a formal and informal way, while they socialise.

\subsection{Methodology}

At the end of the courses qualitative research has been done; focus groups to senior in 7 courses, during last 3 academic years. We consider that the use of ICT for senior citizens' learning could be very beneficial as stated before, but it is also very risky, with significant rate of drop-outs but on the other side, students that found this learning experience very pleasurable and enjoyable. This both groups helped us to know firstly to know which were the aspects to correct, provide more support and improve and secondly, to understand better the learner experience and impact

The courses have been:

- Political structure of the ancient Rome

- Local Geographical and natural resources 
- Revolutions, the motor of history (twice)

- Technology and society; recent history, present and future

- Information and communication technologies

- UNESCO heritages

We offered them using moodle. The average number of participants in each course is 39 , and each course lasted 4 months.

As it can be seen, the subjects belong to the humanistic area, and while some of them are referred to past history, the teachers always try to contextualise and link those concepts to the present situation or regional context. The learners attend the courses mainly because of two reasons. The first is because they feel interest on the subject or at least, they think that can be interesting although they could not feel motivated on the topic directly; they know the trainer because of previous courses or they know a classmate that has attended a virtual course before and has explained them the positive experience. It must be pointed out that the topic is not the most important issue when choosing a course, but who is the teacher. The second reason a senior learner chooses a virtual course is because they like to share this virtual space with other learners. Although the senior citizens' target of this educational program are not on danger for exclusion or other social risks, they are active senior citizens, that like to join with others on useful and creative activities. The existence of virtual communities (as can be Facebook) or using computer for communication (as sending e-mails to relatives) is an activity that requires already existing networks and also a reason and purpose. All the learners in the virtual classroom have one common activity that is about learning together a topic, that helps to build a new community.

The participation in the virtual classroom is therefore directed by the interest to learn a new topic and also to share a space with other learners.

The learners have a lot of life experience, and the trainers take advantage of this characteristic; the pedagogy applied for the learning process is mainly the social constructivism. Although the teaching-learning process could be simple, it is important to remark a fact pointed out by all almost all the learners, that is the fact that during the participation in this learning activity, senior learners acquire 3 competences, that represents a triple challenge: 
- The senior learner, as it happens in any ordinary subject, have to learn about the topic that is being taught, it can be historical facts, relations, social aspects, etc. This varies from one subject to other.

- The virtual environment is not simple (we use moodle). The use of forums, shared documents, wikis, blogs, participating in groups, uploading tasks, searching for information and sharing, etc. represents a very complex activity that should be driven to one specific aim. Senior citizens are not so used to the internet tools and services, and when having to use all those together the difficulty appears to be bigger.

- Senior learners are not used to the on-line methodology. It even happened that senior learners were capable to understand the methodology and course process after finishing the course. Somebody could consider this a failure of the trainer, but taking into account complexity of the process, we are sure that this is a completely success.

During the on-line course, we provide learners materials (as PDF, videos, or webpages). During the learning activities, they have to participate in forums, shared pages (as wikis) or posting messages (simple blogs). The forums are a platform for debates, discussion, agreements and conclusions. The wikis is a platform for workgroup, analysis and synthesis. Learners tend to thing on the final result of the activity, as it can be a summary, the most relevant items, or the report after the agreement during discussion. Here the hardest work (for both the trainer and the learner) is to think from the other side; that is from the process. We do not want learners to demonstrate by writing reports they have learnt a lot, we aim that they share and provide new points of view. To communicate using the computer becomes then a triple challenge (as said before): they talk about a topic they are learning about, they use a tool that feel not confident (yet) and we "force" them to reach the knowledge by networking.

At the end of the course, we meet all the participants face-to-face and following a focus group methodology we ask them about the course, how the felt, the experience and the impact. 


\subsection{Results}

As senior learners are not learning because they need an official degree, but to learn because personal interest and motivation, trainers should link the content of the subject for making senior citizens to learn facts, but always from a understanding perspective, that is explaining better the past and the present and to know what is happening the present society. Being critical, but positive, capable to discuss, explain, and adopt new points of view or perspectives are skills promoted during all the courses. It can be said, that the content of the course and the competences related to the topics of the subjects are as important as other transversal skills, related to soft skills: communication, discussion, control, responsibility, creativity, adoption of new opinions and discovery.

The virtual classroom are spaces where learners also tend to share and participate in more informal way, as forums where they can chat about the topics of the classrooms or provide help in case somebody does not know how to use a specific tool. Those spaces resulted in a place where the learner get support from other learners, creating links between learners outside the classroom; it is common to organise a live meeting so learners can meet each other.

All this process can be seen as an evolution of the learner as an individual, citizens of present technological society, getting more skills to be able to deal with present challenges and a so dynamic context. The results obtained from the focus groups can be differentiated in dimensions detailed in Table 1.

Table 1. Focus groups' results summary

\begin{tabular}{|l|l|l|}
\hline Dimension & $\begin{array}{l}\text { Skill, } \\
\text { competence }\end{array}$ & Impact \\
\hline $\begin{array}{l}\text { Personal } \\
\text { relations }\end{array}$ & Communication & $\begin{array}{l}\text { Better writing skills when having to explain } \\
\text { something, ask for help or provide help, mostly } \\
\text { because having to deal with collaborative tasks. }\end{array}$ \\
\hline
\end{tabular}




\begin{tabular}{|c|c|c|}
\hline & & $\begin{array}{l}\text { Because of having to write (blogs, documents, } \\
\text { forums...), increased awareness of the aim and } \\
\text { target. Importance of the media and final } \\
\text { objective. }\end{array}$ \\
\hline Understanding & $\begin{array}{l}\text { Analyse, } \\
\text { abstraction }\end{array}$ & $\begin{array}{l}\text { Capable to skim better the websites, distinguish } \\
\text { the needed information and compare with other } \\
\text { sites. } \\
\text { On teamwork tasks; increase awareness of other } \\
\text { members opinions, suggestions and points of view. } \\
\text { Acquisition of skills for understanding complex } \\
\text { social processes and events, understanding the } \\
\text { process that originated it and the impact it had. }\end{array}$ \\
\hline Creativity & $\begin{array}{l}\text { Problem } \\
\text { solving }\end{array}$ & $\begin{array}{l}\text { Search skills for solutions, sharing proposals and } \\
\text { agreeing about best approach } \\
\text { "Outside box" and open-minded attitude towards } \\
\text { complex problems }\end{array}$ \\
\hline Collaboration & $\begin{array}{l}\text { Leadership, } \\
\text { flexibility, } \\
\text { responsibility }\end{array}$ & $\begin{array}{l}\text { Teamwork and collaboration skills in } \\
\text { asynchronous environments } \\
\text { Acquisition of values as tolerance, empathy, but } \\
\text { also provide and receive critics, defend own } \\
\text { position and valuate own and other proposals. } \\
\text { Capability to organise and lead others and to be } \\
\text { lead by other. } \\
\text { Understanding of the use of the sense of humour, } \\
\text { assertiveness and sincerity as a facilitator during } \\
\text { the collaborative process }\end{array}$ \\
\hline
\end{tabular}




\begin{tabular}{|l|l|l|}
\hline Planification & $\begin{array}{l}\text { Control, } \\
\text { autonomy, self } \\
\text { improvement }\end{array}$ & $\begin{array}{l}\text { Required organisation of tasks and duties. } \\
\text { Breakdown of a plan in smaller pieces for its } \\
\text { completion. } \\
\text { Increased skills for facing challenges under a } \\
\text { positive perspective } \\
\text { Intelligence for self-reflection and own-aims } \\
\text { construction. }\end{array}$ \\
\hline
\end{tabular}

All the learners participated in these courses were adults (over 55 years old), so they were already aware of Table 1 skills, competences and values, they had a lot of life experience for dealing with collaborative tasks, challenging problems or trying to understand a complex scenario, still, participants showed the significance and the impact the courses had in their own life attitudes based in following factors:

- All the activities were computer-mediated, that required an extra effort for all the learners, so they had to learn the subject, learn to use the tool (Moodle, blogs, wikis, forums, Google docs...) and finally, learning how to collaborate, organise and communicate with each other. This last requirement has been the most difficult and it is a complex task and that required high cognitive skills. These course allowed learners to apply skills and competences they had (because of life experiences) in a new media that not only had its own rules, it was also different from they had previous know (being a global and rich media)

- Participants accepted the fat hat getting older requires a continuous learning and an adaptation. The fact that some of the tasks required and extra effort could be related that the skills, values and attitudes involved in the activity needed to be consolidated and integrated in the learner backpack.

- The increased awareness of the complexity and potentiality of technology, the Internet and the media allowed learners to acquire new points of view, perspectives and uses towards tools and services that are appearing on the 
internet, as it can be social networks, communities, apps for the smartphones and tablets, etc.

\subsection{Aknowledments}

Part of this work has been produced in the framework of the project "European Home Learning Service for Seniors Association". This project has been funded with support from the European Commission. This communication reflects the views only of the author, and the Commission cannot be held responsible for any use which may be made of the information contained therein. Project reference: 2014-1-DE02-KA204001664, website: http://ehlssa.odl.org

\subsection{References}

[1] Eurostats (2016). Internet use in last 3 months EU27

[2] EHLSSA. European Home Learning Service for Seniors Association. http://ehlssa.odl.org

[3] Petter, C., \& Helling, K. Designing ICT-based Learning Scenarios for Special Target Groups-Meeting Senior Learner Needs.

[4] Ala-Mutka, K. \& Punie, Y. (2007). Ageing Societies, Learning and ICT. eLearningpapers, 6.Retrieved, August, 18, 2008 http://publications.jrc.ec.europa.eu/repository/handle/JRC41179

[5] Escuder-Mollon, P., \& Esteller-Curto, R. (2013) Seniors in the Knowledge Society: context, practises and innovation.

[6] Esteller-Curto, R., Escuder-Mollon, P., \& Marin, P. (2012, July). The Virtuous Circle of Use, Attitude, Experience and Digital Inclusion. eLearning Papers, (29). Retrieved from http://www.openeducationeuropa.eu/en/article/The-VirtuousCircle-of-Use\%2C-Attitude\%2C-Experience-and-Digital-Inclusion 


\title{
29 THE USE OF COMMUNITIES OF PRACTISE
} TO CRÉATE STORIES FOR SERIOUS GAMES - EXPERIENCES OF THE EUROPEAN ROJECT E-VITA

Autores (por orden de publicación): P. Escuder ${ }^{1}$, R. Esteller ${ }^{1}$, J.Segura ${ }^{1}$

1. Universitat Jaume I, España.

Presentado en: EDEN 2010 "European Distance and E-Learning NetworkE" 9-12 de junio de 2010, proceedings publicados EDEN 2010 ISBN 978-963-06-9429-2

\begin{abstract}
Serious Games used as pedagogical took offer great possibilities for learning mostly because they have the potentiality to catch the attention of the player and to transmit knowledge in a non-formal way. The Serious Games also allow the transmission of information or abilities that it would be not possible to do in ordinary teaching methods. In the e-Vita project, it was intended to teach cultural and historical facts about Europe but also to transmit feelings or experiences as if the player was living in a former Europe. The challenge here was about how and where stories and feelings are going to be extracted from, and also the best methodological way to allow that transmission to teenagers. This article focus on the first challenge; the senior citizens had to group in communities of practice to be able to collect stories that later had to be incorporated to the games. This process is explained in the article, but also the challenges, problems and solutions found and the impact in seniors that played the game.
\end{abstract}

Keywords: communities of practice, intergenerational learning, serious games, 


\section{$29.1 \quad$ Context}

The e-Vita European cooperation project ("European life experiences") has been supported by the Lifelong Learning Programme of the European Union. In this project, 7 institutions worked together to create a methodological and pedagogical guide on which a Serious Games (SG) can be produced with the aim of enabling a transfer of experiences: when a person plays, you can learn not only historical events, but also live and feel as far as possible experiences. Thus, this educational game facilitates learning past events and other content in order to better understand the present.

Thanks to the capabilities of education of SG, it makes possible an easier transfer of feelings and emotions that may not be achieved by theoretical explanations; the learners are who are learning through experiencing. As the player is really involved in a situation, it makes possible that he/she learns and create the knowledge.

In this project, the script of the play has been produced through Communities of Practise (CP); groups of senior citizens that have lived a transnational and intercultural experience. In this paper we will show the methodology used and the challenges it has faced and solutions found in the process of knowledge construction by communities of practice.

The Universitat Jaume I, in its educational program for adults: Universitat per a majors (Senior Citizens' University - SCU), participated in this project as a partner in various stages, some of them in the creation of stories and another in the production of the scripts for the games.

The SCU is an educational project offered to senior citizens. Senior citizens can attend to the classes that are offered (mainly history, psychology, philosophy, economics, new technologies, languages, etc.), but the SCU also pursues an integrated socioeducational intervention of the elderly (favoring integration, inclusion, critical spirit, participation, etc.) The active participation the elderly is an activity greatly encouraged (e.g. through a wiki, blogs, intergenerational projects, research projects, etc.) It is in this context where CP are created in order to produce the games. 
Information about the e-Vita and methodological proposal is available on the project website (http://www.evitaproject.eu). In this paper we will instead offer the view from the institution creating the $\mathrm{CP}$ and producing the stories, to be later to be transformed into scripts for the games.

\subsection{Communities of Practise}

In the e-Vita project, and any other institution that wants to build a SG based on historical or experiences, will need to first consider the creation of the script (storyboard) that will constitute the base for the SG. This script has to be true to historical reality, for that reason you must use reliable historical references and situations, the experiences must be obtained from the very same people who lived them.

CP are the perfect backdrop for generating this knowledge and experimental living: older people can join in informal groups and so can produce knowledge. However, the creation of these groups and content creation is not easy. In this paper we will explain this process from our own experience.

CP at the SCU, were created in October 2009. A group of 8 people gathered in 4 sessions. The selection of members and the invitation was made knowing in advance the potential of people and their ability to form a group. This community of practice was led by a facilitator who guided the group.

Selection and invitation of the components
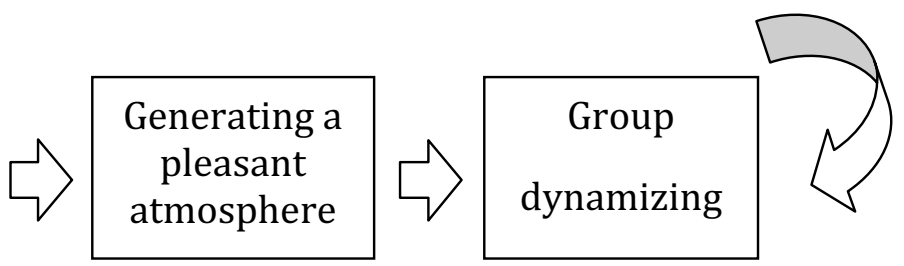

Figure 1. First steps in building the community of practice 
In the first session was very important to introduce the usefulness of what was going to be done and the context. It was also necessary to explain clearly that it was going to be applied a strict confidentiality. It was important that the group was comfortable and free to express their personal experiences with no strings attached. It is also important to highlight that the need was not the collection of important stories or historical facts, but anecdotes, oddities, problems, etc. they had, many of the students thought their story was not worth telling. Students had the life experience and sufficient knowledge, it was only necessary to produce a dynamic action to make it produce the stories.

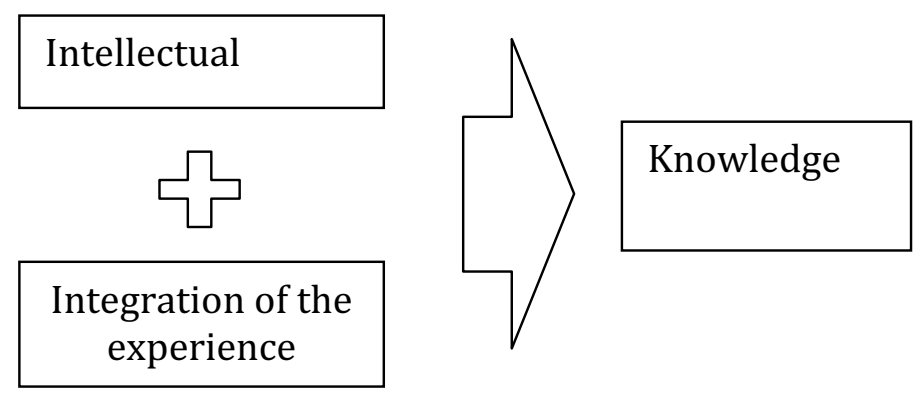

Figure 2. Ingredients for the creation of stories

The serious game would be developed by placing the player in a position where they should react in order to achieve a goal (e.g. collect information from Eastern Germany behind Berlin Wall as a journalist or get a decent job in the context of being an immigrant). To implement this game it is necessary to collect various facts, detailed on in a place and time, which would be contextualized in a historical moment and will be presented to the player in the form of challenge. The player must choose between different options, and the story would develop according to their decisions (branching story) 
The experiences, however, tended to be global and linear, highlighting the main events, but sometimes ignoring the anecdotes. Besides the stories were very different (e.g. each senior stood in a country) and therefore his/her story could not be joined for a game.

The role of facilitator and researcher in the CP was very important, always allowing a balance: not to hinder the explanations of the seniors, but also trying to ask and intervene without feeling seniors to be questioned making possible by this way to lead their experiences to what it was intended to achieve depending on the game: small but vital situations that represent the challenge that could take the form of the game.

During each of the sessions conducted another iteration of the production process started, trying not only to continue explaining the greatest stories but also small anecdotes. In this process, the creation of stories as a group providing feedback and confidence was growing.

\subsection{Production of games and learning}

Figure 3 shows the 3 basic ingredients to build a script for a SG. The creation of the story (or tales) should be reconstructed as the ultimate goal: to design a script that will be used to produce the game. This process is not immediate or easy, and also involved educational requirements and the type of game that will be implemented. 


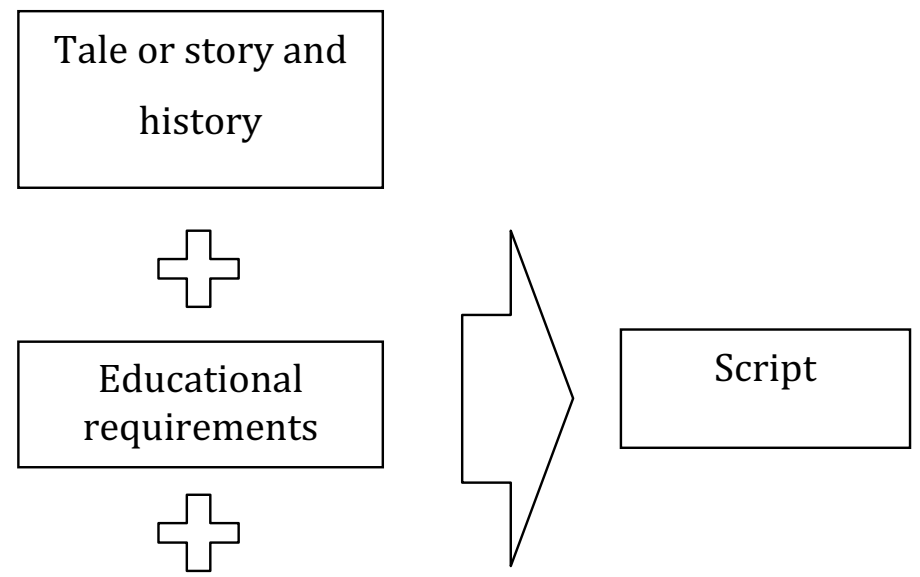

Game Type

Figure 3. Process of creating the game script

During the development of this methodology we found the following difficulties and possible solutions:

- With the aim to test several approaches and types of games, 4 types of games were produced, not all about the same theme: each one experiences of the Eastern bloc, migration, tourism and leisure

○ Experimental: the player assumes the role of a person; you are presented with different situations where you must choose what to do. The following events will depend on your choice. The storyline chose for this kind of game was the Eastern/Wester bloc

○ Question-answer: the player must choose the most appropriate response to a situation. The storyline was about migration

○ Narrative. The player will read a story. The story line was about tourism and leisure.

○ Exploratory. The player must find the solution through other sources. The storyline was about cultural facts.

It does not matter how much the CP facilitator tries to guide the type of story to each of the 4 types of previous games. Seniors are more focused on explaining their history 
than worrying about what kind of stories are needed. The facilitator must not force or require a type of experiences, and should give freedom to the $\mathrm{CP}$ to express themselves. To achieve a sufficient number of stories or scenarios to implement a game it is necessary a very large number of stories, in fact, stories are shared among all project partners.

- The e-Vita states that games must not only teach European history or geography, is also intended produce an impact in the player. The game is an educational tool to be used for the player that will be placed on the skin of another person and thus, experience the feelings, experiences, etc. that has experimented the senior. Of course, complete immersion is impossible, but it is necessary to tray to maximize it. The pedagogical framework indicates what should be taught without forgetting that if the player is not enjoying the game it could lose all effectiveness.

- Another difficulty is to try to make linear storylines in non-linear stories. Scenarios must be considered such as "what if ..." because the player could not make the same decision as the senior, it is necessary to provide feedback to the player about a decision (rightly or not) taken. In these cases, it would be necessary to build communities of practice and these alternative scenarios. 


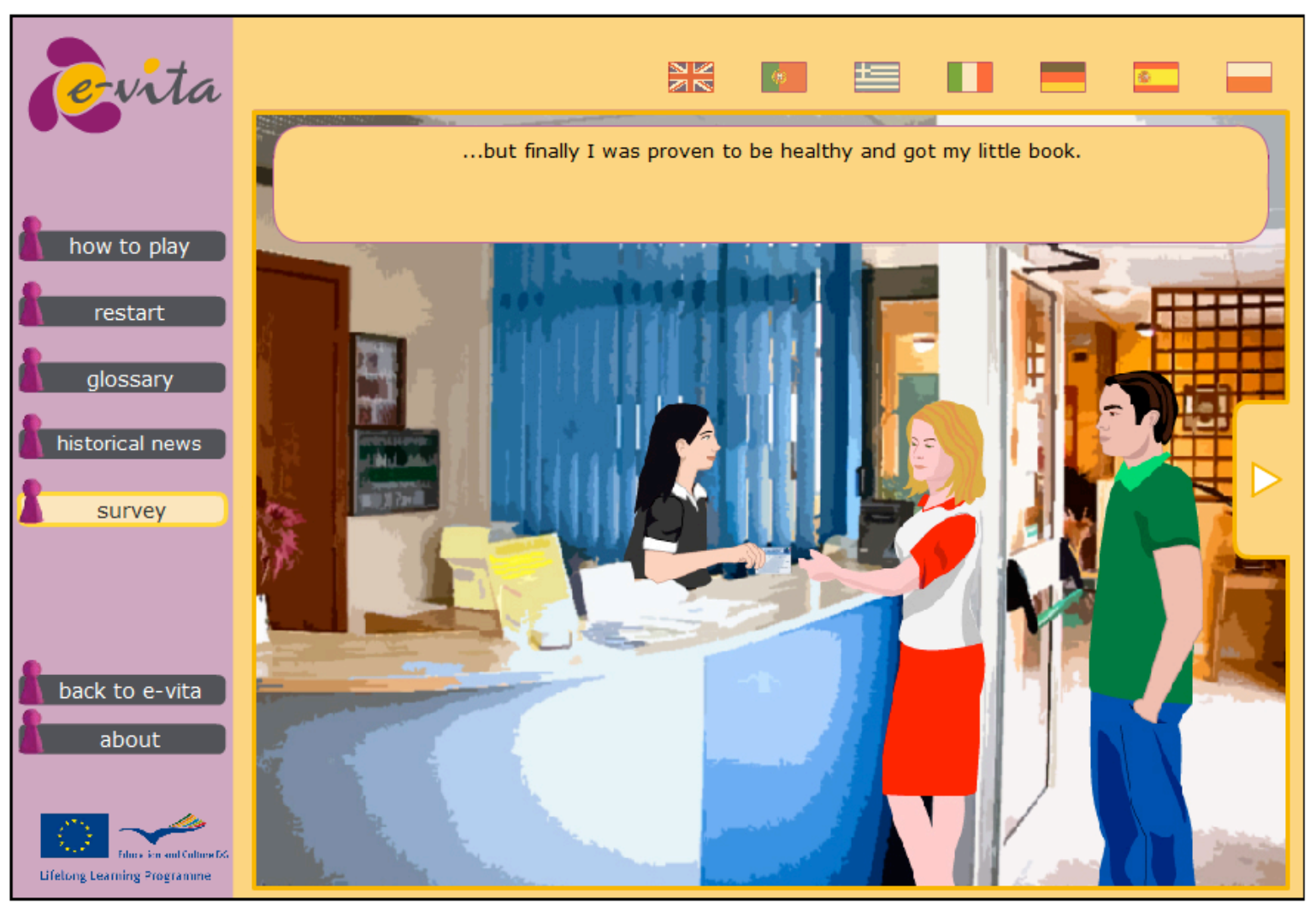

Figure 4. Screenshot of the game. Games available at htt://www.evitaproject.eu "e-Vita Serious Games"

\section{$29.4 \quad$ Results}

4 games were produced, and summarized in the Table 1

Table 1. Summary of the games produced

\begin{tabular}{|l|l|l|}
\hline Type & Description & Situation \\
\hline Experimental & $\begin{array}{l}\text { Branching story Your } \\
\text { decisions will help the }\end{array}$ & $\begin{array}{l}\text { You are a reporter before the } \\
\text { Iron curtain has fallen, you }\end{array}$ \\
& $\begin{array}{l}\text { (you win) or to go to prison } \\
\text { (you find information }\end{array}$ & \\
\hline
\end{tabular}




\begin{tabular}{|c|c|c|}
\hline & (you lose) & \\
\hline Question-answer & $\begin{array}{l}\text { There is a story of a person } \\
\text { going abroad to travel. There } \\
\text { are situations where you have } \\
\text { to choose among several } \\
\text { options. Depending on your } \\
\text { election you get more } \\
\text { integrated and get a good job. }\end{array}$ & $\begin{array}{l}\text { You are an immigrant that has } \\
\text { to go to other country, it is } \\
\text { important to adapt to other } \\
\text { place, culture and people }\end{array}$ \\
\hline Narrative & $\begin{array}{l}\text { The elderly explains you a } \\
\text { story. You can interrupt } \\
\text { him/her to ask some } \\
\text { questions. At the end, you have } \\
\text { to guess something (the place, } \\
\text { the time, the event...) }\end{array}$ & $\begin{array}{l}\text { You find a elderly that } \\
\text { explains you some story about } \\
\text { the past, when he/she } \\
\text { traveled to other country for } \\
\text { leisure or tourist reasons }\end{array}$ \\
\hline Exploratory & $\begin{array}{l}\text { You have to answer some } \\
\text { questions related to historical } \\
\text { or cultural facts. You have to } \\
\text { find the correct answer } \\
\text { looking for other sources (e.g. } \\
\text { Internet) }\end{array}$ & $\begin{array}{l}\text { You have to do some } \\
\text { homework from your school; } \\
\text { you have to find some } \\
\text { information. }\end{array}$ \\
\hline
\end{tabular}

The most difficult aims to reach in those games was to get a balance between the pedagogic restrictions of the type of the game, to be realistic to the story and history and also to find some kind of method to score the player and therefore to motivate the player to keep playing.

In October 2010 the project ended. The 4 prototypes are now available at http://www.evitaproject.eu, in the "e-Vita Serious Games" section. 
In October 201098 people participated in a intergenerational activity between seniors and children: 50 people were students of the senior's program, while 48 children and adolescents played serious games. The age of the players were between 10 and 15 years old, although some of them were under 10.

The assessment about older participants/players was extracted from discussions with them when finalized the process of play and learning. The total scores are positive but are diversify in each person depending about the life situation as they passed by. Many seniors did not pass through similar situations ever, while some of them had the opportunity to travel around Europe of the Cold War for several reasons. Some of these reasons are overseas business trips, tourist trips or traveled minority studies.

The age of the various participants over was less than fifty years, this information indicates that all the people who lived intensely now evaluate the historical period and possibly the games also evoke situations that are explained to them. For many of the greatest stories told in this game are highly emotional because of the memories of past experiences that come to mind them and in some cases come to identify with the protagonists of the game.

Regarding to children is necessary to be differentiating by age. The games are hardly intelligible to children aged between five and thirteen years, most children involved in intergenerational workshops are at this stage of childhood. In these early days of their schooling and at this stage the games are far from their tastes. Otherwise, in this age many participants are starting on the concepts developed in the game and still not know the historical processes that occurred in the second half of the twentieth century. Participants aged between fourteen and eighteen years, who were a minority, know more fully these issues by being in the secondary education period in which addresses these issues and concepts.

These students has more developed their intellectual skills and the topics about the games are more focused on teaching study skills in secondary schools. 


\subsection{Summary}

The co-operation project e-VITA ("European life experiences") is framed within the Lifelong Learning Program of the European Commission. In this project, 7 institutions propose to create a methodological and pedagogical guide that can be used to produce Serious Games with the aim to allow a transfer of experiences; when people (mainly children) play can learn not only historical facts, but also experiences and feel livings as much as possible. By this way, through this educational game, learning of the past or others contents are possible with the aim also to understand better the present.

In this project, the story of the games has been produced through the communities of practices built by seniors that had lived a transnational or intercultural experience. In this communication, we want to show the methodology used, and also the challenges that had to be faced and the solutions found in the process of construction of knowledge by the communities of practice.

In the e-Vita Project, and for any other institution than wants to build a historical or living-experience game, it is need the construction of the script of the game (storyboard). This script has to be faithful to the history. Because of that reason, we have to consider reliable historical references and also choose situations and experiences obtained from the very same people that lived them.

The communities of practice are the perfect context to generate this lived or experiential knowledge: the elderly can take part in groups and in an informal way they can generate knowledge. However, the creation of this groups and the creation of content is not easy. In this communication we want to explain this process based on the own experience; the creation of the group, environment and facilitator.

The stories must be reconstructed and mixed based on the final aim: to develop a storyboard that will be used to implement the game. This process is neither 
immediate nor easy, because it is influenced by the pedagogic requirements and the type of the game that will be produced.

During the development of this methodology the difficulties and possible solutions are presented, depending on the type of game (experiential, narrative-based, problem-based, exploratory) the main aims of the game (living experience of a past Europe) and other difficulties transforming the story (usually lineal) to a funny game that get the player caught.

\subsection{Bibliography}

1. Dunwed, I., et.al. 2009. E-VITA Methodology and Pedagogical concept, available in http://www.evitaproject.eu/images/documents/E-VITA-D2.1-V2.3Pedagogical_Concept.pdf

2. E-VITA. Http://www.evitaproject.eu

3. Hetzner, S., et.al. 2009. Storyboard Development Guidelines, available in http://www.evitaproject.eu/images/documents/e-vita-d2.2-v1.7storyboarddevguidelines.pdf

4. Hetzner, S.; Pannese, L. (2009). E-Vita, life simulations in an intergenerational setting in Journal of e-Learning and Knowledge Society, Vol 5, No 2, June 2009 (pp.59-65) 
SECCION QUINTA; CALIDAD DE VIDA 


\section{QUALITY OF LIFE}

Autores (por orden de publicación): P. Escuder-Mollon

Capítulo parte del libro Education and quality of life of senior citizens. Publicacions de la Universitat Jaume I. Enero 2015, ISBN: 978-84-8021-986-0, ISBN (digital): 978-84697-0109-6. University of Helsinky, enero 2015, ISBN: 978-952-10-7760-9, ISBN (digital): 978-952-10-7761-6

Traducido al español, rumano, polaco, finlandes y letón

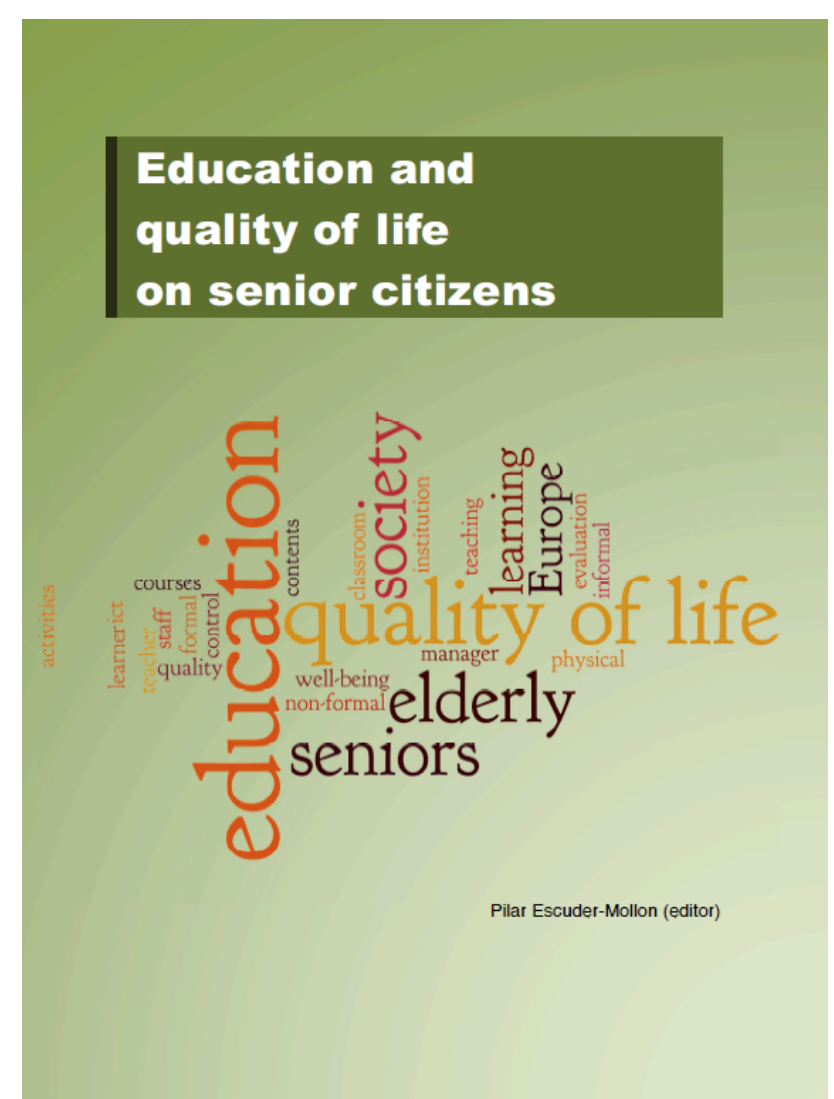

Este capítulo es el primero del libro "Education and quality of life on senior citizens" 


\subsection{Introduction}

Quality of Life (henceforth QoL) is an abstract concept that everybody can work out the meaning of, but which is difficult to define accurately. People usually associate QoL with well-being, a good life, being healthy, happy or having plenty of money. In that sense, it is easily associated with the idea that increasing QoL is a good thing for an individual and for society in general. In modern societies, where the well-being of citizens is a priority, decision makers frequently try to raise our QoL.

It is a widely known term, used not only by governments, psychologists, doctors and sociologists, but also by individuals pursuing the well-being of their families. Despite the use we make of the QoL concept, it is not something we usually think too much about. It is difficult to explain in detail the concept, how it is influenced by personal and external sources and how we or other actors can try to increase it. Curiously enough, evaluating QoL seems easier than defining it - at least this is what can be observed from the established evaluation models available and accepted by the academic community.

This chapter aims to clarify the concept of QoL, starting from a general perspective and then focusing on education and on the elderly. There is no single theory of QoL; each theory considers QoL from different perspectives and also attaches more importance to different life dimensions. In recent years, QoL theories have evolved to embrace what seem to be more psychological and less materialistic considerations, but still considering different dimensions of life. We should not think that these theories are contradictory, nor that they reveal a situation of chaos surrounding QoL. The theories and models of QoL should be taken as tools that will give us a better understanding of social reality, crucial for every human being.

We are sure that what you consider important in life and for your QoL is different from your neighbour's considerations, and from younger or older people living in a different towns or cities. There is no single concept of what QoL is. There are as many 
meanings as people you ask about it. For this reason QoL theories should be considered as a great opportunity to better understand the different meanings of QoL, why it declines and how you can work to increase it for other people.

This chapter will provide the necessary background to best apply the potentialities of education to senior citizens' needs. The final target of the educational intervention in the context of this project is to increase QoL, but some of the QoL dimensions cannot be affected by education, while other dimensions, if the educational intervention is correctly designed, can be greatly improved. It is necessary to know what these dimensions are, to understand them well, and then to know how they can be influenced.

\subsection{Understanding Quality of Life}

Researchers in the areas of sociology, psychology, medicine and philosophy have proposed theories about QoL depending on their point of view, area of research and point in time. The first philosophers in Greece thought much more about happiness and the good life than about QoL; the main purpose of human existence was to fulfil human appetites, a hedonic tradition that was first centred in the body but later also in the mind (Chung et al. 1997, Kubovy 1999). Aristotle believed that true happiness occurs based on what people do (activities) and what people believe (values). This was the eudaimonic perspective (daimon = true nature) that challenged the previous hedonic (pleasure or wish focused) tradition.

Modern QoL theories were steered by health studies, in attempts to argue how treatments and interventions could not directly improve patients' health, but rather their QoL. These actions were aimed to reduce symptoms, to make the patient's life less miserable or reduce unhappiness. This direct target of trying to increase QoL by reducing or removing pain or other problems contrasts with the most recent theories that propose acting to increase QoL through measures that make citizens happier, with greater support and security, for example, in case of governments promoting social services, healthy habits, communication, etc. 
Recent QoL research has placed greater weight on citizens' subjective perception as opposed to objective considerations of their lives. The first intuitive idea is to say that money makes people happier, ergo rich people have a higher QoL. To be healthy can be considered an important determinant for QoL. Of course, health and money do not bring happiness. Beyond a certain income needed to cover the average needs for a given society, money is not correlated to happiness (Myers 2000, pp. 54-60). Other studies found that the more people focus on economic and materialistic issues, the lower their well-being will be (Ryan \& Deci 2001). The important issue here is to be aware of 'average needs', which is a socially determined measure. Below that threshold (poverty) money and well-being are highly correlated.

Thus, when our lifestyle is not challenged by health and money issues, the subjective perception of our life becomes the most important criterion to understand and evaluate QoL. In this chapter we introduce dimensions, facets, components and indicators that are related to QoL, but focusing on the elderly (not disabled or challenged) and on education. The final section of this chapter suggests further reading on general concepts of QoL.

\subsection{Definition}

To find a single and commonly accepted definition of 'Quality of Life' is no easy task; there are as many definitions as there are theories and QoL models. Moreover, everybody has their own view on this subject. Here we offer a starting point that introduces three of the most accepted definitions of QoL.

The World Health Organisation QoL Group (WHO 1997) defines Quality of Life as "individuals' perception of their position in life in the context of the culture and value systems in which they live and in relation to their goals, expectations, standards and concerns". Dimensions can be seen in Table 3.

Research by Schalock (2000) centres more on health issues or disabilities. His definition is as follows: "Quality of life is a concept that reflects a person's desired conditions of living related to eight core dimensions of one's life: emotional well- 
being, interpersonal relationships, material well-being, personal development, physical well-being, self-determination, social inclusion, and rights." Dimensions are detailed in Table 2.

Cummins (1997) proposes a model to suit any population:

Quality of life is both objective and subjective, each axis being the aggregate of seven domains: material well-being, health, productivity, intimacy, safety, community, and emotional well-being. Objective domains comprise culturally-relevant measures of objective well-being. Subjective domains comprise domain satisfaction weighted by their importance to the individual

From the WHO definition, we can deduce that the concept of QoL must be understood in relation to the community where the individual lives, which has a major cultural significance. QoL is also very subjective: it is a 'perception'. Other definitions, such as Schalock's, attempt to define QoL by enumerating its component parts. These dimensions are very useful not only for evaluation purposes, but also in deconstructing QoL to later focus on increasing each specific dimension. However, it is difficult to precisely establish the dimensions, as each theory proposes its own set of QoL dimensions. In the second definition, Schalock puts forward eight dimensions (detailed in Table 2). Fortunately, most of these dimensions are common to all definitions. In his definition, Cummins emphasises the importance of the subjective factor, and evaluates both the subjective and the objective factors.

\subsubsection{BASIC NEEDS}

A person's QoL may be, for example, low, medium or high. Some QoL evaluation tools give a numerical score for QoL. Maslow's hierarchy of needs (Maslow \& Cox 1987) (Figure 1) includes certain basic living conditions (survival conditions) that should be covered initially before higher QoL levels can be reached. From this perspective, a person's QoL level can be associated with his or her met needs according to Maslow's hierarchy of needs. Conditions of great poverty, ill health or discrimination correlate with a very low QoL. People need the basic resources (income, house, security) in order to think about meeting other needs and increasing their QoL. 


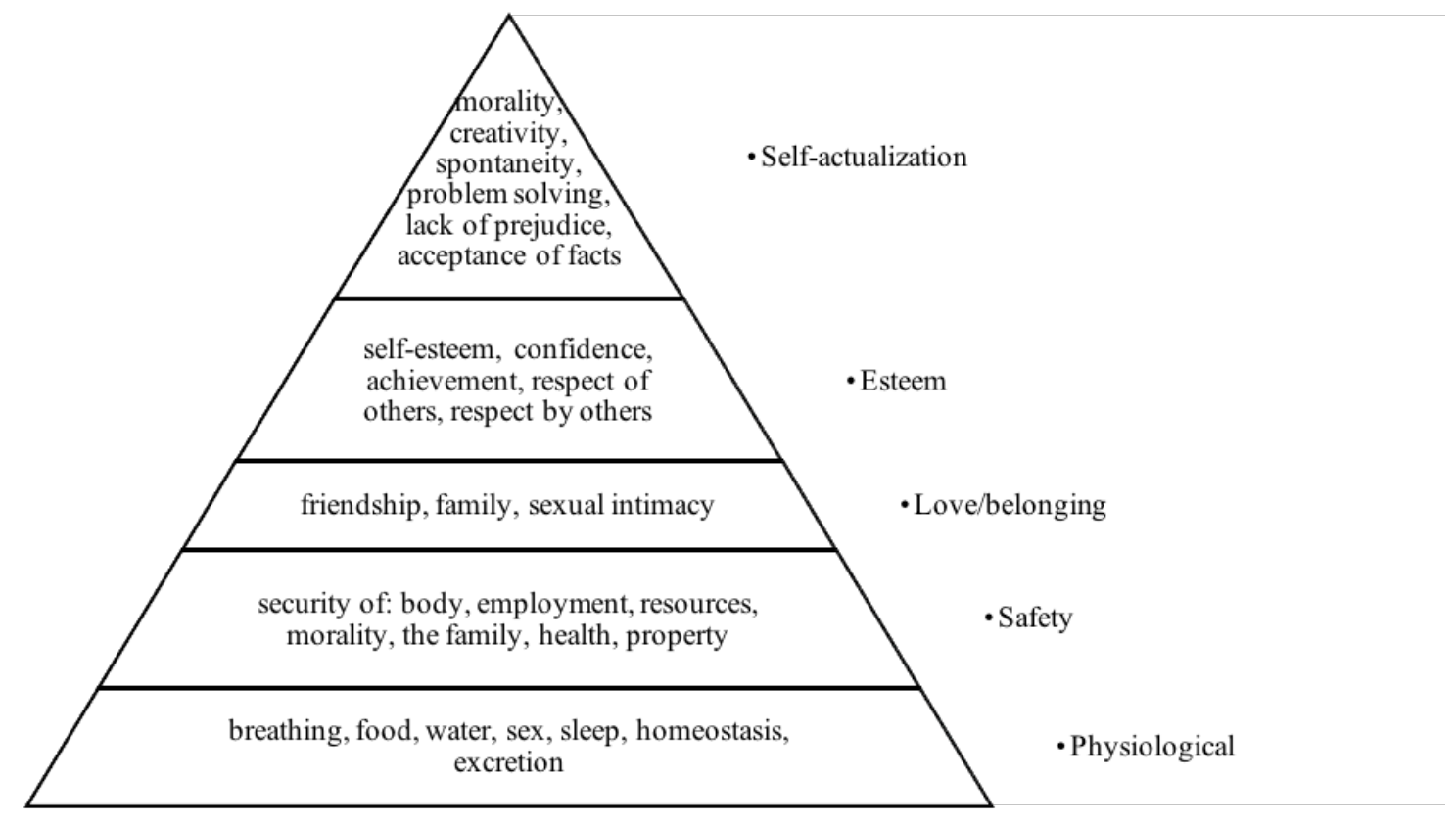

Figure 1. Maslow's hierarchy of needs

It is not aim of this chapter to focus on the unfulfilled basic needs that jeopardise QoL, which would not be met through educational actions, but through social and health services and supporting policies. When people have enough income, housing, security, reasonable health, transport and basic social support, then we can start to deliberate on ways of increasing their QoL, and how that increase can be beneficial not only for them, but for society in general.

Considering how we can increase QoL is only the first part of our target. We should consider the risks that can jeopardize QoL. In the case of the elderly, we must have a thorough knowledge of their social conditions, the psychological process of ageing and the changes and challenges getting older brings. Although those concepts are detailed in following chapters, here, as we start to break QoL down into its component parts, we will focus on any possible requirements that the elderly might have. 


\subsubsection{SUBJECTIVE AND OBJECTIVE}

Generally speaking, theories of QoL coincide that it has a subjective and an objective dimension; however theories focusing on ordinary citizens living in modern societies (not in the third world or in poverty) attribute more weight to subjective aspects.

We might assume that physical health and money have a major impact on QoL, at least intuitively, reflected as a general opinion in surveys that found that "more money would make me happier" (Myers 2000, Campbell 1981). But when comparing nations with different levels of average wealth or comparing people with different levels of material possessions, the correlation with well-being disappeared (Myers 2000). Happiness is not so dependent on external factors and sometimes it shows an inverse relationship: too many possessions decrease happiness (Ryan \& Deci 2001).

As mentioned above, the WHO and the Cummins models place a great deal of emphasis on the subjective factor, as seen in their evaluation tools. The WHO introduces two interesting concepts in its definition: "the perception of the individual" and also "the context of the culture and value systems in which they live". Any assessment of QoL should therefore take into account where people live and their perceptions. In fact, in the abbreviated WHO evaluation tool (WHOQOL-BREF), more than half of the questions are subjective: "How satisfied are you....?" as compared to other more objective ones such as "How much do you need any medical treatment to function in your daily life?"

In Cummin's evaluation tool, all the objective indicators are balanced by a measure of "How important is...?" "How satisfied are you ...?", so a person may have a good income and material well-being, but feels unfortunate. In fact Cummins (in Rapley 2003) states that when basic needs are covered, most people fall into the $70 \%-80 \%$ life satisfaction range; no higher life satisfaction has been reported from studies comparing groups of people with different health or income levels. 


\subsubsection{ADAPTING TO CHANGES}

No one is born old. By definition everyone who reaches old age has a past, a life experience. The ageing process can be understood as normal ageing (average, standard, normative ageing), while successful ageing, generally less common, is ageing with the absence of any disease or illness. This perspective has, unsurprisingly, generated controversy (Schulz \& Heckhausen 1996). The renewed idea of successful ageing is based on developmental phenomena. Older people are confronted with physical, psychological, and social changes that increase their exposure to uncontrollable situations. How we face these changing situations will increase or decrease our subjective perception of QoL. Tools to manage these situations are therefore required, namely primary control and secondary control.

Primary control allows us to change and adapt the environment to ourselves; secondary control is applied when we adapt ourselves to the environment. In younger people or adults, primary control is the most widely applied, while among the elderly, secondary control is more commonly applied in an attempt to retain control (Maher 1999).

Cummins (2000) identifies some "cognitive protective factors", namely self-esteem, perceived control and optimism, that act as buffers to ameliorate the impact of threats from changing life circumstances and make QoL homeostatic (self-regulated and usually at a high level). When negative life events have to be endured, they can be accepted as evidence of a complete loss of control. According to Rapley (2003 p. 206) any aversive extrinsic condition compromises how the person adapts to the environment and then, if the buffer is insufficient, the person perceives unmet needs which brings QoL to below the standard range. This is illustrated in. Figure 2. 


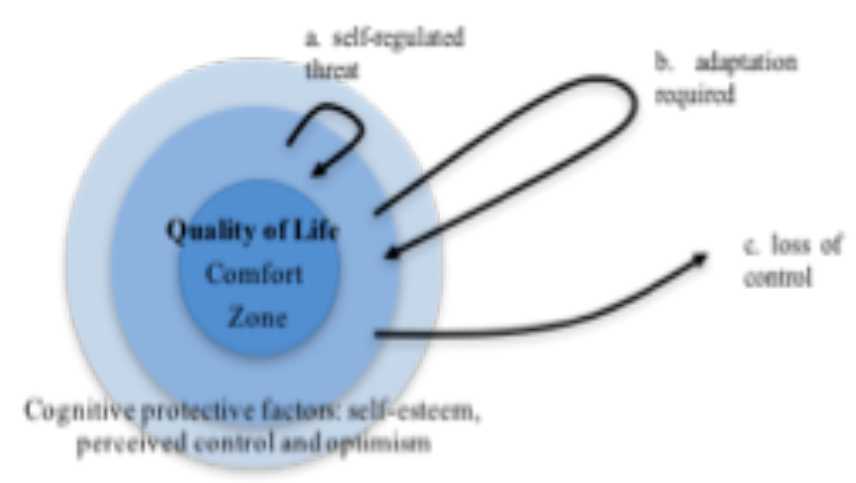

Figure 2. In ordinary situations a person has a high quality of life (darker circles). Threats require adaptation, different situations can arise $(a, b, c)$ depending one cognitive protective factors (Rapley 2003)

\subsection{QoL dimensions}

When defining QoL most authors attempt to break it down into dimensions that can help us to understand it better and also identify the factors we should act on to increase it.

Schalock and Verdugo (2002) affirm that the QoL concept reflects the life conditions desired by an individual related to eight needs or domains, detailed in Table 2 . Schalock (Schalock 2011) also believes that

[...] the best definition of [individual] quality of life is a multidimensional phenomenon composed of core domains influenced by personal characteristics and environmental factors. These core domains are the same for all people, although they may vary individually in relative value and importance. In this regard, the assessment of quality of life domains is based on culturally sensitive indicators 
Table 2. Quality of life dimensions according to Schalock and Verdugo 2002.

\begin{tabular}{|c|c|}
\hline Factors & Domains \\
\hline Independence & $\begin{array}{l}\text { - Personal development } \\
\text { - Self-determination }\end{array}$ \\
\hline Social participation & $\begin{array}{l}\text { - Interpersonal relations } \\
\text { - Social inclusion } \\
\text { - Rights }\end{array}$ \\
\hline Well-being & $\begin{array}{l}\text { - Emotional well-being } \\
\text { - Physical well-being } \\
\text { - Material well-being }\end{array}$ \\
\hline
\end{tabular}

The World Health Organisation's (WHO) proposal to measure quality of life justifies the evaluation procedure based on the division of QoL into 24 facets in 6 domains.

Table 3. WHO Domains and Facets for measuring QoL (WHO 1997)

\begin{tabular}{|l|l|}
\hline Domain & Facets incorporated within domains \\
\hline 1. Physical health & $\begin{array}{l}\text { 1.1. Energy and fatigue } \\
\text { 1.2. Pain and discomfort } \\
\text { 1.3. Sleep and rest }\end{array}$ \\
\hline 2. Psychological & $\begin{array}{l}\text { 2.1. Bodily image and appearance } \\
\text { 2.2. Negative feelings } \\
\text { 2.3. Positive feelings } \\
\text { 2.4. Self-esteem } \\
2.5 . \text { Thinking, learning, memory and } \\
\text { concentration }\end{array}$ \\
\hline 3. & $\begin{array}{l}\text { 3.1. Mobility } \\
\text { 3.2. Activities of daily living }\end{array}$ \\
\hline Independence &
\end{tabular}




\begin{tabular}{|c|c|}
\hline & $\begin{array}{l}\text { 3.3. Dependence on medicinal substances and } \\
\text { medical aids } \\
\text { 3.4. Work Capacity }\end{array}$ \\
\hline $\begin{array}{l}4 . \\
\text { relationships }\end{array}$ & $\begin{array}{l}\text { 4.1. Personal relationships } \\
\text { 4.2. Social support } \\
\text { 4.3. Sexual activity }\end{array}$ \\
\hline 5. Environment & $\begin{array}{l}\text { 5.1. Financial resources } \\
\text { 5.2. Freedom, physical safety and security } \\
\text { 5.3 Health and social care: accessibility and } \\
\text { quality } \\
\text { 5.4. Home environment } \\
\text { 5.5. Opportunities for acquiring new } \\
\text { information and skills } \\
\text { 5.6. Participation in and opportunities for } \\
\text { recreation/leisure } \\
\text { 5.7. Physical environment (pollution/noise/ } \\
\text { traffic/climate) } \\
\text { 5.8. Transport }\end{array}$ \\
\hline $\begin{array}{l}\text { 6. Spirituality / } \\
\text { Religion / Personal } \\
\text { beliefs }\end{array}$ & 6.1. Religion /Spirituality/Personal beliefs \\
\hline
\end{tabular}

Table 3 details the 6 domains and 24 facets that the WHO considered to measure QoL with the WHOQOL-100 evaluation tool. Later research suggested merging 6 dimensions into 4: physical, psychological, social relationships and environment (WHOQL-BREF).

Table 4 shows the main domains following Cummins (1997); each domain has three objective and two subjective measures, which when aggregated, provide a unitary measure of well-being. It has been proven to be a reliable and repeatable test (Rapley 2003, p. 94-95) designed for the adult population in general. 
Table 4. Domains of the Comprehensive

Quality of Life scale - Adult (Cummins 1997).

\begin{tabular}{|l|l|}
\hline Domain & Facets \\
\hline 1. Material well-being & Accommodation, possessions, estimated income \\
\hline 2. Health & $\begin{array}{l}\text { Visits to doctor, disabilities or medical condition, } \\
\text { medication }\end{array}$ \\
\hline 3. Productivity & Work time, spare time, TV hours \\
\hline 4. Intimacy & Talk, care, activity \\
\hline 5. Safety & Sleep, home, anxiety \\
\hline 6. Place in community & Activity, responsibility, advice \\
\hline 7. Emotional well-being & Can do, bed, wishes \\
\hline
\end{tabular}

\subsection{Increasing Quality of Life}

Increasing the QoL of any individual whose basic needs are covered is very difficult and can only be achieved in the long term. We cannot take people with social difficulties to parties because we think they will benefit from the social contact, or tell a person facing a very serious illness that everything will turn out fine. The subjective perception of QoL develops within all individuals; it changes and adapts from cradle to grave. It is like an attitude to life and also an attitude to ourselves. It cannot be taught, it can only be encouraged through a broad educational intervention; it can be learnt by involving people, encouraging them to act and react, to better understand themselves and the environment.

The main actions to increase QoL through education taken from principal theories of QoL are as follows: 


\subsubsection{ADAPT}

Changes occur to our bodies, our lives and our environment. Any change can affect QoL positively or negatively.

According to Cummins, high QoL is better maintained among people who are able to adapt to changes in their lives. These changes can happen from two perspectives:

- Changes to ourselves, caused by illness, accident, progressive disease or the effects of ageing on our bodies. This category includes conscious or unconscious changes in our way of thinking that we cannot dominate or control.

- Changes in the environment, in society in general, our community, families and friends. These may be traumatic changes (e.g. a daughter's divorce) or progressive changes (new roles as grandparents).

First, the new environment, the change itself, the structure and the new role must be understood. Second, the person has several options: to accept the changes, to negotiate or to struggle against them.

\subsubsection{SOCIAL PARTICIPATION}

QoL is closely related to social participation. It is understood as the satisfaction individuals experience as a result of their participation in activities in the family, in the workplace and within their community, for which they use their abilities and develop their personality.

By social participation we mean the 'significant social participation', the personal interaction process that involves taking part in an active and engaged way in a joint activity, which the person perceives as beneficial. Social participation refers to support systems or psychosocial resources as unions between individuals, characterised by material aid, physical assistance, shared thoughts, feelings and experiences, and positive social contacts. Significant social participation essentially consists of four areas: education, occupation, physical activity and group recreation, 
and social relations where the aim is mutual interaction and social integration. But the quality of social contacts is more important than their quantity.

\subsubsection{GET AND GIVE SUPPORT}

Outstanding environmental factors for QoL are mainly those that allow each individual to make contact, get support and socialise with other groups such as friends, family, neighbours, community, etc.

A contradiction therefore emerges, since on the one hand an individual's autonomy and self-sufficiency is promoted, and on the other, inclusion, social support and interaction, in which the individual's autonomy and independence appears to be lost. Schalock and Verdugo (2003 p. 161-181) explore this relationship by evaluating the family, where the individual feels included as another member who can also be evaluated, e.g. leisure and enjoyment can be seen from the point of view of the person being evaluated or from the social group that the person belongs to. Hence, the source of pleasure is the social group, but it is the individual who is enjoying him or herself.

The sense of family varies greatly from one culture to another, and can have different meanings and importance depending on the person, sometimes involving the aspect of authority. In addition, there are other groups of people that everybody has to deal with, sometimes without choice (neighbours, workmates, our children's friends, etc.). However, the important groups are those we can relate to, provide for and get support from, such as groups of friends or colleagues, in which the benefits derived from the group or a friend are sometimes more important than the feeling of individuality. Two important aspects related to QoL therefore emerge:

Choice or perceived control in selecting our group.

Inclusion. Feeling part of and integrated in the group is related to communicative and affective and assertive skills, assuming interpersonal relations and being part of a group, and sometimes, working and deciding collaboratively. 


\subsubsection{BE ACTIVE}

Continuing to have goals and objectives in life and being an active member of a social group is related to continuing good health. According to Erikson (1985), older people must maintain a generative function: on the one hand they should produce and create, and on the other hand, they should build links with other people and feel responsible for them, because all citizens' lives are interlinked, and this implies working together to achieve common goals and causes by interacting with others through communication and social solidarity. But social participation must not only be related to each individual's own initiatives, which could be linked to their individual lifestyles, their internal motivations or other external motivations; social participation is also related to the place that society assigns to its older citizens.

\subsubsection{ALWAYS KEEP LEARNING}

Recent research has shown the importance of lifelong learning (as a psychosocial activity) for better quality of life. Learning can be seen as an activity that keeps individuals active, but also enables them to increase their creativity, personal development, personal skills and life satisfaction (Brocket 1985, Ladmin 1997, Schuller 2004). Lifelong learning is therefore a powerful tool that is frequently part of the 'Personal Development' dimension (Shalock and Verdugo 2002)

\section{$30.6 \quad$ Conclusions}

As we have seen, QoL is a complex status; there is no single and simple way to improve it. Education can help to raise QoL, or at least prevent it from declining. Properly designed socio-educational actions can be used to teach senior learners, but 
also to enable them to acquire new skills, attitudes and aptitudes. This is related individuals' capacity to learn more about themselves, to know more about what is important in the environment (friends, family, or other members of community) and to acquire skills to create useful and positive links between them for social support, giving and receiving help, being able to defend one's own interests, or accepting what cannot be changed.

In this chapter we have made some suggestions on how to increase QoL, but this is not a closed list. The elderly are a very heterogeneous group, and each individual has his or her own needs and problems, so the concept of QoL for each person is even more complex. Education can provide a very useful tool, by encouraging/developing the capacity to keep learning, learning from what happens around us and what happens to us, and adapting.

Another important aspect concerning the elderly and QoL is that of being as young as possible, doing the same things that we used to do, or thinking that we can stop the ageing process. QoL is also about accepting ourselves, our limitations and the obstacles in our lives, but thanks to the learning process, everybody can discover new potentialities, new pleasures we were unaware of, and new ways of being happy, productive and useful to others.

\section{$30.7 \quad$ References}

Brockett, R. G. (1985). The Relationship Between Self-Directed Learning Readiness and Life Satisfaction Among Older Adults. Adult Education Quarterly, 35(4), 210-219. doi:10.1177/0001848185035004003

Campbell, A. (1981). The sense of well-being in America : recent patterns and trends / Angus Campbell. New York: McGraw-Hill.

Chung, M. C. (1997). A critique of the concept of quality of life. International Journal of Health Care Quality Assurance, 10(2), 80-84. 
Cummins, R. A. (1997). Comprehensive quality of life scale : adult: manual (5th ed. (ComQol-A5).). Burwood Vic.: Deakin University School of Psychology. Retrieved from http://www.deakin.edu.au/research/acqol/instruments/comqol-scale/comqola5.pdf

Kubovy, M. (1999). On the pleasures of the mind. En D. Kahneman, E. Diener, \& N. Schwarz (Eds.), Well-being: The foundations of hedonic psychology (Russel Sage Foundation., pp. 134-188). New York.

Landmin, L. (1997). Elderlearning: New Frontier In An Aging Society (1st ed.). Rowman \& Littlefield Education.

Maslow, A. H., \& Cox, R. (1987). Motivation and personality (Vols. 1-1). New York; Reading, Ma ; Menlo Park, Etats-Unis: Longman.

Myers, D. G., Diener, E., \& Scientific American, inc. (1997). Pursuit of happiness. New York: Scientific American, Inc.

Myers, D. G. (2000). The funds, friends, and faith of happy people. The American psychologist, 55(1), 56-67.

Rapley, Mark (2003) Quality of Life Research. A Critical Introduction, Sage, London Ryan, R. M., \& Deci, E. L. (2001). On happines and human potentials: a review of research on hedonic and eudaimonic well-being. Annual Review of Psychology, 52(1), 141-166. doi:10.1146/annurev.psych.52.1.141

Schalock, R. L. (2000). Three Decades of Quality of Life. Focus on Autism and Other Developmental Disabilities, 15(2), 116-127. doi:10.1177/108835760001500207

Schalock, R. L., \& Verdugo, M. A. (2002). Handbook on quality of life for human service practitioners. Washington, DC: American Association on Mental Retardation.

Schalock, R. L. (2004). The concept of quality of life: what we know and do not know. Journal of Intellectual Disability Research, 48(3), 203-216. doi:10.1111/j.13652788.2003.00558.x

Schuller, T. (2004). The benefits of learning. London: RoutledgeFalmer. 
WHO. (1997). WHOQOL. Measuring Quality of Life. World Health Organisation. Retrieved from http://www.who.int/mental_health/media/68.pdf 


\section{EDUCATION ON SENIOR CITIZENS; NEW UNDERSTANDING AND APPROACHES TO INCREASE QUALITY OF LIFE}

Autores (por orden de publicación): P. Escuder-Mollon, S. Cabedo, R.A. Clemente3

Presentado en: 6th International conference on education, research and innovation, 18-20th November 2013, Seville

Publicado en: Proceedings ISBN: 978-84-616-3847-5 | Abstracts ISBN: 978-84-6163849-9

\section{Abstract}

More and more educational institutions are offering courses and other educational activities to senior citizens. It is a fact that the life expectancy is increasing and the health conditions allow people to keep active during more years. Leaning in later life is therefore a good opportunity for learners to do something they like and enjoy, but also to be up to date, integrated, and active in an always changing society an environment. Educational institutions try to increase learners' knowledge, but also social competences, intergenerational exchange or creativity, among a lot of other skills and attitudes. Institutions try senior learners to increase their well-being, happiness and motivation; education on senior learners can have a positive impact on senior's quality of life (QoL), but it is difficult to find a relation between this two elements. The QoL concept and education remains unexplored, sometimes because it is too wide, subjective, or a very long-term aim which is too ambitious. The QEduSen project shows this relation and also proposes an evaluation toolkit to assess the quality of an educational institution that tries to improve the senior learners' QoL. This is a very innovative project with an evaluation toolkit that should be framed and targeted carefully. We show in this paper that this innovation is necessary, it is possible, and we show how it is reached in the QEduSen. 
Keywords: quality of life, seniors, elderly, education, well-being, pedagogy.

\subsection{Introduction}

The citizens' quality of life (QoL) is an issue that public bodies, NGOs and associations try to increase, and also society and individuals try to reach. QoL is a very complex personal status, with objective and subjective components. For understanding and increase the senior learners' QoL it is necessary to consider the cultural context of the individual, their personal living conditions, and also the basic needs and life requirements. All that constitutes the initial requisites for a minimum level of QoL. When basic needs are covered, then QoL becomes more a subjective factor.

Institutions that try to increase citizens QoL act in different levels: health, security, transport, support, integration, social services, etc. It is common to find researches about QoL that focus on disabled, ill, groups in risk or specific context. When the target group is wider and there is not a clear requirement for the needs to be covered, then it is difficult to propose actions to increase the QoL, but it does not mean that it is not possible to maintain and improve QoL.

Focusing on senior citizens (adults over 65 years old or retired) without any specific disability or illness and also with basic need covered; QoL can be maintained and improved thanks to education.

Later life education institutions provide training and educational activities to senior citizens. Institutions provide specific courses and pedagogies designed to seniors. It is important to remark that seniors' motivation is completely personal (not job related skills or competiveness). In this life stage lifelong learning has wide aims: well-being, integration, social participation, keep active, etc. All this can be summarised in the whole concept of QoL.

It is agreed among the professionals and researchers that education has a lot of potentialities, when educational activities are designed properly, those can be used to learners acquire knowledge, skills, and competences that can be useful for 
communicate, share, or to be more active or productive. Even that obvious fact, it is not possible to find researches on educational activities focused to increase senior learners' QoL it is more common to find researches on the area of health, geriatric, psychology, etc., that propose activities that has a positive impact on senior learners health, integration, knowledge, well-being, etc. Although there exists research that relate QoL and elderly learning [1] or the evaluation of the benefits of lifelong learning [2], the institutions perspective is missing, centred too much on the impact in learners, but not on what can be done to evaluate and increase that impact.

The use of education to increase well-being, integration, participation, perceived control, physical and psychological health, etc. is widely used by adult education institution, but strangely, there has not yet build a formal framework about how it can be promoted, evaluated and implemented. The European Project QEduSen (Evaluation toolkit on seniors education to improve their quality of life) started based on previous need.

This article shows the state of the art about researches done on QoL and how those can be related to education, extract main topics and issues that are considered later on the QEduSen project, that is: senior needs, education potentialities, institutional intervention, how to evaluate, how to improve institution's quality.

There is not any guide or evaluation toolkit to assess the quality of an educational institution that tries to improve the senior learners' QoL. The QEduSen project tries to solve this need. This is a very innovative project with a product that should be targeted carefully. We show in this paper, that this innovation is necessary, it is possible, and we show how it is reached in the QEduSen.

\subsection{The senior learners}

Managers, trainers, staff and facilitators should be aware of the specific context, potentialities and risks of senior citizens. The main aim of the senior learners is not to acquire job skills or competences to get a qualification. Their motivation is mainly 
personal. In a wide extension of the researches, projects and pilot activities found [3], $[4],[5],[6],[7],[8],[9]$ the main aims are to increase the...

- knowledge and skills on specific subjects and tools, on which the seniors feel curiosity or interest, as arts, history, economy, science, philosophy, sociology, etc. usually focused on events that can affect them and are currently happening, local or regional history or arts, or general knowledge.

- social competences and other skills related to the capacitates of the learners to get adapted, be more social and active, participating in communities, in their families (intergenerational activity) or being creative. Learning allows create new social roles and thus socializing, creating, sharing collaborating.

- physical, mental and psychological health, through physical or cognitive exercises, improving functional capacities.

- happiness and joy of doing activities senior citizens like and participating in creative activities

In a broader sense, educational institutions try to increase the seniors' well-being. This has a great impact in the senior learners and their communities.

- They feel happier and more committed to do activities together with their families, neighborhood or in associations as volunteers.

- They feel are part of the society, they understand the changes and feel they can act to change things they think are unfair

- Understand the new roles and be more social

- Know and are aware of their rights

Even it has been clearly stated that this kind of teaching requires of specific pedagogies, called educational gerontology or andragogy, it has been always difficult to isolate and define which kind of subjects, skills, models and pedagogies are the most suitable to teach to learners. The reason of this lack has been probably because the senior citizens is a very heterogeneous group, where cultural and social differences, become even greater when we consider the different living experiences of each individual. 
Those differences, should not prevent us to try to propose which educational dimensions are the most suitable for the senior learners, and the QEduSen project proposes them.

\subsection{The quality of life}

As stated in the previous section, the main aim of the educational institutions when teaching to senior learners is to increase their well-being, although this is a very reasonable target, it has a weakness; It is not scientific and neither measurable.

However, the aim to increases the Quality of life not only fits in all of the previous objectives that the institutions teaching senior citizens try to reach, it is also a know concept where extensive research and models exists but still the QoL concept remains very complex; there is not a clear consensus on the definition. The QoL is a state that can be observed at group, community or individual levels. At an individual level, Rapley [10] notes that QoL can be conceived as "an aspect of individual subjectivity, a psychological quantum expressing the satisfaction of particular people with their individual lives". Definitions of QoL based on health or disease are plentiful, but they are too varied and too specific. As the QoL concept is subjective, certain cultural components further complicate its definition, since cultural, social and environmental contexts and local values come into play.

Given the difficulties in finding a precise definition, it is better to consider the QoL model most accepted theories, such as those offered by Cummins [11], Schalock [12], World Health Organisation QoL working Group [13]. The WHOQOL justifies the dimension and facets chosen to evaluate the QOL based on some of people's individual aspects. More detailed information about the QoL dimensions can be extracted from the project website [14] and also from other researchs done in the first phase of the project [15], [16], [17].

The models, dimensions and facets extracted from the different theories of QoL fit on the general aims and objectives that the senior learners pursue when attending the educational institutions, therefore it becomes feasible to define the later life learning 
objectives in terms of the QoL dimensions (Table 5). It is obvious also that some QoL dimensions cannot be impacted directly thanks to education, although those can be affected indirectly, this is the case of physical health, which main responsibility is on health policy or social services, but still, it is possible to design educational activities to improve it (the health perception, control or condition)

Table 5. Link betwen QoL dimensions and aims on senior education

\begin{tabular}{|c|c|}
\hline $\begin{array}{l}\text { Institutional aims and senior learners } \\
\text { interest. Extracted from [3], [4], [5], } \\
{[7],[8],[9]}\end{array}$ & $\begin{array}{l}\text { Quality of Life Dimensions and facets, } \\
\text { extracted from [10], [11], [12],[13] }\end{array}$ \\
\hline $\begin{array}{l}\text { Increase social contact between other } \\
\text { seniors (as classmates) but also increase } \\
\text { social skills to make new friends and } \\
\text { socialise with other people }\end{array}$ & $\begin{array}{ll}\text { Social relationships; } & \text { Personal } \\
\text { relationships and social } & \text { support, } \\
\text { interpersonal relations } & \end{array}$ \\
\hline $\begin{array}{l}\text { Learn new things and skills and } \\
\text { participating in activities (workshops, } \\
\text { seminars) }\end{array}$ & $\begin{array}{l}\text { Environment; opportunities for acquiring } \\
\text { new information and skills, participation } \\
\text { in and opportunities for } \\
\text { recreation/leisure }\end{array}$ \\
\hline $\begin{array}{l}\text { Create learning environments for sharing } \\
\text { and collaborating, intergenerational } \\
\text { contact }\end{array}$ & $\begin{array}{l}\text { Emotional well-being, personal } \\
\text { development, self-determination }\end{array}$ \\
\hline
\end{tabular}

\section{4 methodology}

QoL can be increased through an educational intervention. Here the problem raises to find out how is this related and how this educational intervention should be designed 
and implemented to maximise its impact to the QoL of the learners. Methodologically this can be determined in two ways:

a. Selective methodology. This procedure would focus on the existing QoL evaluation tools. As those tools are currently used to measure the QoL, it makes sense to find out the pedagogies, courses, activities, etc. that points out directly to increase the score of the QoL evaluation tools. One example of this methodology would be to proceed to locate the existing facets and scores of the WHOQOL-100 (e.g. "Do you feel happy about your relationship with your family members?) and then determine what should be offered to the senior learners to increase the score on that question. (e.g. a course about changes in family roles and also a non-formal activity of debate with other learners about their families).

b. Comprehensive methodology. This procedure would focus on existing QL evaluation tools and other research, not directly related to QL but on wellbeing and other social conditions of senior learners (gerontology). A better understanding of several factors that increase, but also decrease QL will allow later to design an educational intervention to maximise the QL impact and minimize the risks and other problems that can lower QL.

The best approach should be a mix of option a. and b. Scientific and well tested procedures of measuring the QoL can provide valuable information about what is important and what must be increased aiming by this way directly to the target. On the other hand, it is needed to have a wide knowledge of the QoL concepts and also the situation of the elderly. Figure 3 shows these two methodologies.

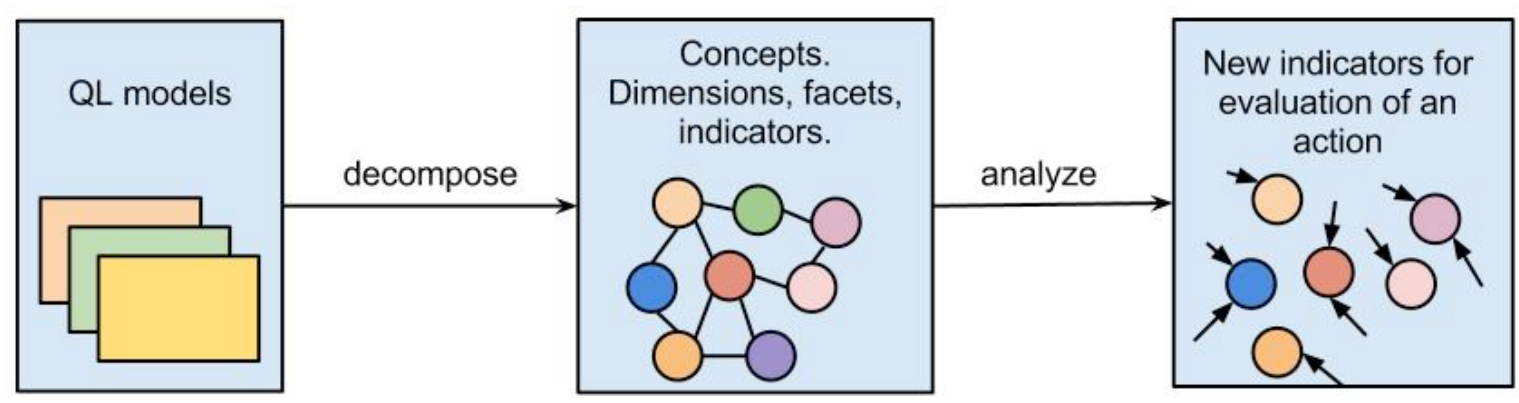

a. Selective methodology. Analysing existing models and theories 


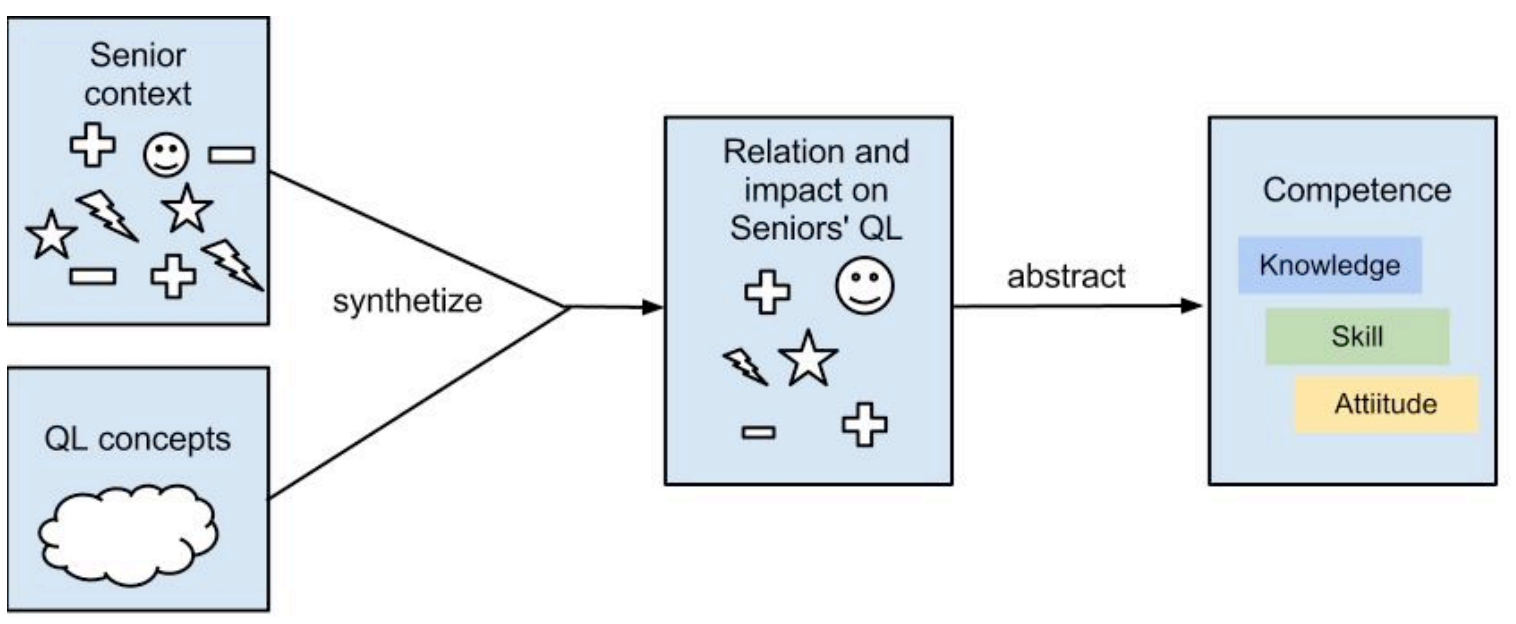

b. Comprehensive methodology. Mixing senior context with $Q L$

Figure 3. Two different methodologies to reach indicators and competences related to the QL

During the QEduSen project and based on the research done [16], [17], and based on the competences necessary to impact on seniors' QoL, there were extracted the educational and QoL dimensions.

\subsection{Compettences to increase quality of life}

While considering competences to increase the job skills or any other tool is easy, to define which competences should be targeted to increase the QoL of senior citizens can be very difficult and should be done carefully following the previous methodology.

Table 6. Relation between QoL Dimensions and competences

\begin{tabular}{|l|l|}
\hline Quality of Life Dimensions & Competences \\
\hline $\begin{array}{l}\text { 1. Health and } \\
\text { physical well-being }\end{array}$ & $\begin{array}{l}\text { - Knowledge of the basic aspects of health education } \\
\text { - Know how to detect themselves and the others } \\
\text { health problems } \\
\text { - Know healthy habits } \\
\text { - Know the influence of the healthy habits in their }\end{array}$ \\
\hline
\end{tabular}




\begin{tabular}{|c|c|}
\hline & $\begin{array}{l}\text { health } \\
\text { - Knowledge of the stress effects } \\
\text { - Know how to maintain an active mind } \\
\text { - Development of positive attitudes towards physical } \\
\text { activities } \\
\text { - Knowledge of the different health services available }\end{array}$ \\
\hline 2. Emotional quality & $\begin{array}{l}\text { - Know how to recognize emotional states in others } \\
\text { - Knowing the importance of emotions in social } \\
\text { relationships } \\
\text { - Knowing understand, manage and modify their } \\
\text { own moods } \\
\text { - To be aware of him/herself } \\
\text { - Autonomy development } \\
\text { - Self-confidence } \\
\text { - Know how to control the attitude towards others }\end{array}$ \\
\hline $\begin{array}{l}\text { 3. Interpersonal } \\
\text { interactions }\end{array}$ & $\begin{array}{l}\text { - Teamwork } \\
\text { - Development of empathic attitudes } \\
\text { - Identification different relationships individual- } \\
\text { culture-society } \\
\text { - Acquisition of skills and strategies of } \\
\text { communication, negotiation and conflict resolution } \\
\text { - Development of abilities in interpersonal } \\
\text { relationships } \\
\text { - Knowing new family structures } \\
\text { - Setting up friendships outside their close circle }\end{array}$ \\
\hline $\begin{array}{l}\text { 4. Community } \\
\text { integration }\end{array}$ & $\begin{array}{l}\text { - Participation in their community activities. } \\
\text { - Participation in leisure activities } \\
\text { - Understand and participate in social networks }\end{array}$ \\
\hline $\begin{array}{l}\text { 5. Personal } \\
\text { development }\end{array}$ & $\begin{array}{l}\text { - Planning and organization of personal time } \\
\text { - Ethical commitment } \\
\text { - Critical awareness of the relationship between } \\
\text { events and processes and past } \\
\text { - Encouraging creativity }\end{array}$ \\
\hline $\begin{array}{l}\text { 6. Personal } \\
\text { management }\end{array}$ & $\begin{array}{l}\text { - Know the aspects that make your life more } \\
\text { comfortable } \\
\text { - Know how to detect architectural barriers that } \\
\text { hinder some of its activities } \\
\text { - Know how to manage personal resources and other }\end{array}$ \\
\hline 7. Self-construction & $\begin{array}{l}\text { - Troubleshooting } \\
\text { - Decision-making } \\
\text { - Critical thinking } \\
\text { - Autonomous learning } \\
\text { - Initiative and entrepreneurial spirit } \\
\text { - Acquisition of values and ethical principles } \\
\text { - Adapting to new situations }\end{array}$ \\
\hline 8. Lifelong learning & $\begin{array}{l}\text { - Know the different basic emotions } \\
\text { - Knowledge of other cultures and customs }\end{array}$ \\
\hline
\end{tabular}




\begin{tabular}{|c|c|}
\hline & $\begin{array}{l}\text { - Recognition of diversity and multiculturalism } \\
\text { - Ability to analyse and synthesize } \\
\text { - } \text { Computer skills related to field of study } \\
\text { - Knowledge, understanding and ability to analyse } \\
\text { - } \text { historical and cultural processes } \\
\text { - Knowisition of argumentative skills } \\
\text { - Knowledge of heritage } \\
\text { - Awareness of the rights and duties of citizens } \\
\text { - Know the responsibilities of citizens } \\
\text { - Knowledge the sources of legal information }\end{array}$ \\
\hline $\begin{array}{l}\text { 9. New future } \\
\text { contexts }\end{array}$ & $\begin{array}{l}\text { - Knowledge of computer skills needed to use the } \\
\text { basic programs } \\
\text { - To know the technological aspects to help them } \\
\text { adapt to the characteristics of the new society } \\
\text { - Predisposition to learn and use new technologies } \\
\text { - Understand and verify the ITC contributions to the } \\
\text { life }\end{array}$ \\
\hline
\end{tabular}

In Table 6, can be observed the relation between QoL dimensions and competences that senior learners should acquire to increase their QoL.

\subsection{Educational and quality of life dimensions}

From the QoL dimensions and facets considered by existing models of evaluation ([10],[11],[12],[13]) not all dimensions can be impacted thanks to education, as it can happen to material well-being facet, medical conditions, security, etc. Even with that limitations, as the QoL is mainly a subjective perception of the individual, it is possible to extract form the main theories the QoL dimensions, and based on the competences that should reach the senior learners (Table 6), the QoL dimensions suitable to be impacted thanks to education (Table 7):

Table 7. QoL Dimensions suitable to be impacted thanks to education

\begin{tabular}{|l|l|}
\hline QoL dimension & Description \\
\hline Physical health & $\begin{array}{l}\text { Increasing: } \\
\text { the health of the individual, reducing pain or illness } \\
\text { (requiring less medication or visits to the doctor) or } \\
\text { increasing independence }\end{array}$ \\
\hline
\end{tabular}




\begin{tabular}{|c|c|}
\hline & $\begin{array}{l}\text { - knowledge about the general ageing process, illness or } \\
\text { good habits; lowering risks, delaying the impact of ageing } \\
\text { or improving self-perception. }\end{array}$ \\
\hline Psychological health & $\begin{array}{l}\text { - positive attitudes towards the ageing process } \\
\text { - cognitive and mental functioning } \\
\text { - protective factors for psychological disorders like } \\
\text { depression }\end{array}$ \\
\hline Integration & $\begin{array}{l}\text { - feeling integrated in society, with more communicative and } \\
\text { social skills } \\
\text { - improved knowledge of the environment }\end{array}$ \\
\hline Participation & $\begin{array}{l}\text { Increasing participation } \\
\text { - in the educational institution } \\
\text { - in communities, families, friends } \\
\text { - in society in general } \\
\text { This participation can be encouraged by creating, sharing or } \\
\text { being an active part of a group }\end{array}$ \\
\hline Control & $\begin{array}{l}\text { Related to increasing perceived control (internal and external, } \\
\text { primary and secondary). } \\
\text { - Improving learners' skills and competences to discuss, } \\
\text { negotiate, and communicate, but also to accept and adapt. } \\
\text { - Acquiring skills to analyse and know more about ourselves } \\
\text { and how we are related to the environment (links with } \\
\text { other people) }\end{array}$ \\
\hline Personal growth & Increasing optimism, motivation, energy to do things \\
\hline Personal fulfilment & $\begin{array}{l}\text { Spending time usefully and pleasurably, feeling comfortable, } \\
\text { spending time on oneself, fruitful leisure time for oneself. }\end{array}$ \\
\hline
\end{tabular}

The learners' competences (Table 6) can re be targeted thanks to courses and learning activities, but the QEduSen project tries to find other educational components that can help to reach those competences. The components are grouped in dimensions (Table 8)

Table 8. Educational dimensions

\begin{tabular}{|l|l|}
\hline Educational dimension & Description \\
\hline Institution & $\begin{array}{l}\text { premises (physical buildings) and operational logic (how } \\
\text { services are offered and organised) }\end{array}$ \\
\hline $\begin{array}{l}\text { Management and } \\
\text { organisation }\end{array}$ & $\begin{array}{l}\text { the general aims of the institution (objectives and } \\
\text { strategic aims), internal processes of the institution, } \\
\text { management decisions and internal regulations. } \\
\text { how the work inside the institution is performed, }\end{array}$ \\
\hline
\end{tabular}




\begin{tabular}{|c|c|}
\hline & $\begin{array}{l}\text { whether regulated or carried out on the basis of } \\
\text { routines and tradition }\end{array}$ \\
\hline Educational models & $\begin{array}{l}\text { ways the learning contents and activities are delivered. } \\
\text { This includes the formal, non-formal and informal } \\
\text { models, but educational models are more about: } \\
\text { - how education is provided by the institution (not how } \\
\text { a specific course is offered) } \\
\text { - the design framework that conditions how it will later } \\
\text { be implemented (pedagogies, courses, content, } \\
\text { evaluation) }\end{array}$ \\
\hline Pedagogy & $\begin{array}{l}\text { application of techniques and educational methods to } \\
\text { courses and activities. }\end{array}$ \\
\hline Courses & $\begin{array}{l}\text { any kind of learning processes where a teacher is } \\
\text { involved and has a related teaching plan even if that plan } \\
\text { has not been formally established (content, competences } \\
\text { to be achieved, pedagogy, timing, objectives, evaluation), } \\
\text { example: } \\
\text { - practical formal courses, such as ICT and language } \\
\text { courses, where learners acquire mainly practical } \\
\text { skills } \\
\text { more formal or theoretical courses, such as } \\
\text { economics, sociology, philosophy, history, arts, etc. } \\
\text { where learners acquire specific knowledge of } \\
\text { understanding in those areas } \\
\text { more informal courses, such as cooking, handicrafts, } \\
\text { dancing, choir, theatre group etc. (where they have a } \\
\text { teaching plan) }\end{array}$ \\
\hline Activities & $\begin{array}{l}\text { any kind of learning process where a teacher is not } \\
\text { involved continuously and has no teaching plan, for } \\
\text { example: } \\
\text { - a website, conference or any dissemination activity } \\
\text { - research or project-related activities } \\
\text { - trips organised by learners, lunches, dinners, other } \\
\text { - social events } \\
\text { extra-academic activities such as a choir or theatre } \\
\text { group (where it is organised as a leisure activity) }\end{array}$ \\
\hline
\end{tabular}




\begin{tabular}{|l|l|}
\hline Staff and trainers & $\begin{array}{l}\text { includes the operational level of the personnel - } \\
\text { coordinators, teachers, tutors, facilitators, administrative } \\
\text { staff, etc. } \\
\bullet \quad \text { competences and skills } \\
\bullet \quad \text { functions and responsibilities }\end{array}$ \\
\hline
\end{tabular}

For each QoL dimension (Table 7) educational dimension (Table 8), it is possible to extract characteristics that educational institutions should apply if they want to impact on senior citizens quality of life. The set of characteristic then can be used by any educational institution as a way of evaluation tool or check-list, mostly when trying to increase the quality of the impact of the educational intervention, or by any other institution willing to implement a senior educational programme. Those characteristics can be also useful also to research deeper on specific components related to senior education. 38 characteristics extracted are available in Table 9.

Table 9. Educational characteristics that should be applied when trying to increase senior learners' QoL

\begin{tabular}{|c|c|c|}
\hline $\begin{array}{l}\text { 1. Accessibility } \\
\text { 2. Meeting points } \\
\text { 3. Spaces for } \\
\text { participation } \\
\text { 4. Institutional self- } \\
\text { evaluation } \\
\text { 5. Social activity } \\
\text { promotion } \\
\text { 6. Senior's } \\
\text { requirements } \\
\text { evaluation } \\
\text { 7. Participation of } \\
\text { learners } \\
\text { management in } \\
\text { 8. Learning provider } \\
\text { 9. Learners' } \\
\text { accreditation } \\
\text { 10. Acquiring social } \\
\text { attitudes informally } \\
\text { 11. Formal learning } \\
\text { provider } \\
\text { 12. Formal learning } \\
\text { groups }\end{array}$ & $\begin{array}{l}\text { 14. Intergenerational } \\
\text { learning } \\
\text { 15. Constructive } \\
\text { pedagogy } \\
\text { 16. Learn by research } \\
\text { 17. Participatory } \\
\text { pedagogy } \\
\text { 18. Learn to learn } \\
\text { 19. Competences for life } \\
\text { changes } \\
\text { 20. Digital adoption } \\
\text { 21. Physical } \\
\text { 22. Languages } \\
\text { 23. Problem-based } \\
\text { learning } \\
\text { 24. Psychological } \\
\text { wellbeing } \\
\text { 25. Cultural trips } \\
\text { 26. Informal learning } \\
\text { outside } \\
\text { classroom the } \\
\text { 27. Increase in cognitive } \\
\text { skills }\end{array}$ & $\begin{array}{l}\text { 28. Social meetings } \\
\text { 29. Artistic } \\
\text { performances } \\
\text { 30. Volunteering as a } \\
\text { social contribution } \\
\text { 31. Digital inclusion } \\
\text { 32. Expertise exchange } \\
\text { 33. Artistic creativity } \\
\text { 34. Gerontology } \\
\text { training } \\
\text { 35. Intercultural } \\
\text { awareness, } \\
\text { diversity } \\
\text { multiculturalism } \\
\text { 36. Trainers } \\
\text { communication } \\
\text { skills } \\
\text { 37. Professional } \\
\text { burnout and stress } \\
\text { management } \\
\text { 38. Motivation and } \\
\text { optimism }\end{array}$ \\
\hline
\end{tabular}


13. Comprehensive educational activity

In http://www.edusenior.eu can be downloaded the evaluation toolkit that includes for each characteristic its respectively dimension, justification and recommendation.

\subsection{Conclusions}

It has been stated as a major challenge to develop new didactic methods suitable for the elderly [3], stating event the teaching to the seniors as an "Art" [4] and focusing on the sills and capacities of the educator [6] adapting learning environments and teaching techniques. It becomes easy to find research that focus on topics of the ageing process where physical and cognitive skills decrease and how pedagogies should be adapted [8]. Ageing process is a life period which risks but also potentialities [9], that should be taken into consideration when designing any educational activity.

There exists pedagogical guides, courses and activities proposals that help institutions to offer adequate educational activities focused to senior learners. Thanks to existing books and experiences, it is possible to gather some ideas and best practices. On the other hand, there are not tools suitable to measure or classify that kind of activity.

The QEduSen project proposes the 7 educational dimensions, and 7 QoL dimensions that can help educational institutions to try to design and implement the educational action, and also try to focus it to target the needs of the senior learners. Teaching is as a powerful tool, but it is necessary to consider the whole educational institution (premises, organisation, managers, staff, trainers, content, model and pedagogy) that allows seniors to improve their QoL.

The QEduSen project also proposes 38 indicators. Even this is not a definitive list, during the testing phase it has been validated by 10 institutions and more than 40 trainers and managers with experience on later life learning area. The results of this research can be observed in the website http://www.edusenior.eu. The partnership 
is aware of the challenges and risks of propose a definite 38-item list, as it would not fit in all kind of institutions (although it has been designed from a intercultural perspective). Even that risk, to have this list, allows other projects and research to keep future work and improving the quality and impact of education on senior learners.

Other areas that can benefit of this evaluation toolkit are the:

- Practitioners; where the competences and skills should be clarified. Managers and other staff can get aware of those characteristics and reccomendations when implementing educational actions.

- Decision-makers, social services and other elderly services; to help consider later life learning as a very valuable activity with impact in certain dimensions of the QoL and even can help to decrease social expenditures.

- Researchers that try to assess, evaluate, improve or compare between pilot activities, projects or programmes. Researchers can also benefit in case they wan to go deeper and improve any of the educational dimensions or QoL dimensions.

- For general public or for future practitioner that thought that later life learning is something useless

\section{Acknowledgements}

This research was undertaken as part of the "Evaluation toolkit on seniors education to improve their quality of life" (http://www.edusenior.eu) project, funded with support from the European Commission with reference 518227-LLP-1-2011-1-ESGRUNDTVIG-GMP. This communication reflects the views of the author only, and the Commission cannot be held responsible for any use which may be made of the information contained therein.

\section{REFERENCES}

[1] George, L. K. (1980). Quality of life in older persons: meaning and measurement. New York: Human Sciences Press. 
[2] Plewis, I., Preston, J., University of London, Institute of Education, \& Centre for Research on the Wider Benefits of Learning (London, E. (2001). Evaluating the benefits of lifelong learning: a framework. London: Institute of Education.

[3] Ruth, J., Sihvola, T., \& Parviainen, T. (1989). Educational Gerontology: Philosophical and Psychological Issues. Educational Gerontology, 15(3), 231-244. doi:10.1080/0380127890150303

[4] Jones, J. E. (1980). On Teaching Art to the Elderly: Research and Practice. Educational Gerontology, 5(1), 17-31. doi:10.1080/0360hyp800050102

[5] Cabedo, S. (2003). Hacia un concepto integral de calidad de vida : La Universidad y los mayores. Castelló Plana: Universitat Jaume I.

[6] Sánchez Torrado, S. (1991). Educación de adultos y calidad de vida (1. ed.). Barcelona: El Roure Editorial.

[7] Schuller, T., Preston, J., Hammond, C., Brassett-Grundy, A., \& Bynner, J. (2004). The Benefits of Learning: The Impact of Education on Health, Family Life and Social Capital. Routledge.

[8] Lamdin, L. S. (1997). Elderlearning: new frontier in an aging society. Phoenix, AZ: Oryx Press.

[9] Pinazo, S., \& Sánchez, M. (2005). Gerontología: actualización, innovación y propuestas. Pearson Educación.

[10] Rapley, M. (2003). Quality of life research: a critical introduction. SAGE.

[11] Cummins, R. (1997). Comprehensive quality of life scale : adult : manual (5th ed. (ComQol-A5).). Burwood Vic.: Deakin University School of Psychology. Retrieved from http://www.deakin.edu.au/research/acqol/instruments/comqolscale/comqol-a5.pdf

[12] Schalock, R. L. (2004). The concept of quality of life: what we know and do not know. Journal of Intellectual Disability Research, 48(3), 203-216. doi:10.1111/j.1365-2788.2003.00558.x

[13] WHO. (1997). WHOQOL. Measuring Quality of Life. World Health Organisation. Retrieved from http://www.who.int/mental_health/media/68.pdf 
[14] Escuder-Mollon, P., Clemente Esteban, R. A., Flores Buils, R., \& Esteller-Curto, R. (2012). Quality of life (No. QEduSen. D.1.1.a). QEduSen project (LifeLong Learning Programme of European Commision). Retrieved from http://edusenior.uji.es/files/QualityOfLife.pdf

[15] Escuder-Mollon, P. (2012). Modelling the Impact of Lifelong Learning on Senior Citizens' Quality of Life. Procedia - Social and Behavioral Sciences, 46(0), 23392346. doi:10.1016/j.sbspro.2012.05.481

[16] Escuder-Mollon, P., Esteller-Curto, R., Issakainen, C., Lubkina, V., \& Lozanova, S. (2013). Pedagogical Proposal to Increase the Quality of Life on Senior Citizens. Presented at the 5th World Conference on Educational Sciences, Rome.

[17] Escuder-Mollon, P., Esteller-Curto, R., Ochoa, L., \& Bardu, M. (2013). Impact on Quality of Life Through Lifelong Learning on Senior Learners. Presented at the 5 th World Conference on Educational Sciences, Rome. 


\section{PEDAGOGICAL PROPOSAL TO INCREASE THE QUALITY OF LIFE ON SENIOR CITIZENS}

Autores (por orden de publicación)

Pilar Escuder-Mollon, Roger Esteller-Curto, Cecil Issakainen, Velta Lubkina, Slavina Lozanova

Presentado en: 5th World Conference on Educational Sciences, 5-8 Febrero 2013. Roma, Italy

Publicado en: Procedia-Social and Behavioral Sciences Journal, Volumen 116, febrero 2014, páginas 3152-3159, ISSN: 1877-0428

DOI: https://doi.org/10.1016/j.sbspro.2014.01.725

\section{Abstract}

Quality of life is a very broad and complex issue. It has objective and subjective components, as well as physical, psychological and social components. High Quality of Life is beneficial to the individual, but also to society. Quality of life can be influenced through education; it can be achieved by comprehensive pedagogy that includes content, but also tries to integrate facilitators, teachers and classmates into the process of lifelong learning. This is a long-term objective, but one that is showing results in increasing the subjective perception of quality of life, well-being, integration and participation of senior citizens in society. This paper reports on a pedagogical proposal focusing on five main topics (pedagogies, contents, contexts, models and trainers), based on analysis and research carried out within the QEduSen project (supported by the Lifelong Learning Programme of the European Commission). 
Keywords: quality of life, lifelong learning, pedagogy, senior citizens, elderly, QEduSen;

\subsection{Introduction}

When educational institutions offer courses or activities, they should first try to focus their aims on a specific target. Educational institutions usually address their courses and activities to citizens who are unemployed or who wish to update their knowledge to increase their competiveness in the labour market. Other institutions endeavour to achieve other social aims, such as integrating immigrants or the socially excluded. Senior citizens (over 65 or retired) in general (not disabled or excluded) do not want to learn because they are seeking promotion at work, but because of personal motivations. Modern societies accept lifelong learning as a right for all individuals and educational institutions offer courses and activities for all citizens from cradle to grave, but these can easily fail when the same pedagogies and courses are applied for all ages. Older people's personal motivations in attending a course may be to increase their knowledge, to keep up-to-date, to be active, to socialise with other classmates or simply because they enjoy learning. However an educational institution's formal aim should be go beyond simply offering courses for fun. In the QEduSen project, we propose a pedagogical guide targeted to educational institutions aiming to increase the quality of life (QoL) among their senior learners.

The European project (within the European Commission's LifeLong Learning Programme) QEduSen started on November 2011, with seven participating adult education institutions. The aims of the project are to develop two products: a guide and an evaluation tool for educational institutions that want to increase the impact of education on their learners' QoL The first stage of the project is now completed. It consisted of a study into the relationship between education and quality of life among senior learners. Quantitative and qualitative research was undertaken with learners to discover their perceptions of quality of life due to education. Staff and teachers groups with experience in teaching seniors were also surveyed to gather their approaches to improving their impact on learners. 
QoL can be influenced through education, but that educational activity should be undertaken in an appropriate way and direction. In this paper, we present the experience of the QEduSen project and qualitative interviews with experts to demonstrate how senior learners' QoL can best be impacted.

\subsection{Quality of Life}

QoL consists of dimensions and facets that help to define, understand and evaluate the QoL of an individual. The World Health Organisation (WHO 1997) defined six dimensions: physical health, psychological, level of independence, social relationships, environment, and spirituality/religion/personal beliefs. Other authors have put forward different dimensions. Cummings (1997), for example, proposes the following seven dimensions: material well-being, health, productivity, intimacy, safety, place in community, and emotional well-being. There are as many different theories and models of QoL as authors writing about it, which demonstrates the complexity of understanding and evaluating QoL. However it is possible to extract some common elements from the most accepted theories.

The work of Escuder-Mollon (2012a, 2012b) introduces the concepts quality of life (QoL) related to education, and from which the following QoL aspects are taken:

- The importance of the subjective factor. QoL is governed by objective and subjective elements, most of which are part of the culture (WHOQOL Group, 1994) or are used to weigh the importance and satisfaction of any objective perception (Cummings 1997)

- Life satisfaction. Once basic needs are met (housing, subsistence, basic relationships), life satisfaction is based on covering other needs (Maslow 1987)

- Personal improvement. Schalock and Verdugo 2002 (p.11-30) state that QoL has the same essential foundations for everyone, regardless of physical or mental disability or age. Once basic needs are met, for QoL to be enhanced, 
the aspects that each individual considers most important in his or her life must be improved

- Adaptation. According to Cummings (in Rapley 2003, p. 206), high QoL is maintained by people with the ability to adapt to any changes in their lives

- Subjective Well-Being. The cognitive protective factors Cummings identifies - self-esteem, perceived control and optimism - are also known as subjective well-being. To raise QoL, actions designed to enhance previous factors must be implemented.

Escuder-Mollon (2012b) also highlights certain needs the elderly have that should be considered by any educational institution:

- Illness and disabilities. Age does not directly determine health status; rather it is related to socio-cultural factors and behavioural styles. There is no single way to live old age; different lifestyles are particularly dependent on the subjective constitution and the type of relationship with the environment. Each person experiences the aging process in accordance with his or her previous life history, which determines the lifestyle that he or she takes at this stage of life. It is important to be sufficiently informed and also to be able to deal with illness or disability.

- Changes and new role. Changes in the environment (structure of the family, social context, home) and the individual's personal and family role can affect his or her own personal status and role either positively or negatively. The new environment, structure and the new role must first be understood. Several options are available in the second stage: to accept changes, to negotiate or to act.

- Social participation. QoL is closely related to social participation. In this sense it is understood as the satisfaction individuals experience as a result of their participation in the activities in the family, in the workplace and within their community, for which they exercise their abilities and develop their personality. By social participation we refer to 'significant social participation', the process of personal interaction that involves taking part 
in an active and engaged manner in a joint activity, which the person perceives as beneficial. Social participation refers to support systems or psychosocial resources as links between individuals, characterised by material aid, physical assistance, shared thoughts, feelings and experiences, and positive social contacts. Significant social participation essentially occurs in four areas: education, occupation, physical activity and recreational groups, and social relations where the aim is mutual interaction and social integration. However the quality of social contacts is more important than their quantity.

- Loneliness and exclusion. In consequence, among the main risk factors of deteriorated QoL is the social isolation linked to the exclusion and rejection of old age. According to Furstenberg (1989), one of the criteria for assuming the status of being 'old' is the decline of social participation and the feeling of uselessness.

- Lifelong learning. Recent research has shown the importance of lifelong learning (as a psychosocial activity) for enhanced QoL. Learning can be seen as an activity that keeps people active, but also enables them to increase their creativity, personal development, personal skills and life satisfaction (Brocket 1985, Ladmin 1997, Schuller 2004). Lifelong learning in this way is a powerful tool that is commonly part of the "Personal Development" dimension (Shalock and Vertugo 2002)

- Usefulness and aims. Continuing to have goals and objectives in life and being an active member of a social group is related to continuing good health. According to Erikson (1985), older people must maintain a generative function: on the one hand they should produce and create, and on the other hand, they should build links with other people and feel responsible for them, because all citizens' lives are interlinked, and this implies working together to achieve common goals and causes by interacting with others through communication and social solidarity. But social participation must not only be related to each individual's own initiatives, which could be linked to their individual lifestyles, their internal 
motivations or other external motivations; social participation is also related to the place that society assigns to its older citizens

\subsection{Research}

Six institutions of the QEduSen project were involved in this research: the Senior Citizens' University (SCU), at Jaume I University, Spain; the Universutà delle LiberEtà del FVG (ULE) in Údine, Italy; the Akademia im. Jana Dlugosza w Czestochowie (AJD), Czestochowa in Poland; the Palmenia Centre for Continuing Education(PCCE) in Helsinki, Finland; Assist Net EOOD (ANE), from Sofia, Bulgaria; and the Personality socialization research institute of Rezeknes augstskola (PSRI-RA) in Rezekne, Latvia. A total of 39 interviews were conducted with teachers, technicians and managers involved in adult education activities, with an average experience of teaching seniors of 10.7 years.

The interview consisted, firstly, of explaining QoL (in the broadest sense of the term) applied to senior learners (over 65 or retired) and also highlighting that when talking about education, we were referring to any component (institution, staff, facilitators, tutors, classmates, environment, etc.) or tool (pedagogies, courses, activities, etc.) available in educational institutions to provide senior citizens not only with content, but also with competences, skills and attitudes.

The first interview question was: "Considering your experience and expertise, how much do you think education can influence quality of life among senior learners?" and was answered on a scale from 1 (not at all) to 7 (a great deal). Responses are reported in Figure 1. 


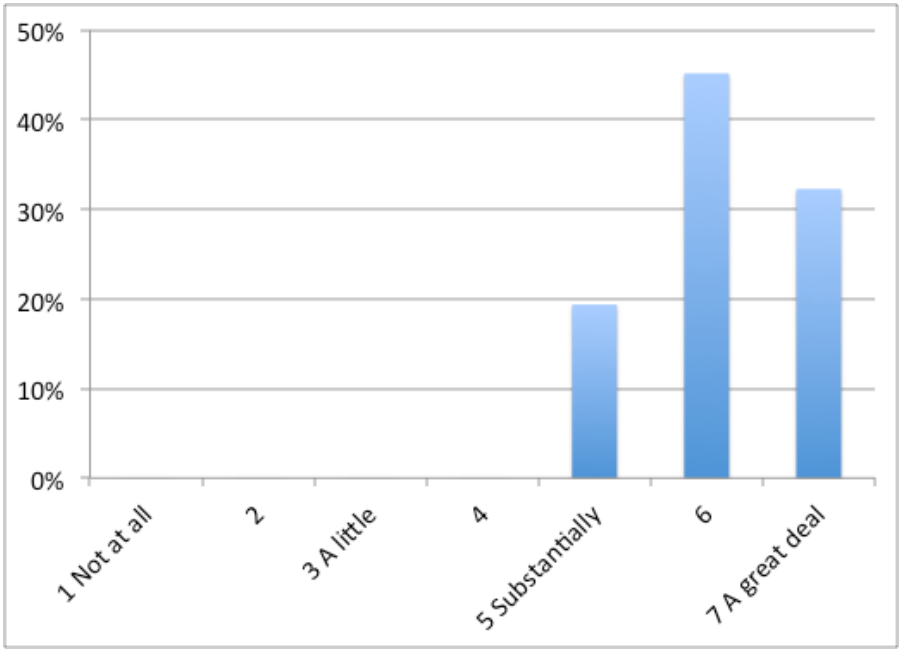

Figure 1. Percentage of responses to the question "How much do you think education can influence QoL?"

The interview consisted of three main questions:

- What are the most important educational aspects that increase the impact on seniors' quality of life?

- How do you think they should be applied? (Which pedagogies, courses, activities, competences, staff, skills, models, etc ...)

- If you had to explain to an inexperienced person how to approach education for seniors, on which aspect would you focus?

\section{$32.4 \quad$ Pedagogical proposal}

Based on the experts' interviews, the following educational proposal was drawn up:

\subsubsection{PEDAGOGIES}

The most appropriate pedagogies when teaching senior learners, and aiming to impact the QoL dimension of their lives, are those that combine group activities, 
conversation and discussion. The basic principle is to encourage active learning, where the learner is not a mere recipient of information. However, it must be remembered that classes are not chat groups or coffee circles, and the educational aims should be always present. Instructional pedagogy therefore also has a major role in senor learning. Some institutions offer theoretical lectures and talks, and from the experience gathered in the interviews, they are a good teaching methodology to match the needs of elderly learners.

On the other hand, there are far more courses and activities where learners play a more active role. As education for the elderly is usually focused on learning skills or attitudes rather than content, constructivist pedagogies are most commonly used. Teachers apply this pedagogy even when new content is being taught (such as philosophy, sociology, history, arts, etc.) because of the long life experience that learners have. Teachers can take advantage of that to complement the content with practical information and examples. Also because learners are not afraid to ask questions in class, participate or share, group activities produce good results. Pedagogies should aim to facilitate the acquisition of parallel skills apart from the subject itself, namely, capacity for discussion, debate and negotiation, but also tolerance and respect.

Teaching pedagogies should take into consideration the physiological changes that occur among the elderly. No teacher bases his or her methods only on learners' memorising capacities; because older people's learning skills are different from those of young people, the teaching method must adapt to the elderly's extensive experience rather than memorising. Even in the case of languages or when learners need to remember facts, words, or dates, teachers use a great deal of practicing and repeating.

Group activities allow learners not only to share and talk about the class subject or activity, but also to receive support, sometimes indirectly, on specific subjects from classmates (such as health, society and family). In this case, this kind of activity can be seen as an excuse to encourage seniors who are not used to talking or to sharing, or who are often at a loss for a subject to talk about. In some examples from the interviews, this kind of activity had been useful for integrating immigrants into the group. 
Educational institutions generally teach young people or adults because they need a degree or a better position at work. The most common pedagogies or techniques tend to produce results in terms of increased knowledge or competences that are evaluated through exams, making it easy to verify a student's improvement during the academic year or at the end of the course. In the case of senior education, there are no exams (or at least, they are usually kept to a minimum) but it is beneficial to provide evidence of a learner's progress and improvement, and also to show what achievements have been made. The sense of having reached the goal and having increased the learner's capacities in a specific subject is highly beneficial.

\subsubsection{CONTENTS}

The simple fact of learning is a very positive activity; it is memory-stimulating process that enables learners to be active members of the society in which they live. An expert from the ULE stated that "learning keeps the mind young, the heart serene and the body active".

The most suitable subjects are:

- Philosophy, psychology and society. It is not a good idea to focus only on "sociology of the elderly" or "psychology of the elderly", as it would seem that instead of a teaching class, senior learners were in a self-help group. These subjects can help students to understand the changes they experience in their lives, in their families and society, enabling them to cope better with changes and adapt to other challenges; the subject must therefore be broad. Learning on these subjects must also aim to promote a positive attitude to facing changes, incorporating constructive feelings and a perception of control.

- Languages and technology. Some ICT and languages teachers took part in the interviews. They stressed the importance of teaching these subjects for practical reasons: integration in a foreign society, access to services, use of communication tools to keep in touch with friends, etc. The teaching of these subjects is unquestionably motivated by practical considerations, focussing 
on needs that should be first identified and then met. However, it is worth noting that learning new languages and ICT skills for their own sake also has a very positive psychological effect as they require cognitive skills that seniors do not generally use. These subjects can be regarded as 'exercises for the brain'.

Secondly, ICT and languages provide the necessary skills to keep up to date in our increasingly technological society. Learning and applying them as much as possible therefore makes citizens feel (and be) included in this society.

- Physical activities. If performed correctly, these activities can provide great benefits to the physical health of seniors, and although they can not be considered strictly as educational activities, institutions have found ways of incorporating an educational approach. This is the case of a dance activity that is also used to improve balance and coordination, or a hiking activity offered as a way of enjoying the environment, socialising and learning informally about healthy habits. The experts usually considered this kind of activity as extra-academic.

- Creative activities. Some courses or activities can lead to a valuable outcome. This could be a short piece of work (research work done by the learner), a product (a web site, or a painting) or through intergenerational or volunteer activities. This has an impact on the senior's environment (family, friends and community); it is a way of recognising the learners' efforts, and also improves their self-esteem, as well as being productive by giving back their knowledge and experience to society.

The context is important because senior learner do not go to a building or classroom only to acquire knowledge; they are also looking for a pleasant learning experience. It is important for them to feel comfortable (seats, temperature, light) and they can sometimes need some specific support (in case of physical difficulties). Spaces for 
socialising, meeting with colleagues, chatting, etc., such as a coffee lounge can be even more important than the classroom itself.

It is important for the institution to have an intergenerational context; the building and classrooms should not appear to be only for old people. Although when teaching, the content should be tailored to senior learners, the shared spaces must allow some intergenerational exchange. Being in a residential home for the elderly or disabled makes learners feel older; being in an adult school or a university, sharing spaces, makes the elderly feel younger.

Senior learners must be an active part of the teaching-learning process, and that participation should be there at all levels; from classroom to management. Therefore, learners should be given some way of participating in institutional decisions (where possible). This may be done through the students' representative.

\subsubsection{MODELS}

The non-formal teaching method is preferred when teaching senior learners, in contrast to more strict or formal methods that are less adaptive and are designed to get results. Teachers usually follow a well structured course content, with clear aims and content to deliver. This is the most formal part of the teaching model. On the other hand, the application of the teaching is usually non-formal.

Some institutions offer a list of courses from which learners are free to choose the ones they want to register on. Other institutions (SCU) offer courses in blocks (first year, second year, and third year). This second, stricter approach obliges the learner to enrol on a specified number of courses each year. This provides great benefits: firstly, learners should follow a learning path of courses designed in the area of the humanities, but also technology and economics. Secondly, it allows learners to be monitored over a period of at least three years; technical staff and a gerontologist can follow their progress. Thirdly, it enables the learner to integrate in a group that is consistent for at least three years. This model offers optional subjects (ICT and languages) that learners are free to choose, depending on their interest and levels. In 
addition, when they finish the third year they can continue learning in more flexible groups of subjects classified by topics.

Extra-academic activities or complementary activities undertaken outside the classroom have revealed that the application of informal learning led to good results among senior learners. This can be seen when teachers motivate learners to share learning activities with members of their families or friends. Through these activities, the main objective of the subject can be learned (e.g. creating an intergenerational blog), but also other competences (e.g. tolerance and respect) can also be learned and sometimes taught. The interviews provided some examples where learners could apply something learnt in class to their daily routines to discover new knowledge or abilities. In this context, education happens in the classrooms but also during daily life.

\subsubsection{TRAINERS/STAFF}

The teacher's social and communicative skills are considered by all the experts as the most critical factor when teaching seniors. Although knowledge and competence in the subject is important, they become a secondary requirement for any trainer. As a teacher from the ULE stated, "It is not important what to teach, but how and why".

The trainer is responsible for creating a good, serene class atmosphere, for motivating students to learn and for providing additional support. They must teach more than contents, but transmit passion and the joy of learning. Other necessary skills are empathy, respect and understanding (ANE)

The trainer can face great difficulties when trying to teach contents, skills or competences because senior learners are a very heterogeneous group, with very different life experiences, knowledge and capacities. This may cause the teacher certain problems in pitching the teaching level.

Some institutions have technical staff members who act as facilitators between the learner and the institution. That lends a human touch to institutions that can sometimes seem very cold. The importance of these technical members of staff has 
been highlighted, as they have to deal with learners throughout the whole academic year, and sometimes for a number of years. The level of trust reached is higher than with the teachers. In some institutions, the senior learners see them as confidants, and they talk to them about issues they would not even discuss with their sons or daughters. These members of the team are trained in gerontology and act as educational advisors; they know the adult leaner very well and can provide educational solutions and support.

\subsection{Conclusion}

QoL can be impacted through education, but certain necessary conditions must first be achieved for this to occur.

All the experts coincided that the most critical factor in increasing senior learners' QoL is the human factor (facilitator, teachers and technicians). The teacher is the main contact with knowledge available to the learners, but he or she is also the facilitator to achieve a better understanding of themselves, their context and the society. The teacher becomes not only a provider of skills and information, but also a friend and a support, who maintains a certain distance and the respect from the learner, but who is near enough to know the learner's needs.

The topics of the activities or courses are the first tool that teachers can use to impact QoL; the second is the pedagogy that they apply. Some topics have been mentioned as teaching suggestions for students and are significant to their QoL, but there are many more topics that senior students can enjoy learning and that can be highly beneficial to their knowledge, self-esteem or personal growth. The teaching-learning process itself is highly valuable, regardless of the content, if there is interest from both parties in the process (the teacher and the learner)

The final factor that has an impact on learners' QoL is the institution or environment that is created. The learning context is important not only because it facilitates the learning process, but also because it allows the learner to become part of a group, providing benefits for socialising and support. 


\subsection{Acknowledgements}

This research was undertaken as part of the "Evaluation toolkit on seniors' education to improve their quality of life" (http://www.edusenior.eu) project, funded with support from the Lifelong Learning Programme of the European Commission, reference 518227-LLP-1-2011-1-ES-GRUNDTVIG-GMP. This communication reflects the views of the author only, and the Commission cannot be held responsible for any use which may be made of the information contained therein.

\subsection{References}

Brockett, R. G. (1985). The Relationship Between Self-Directed Learning Readiness and Life Satisfaction Among Older Adults. Adult Education Quarterly, 35(4), 210-219. doi:10.1177/0001848185035004003

Chung, M. C. (1997). A critique of the concept of quality of life. International Journal of Health Care Quality Assurance, 10(2), 80-84.

Cummins, R. A. (1997). Comprehensive quality of life scale : adult: manual (5th ed. (ComQol-A5).). Burwood Vic.: Deakin University School of Psychology. Retrieved from http://www.deakin.edu.au/research/acqol/instruments/comqol-scale/comqola5.pdf

Escuder-Mollon, P. (2012a). Modelling the Impact of Lifelong Learning on Senior Citizens' Quality of Life. Procedia - Social and Behavioral Sciences, 46(0), 2339-2346. doi:10.1016/j.sbspro.2012.05.481

Escuder-Mollon, P., Clemente Esteban, R. A., Flores Buils, R., \& Esteller-Curto, R. (2012b). Quality of life analysis (No. QEduSen. D.1.1.a). Evaluation toolkit on seniors' education to improve their quality of life - LLP QEduSen project. Retrieved from http://www.edusenior.eu 
Erikson, E. H. (1985). The life cycle completed: A review. New York. Norton \& Co.

Furstenberg, A.-L. (1989). Older people's age self-concept. Social Casework, 70(5), 268-275.

Kubovy, M. (1999). On the pleasures of the mind. En D. Kahneman, E. Diener, \& N. Schwarz (Eds.), Well-being: The foundations of hedonic psychology (Russel Sage Foundation., pp. 134-188). New York.

Landmin, L. (1997). Elderlearning: New Frontier In An Aging Society (1st ed.). Rowman \& Littlefield Education.

Lalonde, M. (1993) El concepto de campo de la salud, una perspectiva canadiense, Boletín Epidemiológico, 4

Maslow, A. H., \& Cox, R. (1987). Motivation and personality (Vols. 1-1). New York; Reading, Ma ; Menlo Park, Ca... [etc.], Etats-Unis: Longman.

QEduSen (2012). Evaluation toolkit on seniors' education to improve their quality of life. http://www.edusenior.eu

Schuller, T. (2004). The benefits of learning. London: RoutledgeFalmer.

Rapley, Mark (2003) Quality of Life Research. A Critical Introduction, London: Sage

Schalock, R. L., \& Verdugo, M. A. (2002). Handbook on quality of life for human service practitioners. Washington, DC: American Association on Mental Retardation.

WHO. (1997). WHOQOL. Measuring Quality of Life. World Health Organisation. Retrieved from www.who.int/mental_health/media/68.pdf

The WHOQOL Group. (1994). Development of the WHOQOL: Rationale and current status. International Journal of Mental Health, 23 (3), 24-56. 


\title{
33 THE QEDUSEN PROJECT; IMPROVING SENIORS' QUALIY OF LIFE THROUGH EDUCATION
}

Autores (por orden de publicación): Pilar Escuder-Mollon²

1 Universitat Jaume I. Spain

Presentado en: International Scientific Conference Society, Integration, Education

Rezekne Higher Education Institution. Faculty of Pedagogy. Rezekne Augstskola. Mayo 2013, Rezekne, Latvia.

Publicado en el libro de actas: ISSN 1691-5887

\begin{abstract}
Learning in later life (citizens over 65 or retired) is becoming common. The motivation and interests of the senior citizens to keep learning are mainly personal, they are not job related needs or labour market qualification requirements. These personal aims can be seen from the quality of life (QoL) perspective, where education increases well-being, integration and participation of the elderly in the present society. Institutions dealing with senior learners then face the challenge to provide a socio-educational intervention to senior learners, which has a requirements, needs and motivation different from other adults, and that specific pedagogy, courses and staff qualifications must be considered. From this need the project QEduSen (supported by the Lifelong Learning Programme of the European Commission) produced a guide and a evaluation toolkit
\end{abstract}

Keywords: senior education, elderly, quality of life 


\subsection{Background}

Ageing is one of the greatest social and economic challenges of the 21 st century for the European societies. It will affect all the Member States and it will cut across nearly all the EU policy domains. By 2025 more than 20\% of Europeans will be 65 or over, with a particularly rapid increase in the number of citizens over 80s (Eurostat).

It is a fact that institutions that teach to seniors ( +65 years old or retired) face the issue to offer courses to a target not aimed to get a degree or to improve at job, therefore they have to apply different methodologies and also create courses, activities and materials specially designed. In broader aspect, their main aim is to increase their well-being and Quality of Life (QoL). In this context, teaching becomes a socio-educational activity, where more formal, non-formal and informal activities mix. The knowledge acquired is important, but there are skills and attitudes that should not be forgotten and other aims as, socialization, integration, adaptation to society, active citizenship, etc.

Existing research define the QoL both as an objective and subjective perception of the individual (Rapley 2003). There are also parameters to help to evaluate it and therefore to take action to increase the QoL of one individual (Cummings 1997, Schalock 2000, WHO 1997). The levels of QoL may decrease because of several kinds of risks (e.g. loneliness, isolation...) and may increase through some other activities promoting integration or communication. Education can be used to minimize the risks and maximize the QoL. The promotion and increase of QoL in senior citizens is greatly positive as it will make not only happier seniors, but also more active, productive, participative, healthier and that require less social services and increase their valorisation in society. 


\subsection{The importance of education}

There are public institutions, non governmental organisations, associations and also laws and regulations that fight against poverty, exclusion, discrimination and other social aspects that crate suffering and unfair living conditions. From global to local (families, friends, individual) it is a good cause to take actions to have a better quality of life.

From the global-local perspective, it is possible to act on individual QoL through education. Learning has many stages in life, while children have to learn the most basic knowledge and social skills, training in adolescents and adults is more oriented to professional skills and competitiveness. On the elderly or retired people, there is not any aim to promote at work, their motivation are purely personal. Most commons reason they want to learn are mainly to know about some subject that they have curiosity, they want to know more about the present society and history, understand it, and be up to date, they do not want to get excluded and they want to be active and creative. On the other hand, institutions offer this kind of educational activities because they know that they are beneficial for seniors citizens; it make them more skilled to face the present society challenges, more active and participative. Those concepts are very related with the purpose of increase the seniors' QoL as we will see in next chapters.

The design of any educational intervention aimed to increase the QoL of learners is not a target that can be reached in short-term through a subject or any other kind of activity. This very broad aim, requires a carefully design of the whole teachinglearning process which involve non only the content, but how it is been thought, how learners interact, the environment, an a lot more other aspects that you will be able to discover through this guide. 
The seniors' QoL can be impacted through education, but as like any other habit, skill or attitude, QoL can be learnt as the same way that tolerance, friendship or to face up challenges conveniently

\subsection{The QEduSen project}

The QEduSen project "Evaluation toolkit on seniors education to improve their quality of life" is supported by the Lifelong Learning Programme of the European Commision with reference 518227-LLP-1-2011-1-ES-GRUNDTVIG-GMP from October 2011 to September 2013

You can find more information about this project in http://www.edusenior.eu and about the LifeLong Learning Programme of the European Commision at http://ec.europa.eu/education/lifelong-learning-programme.

On Figure 1 it can be seen a general overview of the project.

The first product is a guide, with 7 chapters that introduce 7 topics

1. Quality of life

2. The elderly

3. Society

4. Models

5. Pedagogy

6. Content

7. Staff/Trainers

In each chapter, a theoretical background is provided to introduce the basic concepts about each topic. In the same chapter, a more practical sections follows with practical experiences that can be useful for any inexperienced institution, getting by this way ideas and practises that can be implemented. 
Thanks to application of this guide by any inexperienced institution focused to adults or adults education association is that those institution can implement an education program to increase the QoL of senior learners. 


\section{edu}

\section{The project}

EduSen is a Grundtvig multilateral project under the Lifelong Learning Programme of the European Commission

It is undertaken by 7 partner institutions from 7 European countries: Spain, Finland, Italy, Latvia, Poland, Hungary and Bulgaria.

It runs from 01.11.2011 to 31.10 .2013

edusenior@uji.es

\begin{tabular}{|l|}
\hline \multicolumn{1}{|c|}{ Needs } \\
- An ageing society; in 2020 more than $20 \%$ of \\
Europeans will be 65 or more \\
- A lack of research and practical guidance that \\
link education, quality of life and senior citizens \\
- Institutions working with seniors that wish \\
to (re)design their educational programmes to \\
impact seniors' lives positively
\end{tabular}

\section{Aims and objectives \\ - Tooffer a scientificframework for the relationship between education and quality of life amongst the elderly \\ - To increase the skills of staff, technicians and teachers working in education for senior citizens \\ - To produce a positive impact on seniors' lives through education}

\section{Process}

1. Research into senior citizens in the European social context, their requirements, needs and risks

2. Analyse the relationship between education and quality of life and the potentialities of education to impact seniors' quality of life information gathered and experience

4. Test and improve the guide and evaluation toolkit

5. Disseminate results among decision-makers, academia and other institutions and networks http://www.edusenior.eu

3. Produce a guide and evaluation toolkit based on
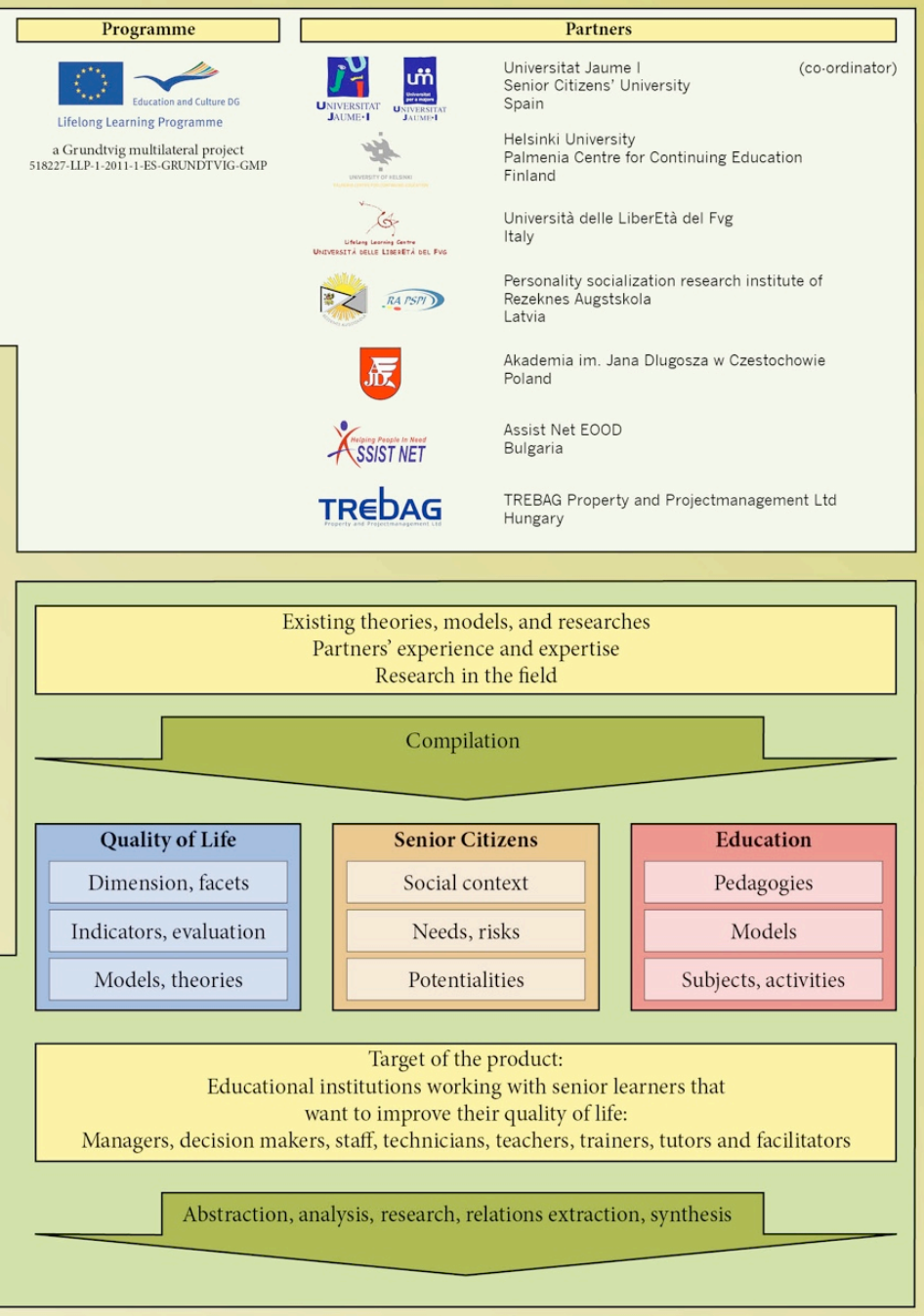

\section{Outcomes and products}

1. A practical guide for institution staff aimed to increase their knowledge and competences

2. A practical evaluation toolkit designed to assess an educational process, identify areas for improvement, and provide recommendations and accreditation

\section{Estimated impact}

- More skilled institution staff, wider reach of institutional aims to impact on senior learners

- Better quality of life for seniors; increased well-being, perceived control and integration

- Society with more active and participative senior citizens. Lower social services expenditure

Design and content by the Senor Citizens' University Universitat Jaume I

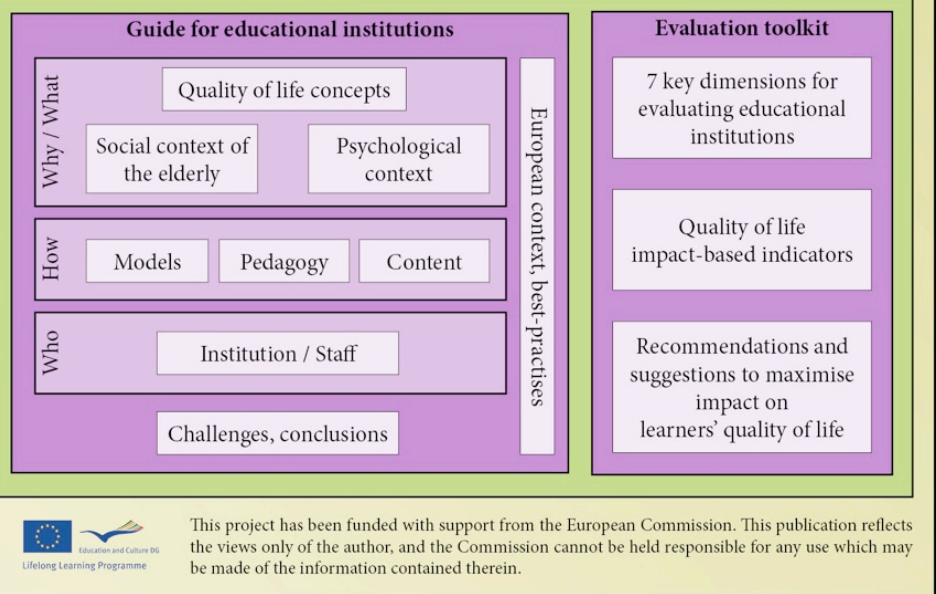

Figure 1. General overview of the QEduSen project 
The second product of the guide is an evaluation toolkit, that is a tool that can be applied in any institution with the aim to evaluate the effectiveness of the educational action impacting the seniors' QoL.

This toolkit can be used as a way of accreditation for any institution, getting by this way a value on which it can be measured, but also as a way to get feedback to improve the weaknesses and getting advices. The toolkit is a very practical tool, as it provides for each indicator a justification and recommendations.

\subsection{Conclusion}

A person's QoL has objective and subjective factors. When basic requirements for living are covered and there are not severe physical or psychological challenges, then it becomes more subjective. It is more related to the personal believes, attitudes, our relation with our environment and our perceived control. All those aspects can be modified thanks to education, but that is not a easy task, neither it can be achieved in short time,

The benefits of having a good QoL is not only beneficial for the individual, but also for the society, that can benefit from a senior more active and participative, also generating less expenses to the society, lowering the chances for depression or illness.

\subsection{Acknowledgments}

The QEduSen project "Evaluation toolkit on seniors education to improve their quality of life" is supported by the Lifelong Learning Programme of the European Commision with reference 518227-LLP-1-2011-1-ES-GRUNDTVIG-GMP from October 2011 to September 2013 
You can find more information about this project in http://www.edusenior.eu and about the LifeLong Learning Programme of the European Commission at http://ec.europa.eu/education/lifelong-learning-programme.

This project has been funded with support from the European Commission. This communication reflects the views only of the author, and the Commission cannot be held responsible for any use which may be made of the information contained therein.

\subsection{Bibliography}

Cummins, R. A. (1997). Comprehensive quality of life scale : adult: manual (5th ed. (ComQol-A5).). Burwood Vic.: Deakin University School of Psychology. Retrieved from http://www.deakin.edu.au/research/acqol/instruments/comqol-scale/comqola5.pdf

Escuder-Mollon, Pilar, Esteller-Curto, R, Ochoa, L \& Bardus, Massimo (2013) Impact on Senior Learners' Quality of Life through Lifelong Learning. Procedia Social and Behavioral Sciences. Inprint.

QEduSen (2013). Analysis of requirments. Available at http://www.edusenior.eu Rapley, Mark (2003) Quality of Life Research. A Critical Introduction, London: Sage Schalock, R. L. (2000). Three Decades of Quality of Life. Focus on Autism and Other Developmental Disabilities, 15(2), 116-127. doi:10.1177/108835760001500207

WHO. (1997). WHOQOL. Measuring Quality of Life. World Health Organisation. Recuperado a partir de http://www.who.int/mental_health/media/68.pdf 


\section{IMPACTO DE LA CALIDAD DE VIDA DE LOS MAYORES A TRAVÉS DE LAS TIC. CONCEPTOS Y METODOLOGIA PARA UNA ACCIÓN EDUCATIVA}

Autores (por orden de publicación)

Pilar Escuder-Mollon

Capítulo de libro, incluido en:

Publicado en: Active Learning methods and New Technology in Adult Education, University of Economics and Administration in Bytom, Polónia, 2010,| ISBN: 978-8388587-38-2

\section{Resumen}

A person's quality of life depends in the 1rst place on whether or not their basic needs are covered. Once these needs are met, other factors then affect quality of life (QL), such as integration, communication, recognition, self-ful llment, etc. Seniors' knowledge and use of information and communication technologies (ICT) have a positive impact on their QL, contributing to the aforementioned factors, and also minimizing others such as loneliness, exclusion, isolation, etc. A person's QL is a subjective value that can be evaluated qualitatively: the in uence of QL is per- ceived by the person. This article clari es the concept of QL, and analyzes the factors that modify QL together with the potentials of ICT. The paper presents a case study and an evaluation of senior learners (over 55 years old), which reveals how their perception is subjectively modi ed. Results show the positive impact that learning, using and participating through ICT has on seniors 


\subsection{Introducción}

En un estudio que pretenda relacionar los conceptos de "nuevas tecnologías" o TIC (Tecnologías de la Información y la Comunicación) y el de Calidad de Vida (en personas mayores, para el caso que nos ocupa) procede, previamente, un acercamiento a dichos conceptos con el $\mathrm{n}$ de saber a qué nos estamos re- riendo y evitar así confusiones terminológicas, de referencia o adulteraciones en las conclusiones del estudio.

Respecto a Calidad de Vida, es un concepto que se ha prestado a diferentes y numerosas interpretaciones desde que se acuñó el término a nales de los años cincuenta para referirse al medio ambiente, al deterioro de las condiciones de vida urbana y a las consecuencias de la industrialización de la sociedad, de forma que "la investigación sobre Calidad de Vida es importante porque el concepto está emergiendo como principio organizador que puede ser aplicable para la mejora de una sociedad como la nuestra, sometida a transformaciones sociales, políti- cas, tecnológicas y económicas" (Schalock). De esta manera, la Organización Mundial de la Salud ha propuesto una de nición de consenso: "la percepción por parte del individuo de su posición de vida en el contexto de cultura y sistema de valores en relación con sus objetivos, expectativas, patrones y preocupaciones" (WHOQOL). Por ello hemos de contemplar dentro de la de nición de Calidad de Vida factores tanto personales (salud, satisfacción de vida, independencia,...) como socioambientales (redes de apoyo, servicios sociales, etc.), siendo, a nues- tra consideración, la participación social signi cativa un elemento especialmente relevante.

En el caso de las personas mayores la educación permanente (entendida como una actividad psicosocial) parece ser de gran importancia para mejorar su cali- dad de vida, pues facilita procesos de interacción personal en los que se adqui- eren papeles activos en actividades que son percibidas como bene ciosas. Ahora bien, en este proceso de (re)integración de las personas mayores en la "sociedad postmoderna de la comunicación" y su implicación como miembros activos, nos encontramos con un problema de fondo: la denominada brecha digital. Con este concepto se pretende de nir la desigualdad que se genera como consecuencia de que determinados grupos de 
ciudadanos no puedan integrarse en las nuevas tecnologías, quedando así excluidos del acceso, asimilación y uso de los frutos de la revolución tecnológica de los últimos años, siendo los mayores y discapac- itados los principales afectados.

Por ello, la "alfabetización digital" de personas mayores como parte del proce- so de educación permanente, aunque tenemos presente que tanto las di cultades digitales como la educación permanente debe de ser para todos/as, independi- entemente de su edad, parece que puede potenciar su participación social signi - cativa, fortalecer sus redes de apoyo social, su autoestima, y hacerlos partícipes de las ventajas materiales que las TIC pueden aportarles; en de nitiva, mejorar su Calidad de Vida.

\subsection{Antecedentes}

Aunque existen numerosos estudios sobre Calidad de Vida o sobre el uso de las TIC, resulta difícil encontrar datos relevantes que relacionen ambos ámbitos y más aún cuando el objetivo de nuestras consideraciones se centra en las personas mayores. Sin embargo, antes de emprender el estudio que aquí nos proponemos, conviene tener en cuenta los antecedentes que nos aportan estudios previos sobre Calidad de Vida en personas mayores por una parte, y del uso de nuevas tec- nologías por otra.

\subsubsection{CALIDAD DE VIDA}

Una de las características que de nen las sociedades desarrolladas actuales es el progresivo envejecimiento de la población y el incremente de la esperanza de vida, por lo que las personas mayores adquieren cada vez más peso demográ - co aunque su presencia y relevancia social no es siempre equivalente. En el caso de España, según datos del Instituto Nacional de Estadística con fecha del 2004, la esperanza de vida es de 83'8 años en mujeres y 77'2 años en varones, siendo un total de 7 millones el número de personas mayores de 65 años (el quinto puesto de la UE en cifras absolutas y el quinto del mundo en cifras relativas), mientras que las previsiones para el año 2050 sitúan a España como el país más viejo del mundo con un total de 12’5 
millones de personas mayores, lo que supondrá un tercio de la población total, siendo octogenarios un $10 \%$ sobre esta cifra.

Ante estos datos, cabe preguntarnos en qué medida un envejecimiento tal de la población va acompañado de la necesaria de fomentar la calidad de vida que, de forma natural, se requiere en los estados de bienestar. En este sentido, convendría detenernos en cuatro elementos destacados relacionados con el bi- enestar social de las personas mayores: la jubilación, el nivel de ingresos, los problemas de salud, y la soledad en los mayores.

Respecto a la jubilación, adquiere importancia el considerarla como un instrumento de plani cación que elude la consideración del bienestar individual de las personas al priorizar argumentos de tipo económico relacionados con el em- pleo pues, de hecho, se anticipa o retrasa la edad de jubilación a conveniencia del sistema económico. Según el estudio realizado por la Asociación de Economía de la Salud (FernándezBolaños) en 2005, "la jubilación afecta de manera signi - cativa a la valoración que los jubilados hacen tanto de su calidad de vida como de su salud", pues ésta les permite disponer de más tiempo libre para las re- laciones personales o para hacer actividades que querían realizar pero para las que antes no disponían de tiempo su ciente. Por otro lado, aspectos negativos destacados son los períodos de depresión y el envejecimiento acelerado que ésta conlleva (CES), o la variación que se genera en los ingresos.

Es, precisamente, la merma en el poder adquisitivo de las personas may- ores uno de los problemas importantes que atañen a su calidad de vida, siendo la combinación "mujer, muy mayor y viuda" el mejor predictor estadístico de pobreza en España, pues las pensiones medias por jubilación y por viudedad son de 718'91€ y 475'51€, respectivamente (CC.00., 2006) y, en el caso de la provin- cia de Castellón, por debajo de la media nacional.

En lo referente a los problemas de salud, es de destacar que, a nivel nacio- nal, el 59\% de personas discapacitadas son mayores de 65 años, mientras que en la Comunidad Valenciana el $30 \%$ de personas mayores tiene algún tipo de dis- capacidad, destacando los problemas para desplazarse, utilizar brazos y manos, para ver y para oír (INE, Encuesta sobre discapacidades, 1999). Obviamente, el número de personas 
dependientes es considerable entre las personas mayores, con las consiguientes de ciencias en su calidad de vida: el $12 \%$ de los mayores tienen una dependencia grave/moderada de otras personas para realizar activi- dades cotidianas, y el $26 \%$ una dependencia leve. En estos casos se pre eren los cuidados informales frente a los institucionales, pero las mujeres son quienes principalmente desempeñan estos papeles de cuidadores; sin embargo, el prob- lema se revela más preocupante al existir un 6'7\% de personas mayores discapac- itadas que viven solas en el hogar.

Como hemos mencionado, la soledad es uno de los grandes problemas que afectan a las personas mayores, pues un 60'3\% de ellas viven solas, según da- tos del INE. En este sentido, la edad y el sexo son variables clave para analizar la soledad de las personas mayores.

En de nitiva, los procesos vitales que más se encuentran ligados a las perso- nas mayores y que afectan considerablemente a su calidad de vida son: el retiro de la actividad laboral, la obsolencia de conocimientos, la pérdida de familiares y amistades, la disminución de responsabilidades familiares y el deterioro físico y/o psíquico. En este contexto, las actividades que más destacan entre las perso- nas mayores, según datos del CIS son ver la televisión, pasear, hacer compras, oír la radio y leer, mientras que en los niveles de participación social predominan el mantenimiento de las relaciones más próximas (familia, amistades) y las tar- eas de apoyo al hogar de los/las hijos/as. La predominancia de actividades que se desarrollan en soledad y la escasa participación en entidades sociales o aso- ciativas por parte de los mayores tienen como consecuencia la mayor incidencia del aislamiento social que, sin embargo, puede ser suplido mediante el ejercicio de nuevas actividades y la implicación en procesos de educación permanente en terrenos como las TIC.

\subsubsection{NUEVAS TECNOLOGÍAS}

En lo referente a las nuevas tecnologías y las TIC, la mayoría de estudios real- izados sobre personas mayores giran en torno a la incidencia y difusión que éstas tienen 
entre el segmento de la población que aquí nos ocupa, así como los usos y frecuencias de utilización.

Según el estudio realizado por el Media Planning Group la televisión es el soporte fundamental de información y entretenimiento en las personas may- ores, siendo el consumo televisivo de mayores de 55 años superior al de la media nacional. Por la tarde/noche destaca la audiencia de mayores de 55 años, y de madrugada la de mayores de 65 años. Respecto al tipo de programas con- sumidos destacan, por este orden: concursos, telenovelas, películas e informativos. Datos de la Fundación AUNA (Miranda de Larra) muestran que el 98'5\% de los mayores tiene televisor en casa, el cual supone su actividad principal: un 84'9\% la ve todos los días, el 50\% entre 1 y 3 horas diarias, y el 25\% más de cuatro horas al día. Respecto a la radio, el consumo por parte de los mayores es inferior a la media nacional para la mayoría de países europeos, no así para España, con un predominio de la franja horaria matutina.

En lo referente al uso del ordenador, según datos del INE (Encuesta de Tec- nologías de la Información en los Hogares, 2003) el acceso por parte de los may- ores se sitúa en un $25 \%$ en lugares de trabajo y un $85 \%$ en la vivienda. Respecto a los usos, el estudio del INE destaca el de procesadores de texto, bases de datos y programas de tratamiento y reproducción de imágenes y sonido. En el mismo sentido se revelan los datos aportados por el estudio de la Fundación AUNA, según el cual, aunque los mayores utilizan el ordenador en menor medida que el resto de la población (sólo el $10 \%$ de los mayores tienen un ordenador personal, frente al 30\% del total de la población española, y sólo el 3\% lo usan personal- mente), un 41'7\% hace un uso diario del ordenador y un $371 \%$ al menos una vez por semana, destacando las siguientes aplicaciones: procesadores de texto (63\% de los usuarios), Internet (60\%), bases de datos (46\%), visión/edición de fotos, vídeos, dvd, música (41\%), hoja de cálculo (33\%) y juegos (24\%). El mismo estudio aporta datos sobre las razones esgrimidas por los mayores para no usar el ordenador: un 51'1\% consideran que son demasiados mayores para aprender a manejarlo; un 31'6\% mani estan falta de interés y sólo un $26 \%$ lo considera necesario (frente al 52\% de la media nacional).

En lo referente al uso de Internet, según datos del estudio realizado por Nielsen/NetRatings (septiembre 2003) el crecimiento más rápido de usuarios a nivel europeo se sitúa en el segmento de edad de mayores de 50 años, con un índice de 
crecimiento del 28\% en un año, y un predominio de visitas a sites con información nanciera y mapas. Así, según David Day, vicepresidente de Nielsen/NetRatings, su estudio "demuestra que cada vez es mayor el número de internautas mayores de 55 años. Los propietarios de portales cada vez tienen más oportunidades de promocionar sus productos y servicios a este público que, en muchos casos, ya utiliza las redes para organizar sus nanzas y efec- tuar reservas de vacaciones". En este sentido, la Fundación AUNA (Miranda de Larra) a rma que el 60\% de mayores que usan el ordenador acceden con fre- cuencia a Internet, aunque sólo el 0’9\% del total de usuarios es mayor de 65 años y la penetración de Internet en este segmento de edad es del 1'5\%, frente al $34^{\prime} 7 \%$ de la media nacional. Respecto a la frecuencia de uso, el estudio a rma que el $73 \%$ accede a Internet al menos una vez por semana, siendo los usos pri- oritarios la comunicación/correo electrónico (63’9\%), buscar información sobre productos y servicios (61'6\%) y relacionarse con la administración (44'3\%). Por su parte, los principales motivos para no hacer uso de esta tecnología son: falta de interés (85'63\%), falta de acceso (37'42\%), elevado coste (14'43\%) y sensación de ausencia de seguridad (8’15\%).

Finalmente, la telefonía móvil es el recurso más valorado entre los mayores por considerarla necesaria para la vida cotidiana (36'2\%), frente al $26^{\prime} 3 \%$ del ordenador personal o el 13\% de Internet, según datos de la Fundación AUNA. La tasa de penetración de los teléfonos móviles es del 32\% en los mayores, lo cual supone situar a España en la cola europea, frente al quinto puesto si se considera la media nacional de todas las edades (69'9\%). Aunque las cifras de disponibi- lidad son las más elevadas entre las TIC para los mayores, su uso es poco fre- cuente, pues sólo el $27 \%$ es usuario habitual (18'2\% a diario), y el 43'2\% menos de una vez por semana.

El estudio de la Fundación AUNA aporta datos relevantes en torno a las barreras de exclusión que di cultan la penetración y uso de las TIC por parte de las personas mayores, las cuales se agrupan en cuatro ámbitos a considerar: funcionales o físicas, dimensión social, económicas y del entorno. Así, el 37\% de los mayores tiene di cultades para hacer uso de las TIC por problemas en las articulaciones y huesos, y el $35^{`} 4 \%$ por problemas en la vista y/o el oído. Así mismo, les resulta di cultoso utilizar las teclas especiales simultáneas al teclado ordinario del ordenador, o usar el ratón, y mani estan con asiduidad problemas para utilizar los teléfonos móviles por su 
tamaño, las dimensiones del teclado y la pantalla y el sistema de menús. La necesidad de procesos de edu- cación y formación, el elevado coste del hardware y del acceso a Internet y las variables geográ cas (entorno rural) son otros de los factores a tener en cuenta como barreras de exclusión que repercuten de forma claramente en la calidad de vida de las personas mayores.

\subsection{Justificación}

La aplicación de las TIC, en todos los ámbitos humanos, parece resultar especialmente irresistible. No obstante, la presencia de una tecnología cada vez más completa, compleja y con más posibilidades, no es sinónimo de un uso apropiado por parte de todos los sectores de población, que podrían sacar más provecho de ésta. No es de extrañar, por tanto, que en los últimos tiempos sea común oír hablar de una brecha digital, la cual supone la falta de posibilidades de acceso y uso a esta nueva tecnología por parte de ciertos grupos de ciudadanos, entre los que destacan las personas mayores.

Considerado lo anterior, no nos cabe duda de que el conocimiento, uso y posibilidades de acceso a las TIC por parte de las personas mayores puede influir positivamente en su calidad de vida mediante procesos de educación con- tinua que contemplen la alfabetización digital, pues si de algo estamos necesita- dos todos, pero especialmente las personas mayores, es de comunicación, ya que ésta es una de las más importantes capacidades de los seres humanos. Una de las consecuencias más implícitas que lleva consigo la idea de jubilación es la de soledad física o psíquica y es en esta época de la vida donde se tienen más perdidas; familiares, amigos y en el caso de las mujeres el llamado síntoma "del nido vacío". La vida social está cimentada sobre la comunicación entre sus miembros y, en la actualidad, los medios de comunicación, en particular Internet, pueden contribuir a la correspondencia de las personas mayores con su medio porque:

1. Facilita la interacción. Los datos estadísticos demuestran que la lucha contra el aislamiento y la soledad es un seguro de ralentización de la vejez. De esta manera, se 
puede conseguir la mejor realización personal y la mayor participación social, siendo la interactividad la característica fundamental de Internet y de la informática.

2. Facilita una mejor relación intergeneracional. Cada día más se insiste en la conveniencia de que tras la jubilación no se produzca esa ruptura brusca que conlleva no sólo perjuicios psicológicos para el jubilado sino también para la misma sociedad, puesto que se desaprovecha un cúmulo de conoci- mientos y sabiduría. Nuestros mayores son "memoria del pasado para ilumi- nar el futuro"; y creemos que con las nuevas tecnologías se puede promover el principio de solidaridad entre generaciones, fomentar el voluntariado de las personas mayores hacia los jóvenes a la hora de transmitirles sus conoci- mientos y experiencias profesionales o de otro tipo.

3. La actividad da vida. Creemos en un principio de actividad para cualquier edad, ya que la acción representa la capacidad de revaluar la personalidad. Toda actividad encierra vida y la capacidad de mantenerse activo median- te un proceso educativo de amplia cobertura social incrementa la felicidad y la autorrealización.

4. Mejora de la autoestima. Frente al tópico de la incapacidad de las personas mayores para emprender actividades nuevas o para aprender, la experiencia nos indica que el facilitarles las posibilidades para incorporarse a la socie- dad tecnológica les ayuda a desprenderse ellos mismos de tales prejuicios y, en consecuencia, a aumentar su autoestima: "Yo quería aprender cosas y ellos decían que yo no podía. Yo nunca había escrito a máquina ni usado el ordenador en mi vida. Mis nietos no pensaban que yo podía hacer esto. Les he probado que estaban equivocados y esto aún no ha terminado" (Expe- riencia presentada en el congreso AIUTA de Québec-2000).

5. Permite una mayor participación social y aportación creativa. El actual si- stema de preferencias económicas no deja mucho sitio en el juego social para aquellos que han entrado ya en la jubilación. La sociedad política, por su parte, es también propensa a olvidarse del segmento social de las personas mayores. Con Internet podemos tener una puerta abierta, un buen instrumen- to para propiciar un mayor grado de participación social: para dar respuestas propias, inventar re exiones sobre lo que pensamos y sentimos, conocer la realidad para hacerle frente y cambiarla. Correo electrónico, chats, cafeterías virtuales o encuentros en la red o viajes por el ciberespacio; a todo ello sería factible acudir si por circunstancias determinadas nos sentimos físicamente incapacitados para hacerlo de una manera presencial o no podemos hacerlo. 
Más aún, en nuestro mundo han surgido nuevas realidades como el comercio electrónico a través de Internet, videoconferencias, la telemedicina o las platafor- mas digitales. Hasta ahora, nunca nuevas tecnologías habían tenido un papel tan preponderante en la vida cotidiana, pues no sólo nos ofrecen todo tipo de información sino que nos sirven para comunicarnos con los demás, introduciéndose en todos los ámbitos de nuestra vida, y parecen tener, a nuestra consideración, una fuerte incidencia en la calidad de vida. Las personas mayores no pueden quedar al margen de este movimiento y por ello han de aprender también con las nuevas tecnologías.

Sin embargo, una tarea tal ha de tener en cuenta cual es el punto de partida, la realidad social de las personas mayores a fecha de hoy en nuestra sociedad, y cuál es su nivel de acceso y uso de las TIC, y cuáles los problemas a los que se enfrentan.

Por ello, para poder a rmar rotundamente la vinculación entre las TIC y el nivel de calidad de vida en las personas mayores, y para poder diseñar es- trategias de futuro e caces, junto con una contemplación realista del punto de partida hemos de con rmar o refutar la tesis expuesta mediante la pregunta que el presente proyecto espera contestar a rmativamente: ¿el uso de las TIC por par- te de las personas mayores tiene una in uencia real y efectiva sobre su calidad de vida? Y si es así, ¿en qué sentido?

\section{$34.4 \quad$ Objetivos}

Objetivo General:

- Estudio y análisis de la relación entre el uso de las nuevas tecnologías por parte de las personas mayores y su calidad de vida, y cómo ésta se ve in uida por aquellas, con el $\mathrm{n}$ de con rmar/refutar la importancia de las TIC en las actuales sociedades de la Información en su incidencia sobre el nivel de cali- dad de vida en personas mayores de 55 años.

Objetivos Específicos: 
- Aproximación a la realidad social de las personas mayores en nuestra sociedad actual, en relación con su calidad de vida.

- Adquirir un conocimiento aproximativo al uso de las TIC por parte de las personas mayores en nuestra sociedad.

- Aproximación al nivel de conocimiento/desconocimiento por parte de las personas mayores de las aportaciones de las TIC.

- Conocer si existe una evolución positiva, o no, del aprendizaje de las TIC por parte de las personas mayores.

- Conocer las di cultades con las que las personas mayores se encuentra a la hora de aprender y hacer uso de las TIC.

- Aportar datos a los educadores de cómo mejorar los procesos motivacionales y de aprendizaje de las personas mayores en relación con las TIC.

\subsection{Metodología}

La investigación que aquí nos hemos propuesto se ha centrado en un estudio sobre las personas mayores de 55 años en la provincia de Castellón, para lo cual hemos optado por la encuesta como forma estadística con la nalidad de obtener datos relevantes a tener en cuenta (Anexo I). Dicha encuesta consta de dos gru- pos de ítems: para el primero hemos utilizado como base el medidor del índice de calidad de vida propuesto por Mezzich, Cohen y Ruipérez; el segundo, de elaboración propia, versa sobre el uso de nuevas tecnologías.

PRIMERA FASE: ENCUESTA PILOTO.

Con la nalidad de comprobar la adecuación del cuestionario, en una primera fase éste ha sido realizado a una muestra de prueba constituida por estudiantes pertenecientes a la Universitat per a Majors de la Universitat Jaime I, lo cual nos ha servido de referencia para hacer una evaluación previa de la validez, claridad y e cacia de la encuesta propuesta. 
A fin de evitar sesgos en el resultado de la encuesta, y una vez comprobada la pertinencia del cuestionario, se ha procedido a una selección aleatoria de la muestra, en función de dos parámetros:

a. Lugar de residencia: Para obtener un resultado lo más adecuado posible a la diversidad territorial de la provincia de Castellón, y tener en cuenta la po- sible incidencia del entorno sobre la calidad de vida y el uso de las nuevas tecnologías, se ha decidido realizar la encuesta a un número signi cativo de personas en municipios de diversa índole y naturaleza: Castellón de la Plana, Vinaroz, Segorbe, Morella, Vilafranca y Sant Mateu.

b. Actividad: Considerando que el presente estudio no puede centrarse sólo en las personas mayores pertenecientes a programas de formación tales como la Unversitat per a Majors, dado que se conoce que el uso de N. Tecnologías se fomenta por las redes que se generan, haciendo que un grupo haga que otro aprenda, por ello; se ha procedido a una selección de la muestra que intenta re ejar la diversidad de actividades, ocupaciones, intereses, posibilidades y circunstancias que atañen a las personas mayores en la provincia de Castellón. Por eso, junto a estudiantes del programa de formación permanente de la Universitat Jaime I, se ha procedido a contactar con otro tipo de asociaciones de diferente índole a $\mathrm{n}$ de ampliar el espectro muestral. Finalmente, la selección de las personas encuestadas ha sido aleatoria, entre mayores pertenecientes a algún tipo de asociación o programa de formación, y personas ajenas a los mismos, en cada uno de los municipios considerados.

\section{TERCERA FASE: FORMULACIÓN DE LA ENCUESTA}

Una vez considerados los parámetros de selección muestral, se ha procedido a realizar las encuestas entre las personas mayores de 55 años en la provincia de Castellón, residentes en Castellón de la Plana, Vinaroz y Sant Mateu; y pertenecientes o no a cualquier tipo de asociación o programa de formación.

Para la formulación de los cuestionarios se han aprovechado los contactos previos en la fase de selección muestral, se han desarrollado desplazamientos a los lugares mencionados y se ha procedido a la encuesta mediante una selec- ción aleatoria de los encuestados en cada una de las situaciones posibles. A cada persona encuestada se le 
han formulado los dos ítems de preguntas, relaciona- dos uno con la calidad de vida y el otro con el uso de nuevas tecnologías, a n de obtener datos pertenecientes a ambos ámbitos por parte de las mismas personas.

Cuarta fase: Estructuración de los datos obtenidos y análisis de los mismos

Una vez realizadas las encuestas, y con el $\mathrm{n}$ de responder a la pregunta plan- teada de si el uso de las TIC in uye o no en la Calidad de Vida de las perso- nas mayores, y en qué sentido, se ha procedido a organizar los datos obtenidos. Así, tanto en el conjunto como en cada sección muestral, se ha intentado obser- var si existe una relación entre los ítems pertenecientes a calidad de vida y a los de uso de nuevas tecnologías; es decir, se ha intentado analizar si las personas que hacen un mayor uso de las nuevas tecnologías experimentan una percepción más positiva en su calidad de vida, o no, y cuáles son los motivos.

\subsection{CONCLUSIONES}

Finalizadas las cuatro fases mencionadas del Proyecto, algunas conclusiones pueden ser enumeradas a través de los datos obtenidos.

En este sentido, conviene destacar que el espacio muestral ha consistido, de forma de nitiva, en 225 personas encuestadas ( $\mathrm{N}=225)$, siendo la media de edad de las mismas de 64'7 años. Respecto al lugar de residencia, un 76\% de la muestra vive en zona urbana, un 14\% en zona rural de más de 2000 habitantes, y un 9\% en zona rural de menos de 2000 habitantes; mientras que si considera- mos la distribución de género, un $64 \%$ son mujeres y un $36 \%$ hombres. En lo referente a la ocupación, un 52\% de las personas encuestadas están jubiladas o prejubiladas, frente a un 14\% que continua trabajando; a su vez, un $31 \%$ son amas de casa. En cuanto al nivel de estudios destacan los Primarios (31\%), seguidos por los de Bachillerato/FP (20\%), Diplomados (19\%) y Secundarios (17\%), mientras que el porcentaje muestral sin estudios y licenciados es, en ambos casos, del 6\%.

Sobre la Calidad de Vida de las personas encuestadas, los datos que se bara- jan indican que la media de la percepción propia es de 7’4, en una escala formal del 1 al 
10 (re ejo de los valores extremos "Mala" y "Excelente"). Sin embargo, hay dos consideraciones a tener en cuenta: en primer lugar, que las personas que usan Internet de forma frecuente, muestran una mayor tendencia a manifestar una mejor percepción de su propia calidad de vida (7'85 de media, frente al 6'75 de aquellas personas que no hacen uso de dicha tecnología); y en segundo lugar, podemos con rmar que aquellas personas que viven en zonas rurales normal- mente tienen una peor consideración hacia las nuevas tecnologías y la mayoría de ellos creen que ellas son innecesarias para su vida diaria.

Respecto a las TIC, las razones esgrimidas por las personas mayores para no hacer uso del ordenador/Internet, parecen con rmar los datos previos y revelan parte de la naturaleza problemática de la "brecha digital". Estas razones son: Falta de conocimiento (49\%), Falta de interés (34\%), Imposibilidad de acceso (20\%), Alto coste (12\%) y sensación de falta de seguridad (7’9\%). Considerando estos datos, y si tenemos en cuenta que la "Falta de interés" en muchos casos viene derivada por una falta de conocimiento, observamos la importancia de los procesos de educación permanente en las TIC en las personas mayores. Más aún, si observamos las a rmaciones con las que las personas mayores encuestadas manifestaron estar de acuerdo, los datos estadísticos indican una buena consid- eración general hacia las TIC y la posible in uencia sobre su calidad de vida, por lo que los procesos de formación permanente no sólo son susceptibles de suplir esta falta de conocimiento, sino que también tienen el potencial de "crear interés" entre este sector de la población.

En este sentido, la buena consideración general hacia las TIC por parte de las personas encuestadas se rea rma cuando el $62 \%$ dice mostrar mucho o bas- tante interés hacia las mismas, y el $68 \%$ que éstas pueden in uir positivamente en su calidad de vida. No es de extrañar, por tanto, que el 88\% de los encuesta- dos usen algún tipo de tecnología (cámara digital, reproductor de MP3, Internet, GPS o PDA); que el 55\% haga uso de Internet, y que el 98\% de éstos lo haga en combinación con otras tecnologías, principalmente el teléfono móvil, que es la que se muestra como la más valorada y utilizada (73\%). Sin embargo, también es cierto que el $71 \%$ de los encuestados llevan utilizando Internet durante menos de cuatro años, lo que signi ca que muchos de ellos se encuentran aún en pro- ceso de aprendizaje; de hecho, el 67\% 
a rma aprender a usar Internet por medio de cursos de informática, lo que signi ca que su aprendizaje no es espontáneo ni por sí mismo, y que han recurrido a este medio por distintos motivos, entre ellos las demanda social, necesidades personales y de comunicación, u otros.

Respecto a los servicios más utilizados por parte de los usuarios de Internet, destacan los relacionados con la necesidad de obtener y manejar información (páginas web, 83\%), y los relacionados con la necesidad de comunicación (correo electrónico, 88\%), siendo, pues, los Informativos los contenidos más visitados (76\%). Estos datos parecen con rmar la necesidad de integración por parte de las personas mayores en la llamada Sociedad de Información. Como dato curioso, destaca que el 50\% de las gestiones realizadas son de tipo bancario y el $47 \%$ de compra-venta o intercambio de productos, lo que, a primera vista, indica un cierto grado de con anza en la seguridad de la red, si bien es cierto que los usuarios que realizan gestiones a través de Internet suelen corresponder a la minoría de usuarios que lleva más de cinco años haciendo uso de Internet por motivos laborales y que se encuentran a punto de retirarse o se han jubilado hace poco, es decir, que corresponden a la franja de edad más joven.

Finalmente, cabría considerar en qué sentido se mani esta esta mejora de la calidad de vida por parte de los usuarios mayores de nuevas tecnologías. Si consideramos las ocho necesidades básicas enumeradas por Schalock en su de nición de calidad de vida (bienestar emocional, relaciones interpersonales, bienestar material, desarrollo personal, bienestar físico, autodeterminación, in- clusión social y derechos), y analizamos las posibles relaciones entre cada una de éstas y el uso de las TIC, podremos entonces conocer la relación inherente entre nuevas tecnologías y calidad de vida, y el porqué las personas mayores que hacen uso de aquellas parecen tener una mayor percepción global ésta.

En la necesidad de bienestar emocional, pues, cabe destacar de forma importante el concepto de autoestima y, en este sentido, el aprendizaje y uso de las nuevas tecnologías (en especial de Internet) por parte de las personas may- ores parece tener la facultad de potenciar la "participación social signi cativa" y la posibilidad de sentirse integrados, no sólo en la Sociedad de la Información, sino con la familia y sus miembros más jóvenes. Simplemente el hecho autoperci- bido de que son capaces y 
pueden hacer uso de una tecnología que, en principio, generacionalmente les es ajena, puede incidir positivamente en su autoestima.

Respecto a las relaciones interpersonales, como hemos apuntado, los datos indican la preferencia por los servicios relacionados con la comunicación, lo cual aporta una mayor posibilidad a las relaciones interpersonales e intergeneracio- nales. En ciertas situaciones la falta de acceso a las TIC podría incluso impe- dir o di cultar dichas relaciones, y de aquí la importancia de la difusión y uso de la telefonía móvil y del correo electrónico.

La relación entre el bienestar material y el uso de nuevas tecnologías es más ambigua. Si consideramos dos de las dimensiones que se engloban dicho término podremos, sin embargo, establecer una relación con el uso de las TIC: el poder adquisitivo y el acceso a los dispositivos físicos. Respecto a la cuestión económi- ca, es de destacar que sólo el 12\% de los encuestados a rma carecer de conex- ión/equipo en el hogar por considerarlo muy caro, lo cual viene a con rmar la tendencia de los últimos años a la reducción de los costes de conexión y del mis- mo equipamiento. Es decir, si bien el uso de las TIC no repercute directamente en el aspecto económico del bienestar material, sí es cierto que el acceso a Inter- net y las nuevas tecnologías dependen cada vez menos de la situación económica. Más aún, el acceso es cada vez más fácil gracias a los organismos o ciales, si bien tenemos que distinguir entre las zonas urbanas, en las que es común encon- trar lugares de conexión pública, y las zonas rurales, en las que la disponibilidad es escasa; por tanto, en las primeras el bienestar material se encuentra cubierto.

La necesidad de desarrollo personal, en parte pero no sólo, también puede ser satisfecha por el uso de las nuevas tecnologías, ya que éstas pueden permitir la realización de determinadas inquietudes personales, de conocimientos, for- mación e información, actividades, contactos, etc. El conocimiento y el uso de las TIC facilita, así, las posibilidades de utilizar todos los medios posibles que en la actual sociedad están potencialmente al alcance para el desarrollo personal.

En lo referente al bienestar físico, las TIC no solventan los problemas de salud, pero ayudan a una mejor de calidad de vida ante una falta de bienestar físico, tal y como 
numerosos estudios y programas de investigación han con rmado repeti- damente en su aplicación, por ejemplo, a personas con discapacidad.

Por su parte, la autodeterminación, si la entendemos como la facultad per- sonal que posibilita la toma propia de decisiones, y la actuación en consecuencia, y si consideramos que el acceso a la información es un requisito indispensable para la toma consciente y efectiva de dichas decisiones, queda patente que las TIC, y en especial Internet, suponen un medio especialmente útil en dichos procesos, facilitando así el conocimiento del entorno y posibilidades para actuar sobre él.

La Sociedad de la Información, sin duda, recibe este nombre por la in uencia de las TIC en los contextos actuales, por lo que su conocimiento y uso tienen gran importancia para una inclusión social efectiva. No cabe duda, pues, que para entender el mundo en el que nos movemos, integrarse y sentirse parte de él, y ser capaces de dar respuestas a las demandas sociales que por el hecho de vivir en sociedad se nos exigen, es necesario, por lo menos, conocer las TIC.

Finalmente, respecto a los derechos, es de destacar que el ya mencionado derecho básico a la información y difusión de la misma "sin limitación de fron- teras, por cualquier medio de expresión" (Art. 19, Declaración Universal de Derechos Humanos), es facilitado gracias a Internet y a las TIC, por lo que para hacerlo efectivo en su totalidad parece necesario que no exista discriminación al- guna en las posibilidades de acceso a las mismas por razón territorial o de edad. En de nitiva, el acceso a las TIC facilita no sólo el cumplimiento del anterior derecho básico, sino también otros derechos inherentes a la persona.

En de nitiva, y como conclusión ante los datos obtenidos, podemos con rmar aquello que ya intuíamos al empezar el presente estudio, a saber: que el concepto de calidad de vida necesariamente ha de considerar tanto factores personales como socioambientales, entre los que las redes de apoyo y los servicios sociales tienen gran incidencia. Por ello, para mejorar la calidad de vida de las personas mayores hemos de intentar potenciar su participación social signi cativa, la cual, necesariamente, necesita en nuestra sociedad actual de procesos de formación permanente (Alfabetización digital) capaces de facilitar una participación tal, fortalecer las redes sociales de apoyo y su autoestima y, sobretodo, hacer partícipes a las personas 
mayores de las ventajas materiales que las TIC pueden ofrecerles, pues, de hecho, los datos parecen con rmar que existe una relación entre la percepción propia de calidad de vida y el uso (y por tanto, capacidad y conocimiento para ello), de las TIC.

\subsection{Bibliografía}

Ballestero F., La Brecha Digital. El riesgo de expulsión en la Sociedad de la Información. Madrid. Fundación Retevisión/AUNA. 2002.

Bermejo E., Dependencia y calidad de vida en las personas mayores. Rev. Mult. Gerontol 2005; 15(3): 144-154.

CIS. Centro de Estúdios Sociológicos. Apoyo informal a las personas mayores, Estudio 2072. 1993.

Hidalgo Á., Fernández-Bolaños A., Calderón M.J. et al. El impacto de la ju- bilación sobre la salud, la calidad de vida de las personas mayores y la utilización de servicios sanitarios. XXV Jornadas de economía de la Salud. Barcelona 2005.

Media Planning Group. Los mayores en Europa: la madurez del siglo XX, 2005.

Impacto de la calidad de vida de los mayores a través de las tic... 119

Mezzich J.E., Cohen N.L. and Ruiperez M. A., A quality of Life Index: brief de- scription and validation. International Congress of the International Federa- tion for Psychiatric Epidemiology. Santiago de Compostela. 1996.

Miranda de Larra R., Los mayores en la sociedad de la información: situación actual y retos de futuro. Cuadernos / Sociedad de la información 4. Funda- ción AUNA / France Telecom. Madrid. 2004.

Schalock R.L., Quality of Life. Aplication to Persons with Disabilities. Vol. I I (1996). pp. 43-61.

WHOQOL Group. Study protocol for the Word Health Organization Project to develop a quality of life assessment instrument. Qual Life Res 2(1993) 153- 159. 
SECION SEXTA

VALIDACIÓN Y CALIDAD 


\section{INDICATORS FOR QUALITY EVALUATION FOR THE DEVELOPMENT OF THE STAFF IN EDUCATIONAL INSTITUTIONS}

Autores (por orden de publicación): P. Escuder-Mollon ${ }^{1}$, R.Esteller-Curto ${ }^{1}$, E. Biffi ${ }^{2}, \mathrm{~K}$. Koutra $^{3}$

1. Universitat Jaume I

2. University of Milan Biccoca

3. Technological Educational Institute of Crete

Presentado en: ICERI2015 8th International Conference of Education, Research and Innovation, 18-20 noviembre, 2015, Sevilla

Publicado en ICERI2015 proceedings, páginas 1564-1568, ISBN: 978-84-608-2657-6, ISSN: 2340-1095

\section{Abstract}

The EduEval project is a project of the Lifelong learning programme of the European Commission (http://www.edueval.eu). During the first phase of the project, it was aimed to explore and understand how non-official evaluators performed the processes for quality increase in their own educational institutions. We focus on the staff development. In this paper we try to define indicators that make the evaluation process more systematic and verifiable, while on the other side, we add formality to a soft process that usually is performed by non-official evaluators and also includes personal dynamics and relations. We offer the EduEval model (self-assessment, external, and context evaluation) focused for community development, professional development and personal development.

Keywords: Evaluation, staff, education, professional development 


\section{$35.1 \quad$ Background}

Any institution that pursues the excellence and the highest quality when reaching their aims should follow a continuous quality process and evaluation. In this paper, we focus in the educational institutions, therefore this evaluation can be performed in a variety of ways, depending if the evaluation is needed for an official accreditation (usually when validating any of the processes or results because of law requirements), a standard industry-based quality system (as EFQM or ISO 9001) or other evaluation methods performed because of internal or external needs that can help to increase the quality of the results, assist the decision making or help the development of the staff.

In the EduEval project, we focus on this last issue: the evaluation for the development of the staff in educational institutions. The reason of choosing this target is motivated because the teaching-learning processes and all the services and activities that frame that work have a high human component. There, not only the skills and capacity of the staff is important, also the context, the dynamics and the relations among all people involved on training affects how the education is delivered, and therefore, affects the quality.

We understand education from a wider perspective. Therefore educational institutions are not only those focused to offer training courses, but also educational projects, as it can happen in disabled people services, rehabilitation services, intercultural integration services, community centres, inmates custody services, etc. We wanted to consider the education that is performed in a formal, non-formal and also informal way.

In this kind of educational institutions, the staff have a very important role. They are the one that keeps direct contact with the learners, but also influences them by trying them to acquire skills, competences and attitudes. In this project we believe that for the quality of institutions it is important to evaluate the staff from a positive 
perspective, always for improving and their development. If they can make their work more effectively and with highest quality, then the overall quality of the institution processes and results effectiveness will also increase.

\subsection{Research}

This papers' results are based on two activities of the EduEval project. The first is the workshop performed in Creta (Greece) on July 2014, the second are the training activities and the feedback of the practitioners during the testing phase, May-June 2015.

\subsubsection{WORKSHOP}

The main aim of the workshops was to share theories and practices about the evaluation of adult education staff, including practitioners and researchers, in order to build up collaborative knowledge. The summary and results of the workshop can be obtained from the wiki as those are public [2]. During the workshop it was observed that the non-formal level evaluation can have some similarities with more strict procedures of quality and accreditation, as it could include also observation, surveys, interviews, etc. by somebody that later will emit a judgment, but it was observed that the main task and work done in related to evaluation in institutions was done daily, as a routine, in the usual and ordinary processes of the educational institutions, those could be also merged with other processes as project monitoring, risk assessment, planning, management, and even teaching itself. For this reason, we called it the "intraevaluation" process [1].

This intraevaluation process was so very well integrated in the own daily procedures that it has obvious implications, as opposite to more official evaluation systems (focused to external accreditation or assessment). These implications were because of the tight relation between the role of the staff and the evaluation done, having direct impact as the plan-do-check-action cycle or the continuous quality increase. On the 
opposite, this level of evaluation, relies very much on the staff and trainers that are very motivated and with huge experience in the institution, and that even could be misunderstood as selfevaluation, the intraevaluation has more to do with and evaluation which source is the own experience and expertise of the staff and is applied to the range on which the staff could have some effect.

\subsubsection{FOCUS GROUP}

Trainers, managers and coordinators (10 in total) were meet to understand the intraevaluation processes in their work. That is the evaluation processes that already existed in their work environments (formal, non-formal and informal). The most obvious were the ones linked to the ISO 9001, EFQM or indicators needed for accreditation. We wanted to focus on those that are related on the personal development of the staff, and we noticed that firstly it was necessary to clarify what is "personal development", and under which perspective it should be observed. The second topic to analyze was the indicators that should be considered when evaluating and improving the staff development. Mostly appeared subjective not measurable indicators, that are described afterwards.

\subsection{Indicators' context}

Indicators could be originated because of internal needs or external regulations. Example of an indicator that is caused because of a policy regulation could be "Number of students that finish the degree compared to starters". If the indicator is created because it exists an aim in the institution, then it could be "Average score of the learner satisfaction in the extra-academic activities". No matter if the need of the indicators has been originated because of internal or external needs, it must exists always a need or a purpose. 
The indicators should be relevant to the strategic aims of the institution, objectives or policy-level requirements. From now on, we are not going to differentiate if the source of this need is internal to the institution or external.

It must be useful; some indicators are mandatory because of policy-level requirements, other could provide management information about the quality level of what is being evaluated or to help for decision making.

Convenient, that is created because of a need, based on the strategic or operational aims of the institution (internal need) or because of a policy-level requirement (external need)

By creating an understandable indicator we will make possible that people accepts it more easily. Simplicity here is an advantage. Complex indicators should be avoided; those are difficult not only to understand the meaning, but sometimes, to know how to apply them.

A good indicator should be comparable, if so, then it is possible to know the evolution over years, or between departments or institutions.

The best indicator would be the one that is originated faithfully from the strategic aims of the institution or the policy regulations, but sometimes, when doing that, it results to an indicator that is difficult to process or obtain; it could involve a long term process, gather a lot of information that is difficult to access or process or even involve so many people that makes the indicator very expensive to obtain. An economical indicator should have a good ratio benefit/cost.

An indicator can be quantitative and qualitative, but in any case, we should obtain a value. A quantifiable indicator makes easy the later post-processing (as grouping indicators or compare over years) but also to communicate with management or the members of the staff

By agreed we mean, that as far as possible, the indicator definition and its way to be obtained should be agreed by all people involved. When this agreement is not possible, at least it is good they are conveniently informed and the selection of the indicator is justified. The evaluation and quality management involve at the end 
human resources. They will be more motivated for improving and participate in the evaluation process when they agree with the indicators chosen.

In the whole evaluation process, indicators should not be confidential but communicated. When results of evaluation are reported, the way the evaluation has been made should not remain obscure, but transparent. Only by this way, it will make that staff trust the results and provide confidence to the conclusions of the evaluation report.

Indicator should be defined trying to fulfil previous attributes, and should include information about how it should be calculated, when, who, and which is the source of information.

The basic reason of having indicators is because of the principle in that what we want to improve, it needs to be measured. By measuring things we will know the effectiveness of a process, predict the future evolution and to take decisions.

Indicators are created and defined because there is some kind of requirement. The need could have several origins, following are the most common:

- Strategic aims of the institution, or operational objectives for a specific department or service. Firstly the indicators can be used to verify that the aims or objectives are fulfilled. Secondly, indicators can also provide information about quality and progress, begin a source of information for decision making. Example of a strategic aim is: "We should target the excellence on the pedagogy-based technology". It is possible then to create several indicators, as "Average number per year of courses/conferences that staff attend related to technology enhanced teaching" or "drop out rate in e-learning courses"

- Policy regulations. There could be some aims that are mandatory because of policy regulations or contracts among institutions, for example, it could exist a regulation saying that "at least, $1 / 5$ of the classes should be in English", then the indicators can be used to verify that this is done correctly.

- The institution offers a charter of services. This is a document where an institution informs to the users about the services that offers and about the quality of those services. It can be seen as a commitment between the 
institution and the clients or users. Example of an item in a charter of services is: "we will give a reply to any user inquiry in less than 3 days". This item in the charter of services would then originate an indicator: "average time when replying a question, suggestion or complain made by a user"

\subsection{Indicators}

As said before, the centre of the EduEval project is the evaluation for the personal development. This is a completely personal and subjective perception; what is personal development for one person, could be different for other. Fortunately, we focus on the enterprise environment, or at least, inside an institutional framework driven by strategic and operational aims. In this context, the personal development is considered to be, based on the common points extracted during interviews in the focus group research phase:

- Professional grow, with the possibility to increase on the responsibilities and ascend on the hierarchical structure of the institution based on the personal skills and capacities.

- Support and help, from colleagues, heads and external resources staff, mostly when dealing with difficult or unknown situations.

- Valorisation, which is different than reward. We consider than valorisation is the fact of recognition of the work done and also with the capacity of being useful and profitable, seeing the results and the effects

- Training and improvement, to be able to perform the work more effectively and without mistakes. Learning new tools, techniques or methods.

- Participating in decisions. When possible it is good the staff to provide feedback or could participate (or at least, suggest) from the institution decisions that affect the way the daily work is managed and organised. 
Based on previous criteria, we propose following indicators. We are aware that those do not fulfil completely the requirements that an indicator should have, these are mainly qualitative, and their measurement is subjective, but those should be used in institutions to later define more precisely depending on the specific context of the institution:

- Practises and the experience of the staff is stored and shared among all the team, with possibility to improve this resource (transfer of skills and synergies)

- Staff can collaborate (suggest) on the management of the organisation.

- The routines and own organisation of the staff is agreed by all the people affected. When decisions are made by the manager, staff if consulted.

- There exists training opportunities for trainers, participating in exchange programs and publishing and innovating (address gaps in knowledge)

- There exists a well-know criteria and processes when a position is vacant or is needed to be covered by other person of the staff. Is there a way somebody can reach the own potential?

- The results of the staff work are visible and identifiable outside the institution.

- Is there a process for the personal development?, it can be a file to record the each one individual aims and objectives, and how to achieve that. Each person can decide to share it or not, while other people can collaborate to help him/her. Support from management should be provided to implement this plan.

\subsection{Conclusions}

The institutions tend to assess and evaluate the quality and impact of the results (that is the product) of their activities, in educational institutions are the courses and the 
training activities, in this context, the main source of information is are surveys or questionnaires obtained from the target or users. The processes could be also evaluated and improved, making those more effective. The evaluation then can be used as a source for management, helping the decision-making. While the reduction of costs, increase of impact, image, efficient of processes and general quality of the product are the most common aims when performing a quality assessment. The staff is seen as part of the process in any of the organisation chain to get a purpose, it is not seen as a process itself, and we consider that it should be observed and evaluated as a human resource with their own input and output, that is a process, which is not directly affect by the institution aims (although those are very important) but personal motivations, interests and links with other people.

The quality assessment and improvement of the personal development of the staff, helps to increase the quality of the education and therefore should be taken into account.

\subsection{Aknowledments}

This work has been produced in the framework of the project "Evaluation for the Professional Development of Adult Education Staff". This project has been funded with support from the European Commission. This communication reflects the views only of the author, and the Commission cannot be held responsible for any use which may be made of the information contained therein. Project reference: 538743-LLP-12013-1-IT-GRUNDTVIG-GMP, website: www.edueval.eu

\subsection{References}

[1] R. Esteller-Curto, P. Escuder-Mollon, E. Biffi, K. Koutra, R. Escamilla (2015). Experiences from EduEval project; the intraevaluation processes. 7 th 
International Conference on Education and New Learning Technologies.

Barcelona - 6th - 8th of July 2015

[2] Practioners' publication. EduEval Project. Available on-line http://wiki.edueval.eu/

[3] European Foundation for Quality Management (2012). Belgium. http://www.efqm.org/

[4] Moen, R., \& Norman, C. (2006). Evolution of the PDCA cycle.

[5] Egetenmeyer, R., \& Nuissl, E. (2010). Teachers and Trainers in Adult and Lifelong Learning: Asian and European Perspectives. 


\section{BEYOND QUALITY ASSESMENT TOOLS; POTENTIALITIES OF QEDUSEN EVALUATION TOOLKIT}

Autores (por orden de publicación): P. Escuder-Mollon ${ }^{1}$, R.Esteller-Curto ${ }^{1}$

1. Universitat Jaume I

Presentado en: ICERI2013 6th International Conference of Education, Research and Innovation, 18-20 de noviembre de 2013, Sevilla

Publicado en ICERI2013 proceedings, páginas 4115-4119, ISBN: 978-84-616-3847-5, ISSN: 2340-1095

\section{Abstract}

It is common to evaluate and assess learners' achievements in knowledge and other skills and competences. This evaluation is commonly done based on the level of achieveness. On the other hand, it is also common to evaluate institutions in terms of the impact and success of their learners. Evaluation in institutions is an important issue because it is a formal source of information for internal and external accreditation and to increase the quality and impact of the institution. An evaluation procedure allows management to know the general status of the institution and take any corrective action to improve it. The European project QEduSen (Evaluation toolkit on seniors education to improve their quality of life) has produced a toolkit that can be used to assess the institution when offering educational activities to senior learners. In this paper we introduce how the evaluation tool was produced specially after the testing phase, when new uses have been uncovered. An evaluation toolkit, when correctly designed, is a very powerful took, useful not only to increase the quality of educational institutions, but as in the case of the QEduSen project for other processes related to validating, guidance, learning, management, research and policymaking. 
Keywords: evaluation, assessment, quality, seniors' education, quality of life

\subsection{The QEduSen Process}

In the European project QEduSen (Evaluation toolkit on seniors education to improve their quality of life), 7 institutions have been collaborating since November 2011 to create an evaluation tool that could be applied to educational institutions to improve their quality. The framework of this evaluation tool, and therefore, the context on which the educational institutions was going to be evaluated would be in the effectiveness when providing courses, activities or any other educational activity to senior learners.

Senior learners (over 65 or retired) do not aim to improve in their work or acquire job skills. Their motivation to keep learning is mainly personal, and the senior educational institutions, offer courses aimed to keep them up to date in an always changing society, to be integrated and active, with social contacts and participative. The most common aim target is to increase the well-being and quality of life of the senior learners.

The Quality of Life (QoL) then becomes an agreed target to be reached. There exist theories and models about QoL with no consensus on a definition, but with a common agreement that QoL has objective and subjective components, also based on cultural and environment status, composed by dimensions and facets. Cummings (in Rapley [10]) states that when basic needs are covered, most people fall into 70\%-80\% life satisfaction range; no higher life satisfaction has been reported from studies comparing groups of people with different health or income levels. In that people (with basic needs covered) the QoL has mainly subjective components, which can indeed be increased thanks to education. The QoL can be decreased because of external factors (provoking the loose of control). The education can help to increase protective skills to keep optimism, motivation and perceived control high.

When The QoL is composed by several dimensions (depending on the theory), the most agreed dimensions are: physical, psychological, social relationships and 
environment considering the WHO tool [13]; material well-being, health, productivity, intimacy, safety, community, and emotional well-being considering Cummings 0 , or personal development, self-determination, interpersonal relations, social inclusion, rights, emotional well-being, physical well-being, material well-being by Schalock [12]. A more detailed research about the QoL dimensions can be found in the project website http://www.edusenior.eu [14].

Among all QoL dimensions and facets, some of then are more relevant for senior citizens (depending on the social context, risks, potentialities) and also can be easily impacted thanks to education, those are: physical health, psychological health, integration, participation, control (perceived control, primary and secondary), personal growth (optimism motivation, energy), personal fulfilment ( spending time usefully, fruitful activity). Research and analysis done during the first phase of the project and published in http://www.edusenior.eu and [15], [16], [17] can be read to know in detail how the dimensions where extracted. Only those dimensions where considered when trying to define which educational activities should be implemented to impact the seniors QoL.

The main tool used for education when trying learners acquire competences, knowledge or skills is through courses or activities. But in the QEduSen project, we found that there are other aspects related to educational institutions than can be used to impact the senior learners, those are: Institution (premises, but also how services are offered and organised), management and organisation, educational models (formal, informal, non-formal, but also the framework of the educational activities), pedagogies, courses, activities, and staff and trainers roles and competences.

Based on the educational and QoL dimensions, 38 educational characteristics were extracted (Table 10)

Table 10. the 38 Characteristics that an educational institution should meet considering the senior learners QoL

\begin{tabular}{lr|c}
$\begin{array}{l}\text { 39. Accessibility } \\
\text { 40. Meeting points }\end{array}$ & 52. Intergenerational \\
$\begin{array}{l}\text { 41. Spaces } \\
\text { participation }\end{array}$ & for & 53. Constructive \\
42. Institutional & self- & 5edagogy \\
54. Learn by research
\end{tabular}

66. Social meetings

67. Artistic performances

68. Volunteering as a social contribution 


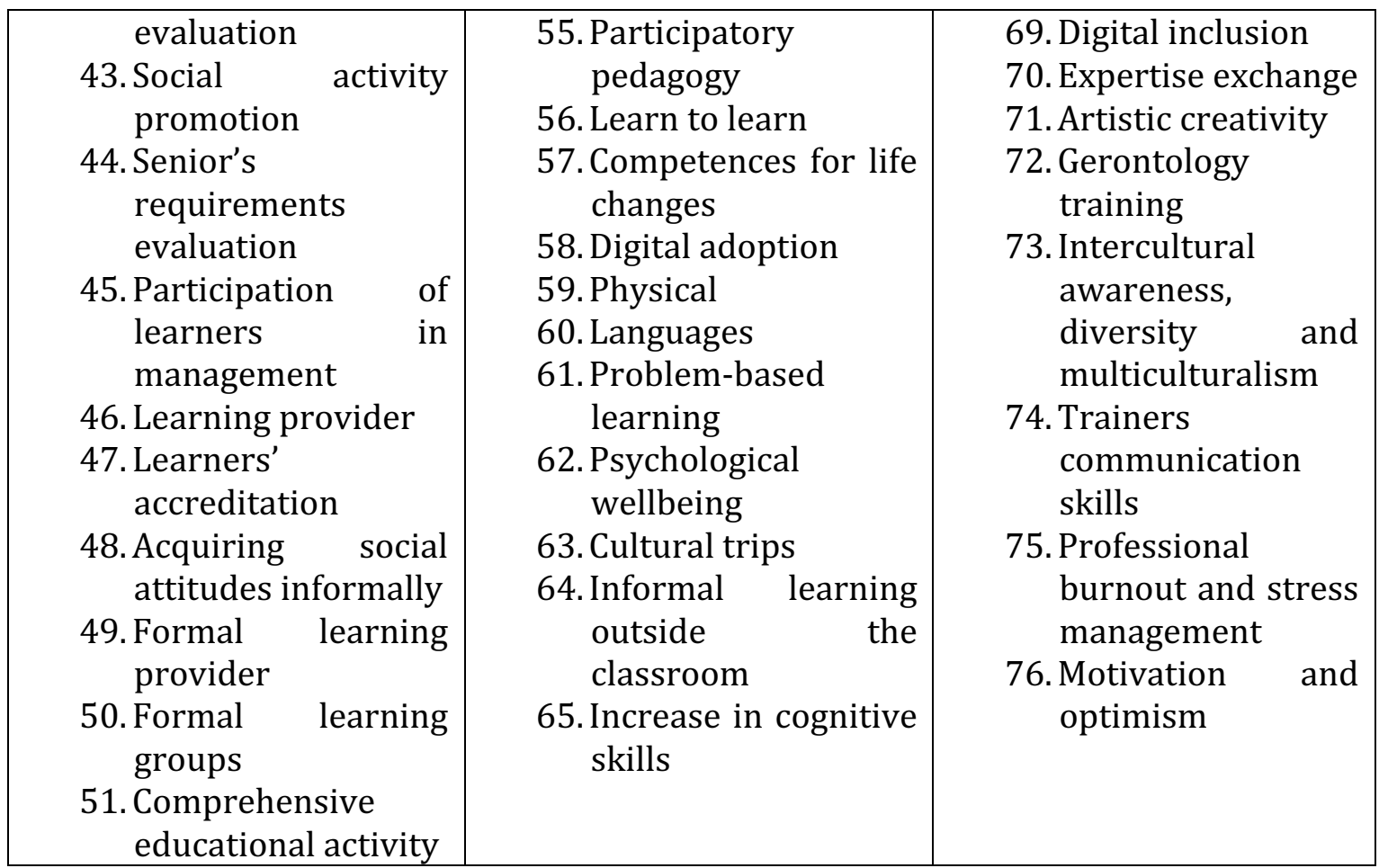

\subsection{The evaluation toolkit}

The QEduSen evaluation toolkit is composed by 38 characteristics (Table 10). For each characteristic, it has been included the requirements that has to meet, the justification and the recommendations (Table 11), now then, it can be considered an indicator for evaluation.

Table 11. Structure of an indicator

\begin{tabular}{|l|l|}
\hline Field & Description \\
\hline id & a sequential number for ease of reference. \\
\hline Title & a single descriptive sentence \\
\hline Source & proposed sources for gathering evidence \\
\hline Educational & one or several of the above-mentioned dimensions in which an \\
\hline
\end{tabular}




\begin{tabular}{|l|l|}
\hline dimension & $\begin{array}{l}\text { institution has control and power to act. } \\
\text { QoL dimension } \\
\text { One or several of the above-mentioned dimensions that can } \\
\text { have an impact on the senior learner's QoL }\end{array}$ \\
\hline Justification & $\begin{array}{l}\text { description of the indicator, why it must be considered, what } \\
\text { the relationship is between the education and QoL. How the } \\
\text { indicator, QoL and the institutional dimension are related. } \\
\text { How QoL is increased through that educational action. }\end{array}$ \\
\hline Proof or evidence & $\begin{array}{l}\text { how the evaluator can check that the indicator requirements } \\
\text { are met. }\end{array}$ \\
\hline Recommendations & $\begin{array}{l}\text { these alert the evaluator to the institution's failure to meet the } \\
\text { indicator requirements, and also can be useful to learn how to } \\
\text { meet the requirements as a way of suggestions }\end{array}$ \\
\hline
\end{tabular}

Any evaluation and quality assessment procedure in an institution should be designed carefully. Evaluation procedures should be put in a very strict framework, otherwise, if they are too ambiguous or the context is not defined clearly, those will be difficult to apply and understand their conclusions. Nevertheless, if that framework is too strict, it will be difficult to be applied in a sufficient and variable quantity of institutions. In QEduSen evaluation toolkit each indicator belongs to at least one QoL dimensions and at least one of the educational dimensions defined the first phase of the QEduSenior project. This allowed starting from a very wide and abstract concept, to a low level indicators, which can be easily checked, to know whether the institution meets them, but also allow to know in detail (from an operational level) what kind of educational action should be implemented. In Table 12 an indicator is provided as example. A full list detailed of indicators is available in the project website (http://www.edusenior.eu) 
Table 12. Example of an indicator

\begin{tabular}{|c|c|}
\hline Title & 17. Participatory pedagogy \\
\hline Source & $\begin{array}{l}\text { - Trainers } \\
\text { - Learners }\end{array}$ \\
\hline Edu. dim. & - Pedagogy \\
\hline QoL dim. & $\begin{array}{l}\text { - Control } \\
\text { - Participation } \\
\text { - Social }\end{array}$ \\
\hline Justification & $\begin{array}{l}\text { - When the trainer explains something in class, learners should } \\
\text { be given a way of adding some value to the explanations. While } \\
\text { participation should be moderated, an opportunity must } \\
\text { always be given to ask questions or make comments. This } \\
\text { participation in class is the first step to increasing participation } \\
\text { and communication in other activities, and subsequently in } \\
\text { society. } \\
\text { Trainers can also ask shy learners or those who think they } \\
\text { have no opinion for their views. This helps to increase their } \\
\text { perceived control, and learners then become aware that their } \\
\text { opinions are important. }\end{array}$ \\
\hline Requirements & $\begin{array}{l}\text { 1. Learners feel free to participate in class when they have a } \\
\text { doubt or a question; they can also add information and trainers } \\
\text { are keen to discuss any aspect of the subject with them. } \\
\text { 2. Trainers allow and encourage feedback among learners by }\end{array}$ \\
\hline
\end{tabular}




\begin{tabular}{|c|c|}
\hline & $\begin{array}{l}\text { moderating and providing useful information, particularly } \\
\text { when it is necessary to contradict or argue with a learner. }\end{array}$ \\
\hline $\begin{array}{l}\text { Recommen- } \\
\text { dations }\end{array}$ & $\begin{array}{l}\text { - Trainers should encourage learners to participate during class. } \\
\text { Even in formal talks or theoretical lectures, a turn for } \\
\text { questions should be built in. } \\
\text { - When learners provide feedback (a question, or a suggestion) } \\
\text { trainers must have the necessary skills to resolve the question, } \\
\text { and accept or reject the suggestion as appropriate. This } \\
\text { exchange should be made appropriately, by balancing } \\
\text { negotiation between learner-trainer but also taking into } \\
\text { account the trainer's authority. } \\
\text { - Trainers must have sufficient skills not only in their own } \\
\text { subject, but also in communication. }\end{array}$ \\
\hline
\end{tabular}

\section{7 applicaton the evaluation toolkit}

During May - September 2013, in the QEduSen project, the guide and the evaluation toolkit was tested in 7 institutions, where 32 evaluators assessed the toolkit, in this research the information is extracted from quantitative interviews. The toolkit can be downloaded from http://www.edusenior.eu.

The evaluation toolkit can be used in an ordinary way: to obtain a mark about the effectiveness and efficacy of the educational activity, but after testing procedure (as part of the quality increase project work package), it showed a lot more of applications, those are:

- To find an institution's weaknesses and potentialities and raise its quality

- For accreditation by external evaluators and for advice and recommendations about how to improve the quality of your institution 
- to uncover/discover the most suitable educational characteristics that can impact seniors' quality of life and its relation

- to recognize some important issues of one educational institution for: study visit, exchange of best practises, experiences, classification of the characteristics, etc.

Indicators provide clear characteristics with recommendations that can be transferred and applied, far from general and broad concepts. Therefore, an evaluation toolkit, when correctly designed, is a very powerful took, useful not only to increase the quality of educational institutions, but as in the case of the QEduSen project for other processes related to validating, guidance, learning, management, research and policymaking.

\subsection{Conclusions}

Usually institutions are reluctant to apply any procedure of evaluation or assessment; it can be seen as a procedure where they get a score, and no matter how high this score is, it is never good enough, or focus more on the lacks that in the potentialities. This evaluation toolkit provides firstly a score. In the testing phase (but also during the design of the evaluation toolkit), there were design problems on this issue. The main reason is about the repeatability and reliability of a mark that relies too much on the subjective perception of the evaluator and also the people that is evaluated (managers, trainers, tutors, and senior learners). The general agreement was that to get a score was necessary; only with that number (one number per each indicator, plus a total average mark) it was possible to focus later on the indicators that had low score.

During the design of the evaluation toolkit, it was agreed, and also during the testing phase it was proven its validity, to use an overall performance rating model instead of a psychometric value (agree /disagree). The performance model does not measure whether the evaluator agrees or disagrees with the indicator it is based on the evidence and proof related to each indicator. In this model, each indicator is given a 
score based on the level to which the indicator requirements are met. The evaluation toolkit includes a methodology procedure where the evaluator gathers the proofs.

Even so, the evaluation toolkit relies a lot on the experience and expertise of the evaluator. To make it more flexible and also to help the evaluator, the final step of the evaluation procedure is to fill an open form. The evaluator, based on each indicator recommendations, should fill the fields about weakness, potentialities, risks, and opportunities.

The evaluation toolkit was directly designed for assessment of institutions, but as each indicator includes context relevant information (the dimension it belongs, justification, recommendations), then the evaluation toolkit can be used for a lot more applications.

In fact, during the testing procedure, it has been very positivelly valuated the fact that the 38 indicators provide a very practical information about the pedagogies, courses, activities, models, staff competences and institution organisation, which is difficult to obtain when reading other books or guides.

In the same way that happens with the concept of Quality of Life, there are a lot of definitions, models and theories, which can seem completely open and wide, but when going to the QoL evaluation tools (as the one of the World Health Organisation proposes [13]), then it becomes clear for anybody interested (social services, researchers, institutions, etc.) which are the dimensions and facets that should be impacted to increase the citizens QoL.

The creation of the 38 indicators is not definitive and of course those can be changed, but after the testing procedure, it has been demonstrated that those indicators are valid and suitable for institutions that try to increase senior learners' QoL and therefore, can be used for evaluation or as a source of information for any other institution.

\section{Acknowledgements}

This research was undertaken as part of the "Evaluation toolkit on seniors education to improve their quality of life" (http://www.edusenior.eu) project, funded with support from the European Commission with reference 518227-LLP-1-2011-1-ES- 
GRUNDTVIG-GMP. This communication reflects the views of the author only, and the Commission cannot be held responsible for any use which may be made of the information contained therein.

\section{REFERENCES}

Rapley, M. (2003). Quality of life research: a critical introduction. SAGE.

WHO. (1997). WHOQOL. Measuring Quality of Life. World Health Organisation. Retrieved from http://www.who.int/mental_health/media/68.pdf

Cummins, R. (1997). Comprehensive quality of life scale: adult: manual (5th ed. (ComQol-A5).). Burwood Vic.: Deakin University School of Psychology. Retrieved from http://www.deakin.edu.au/research/acqol/instruments/comqol-scale/comqola5.pdf

Schalock, R. L. (2004). The concept of quality of life: what we know and do not know. Journal of Intellectual Disability Research, 48(3), 203-216. doi:10.1111/j.13652788.2003.00558.x

Escuder-Mollon, P., Clemente Esteban, R. A., Flores Buils, R., \& Esteller-Curto, R. (2012). Quality of life (No. QEduSen. D.1.1.a). QEduSen project (LifeLong Learning Programme of European Commision). Retrieved from http://edusenior.uji.es/files/QualityOfLife.pdf

Escuder-Mollon, P. (2012). Modelling the Impact of Lifelong Learning on Senior Citizens' Quality of Life. Procedia - Social and Behavioral Sciences, 46(0), 2339-2346. doi:10.1016/j.sbspro.2012.05.481

Escuder-Mollon, P., Esteller-Curto, R., Issakainen, C., Lubkina, V., \& Lozanova, S. (2013). Pedagogical Proposal to Increase the Quality of Life on Senior Citizens. Presented at the 5th World Conference on Educational Sciences, Rome.

Escuder-Mollon, P., Esteller-Curto, R., Ochoa, L., \& Bardu, M. (2013). Impact on Quality of Life Through Lifelong Learning on Senior Learners. Presented at the 5th World Conference on Educational Sciences, Rome. 


\section{A TOOLKIT TO EVALUATE THE IMPACT OF AN EDUCATIONAL ACTION TO SENIORS' QUALITY OF LIFE}

Autores (por orden de publicación): Roger Esteller-Curto ${ }^{1}$, Pilar Escuder-Mollon², Luis Ochoa ${ }^{3}$

1. Universitat Jaume I. Spain

2. Universitat Jaume I. Spain

3. Jan Dlugosz University in Czestochowa, Poland.

Presentado en: International Scientific Conference Society, Integration, Education Rezekne Higher Education Institution. Faculty of Pedagogy. Rezekne Augstskola. Mayo 2013, Rezekne, Latvia.

Publicado en el libro de actas: ISSN 1691-5887

\section{Abstract}

When an institution needs to evaluate the teaching-learning process then it can be done evaluating the knowledge and skills acquired by the learners or by the selfevaluating the trainers from the students perspective. The qualifications in this context is the main measure to get the metrix for evaluation. On the other hand, when there is not a need to acquire a specific knowledge or expertise but when the learners wants to continue learning because he/she enjoys it, wants to keep learning and being active or any other personal motivation, then evaluation becomes a big challenge. This is the case of seniors' education (citizens over 65 or retired). Which metrics should be used when evaluating institution ? how we can know if those institutions are doing the work correctly? how can the institution increase the quality and effectiveness ? From this need the project QEduSen (supported by the Lifelong Learning Programme of the European Commission) produced an evaluation toolkit 
Keywords: senior education, elderly, quality of life, quality, indicators

\subsection{The Quality of Life}

The work of Rapley (2003) provides extensive analysis of the Quality of Life (QoL) concept. He firstly recognizes the complexity of the term and highlights the difficulty of reaching a general consensus on the definition. QoL is a complex state that can be observed at group, community or individual levels. At an individual level, Rapley notes that QoL can be conceived as "an aspect of individual subjectivity, a psychological quantum expressing the satisfaction of particular people with their individual lives". Definitions of QoL based on health or disease are plentiful, but they are too varied and too specific. As the QoL concept is subjective, certain cultural components further complicate its definition, since cultural, social and environmental contexts and local values come into play. Given the difficulties in finding a precise definition, we must start with the most accepted theories, such as those offered by the WHO (WHOQOL 1997), Cummings (Cummins 1997) and Schalock (2004).

The WHOQOL justifies the dimension and facets chosen to evaluate the QoL based on some of peopl's individual aspects. These aspects are explained in the Manual of WHOQOL (WHOQOL 1998); some of the facets are detailed in Table 1, together with other theories from Cummins (1997b) and Schalock (2004)

Each of previous research establishes facets and dimensions to define and evaluate the QoL, but some of them cannot be affected because of education while other are very important, firstly because they are more related to social and psychological situation of the elderly, secondly, because they can be impacted from an educational action. From previous works of Escuder-Mollon (2013) and analysis and research (QEduSen 2012) following QoL dimensions has been extracted:

1. Physical Health

2. Psychological Health 
3. Social

a. Feeling integrated in society, with more communicative and social skills

b. Getting a better knowledge of the environment

4. Increase participation

a. in the own educational institution

b. in communities, families, friends

c. in the society in general

5. That participation can be done: creating, sharing or being an active part of a group

6. Increase perceived control (internal and external, primary and secondary).

a. Improving the skills and competences to discuss, negotiate, and communicate but also to accept and adapt.

b. Acquire skills to analyse and know more about oneself and how we are related with the environment (links with other people)

7. Personal grow: optimism, motivation, energy to do things

8. Personal fulfilment: Leisure, spend time on oneself, useful time

9. Transversal: The indicator does not fit any of the previous QoL dimensions directly, but it makes possible to increase the quality of the institution effectiveness to impact the QoL of the senior learners, therefore, that indicators can affect all the QoL dimensions.

Any of those 7 dimensions (as one is transversal, it is not a true dimension), can be affected thanks to education, by any of following dimensions (Escuder-Mollon 2013):

1. Institution: that are the premises and the physical institution.

2. Management and organisation: that includes

a. The general aims of the institution (objectives and strategic aims), internal processes of the institution, management decision and internal regulations. 
b. How the work inside the institution is performed, no matter if it is regulated or it done because of costumes

3. Educational models: ways of providing the learning contents and activities. It includes the formal, non formal and informal models, but educational models is more about:

a. How education is provided by the institution (not how a specific course is offered)

b. The design framework that later directs how it is going to be implemented (pedagogies, courses, content, evaluation)

4. Pedagogy: application of different techniques and educational methods to courses and activities.

5. Courses: any kind of learning processes where it is involved a teacher and has a teaching plan related even if that plan has nor formally stabilised ( content, competences to reach, pedagogy, timing, objectives, evaluation), example:

a. ICT or language courses

b. Economy, sociology, courses

c. Cooking, arts, courses, chorus or theatre (in case they had attached a teaching plan)

6. Activities: any kind of learning process where it is not involved any teacher and has not a teaching plan attached, example:

a. a web-site, conference or any dissemination activity

d. Research or projects related activities

e. trips that learners can organise, lunch or dinners, festivity, fairs

f. Extra academic activities: as chorus or theatre (in case it is organised as a leisure activity)

7. Staff and trainers: That includes the operational level of the personnel: coordinators, teachers, tutors, facilitators, administrative staff, etc.

a. Competences and skills 
b. Functions and responsibilities

\subsection{The evaluation toolkit}

An evaluation toolkit was produced in the QEduSen project, "Evaluation toolkit on seniors education to improve their quality of life" is supported by the Lifelong Learning Programme of the European Commision with reference 518227-LLP-12011-1-ES-GRUNDTVIG-GMP from October 2011 to September 2013

You can find more information about this project in http://www.edusenior.eu and about the LifeLong Learning Programme of the European Commision at http://ec.europa.eu/education/lifelong-learning-programme.

This evaluation toolkit is aimed to evaluate an educational institution that is teaching to senior learners (over 65 or retired) which main motivation to keep learning is completely personal (not job related). In this context, the education which will be evaluated is done on the point of view of the impact of the Quality of Life (QoL) of the learners.

This evaluation toolkit does not measures the QoL of the senior learners. For that purpose, there are already a lot of other tools and questionnaires

This toolkit tries to evaluate an education institution. That is a very ambitious objective which is in fact difficult to get, and we recognise the limitations; there a lot of different kind of educational institutions which objectives can be very dissimilar, also the target of each institution can be different (elderly with good health, elderly immigrants, or at risk, etc.), social context of the institutions and their limitations makes also a big difference. Because of this, an exhaustive, strict and objective evaluation would be impossible, but being aware of this limitation, we design this toolkit as a powerful tool not centred on evaluation for getting an award where get a high rank is the most important objective, but to be applied in an institution together 
with the guide (the other product of the project) and as very practical tool to get advise about how to improve.

This toolkit can be applied:

- To know the institution weaknesses and obtain information about how to increase the impact of your educational action on your senior learners quality of life

- Use it for internal or external accreditation

This evaluation toolkit is designed to be targeted the educational intervention of an institution that encompass (Figure 4):

- Human resources: managers, technicians, staff, teachers

- The results and impact: subjective perception of the senior learners when attending to lectures and activities

- Processes, methodologies and workflows of the institution

- Materials, activities, courses and pedagogies applied
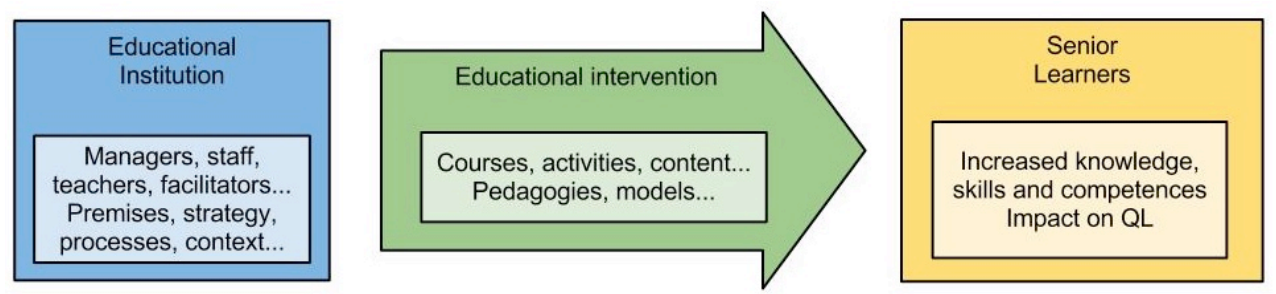

QEduSen evaluation tool

Figure 4. The toolkit aims to evaluate the educational institution and its processes. Not the QL itself

This evaluation toolkit is not aimed to:

- Evaluate the quality of life of senior learners 
Evaluation can be made in both directions, so an indicator can be double checked from the institution perspective (a) or the learners point of view (b) in Figure 5

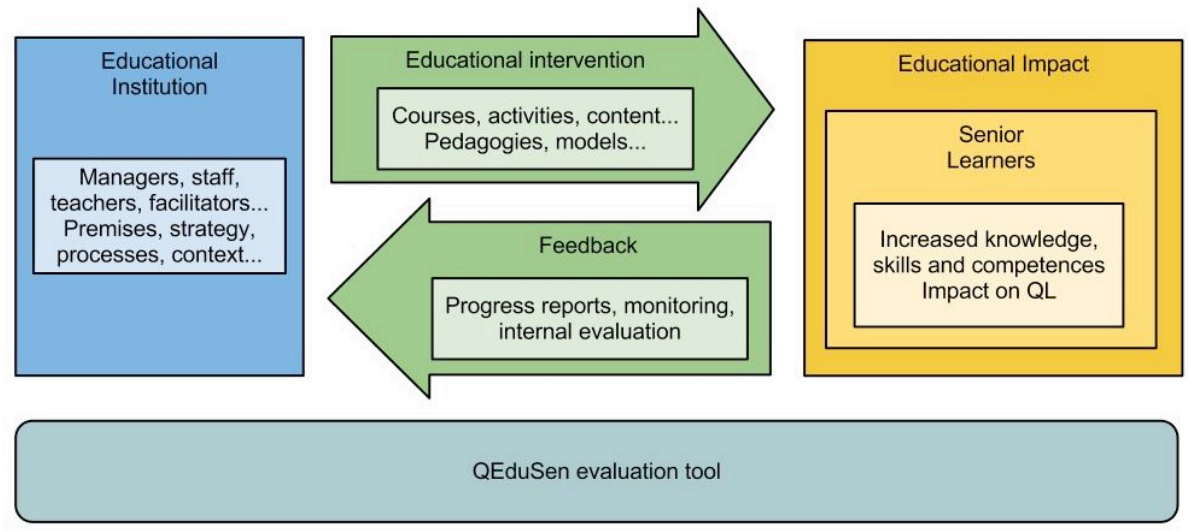

Figure 5. The action (a) and the feedback (b) can be evaluated

\subsection{The target}

This evaluation toolkit can be used in two ways:

- As a check-list for self-evaluation: if you are a manager, technician or teacher, and you are worried if you are doing the appropriate things to increase the QoL of your learners, or even, if you feel curiosity about what you could do, then you can take a look to the recommendations.

- As external evaluation. In this case, a person outside the institution, with experience on seniors' education, should apply the evaluation methodology to provide at the end a mark and recommendations. 


\subsection{The indicators}

As numbered before, there are 7 educational dimensions and 7 QoL dimensions, on which all indicators have been distributed. Each indicator has the following structure

- Id: a correlative number that makes easy later to make reference.

- Title: one single sentence descriptive

- Educational dimension: One or several of the previous dimensions that institution has control and power to act.

- QoL dimension. One or several of the previous dimension on which the senior learner QoL can be impacted

- Justification: description of the indicator, why this must be considered, what is the relation of the education with QoL. In which way are the indicator, QoL, and institution dimension related. How the QoL is increased thanks to that educational action.

- Proof of evidence: how the evaluator can check that the indicator is fulfilled

- Recommendations: this is a first advice in case the institution fails to fulfil the indicator.

There have been produced 38 indicators that belong to each of the previous Educational dimensions and that affect one or more of the QoL dimensions. Following a list of the indicators.

1. Better accessibility for better learning

2. Meeting points in the building

3. Evaluation of Senior Education Programmes

4. Promotion of social activities

5. Evaluation of the senior's requirements

6. Participation of learners in management 
7. Non-formal learning provider

8. Formal learning accreditation

9. Learn social attitudes informally

10. Formal learning provider

11. Formal learning groups

12. Reciprocity, peering and participation

13. Intergenerational learning

14. Constructive pedagogy

15. Learn by research

16. Participatory pedagogy

17. Learn to learn

18. ICT for communicative skills

19. Increase the efficiency of seniors through physical exercise

20. Art activities

21. Teaching languages to senior learners

22. Problem-based learning

23. Coping with stress and relaxation

24. Occasional meetings for social contacts

25. Common holiday trips

26. Emotions through sound

27. Increasing satisfaction through participation in walking sightseeing tours

28. Artistic performances

29. Volunteering as a form of Seniors social productivity

30. Memory and Alzheimer disease (AD) and related disorders

31. Impact of ICT courses on the social life of seniors

32. Sharing hits and tips

33. Gerontology teachers training

34. Intercultural awareness, diversity and multiculturalism

35. Intercultural awareness, diversity and multiculturalism

36. Enhance the communication skills of the teachers in class

37. Professional burnout and stress management

38. Developing skills in motivation and optimistic view of the world 


\subsection{Conclusion}

The application of previous to any educational intervention to seniors provided a rank of effectiveness and achievement. That makes possible to score an institution, for internal or external accreditation. But this is not the main aim of this toolkit and the indicators. Each indicator has detailed information about why it is important (justification), how it can be evaluated (proof of evidence) and a recommendation. The recommendation is very useful as it provides information about the corrective actions that can be taken to improve the effectiveness of the education that provide an educational institution.

Those recommendations should be taken into account with the guide, that has been produced also in the QEduSen project. The guide provides a basic theoretical background and practical experiences for each of the educational dimensions.

\subsection{Acknowledgments}

The QEduSen project "Evaluation toolkit on seniors education to improve their quality of life" is supported by the Lifelong Learning Programme of the European Commision with reference 518227-LLP-1-2011-1-ES-GRUNDTVIG-GMP from October 2011 to September 2013

You can find more information about this project in http://www.edusenior.eu and about the LifeLong Learning Programme of the European Commission at http://ec.europa.eu/education/lifelong-learning-programme.

This project has been funded with support from the European Commission. This communication reflects the views only of the author, and the Commission cannot be held responsible for any use which may be made of the information contained therein. 


\subsection{Bibliography}

Cummins, R. A. (1997). Comprehensive quality of life scale: adult: manual (5th ed. (ComQol-A5).). Burwood Vic.: Deakin University School of Psychology. Retrieved from http://www.deakin.edu.au/research/acqol/instruments/comqol-scale/comqola5.pdf

Cummins, R. A. (1997b). Assessing quality of life. Quality of life for people with disabilities: models, research and practice (pp. 116-150). Stanley Thornes Ltd.

Cummins, R. A. (2000). Objective and Subjective Quality of Life: An Interactive Model. Social Indicators Research, 52(1), 55-72.

Escuder-Mollon, Pilar, Esteller-Curto, R, Ochoa, L \& Bardus, Massimo (2013) Impact on Senior Learners' Quality of Life through Lifelong Learning. Procedia Social and Behavioral Sciences. Inprint.

QEduSen (2013). Analysis of requirments. Available at http://www.edusenior.eu Rapley, Mark (2003) Quality of Life Research. A Critical Introduction, London: Sage Schalock, R. L. (2000). Three Decades of Quality of Life. Focus on Autism and Other Developmental Disabilities, 15(2), 116-127. doi:10.1177/108835760001500207

WHO. (1997). WHOQOL. Measuring Quality of Life. World Health Organisation. Recuperado a partir de http://www.who.int/mental_health/media/68.pdf 


\title{
39 TECHNOLOGY-ENHANCED TRANSVERSAL SKILLS FOR LIFELONG LEARNING: METHOD, COMPETENCES, VALIDATION
}

Autores (por orden de publicación): P. Escuder-Mollon', A. Beltran-Pueyo², H. Saiz-Sanchez ${ }^{2}$, R. Esteller-Curto ${ }^{2}$

1. Universitat Jaume I. Spain

2. Centre for the Innovation and Development of Education and Technology

Presentado en: th annual International Conference of Education, Research and Innovation, 14-16 de noviembre, 2016, Sevilla

Publicado en ICERI2016 Proceedings, páginas 1437-1446, ISBN: 978-84-617-5895-1, ISSN: 2340-1095, doi: http://dx.doi.org/10.21125/iceri.2016.1326

\begin{abstract}
This paper is framed in the www.ed-way.eu KA2 Erasmus+ European project. In this project we propose the use of information and communication technologies (ICT) tools and services to promote the informal continuous learning in adults and senior citizens. In this paper we show the foundations of the method selected to make possible the informal learning, the acquisition of soft-skills and transversal competences and the validation. During the first phase of the project, an initial analysis and research was performed to a group of senior students to know their motivation and impact in life of attending to formal and non-formal education. Trainers were also interviewed. We obtained by this way the understanding and experience to offer the most appropriate educational methods in the Ed-Way manual for trainers. We conclude the best way to promote an informal learning and the
\end{abstract}


permeability to the ordinary teaching classes was to include highly emotional activities, we propose the kind of methods and the best approach.

Keywords: ICT, technology, adult, training, soft skills, motivation, emotion, informal.

\section{$39.1 \quad$ Context}

\subsubsection{THE ED-WAY PROJECT}

The name of the project "Education on the way" Ed-Way [1] makes direct reference to the two main keystones the project is developing:

"Education" understood as continuous or life-long learning through the different stages and circumstances of life. This includes formal contents but also competences, skills, qualifications and values. This concept becomes a basic aspect for achieving the objective of building in balance and tolerance the multicultural and diverse societies of the future that European countries are facing.

"On the way" meaning not only "through life" or towards our near future but also, literally, "on the go" as a direct reference to the new technologies that are emerging during the last years and that bring us never-known-before possibilities and that include a wide scope of possibilities of cooperation, equity, integration, disparitiesreduction, inclusion and communication due to their usability, connectivity and impact. Technology that moves along with the user means also a new chance for learning and an opportunity to introduce informal learning into the reality of individuals as a strong way for educating, teaching and training.

The logic of this technology-enhanced continuous or life-long learning process is at the reach of almost the totality of the European population and consequently its applicability would have a considerable impact in the creation of a European Area of Skills and Qualifications. Therefore, the creation of training and conceptual materials for this purpose for educators, facilitators, teachers, trainers and those responsible of 
adults and seniors becomes essential. They become the specific target group of this project.

Additionally, as the Population Division, DESA, from the United Nations estimates (World Population Ageing 1950-2050 report)[2], "about 37 per cent of the European population is projected to be 60 or over in 2050 ". This sector of the population are in some cases at risk of social exclusion and technologically marginated despite the fact they are a basic participant of the "intelligence society". In this sense, Education on the way will produce tools and resources that will help to:

Educate, train and qualify the adults and young professionals of today that will be the elderly of tomorrow. The existence of a future society where the elderly are integrated, participants and active contributors of the society relies on the present preparation of their members.

Prepare the instruments and technologically applied pedagogies that will contribute to an active and collaborative ageing of the elderly in present societies. This will occur not only by them achieving a mastery of new technologies in general but also by (through the customary use of new technologies) awakening their social awareness, collaborative integration, participation, learning to learn skills... which will keep them integrated in the knowledge society and away from the risk of exclusion and social margination.

The project facilitates, by means of utilization of new technologies, the recognition and use of non-formal and informal learning (and its permeability with interdisciplinary formal pathways) in the field of adult education and training, paying particular attention to the acquisition of personal, social and formal skills, competences and qualifications.

\section{1 .2}

LEARNING INFORMALLY

By definition, the informal learning is produced unintentionally [3]. If it is planed and directed, it becomes formal or informal. The formal learning is organised and concludes with a certificate or any other kind of recognition (as it happens in 
secondary school, vocational training, university studies, languages certification, etc.). The informal learning is more flexible, it can have aims, timetables and even evaluation as the formal learning, but it is not officially regulated. It is far more flexible and can miss some of previous components (as evaluation, or curricula). The informal learning is usually organised in a more flexible way, as it can be workshops, seminars, attendance to conferences, self-learning activities, intergenerational activities or any other educational event not regulated.

Although the formal and informal education has received the main attention during the last decades, there is a growing interest on informal education as it allows acquiring competences and skills that cannot be learn inside a classroom [4][5]. This informal education is produced usually in places where high components of iteration between other people and also where the individual has to deal with an emotional task or activity. Those places can be the workplace, dealing with collaborative work, or assuming responsibilities. Informal learning happens while people are doing other things: working, traveling, doing some activity with friends or family, etc.

We propose the informal learning to happen inside the classroom, but still without being the main target of the training activity; that is while the trainer is teaching other subjects (economy, arts, sciences, business, etc.). Three positive aspects raise from this approach:

- We add activities in the course to potentiate the interaction and group dynamics of the students; they become more active, aware and responsible of the main subject of the course and the learning objectives. By motivating them to take a more active role during the teaching-learning process we also encourage them to incorporate the main subject of the course to their personal needs and interests. In Ed-Way we provide tools and guide to the teacher to go through this path, making possible a new concept of education, not understood as content-delivery process or memory-based evaluation which was used in traditional schools, but on skills and abilities of the present society, based on the capacity to use and apply the knowledge to real situations.

- Informal learning is only produced after months or even years, as some attitudes and skills can only be acquired after years of experience. By 
promoting the informal learning inside a course or other planed learning activity we aim to initiate a habit on the students; those are the soft skills and transversal competences we aim: responsibility, leadership, collaboration, teamwork, problem solving, initiative, etc.

- Information and Communication Technologies (ICT) as computer and the Internet use are becoming more necessary for daily routines, communication with friends and family, and also in the workplace. First step is to learn ICT; that is to use a specific tool or service, but secondly, everybody should learn to apply those tools for our purposes helping us to fulfil our expectations and aims. That makes the ICT meaningful.

\section{2 research}

In Ed-Way project we aim to promote the informal learning to adults and senior citizens. This is a very broad target, even so, we wanted to focus on the group of learners that had an intrinsic motivation to learn not matter of age, not motivated by getting a degree or required certificate but because they feel that interest or think that training could be positive for some aspect of their life (as a professional career, grow as a person, or simply enjoy). Therefore, the targets of the Ed-Way are adults that attend a training institution to acquire knowledge and expertise on varied topics. We do not restrict to the area of those topics, it can be courses as financing, business, psychology, sciences, arts, etc.

42 Adults (average 58 years old) from the University of the third age of Castellón were interviewed in 3 groups. We wanted to know the motivation and interests of the learners on the education (not the course itself) and how that could be important in their lives. 
3 questions were asked during the interviews, prior to registration of the learner in a new course (each course, lasts one year, has 10 subjects and has an effort of 120 hours): Which are your expectations for this year? Why are those important to you? How you will know that those have been reached?

Table 1. List of the main common motivations to learn

\begin{tabular}{|c|c|}
\hline Question & Answers \\
\hline $\begin{array}{l}\text { Which are your } \\
\text { expectations for } \\
\text { this year? }\end{array}$ & $\begin{array}{l}\text { Common expectations: Acquire new knowledge/Increase } \\
\text { knowledge. Learn as much as possible, keep the mind active. } \\
\text { Very common: improve the social relationships. To grow } \\
\text { Some: to have new experiences, learn to communicate and express } \\
\text { myself better. To enjoy. Fill my free time with interesting topics. } \\
\text { To participate more in society. }\end{array}$ \\
\hline $\begin{array}{l}\text { Why are those } \\
\text { important to } \\
\text { you? }\end{array}$ & $\begin{array}{l}\text { Almost everybody: improve the quality of life. Feel better. To } \\
\text { relate with other people, To share, give and receive. } \\
\text { Very common: to grow (enrich) as a person. To be integrated, } \\
\text { increase social network. To understand better the context. To be } \\
\text { active } \\
\text { Some: Satisfy curiosity. To be up to date is a duty of each } \\
\text { individual. }\end{array}$ \\
\hline $\begin{array}{l}\text { How you will } \\
\text { know that those } \\
\text { have been } \\
\text { reached? }\end{array}$ & $\begin{array}{l}\text { Very varied answers: } \\
\text { Satisfaction about having learnt a lot / general satisfaction. Ending } \\
\text { with same excitement. Being happier. Friends made. Apply the } \\
\text { experiences. Feel better with myself. Growth as a person, better } \\
\text { personal perception. Improved well being. Being happier. }\end{array}$ \\
\hline
\end{tabular}

In Table 1 can be seen the results of the interviews from the learners. Those have been very varied, but still it is possible to extract some conclusions: 
The main expectation to enroll in a training programme is to learn. It seems obvious, but here we have the most broad definition of "learning": from "acquire new knowledge", to "grow as a person"

From one side, students will know that they reached those expectations by individual variables: feel better, happier, personal satisfaction. On the other side, the source of the importance are the very near relations and their place in society; that is to be integrated, to find new friends, relate with others.

The duality against individual perception and the environment where everybody lives supports the idea of the social character and the relational characteristic that learning have and the impact that it has in the family and friends. The learning should be understood as a grow process, that links us with our environment in several levels (classmates, family, friends, neighborhood, society) and that returns intensified (personal perception, happier, satisfaction, experiences).

This kind of interactions are in line with the informal learning approach that happens in workplaces, families, or other activities) and affect the personal bag of skills and competences acquired. The Ed-Way project should take into account the relationship between the individual skills and competences and the environment, together with the motivation (that is expectations).

\subsubsection{SKILLS AND COMPETENCES}

161 adults ( $>25$ years old to 65) were asked about which skills and competences should be considered important not focusing on specific subject or courses, but skills that were important for them. The methodology for this research was based on the SG4Adults project[6], list of competences were selected from the Nielson Group List of Soft skills competences[7] . Figure 1 shows the results.

It is not possible tot choose the most important competence that Ed-Way project should target. No survey (valid surveys) received in any competences "not important" "or "Little importance" option. All competences and skills should be considered important, furthermore, in Figure 2, can be observed some replies to a open question 
(in case any respondand wanted to add something). We asked here directly for skills and competences, and also for aptitudes, attitude and values.

Figure 1. Results: soft-skills importance

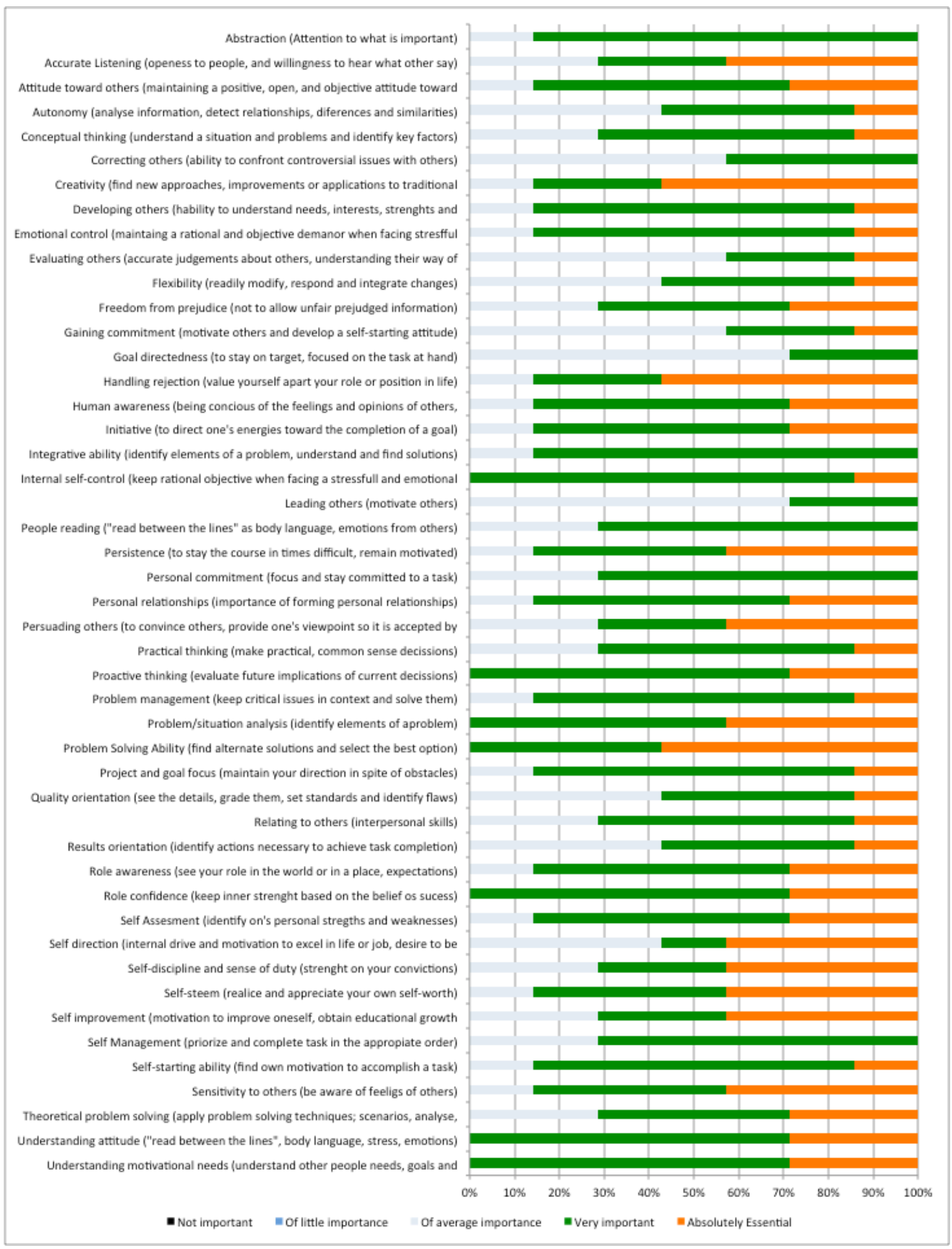


Figure 2. Results: comments observations

Empathy is the most important attitude

Be open minded

Being all skills almost equally important, and being the Ed-Way a project grounded on the digital integration and the use of technology, we consider that the selection of the competences should be grouped among big areas skills and competences, in a way of learning units (later in the Ed-Way manual) trying each of that to help to provide activities and methods to be implemented in learning activities. The areas proposed are:

- Understanding of the environment, problems, challenges, solutions

- Individual skills and responsibilities, individual leadership

- Interpersonal relations, collaboration and teamwork

- Change management, adaptation, control

\subsubsection{PRACTISE AND EXPERIENCES}

7 trainers of the University of Third Age (U3A) of Castellón participated in a focus group [8] to analyse and understand, how the skills and competences of Figure1 were facilitated in learning environment. It is important to remark that being volunteer trainers from the U3A they were highly involved in a kind of education that has not as a main aim the personal qualification of the learners. The main aim of this studies were to transmit the knowlege, while also targeting the needs of the senior learners; that is to increase quality of life components and dimensions [9][10], while integrating adult learning pedagogies [11]. This pedagogy is lined with the main target of the Ed-Way product.

To interview directly this kind of trainers allowed us to gather the convenient experience from trainers that offer courses to several areas of knowledge (arts, ICT, 
philosophy, sociology, law and sciences) while integrating activities to reach other kind of skills of competences, not directly related to the subject.

The methods proposed by the trainers can be summarised by following principles:

- Have in mind what are the learner's needs, their objectives, environment and social context. Link those needs, interests, and motivations with part of the subject your are teaching, by means of examples, exercises, activities, etc. to increase the interest, and also to help them to later apply or use things learnt. If the activities are challenging problems, then students can then reflect and use what they learnt to find solutions.

- The process of learning can be as powerful as the content. The information and data can be easily retrieved from the Internet, or consulted in books. The process of searching, comparing, analysing, and understanding, is more useful and gratifying. It increases the learning experience and also make learners to use some cognitive tools (understanding, analysing, valuating). Facilitate them to build their own knowledge and discover innovative solutions and even a make their own mistakes.

- The group is a potentiator of the learning experience. It is necessary that the learner acquire teamwork and collaboration skills, but furthermore, thanks to this kind of activities, the learning experiences is enriched by the contribution of new points of view points of view, constructive criticism and the sense of common aim of the group.

\section{0 method}

Based on previous practises and experiences, in Ed-Way, we propose following methods to be applied to facilitate the informal acquisition of skills, competences, and values, and further transferability to formal and informal pathways. Activities that Ed-Way methodology should include:

- Extract from the learner what is important for him/her, why, and how can this aims can be achieved. Let the learner construct this path from him/herself. 
- Constructivist activities to increase the responsibility and management of the education on the learning, focusing on those activities that take into account the learner experience, engage the learner and challenge him/her.

- Interaction and dynamics with the group and with the environment. Those kind of interactions can be between equals (collaborative) or with different role (teamwork). The meaningful communication here is crucial.

In Ed-Way, as an innovative aspect of the project, we propose to plan previous activities mediated by technology but grounded on the Field theory [12] and Gestalt psychology [13]. The competences, skills and values proposed are going to be acquired transversally while learning other subjects; we guide the learners through several states, motivating them by mixing emotions, personal interest and the aim of personal growth to make possible, thanks to the ICT, that everybody could learn the subject from a net-based perspective. Thanks to this approach we make possible that students acquire transversal skills and values and keep learning informally once the course ends.

In table 2 we propose 7 areas where the activities, methods and skills and competences are grouped. Those areas of expertise are provided as steps or phases where a learner can be guided, starting from being guided and directed to a more independent and autonomous learner, although it is not a requirement to follow this path, it represents a natural way to grow as a learner.

Table 2. List of the areas included in the Ed-Way manual for trainers

\begin{tabular}{|l|l|l|l|}
\hline Step & Title & ICT tools model & $\begin{array}{l}\text { Experiences, including } \\
\text { tasks to increase emotion }\end{array}$ \\
\hline 1 & Awareness & Readers, Searchers & $\begin{array}{l}\text { Motivation as a learning } \\
\text { experience }\end{array}$ \\
\hline 2 & $\begin{array}{l}\text { Involved } \\
\text { learner }\end{array}$ & $\begin{array}{l}\text { Blended learning, technology } \\
\text { in the classroom, autonomous }\end{array}$ & $\begin{array}{l}\text { Situational leadership } \\
\text { (directing, }\end{array}$ \\
\hline
\end{tabular}




\begin{tabular}{|l|l|l|l|}
\hline & & learning & supporting, delegating) \\
\hline 3 & Collaboration & Collaborative tools & $\begin{array}{l}\text { Teamwork norming, } \\
\text { storming, } \\
\text { performing) }\end{array}$ \\
\hline 4 & $\begin{array}{l}\text { Complex } \\
\text { thinking }\end{array}$ & Virtual sharing spaces & $\begin{array}{l}\text { Perception phases (Grow } \\
\text { model) }\end{array}$ \\
\hline 5 & Networking & $\begin{array}{l}\text { Virtual learning networks, } \\
\text { social networks }\end{array}$ & $\begin{array}{l}\text { Use of language, diversity } \\
\text { management }\end{array}$ \\
\hline 6 & Power & Creativity tools & $\begin{array}{l}\text { Building new realities } \\
\text { (objectives, } \\
\text { needs, alternatives, action) }\end{array}$ \\
\hline 7 & Adaptation & New ICT tendencies and tools & Managing changes \\
positively
\end{tabular}

The first target of the Ed-Way manual are the trainers that later have to teach to adult and senior students. Taking into consideration the practises and experiences from the trainers (section 2.3) and also the agreements from the first meeting of the Ed-Way project where experts from the partnership participated (Castellón March 3-4 2016), we propose a very practical manual, with following characteristics:

- As the maim aim of Ed-Way is the use of technology and the transferability to formal pathways to increase skills, competences and values, that linked and relation should be clearly provided, so trainers that wish to train in certain competences can locate the most appropriate technology, and vice-versa: trainers interested on certain kind of activities, can locate how to potentiate the competences by the use of technology

- An introduction to the previous (Table 2) steps should be done, so the trainer knows the fundamentals, concepts, and knows why it is important.

- Very practical information about what kind of technology, and how it should provided, must be included in each learning unit. 
- Experiences, practises, or existing courses, projects and activities, should be provided as example, making possible by this way to learn by example and transfer the already existing knowledge.

- To be practical, easy to use and motivating manual is more important than to be scenic, although references (as a more information section) and good foundations should be provided.

\section{1 validation of the method}

The validation of the model has been done by implementing the methods proposed in 4 activities of the University of the Third Age of Castellón (average age 61). The method has been applied while learners were attending subjects "Local history and arts", "The UNESCO World natural heritage resources", "Knowledge and information society" and also in a workshop for ICT learning for advanced groups.

As stated in the previous section, the validation of the competences acquired is done by the subjective perception of the learner, quantitative and qualitative group dynamics, and trainers feedback. In Table 2 it can be observed the competences reached by the application of the activities described in Table 3.

Table 2. List of the competences reached thanks to the activities proposes

\begin{tabular}{|l|l|l|}
\hline Unit & Activities & Competences \\
\hline Awareness & Getting information and & Responsibility, Self-improvement, \\
& understanding context: & Individual leadership \\
& newsclips, reflection, changes, & \\
& impact, potentialities & \\
\hline Involved & Blended learning by ways of & Control, autonomy, responsibility, \\
& constructivism pedagogy and & \\
\hline
\end{tabular}




\begin{tabular}{|c|c|c|}
\hline learner & independent learning & planification \\
\hline Collaboration & $\begin{array}{l}\text { Sharing spaces as a group, } \\
\text { constructing common aims } \\
\text { and using organisative tools }\end{array}$ & $\begin{array}{l}\text { Teamwork, communication, } \\
\text { initiative, Leadership, flexibility, } \\
\text { role awareness }\end{array}$ \\
\hline $\begin{array}{l}\text { Complex } \\
\text { thinking }\end{array}$ & $\begin{array}{l}\text { Data representation, } \\
\text { brainstorming, } \quad \text { discussion. } \\
\text { "Learning by research" activity }\end{array}$ & $\begin{array}{l}\text { Problem solving, abstraction, } \\
\text { analysis, creativity. }\end{array}$ \\
\hline Networking & $\begin{array}{l}\text { Virtual learning networks, } \\
\text { using social networks, } \\
\text { networks of interest and } \\
\text { linking }\end{array}$ & $\begin{array}{l}\text { Self improvement, personal } \\
\text { relations, human awareness }\end{array}$ \\
\hline Power & $\begin{array}{l}\text { Publishing of content in web } \\
2.0 \text { tools, receiving feedback }\end{array}$ & $\begin{array}{l}\text { Communicator, results } \\
\text { orientation, role awareness, } \\
\text { handling rejection }\end{array}$ \\
\hline Adaptation & $\begin{array}{l}\text { New tools for learning, learn to } \\
\text { learn, learn to provide help }\end{array}$ & $\begin{array}{l}\text { Flexibility, versatility, internal } \\
\text { self-control }\end{array}$ \\
\hline
\end{tabular}

The manual can be used by trainers, by offering the background, methods and experiences so they can use the Ed-Way approach in their courses by guiding the learners from a directed way of learning (in the first units of the manual) to a more independent and flexible education (the last learning units of the manual). As stated before, we used it in 4 activities, in Table 3 it can be observed the summary:

Table 3. List of the learning activities that included the Ed-Way methods, used for method validation

\begin{tabular}{|l|l|l|}
\hline Activities & Method & $\begin{array}{l}\text { Participan } \\
\text { ts / drops }\end{array}$ \\
\hline Local history & $\begin{array}{l}\text { Application of "Learn researching" method, together with } \\
\text { Creativity and power. Students had firstly to choose what }\end{array}$ & 181 \\
\hline
\end{tabular}




\begin{tabular}{|c|c|c|}
\hline and arts & $\begin{array}{l}\text { they wanted to research, usually they chose some } \\
\text { historical or artistic part they liked in their town. They } \\
\text { used Internet and also other resources (even interviews } \\
\text { with experts) to get more information. The group meet } \\
\text { once per month with a facilitator and they publish the } \\
\text { results in a blog. Finally, the results were presented } \\
\text { publicly in an event and also video (activity about } \\
\text { communication). } \\
\text { Length: } 2 \text { semesters ( } 8 \text { moths), blended learning }\end{array}$ & \\
\hline $\begin{array}{l}\text { The UNESCO } \\
\text { World heritage } \\
\text { resources and } \\
\text { properties }\end{array}$ & $\begin{array}{l}\text { This courses was used to apply the deep thinking method, } \\
\text { to understand, analyze, and try to solve the present social } \\
\text { challenges about preservation of the natural and } \\
\text { historical resources and other singular places, including } \\
\text { even immaterial resources. } \\
\text { This was a course offered completely on-line, which } \\
\text { required a very active and autonomous role of the } \\
\text { learner. This also included collaborative works } \\
\text { Length: } 1 \text { semester ( } 4 \text { months), virtual learning }\end{array}$ & $68 / 18$ \\
\hline $\begin{array}{l}\text { Knowledge and } \\
\text { information } \\
\text { society }\end{array}$ & $\begin{array}{l}\text { Increasing the awareness and understanding of the social } \\
\text { context. Put together with workshops about the future } \\
\text { innovations and challenges (as privacy, biotetics, } \\
\text { dependency, gadgets in our hose, etc.) was used to apply } \\
\text { the methods about awareness and adaptation. } \\
\text { Length: } 10 \text { weeks ( } 2 \text { h. per week plus homework) }\end{array}$ & $89 / 0$ \\
\hline $\begin{array}{l}\text { ICT course, } \\
\text { advanced level }\end{array}$ & $\begin{array}{l}\text { In the basic ICT levels (computer and internet skills) we } \\
\text { train students on the use of services and tools. On the } \\
\text { most advanced levels, they are becoming sufficiently } \\
\text { autonomous to try to learn by themselves, teach each } \\
\text { other and share their ideas and give and receive }\end{array}$ & $48 / 13$ \\
\hline
\end{tabular}




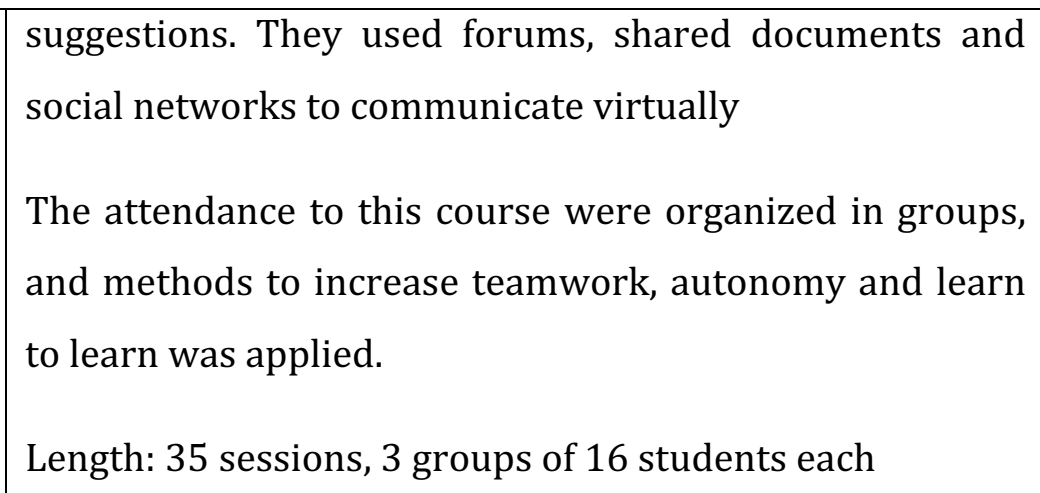

- Students could learn the topics of the course from a very different perspective, not restricted on books or fixed, but open and with some degrees of freedom.

- They had to learn new methods of learning, collaborating, sharing and discussing. In some of the courses, it was so different from the traditional way of learning that it took some weeks to understand the process (courses last a semester; 4 months, but the "Local history and arts" that lasts 2 semesters)

- They had to use the ICT for a purpose in a course that lasted a semester, not as a tool or service, but as something that has an objective and has a results (as it happened in wikis, blogs, or videos after they were published) 


\section{2 validation of the competences and ksills}

The evaluation and validation of the acquisition of skills and competences in an informal learning is difficult, even more when those competences are soft skills and transversal attitudes and values, which require a long-term teaching process. However, we propose a method for evaluation based on individual subjective perception:

- Self-reflection of the learner; if he/she is aware of the process and what happened, the problems, challenges and the lessons learnt

- Results of the activity; mainly in the activities that consist on creating or sharing content it is possible to measure the quantity of the interactions between the learners and the content created. Even so, we propose the quantitative evaluation, instead of quantitative, being more important the quality of the experience than the quantity.

- The trainer in the activities we propose should be considered a facilitator. We remind that the trainer already teaches the main subject of the course, while these kinds of activities are proposed to reinforce the main contents and aims while the learners make a more dynamic activity in a more independent way. The trainer here becomes a facilitator, helping and guiding. The trainers' participation in this activity should provide enough freedom to the learners so they can use the ICT tools as they think convenient, solving communication, leadership or doubts by their own. Only with this freedom space, it will be possible an informal learning. On the other side, that does not mean that students will be left alone. The trainers' guidance and accompaniment is crucial for to reach the learning objectives (and not to get too spread results) and at the same time for evaluation of the learners. 
Finally, in Ed-Way, we aim to create a virtual badge to provide visibility to the skills and competences acquired and assesses. We offer it as an example for any institutions willing to implement a similar way for accreditation, or also use it directly from our project.

\subsection{Conclusion}

The informal education, the teaching of soft skills and the validation and visibility of the competences acquired is being considered as one of the key aspects for a lifelong learning process. In Ed-Way we potentiate this informal education, making possible its permeability with interdisciplinary formal pathways. We offer a manual and an on-line environment where trainers will be able to practice the methods proposed to later on offer them to their students.

Although the acquisition of the soft skills and other transversal competences require a long term activity, from the feedback provided by the learners, the application of the methods we proposed caused a learning that goes further than the simple course content. Those are directly correlated with the competences, skills and also values that we try to impact by the Ed-Way method;

After the research conducted, we found out which transversal competences and soft skills learners now can acquire thanks to the use of the technology; control, autonomy, leadership, self- improvement, teamwork, flexibility, initiative, creativity, among others. We propose the states we can guide the learner to reach those competences: awareness, active learning, collaboration, complex thinking, networking, power, adaptation. To facilitate the non-formal acquisition of skills, values and attitudes through the integration of ICT tools in formal and non-formal education methodologies requires to mix emotional and motivational activities, we propose several methods based on force- field analysis theories of humanism (Kurt Lewin) and Gestalt psychology. 


\subsection{Acknowledgments}

This paper has been developed from the experience in the KA2 Erasmus+ Strategic Partnership project "Education on the way: Introducing technology-enhanced informal learning" with reference 2015-1-ES01-KA204-016354 www.ed-way.eu This paper reflects the views only of the author, and the Commission cannot be held responsible for any use which may be made of the information contained therein.

\subsection{REFERENCES}

Education on the way: Introducing technology-enhanced informal learning [Internet]. Centre for the innovation and development of education and technology [cited 2016 September 29] http://www.ed-way.eu

United Nations, editor. World population ageing, 1950-2050. New York: United Nations; 2002. 483 p.

Cedefop: European guidelines for validating non-formal and informal learning. Publications Office. Cedefop references series; 2015.

Marsick VJ, Watkins KE. Informal and Incidental Learning. New Directions for Adult and Continuing Education. 2001 Mar 1;2001(89):25-34.

Coffield F, editor. The Necessity of Informal Learning. Bristol: Policy Press; 2000. 90 p.

Serious Games for Entrepreneurship Skills of Adult Learners [internet]. CVO Antwerpen [cited 2016 September 29]

List of Soft Skills Comptencies with descriptions. [Internet] the Nielson Group. http://www.nielsongroup.com/articles/list_of_competencies.pdf [cited 2016 September 29] 
Parker A, Tritter J. Focus group method and methodology: current practice and recent debate. International Journal of Research \& Method in Education. 2006 Apr $1 ; 29(1): 23-37$.

Escuder-Mollón P, Manuel SC, editors. Education and quality of life of senior citizens. Publicacions de la Universitat Jaume I; 2014.

Escuder-Mollon P, Esteller-Curto R, Ochoa L, Bardus M. Impact on Senior Learners' Quality of Life through Lifelong Learning. Procedia-Social and Behavioral Sciences. 2014 May 15;131:510-6.

Knowles MS, Holton III EF, Swanson RA. The adult learner: The definitive classic in adult education and human resource development. Routledge; 2014 Dec 5.

Lewin K, Rivera JD. Field Theory As Human-Science: Contributions of Lewin's Berlin Group. Gardner Press; 1976. 552 p.

Köhler W. Gestalt Psychology: An Introduction to New Concepts in Modern Psychology. Liveright; 1970. 388 p. 


\section{SECCION SEPTIMA; CONCLUSIONES}




\section{CONCLUSIONES}

Esta tesis ha pretendido mostrar los resultados de los últimos años obtenidos en el campo de la educación de las tecnologías de la información y comunicación (TICs) en el ámbito de las personas mayores. Este trayecto se inicia por la Universitat per a Majors de la Universitat Jaume I, a partir de la lección de clausura «La Internet para los m@yores» (2000a) que se impartió por José Luis Pardos, embajador español en Dinamarca y miembro del Consejo de Dirección de la Internet Society. La Universitat per a Majors inició en el siguiente curso la oferta en nuevas tecnologías. Ante los retos que esto presentaba, pero también las potencialidades que podía ofrecer al estudiante mayor, iniciamos una trayectoria para favorecer primero la adopción, luego la inclusión digital, para comprender, proponer y evaluar acciones educativas que tuvieran un impacto positivo tanto en la persona mayor, como en la sociedad de la que forma parte, fomentando cada vez más un espíritu activo y participativo.

Las tecnologías de la información y comunicación han pasado de ser una herramienta con un fin determinado y usado para una tarea en particular, a su uso habitual en las relaciones con los amigos, familia, cuando se pretende crear, difundir las ideas propias, aprender, colaborar y compartir. Además, nos afectan emocionalmente e influyen nuestra identidad, seguridad y privacidad. Todo esto hace que tenga una fuerte relación con la inclusión social, apoyo, participación, control, independencia, y otros muchos factores que influyen en la calidad de vida.

Hemos pretendido abordar la formación en nuevas tecnologías y también la educación a través de ellas, como un nuevo método que favorece no solo un mejor aprendizaje, sino también la adquisición de nuevas capacidades transversales o habilidades blandas, tales como la comunicación, autodeterminación, capacidad de trabajo en equipo, y también aptitudes y actitudes, como la empatía, apoyo, tolerancia y actitud positiva hacia los cambios.

De la experiencia extraída tras la participación en los Proyectos europeos, durante sus diferentes fases, desde la investigación inicial, análisis, para luego el desarrollo, prueba y testeo, pueden observarse multitud de productos y resultados que, dentro 
de cada contexto, han tenido un efecto innovador significativo; desde métodos para la educación on-line en personas mayores, a herramientas para la evaluación y mejora de la calidad de vida de los mayores. Tras esta experiencia y como resultado común de los papers publicados, es posible extraer las siguientes conclusiones en relación al objetivo de esta tesis:

Todas las personas, y por supuesto los mayores, poseen una necesidad intrínseca de aprender. No se trata de saber más sobre ciertos temas en particular, sino de crecer, mejorar, comprender mejor el entorno, y cómo se puede transformar. Partiendo de esta premisa, es posible luego diseñar ya una oferta concreta formativa basándose en las necesidades actuales del estudiante mayor. El diseño de actividades educativas en nuevas tecnologías que requieren de teoría y práctica y que afectan tan emocionalmente y poseen enorme carga experiencial, posee su propia complejidad que debe ser considerada por los profesionales, profesores y de forma general por los centros. Es en este aspecto, en el de los centros educativos, que las acciones formativas deben ser diseñadas dentro de un marco, una actuación individual, parcial o concreta en el tiempo posee escaso efecto. Es solo a lo largo de un periodo extenso y mediante la actuación desde diferentes perspectivas (desde el entorno y desde un enfoque individual) y habilidades (técnicas, sociales, grupales) y mediante una mejora en conocimiento y aptitudes (actitud positiva, de mejora, de impacto y retroalimentación) es posible favorecer estados de inclusión digital.

La educación no debe entenderse como un mero proceso formativo, implica también la creación de entornos de aprendizaje (en nuestro caso, tanto reales como virtuales), promoción de actitudes hacia un aprendizaje informal, de mejora continua e integradoras, pero lo más importante, es la participación activa del estudiante mayor, que llega a la co-responsabilidad, conjunta con el centro educativo.

En una primera fase, se pretende que el estudiante mayor sea consciente de las posibilidades que ofrece la tecnología no sólo a él o ella de forma particular sino también del poder que posee, esto es, en la sociedad del conocimiento. Se alcanza de este modo una comprensión inicial del entorno, de hechos que suceden tanto a nivel local como global que nos anuncian en las noticas o que suceden al entorno más cercano, amistades o familiar. La globalidad, economía, sociedad, ética, salud, legislación, etc. son aspectos que también deben ser tratados desde un punto de vista 
tecnológico. El espacio educativo puede ofrecer actividades en forma de clases teóricas, talleres, seminarios o conferencias, ofrecidas de forma transversal junto con otras materias y por profesores de otras áreas. En esta fase también se pretende crear una actitud positiva, afrontar los peligros y retos y promover una estrategia basándose en las propias necesidades e intereses personales. La decisión de no adoptar una tecnología por parte de la persona mayor es totalmente válida, siempre que esta sea una decisión consciente. Además, también es positivo adoptar una actitud de aprendizaje continua, sabiendo que es imposible conocerlo todo, pero podemos acceder a información, preguntar y aprender lo que deseemos.

El uso inicial de la tecnología se alcanza gracias a la alfabetización digital, esto serían los cursos tradicionales de Internet, Windows, Word, Smartphone, Tablets, etc. Cada vez más los estudiantes mayores son más capaces, la brecha digital no es tan profunda como lo era hace una década. El aprendizaje no se puede basar en una adopción básica (aunque este sería el primer paso), sino en el uso para un aprovechamiento propio. El modo tradicional de aprendizaje de herramientas basadas en internet $\mathrm{u}$ otros medios (Smartphone o tablets), intentando equipararlo a lo que sería aprender otras aptitudes (p.ej. física, economía, historia, psicología) fracasa estrepitosamente por diferentes factores: evolución muy rápida de los entornos, aparición continua de tecnología, complejidad inherente a aparatos multifuncionales. La estrategia de aprendizaje debe dirigirse a "aprender a aprender", probar el error, comprender y preguntar. Los grupos de aprendizaje entre iguales, o grupos pequeños funcionan, pero siempre es clave la función del profesor, que debe actuar como facilitador, motivando y acompañando al mayor, dado la enorme carga emocional que posee el aprendizaje de este tipo de tecnología y teniendo en cuenta en cuenta las competencias transversales.

El uso de la tecnología para aprender otras materias (como arte, sociedad, filosofía, etc.) sería el siguiente paso, muy complejo, pero a la vez, enormemente satisfactorio y con enormes posibilidades. En los Proyectos en los que hemos colaborado como Taller de la memoria (mediante blogs), de difusión del conocimiento (usando wikis), u otras asignaturas (usando entornos virtuales de aprendizaje) muestran cómo los mayores alcanzan niveles de comprensión (más allá de su uso) de una tecnología de forma inconsciente, ya que no tienen como objetivo aprender a usar una herramienta 
tecnológica (como documentos compartidos, foros, redes sociales) sino que deben de usarlas para la asignatura en cuestión, aplicándolas.

El aprendizaje on-line o virtual, o cuando se incorporan a una asignatura (que requiere trabajo en grupo, búsqueda de información, creación, etc.) servicios de internet u otro tipo de herramientas, hacen que pedagogías como la connectivista o constructivista sean aplicadas de modo transversal, de modo inconsciente, lo que resulta que luego sea posible que sean aplicadas de forma automática. Se alcanza así la integración de la tecnología dentro de las rutinas diarias del estudiante, en forma de costumbre o hábito. Además, y gracias a la tecnología, es posible difundir los trabajos realizados en los cursos, favoreciendo la obtención de retroalimentación (de otros compañeros, familia, o de otras personas del resto del mundo), produciendo un efecto de circulo virtuoso donde se vuelve a iniciar la fase de consciencia para seguir aprendiendo nuevos conceptos.

La inclusión digital representa un estado complejo del individuo en su contexto social, el cual es posible medir cuantitativamente, pero que en esta tesis se ha querido tratar de forma cualitativa al relacionarlo esto con características subjetivas vinculadas con la calidad de vida, bienestar e integración. Diferentes dimensiones de calidad de vida han sido relacionadas con un uso adecuado de la tecnología, de este modo los profesores y centros educativos podemos favorecer este estado, pero siempre teniendo claro que esto debe ser una meta hacia la cual debemos dirigirnos de forma reflexiva, progresiva y con la participación de los estudiantes en su contexto.

Un programa socio-educativo que incluya las tecnologías de la información y comunicación de forma transversal tiene un enorme potencial para favorecer una persona mayor más integrada y activa. De forma adicional, hace posible difundir el conocimiento y experiencia de las personas mayores y gracias a las tecnologías, se posibilita que la sociedad aproveche todo este capital social. Finalmente, una mayor calidad de vida, integración y autonomía, gracias a la tecnología, promueve una percepción positiva hacia el envejecimiento, por lo que, también los mayores, pueden ayudar a construir una sociedad tecnológica, más justa y solidaria. 


\section{PROPUESTAS}

El diseño y la oferta de cursos para favorecer una adopción de la tecnología por parte de los mayores que potencie sus aptitudes básicas es un campo suficientemente explorado. Con la propuesta que se realiza en esta tesis, es posible avanzar desde esta situación inicial y fomentar que las instituciones diseñen un programa educativo para la inclusión digital.

No obstante, han sido identificas dos carencias en las que debería actuarse en la actualidad. El primero es la falta de recursos existentes en los centros para desplegar un programa hacia la e-inclusión, y aunque exista el interés y la estrategia haya sido fijada adecuadamente, los centros deberían disponer de sistemas y métodos, a la vez que herramientas y servicios que, bajo el prisma de la reutilización y el uso de recursos poco costosos, permitiera implementar la acción educativa que en esta tesis se propone.

La segunda carencia es relativa a la capacitación del profesional formador, o en ocasiones, no tan profesional (ya que muchos formadores son voluntarios), que necesita en un primer lugar conocer las capacidades de la tecnología para sus alumnos $\mathrm{y}$, en segundo lugar, como facilitador del proceso de enseñanza que estos realizan. Existen multitud de herramientas y servicios en Internet que pueden ser usados como apoyo a la docencia, no en un sentido de gestión o administración o de simple acceso a información (como lo haría una enciclopedia), sino de inclusión dentro de las actividades propias de clase (colaboración, creatividad, resolución de problemas, gestión del conocimiento, redes, espacios de innovación, etc.). Es en este sentido que queda aún mucho por hacer. Cuando los profesores integren las tecnologías de la información y comunicación de forma natural en los currículos de sus asignaturas habituales, habremos logrado el siguiente escalón, y se conseguirá que los alumnos aprendan, trabajar, sigan practicando y también disfrutando de forma inconsciente (esto es, habiéndolo adoptado de forma natural), de las nuevas tecnologías, como hace siglos sirvió la incorporación del libro, papel y lápiz en las aulas. 
Por estos motivos estamos colaborando en dos Proyectos europeos, el Ed-Way (www.ed-way.eu) y el Seniors@DigiWorld (www.digital-seniors.eu). En estos dos Proyectos seguimos investigando y buscando las soluciones para los retos que han sido identificados en la educación tecnológica de mayores: el uso de la tecnología para favorecer un aprendizaje informal en aptitudes y actitudes, a la vez que su validación (Ed-Way). También se pretende promover un efecto multiplicador en la educación de mayores para alcanzar a más población (Seniors@DigiWorld) a la vez que reducir costos.

En el caso del Ed-Way, aun sin concluir, aunque con los primeros resultados ya publicados (Escuder-Mollon et Al. 2016, Esteller-Curto \& Escuder-Mollon 2017), proponemos diferentes fases o estados por lo que es posible acompañar a un estudiante durante una educación formal y no-formal (CEDEFOP 2009), favoreciendo la transferabilidad de actividades y métodos basados en herramientas TIC, para que de este modo, el estudiante integre de forma informal prácticas, habilidades y competencias mediadas por la tecnología. Las habilidades que se fomentan son las soft skills (Heckman \& Kautz 2012) y las competencias transversales. El método propuesto en el proyecto Ed-Way puede verse en la Figura 13 , y las diferentes unidades, con sus competencias en la Figura 14.

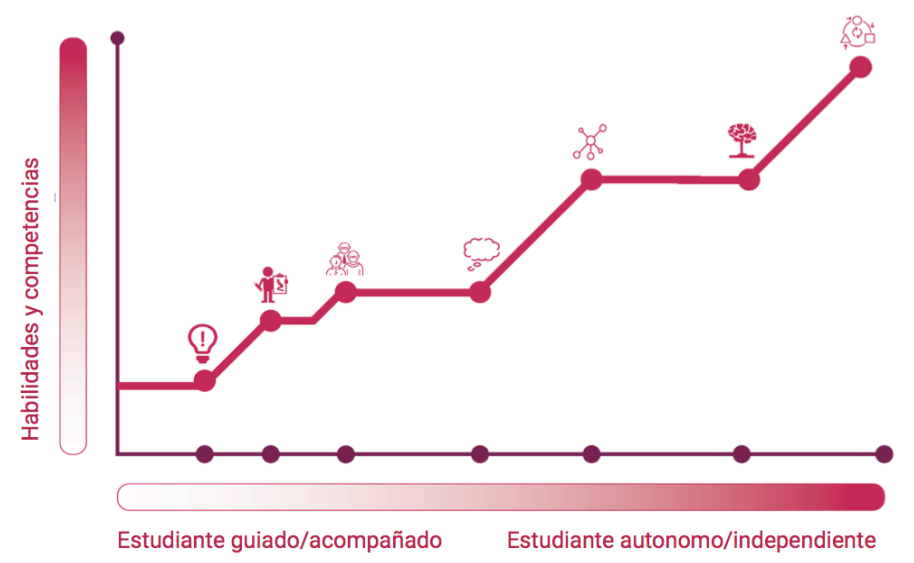

Figura 13. Método propuesto en el proyecto Ed-Way 


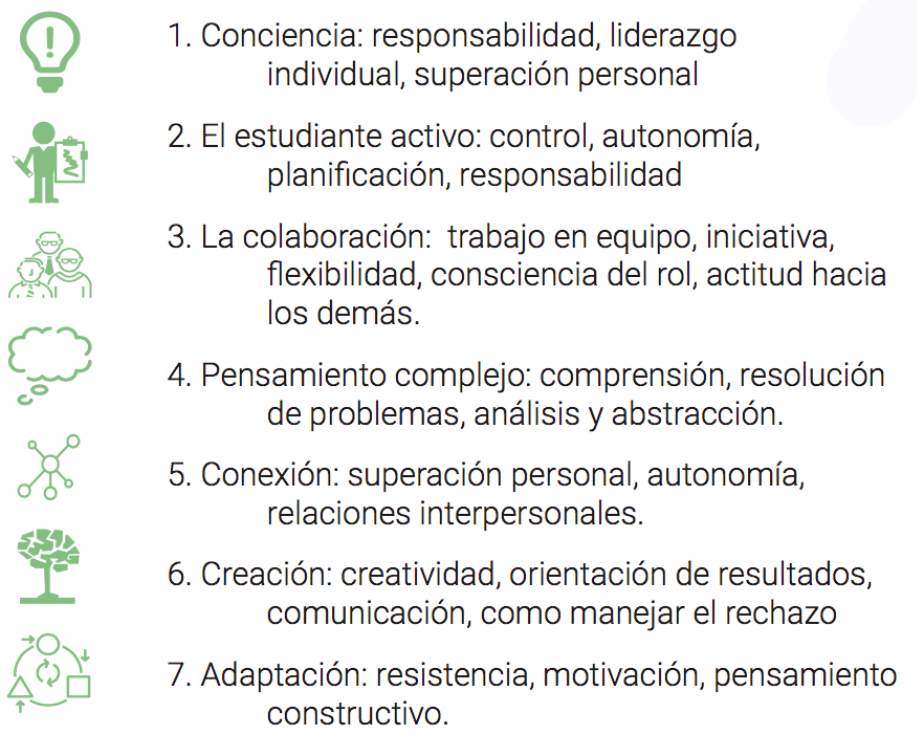

Figura 14. Diferentes fases del método Ed-Way

El trabajo realizado en estas investigaciones y Proyectos contenidos en esta Tesis, muestran la importancia de las tecnologías de la información y comunicación en los diferentes aspectos personales: en sus diferentes contextos, objetivos y propósitos vitales. Por supuesto, la educación, también se ve influida por este avance tecnológico (tanto en contenido, en modelos, métodos, actividades y pedagogías), y por este motivo requiere de nuestro esfuerzo y dedicación para que la tecnología sea aplicada y usada por las personas de una forma útil, constructiva y con un impacto positivo para las personas y sociedad en la que formamos parte.

En un contexto tan global, y donde los cambios se producen tan rápidamente (Toffler \& Aleu 1972), las personas adultas y mayores deben de ser conscientes de que es necesario aprender, desaprender y reaprender. Los investigadores debemos dar continuidad a los Proyectos que hacen posible la comprensión de la complejidad existente y la propuesta de escenarios, modelos y técnicas para que tanto los formadores como los alumnos puedan aprovechar, para estar y sentirse incluidos en la sociedad digital actual colaborando al mismo tiempo para construir la sociedad del futuro. 


\section{REFERENCIAS}

Abate, J. (2000): Inventing the Internet, Cambridge, Massachusetts, MIT Press.

Adell, J. (1998). Redes y educación. Nuevas tecnologías, comunicación audiovisual y educación. Barcelona: Cedecs, 177-211.

Adell, J. (1997). Tendencias en educación en la sociedad de las tecnologías de la información. EDUTEC, Revista electrónica de tecnología educativa, 7, 1-15.

Adell, J, \& Castaññeda, L. (2010). Los Entornos Personales de Aprendizaje (PLEs): una nueva manera de entender el aprendizaje. Roig Vila \& Fiorucci M.

AEPUM (1996). Actas del encuentro nacional de la Asociación Estatal de Programas Universitarios para Mayores. Granada.

Alfageme, A, Cabedo, S., \& Escudero, P. (2006). Los programas universitarios para mayores en el espacio europeo de aprendizaje permanente. VIII Encuentro Nacional de Programas Universitarios para Mayores: Una apuesta por el aprendizaje a lo largo de la vida, 87-94.

Aguilar, L., García Tobío, J., Millán, J. C., Rodríguez Malmierca, M. J., Perenas, M. P., \& Orive, P. (2003). Los mayores y las nuevas tecnologías de la comunicación. Revista multidisciplinar de gerontología, 13(1), 37-42.

Amat, C., Leon, J. Franco, C., \& Basan, J. (1989). El Bienestar. Informe UNICEF necesidades y calidad de vida. pp 23-25

Andersson, G. (2005): Internet-based self-help for depression: randomised controlled trial, en The British Journal of Psychiatry, 187, 456-461.

Ballestero, F. (2002). La Brecha digital : el riesgo de exclusión en la sociedad de la información. Madrid: Fundación Retevisión.

Bean, C., \& Laven, M. (2003). Adapting to seniors: Computer training for older adults. Florida Libraries, 46(2), 5-7. 
Belando, M.R. (2000). Educación y vejez social, ámbitos y propuestas de intervención. Barcelona, Promociones y publicaciones universitarias.

Beltran, J.A. \& M. Vega (2003). Aprender con tecnología en el aula inteligente, en SEGOVIA, F. (dir). El Aula Inteligente, nuevas perspectivas, Madrid, Espasa Calpe.

BOE (2001). Ley Orgánica de Universiades. 307 de 24/12/2001

BOE (2008). Versión consolidada del Tratado de la Unión Europea. DOUE. núm. 83, de 30 de marzo de 2010, 13 a 46

Cabedo, S. (2003). Hacia un concepto integral de calidad de vida: la universidad y los mayores. Publicacions de la Universitat Jaume I. Castellón.

Cabedo, A. (2010). La educación permanente: la universidad y las personas mayores. Castellón. Publicacions de la Universitat Jaume I.

Cabedo, S. \& Alfageme, A. (2005). Los programas universitarios para mayores en España: una investigación sociológica. Publicacions de la Universitat Jaume I.

Cabedo, S. (2008): Jornadas de mayores y nuevas tecnologías, Castelló de la Plana, Publicacions de la Universitat Jaume I.

Cabedo, S., \& Cabedo, A. (2015). La educación a lo largo de la vida y la universidad. Castelló, Publicacions de la Universitat Jaume I.

Castells, M. (2000): La era de la Información. Madrid. Alianza Editorial.

Castells, M. (2001): La Galaxia Internet, Barcelona, Plaza \& Janés Editores.

Castells, M. (2004). La era de la información: economía, sociedad y cultura (Vol. 3). siglo XXI.

Castells, M. (2006a). Informacionalismo, redes y socedad red: una propuesta teórica. La sociedad red: una visión global (pp. 27-75). Alianza Editorial.

Castells, M. (2006b). La sociedad red: una visión global. Madrid: Alianza Editorial.

Castells, M. (2009). Comunicación y poder. Alianza Editorial. 
CE (2000). Comunicación de la Comisión de 21 de noviembre de 2001 - Hacer realidad un espacio Europeo del aprendizaje permanente. COM (2001) 678. final Diario oficial de la Unión Europea.

CEDEFOP. (2009). European guidelines for validating non-formal and informal learning. Luxembourg: Office for Official Publications of the European Communities.

Cheung-Ming, A., Cheng, Edo., \& Phillips, D. (2007). The ageing of Asai: ploicy lessons, challenges. Journal of the East Assia Foundation. 2(2)

Clemente, R.A. y C. Andrés (2008): Miedo al ratón. Aspectos psicológicos y pedagógicos del uso de nuevas tecnologías por personas mayores en CABEDO, S. (dir): Jornadas de mayores y nuevas tecnologías, Castelló de la Plana, Publicacions de la Universitat Jaume I

Cheung-Ming, Alfred Chan, Tak-Cheng, Sheung \& Philips, David (2007). The Aging of Asia: Policy Lessons, Challenges. Jorunal of the East Asia Foundation, 2(2). 2007. Disponible en http://globalasia.org/articles/issue3/iss3_11.html

Cody, M., Dunn, D., Hoppin, S., \& Wendt, P. (1999). Silver surfers: Training and evaluating internet use among older adult learners. Communication Education, 48(4), 269-286. doi:10.1080/03634529909379178

Comisión Europea. (2000). Memorándum sobre el aprendizaje permanente. $\operatorname{SEC}(2000) 1832$.

Comisión Europea (2005): i2010 - Una sociedad de la información europea para el crecimiento y el empleo, Bruselas, COM(2005) 229.

Comisión Europea. (2006). Aprendizaje de adultos: nunca es demasiado tarde para aprender. $\operatorname{COM}(2006) 614$ final.

Comisión Europea (2007): Iniciativa Europea i2010 para la inclusión digital Participar en la sociedad de la información, Bruselas, COM(2007) 694. 
Colom Cañellas, A. J., \& Orte Socías, C. (Eds.). (2001). Gerontología educativa y social : pedagogía social y personas mayores. Palma de Mallorca: Universitat de les Illes Balears Servei de Publicacions i Intercanvi Científic.

Crovi, D. (2004). Sociedad de la información y el conocimiento: algunos deslindes imprescindible. Sociedad de la información y el conocimiento: entre lo falaz y lo posible. Buenos Aires: La Crujía, 17-55.

Cuciti, J.M. (2005): Computer Instruction and Andragogy: Best Methods to Teach the Elderly E-mail as a Communication Tool, Oregon, University of Oregon, Applied Information Management Program.

Czaja, S.J. y Sharit, J (1998): Age differences in attitudes towards computers, en Journal of Gerontlogy, 53B(5), 329-340.

Dijk van, J., \& Hacker, K. (2003). The Digital Divide as a Complex and Dynamic Phenomenon. The Information Society, 19(4), 315-326. doi:10.1080/01972240309487

Dosi, G. (1982): Technological paradigms and technological trajectories: A suggested interpretation of the determinants and directions of technical change, Research Policy, Elsevier, vol. 11(3), 147-162.

Drucker, P. F. (1961). The technological revolution: notes on the relationship of technology, science, and culture. Technology and Culture, 2(4), 342-351.

Eastman, J. K., \& Iyer, R. (2004). The elderly's uses and attitudes towards the Internet. Journal of Consumer Marketing, 21(3), 208-220. doi:10.1108/07363760410534759

Erikson, E. H., \& Erikson, J. M. (1998). The life cycle completed (extended version). WW Norton \& Company.

Escuder, P. (2007). The influence of the quality of life on senior citizens through long-life learning, en VI European Congress. Healthy and active ageing for all Europeans, International Association of Gerontology and Geriatrics, 3(20). 
Escuder, P. (2008): El “aprendizaje permanente” desde Europa en CABEDO, S. (dir) (2008): Jornadas de mayores y nuevas tecnologías, Castelló de la Plana, Publicacions de la Universitat Jaume I.

Esteller, R. y Escuder, P. (2009a): Structure of the teaching and learning process of information and communication technologies for seniors, International Scientific Conference Society. Integration. Education. Proceedigns book. Rezekne, Letonia, Rezekne Higher Education Institution. Faculty of Pedagogy.

Esteller, R. y otros (2009b): Methodological proposal for an ICT activation among senior learners, en Proceedings CD of the International Conference on Education and New Learning Technologies, Barcelona, International Association of Technology, Education and Development.

Esteller, R. y otros (2009c): Enhancing ICT education for senior students: Senior Citizens' University in Spain is promoting a comprehensive formal, non-formal and informal approach to ICT learning among senior citizens, en Lifelong learning in Europe, 3/2009.

Escuder-Mollón, P., \& Esteller-Curto, R. (2011). Mejora de la calidad de vida del mayor a través de la e-inclusión en la sociedad del conocimiento: propuesta de una intervención educativa. Aprendizaje a lo largo de la vida, envejecimiento activo y cooperación internacional en los programas universitarios para mayores (Vol. 1, pp. 469-487). Presentado en el IV congreso iberoamericano de universidades para mayores, Alicante: Asociación estatal de programas universitarios para mayores.

Escuder-Mollon, P., Beltran-Pueyo, A., Saiz-Sanchez, H. \& Esteller-Curto R. (2016) Technology-enhanced transversal skills for lifelong learning; method, competences, validation. 9th annual International Conference of Education, Research and Innovation. Seville, Proceedings book.

Esteller, R., Escuder, P., \& Traver, J. (2009a). Enhancing ICT education for senior students: Senior Citizens' University in Spain is promoting a comprehensive formal, non-formal and informal approach to ICT learning among senior citizens. Lifelong learning in Europe, 3. 
Esteller, R., Escuder, P. \& Traver J.(2009b) Methodological proposal for an ICT activation among senior learners. International Conference on Education and New Learning Technologies (EDULEARN09) International Association of Technology, Education and Development. Barcelona, Spain.

Esteller-Curto, R., \& Escuder-Mollon, P. (2017). Outside-the-box informal learning through technology; Methods for trainers in the digital age. Castellón. Centre for the innovation and development of education and technology. En impresión.

Furstenberg, A.L. (1989) Older people's age self-concept. Social Casework, 70 (1989), pp. 268-275

García, J.A. (2007): Nuevas Tecnologias \& Resolucion de Conflictos, disponible en http://www.resolucionelectronicadedisputas.com/?p=39. Fecha de consulta: 01/08/2009.

Grossman, L. (2006): Person of the year: You, en TIME Magazine, 168(26), 38-41.

Hanson, V. L. (2009). Age and web access: the next generation. Proceedings of the 2009 International Cross-Disciplinary Conference on Web Accessibililty (W4A) (p. 7-15).

Heckman, J. J., \& Kautz, T. (2012). Hard evidence on soft skills. Labour economics, $19(4), 451-464$.

Hogeboom, D. L., McDermott, R. J., Perrin, K. M., Osman, H., \& Bell-Ellison, B. A. (2010). Internet Use and Social Networking Among Middle Aged and Older Adults. Educational Gerontology, 36(2), 93-111. doi:10.1080/03601270903058507

Ianculescu, M. \& Parvan, M. (2008): ICT - An Agent of change that can enrich a “Society of all ages", en Applied medical Informatics, 23(3-4), 73-80.

IMSERSO (1992). Plan gerontológico. Madrid. IMSERSO. ISBN: 84-86852-34-X

Jay, G.M. \& Willis, S.H. (1992): Influence of direct computer experience on older adult' attitudes towards computers, en Journal of Gerontology, 47(4), 250-257. 
Kahana B. y otros (2006): Compensatory use of computers by disabled older adults, en Proceedings book 10th International Conference, ICCHP 2006, Linz, Austria: Computers Helping People with Special Needs, 766-769.

Lalonde, M. (1993) El concepto de campo de la salud, una perspectiva canadiense, Boletín Epidemiológico, 4

Lemieux, A., \& Martínez, M. S. (1997). Los programas universitarios para mayores: enseñanza e investigación. Madrid. Instituto de Migraciones y Servicios Sociales.

Lorente, X. (2008): Programa universitario para mayores - Universidad Ramón Llull en Cabedo S. (dir): Jornadas de mayores y nuevas tecnologías, Castelló de la Plana, Publicacions de la Universitat Jaume I.

Martí Puig, M. (2007). La educacion de adultos en Europa. Valéncia: Universitat de Valencia Servei de Publicacions.

Means, B. y otros (2009): Evaluation of evidence-based practices in online learning: a meta-analysis and review of online learning studies, Washington D.C., U.S. Department of Education, Office of Planning, Evaluation, and Policy Development.

MEC (1995). III Conferencia europea de educación de adultos. San Lorenzo de El Escorial. Ministerio de Educación y Ciéncia. Madrid

MEC (2008). Reconocimiento de los aprendizajes no formales e informales. Ministerio de Educación Política Social y Deporte. Disponible en http://www.oecd.org/dataoecd/5/2/41680537.pdf

Morris, M. G., \& Venkatesh, V. (2000). Age differences in technology adoption decisions: Implications for a changing work force. Personnel psychology, 53(2), 375-403.

Mesh, G.S. (2006): Family relations and the Internet: Exploring a family boundaries approach, en The journal of family communication, 6(2), 119-138. 
Monstad, S.J. (2006): Gerontology and ICT, ICT50+ seminar, May 2006, Castellon, disponible en: http://www.elearningeuropa.info/files/media/media10167.pdf. Fecha de consulta: 01/02/2009.

Navarro, J.C. \& Morales, R. (2001): Adicción a Internet: ¿verdad o ficción?, en Rev Psiquiatría Fac Med Barna, 28(3), 168-169.

Nie, N.H. (2002): The impact of Internet use on sociability: time-diary findings, en IT\&Society, 1(1), 1-20.

ONU (1983). Vienna International plan of action an aging. Disponible en http://www.un.org/es/globalissues/ageing/docs/vipaa.pdf

ONO (1991). Pincipios de las Nanaciones Unidas a favor de las Personas de Edad. Asamblea General de las Naciones Unidas el 16 de diciembre de 1991 Resolución 46/91.

ONO (2001). del Secretario General, Kofi Annan, en el día internacional de las personas de edad. Disponible en http://www.un.org/es/sg/annan_messages/2001/envej.htm

O’Reilly, T. (2007): What is Web 2.0: Design Patterns and Business Models for the Next Generation of Software, en Communications \& Strategies, no. 65 (1st q. 2007), 17-37.

Pardos, J.L. (2000a): La Internet de los mayores. Conferencia de clausura del curso académico 1999-2000 de la Universitat per a Majors. Castellón de la Plana, 19/06/2000. Publicado por Ministerio de Asuntos Exteriores. Secretaria General Técnica. Centro de Documentación y Publicaciones, Madrid.

Pardos, J.L. (2000b). La empresa digital en la sociedad de la información y de las comunicaciones, Conferencia para la inauguración del curso de verano de la Universidad del País Vasco, San Sebastián, 04/09/2000.

Pinazo, S. \& Sánchez, M. (2005): Gerontología. Actualización, innovación y propuestas. Madrid, Pearson educación. 
Repetto, M. y Trentin, G. (2008): ICT and lifelong learning for senior citizens, en Journal of e-Learning and Knowledge Society, 4(1), 189-198.

Ramos, J. C. (2009). Modelo de relación entre la Gestión del Conocimiento y la actividad Innovadora en las organizaciones. Universidad Politécnica de Valencia, Valencia.

Requejo Osorio, A. (2009). La educación de "personas mayores" en el contexto europeo. EFORA, 3(1), 45-63.

Roe Smith, M. (1996). Historia y determinismo tecnológico. Madrid: Alianza.

Ruiz, C.I. \& Fernández, M.D. (2005): Reflexiones: ¿son factibles las plataformas virtuales en la enseñanza a mayores? Revista lationamericana de tecnología educativa, 4(1), 141-151

Sáez, J. (1996). Reconstruyendo el discurso educativo de la tercera edad. Pedagogía social: revista interuniversitaria, ISSN-e 1989-9742, №. 13

Sáez, J., Campillo, M., \& Escarbajal, A. (1997). ¿ Puede la educación transformar situaciones sociales?. Revista Interuniversitaria de Pedagogía Social, ISSN-e 1989-9742, 13, 15-16.

Selwyn, Neil, Stephen Gorard, John Furlong, and Louise Madden. 2003. “Older adults' use of information and communications technology in everyday life." Ageing and Society 23(5):561-582. Retrieved July 18, 2011.

Serdült, U. (2006): ICT and Social Inclusion, en Eighth Thematic Workshop. URBACT Programme, June 2006. Crotone, Italy.

Shaw, L.H. y M.G. Larry (2004): In Defense of the Internet: The Relationship between Internet Communication and Depression, Loneliness, Self-Esteem, and Perceived Social Support, en CyberPsychology \& Behavior, 5(2), 157-171.

Small, G. y otros (2009): Your Brain on Google: Patterns of Cerebral Activation during Internet Searching, en American Journal of Geriatric Psychiatry, 17(2), 116-126.

Toffler, A., \& Aleu, J. F. (1972). El "shock" del futuro. Plaza \& Janés. 
Traver, J. Esteller, R., \& Escuder P. (2009). Pilot experience of using a wiki for learning and communicating among senior students. International Conference on Education and New Learning Technologies (EDULEARN09). International Association of Technology, Education and Development. Barcelona.

UJI (2007): Projecte clauer, Universitat Jaume I, en http://clauer.uji.es. Fecha de consulta: $01 / 08 / 2009$

UNESCO (1960). Segunda Conferencia Internacional sobre la Educación de Adultos. Montreal. Disponible en http://unesdoc.unesco.org/images/0013/001338/133863so.pdf

UNESCO (1962) UNESCO 1960-19262 a review of developments and prospects. Disponible en http://unesdoc.unesco.org/images/0016/001604/160443eb.pdf UNESCO (1985) Cuarta conferencia internacional sobre la educación de adultos. Paris. Disponible en http://unesdoc.unesco.org/images/0016/001604/160443eb.pdf

UNESCO, 2003. Towards Knowledge Societies. An Interview with Abdul Waheed Khan, World of Science Vol. 1, No. 4 July-September 2003, UNESCO's Natural Sciences Sector. Disponible en http://portal.unesco.org/ci/en/ev.phpURL_ID=11958\&URL_DO=DO_TOPIC\&URL_SECTION=201.html

UNESCO. (1960). Segunda conferencia mundial de educación de adultos. Elsinore, Dinamarca: UNESCO. Retrieved from http://unesdoc.unesco.org/images/0013/001338/133863so.pdf

UNESCO. (2005a). Education for all : literacy for life. Paris: Ediciones UNESCO

UNESCO (2005b). Hacia las sociedades del conocimiento. Paris: Ediciones UNESCO

Webb, S. (2006): Can ICT reduce social exclusion? The case of an adults' English language learning programme, en British Educational Research Journal, 32(3), 481-507 
Winden Van VAN, W. (2001): The End of Social Exclusion? On Information Technology Policy as a Key to Social Inclusion in Large European Cities, en Regional Studies, 35(9), 861-877.

World Health Organisation. (1997). WHOQOL. Measuring Quality of Life. 